\title{
Tru på \\ Vestlandet
}

Birger Løvlie, Per Halse og Kristin Hatlebrekke (red.)
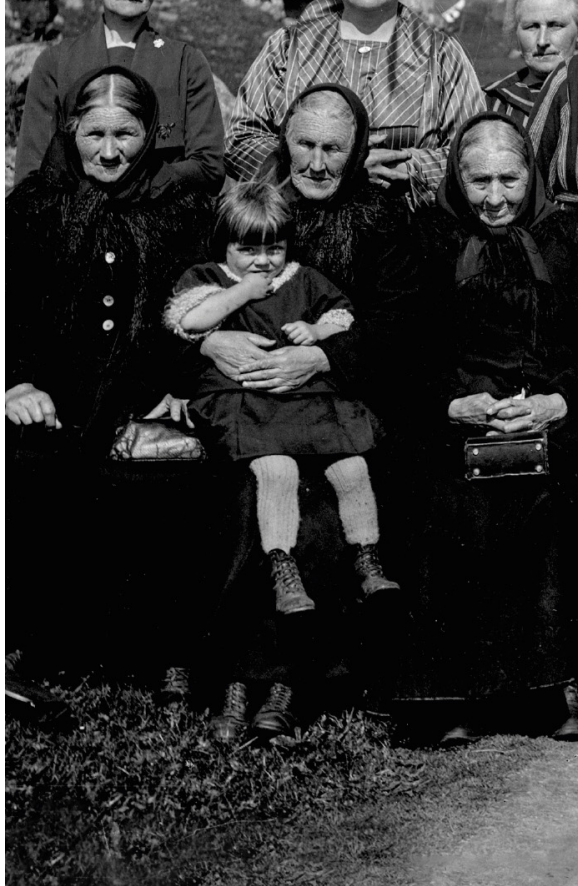
Tru på Vestlandet 

Birger Løvlie, Per Halse og Kristin Hatlebrekke (red.)

\section{Tru på Vestlandet}

\section{TRADISJONAR I ENDRING}


(C) 2020 Birger Løvlie, Per Halse, Kristin Hatlebrekke, Arne Apelseth, Anders Aschim, Ottar Berge, Leidulv Øyvind Grimstad, Hildegunn Valen Kleive, Sidsel Lied, Arnljot Løseth, Torrey Seland, Åsa Thorstvedt, Andreas Tjomsland, Jan Ove Ulstein, Per Magne Aadnanes og Olaf Aagedal.

Dette verket omfattes av bestemmelsene i Lov om opphavsretten til åndsverk m.v. av 1961. Verket utgis Open Access under betingelsene i Creative Commons-lisensen CC BY-ND 4.o (https://creativecommons.org/licenses/by-nd/4.o/). Denne tillater tredjepart å kopiere, distribuere og spre verket $\mathrm{i}$ hvilket som helst medium eller format under betingelse av korrekt kreditering og at en lenke til lisensen er oppgitt. Lisensen tillater ingen bearbeidelser.

Boka er utgitt med støtte fra Høgskulen i Volda. Denne boka er utgivelse nr. 36 i skriftserien Kyrkjefag Profil.

ISSN: 1502-7929

ISBN trykt bok: 978-82-02-68652-9

ISBN PDF: 978-82-02-67722-0

ISBN EPUB: 978-82-02-68657-4

ISBN HTML: 978-82-02-68658-1

ISBN XML: $978-82-02-68659-8$

DOI: https://doi.org/10.23865/noasp.104

Dette er en fagfellevurdert antologi, med unntak av kapittel 16.

Forsidebilde: Bilete er tatt av fotograf Andreas Berge (1886-1960) som gjennom bileta sine dokumenterte kvardagslivet i Herøy kommune på Sunnmøre i perioden frå 1905 til 1950. I hans protokoll står bilete oppført som «Nærø Kvindeforening», og er tatt på Nærøya i april 1927. Biletet er nytta med løyve frå førstelektor Magnar Hjertenæs ved Høgskulen i Volda. Han disponerer biletarkivet etter morfaren Andreas Berge. Framme frå venste sit Kristianne Olsen (Nærø), Karoline L. Nærø med barnebarnet Lilly, Oline G. Leine, Anna Smådal, Gurine Lund, Berte I. Leine, Samoline Sundnes og Karoline Voldsund. I neste rekkje frå venstre står Amalie Nærø, Stevline Leinebø, Antonia Nærø, Henna E. Leine, Sevrin Sundnes, Elisa J. Leinebø, Gurine Nærø, Anna P. Leine og Berte Espeset. Bakerst frå venstre står Anna Sundnes, Gina E. Leine, Anna M. Leine, Selma Leinebø, Olga E. Ellingsen og Pauline Leinebø.

Omslagsdesign: Have a Book

Cappelen Damm Akademisk/NOASP

noasp@cappelendamm.no 


\section{Innhold}

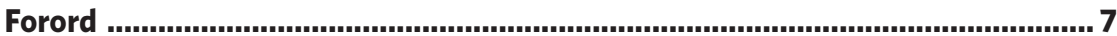

Kapittel 1 Himmel og hav: Introduksjon til innhaldet i boka..............................9

Per Halse

Kapittel 2 Religiøsitet og livssyn i Kyst-Norge på 1800-talet i eit komparativt nordisk og nordatlantisk perspektiv .17

Arnljot Løseth

Kapittel 3 Vekking og modernitet: Nokre kulturanalytiske merknader 41

Per M. Aadnanes

Kapittel 4 Kristen eller kristeleg? Fjordingar mellom kyrkje og bedehus ......59 Olaf Aagedal

Kapittel 5 Lesing som protestantisk utfordring 83 Arne Apelseth

Kapittel 6 Vestlandsk kyrkjesyn: Med Johs. Solem som orienteringspunkt

Jan Ove Ulstein

Kapittel 7 Bedehus, vekkelse og bevegelse 163

Birger Løvlie

Kapittel 8 Frå indremisjon til mindre misjon: Nordfjord indremisjon 1970-2000. 193

Andreas Tjomsland

Kapittel 9 I kjølvannet av varme vinder - Weenaas og vekkelsen 217 Åsa Thorstvedt

Kapittel 10 Det kulturkristne Hareid i det pietistiske Sunnmøre 231

Leidulv Øyvind Grimstad 
Kapittel 11 Læraren i skulefolkets stordomstid: Om ein einskild lærar sitt forhold til presten og til skuledemokratiet

Kristin Hatlebrekke

Kapittel 12 Levd hverdagsreligion

Hildegunn Valen Kleive

Kapittel 13 Da katolisismen kom att til Nordvestlandet. 311

Anders Aschim

Kapittel 14 Elever i dialog med kristendommens fortellinger .339

Sidsel Lied

Kapittel 15 Lex Borgen: Et blad i norsk skolehistorie om ikke-lutheraneres rett til å undervise i høyere utdanning.............363 Torrey Seland

Kapittel 16 Strid om misjon og kirke: H.P.S. Schreuders forhold til Det Norske Misjonsselskap, sett fra Madagaskar 391 Ottar Berge

Om forfatterne 415

Tidligere utgivelser i Kyrkjefag Profil. 419 


\section{Forord}

For eit fagmiljø som kallar seg Institutt for religion, livssyn og kyrkjefag, og som held til ved Høgskulen i Volda, er det naturleg, nærast ei plikt, å forske på det som går føre seg av kulturelle og religiøse endringar i regionen. Denne boka er eit resultat av denne interessa.

Det regionale aspektet er ramma kring arbeidet. Vi har sett søkjelyset på det særeigne ved kristendomen på Vestlandet, og særleg på Nordvestlandet, historisk så vel som aktuelt. Populære framstillingar har forma eit klisjeaktig bilete av Vestlandsfanden som det er grunn til å sjå på med forskarblikk.

Eit nasjonalt perspektiv høyrer sjølvsagt med, som eit bakteppe. Det vi finn som særdrag ved Vestlandet, må vi sjå i samanheng med viktige trekk ved den nasjonale utviklinga i nyare tid, knytte til stikkord som individualisering, demokratisering og pluralisering.

Når vi studerer kulturelle og religiøse endringar i eit regionalt perspektiv, er det historiske viktig. Er det særeigne meir eller mindre tydeleg no enn tidlegare? For å nærme oss eit svar på det spørsmålet er vi også avhengige av eit aktuelt aspekt. Kva har til dømes teknologisk utvikling, velferdsstat og innvandring gjort med vestnorsk religiøsitet?

Nokre av artiklane er ikkje skrivne i eit spesifikt vestnorsk perspektiv, men er likevel rekna som relevante og fortener plass i antologien. Ein god grunn for at Torrey Seland og Ottar Berge er med, er at dei i mange år har vore kollegaer med førstelektor Bente Mari Afset. I tre tiår har ho vore ved Høgskulen i Volda, som ein dyktig, humørfylt og gledespreiande lærar, og i mange år har ho administrert instituttet med kjærleg mynde. No fyller ho 65 år, og alle forfattarane i boka gratulerer i stor takksemd.

Volda, februar 2020

Birger Løvlie, Per Halse og Kristin Hatlebrekke

Redaktørar 



\title{
KAPITTEL 1
}

\section{Himmel og hav Introduksjon til innhaldet i boka}

\author{
Per Halse \\ Høgskulen i Volda
}

Opplæring i luthersk kristendom var ein viktig del av reformasjonen på 150o-talet. Det pedagogiske prosjektet vart intensivert med pietismen og opplysningstida på 170o-talet. Prestar og lærarar formidla kunnskap om tru og moral med basis i Luthers vesle katekisme og Pontoppidans forklaring til henne. Den religiøse kulturen utvikla seg dermed temmeleg einskapleg i landet vårt til langt ut på 18oo-talet. Vekkingane som kom, fyrst med haugerørsla og seinare med luthersk indremisjon, hadde ei sterk folkekyrkjeleg ramme rundt seg. Men det kollektive kristendomssynet vart etter kvart meir individualistisk. Konservative prestar kjempa mot endringane, men mange spelte på lag med lekfolket og tok del i vekkingane. Tradisjonane frå Hans Nielsen Hauge og dei «johnsonske» prestane gjorde sitt til at dei vakte på Vestlandet i liten grad braut med statskyrkja. Men om ikkje mange vart frikyrkjelege, ser vi at religiøse vekkingar prega det vestlege Noreg meir enn dei fleste andre landsdelar. Lekmannsrørsla og bedehuskulturen kom for mange på kysten til å definere korleis kristendom burde opplevast og praktiserast. Det biletet har likevel aldri vore einsarta, og over tid har det funne stad vesentlege endringar. Denne boka handlar om slike endringar.

Sitering av denne artikkelen: Halse, P. (2020). Himmel og hav: Introduksjon til innhaldet i boka. I B. Løvlie, P. Halse \& K. Hatlebrekke (Red.), Tru på Vestlandet. Tradisjonar i endring (Kap. 1, s. 9-15). Oslo: Cappelen Damm Akademisk. https://doi.org/10.23865/noasp.104.ch1

Lisens: CC BY-ND 4.0. 
I salmen «Gud signe vårt folk der dei sigler og ror» sette fiskarbondesonen og biskopen Bernt Støylen ord på det farefulle tilværet: «Sitt levebrød har dei på brusande hav, med berre ei fjøl mellom seg og si grav». Perspektivet med eit kvardagsliv så tett på både livs- og dødskreftene har lenge vore brukt som forklaring på at kystfolket skulle vere meir grunnleggande religiøse og mottakelege for vekkingar enn fjordbuar og innlandsfolk.

Den oppfatninga vert problematisert av Arnljot Løseth, som samanliknar fleire nordatlantiske samfunn på 180o-talet. Med tilvising til nyare forsking diskuterer han den klassiske teorien frå Max Weber om reformert teologi og puritansk livsførsel som grunnlag for industrialisering og økonomisk framgang. Løseth viser at sosioøkonomiske strukturar og danninga av personlege nettverk truleg spelte viktigare roller for framgangen enn religiøs vekking og fråhald frå alkohol.

Dei store vekkingane på Vestlandet kom i ei tid der det norske samfunnet gjekk gjennom djuptgripande endringar. Per Magne Aadnanes studerer vekkingsfenomenet i lys av modernitetsutviklinga. Samstundes som pietistisk vekkings- og omvendingsforkynning markerte avstand til visse uttrykk for det moderne, viser artikkelen korleis nettopp moderne mentalitetar og haldningar var ein føresetnad for vekkingsrørslene. I vekkingane var det ikkje nok å kjenne til læra om frelsa og nytte seg av sakramenta i kyrkja, men kvar og ein måtte tileigne seg frelseverket som si eiga personlege røynsle. Slik vektlegging på subjektiv oppleving og kjensle er ei vesentleg side ved moderniteten.

Vekkingane på Vestlandet gjennom 1800- og 1900-talet hadde temmeleg einskaplege folkereligiøse rammer som føresetnad. Med forvitringa av kristendomsfaget i skuleverket har allmennkulturen ifølgje Aadnanes mista dei referanserammene, og dermed ser han inga framtid for vekkingskristendomen no når moderniteten har gått over i sein- eller postmodernitet.

Graden av spenning mellom oppsedings- eller kulturkristendom og omvendings- eller bedehuskristendom har variert mykje både mellom regionar og enkeltbygder. Olaf Aagedal skriv om «kristen eller kristeleg?» ut frå både samfunnsvitskaplege teoriar og eigne oppveksterfaringar. I Nordfjord har det vore mindre skilje mellom vekkingskristne og folket 
elles enn andre stader på Vestlandet, og på Vereide, der Aagedal voks opp, synest skilja å ha vore særleg små. Bygda opplevde inga stor vekking og fekk heller ikkje eige bedehus. Dette kan sjåast som uttrykk for gamal einskapskultur, og forfattaren karakteriserer det som «inklusiv eksklusivitet»: Ein er medvitne om at skilja er der, men dei vert ikkje aksentuerte fordi partane har sams interesse av dagleg omgang og samhandling i grendesamfunnet.

Luthersk kristendom sette preg på vestlendingane lenge før dei store vekkingane. Arne Apelseth tek oss med attende til 1700-talet og teiknar bilete av ein kultur som var basert på autoritative tekster frå reformasjonstida og pietismen. Katekismeutgåver, salme- og bønebøker var sentrale i forminga av tru, moral og røyndomsforståing. Mot slutten av 1700-talet var meir rasjonalistisk teologi i ferd med å vinne innpass, og ein kar som skulle skysse biskop Irgens på visitas spurde om dei måtte endre på noko i katekisma.

Studien av Apelseth syner at skriftkulturen som trykkekunsten la grunnlag for, var avgjerande for protestantismen sin veg ut til folket. Samstundes vert det klart at lesande bønder ikkje vart skjerma for verknadene av stendig meir omfattande prenteverksemd. Dermed vart ein opphavleg stilleståande og konservativ religiøsitet og eit uniformert meiningsunivers utfordra. Endringa gjekk mot meir mangfald - som biskopen kalla «Fritænken» og «Pralerie med nye Ord og Talemaader».

Har bedehusrørsla på Vestlandet hatt eit tydeleg kyrkjesyn, og korleis har i så fall det utvikla seg? Artikkelen av Jan Ove Ulstein gjev ikkje eintydige svar, men gjer greie for vesentlege spenningar både i fortid og samtid. Lekmannsleiarar i vest har tradisjonelt stått for ei meir kyrkjekritisk sjølvstendelinje enn den «johnsonske» indremisjonen på Austlandet. Ulstein gjer oss kjende med argumentasjonen i eit par talar av Johannes Solem frå 1930-talet - som vart prenta opp att i 1995.

Hundre år etter at Det vestlandske indremisjonsforbund vart skipa, skjer det ei nyorientering der foreiningar vert frikyrkjer med full sakramentsforvaltning, og oppfatningar om hyrde- og lærefunksjonen vert aktualiserte i relasjon til ulike roller for kvinner og menn. Dersom alle truande har del i det allmenne prestedømet, kvifor er då berre det eine kjønnet kvalifisert til å leie bedehusforsamlinga? 
Kor stort sjølvstende skulle lekfolket og forsamlingane deira ha? Birger Løvlie bruker lokale spenningar på Sunnmøre og diskusjonen på eit stort lekmannsmøte i Ålesund i 1893 til å gjere greie for tilhøvet mellom vekkingane og den kyrkjelege reformrørsla. I dei siste tiåra av 180o-talet vart lekmannsforkynninga meir roseniansk enn haugiansk, og dei vekkingskristne delte «reformvenene» si interesse for folkeopplysning, sosiale reformer og demokratisering. Slik vart dei ein avgjerande del av den vide venstrerørsla som sytte for store politiske og kulturelle samfunnsendringar ved overgangen til 1900-talet.

Indremisjonen må seiast å ha vore ei verkeleg folkerørsle på Vestlandet gjennom det meste av 1900-talet, men fekk redusert oppslutnad og innverknad i dei siste tiåra fram mot tusenårsskiftet. Andreas Tjomsland har studert utviklinga i Nordfjord indremisjon frå 1970 til 200o. Bedehusa verka der i lojalitet til og i nært samarbeid med Den norske kyrkja. Både aktivitet og gåveinntekter nådde ein topp midt i 1980-åra, og deretter peika pilene raskt nedover. Tjomsland syner korleis det heng saman med store endringar i samferdsel, utdanningsnivå, busetnadsmønster, kultur og haldningar. Gjennom aktiv bruk av krinsbladet Ljosstrålar får artikkelen med interessante innanfråperspektiv på endringane i perioden.

Artikkelen av Åsa Thorstvedt markerer sterk kontrast til den nordfjordske harmonien mellom embetskyrkja og bedehuset. Ho syner at det til tider har vore utfordrande å vere prest i eit bygdemiljø med uregjerlege lekfolk. Om presten då er av det myndige slaget, med sterk kjensle av ansvar for rett lære, vert det ikkje enklare. Det fekk August Weenaas merke då han vart sokneprest i Volda i 1889. Der vart han ein av hovudpersonane i ein konflikt som toppa seg då to lærarar vart oppsagde fordi dei hadde teke del i fri nattverd.

Wenaas var ikkje ukjend med vekking. Han vart påverka av haugianismen som ung mann, og han studerte teologi under Gisle Johnson. I mange år arbeidde han med utdanning av prestar for norske kyrkjer i USA. I Volda prøvde han å få kontroll over vekkingsrørsla, men lukkast ikkje med det. Thorstvedt drøftar handlingsmønster og motiv i lys av Wenaas sine tidlegare røynsler og hans kompromisslause overtyding. I motsetnad til tidlegare forklaringar, som finn hovudårsaka til konflikten 
i prestens personlegdom, konkluderer Thorstvedt med at Weenaas utførte det pastorale oppdraget på basis av ei sterk konfesjonell overtyding.

Korleis foreiningar og lag med kristelege føremål har samarbeidd seg imellom og med resten av kulturlivet, har variert - også på Sunnmøre. Men det kan sjå ut til at viktige grunnsteinar for samarbeidsklimaet vart lagde i siste halvdel av 180o-talet då store vekkingar i pietistisk eller roseniansk ånd sette preg på regionen. Leidulv Øyvind Grimstad fortel om korleis nokre få personar kom til å prege Hareids-bygda med grundtvigiansk kristendoms- og kultursyn. Det har verka til at kulturen og kyrkjelivet der skil seg ut frå det som har vore vanlegast på Sunnmøre.

Skulen var lenge kyrkja si forlenga arm i lokalsamfunna. Kristin Hatlebrekke gjer oss kjende med ein lærar i Sande på sunnmørskysten som praktiserte dei siste tiåra av 18oo-talet. Det er ei viktig tid i norsk skulehistorie. Til dels er det nok også ein myteomspunnen epoke der lærarane i ettertid har fått heiderstitlar som folkeførarar og nasjonsbyggarar. Politisk var tida spenningsfylt med konfliktar mellom anna kring sekulariseringa av skulen. Med utgangspunkt i dagboka til den eine læraren teiknar artikkelen eit bilete av bygdelærarlivet i samarbeid med prest, skulestyre og tilsynsutval.

Forsking på religion er ein aktivitet som til liks med religiøs praksis er i stendig endring. Hildegunn Valen Kleive gjer greie for både fenomenet og forskingsperspektivet «levd kvardagsreligion». Forskingstradisjonen vert ført tilbake til 1990-talet då religionssosiologien vart oppteken av etnografiske metodar og funksjonelle religionsforståingar. Kleive forklarar «kvardagsreligion» i kontrast til mellom anna folkeleg religion, nyreligiøsitet og religion i populærkulturen. Ho argumenter for at perspektivet er relevant og viktig også med tanke på religionsundervisninga i grunnskulen.

Frå reformasjonen i 1537 og fram til dissenterlova i 1845 hadde ikkje norske borgarar lov til å organisere kyrkjelydar utanom den lutherske statskyrkja. På Nordvestlandet gjekk det nesten hundre år etter lovendringa før den romersk-katolske kyrkja etablerte seg. Anders Aschim skildrar korleis katolisismen kom attende til denne delen av landet i mellomkrigstida. Artikkelen viser at den katolske kyrkja kom styrka ut av verdskrigen trass $\mathrm{i}$ at prestane i Møre-byane var tyske og at mange 
tyske soldatar gjorde seg nytte av katolske kyrkjetenester. I etterkrigstida vert klimaet mellom katolikkar og lutheranarar gradvis meir tillitsfullt. Med nyare tilstrøyming til kyrkjelydane av innvandrarar frå alle verdsdelar er den katolske kyrkja i dag den største livssynsminoriteten i Møre og Romsdal.

Den norske skulen har vore ein viktig formidlar av kristendomskunnskap gjennom snart tre hundreår. Sidsel Lied samanliknar multimodale ytringar frå barneskuleelevar i 1987/88, 1990/91 og 2018/19. Materialet er i alle tre tilfella frå bygder på Vestlandet. Ytringane er respons på forteljinga om Jesu fødsel og likninga om den bortkomne sonen. Forskingsspørsmålet er om eller på kva måte dei ulike målsetjingane for skulefaget (kristendomskunnskap/KRLE) kan ha verka inn på dialogen mellom elev og tekst. Mønsterplanen av 1987 sa tydeleg at det eleven lærte i faget, skulle vere grunnlag for trua og til rettleiing for livet, men etter «Kunnskapsløftet» 2006 er målet å orientere om ulike tradisjonar utan å framheve nokon som sannare eller meir relevant enn andre. Lied finn i forskingsmaterialet ingen markante ulikskapar mellom elevtekster frå dei ulike læreplanperiodane med omsyn til personlege trusuttrykk.

Kva krav skal ein stille til ein lærar når det gjeld religion? Dissenterlova av 1845 opna for at nordmenn kunne vere medlemer av andre kyrkjesamfunn enn det lutherske, men lærarane i den offentlege grunnskulen måtte framleis høyre til statskyrkja. Lov om Embedsmoends Troesbekjendelse av 1894 heldt fast på kravet om kyrkjemedlemskap også for lærarar i høgare utdanning. Interessant nok vart vegen til trusfridom lenger for denne siste gruppa enn for den fyrste. Torrey Seland fortel historia om då Universitetet i Bergen ville tilsetje ein metodist som professor i kristendomskunnskap - og om korleis den gamle lova vart oppheva i 1972.

Frå misjonshistoria er det kjent at det i 1870 -åra vart ein alvorleg konflikt mellom Zulu- misjonæren Hans Paludan Smith Schreuder og leiinga i Det Norske Misjonsselskap. Schreuder vart ordinert som misjonsbiskop i 1868 og rekna seg som øvste leiar for norsk misjon i det sørlege Afrika inkludert arbeidet på Madagaskar. Men misjonærane på Madagaskar meinte at misjonærkonferansen skulle vere det avgjerande organet der. Schreuder protesterte, og då protesten ikkje førte fram, sa han opp stillinga i 1873 . 
Den vanlege forklaringa på at det gjekk som det gjekk, har vore Schreuder sin personlegdom og hans høgkyrkjelege innstilling. Men ikkje alle har akseptert den tolkinga. Ottar Berge har løfta fram misjonspresten Adolf Thunem si alternative forståing av konflikten og finn støtte for Thunems syn i arkivmateriale og andre forskarar sine analysar. Personlege motsetnader mellom folk som hadde same syn på kyrkje og misjon, gjorde konflikten så hard at det vart uråd med forsoning. Christian Dons, som var sekretær for styret i NMS, handsama saka i lag med Madagaskarmisjonær og seinare generalsekretær Lars Dahle, og det gjorde dei på ein måte som ifølgje Berge vart sterkt medverkande til brotet.

Når boka slik endar med ein artikkel om Madagaskar, kan det verke som om redaksjonen har villa seg vel langt vekk frå det vestlandske utgangspunktet. Men det er berre tilsynelatande. For det eine høyrer «misjonshovudstaden» Stavanger absolutt med til Vestlandet. Og for det andre har misjonsinteressa vore så sterk langs heile kyststripa at fleire generasjonar vestlendingar opplevde nærare tilknyting til Madagaskar enn til europeiske granneland. Som mykje anna har også det endra seg gjennom dei siste tiåra.

Redaktørane håper at boka vert til nytte og glede for mange. Vonlegvis vil fleire av artiklane vekke fagleg debatt og stimulere til vidare forsking på regionale aspekt ved religiøs endring. 



\title{
Religiøsitet og livssyn i Kyst-Norge på 1800-talet i eit komparativt nordisk og nordatlantisk perspektiv
}

\author{
Arnljot Løseth \\ Høgskulen i Volda
}

Samandrag: Artikkelen vil konsentrerer seg om dei religiøse vekkingane, fråhaldsrørsla og seksuell åtferd i Kyst-Norge på 1800-talet, og alt vil bli sett inn i eit komparativt nordisk og nordatlantisk perspektiv. Artikkelen vil også kome inn på kva slags eventuelle verknader puritanske rørsler og livsførsel kunne ha hatt å seie for den økonomiske utviklinga i kystsamfunna.

Nøkkelord: drukning, religiøsitet, alkohol, disiplin, seksualitet, borgarskap

\section{Religiøsiteten og drukningsdøden}

«Vi må ha ei sterk gudstru her ute ved havet, fordi vi har berre ein planke mellom oss og døden når vi ferdes der ute,» fortel Arnt Sæterbø (f. 1902) frå Averøy (Løseth, 1996, s. 57). Det har vore vanleg å hevde at frykta for drukningsdøden har gjort gudstrua ekstra sterk for folk som budde ved kysten og hadde fiske eller sjøfart som hovudyrke. Den danske historikaren Poul Holm finn derimot ikkje støtte for dette synet når det gjeld vekkingane i dei siste tiåra av 180o-talet. I Agder «kan der ikke konstateres noget klart skel mellem indland og kyst eller mellem bønder, søfolk og

Sitering av denne artikkelen: Løseth, A. (2020). Religiøsitet og livssyn i Kyst-Norge på 180o-talet i eit komparativt nordisk og nordatlantisk perspektiv. I B. Løvlie, P. Halse \& K. Hatlebrekke (Red.), Tru på Vestlandet. Tradisjonar i endring (Kap. 2, s. 17-39). Oslo: Cappelen Damm Akademisk. https://doi. org/10.23865/noasp.104.ch2

Lisens: CC BY-ND 4.o. 
fiskere». Og i Bohuslän og på Nord-Jylland slutta bønder seg tidlegere til vekkingsrørsler enn fiskarar og sjøfolk. Holm går altså imot det synet at fiskarane på grunn av yrket («en planke mellom dem og døden») automatisk er sterke i trua (Holm, 1991, s. 245-246, 258-259, 263-267).

Store delar av det protestantiske Europa og ikkje minst dei protestantiske delane av USA opplevde omfattande religiøse vekkingar frå slutten av 170o-talet og gjennom 180o-talet. Også mange stader i det katolske Europa var der tilsvarande rørsler, mellom anna i Frankrike. Der la mange observatørar merke til fiskarane sitt fromheitsliv, særleg frå 1830åra, då ein ny «evangelisme» - oppmuntra av den romersk-katolske kyrkja - voks fram i fiskerisamfunna. Også franske historikarar har meint at folk i kyststrøk var spesielt religiøse. Den franske historikaren Alain Cabantous meiner derimot at dette berre galdt enkelte kyststrøk, og då først frå 1830- og 1840-åra. Bakgrunnen var nettopp ei systematisk evangelisering i første halvparten av 1800-talet. Dette er ein interessant parallell til Norge. Først med haugianismen på byrjinga av 18oo-talet er det mogleg å peike ut enkelte strøk langs kysten som vart prega av ein puritansk og personleg kristendom (Johansen, 2017; Langhelle, 2002, s. 6; Nedkvitne, 1991, s. 66; Pavé, 2009, s. 219).

Sør-Vestlandet stod i ei særstilling når det galdt vekkingane i første halvdelen av 180o-talet, men der var ein del haugianaraktivitet og ei rekkje vekkingar også i mange andre bygder lenger nord på Vestlandet frå særleg 1820-åra og utover. Haugianarane fekk også oppslutning på Namdalskysten, men Hauge-vekkinga slo i liten grad rot i Nord-Norge. Der var kyststrøka og heile Finnmark nesten urørd, og den haugianske vekkinga slo sterkast rot i Bardu-dalen, som var kolonisert av folk frå Østerdalen og Gudbrandsdalen (Aadnanes, 1986, s. 32; Meistad, 1994, s. 312).

\section{Religiøsiteten og alkoholen}

Særleg i sør og i vest vart dei religiøse vekkingane kopla til «det 11'te bodet» (du skal ikkje nyte alkohol) (Øidne, 1975, s. 4-5; Løseth, 1996, s. 52ff.). Fyll var heilt vanleg i Norge tidleg på 1800-talet og har samanheng med at brennevinsbrenninga nesten vart heilt fri i 1816. I 1835 kan konsumet av brennevin per innbyggar ha lege på om lag 17,5 liter per år. I 
tillegg var ølkonsumet høgt. Brennevinsbrenninga var mest utbreidd på Austlandet, Trøndelag og Indre Sogn, og biskop Neumann skreiv dette om edruskapsforholda i sistnemnde distrikt i 1835: «Himlen se i Naade til Indre Sogn» (Hodne \& Grytten, 2000, s. 280-81; Johansen, 2019, s. 94).

Festlege samkomer i Rogaland var til dømes også prega av mykje drikk fram til 1830-åra. I 1826 skreiv biskop Munch at «unge Mennesker komme til kirken om Søndagen med Brændeviinsflasker i Lommen, hvoraf følger Svir og undertiden Slagsmaal». Slikt vart meir og meir uvanleg på kyrkjeplassen og i bryllaupa frå 1840-åra og utover. Grunnleggaren av norsk sosiologi, Eilert Sundt (1817-1875), samanfattar det slik for Ryfylke i 1859: «beruselse en skam, nydelse av br.vin og anden berusende drik ved bryllupper og begravelser kun undtagelsesvis.» Denne utviklinga i Nord-Rogaland kan, etter historikaren Svein Ivar Langhelle, krediterast haugianarane. Dei hadde ikkje vore ideologiske motstandarar av alkohol i sin tidlegaste fase, men dei vart det. Sjølv om dei vart mange, var dei overalt i mindretal i åra 1820-1850, men dei «oppnådde eit normativt hegemoni» i lokalsamfunna og påverka ein stor del av befolkninga (Langhelle, 2002, s. 7-15; Langhelle, 2006, s. 119; Sundt, 1859/1976, s. 129).

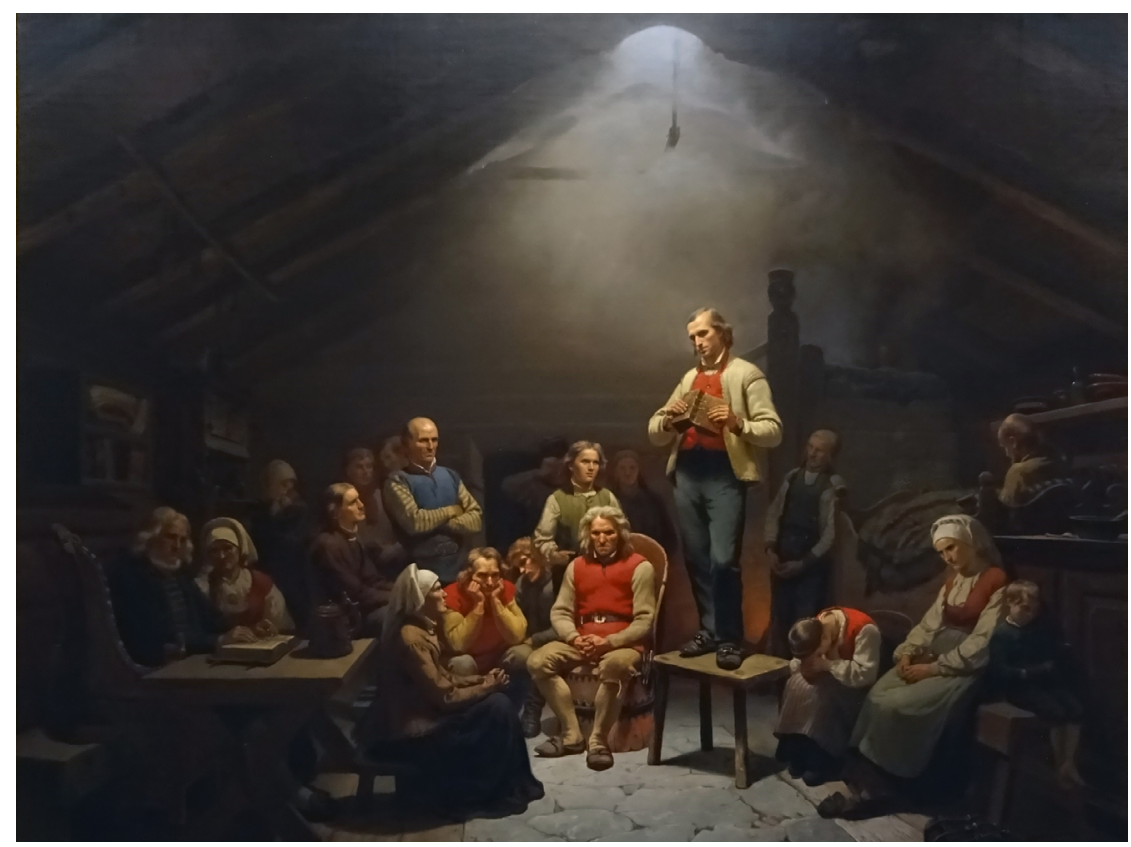

Haugianerne, 1848, Adolph Tiedemann. (Hentet fra: Wikimedia Commons.) 
Langhelle set denne åtferdsutviklinga i samband med det rike vårsildfisket frå 1808 til 1870. Der var kanskje ein samanheng mellom vekkingane og det at så mange møttest under sildefisket. Påverknad kunne då lettare gå frå person til person, og det i eit område der folk ikkje følte stor klassemessig avstand til kvarandre. Også historikaren Hans Try (19341990) har peika på det påfallande med kor nøye innsigsområdet for silda tidleg på 180o-talet fall saman med det tidlege misjonsforeiningsområdet (Langhelle, 2002, s. 15-18; Try, 1986, s. 29-33).

Rogaland var også eit område der folk gjennom eit par hundreår hadde hatt tett kontakt med dei kalvinistprega landa Nederland og Skottland. Eit «jordsmonn» som gjorde det lettare for haugianismen å få innpass, hadde kanskje gjennom lang tid blitt opparbeidt. Også dei områda i Hardanger og Sunnhordland som tidleg vart prega av haugianismen, hadde lenge vore sentrale i samhandelen med Skottland, og etter Langhelle tyder mykje på at ytre Sunnhordland likna på forholda i Rogaland. Men få område i Agder var prega av haugianske vekkingar før 1840-åra (Langhelle, 2002, s. 20-24). Agder hadde tidleg hatt tett kontakt med Nederland, likevel fekk vekkingane først omfang i åra frå rundt 1850. Det at haugianske vekkingar ikkje kom like tidleg som i Rogaland, svekker oppfatninga av at tidlegare kontakt med kalvinistprega land la til rette for religiøse vekkingar. Men Agder vart i alle fall, saman med Rogalandskysten, sjølve bibelbeltet i Norge etter 1850.

Eit lovforbod mot heimebrenning kom i 1848 i Norge. Det var med på å redusere alkoholbruken, men fråhaldsrørsla fekk oppslutning sørvest $\mathrm{i}$ landet ein god del år før dette. Eit restriktivt syn på alkoholbruk hadde røtene sine i Storbritannia. Eit par dusin av dei 5000 norske sjøfolka som hadde hamna i den engelske prisonen under Napoleonskrigane, tok med seg den alkoholfiendtlege kvekarlæra tilbake til Norge. Dei fleste var frå Stavanger, og dei fekk ei viss oppslutning der. Størst påverknad på det norske samfunnet fekk kvekarane nettopp når det galdt kampen mot alkoholbruken (Johnsen, 1993, s. 9off. og 110-111).

Haugianarar og brødrevenar i Stavanger starta opp med måtehaldsarbeid i 1830-åra. Det var først og fremst brennevinet dei ville til livs i første omgang, og like før midten av hundreåret hadde fråhaldsrørsla først og fremst oppslutning i kystområda mellom Kristiansand og Bergen. 
Kystområda nordover vart også etter kvart sterke område, og Eilert Sundt nemner frå Haram på Sunnmørskysten i 1856 at det hadde blitt mindre med drikking der i dei siste åra. I 1859 refererer han til ein brevskrivar frå Fosen i Trøndelag som trudde «at br.vins-ondet [der var] sin ende nær, [...] især på grund af den religiøse vækkelse, der i de sidste år har gjort så mærkelige fremskridt blant almuen» (Sundt, 1859/1971, s. 54; Sundt, 1859/1976, s. 157).

I Sundts studie Om Adrueligheds-Tilstanden i Norge (1859) går det klart fram at «drikkeondet» var avtakande over heile landet, og fråhaldsarbeidet spreidde seg frå sør mot nord i Kyst-Norge. Slik var det også med haugianismen (eller lågkyrkjelege rørsler). Då Ivar Aasen oppheldt seg i Skånevik i Sunnhordland i 1840-åra, la han merke til at der

gives et stort Antal af de saakaldte Læsere i denne Egn [...] Nyere gudelige Bøger og Tidsskrifter, især fra Stavanger, forefindes i flere Huse. Ogsaa i andre Dele af det huuslige og selskabelige Liv synes Folket her mest at danne sig efter sine sydlige Naboer; og man paastaar, at mange Sæder og Skikke ere i den senere Tid indkomne fra Stavanger Amt og udbrede sig bestandig mod Norden. (Christophersen, 1962, s. 182; Aasen, 1917, s. 58)

Også nordpå vart ein gripne av vekkingar, mellom anna vart væreigaren og handelsmannen Erasmus Zahl på Kjerringøy og nokre andre handelsmenn i Nordland det då det gjekk ei vekking over fylket i 1860-åra. Når det galdt fråhaldssaka, var Zahl i byrjinga ikkje for denne. Han meinte og det var ei ganske vanleg oppfatning - at brennevin var «et nødvendigt Styrkingsmiddel» under vinterfisket, men han gjekk over i historia som motstandar av alkohol. Tidleg i 188o-åra avvikla han brennevinssalet og vart sjølv totalist og gjekk med i fråhaldsrørsla. Ein kvinneleg slektning likte ikkje det:

Kjære Zahl hvad har jeg hørt! Du bleven Total Afholdsmand. ... Jeg tænker med 'Sorg og Bedrøvelse' paa Din deilige Vinbeholdning, paa Din extra gamle Rom, Genever, kort sagt hele Herligheden. Det er da vel ikke rimeligt, at $\mathrm{Du}$ ikke skal være tilladt at byde en gammel god Ven et Glas, som Marie fortalte Du havde skrevet. (Fulsås, 1988, s. 89-91; Fulsås, 1983, s. 184-188) 
Det er godt mogleg at impulsar sørfrå forholdsvis tidleg gjorde seg gjeldande også lenger nord i Nord-Norge, særleg gjennom fiskarar sørfrå. Eilert Sundt nemner frå Aust-Finnmark sist i 1850-åra «at det er nordfarere, som have bragt med sig den religiøse vækkelse, der har grebet folket på et enkelt sted her i prestegjeldet og fremkaldt en glædelig forandring: før drukkenskab, banden, uenighed o.s.v., nu velvære og hygge og godt exempel». Dette galdt berre ein avgrensa del av Aust-Finnmark. «Ædrueligheden» var dårleg i fylket på slutten av 1850-åra, og særleg blant samar og kvenar. Elles fann Sundt ut at den gjennomgåande var betre i kystbygdene både i sør og i nord enn i innlandsbygdene i Norge. I Telemark var det forskjell på ytre og indre bygdelag både blant allmugen og det øvre sosiale laget. Mykje tyder på at det var meir kontakt og kulturpåverknad frå land utanfrå i kystbygdene enn i innlandsbygdene, der det var mangel på kontakt med omverda (Christophersen,1962, s. 180; Sundt, 1859/1976, s. 194, 198-200; Schrumpf, 2019).

Det var frå om lag 1870 og utover at dei verkeleg store religiøse vekkingane skylde over Sør- og Vestlandet. Det var få område som ikkje var påverka, og i Agder var neppe ei einaste bygd eller ein by urørt. Det same galdt Møre og Romsdal frå sist i 1880-åra. Lekmannsrørsla fekk stor tyngd i kyststrøka også i Trøndelag, og Trøndelag var også ein landsdel der fråhaldsrørsla fekk særleg sterk fotfeste. Berre Agder, Rogaland og Møre og Romsdal hadde større oppslutning om fråhaldsrørsla i forhold til folketalet rundt hundreårsskiftet. Men det er også god grunn til å tru at polariseringa var ekstra stor i Trøndelag. Kløfta i folkelivet, eller ei skarp todeling, finn vi også i landsdelen - og også på Nordmøre - utover i neste hundreåret, men det religiøse innslaget var sterkare langs kysten enn i indre strøk (Aud Mikkelsen Tretvik i Tretvik, Sandvik, Kirkhusmo \& Stugu 2005, s. 209-210; Slettan, 1979, s. 64, 88).

\section{Kyst kontra fjord og fjell}

Lekmannsrørsla og fråhaldsrørsla - som etter kvart vart ei totalfråhaldsrørsle sør- og vestpå - fekk oppslutning i alle delar av landet, men fekk altså særleg gjennomslag i dei vestlege og sørlege kyststrøka, og foreiningane spegla den jamne befolkninga. Det dreier seg om ein kultur med 
røter tilbake til kvekarane og den haugianske rørsla. Sistnemnde fekk langt på veg hegemoni sør og vest i landet på slutten av 180o-talet (då helst med nemningar som bedehusfolket, misjonsfolket og dei lågkyrkjelege). Den frilyndte ungdomsrørsla gjorde seg rett nok også gjeldande og vart gjerne ståande som ein motpol til pietismen, men denne rørsla fekk breiast oppslutning i fjord- og fjellbygder og i dalstrøk på Austlandet. Den frilyndte ungdomsrørsla i til dømes Sogn og Fjordane fekk mykje seinare og i langt svakare grad fotfeste i kystbygdene enn i fjord- og innlandsbygdene. Lekmanns- og fråhaldsrørsla fekk derimot stor gjennomslagskraft ute ved kysten. Men der fanst nyansar. Då silda på nordafeltet skapte velstand for mange i 1850-åra, mottok Eilert Sundt dette hjartesukket frå ein skulelærar og heimelsmann frå Sunnfjord i 1858: «Så glad som jeg forhen var over mange forholde her, så sørgmodig blev jeg nu, da br.vinet i sådan fart som en syndflod flød ind i husene og skulle blive et dagligt traktement.»

Det vart altså eit grovskilje mellom kystens pietisme og Fjord- og Fjell-Norges meir «lyse» kristendom, og massevekkingane i 1870og 1880-åra markerte gjennombrotet for den lågkyrkjelege rørsla. På Sørog Vestlandet, der vekkingane sette djupare merke på samfunn og kultur enn elles i landet, var bygdene i det store og heile prega av egalitet eller relativ små sosiale forskjellar på folk. Derfor fengde dei også breitt. På grunn av små sosiale barrierar innanfor bygdesamfunnet vart det lettare å oppnå felles normer og verdiar (Seland \& Aagedal, 2008, s. 13, 32, 36-37, 128; Johansen, 1982, s. 73; Sundt, 1859/1976, s. 147-148). Men fronten var klar mot prest og embetsmenn. Sør- og vestpå var der eit sterkt krav om full godkjenning av lekmannsrørsla og dessutan kyrkjeleg demokrati gjennom ein skipnad av sokneråd som skulle samarbeide - og kontrollere - presten. («I kyrkja, med kyrkja, men aldri under kyrkja.») Som til dømes mange stader i Storbritannia var fronten mot det øvre sosiokulturelle sjiktet klart, men ikkje i den grad at ein forlét statskyrkje (som mange gjorde i England) (Døssland \& Løseth, 2006, s. 271; Perkin, 1969/76, s. 33-38).

Forfattaren Arne Garborg (1851-1924) - sjølv frå Jæren - harselerte grundig over pietismen og fråhaldssaka i skriftet Fra det mørke fastland då han var på gjennomreise i Stavanger rundt 1890: 
Jeg befandt mig i 1ste Klasses Venteværelse. Der hersker den allerhelligste Stavangerske Bedehusstilhed. Mine Skridt gjenlyder uhyggeligt i den høje, mørke, nymalede Sal. Den i mere verdsligsindede Byer sædvanlige Jernbanerestauration markeres her af en stor, dydig Vandkaraffel midt paa det ensomme, mørke Bord. Jeg syntes forresten, det var uforsigtigt af de stavangerske Totalister at anbringe Vand og Glas paa dette Sted; er det ikke ligefrem en Opfordring til de Reisende om at medhave lidt Kognak til «grov Kjæft» - paa sin Lommelærke?

Maaske for at sikre sig mod den slags Argelist er der ved Siden af Vandflasken nedlagt en stor, velindbunden - Bibel. (Garborg, 1893, s. 8, 20)

\section{Skandinaviske kontrastar}

Sett bort frå Island - der motstanden mot unionen med Danmark tok mest kraft - fekk alle dei nordiske landa ei brei oppslutning om religiøse lekmannsrørsler ut på 18oo-talet. «Bibelbeltet» på Sør- og Vestlandet har parallellen sin i Sverige. Der utmerka dei vestlege områda seg tidlegast og sterkast. I Danmark var Jylland lite berørt tidleg på 180o-talet, men vart ein sterk bastion for indremisjonen dei siste åra på 18oo-talet. Synet på alkohol vart meir restriktivt, og open drukkenskap blant fiskarane vart etter kvart oppfatta som nedverdigande. Tidlegare tiders alkoholkultur vart avløyst av ein meir nøktern kultur (Holm, 1991, s. 233, 272).

Det var religiøst samkvem mellom regionar i Norden som gjekk på tvers av statsgrensene, men i løpet av 1800-talet var tendensen at nasjonal integrasjon i stadig sterkare grad la føringar på religiøsiteten i dei ulike landa. Det utvikla seg altså særnasjonale trekk i folkeleg religiøs kultur i Norden, og dette var i særleg grad medverkande til å skilje kystane i dei tre landa frå kvarandre. Ingen fiskar eller sjømann ville kjenne seg heilt igjen i fromheitslivet på nabokysten: «Alle de små nationale forskelligheder, som vækkelserne havde skabt, blev bemærket og forstørret til mistro og måske endog fjendebilleder» i SkagerrakKattegat-området, hevdar Poul Holm. I Sverige la ein meir vekt på at ein oppnådde frelse gjennom ei inderleg tru («trusrettferd» og også underordning kyrkje og prest), og i Norge la ein, i tradisjonen etter Hauge, stor vekt på at frelsa skulle bli synleg i gode gjerningar («gjerningsrettferd»). Dansk lekmannskristendom likna meir den norske, først og fremst gjennom 
misjonsiver og praktisering av kristentrua, men la meir vekt på «trusrettferd» (Seland, 2004, s. 164; Holm, 1991, s. 232, 238, 243-247, 264, 272-273).

Lekmannsrørsla i Norge vart prega av ei songglad kristentru, og det stod i noko kontrast til Bohuslän, der bonde- og fiskarmiljøet vart prega av meir alvor. Bohuslenfiskarane hadde frå siste halvparten av 180o-talet drive linefiske i Nordsjøen, og ein del av dei henta ektemake frå kystane i nabolanda. Etter hundreårsskiftet henta til dømes bohuslenske fiskarar hustruer frå Ålesund og Egersund. Desse hadde ofte ikkje så lett for å bli godtatt i den puritanske kulturen som prega Bohuslän. I desse miljøa var det lett å bli stempla, viss ein som dei fleste norske kvinnene tok med seg ei songglad kristentru: «All falsk lära kommer från Norge.» Svaret frå dei norske kvinnene vart å bygge opp eit kontaktnett mellom seg, og å bevare kontakta med slekta i Norge. Men skilnaden var likevel neppe så stor. Kulturar tenderar alltid mot å overdrive seg sjølv for å tydeleggjere og stadfeste eigen identitet i forhold til andre (Gustavsson, 1986; Klepp, 1992, s. 10).

\section{Det vestvendte Norge}

Mens dei svenske og danske vekkingane ut på 180o-talet spreidde seg frå innlandet og ut mot kysten, var det - med unntak - omvendt i Sør-Norge. Her gjekk dei mest frå kysten og innover landet. Og Kyst-Norge (særleg i sørvest) var altså utsett for tidlege vekkingar, tidlegare enn i Sverige og Danmark, og ein grunn var skipsfarten. Norge var meir vestvendt enn dei to andre skandinaviske landa. Påverknaden kom særleg frå angloamerikansk kultur, mellom anna også tankar om frie trussamfunn og skilje mellom kyrkje og stat. I Arendal vart den lutherske frikyrkja danna i 1877, men berre med 111 medlemmar. Mange hadde venta ein straum av innmeldingar, ikkje minst fordi det like før hadde blitt invitert til «et større Møde til Diskussion af frikirkelige Spørgsmaal». Møtet samla minst 6000 deltakarar (Holm, 1991, s. 247; Løvlie, 2002, s. 139-143). Svaret på kvifor frikyrkja ikkje fanga opp fleire av desse, må ligge i at mange gjekk inn i andre dissentarsamfunn (utmelde av statskyrkja). Arendalsområdet var gjennom skipsfarten ein av Norges mest internasjonalt orienterte regionar på den tida med forskjellige impulsar frå utlandet (og ikkje minst religiøse). 
Av fylka i Norge hadde Aust-Agder relativt flest dissentarar etter folketeljinga i 1891 (4,2 \%). Høgt låg også kyststrøka austover til Østfold og nokre av byane vest og nordvest for Arendal (Kristiansand, Stavanger, Bergen og Kristiansund). Vesterålen (Andøya og Hadsel) og Troms peiker seg ut nordpå, og Troms kjem opp mot om lag det same nivået som kystfylka frå Aust-Agder og austover. Troms $\emptyset$ hadde 6,4 prosent dissentarar i 1891 (om lag det same som Arendal) (Folketeljinga, 1891. NOS. Tredie Række No. 278. Kristiania, 1897, s. 74-8).

\section{Læstadianismen}

Det er to viktige trekk ved det nordnorske religiøse oppbrotet på 18oo-talet: dei relativt mange dissentarane og den læstadianske rørsla. Av dissentarane var det folk frå det breie lag, og kanskje helst frå den betrestilte delen, som tok skrittet ut av kyrkja. Tilhengarane av Lars Levi Læstadius (180o-1861) kom helst frå fattigare kår og profilerte seg i pietistisk opposisjon, men - til liks med den lågkyrkjelege rørsla sørpå - braut ikkje rørsla med kyrkja.

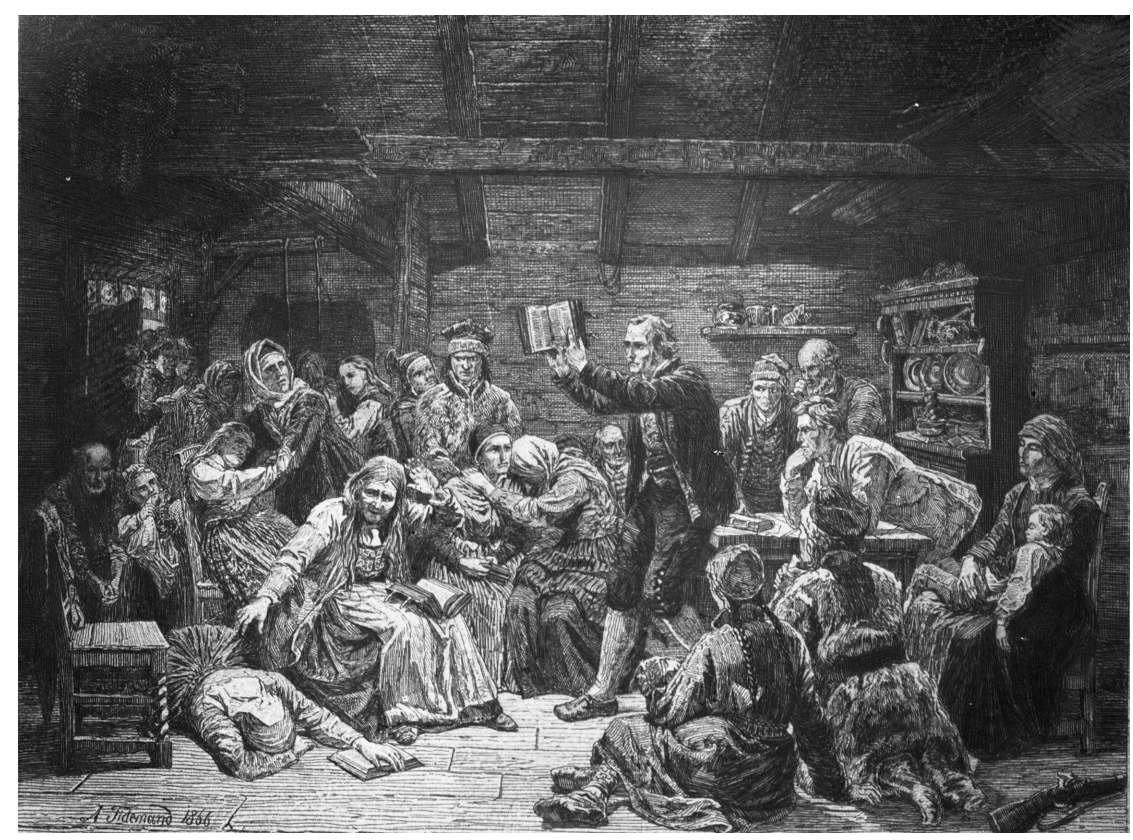

Fanatikerne, 1865, Adolph Tiedemann. (Foto: Severin Worm-Pettersen. Hentet fra digitaltmuseum.no. Lisens: CC BY 4.0.) 
Læstadius stod på 1840-talet i spissen for ei vekkingsrørsle som kom til å breie seg over heile Nordkalotten. Ho stod ikkje i samband med vekkingslivet i Sør-Norge, og rørsla oppstod i eit stort sett samisk miljø i Nord-Sverige. Samar og kvenar i Norge slutta seg tidleg til den norske greina av den læstadianske rørsla, og etter kvart kom også nordmenn med. Vadsø og landskapet rundt Varangerfjorden kom til å peike seg ut som eit område med mange læstadianarar frå 1860-åra og utover i samband med den aukande finske innvandringa der. Kvenar stod også sentralt i ei vekking i Hammerfest i 1860-åra. Lenger vest vart Alta ei høgborg, og læstadianske kjerneområde lenger sør vart Lyngen, Ibestad og Ofoten. Sist i 1870-åra spreidde rørsla seg også til Lofoten.

I motsetning til i Sør-Norge var det ei rørsle som i utgangspunktet spreidde seg frå innlandet og ut mot kysten. Læstadianismen står likevel i forlenginga av, og er eit bidrag til, den breiare pietistiske vekkings- og lekmannskristendommen som kom til å spele ei stor rolle i det protestantiske Nord-Europa, og den kom altså til Nord-Norge med flyttsamar og finske innvandrarar. Særleg var 1870- og 1880-åra ein sterk vekstperiode for vekkinga på heile Nordkalotten (Drivenes \& Jernsletten, 1994, s. 217; Seland \& Aagedal, 2008, s. 24-25; Aadnanes, 1986, s. 11, 49, 67-69, 74).

Ibestad prestegjeld hadde til dømes nokre få aktive vakte i åra rundt 1850, og i løpet av dei neste tiåra spreidde rørsla seg til alle fjordane i prestegjeldet, og rørsla fekk også stor oppslutning blant etniske nordmenn. Den læstadianske vekkinga var også bakgrunn for at det vart slutt med brennevinshandelen på handelsstaden Hamnvik. Med læstadianismen si strenge fråhaldsforkynning, der brennevinet vart kalla slikt som «flytande djevleskit» og «djevelens piss», kunne brennevinshandelen gå kraftig ned enkelte stader der vekkinga slo rot. Prestar som kunne vere kritiske til Læstadius, måtte medgi at der læstadianske vekkingar fekk feste og makt, forsvann fylleriet: «Mot det raa, ryggesløse liv har læstadianismen vært som en fortærende ild.» For læstadianarane vart alkoholspørsmålet også ein sosial protest mot nordnorske handelsmenn (Bakkemo, 1998, s. 117; Drivenes \& Jernsletten, 1994, s. 220; Johansen, 2019, s. 99; Aadnanes, 1986, s. 27, 41, 87). 


\section{Religiøsiteten og disiplinen}

Med læstadianismen fekk fattigslege levekår ei religiøs grunngiving. Rikdom og velstand vart fordømd og forakta av Læstadius, og denne haldninga kom store delar av denne vekkinga i Norge også til å overta. I staden for å kjenne seg underlegne overfor nordmenn og norsk overklasse fekk fattigfolk gjennom læstadianismen ei ny sjølvkjensle. Fattigdom vart gjort til eit ideal, til ein dyd, og klassemotsetnaden fekk dermed ei religiøs tolking. «Økonomisk framgang [...] var ifølgje læstadianerne lite verd under evighetens synsvinkel. Det var fattigfolket som var Guds utvalgte,» heiter det i Nordnorsk kulturhistorie (Aadnanes, 1986, s. 27, 34, 96; Drivenes \& Jernsletten, 1994, s. 220. Sjå også Bjørklund, 1985, s. 312-322).

Mens haugianismen hylla den vellykka entreprenøren, såg læstadianismen «ingen verdi i økonomisk framgang». Den fungerte som ei bremse på modernisering og framsteg, mens haugianismen var ein pådrivar for det same på Vestlandet, hevdar historikaren Jan Vea. Samanhengane her er omstridde (Vea, 2009, s. 102, 103, 110-111, 169, 454), ${ }^{1}$ men den britiske maritime historikaren Paul Thompson peiker på noko av det same når det gjeld Skottland. I fiskarbyen Buckie fekk - som elles langs kysten av Skottland - religionen og fråhaldsrørsla mykje å seie frå siste halvparten av 180o-talet. Det som gjennomsyra Buckie, var nøysemd og det å vere driftig i arbeidet. Paul Thompson legg vekt på desse faktorane når han forklarer den økonomiske framgangen blant fiskarane. Men puritansk religion kunne også verke motsett. På Lewis på Hebridane fremma kalvinismen konformitet slik at det gjekk utover individualitet. I motsetning til på Buckie var religiøsiteten ei hindring for individuelt initiativ (Thompson, 1983, s. 256-259, 266, 293-296). Men Thompson viser også at «the lairds» hadde mykje meir å seie over folk på Lewis («quasi-feudal in character») enn i Buckie, og derfor også i større grad virka hemmande på folks initiativ der. Eit anna sentralt spørsmål er om ikkje nettopp sosiale strukturar generelt har

1 Læstadianismen har også blitt brukt for å forklare økonomisk framgang, sjå t.d. Bakkemo, 1998, s. $111 \mathrm{ff}$. 
størst forklaringskraft når vi skal forklare økonomisk framgang eller stillstand.

I sine barndomsminne spekulerer forfattaren Johan Bojer på samanhengen mellom sterk religiøsitet, økonomi og fatalisme blant husmannsfiskarane i Rissa ved Trondheimsfjorden, der han hadde sine barneår som fosterbarn:

Om de noen gang drømte om å arbeide seg opp i rang med kameratene, aner jeg ikke. De mente vel det var Vårherres vilje at det var som det var, husene falt sammen, og de så på det, og de tenkte vel at om fisket engang slår til - men ellers trøstet de seg med salmesangen og Guds ord. (Bojer, 1942/1972, s. 8-9)

Frå Haugesund - ein del år før den vart by - heiter det at fiskarane sat på kroa til Ditlef Møller og drakk, røykte og prata. Morgonen etter stod det dårleg til med både hovud og pengepung, men etter kvart såg fiskarane «paa bønefolki. Dei samlast kvar kveld til bøn og song paa eit sjøhusloft. Altid vakna dei paa tidi um morgonen, aldri var dei laake etter rangel, makalause folk var dei.» (Sitert frå Langhelle, 2006, s. 128). Noko tilsvarande skjedde altså i mange lokalsamfunn på nord- og austkysten av Skottland frå 1870-åra og utover. Skipperane på fiskefartøya var ofte fråhaldsfolk, og då var mannskapet det gjerne også. Kva godt gjorde fråhaldsrørsla? spør den skotske historikaren T. C. Smout. Han gir sjølv svaret: «The achievements of self-control can never be measured and should not be belittled.» (Smout, 1997, s. 143, 199; Thompson, 1983, s. $256-259$ ).

\section{«Den industriøse revolusjonen»}

Nemninga «den industriøse revolusjon» har blitt brukt for å karakterisere trekk ved den økonomiske utviklinga i Vest-Europa frå midten av 1600-talet og inn på 180o-talet. Historikaren Sølvi Sogner meiner at nemninga også kan passe på Norge i dette tidsrommet. Industriøs betyr flittig, verksam, og fliden resulterte i materiell framgang for mange. «Sjølv-eksploatering» og frivillig avkall på fritid blir trekt fram i denne samanhengen. Arbeid var menneska sitt lodd, det lærte ikkje 
minst dei religiøse vekkingsrørslene. I denne samanhengen må vi trekkje inn Max Weber (1864-1920), som la fram teorien om at puritanske protestantiske rørsler, og særleg den kalvinistiske, var ein hovudfaktor bak framveksten av ein moderne kapitalistisk økonomi i Vest-Europa frå 1500-talet og framover. Desse rørslene framheva det å leve dydig og nøkternt og det å være flittig i arbeidet som noko positivt. Der dei fekk innpass, vart klosteraskesen i varierande grad innført i dagleglivet, og streng arbeidsetikk var ein av faktorane som førte til økonomisk vekst (Sogner, 1996, s. 232-234; Vries, 1994; Weber, [1904-1905] 1971).

Hans Nielsen Hauge kravde at ei sunn tru måtte vise seg og bere frukt i ein streng, forsakande og arbeidssam livsførsel, og dei fleste i rørsla la vekt på dette. Sjølv om nokre sokk ned i tungsinn og passivitet, var det motsette vanleg, skriv historikaren Ståle Dyrvik. Og historikaren Francis Sejersted (1936-2015) meinte at den haugianske vekkingsrørsla har hatt mykje å seie for den kapitalistiske utviklinga i Norge. Ho fremma det å vere driftig og sørgde for at det vart ein vellykka symbiose mellom Gud og Mammon. Det vart moralsk legitimt og sosialt akseptert å søkje profitt i marknaden. Haugianismen godkjente moralsk og religiøst det som før var moralsk tvilsamt (Mammon). Dei kristne skulle bruke verda, og ved sida av å vere strenge kristne med fast etisk forankring skulle dei vere nøkterne i livsførsla si og ha ei avvisande haldning overfor verdslege gleder. Arbeidet fekk ein religiøs dimensjon. Som Sejersted har statsvitaren Christer Tonnes Jonassen peikt på at haugianismen, slik som kalvinismen, «befridde de troende fra den belastningen som tidligere hadde vært forbundet med det å skaffe seg jordisk gods og fortjeneste» (Dyrvik, 1999, s. 186-187; Jonassen, 1963, s. 64; Sejersted, 1993, s. 72-74; Tveite, 1983, s. 51).

For dei fleste betydde nok dette eit kvardagsstrev utan nødvendigvis sosialt avansement, men historikaren Stein Tveite ser til dømes på den jærske pietismen som ein viktig føresetnad for den økonomiske framgangen der: «Ei sterk understreking av arbeidet som plikt, lediggang og forbruk som synd.» Arne Garborg formulerte det lakonisk slik: «Jærbuen er i regelen 'moderat', og det med Fanatisme.»(Garborg, 1893, s. 35). 


\section{Fødslar utanfor ekteskap}

Moderate var - i motsetning til aust og vest i landet - også jærbuen og andre sør- og vestlendingar på det seksuelle området, der også sjølvkontroll og nøktern livsførsel kan vise seg. Eilert Sundt var den første som påviste klare regionale kontrastar i sedelegheita i Norge, og han målte den i talet på barn fødde utanfor ekteskap. Det var vanleg å få barn utanfor ekteskap nokre stader, nokre stader ikkje, og kart 1 viser klare regionale kontrastar for åra 1846-1855: Talet på «uekte» barn var moderat i dei søraustnorske kystprostia, lågt i kystprostia i sørvest og vest nord til og med Sunnmøre, og høgt i sentrum av landet og nordover. Figuren viser også at ratane var vesentleg lågare i 1762-1771 enn i 1846-1855 (Drake, 1981; Løseth, 2012, s. 376-379; Sundt, 1857/1968). Indikerer dette ein kontrast i mentalitet og kultur mellom sør- og vest i landet samanlikna med område lenger aust og nord?

Restriktive puritanske normer vart kanskje skapt på 1600- og 1700talet på grunn av vanskelige tider for tømmereksporten i sør og sørvest, knappheit på dyrkbar jord og store fluktuasjonar i fiskeria i vest. Restriktive etablerte normer kan ha lagt noko av grunnlaget for seinare religiøse og puritanske rørsler på 180o-talet.

Der var også regionale forskjellar i Skottland. Illegitime fødslar var få på det skotske høglandet og på Orknøyane, Shetland og Ytre Hebridane samanlikna med resten av Skottland på 180o-talet. Smout brukar $ø$ konomiske forklaringsmodellar. Der dei illegitime fødslane var høge, der var det lett for jentene å finne seg arbeid. Sør-Skottland - eller det skotske låglandet - gjekk gjennom ei rivande økonomisk utvikling (den industrielle revolusjonen). Slik var det ikkje på dei skotske øyane og på det skotske høglandet. Eit uønskt barn var til større byrde der (Abrams, 2005, s. 154; Smout, 1997, s. 168-71).

Kartet viser at det var store variasjonar i talet på fødslar utanfor ekteskap frå den eine delen av landet til den andre. Mønsteret for åra 1846-1855 er tydeleg: eit moderat nivå i søraust, lågt i vest og sørvest og høgt i sentrum av landet og nordover. (Frå Drake, 1981, s. 19) 
Fødsler u tenfor ekteskap pr. 100 giftermål.
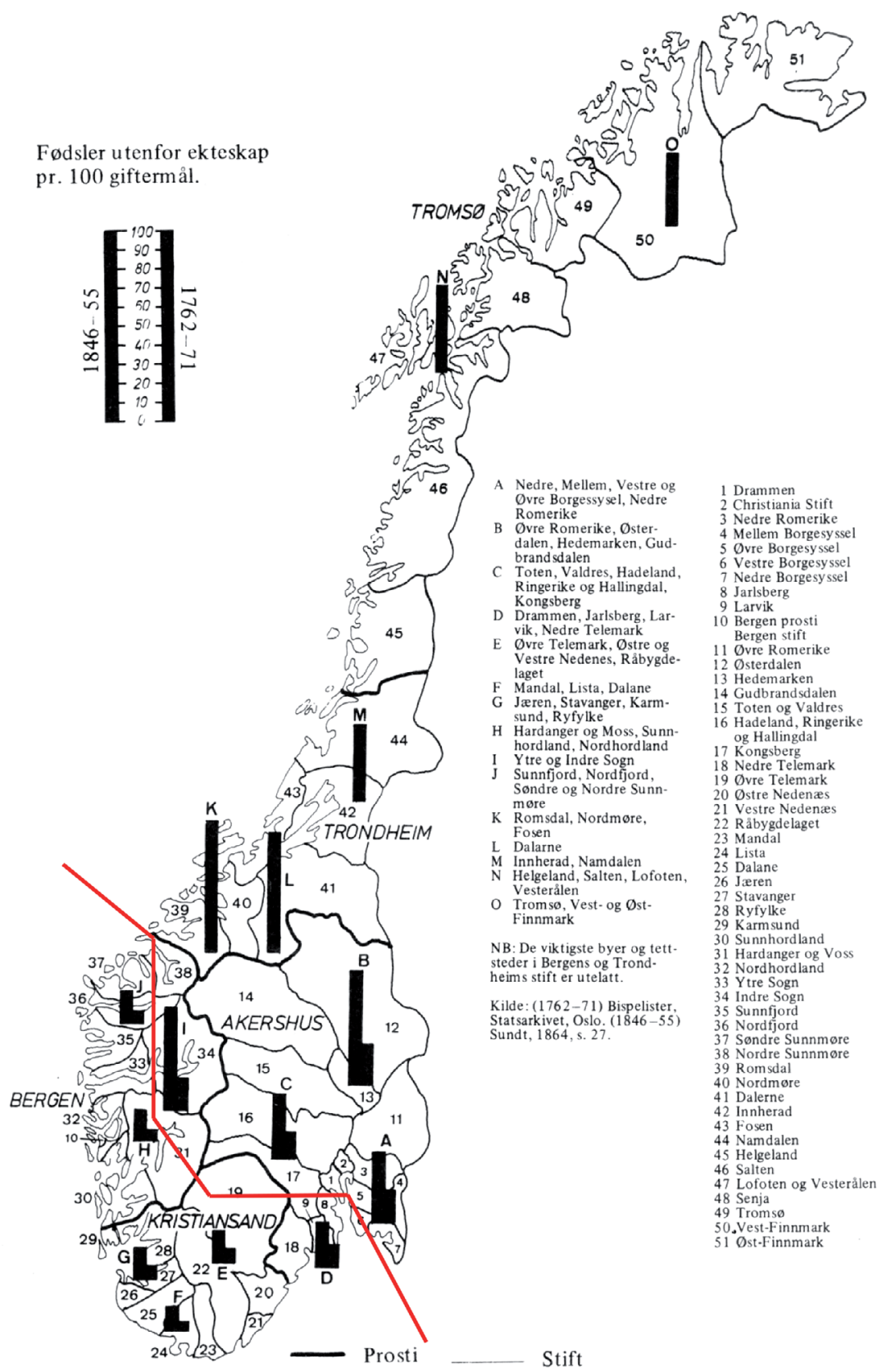

1 Drammen

2 Christiania Stift

3 Nedre Romerike

4 Mellem Borgesysse

5 Øvre Borgesyssel

6 Vestre Borgesyssel

7 Nedre Borgesyssel

8 Jarlsberg

9 Larvik

Bergen prost

Bergen stift

1 Øvre Romerike

3 Hedemarken

4 Gudbrandsdalen

5 Gudbrandsdalen

6 Hadeland, Ringerike

og Hallingdal

Nedre Telemark

9 Øvre Telemark

0 Østre Nedenæs

1 Vestre Nedenæs

2 Råbygde laget

23 Mandal

24 Lista

5 Dalan

6 Jæren

27 Stavange

8 Ryfylke

$9 \mathrm{Karmsund}$

Sunnhordland

Hardanger og

2 Nordhordland

(3) Ytre Sogn

5 Sunnfiord

(

7 Sondre Sunnmore

8 Nordre Sunnmore

39 Romsdal

1 Dalerne

42 Innherad

43 Fosen

44 Namdalen

45 Helgeland

46 Salten

Lofoten og Vesterålen

48 Senja

Tromso

0.Vest-Finnmark

1 Øst-Finnmark

Kart 1. Fødslar utanfor ekteskap per 100 giftarmål i forskjellige norske prosti 1846-1855. (Kartet er tilrettelagt av Sigurd Kristiansen og tidligere publisert i Døssdal (red.). 2014: Norges fiskeri- og kysthistorie bind 2. Bergen: Fagbokforlaget. Kartet er gjengitt med tillatelse. Kartet er basert på en original fra Michael Drakes artikkel i Eliassen, Jørgen og Sølvi Sogner (red.). 1981. Bot eller bryllup. Ugifte mødre og gravide bruder i det gamle samfunnet. Oslo: Universitetsforlaget.) 


\section{Nytt borgarskap}

Sild og fisk var grunnlaget for byvekst og for nye byar og tettstader utover 180o-talet langs kysten i Norge. På Vestlandet oppstod eit «nytt» borgarskap med utspring frå bygdene omkring. I Haugesund var det

gudfryktige våghalser som slo seg opp fra ingenting og tjente seg rike på sild. [...] Praktisk talt alle var av bondeætt, de hadde sikkert alle fătt den same grundige oppdragelse i nøysomhet og gudsfrykt, [og] [d]e skilte seg ut fra de fremmede sildesalterne, særlig handelspatrisierne fra Bergen og Stavanger med deres polerte bakgrunn i gammel, forfinet bykultur,

heiter det i Haugesund si byhistorie av Reidar Østensjø (1950, s. 33, 38).

Historikaren Kåre Olsen stadfester dette i ein studie av det framveksande borgarskapet i byen. Vel 60 nye handelsborgarar vart registrerte i Haugesund i 1840- og 1850-åra, og dei fleste av desse kom frå gardbrukarmiljø frå dei næraste bygdene. Dei kom helst frå større gardsbruk, men vi har også døme på at ein del kom frå lågare sjikt i bondesamfunnet. Dei fleste dreiv med sildetilverking, ei næring som kravde lite startkapital, og som folk hadde god kjennskap til då dei gjerne hadde erfaring frå fiske eller jaktefart. Haugesund var lenge eit «ope» klassesamfunn, men i dei par-tre siste tiåra av hundreåret auka sjølvrekrutteringa til borgarskapet, den sosiale strukturen «stivna» til.

I byens første tid - frå 1830-åra til 1850-åra - sette haugianarane preget på det «nye» borgarskapet. Byen vart langt på veg grunnlagt av sild og haugianarar, men etter 1870 høyrer ein sjeldan at folk vart omtala som haugianarar, dei blir då helst omtala som «bedehusfolket» og liknande (Olsen, 1980, s. 13, 22, 62, 82, 101-104, 213-221, 228, 259-261).

I romanen Skipper Worse (1882) av Alexander Kielland, med handling frå 1840-åra i Stavanger, var konsul Garman - ein kjøpmann frå det «gamle» storborgarskapet - uroleg over den nye tid og dei nye menn:

Ganske nye folk dukket op med lommen full av penger, kjøpte sild og saltet for egen regning og udskibet $\mathrm{i}$ tusenvis av tønner om våren. Hele formuer tjentes av 
haugianere og hengehoder, som blandet bibelsprog i sine handelsbrev og ikke hadde idé om et ordentlig bokholderi.

Seinare i romanen:

År efter år gikk det dem godt; deres kapital øket; men de satte den straks i forretningen. Den som et år hadde saltet 1000 tønner, vilde til næste år ta 3000; de var ute om sig på alle kanter, satte alle seil til, og mens de gikk så stille med sine salmer og saktmodig tale, var de i virkeligheten dristige - ja forvovne spekulanter. (Kielland, [1882] 1968, s. 14, 73)

«Nye» menn kom til å prege borgarskapet i Stavanger utetter 180o-talet. Ved eksporten av sild i Stavanger i 1840 stod heile 77 ulike namn bak dei 126 utskipingane frå byen. Kvar eksportør stod i gjennomsnitt for berre ein til to sendingar. Det kravde forholdsvis lite kapital for å bli eksportør, og her var det mogleg for «oppkomlingar» å etablere seg. I Stavanger gjorde mange det, og dei sprengde hegemoniet til dei etablerte handelshusa i byen.

Det var ein eksplosiv vekst i talet på handelsmenn og eksportørar i åra frå slutten av 1830-åra og byrjinga av 1840-åra, og felles for dei nye var - som for Haugesund - at dei var tilflyttarar frå distrikta rundt byen. Økonomihistorikaren Helge W. Nordvik (1943-1998) gav eit døme på ein slik innflyttar: Erik Berentsen var fødd på garden Høiland i Time på Jæren i 1805. Etter å ha arbeidd som tenestegut i heimbygda fekk han plass som butikksvein i eit handelshus i Stavanger i byrjinga av 1830-åra. Han begynte som sildeeksportør på slutten av tiåret og ekspanderte raskt, og sildeeksporten la grunnlaget for engasjement i skipsfart, som etter kvart vart viktigast i Berentsen si næringsverksemd. Nordvik ser på Berentsen som «en typisk representant for den nye entreprenørgruppen som i 1860og 70-årene kom til å danne ryggraden i Stavangers næringsliv» (Kallelid, 2012, s. 37; Nordvik, 1982, s. 12, 20-21, 29-35).

Distansen mellom den gamle storborgar og det nye borgarskapet med sitt bibelspråk karakteriserte store delar av landet gjennom 180o-talet, hevdar Francis Sejersted: Puritansk religiøsitet vaks fram i byane «ikke ved at byborgerne ble vakte, men ved at de vakte ble byborgere og handelsmenn» (Sejersted, 1993, s. 33). 


\section{Omdiskutert}

Den franske globalhistorikaren Fernand Braudel (1902-1985) la ikkje vekt på trusinnhald og «ideologi» i religionen når han skulle forklare kvifor folk i til dømes religiøs diaspora ofte var leiande i forretningslivet i sine nye heimland. Dei heldt seg - gjennom religionen - saman for gjensidig hjelp og i sjølvforsvar mot dei nye omgivnadane. Religionen var ein markør for gruppedanning. I Londons forretningsliv danna dei franske hugenottane nettverk, og dei utgjorde ei kompakt gruppe som heldt på sin eigen identitet. Det var også desse som kom til å dominere i framstillinga av silkeklede i London og andre stader i England (Braudel, 1982, s. 165; Burke, 2009, s. 74, 103).

Sosiokulturelle gruppedanningar har vore - og er - i visse fasar vanlege overalt i verda, og viste seg ikkje minst ved til dømes det transatlantiske kvekarsamfunnet. I Storbritannia vart dei lenge nekta tilgang til dei frie yrka og parlamentet, og særleg på 170o-talet var dei sterkt knytte saman ved slektskap, handelsinteresser og felles teologisk forståing. På 17oo-talet stod mange kvekarar frå den midtre og vestlege delen av England bak mange av oppfinningane i jern- og metallsmelting, og innanfor mange kvekarsamfunn vart det utvikla teknikkar for å smelte messing og framstille sink og frå slutten av 160o-talet teknikkar for å smelte kopar, tinn og bly (Allen, 2009, s. 250-51; Dandelion, 2008, s. 24).

Religionens rolle har vore meir viktig som eit organisasjonsprinsipp for religiøse sekter enn som ein særskilt teologi. Jødiske samfunn med sine økonomiske funksjonar har vore viktige overalt i Vest-Europa, arabiske minoritetar har vore viktige i handel i Vest-Afrika og delar av AustAfrika, indarar i Sør Afrika, kinesarar i Sør-aust Asia og armenarar i det austlege Middelhavet. Dette stiller spørsmål ved kor viktig éin (einaste) teologi er som hovudfaktor bak økonomisk framgang (Mathias, 2001, s. $140-47)$.

Teorien til Weber er ein av dei mest omdiskuterte blant historikarar og samfunnsvitarar, og den langvarige debatten vart i magasinet New Yorker i 2004 kalla «the academic Hundred Years' War». Det har sjølvsagt også vore vanleg å bruke teorien for å forklare økonomisk oppsving til dømes i det kalvinistprega Nederland i tidleg nytid. Dei nederlandske historikarane Jan de Vries og Ad van der Woude meiner at det kan vere 
plausible teoretiske argument for at kalvinismen har fremma ein meir rasjonell måte å vere på, men likevel er bevismaterialet lite og også motsetningsfullt, «and will probably always remain so», hevdar dei (Brown, 2007, s. 228; van der Woude \& de Vries, 1997, s. 169).

Det viktige i det å vere nøysam og flittig kan vanskeleg bli redusert som T. C. Smout framhevar - og utan å ønske at vi burde bli «kvitt» Max Webers «subtile tese [...] en gang for alle» - som Fernand Braudel ønska seg (1985/86, s. 57) - er spørsmålet om ikkje sosioøkonomiske strukturar og danninga av personlege nettverk spelte ei større rolle for økonomisk framgang enn religion og fråhald i dei nordatlantiske kystsamfunna. Puritanske livshaldningar sette rett nok preget sitt og verka normdannande på mangt eit samfunn i Nord-Atlanteren, også langt inn i det neste hundreåret. Men ein må likevel vere forsiktig med einsidig å slutte frå pietistiske dydar til økonomisk framgang - sjølv om det kan vere noko plausibelt i det.

\section{Litteraturliste}

Abrams, L. (2005). Myth and materiality in a woman's world. Shetland 1800-2000.

Manchester: Manchester University Press.

Allen, R. C. (2009). The British industrial revolution in global perspective. Cambridge: Cambridge University Press.

Bakkemo, D. A. S. (1998). Ibestad - foregangskommune i fiskeriene ca. 189o-1920. Upublisert hovudfagsoppgåve i historie. Universitetet i Bergen.

Bjørklund, I. (1985). Fjordfolket $i$ Kvenangen: Frå samisk samfunn til norsk utkant 1550-1980. Tromsø: Universitetsforlaget.

Bojer, J. ([1942]1972). Loregutt. Oslo: Gyldendal.

Brown, C. S. (2007). Big history. From the big bang to the present. New York: New Press. Braudel, F. (1982). Civilization \& capitalism 15th-18th century. Volume II. The wheels of commerce. London: Fontana Press.

Braudel, F. ([1985]1986). Kapitalismens dynamikk. Oslo: Forlaget ARS.

Burke, P. (2009). Cultural hybridity. Cambridge: Polity Press.

Christophersen, H. O. (1962). Eilert Sundt. En dikter i kjennsgjerninger. Oslo: Gyldendal.

Dandelion, P. (2008). The Quakers: A very short introduction. Oxford: Oxford University Press.

Drake, M. (1981). Utenomekteskapelig fruktbarhet i Norge 1760-1960. En oversikt. I Eliassen \& Sogner (Red.) (s. 15-21). 
Drivenes, E.-A. \& Jernsletten, R. (1994). Det gjenstridige Nord-Norge. Religiøs, politisk og etnisk mobilisering 1850-199o. I Drivenes, Hauan \& Wold (Red.), bind 2 (s. 210-281).

Drivenes, E. A., Hauan, M. A. \& Wold, H. A. (Red.) (1994). Nordnorsk kulturhistorie. Oslo: Gyldendal.

Dyrvik, S. (2011). Norsk historie 1536-1814. Oslo. Det Norske Samlaget.

Døssland, A. \& Løseth, A. (2006). Lokalmakt og sentralmakt, periferi og sentrum. I Helle, Grepstad, Lillehammer \& Tryti (Red.), bind 2 (s. 248-295).

Døssland, A. \& Løseth, A. (2006). Mot fjernare farvatn. 1860-1960. Havfiskeflåten $i$ Møre og Romsdal og Trøndelag. Bind 1. Trondheim: Tapir Akademisk Forlag.

Døssland, A., Løseth, A. \& Elstad, Å. (2014). Ekspansjon i eksportfiskeria 1720-1880. Norges fiskeri- og kysthistorie. Bind II. Bergen: Fagbokforlaget.

Eliasen, J. \& Sogner, S. (Red.) (1981). Bot eller bryllup. Ugifte mødre og gravide bruder $i$ det gamle samfunnet. Oslo: Universitetsforlaget.

Fulsås, N. (1983). Voksteren og fallet til ein nordlandsk handelsstad. Kjerringøy $i \mathrm{~K}$. Zahl si tid 1850-19oo. Upublisert hovudoppgåve i historie. Universitetet i Tromsø.

Fulsås, N. (1988). Zahl og Kjerringøy 1850-19oo. I Knutsen (Red.) (s. 83-96).

Gammelsæter, H., Bukve, O. \& Løseth, A. (Red.) (2004). Nord-Vestlandet - liv laga? Ålesund: Sunnmørsposten forlag.

Garborg, A. (1893). Fra det mørke Fastland. Kristiania: Det gastrosofiske klubselskab Stavanger.

Gustavsson, A. (1986). Norskfödde kvinnor i bohuslänska kustorter. I Skärgård 3 (s. 9-21).

Hasslöf, O. (1949). Svenska västkustfiskarna. Studier i en yrkesgrupps näringsliv och sociala kultur. Göteborg: Svenska västkustfiskarnas centralförbund.

Hodne, F. \& Grytten, O. H. (200o). Norsk økonomi i det nittende århundre. Bergen: Fagbokforlaget.

Holm, P. (1991). Kystfolk. Kontakter og sammenhonge over Kattegat og Skagerrak ca. 1550-1914. Esbjerg: Fiskeri- og Søfartsmuseet - Salvandsakvariet.

Johansen, K. E. (1982). Fiskarsoga for Sogn og Fjordane 1860-1980. Oslo:

Universitetsforlaget.

Johansen, K. E. (2017). Puritanarar, pietistar og alkoholen. I Syn og Segn 2 (s. 83-91).

Johansen, K. E. (2019). Måtehaldsfolk og totalistar. I Syn og Segn 1 (s. 93-99).

Johnsen, B. E. (1993). Han sad i prisonen. Sjøfolk i engelsk fangenskap 1807-1814.

Oslo: Universitetsforlaget.

Jonassen, C. T. (1963). Etiske systemer og økonomisk atferd. Tidsskrift for samfunnsforsking, 4, 52-72.

Kallelid, O. (2012). Stavanger bys historie. Bind 2: Sild og seil 1815-189o. Bergen: Wigestrands forlag.

Kielland, A. ([1882]1968). Skipper Worse. Oslo: Gyldendal. 
Klepp, A. (1992). Hva er kystkultur? I Løseth \& Sæther (Red.) (s. 7-16).

Knutsen, N. M. (Red.) (1988). Nessekongene. Oslo: Gyldendal.

Langhelle, S. I. (2002). Religiøse svar på samfunnsmessige utfordringar? Det kulturelle og religiøse normskiftet i Nord-Rogaland 1820-1850. Historisk tidsskrift, 1, 5-26.

Langhelle, S. I. (2006). Frå religiøst fellesskap til personleg val. I Helle, Grepstad, Lillehammer \& Tryti (Red.), bind 3 (s. 106-145).

Løseth, A. (1996). Likskap og lagdeling. Fylkeshistorie for Møre og Romsdal. Bind 3. Oslo: Det Norske Samlaget.

Løseth, A. (2004). Region, kultur og økonomi - Nord-Vestlandet 1850-1970. I Gammelsæter, Bukve \& Løseth (Red.) (s. 22-51).

Løseth, A. (2012). Eilert Sundt og Haram. En oppdragers møte med et kystsamfunn. I A. Døssland, A. Kjelland, H. Krøvel \& M. Sinderud (Red.), Frå Volda til verda fjerne og nøere kulturmøte. Trondheim. Akademika forlag.

Løseth, A. (2014). Sjø og land, Folkebevegelsens strøm, Høg, låg og midt i mellom i Fiskar-Norge, Tru, livssyn og tenkjemåtar. I Døssland, Løseth \& Elstad (s. 427-475, 505-551).

Løseth, A. \& Sæther, P. (Red.) (1992). Kystkultur. Sarpreg og mangfald. Volda: Sunnmøre Museum og Møre og Romsdal distriktshøgskule.

Løvlie, B. (2002). Vestavind. 1870-årenes debatt om kristenliv og kirkeordning under innflytelse fra Skottland. Trondheim: Tapir.

Mathias, P. (2001). The first industrial nation. An economic history of Britain 1700-1914. London: Routledge.

Meistad, T. (1994). I min fars hus er der mange rom. I Drivenes, Hauan \& Wold (Red.) bd. 2 (s. 307-316).

Nedkvitne, A. (1991). Mentalitetshistorie - en historiografisk blindgate? Historisk tidsskrift, 1, 62-71.

Nordvik, H. W. (1982). Sildehandelens struktur og utvikling i Stavanger 1820-186o. Stavanger Museum Årbok 1981 (s. 5-42).

Olsen, K. (1980). En del trekk ved oppkomsten av borgerskapet $i$ Haugesund i perioden ca. 1840-19oo. Upublisert hovudoppgåve i historie. Universitetet i Oslo.

Pavé, M. (2009). France’s Atlantic coastal fisheries, c. 1600-1850. I I Starkey, Thór \& Heidbrinck (Red.) (s. 229-249).

Perkin, H. ([1969]1976). The origins of modern English society, 1780-1880. London: Routledge \& Kegan.

Schrumpf, E. (2019). Drikkeskikker og politisk kultur i Telemark på 180o-tallet. Heimen, 1, 25-38.

Sejersted, F. (1993). Demokratisk kapitalisme. Oslo: Universitetsforlaget.

Seland, B. (2004). Religiøse folkebevegelser i Norden fra midten av 180o-tallet.

Tidsskrift for kirke, religion og samfunn, 2, 153-170. 
Seland, B, \& Aagedal, O. (2008). Vekkelsesvind. Den norske vekkelseskristendommen. Oslo: Det Norske Samlaget.

Slettan, D. (1979). Kystfolk ser tilbake. Oslo: Tiden.

Smout, T. C. (1997). A century of the Scottish people 1830-1950. London: Fontana Press.

Sogner, S. (1996). Aschehougs Nogeshistorie. Bind 6: Krig og fred 1660-1780. Oslo: Aschehoug.

Starkey, D. J., Thór, J. Th. \& Heidbrink, I. (Red.) (2009). A history of the North Atlantic fisheries. Volume 1. Bremen: Verlag H. M. Hauschild.

Sundt, E. ([1857]1968). Om soedelighedstilstanden i Norge. Oslo: Pax.

Sundt, E. ([1858-59]1971). Harham. Et eksempel fra fiskeridistriktene. Bergen: Universitetsforlaget.

Sundt, E. ([1859]1976). Om ÆEdrueligheds-tilstanden i Norge. Verker i utvalg. Bind 5. Oslo: Gyldendal.

Thompson, P. (1983). Living the fishing. London: Routledge \& Kegan.

Tretvik, A. M., Sandvik, P. T., Kirkhusmo, A. \& Stugu, O. S. (2005). Trøndelags historie. Bind 3: Grenda blir global 1850-2005. Trondheim: Tapir Akademisk Forlag.

Try, H. (1986). Lekmannsrørsle og "associationsaand” ca. 1820-188o. I Aagedal (Red.) (s. 15-39).

Tveite, S. (1983). Den driftige jærbu - myte eller realitet? Stavanger Museums Årbok 1982 (s. 45-51).

Vea, J. (2009). To kulturer. En sammenlignende undersøkelse av det vestnorske og det nordnorske kystsamfunnet med hovedvekt på det 19. og 20. århundret. Kristiansand: Høyskoleforlaget.

Veblen, T. ([1899]2014). Den uproduktive klasse. Oslo: Res Publica.

Vries, J. de (1994). The Industrial Revolution and the industrious revolution. Journal of Economic History, 54, 249-270.

Vries, J. de \& Woude, A. van der (1997). The first modern economy. Success, failure, and perseverance of the Dutch economy, 150o-1815. Cambridge: Cambridge University Press.

Weber, M. ([1904-1905]1972). Den protestantiske etikk og kapitalismens ånd. Oslo: Gyldendal.

Aadnanes, P. M. (1986). Loestadianismen i Nord-Norge. Oslo: TANO.

Aagedal, O. (Red.) (1986). Bedehuset. Rørsla, bygda, folket. Oslo: Det Norske Samlaget.

Aasen, I. (1917/1990). Reise-Erindringer og Reise-Indberetninger 1842-1847. Voss: Det Kgl. Norske Videnskabers Selskab ved Halvdan Koht.

Øidne, G. (1957/1975). Litt om motsetninga mellom Austlandet og Vestlandet. Syn og segn, 1, 3-19.

Østensjø, R. (1950). En by blir til. Haugesund: Lothes Bokhandel A/S forlag. 



\title{
KAPITTEL 3
}

\section{Vekking og modernitet: Nokre kulturanalytiske merknader}

\author{
Per M. Aadnanes \\ Høgskulen i Volda
}

\begin{abstract}
Samandrag: Dei pietistisk prega vekkingane landet vårt har opplevd dei siste par hundreåra, vitaliserte ei religiøs førestillingsverd det ikkje var lett å sameina med dei oppfatningane av verda og tilværet som moderniteten favoriserte. Det er såleis ikkje uvanleg å meina at desse vekkingane fremja ei forakt for fornuft og vitskap, og at dei dermed eigentleg fungerte som bremseklossar på moderniseringa. I denne artikkelen blir det likevel argumentert for ei meir nyansert oppfatning, nemleg at vekkingane trass alt var uttrykk for sentrale moderne idear, ideal og haldningar, og at dei i kraft av dette faktisk også fekk vera viktige moderniseringsaktørar. Det paradoksale er då at dei med dette likevel bidrog til den sekulariseringa som på det næraste har fjerna den tradisjonelle religiøse førestillingsverda deira frå samtidskulturen. Og det reiser spørsmålet om ikkje dette slaget vekkingar no har mista fotfestet sitt for godt.
\end{abstract}

Nøkkelord: vekking, vekkingskristendom, pietisme, modernitet og seinmodernitet

I kyrkjehistoriske framstillingar blir religiøse vekkingar og vekkingsrørsler helst oppfatta som moderne fenomen, som eit særeige slag religiøse masserørsler knytte til visse opplevingar, erfaringar og uttrykk som protestantisk kristendom har produsert dei siste to-tre hundreåra. Desse vekkingane har såleis oppstått og utfalda seg i ein historisk og geografisk kontekst prega av den vestlege sekulariseringa og modernitetsutviklinga.

No kan ein sjølvsagt sjå likskapar mellom slike moderne vekkingar og visse religiøse uttrykk og rørsler me kjenner både frå tidlegare tider

Sitering av denne artikkelen: Aadnanes, P. M. (2020). Vekking og modernitet: Nokre kulturanalytiske merknader. I B. Løvlie, P. Halse \& K. Hatlebrekke (Red.), Tru på Vestlandet. Tradisjonar i endring (Kap. 3, s. 41-58). Oslo: Cappelen Damm Akademisk. https://doi.org/10.23865/noasp.104.ch3

Lisens: CC BY-ND 4.0. 
og fjernare himmelstrøk. At predikantar har mana folk til omvending og bot, og såleis gjeve opphav til masserørsler, finst det gode døme på også frå oldtid og mellomalder.

I denne artikkelen skal likevel eit slikt komparativt perspektiv for det meste få liggja ubrukt. Det skal heller ikkje gjerast noko forsøk på å kommentera noka konkret vekking eller sjølve vekkingsfenomenet ut frå ein definert teologisk synsstad. I staden er målsetjinga her avgrensa til å studera vekking nett som eit moderne fenomen. Og det skal me gjera ved å sjå det slaget vekkingar me kjenner frå vår eiga kyrkjehistorie, i lys av den modernitetsutviklinga som har endra vestleg kultur og samfunnsliv på så dramatisk og grunnleggjande vis i løpet av nyare tid.

Frå (idé)historisk synsstad er det ikkje uvanleg å knyta sekulariseringa og framveksten av modernitet først og fremst til den protestantiske delen av den kristne verda, og dermed til visse føresetnader for ei slik utvikling i dei protestantiske kristendomsformene. ${ }^{1}$ Og sidan vekkingar er eit typisk og til dels dominerande innslag i dei formene som protestantisk religiøsitet har teke i moderne tid, slik metodismen på den reformerte sida og pietismen på den lutherske gjev gode døme på, blir det sjølvsagt også eit spørsmål om kva for plass og rolle desse vekkingsrørslene har hatt i modernitetsutviklinga. Tesen vår her er at vekkingsrørslene, trass i at dei på fleire måtar stod fram som ein protest mot enkelte sentrale element i moderniteten, likevel var eit ekte uttrykk for visse moderne mentalitetar og haldningar sjølve, og at dei eigentleg først kunne utfalda seg i kraft av desse.

Det er sjølvsagt umogleg å teikna eit rimeleg dekkande riss av heile den historiske bakgrunnen av sekulariserings- og moderniseringsprosessar her. For å visa korleis denne bakgrunnen har gjeve dei allmenne føresetnadene, ikkje berre for teologi og kyrkjeliv, men altså også for vekkingsfenomenet, lyt me i staden nøya oss med å fokusera på berre nokre få

1 Ei av dei mest kjende, og omdiskuterte, oppsummeringane av denne oppfatninga er den som religionssosiologen Peter Berger lanserte i boka The Sacred Canopy frå 1967, der han langt på veg gav protestantisk kristendom ansvaret for sekulariseringsprosessen. Mellom protestantiske teologar er det først og fremst Friedrich Gogarten som mest konsekvent har utfalda ei slik oppfatning. Jf. særleg boka Verhängnis und Hoffnung der Neuzeit frå 1953. Men også den katolske kulturfilosofen Charles Taylor føreset ein slik samanheng i det monumentale verket A Secular Age frå 2007. Jf. t.d. s. 772. 
av dei mentalitetsformande haldningane og livsperspektiva som har blitt typiske for den vestlege moderniteten.

Gangen i det heile blir slik: Først skal det gjevast ein kort karakteristikk av sjølve fenomenet vekking i moderne fasong. Så skal visse sider av pietismen og dei seinare vekkingsrørslene sjåast i lys av nokre sentrale idéar i moderniteten. Og til sist har eg ein kort merknad om kvifor epoken med dette slaget vekkingar no ser ut til å ha teke slutt.

\section{Vekking - ordet, metaforen og fenomenet}

Det er nærliggjande å tru at skandinaviske språk har fått ordet/omgrepet «vekking» prega av språkbruken i tysk pietistisk litteratur. I alle høve er ordet «Erweckung» å finna i denne samanhengen frå 1770-åra av. I første omgang vart det bruka om den ståande pietistiske oppfordringa til å kjempa mot freistingar, syndige lyster og åndeleg vanegjengeri, og i staden prøva å leva eit meir heilagt liv. Etter kvart har det så blitt kopla til omgrepet 'omvending' («Bekehrung») og har delvis fått erstatta dette. ${ }^{2}$ Sidan har det blitt vanskeleg å operera med vekking og omvending som to ulike og heilt skilde religiøse fenomen. I gjengs kristeleg språkbruk hos oss har ordet «vekking» i alle høve blitt ståande som eit namn på ei sterk oppleving av å vera fortapt og difor ha eit akutt behov for frelse.

Lat oss sjå litt nærare på sjølve metaforen vekking. Reint språkleglogisk er føresetnaden for å bli vekt at ein søv. Er ein alt vaken, treng ein sjølvsagt ikkje å bli vekt opp. Når ein søv, er ein derimot ute av stand til å vekkja seg sjølv. Sjølve vekkinga må altså komma utanfrå. Og det gjev omgrepet 'vekking' ein litt annan dogmatisk - og eigentleg meir luthersk - aksent enn 'omvending'. For i omgrepet 'omvending' ligg det også eit element av eigeninnsats for å kunna bli frelst. Men også vekkinga dreg ein til ansvar. For er ein først vekt opp, og såleis påført eit medvit om eigen fortapt tilstand, opplever ein også eit slags ansvar for å berga seg ut av denne. ${ }^{3}$

TRE, 1982, s. 205 f.

Jf. TRE, 1982, s. $221 f$. 
No er det eigentleg søvn som er den konstituerande metaforen her. Og då blir det avgjerande kva ein legg i denne. For pietismen var det først og fremst tale om «syndesøvn», gjerne oppfatta som eit kristeleg vanegjengeri, der ein lever utan eit tilstrekkeleg klårt medvit om synda si og dermed om den fortapte situasjonen sin. Ein treng altså å bli vekt opp frå «den døde trua» som vanekristendommen representerer, og innsjå at ein eigentleg er i ferd med å «sova» seg inn i fortapinga. Slik pietismen såg det, var nett det å bli vekt opp til ei slik erkjenning sjølve føresetnaden for å kunna tileigna seg den frelsa som evangeliet om Kristus gjev del i.

$\AA ̊$ vera «vakt» på pietistisk (og metodistisk) vis skal altså vera ei djuptgripande personleg erfaring, i prinsippet ei livsendrande, ja, kanskje personlegdomsendrande, oppleving. Og når det er det å ha gjennomgått ei personleg vekkingsoppleving som så å seia får konstituera den ekte og sanne kristentrua, plasserer det alle uttrykk og metaforar for å vera truande kristen i eit psykologisk og erfaringsteologisk perspektiv. Anten ein talar om å ha ei «levande tru», bli «fødd på ny» eller ha "Jesus i hjarta», er det sjølve den kjenslemessige opplevinga og erfaringa den vakte har av dette som er pantet på at ho eller han er frelst frå den tidlegare «sovande» og fortapte tilstanden.

Opphavet til og bruken av omgrepet 'vekking' er altså nært knytt til det fokuset på oppleving og erfaring, kort sagt til den vendinga mot dei indre, kjenslemessige sidene av religionen, som breidde seg i protestantisk kristendom med pietisme og metodisme. I eldre protestantisk teologi var derimot ordet/omgrepet på det næraste fråverande. Det hadde såleis ikkje nokon plass i ortodoksien si ordo salutis-lære. Men det har påfallande nok heller ikkje blitt utfalda i nokon særleg monn i seinare luthersk dogmatikk, ${ }^{4}$ trass $\mathrm{i}$ at fenomenet frå pietismen av faktisk har fått spela ei viktig og til tider definerande rolle for sjølve trusoppfatninga i protestantiske kyrkjer.

Den dogmatiske sida av saka skal likevel få liggja her. I staden skal me altså nøya me oss med å studera korleis den historiske konteksten gjer vekkingsfenomenet til eit moderne uttrykk for kristeleg religiøsitet. 
Så langt har me retta søkelyset mot den individuelle vekkinga, og dermed mot den subjektive opplevinga av å bli vekt opp frå syndesøvn og vanekristendom. I kyrkjehistorisk samanheng talar ein helst om vekkingar og vekkingsrørsler, altså om kollektive forhold og sosiologiske storleikar. Ein granskar då korleis slike oppstår, grip om seg og fører til endringar av ulikt slag i kyrkje- og samfunnsliv. Likevel vil inga kyrkjehistorisk - eller religionssosiologisk - gransking kunna oversjå at ei kvar kollektiv vekking kviler på individuelle og subjektive opplevingar og erfaringar. Utan å ha ei viss innsikt i det djuptgripande kjenslemessige engasjementet hos den enkelte vakte, i sjølve «vekkingspsykologien» om ein vil, kan ein knapt oppnå ei tilstrekkeleg adekvat forståing av det særeigne ved vekkingar og vekkingsrørsler som kollektive fenomen heller.

Denne samanhengen mellom det individuelle og det kollektive lyt også studerast frå den andre sida. For ein forstår heller ikkje den individuelle opplevinga av å bli vekt godt nok utan å kunna referera henne til visse felleskulturelle forhold. Og då talar me ikkje berre om den massesuggesjonen som vekkingar gjerne lever av. For den suggestive påverknaden er det sjølvsagt berre mogleg å oppnå mot ein høveleg klangbotn av rådande mentalitetar og haldningar. Ja, eigentleg er føresetnadene for den enkelte si oppleving av å bli vekt, og såleis for at vekkingar i det heile skal kunna oppstå, knytte til det slaget førestillingsunivers og livsperspektiv som gjer seg gjeldande i den aktuelle samtida. Og det tyder at ei idéhistorisk og kulturanalytisk tilnærming er avgjerande viktig for å kunna forstå dynamikken i dei vekkingane og vekkingsrørslene me kjenner frå nyare tid.

\section{Frå statspietisme til vekkingskristendom}

«Av døpte vrimler stad og land, men hvor er troens brann?», klaga Hans Adolph Brorson i ein salme frå ei samling han gav ut i 1765.5 Med det gav han også uttrykk for ei typisk pietistisk vurdering av den folkelege vanekristendommen han kunne observera i si danske samtid.

Paradoksalt nok levde Brorson likevel i ei tid der folkereligiøsitet og felleskultur i kongeriket Danmark-Noreg etter kvart hadde blitt grundig

«O Fader, la ditt ord, din Ånd.», Norsk Salmebok, Oslo 2013, nr. 525. 
prega av pietismen. Det avgjerande tidsskiljet i så måte plasserer seg på 1730-talet. Det var nemleg då den sterkt pietistisk påverka kongen, Christian 6., fekk sett i gong eit program med obligatorisk konfirmasjon knytt til ei allmenn opplæring i kristendom. I tiåra som følgde vart så den dansk-norske allmugen effektivt indoktrinert med pietistisk kristendomskunnskap gjennom den like berykta som berømte Pontoppidans forklaring til Luthers katekisme. Knapt noka bok har hatt ei så omfattande og varig verknadshistorie hos oss som denne. Pontoppidan si kristendomstolking har såleis fått forsyna folk med både religiøse førestillingar, haldningar og i nokon monn også livsideal til langt inn på 1900-talet, lenge etter at boka hans var kassert som lærebok i kristendom i den norske folkeskulen.

Den pietistisk informerte folkereligiøsiteten Pontoppidan produserte, gjorde likevel aldri Brorson sitt spørsmål uaktuelt. For etter ekte pietistisk forståing av trua er slett ikkje den «teoretiske» katekisme- og forklaringskunnskapen nok til å bli frelst. Dersom ein ikkje hadde tileigna seg «troens brann» i tillegg, ville ein nemleg gå rundt med ei død tru, om aldri så velinformert, framleis. Det er denne trusoppfatninga som ligg til grunn for den vekkingsforkynninga som pietismen inspirerte til, og som i landet vårt har fått avgjerande innverknad på både kyrkje- og samfunnsliv frå Hans Nielsen Hauge si tid og heilt fram til dei vekkingspredikantane også denne forfattaren kunne lytta til i ein oppvekst på 1950-talet.

Poenget er altså at den viktigaste føresetnaden for at vekkingar etter pietistiske ideal i det heile skulle kunna oppstå, var at det fanst eit minimum av «forsanthalden» kristeleg kunnskap mellom folk, at det faktisk fanst ei allment utbreidd «død tru». Og så seint som på 1950-talet over 200 år etter innføringa av ei kristendomsopplæring orkestrert av Pontoppidans forklaring - sat framleis mykje av den pietistisk prega kristendomskunnskapen framleis i bakhovudet hos dei ungdommane som lytta til vekkingspredikantar sine appellar frå eit bedehusgalleri i ei vestlandsbygd. Så godt som alle desse jentene og gutane var nemleg ikkje berre døypte, men også grundig kristendomsunderviste både i folkeskulen og $\mathrm{i}$ «lesinga for presten» til konfirmasjonen. Ja, det er grunn til å tru at mange av dei innerst inne trudde på heile pakka, til og med. Men slik vekkingspredikanten la fram saka, var denne trua deira likevel 
«død», og ville slett ikkje kunna berga dei frå fortapinga. Dei mangla nemleg enno den «troens brann» som berre ei gjennomgripande og livsendrande overgjeving til Jesus kunne gje dei.

Eit anna viktig poeng er at det slaget vekkingar som treivst i dei lange etterdønningane etter statspietismen på 1700-talet, også påførte dei vakte ganske strenge livsideal. Å «bli frelst» skulle nemleg også vera starten på eit nytt og heilagt liv, og det måtte demonstrerast gjennom ei strengt forsakande livsførsle. Det ramma særleg dei såkalla adiafora, aktivitetar som leik og dans, spel og teater, song og musikk utan kristeleg innhald, og etter kvart også det å nyta alkohol og tobakk. For endå om slikt ikkje kom i direkte konflikt med dei ti boda, var det slett ikkje uskuldige ting. Tvert om var dette «verdslege» aktivitetar og nytingar som eigentleg stod i vegen for eit ekte og alvorleg kristeleg liv. Poenget var såleis at vekkinga måtte få ta tak i kjensler og vilje på slik vis at det endra både livsoppleving og livspraksis. Berre ved å forsaka alt det dei oppfatta som verdsleg i negativ meining, kunne dei vakte overtyda både seg sjølve og omgjevnadene om at dei hadde «gått over frå døden til livet».

At slik streng verdsforsaking kunne bli svært krevjande for den enkelte, finst det mange personlege forteljingar om frå norsk vekkingskristendom, også så seint som på 1950- og 60-talet. Å praktisera «det nye livet» etter dei tradisjonelle pietistiske livsideala i ei tid der allmennkulturen støtt vart meir og meir sekulær, liberal og mangfaldig, stilte sjølvsagt store krav til både overtyding og viljestyrke. Endå om den «nyfrelste» ungdommen framleis kunne henta styrke både frå omvendingserfaringa si og frå den støtta det nye miljøet kunne gje, hende det nok at enkelte av freistingane frå det gamle livet, anten det no var eit slag kortspel eller eit kinobesøk, vart for sterke. Og då var det fare på ferde. For sjølv med slike heilt bagatellmessige «syndefall» - sett med våre augo i dag - kunne nok bedehusfolket også langt inn på 1960-talet frykta at ein hadde sett seg i akutt fare for «å falla ut av nåden».

Eit like viktig poeng er det likevel at vekkingsfolket slett ikkje avstod frå andre sider av «denne verda», men heller engasjerte seg meir enn gjerne i visse meir eller mindre verdslege syslar. At det var pietistane som tende misjonsgløden i dei lutherske kyrkjene i Nord-Europa og Skandinavia, er ei kjend sak. Endå om motivasjonen for dette i utgangspunktet sjølvsagt 
var reint kristeleg, drog misjonsverksemda deira også med seg eit «verdsleg» engasjement av både sosialt og pedagogisk slag. På heimebane var dei i alle høve sterkt engasjerte i møte med sosiale problem, noko som mellom anna resulterte i etablering av barneheimar og eit betre fattigstell. Og pietistane var heilt $\mathrm{i}$ front $\mathrm{i}$ si tid når det galdt skule og opplæring; $\mathrm{i}$ Danmark-Noreg kom det såleis på plass ein skule for alle alt i 1739, kort tid etter at pietismen hadde slått gjennom i hoffet. Det mest overraskande var likevel at pietistiske vekkingsrørsler også kunne dra med seg eit engasjement i næringsverksemd og etter kvart i politikk, slik haugianarane og deira etterfølgjarar her til lands gjev eit slåande døme på.

\section{Modernitet- eit idémessig spenningsfelt}

Som så mange andre allmenne karakteristikkar me utstyrer historiske straumdrag og epokar med, blir også ordet «modernitet» bruka på nokså omtrentleg vis. Her skal me likevel halda oss med ei meir handterleg avgrensing der me reserverer uttrykket for nokre hovudidéar det er vanleg å oppfatta som typiske produkt av den vestlege kulturutviklinga i nyare tid. No bergar heller ikkje dette oss heilt frå å gjera nokre val og vurderingar av kva som skal høyra med og ikkje. Det tyder også at karakteristikken «modernitet» i nokon monn er ein konstruksjon, gjort på grunnlag av meir eller mindre omfattande historiske overblikk og tolkingar. Det er tale om ei slags oppsummering av dei idéar, haldningar og mentalitetar, i det heile av dei særeigne livsperspektiva som ein meiner tydelegast skil denne perioden frå tidlegare tider. Men det kan sjølvsagt diskuterast kva for idéar som bør høyra med her, og kor moderne dei eigentleg er. Likevel må det seiast at det knapt er særleg stor usemje om dei mest sentrale og grunnleggjande.

Det er særleg tre hovudmotiv ein peikar på då, nemleg ei tru på menneskets fornuft, eit ideal om fridom og sjølvstende for individet og ei von om framsteg på nær sagt alle felt. ${ }^{6}$ Korleis desse tre blir forstått og utvikla, til dømes av ulike forfattarar og i ulike historiske kontekstar, kan likevel variera ein del. Det gjeld også forholdet mellom dei og korleis dei lèt seg

6 Jf. til dømes Østerberg, 1999, s. 11ff. 
kopla saman. Og dei spenningane som ulik forståing og vekting har lagt til rette for, har då også fått prega modernitetsutviklinga. Det klassiske dømet er sjølvsagt forholdet mellom opplysning og romantikk. Såleis gav rasjonalismen frå Descartes til Kant fornufta ein overordna status som allmenn og intersubjektiv. Men etter at fornuftstrua hadde nådd eit høgdepunkt med opplysningsfilosofien utover på 1700-talet, kom den romantiske åndsrørsla som ein reaksjon mot slutten av hundreåret. I staden for å framheva den allmenne fornufta som kjelde til kunnskap tok talsmenn for romantikken utgangspunkt i det individuelle subjektet og framheva dei indre subjektive kjenslene som grunnlag for meir eigentlege og difor «sannare» erfaringar av røyndommen. Fornufta vart så å seia underordna det individuelle subjektet, og måtte gje frå seg førarplassen som konstituerande for moderniteten. I staden fekk det autonome subjektet, med sine heilt individuelle og unike kjensler, opplevingar og erfaringar, denne rolla. Individet, det individuelle subjektet, sjølvet om ein vil, hadde dermed blitt den siste instansen for både epistemologisk, ontologisk og moralsk sanning.

Den indre spenninga i og mellom dei idéane som konstituerer moderniteten, gjer seg gjeldande på mange vis. Dei tankane, ideala og målsetjingane som med tida har fått status som typiske modernitetsprodukt, lever såleis ikkje heilt friksjonsfritt med kvarandre. Ta til dømes førestillingane våre om menneskeverd og menneskerettar, om likeverd mellom kjønn og folkeslag, om religionsfridom og toleranse, og om demokrati og rettsstat. I vår vestlege humanistiske tradisjon kan det kjennast som om slike idéar og ideal er nærpå sjølvinnlysande uttrykk for fornuft, individualisme og framsteg. Men kor godt heng dei eigentleg saman? Når ein definerer mennesket som eit fornuftsvesen, samstundes som ein meiner at den enkelte må tilkjennast både fridom og autonomi, viser det seg nemleg ofte å gje rom også for openbert ufornuftige handlingar. Og endå om ein oppfattar kombinasjonen av individuell fridom og fornuft som sjølve drivkrafta bakom alt framsteg, slik ein gjerne har gjort i Vesten, er det vanskeleg å oversjå at framstega i vitskap og teknologi slett ikkje alltid har følgje av tilsvarande moralske og sosiale framsteg.

Poenget er altså at samanhengen i det me kallar modernitet, ikkje utan vidare lèt seg etablera som ein slags naudsynleg ideologisk logikk. 
Moderniteten er heller å forstå som eit særeige historisk produkt, skapt i samspelet mellom ulike rørsler og straumdrag heilt frå renessanse og reformasjon av, med eit avgjerande tyngdepunkt i opplysningstida. I kjølvatnet av dette såkalla opplysningsprosjektet har så dei sentrale idéane denne utviklinga har etterlate seg, både blitt utdjupa, granska og diskutert, men utan at det har resultert i nokon samlande og heilskapleg ideologi om mennesket og samfunnet.

Likevel, endå om moderniteten såleis er både spennings- og motsetnadsfylt, opplever me han som sjølve kjernen i ein fellesvestleg kulturell identitet. Og det forundrar oss difor at ein i andre delar av verda synest å kunna dyrka visse sentrale aspekt av moderniteten «vår», som naturvitskap, teknologi og kapitalistisk økonomi, utan å overta dei samfunnsideala, dei menneskesyna og verdiane me utan vidare meiner høyrer med.

For å forstå kvifor det er slik, og for å få dei spenningane me har nemnt på ein slags formel, har den svenske idéhistorikaren Sven-Eric Liedman føreslått å skilja mellom det han kallar hard og mjuk opplysning.? Dei harde elementa i opplysningsprosjektet finn han utfalda først og fremst i dei eksakte vitskapane, teknologien og økonomien, medan dei mjuke sidene har gjort seg mest gjeldande innanfor område som etikk, politikk, filosofi, religion og kunst. Denne fordelinga svarar då også nokså nøyaktig til det nemnde paradoksale forholdet mellom trua på ei allmenngyldig fornuft og idealet om ein individuell og subjektiv autonomi. Dei typisk moderne ideala om individuelle fridommar, toleranse og demokrati høyrer såleis til på den mjuke sida. Og det at produkta frå den harde sida har kunna gå sin sigersgang verda rundt utan at dei mjuke ideala følgjer med på kjøpet, demonstrerer det hovudproblemet moderniteten lid under, slik Liedman ser det.

\section{Modernitet og vekkingskristendom}

Den romantiske forma for individualisme, der kjeldene til det sanne, eigentlege og gode er å finna i den enkelte sitt indre liv, er altså ein av fleire moglege aksentar innanfor moderniteten. Og nett denne var pietistane

Liedman, 2013, s. 26ff. 
tidleg ute med å realisera på det religiøse feltet, alt før romantikken slo gjennom som ei meir allmenn rørsle, i protest mot ei intellektualistisk oppfatning av trua. Å leggja hovudvekta på den enkelte sine indre subjektive kjensler er rett og slett den avgjerande føresetnaden for den pietistiske trusoppfatninga og dermed altså for vekkingsfenomenet i nyare tid. ${ }^{8}$

Den spenninga mellom den allment fornuftige erkjenninga og den subjektive erfaringa me finn i moderniteten, har også fått utfalda seg i fleire omgangar innanfor protestantisk teologi og kyrkjeliv frå 160o-talet av. Me finn altså denne tidleg, i forholdet mellom ortodoksi og pietisme, og sidan mellom rasjonalisme og ulike reaksjonar mot denne av meir eller mindre pietistisk slag. Alle desse teologiske nyansatsane kan likevel lesast som ulike uttrykk for den gryande moderniteten. I den lutherske ortodoksien tok ein såleis fornufta, til og med i aristotelisk modellert utgåve, i bruk for å rekonstruera den rette frelsande læra ut frå Bibelen, rett nok ved ei lesing av dei bibelske skriftene som i dag blir oppfatta som fullstendig uhistorisk og difor ofte mistydd. I pietismen fekk derimot den subjektive opplevinga og erfaringa ta over fornufta sin plass som kjelde til den frelsande gudskunnskapen. Og det gjorde ortodoksien si såkalla forensiske forståing av frelsa, som Guds «objektive» frelsehandling gjennom Kristus, på eit vis utilstrekkeleg for den enkelte sin del. Heller ikkje ei tilslutning til det objektivt sanne læregrunnlaget som ortodoksien søkte, var nok. Utan at den ortodokse frelseslæra i og for seg vart direkte fornekta, innførte pietismen i tillegg altså den subjektive og kjenslemessige opplevinga av å venda om, som sjølve den frelsande hendinga for enkeltmennesket. Den enkelte måtte altså tileigna seg gudsrelasjonen som ei eiga indre erfaring; den frelsande erkjenninga måtte bli subjektiv sann. Eller som det heiter med ein Kierkegaard-referanse: «Subjektiviteten er Sandheden». Ein var rett og slett ikkje frelst utan å ha opplevd det på inderleg og personleg vis sjølv. Først då var ein gjenfødd og hadde gått over frå døden til livet. ${ }^{9}$

8 At det er eit tydeleg samband mellom vekkingsrørslene sitt fokus på kjensler og den aukande sansen for kjenslelivet i allmennkulturen på 17- og 180o-talet, har m.a. Charles Taylor peika på. Jf. Taylor, 1989, s. 302.

9 Jf. t.d. Hägglund, 1966, s. 274ff og 302ff. Hägglund står seg godt framleis som ei oversiktleg innføring i forholdet mellom ortodoksi og pietisme. 
Motsetnaden mellom pietisme og ortodoksi i teologihistoria er altså ei tidleg utgåve av den grunnleggjande spenninga mellom fornuft og kjensler, mellom det allmenne, objektivt gyldige og det individuelle, subjektivt opplevde, som moderniteten utvikla. Og poenget er at når den pietistiske vekkingskristendommen såleis knyter frelsa til subjektive, kjenslemessige religiøse erfaringar, er det samstundes eit klårt uttrykk for ein viktig aksent i moderniteten.

I neste omgang realiserte likevel pietistane moderniteten i meir omfattande meining òg. For erfaringa av å vera vakt og gjenfødd gav også grunnlag for ei kjensle av menneskeleg likeverd på tvers av stand og stilling elles. Og dette kunne i sin tur medføra ein motivasjon for å agera på meir sjølvstendig vis i samfunnslivet. Rett nok skulle omvendinga følgjast opp gjennom eit verdsforsakande liv. Men det kunne ein visst demonstrera tilstrekkeleg ved å avstå frå ulike adiafora. Når det galdt engasjement og innsats på ulike felt i det verdslege livet elles, vart pietistane derimot ofte føregangsmenn. Som nemnt kunne dei såleis utfalda seg på til dels revolusjonerande vis både i sosialt hjelpearbeid, i skule og utdanning, og i næringsliv, økonomi og politikk. Og det måtte også gje nokre av dei «hardare» elementa i moderniteten eit visst spelerom.

Dette er typiske drag også i den norske utgåva av pietismen, nemleg den vekkingskristendommen som vaks fram i kjølvatnet etter Hans Nielsen Hauge si predikantverksemd. I den mangfaldige arven etter Hauge ligg det nemleg ei ganske revolusjonerande likeverdstenking. Denne har ein sidan søkt å legitimera som hovudsakleg luthersk, til dømes ved å visa til tanken om det allmenne prestedømmet. Rett nok gjorde pietismens opphavsmann Phillip Jacob Spener også det. Men det kan likevel diskuterast om pietismen og vekkingsrørslene si likeverdstenking går heilt godt i spann med den lutherske forståinga av forholdet mellom tru og gjerningar. Dessutan er det nokså tydeleg at typisk kalvinske element også har gjort seg gjeldande både i den opphavlege pietismen og i vekkingsrørslene etter denne sidan. Denne påverknaden viser seg ikkje berre i den vekta som blir lagt på ei streng livsførsle, men også i haldningar me i dag opplever som langt meir moderne enn dei Luther sjølv stod for. At tanken om likeverd og personleg sjølvstende skulle kunna trumfa dei skilje stand og status elles sette mellom menneske, og dermed bli eit trugsmål mot den 
eksisterande samfunnsordninga, var nok fjernt for Luther. For han var slike tankar ei farleg og svermerisk blanding av lov og evangelium.

Denne nye likeverdskjensla kan altså forklara mykje av desse rørslene sine effektar på samfunnsutviklinga sidan. Såleis kan denne haldninga grunngje både den sivile ulydnaden som desse rørslene kunne møta både kyrkjelege og verdslege autoritetar med, den demokratiske organiseringa dei utvikla i eigne samanhengar, og det nyskapande entreprenørskapet dei utfalda i næringsliv og økonomisk verksemd. At vekkingsfolket heile tida har utmerkt seg med både høg arbeidsmoral, økonomisk nøysemd og meir allment gründerskap, er jo Vestlandet si historie dei siste 150 åra ein tydeleg demonstrasjon av. Max Weber sin tese om forholdet mellom protestantisme og kapitalistisk økonomi kan altså framleis gjelda som ein treffande idéhistorisk observasjon av nett dette. ${ }^{10}$ Alt i alt er det ei godt etablert historisk sanning at vekkingsrørslene har gjeve eit avgjerande viktig bidrag til heile den moderne samfunnsutviklinga, inkludert demokratiseringa av det politiske systemet vårt.

No vil enkelte kanskje seia at vekkingsrørslene sin effekt på moderniseringa av samfunnet berre er ein meir eller mindre tilfeldig biverknad av dei, og ikkje noko som følgjer direkte av kjerneelementa i vekkingskristendommen. Etter mitt skjøn er ein slik påstand likevel nokså misvisande. Poenget er nemleg at så nært som nøysemd og arbeidsmoral, likeverd og demokratiske organisasjonsformer har late seg knyta til den pietistiske subjektivismen, så har det rett og slett forsynt vekkingsfolket med ein klårt modernitetsfremjande, eller om ein vil: direkte framstegsretta, mentalitet. Følgjer me Liedmans forståing av moderniteten som ein kombinasjon av både mjuke og harde element, blir såleis også den pietistiske vekkingskristendommen si historiske rolle ein demonstrasjon av dette. For ei meir mjuk side enn pietismens subjektivisme i si inderlegaste, kjenslelada form kan vel knapt tenkjast. Men samstundes må det ha følgt med såpass mykje av både luthersk skapingsteologi og kalvinsk gjerningskristendom at det stort sett hindra denne subjektivismen frå å hamna i verdsflyktande mystikk. Pietistane gjekk slett ikkje i kloster. Men dei vart heller ikkje sitjande fast i teknologi og livsformer frå 1700-talet, som eit 
slags «amish people». I staden tok dei straks steget over på moderniteten si harde side, der både forvaltaransvar og nestekjærleik like gjerne kunne utfaldast ved kalkulerande fornuft, teknologisk nyvinning og økonomisk kløkt og gründerskap.

Så seint som på 1950-talet kunne dette slaget spenningsfylt modernitet framleis observerast i vestnorske kystbygder. For kven var det som la seg på kne mellom bedehusbenkene og bad med sukk og tårer for dei ufrelste i bygda? Slett ikkje berre dei aktive misjonskvinnene, men også læraren, handelsmannen, småindustrigründeren og fiskebåtreiaren, gjerne side om side med småbrukaren og industriarbeidaren.

Når dei pietistiske vekkingsrørslene framheva det individuelle og subjektive så sterkt, samstundes som dei følgde dette opp med likeverdstenking, fridomsstrev og pragmatisk framstegstru, var dei såleis tydelege uttrykk for sentrale om enn spenningsfylte sider av moderniteten. Og det gjorde dei paradoksalt nok også i stand til å gje verknadsfulle bidrag til dei moderniseringsprosessane som til sist skulle komma til å plassera kristendomsforma deira på sidelina av samfunns- og kulturutviklinga elles.

\section{Vekking på seinmoderne føresetnader?}

Sett i forhold til moderniteten slik han helst tek seg ut i ein meir gjennomsekularisert tidsalder, kan nok pietistiske vekkingsrørsler verka temmeleg lite moderne. For endå om dei engasjerte tilhengjarane sine sterkt i verdslege sysler, til og med på moderne samfunnsreformerande vis, heldt dei lenge fast på verdsforsakande livsideal av eit nokså «umoderne» slag. Og endå om dei representerte ein klårt moderne subjektivisme, var dei likevel heilt og fullt avhengige av at folk stort sett gjekk rundt med eit tradisjonelt og til dels førmoderne religiøst førestillingsunivers. Særleg dette siste har vist seg å vera den pietistiske vekkingskristendommen sin akilleshæl etter kvart som samtidskulturen har teke ei meir og meir sekulær form.

Den moderniteten som vekkingsfolket på Vestlandet kunne leva godt med til langt inn i andre halvparten av det førre hundreåret, kvilte altså på ein avgjerande føresetnad, nemleg at det rådde ein tilnærma kristeleg einskapskultur i bygdene der då. For kjernen i denne einskapskulturen var lenge ein pietistisk prega folkereligiøsitet. Som nemnt vart 
grunnlaget for denne folkereligiøsiteten lagt alt i statspietismen si tid i Danmark-Noreg, då obligatorisk konfirmasjon og ei tilsvarande allmenn kristendomsopplæring vart innført. Og trass i at skulen etter kvart fekk ei allmenndannande målsetjing, skulle han likevel gje rom for ei konfesjonell kristendomsundervisning gjennom nær på heile 1900-talet. Det sikra at folk flest lenge hadde nærkontakt med det kristelege førestillingsuniverset, og at dei dermed var eksponert for ein påverknad av det slaget mange sidan har referert til som «barnetrua» si. ${ }^{11}$

Mykje tyder altså på at både Gud og djevel, himmel og helvete, kunne opplevast som realitetar også for mange av dei som ikkje trakka ned dørstokken på bedehuset til vanleg. Når skulen så i tillegg hadde forsynt dei med rimeleg eintydige oppfatningar om rett og gale på ulike livsområde, gjerne tilsett den pietistiske skepsisen mot adiafora, visste dei innerst inne òg noko om kor «syndig» dei eigentleg levde til kvardags. Og det var nett ein slik kombinasjon av langt på veg allment aksepterte kristelege førestillingar og latente samvitskvalar den klassiske vekkingsforkynninga var utvikla for å adressera.

Ein rask forvitringsprosess dei siste tiåra før tusenårsskiftet har likevel sytt for at den folkereligiøse klangbotnen for pietistisk prega vekkingsappellar praktisk tala er heilt borte no. Det er mangt i den allmenne samfunns- og kulturutviklinga dei siste 50-60 åra som kan forklara det. Her skal me likevel nøya oss med å peika på éin sentral faktor i dette, nemleg skulefaget kristendomskunnskap si «forfallshistorie». At dette faget i løpet av den siste halvparten av 1900-talet tapte det meste av den opphavlege pietistiske profilen sin, er berre éi side av denne historia. At mykje av det konfesjonelt lutherske preget - og innhaldet - etter kvart også måtte vika for meir allmennetiske og økumeniske perspektiv, var nok endå viktigare, og representerte ei langt på veg naudsynleg tilpassing til den allmenne kulturutviklinga. Men det viktigaste var likevel at kristendomskunnskapen dei siste tiåra av historia si, trass i alle tilpassingsforsøk, litt etter litt tapte den tradisjonelle posisjonen sin som det sentrale verdiberande faget i skulen. Ja, dette skulefaget sin lagnad må truleg

11 Eit vesentleg moment i vedlikehaldet av denne kristelege folkereligiøsiteten var det nasjonalkristelege danningsprosjektet som lærarskulane på Vestlandet representerte, der særleg Henrik Kaarstad i Volda stod fram som den leiande ideologen. Jf. Løvlie, 2007, s. 1off. 
oppfattast som det viktigaste momentet i dei prosessane som til sist har plassert ikkje berre vekkingskristendommen, men også kyrkjelivet i det heile på sidelina i den norske allmennkulturen. For når den elementære og opphavleg rimeleg eintydige innføringa i kristendomskunnskap såleis vart svekt og til sist avvikla heilt, gjorde det sjølvsagt også vedlikehaldet av ein kristeleg folkereligiøsitet på det næraste umogleg.

Den sekulariserande dynamikken som har utfalda seg i samspelet mellom dei idéar og ideal, haldningar og mentalitetar me plasserer under stikkordet «modernitet», synest altså til sist å ha etsa bort sjølve føresetnadene for det slaget vekkingsrørsler me har tala om her. Men i tillegg har utviklinga dei siste tiåra til og med gjeve oss ei kjensle av at sjølve den vestlege moderniteten, som ein lenge trudde skulle kunna gje oss ein slags ny einskapskultur, kanskje til og med i global målestokk, no er i oppløysing. Når me i dag karakteriserer kultursituasjonen vår som seinmoderne, for ikkje å seia postmoderne, er det såleis ikkje utan at det følgjer ei oppleving av krise med på kjøpet.

Spørsmålet er då om ikkje sjølve det moderne fenomenet vekking med dette rett og slett er ute av soga. Det er sjølvsagt umogleg å gje noko eintydig svar på det. Men det er i alle høve vanskelegare å oppfatta det slaget religiøsitet og religiøse rørsler som utfaldar seg på seinmoderne føresetnader, som moderne på same vis som dei pietistiske vekkingane.

Sett frå ein eller annan «klassisk» modernitetsprega synsstad kan den seinmoderne kulturutviklinga verka mildt sagt forvirrande. For endå om sekulariseringa heilt klårt held fram på fleire viktige samfunnsområde, har religion og religiøsitet likevel fått ein slags renessanse, men då ofte i nye og overraskande former. Såleis har rørsler av såkalla nyreligiøst slag, saman med ei meir allmenn «åndeleg» interesse, lenge under den samlande etiketten New Age, vekt ei viss merksemd heilt frå 1970-åra av. Samstundes, og som ein slags kristeleg parallell til dette, har såkalla karismatiske rørsler fått utfalda seg i fleire bølgjer både i og utanfor dei tradisjonelle kyrkjene i Vesten.

Dei kyrkjelege og kristelege miljøa har streva ein del med å finna måtar å møta denne seinmoderne religiøsiteten på. ${ }^{12}$ Det gjeld ikkje minst dei

Jf. Aadnanes, 2008, s. 43ff. 
modernitetstilpassa pietistiske vekkingsmiljøa. Der har ein helst fordømt og demonisert dei fleste formene for ikkje-kristeleg nyreligiøsitet, samstundes som ein heldt lenge fast på ein viss skepsis til sjølv ein moderat karismatikk.

Eit viktig felles kjennemerke ved det meste av denne nye religiøsiteten, anten han definerer seg innanfor eller utanfor tradisjonelle kristelege rammer, er likevel ein endå meir reindyrka subjektivisme enn det dei tradisjonelle vekkingsrørslene har stått for. Såleis kunne det religiøse engasjementet der også gje rom for ekstatiske former. Det er då eit poeng at ein med slike erfaringar ser ut til å ha langt mindre bruk for eit fundament av allment utbreidde førestillingar og læresetningar, slik dei pietistiske vekkingane trass alt var avhengige av. I den seinmoderne religiøsiteten synest såleis den individualismen og subjektivismen me elles oppfattar som sentrale moderne haldningar, å ha mista all korrigerande kontakt med det like moderne idealet om ein argumenterande intersubjektivitet. For det er vanskeleg å oversjå korleis slike nyare religiøse miljø og rørsler ofte innrettar seg i reine ekkokammer, der dei kan dyrka sine eigne fantasifulle teoriar og forklaringar, utan å lata seg uroa av det slaget "gammaldags» modernitet som krev både gransking og etterprøving, og som må tola konfrontasjonar med både samtidig felleskultur og vitskapeleg etablerte sanningar.

Dette slaget seinmoderne religiøsitet, som ein altså kan treffa på også i kristelege utgåver, tøyer i alle høve subjektivismen eit godt stykke lenger enn det dei tradisjonelle vekkingsrørslene til vanleg gjorde. Og om slik subjektivisme gjev eit tilstrekkeleg grunnlag for vekkingar av eit meir eller mindre kristeleg slag i ei elles temmeleg avkristna tid, kan det vel vera gode grunnar til å tvila på.

\section{Litteratur}

Berger, P. (1967). The sacred canopy. Elements of a sociological theory of religion. New York: Doubleday. «Erweckung/Erweckungsbewegungen», Theologische Realenzyklopädie (TRE). (1982). Band X, Berlin/New York: De Gruyter.

Gogarten, F. (1966). Verhängnis und Hoffnung der Neuzeit. München/Hamburg: Siebenstern Taschenbuch Verlag. 
Hägglund, B. (1966). Teologins historia. Lund: CWK Gleerups Förlag.

Liedman, S.-E. (2013). Den moderne verdens idéhistorie. I skyggen av fremtiden. Oslo: Dreyer.

Løvlie, B. (2007). Kor mykje stort ... Matias Orheim, hans bidrag til vestnorsk kulturog kristenliv, Trondheim: Tapir Akademisk Forlag.

Taylor, C. (2007). A secular age. Cambridge, MA/London: Harvard University Press. Taylor, C. (1989). Sources of the self. The making of the modern identity. Cambridge, MA: Harvard University Press.

Weber, M. (1972). Den protestantiske etikk og kapitalismens ånd (tysk originalutgåve 1920). Oslo: Gyldendal.

Østerberg, D. (1999). Det moderne. Et essay om Vestens kultur 1740-200o. Oslo: Gyldendal.

Aadnanes, P. M. (2008). Gud for kvarmann. Kyrkja og den nye religiøsiteten. Oslo: Universitetsforlaget. 


\title{
Kristen eller kristeleg? Fjordingar mellom kyrkje og bedehus
}

\author{
Olaf Aagedal
}

KIFO (Institutt for kyrkje-, religions- og livsynsforsking)

Samandrag: Det finst ulike måtar å vere kristen på i Noreg, og ulike namn på desse måtane. Skilje mellom "omvendingskristendom» og "oppsedingskristendom» har prega det religiøse livet i Noreg og ofte skapt sterke spenningar og konfliktar. Korleis har dette skiljet prega Nordvestlandet samanlikna med andre landsdelar? Finn ein her døme på meir fredeleg sameksistens mellom desse kristendomsformene?

Nøkkelord: lekmannsrørsla, einskapskultur, personleg kristen, vekking, oppsedingskristendom, identitet

\section{Innleiing: «Er du kristeleg?»}

Det hende $i$ min barndom $i$ ei bygd på Vestlandet, eg kunne vel vere $i$ 10-12-årsalderen. Vi var nokre kameratar som var ute og leika då ein av dei plutseleg seier: «Du Aagedalen» (her må eg forklare at vi gutungar på den tida ofte tiltalte kvarandre med etternamn) «er du kristeleg?». Spørsmålet kom heilt uventa, eg blei paff og visste ikkje kva eg skulle svare. Men ein annan av gutane i flokken kom meg i forkjøpet med å seie: «Kristne er vi no alle, vi er no døypte». Dermed slapp eg å svare, og eg slapp å gjer greie for om eg var kristen på ein annan måte enn dei andre, det han kalla «kristeleg».

Sitering av denne artikkelen: Aagedal, O. (2020). Kristen eller kristeleg? Fjordingar mellom kyrkje og bedehus. I B. Løvlie, P. Halse \& K. Hatlebrekke (Red.), Tru på Vestlandet. Tradisjonar i endring (Kap. 4, s. 59-81). Oslo: Cappelen Damm Akademisk. https://doi.org/10.23865/noasp.104.ch 4 Lisens: CC BY-ND 4.0. 
I ettertid har eg reflektert over kva som låg bak dette spørsmålet. Det måtte tydelegvis vere eit skilje i kulturen mellom ulike måtar å vere kristen på som også barn hadde oppfatta. Kva gjekk dette skiljet ut på? Var dette spesielt for denne bygda, eller kunne eg ha fått same spørsmålet andre stader $i$ Noreg? Og kva med svaret frå ein av mine kameratar? Kvar hadde han fått det frå at vi alle var kristne, og kvifor var han så rask til å svare på vegne av meg?

Temaet for denne artikkelen er ulike måtar å vere kristen på i Noreg, eller om ein skulle sagt det meir teoretisk, ulike religiøse kulturar og identitetar. Eg vil først nærme meg temaet teoretisk og nasjonalt ved å sjå på kjenneteikn på det eg vil kalle religiøse kulturar i Noreg. Eg vil særleg drøfte skiljet mellom på den eine sida omvendingskristendom og bedehuskristendom, og på den andre sida oppsedingskristendom og kyrkjekristendom, som eg meiner kan vere noko av bakgrunnen for den samtalen eg fortalde om ovanfor.

Deretter beveger eg meg frå det nasjonale til det regionale og ser på teoriar og data som kan seie meg noko om korleis ulike kristendomsoppfatningar og religiøse kulturar varierer i Noreg. Kva kan dette seie meg om den religiøse kulturen i landsdelen og fylket der eg voks opp? Neste steg går frå det regionale til det lokale. Kva kjenneteikna bygda der eg voks opp og forholdet mellom å vere «kristen» og «kristeleg» der? Her trekker eg inn eigne oppveksterfaringar og prøve å tolke desse ut frå teoriar om forholdet mellom ulike religiøse kulturar.

Grunnlaget for framstillinga er ei blanding av sosiologisk teori, statistiske data, andre studiar av vestlandsreligiøsitet og eigne oppvekstveksterfaringar. Framstillinga er essayistisk. Det vil vere ei kulturvandring i tid og rom som handlar om «fjordingar mellom kyrkje og bedehus». Ein av desse fjordingane er meg.

\section{Den kyrkjelege einskapskulturen og oppbrotet frå denne}

Innleiingshistoria illustrerer fleire ulike måtar å oppfatte og omtale den kristne religionen på. Svaret «Kristne er vi no alle» viser til ein kultur der religionen er ein del av samfunnsmedlemskapet. Dette blir ofte omtalt 
som kollektiv kristendom eller kulturkristendom. Men samtalen viser også at det fanst ein annan definisjon av å vere kristen; å vere «kristeleg», som skapte eit skilje mellom dei kristelege og dei andre «vanlege kristne». Dette skiljet blei på mange måtar skapt av vekkingskristendomen og bedehuskulturen som, då den oppstod, representerte eit oppbrot frå den kollektive kristendomsforma.

Går vi eit par hundre år tilbake var Noreg prega av ein religiøs einskapskultur. Kyrkje-medlemskap var nærmast ein del av samfunnsmedlemskapet. Som medlemmer av ein kristen nasjon med statskyrkje var nordmenn kristne. Nattverdsgang var til dømes pliktig (Sandvik, 1998). Det var vanleg å gå to gonger i året, nattverdsplikta var først oppheva tidleg på 1900-talet. Presteskapet hadde også mange offentlege funksjonar som varte lenge ut over på 1900-talet, som å skrive ut dåpsattest, som var den tida sin fødselsattest.

Det var dette samfunnet og denne religiøse kulturen vekkingane og bedehuskristendomen representerer eit brot med. Bedehusfolket ser ofte på Hans Nielsen Hauge som sin åndelege far. Han braut med kyrkja sitt religiøse monopol ved å trasse den sokalla konventikkelplakaten, som var ei lov som forbaud lekfolk å halde religiøse samlingar utan løyve av presten. Lova vart oppheva i 1842, og framveksten av bedehuskristendomen er såleis også ein viktig del av kampen for forsamlingsfridom.

Lekfolket sine første religiøse samlingar var i heimane, men etter kvart dukka behovet for eigne forsamlingshus opp. Det første bedehuset vart reist midt på 180o-talet, og bedehusbygginga skaut for alvor fart mot slutten av hundreåret. Sjølve husa var gjerne enkle bygg. Dei vart reiste gjennom dugnad og innsamling. Det kom mange hus, og dei kom fort. Ingen veit sikkert kor mange bedehus som er bygd i Noreg, men basert på ei registrering frå 1972 er det vanleg å rekne med ca. 3000 bedehus (Årbok for Den norske kyrkje, 1974, s. 74-78). Dette er til samanlikning nesten det doble av talet på kyrkjer.

Dei nye kristne fellesskapa som i starten kunne vere meir uformelle fellesskap, blei etter kvart formelle organisasjonar, først for ytremisjon og seinare også for indremisjon. Det siste var mest kontroversielt. Ein ting var å dra til fjerne land for å fortelje heidningar om Jesus, meir provoserande var det å seie at også sambygdingar trong omvending. 


\section{Kjenneteikn ved omvendingskristendomen}

Kva var forskjellen mellom den gamle og den nye forståinga av å vere kristen? Dette er eit komplekst skilje som er blitt omtalt og analysert med ulike omgrep. Ein måte å beskrive dette på er ei forandring frå kyrkjeleg sakramentkristendom til ei meir individualistisk og subjektiv kristendomsform (Ropeid, 1984). I den kyrkjelege sakramentkristendomen var det å vere kristen å tru på Gud og å bruke kyrkja sine sakrament og ritual, særleg ved høgtider. Ein kunne kanskje kalle det ein ritual- og høgtidskristendom. For den nye forståinga av kristendomen var ikkje dette nok. Kristen var ikkje noko ein var, men noko ein kunne bli gjennom å vedkjenne synder og ta imot frelsa i Kristus. Derfor kunne denne kristendomsforma også omtalast som «omvendingskristendom» til skilnad frå «oppsedingskristendom». Ein var ikkje rett kristen sjølv om ein hadde fått ei kristen oppseding, var døypt og gjekk i kyrkja. Å bli kristen kravde eit personleg val, derfor vart dei som hadde teke dette valet ofte også omtalte som «personleg kristne». Denne vendinga mot det meir individuelle og personlege kom ikkje berre frå vekkingskristendomen, det var ei endring som låg i tida, en del av eit moderne oppbrot. Kyrkjehistorikar Bjørn Sandvik bruker eit eksempel frå Ibsen sitt drama Et dukkehjem (1879) for å vise korleis religionen ikkje lenger er ei kollektiv sanning, men er blitt ei personleg sak. Det er ei replikkveksling like før Nora er i ferd med å forlate heim, mann og barn. Mannen Helmer prøver å tale ho til rette ved å minne ho på at ho har religionen som ein «usvikelig veileder», men Nora svarer at ho ikkje lenger veit «riktig kva religionen er» eller «iallfall om det er riktig for meg» (Sandvik, 1998, s. 14).

Å bli «personleg kristen» innebar ei individualisering og inderleggjering av det religiøse. Avgjerdsla om å bli ein «personleg kristen» skjedde ofte gjennom vekkingar der mange omvende seg samstundes (Seland \& Aagedal, 2008). Det kunne heite seg at «heile bygda blei omvendt». Dette var nok ei overdriving, men det finst døme på at mange i ei bygd kunne «bli med». Vekkingane forkynte ein dramatisk dualistisk religion om to ulike utgangar av tilværet: frelse eller fortaping. Den einskilde sin lagnad blei avgjort gjennom kva veg ein valde. For nokre kunne ei omvending berre representere ei kortvarig forandring der ein fort vende tilbake til 
«det gamle livet». Men for mange blei det ei hending som forandra dei for godt; korleis dei såg på seg sjølv og brukte livet sitt. Det tydde også ei intensivering av den einskilde si religionsdyrking i form av personleg bøn og bibellesing.

Medan forkynning tidlegare hadde vore ei oppgåve berre for prestar, blir det no ei oppgåve også for lekfolk utan særskild utdanning eller vigsling. Nokre vart lekpredikant på deltid ved å kombinere forkynnargjerning med eit anna yrke, som til dømes å vere bonde vår, sumar og haust, og predikant om vinteren. Andre blei fulltids omreisande emissærar. I stabile bygdesamfunn med få andre tilreisande var desse eit innslag i det sosiale livet som blei lagt merke til og omtalte. Nokre av dei blei si tid sine kjendisar som blei både beundra og forakta. Dei fleste emissærane kom frå folket utan akademisk utdanning, kjende tilhøyrarane sin livssituasjon og hadde ofte ein folkeleg stil. I kyrkja hadde ein vore vant med at det heilage vart omtalt i eit høgtidleg og offisielt språk, men fleire av lekpredikantane tok i bruk dialekt og oppdaga et det kunne vere eit «hjartespråk» som trefte kjenslene til tilhøyrarane meir direkte. Forkynnarane hadde også eit «uakademisk» forhold til Skrifta, dei brukte Bibelen på sin måte, selektivt og bokstavleg. Dei forkynte til omvending. Det vart også forventa at dei omvende tidleg skulle å stå fram og vitne om si nye tru. Å vere personleg kristen var ikkje noko ein kunne halde for seg sjølv, å vere personleg kristen var også å vere ein «vedkjennande kristen». Dette kunne skje offentleg ved at ein reiste seg på bedehuset og vitna om si synd, si frelse og sitt nye liv. Denne nye talesjangeren fekk også sosiale og politiske konsekvensar. Mange lærte å ta ordet offentleg, ein kunnskap ein kunne ta med seg inn i andre organisasjonar og samanhengar.

\section{Eksklusiv eller inklusiv? Omvendingskristendomen og omverda}

Rørsler som bryt ut og vil skape noko nytt, møter utfordringar når dei skal ta vare på det nye og overleve. Det er mange måtar å møte slike utfordringar på, men i denne samanhengen vil vi snakke om to hovudstrategiar: ein sektstrategi og ein erobrings- og tilpassingsstrategi. Sektstrategien 
handlar om å ta vare på det nye ved å verne det gjennom isolasjon og tilbaketrekking. Erobrings- og tilpassingsstrategien handlar om å forandre omgjevnadane i tråd med rørsla sine ideal, og/eller å tilpasse seg ved å forhandle og inngå kompromiss med omgjevnaden (Aagedal, 2003, s. 468-502).

I kulturlivet sin omtale av bedehuskristendomen har ein ofte fokusert på sekteriske trekk. Det finst mange døme på skjerming og tilbaketrekking frå arenaer og aktivitetar som folk flest elles var med på. Det gjeld til dømes forholdet til kunst og kultur og underhaldning og livsstil der bedehusfolket har markert seg gjennom skepsis og motstand mot teater, film, dans og alkoholbruk. Dette kunne ha som konsekvens at bedehusfolket heldt seg unna fleire av dei arenaer som folk flest deltok på og såleis kunne få likskapstrekk med det som på folkemunne blir omtalt som «sekt».

Men saman med desse ekskluderande trekka fanst det også mykje av det vi har kalla erobrings- og tilpassingsstrategi i denne rørsla. I denne artikkelen skal vi særleg sjå nærare på nokre av dei inkluderande trekka ved den norske bedehuskulturen. Det blir vanskeleg å forstå den utbreiinga og sentrale plassen som denne kulturen kunne få i norske bygdesamfunn utan å ha med denne dimensjonen i lekmannsrørsla. Det gjeld ikkje minst vekkingskristendomen sin plass på Nordvestlandet og i den bygda kor eg opplevde samtalen om å vere kristen eller kristeleg.

For det første hadde vekkingskristendomen inkluderande trekk i forholdet til den organiserte majoritetsreligionen i samfunnet. Det var ikkje slik at vekkingane fjerna den kollektive kyrkjelege religiøsiteten. Majoriteten av befolkninga blei framleis verande innanfor statskyrkja, og det galdt også bedehusfolket. Det blei eit kjenneteikn ved den norske vekkingskristendomen at den blei ei rørsle innanfor statskyrkja, i motsetning til religiøse minoritetar som braut ut og organiserte seg i eigne trussamfunn. Det tyder også at bedehusfolket har brukt Den norske kyrkja sine livs- og dødsritual, og, om enn i varierande grad, slutta opp om søndagsgudtenestene. Dei har også mange stader prøvd å prege denne kyrkja ved å involvere seg i kyrkjestyret. I ein analyse av soknerådsmedlemmene over ein 50-årsperiode i tre bygder på Sørvestlandet viste 
resultata at to av tre soknerådsmedlemmer var bedehusfolk (Aagedal, 2003, s. 391). Den kristne lekmannsrørsla var også tidleg ute med å skape si eiga presteutdanning gjennom Menighetsfakultetet i 1907, og alt få år seinare (frå 1920) var det denne institusjonen som utdanna flest prestar i Noreg. Dette endra også den geistlege standen som hadde vore dominert av embetsmannssøner ved at ungdom med bygde- og bondebakgrunn no vart prestar.

På det politiske feltet ser vi noko av det same. Bedehusfolket var opptekne av å prege både lokalsamfunnet og nasjonen med sine verdiar, og engasjerte seg i politikk. Ei kartlegging av kommunestyra i dei tre bygdene eg nemnde viste at kvar fjerde kommunestyrerepresentant var bedehusmann eller bedehuskvinne (Aagedal, 2003, s. 366). Bedehusfolket engasjerte seg først og fremst gjennom Kristeleg Folkeparti, men også i andre parti i det politiske sentrum og i alliansepolitikk i samband med folkerøystingar om norsk EU-medlemskap.

På skolefeltet kom erobringsstrategien til uttrykk ved at ein ikkje trekte borna ut av grunnskolen og starta sitt eige skolelalternativ, men i staden prøvde å prege den offentlege skolen gjennom lærarutdanning og politisk arbeid for å påverke målsettingsparagraf og timetal i kristendomsfaget.

Som vi har vore inne på, hadde bedehuset ei avvisande haldning til «underhaldningskultur» som kino, revy og teater. Avvisinga kunne vere absolutt, slik Ivar Grimstad fortel frå ein diskusjon der den mest stridbare debattanten avslutta diskusjonen med replikken: «Det er ikkje noko å diskutere eingong - sjølve ordet teater fortel oss at det er synd» (Grimstad, 1986, s. 216). Men det finst også eksempel på at ein var villig til å inngå kompromiss. I ei bygd med eit aktivt revymiljø såg det dårleg ut for den komande bygderevyen fordi fleire av aktørane og dei potensielle tilhøyrarane var blitt med i ei vekking på bedehuset og dermed var i ferd med å trekke seg frå revyen. Men problemet vart løyst ved at ein forhandla seg fram til eit kompromiss der dei kunne vere med dersom årets revy var utan «bannskap og kjønnsliv» (Aagedal, 2003, s. 313).

Når det gjeld forholdet til sambygdingar, har bedehuset ofte blitt kritisert for å fungere som eit eksklusivt, sektliknande fellesskap med 
dyrkinga av «venesamfunnet» i «småmøta» som var lite tilgjengelege for dei som ikkje høyrde til i den «indre kretsen». Men det høyrer også med til biletet at det fanst eit større, meir inklusivt bedehusfellesskap der bedehuset var samlingsplass for lokalmiljøet. I bygder der bedehuset kunne vere einaste forsamlingshuset og det elles ikkje var så mykje å gå på, kunne vekkingar fungere som underhaldning for dei som sat på galleriet og kunne følgje dramaet nede i salen på trygg avstand. Men denne avstanden var ikkje alltid meir trygg enn at dei som sat på galleriet kunne bli råka av predikanten sine kall til omvending. I vitnemåla på bedehuset kunne ein høyre dei «frelste» fortelje om si omvending som «då dei kom ned frå galleriet». Slik kunne galleriet både fungere som underhaldingstribune for bygda, og som misjonsmark for bedehusfolket. I tillegg kunne bedehuset gjennom basarar og juletrefestar fungere som storstove for bygda. På denne måten blei bedehuset ein del av oppvekstmiljøet også for barn og vaksne som ikkje kom frå «bedehusfamiliar».

\section{Teoriar om norsk religiøs geografi Geografisk avgrensing}

Så langt har vi sett på trekk ved vekkingskristendomen og bedehuskulturen nasjonalt. Men dette er ei kristendomsform som har vore ujamt fordelt geografisk, den har stått sterkare i nokre område av landet enn i andre. Korleis kan Nordvestlandet plasserast i denne samanhengen? Samtalen eg fortalde om i innleiinga om kven som var «kristeleg» til skilnad frå «kristen», tyder på at det fanst ulike kulturar og oppfatningar på dette området. Kor sterkt står det «kristelege» og det «kristne», kva plass har «bedehuskulturen», og korleis er lekmannsrørsla sitt forhold til Den norske kyrkja og til andre folkerørsler i dette området? Dette er nokre av dei spørsmåla vi skal sjå nærare på i det følgjande. Men først må eg gjere nokre metodiske avgrensingar når det gjeld område og datagrunnlag. Ei rimeleg geografisk avgrensing av Nordvestlandet kan vere fylka Sogn og Fjordane og Møre og Romsdal. Eg vil primært avgrense meg til mitt heimefylke, Sogn og Fjordane, og dei fleste eksempla vil 
vere henta frå Nordfjord. Det er fleire grunnar til denne fokuseringa. Det er dette området eg kjenner best gjennom eigne oppveksterfaringar. Dessutan er Nordfjord eit område der vekkingar og bedehuskultur er dokumentert og analysert gjennom ein annan studie i denne boka som eg vil trekke inn (Tjomsland, 2018; Tjomsland, 2019). Rammene for denne artikkelen tilseier at det ikkje kan bli ein omfattande og grundig analyse, men ei eksemplifiserande framstilling om «fjordingar» sitt forhold til kyrkje og bedehus.

\section{Religiøse skiljeliner mellom Austlandet og Vestlandet, og mellom kyst og fjord og fjell (Gabriel Øidne)}

Fleire historikarar og samfunnsforskarar har registrert at det har vore store regionale skilnader i Noreg når det gjeld det religiøse livet. Vi skal nemne eksempel på nokre av dei mest kjende inndelingane og forklaringane på desse skiljelinene. (For den som er interessert i ei meir inngåande skildring og drøfting av desse skiljelinene, viser eg til ein komande artikkel av historikaren Bjørg Seland om «det norske bibelbelte» (Seland, 2020).

Den mest kjende framstillinga om dette teamet er historikaren Gabriel Øidne sin artikkel om motsetninga mellom Austlandet og Vestlandet (Øidne, 1986). ${ }^{1}$ Han dokumenterer religiøs oppslutning ved å sjå på variasjonar i misjonsgåver og utbreiing av misjonsforeiningar og religiøse blad. Desse opplysningane blir samanlikna med data om stemmefordeling ved stortingsval og folkerøystingar om brennevinsforbod (i 1919 og 1926). På grunnlag av desse opplysningane meiner han at ein kan skilje mellom tre ulike religiøse kulturregionar:

Øidne sin artikkel vart opprinneleg trykt i tidsskriftet Syn og Segn i 1957. Mine referansar til artikkelen viser til opptrykket av artikkelen i artikkelsamlinga Bedehuset. Rørsla, bygda, folket frå 1986. 
- «Den mørke kyststripa», som er dei pietistiske kystbygdene på Sørog Vestlandet

- «Fjell og fjord-Noreg», som er den frisinna folkehøgskoleregionen prega av meir kulturopen kristendom, lokalisert til fjell- og fjordbygder

- Det indre Austlandet, som eit område prega av «religiøs indifferens», eit område som «religiøst sett kan samanliknast med ei øydemark med berre spreidde oasar» (Øidne, 1986, s. 43)

\section{Områda for «assosiasjonsbølgja» og restar av gamal einskapskultur (Hans Try)}

Historikaren Hans Try har brukt omgrepet «assosiasjonsånd» når han ser på framveksten av foreiningsverksemd (Try, 1986, s. 15-37). Han viser at kristelege foreiningar er ein del av ei breiare assosiasjonsbølgje på 180o-talet, men at dei kristelege er tidleg ute.

Alt i 1870-åra hadde det foreiningskristelege Norgeskartet fått sine hovuddrag: Brei og sterk lekmannsdominert kristeleg foreiningsverksemd på Sørlandet og det meste av Vestlandet, til dels så sterk at normsystemet prega heile lokalsamfunnet også langt inn i flokken av «uomvende». Foreiningane hevda sjølvstende andsynes kyrkje og prest, men hadde likevel dominerande hemningar mot å bryte med kyrkja. (Try, 1986, s. 35)

Det var mange spenningar mellom den offisielle kyrkja si verksemd og vekkingskristendomen. Når det gjeld forklaringar på kvifor denne i så stor grad blei verande innanfor statskyrkja, meiner Try at det kan henge saman med at det i dei deler av landet der den innomkyrkjelege vekkingskristendomen fekk særleg feste, fanst trekk av gamal einskapskultur: «Men vi vågar oss frampå med ein påstand om at ein på Vestlandet lengst fann drag av det noen vil kalle ein gamal einskapskultur, ei holdning der ein mellom anna i høgare grad enn austpå, oppfatta lokalsamfunnet som ei eining» (Try, 1986, s. 35$)$. 


\section{Bedehuskulturen og andre motkulturar (Stein Rokkan)}

Statsvitaren Stein Rokkan har arbeidd vidare med mange av dei same problemstillingane som Øidne gjennom analyse av motsetningar mellom sentrum-periferi og omgrepet «motkultur», som blir brukt til å forklare regionale skilnader i røystegjeving ved politiske val (Rokkan, 1987). Han legg vekt på at mindre klasseskilnader på Vestlandet enn på Austlandet (mellom anna ved meir jamstore bruk og mindre utbreidd husmannsvesen på Vestlandet) har skapt veikare grunnlag for politisk mobilisering basert på klasse på Vestlandet. Dette meiner han kan forklare den lågare oppslutninga om Arbeiderpartiet på Sør- og Vestlandet. Viktigare for den politiske mobiliseringa i denne regionen har vore dei sokalla motkulturane: målsak, fråhaldssak og lekmannskristendom, som har fått sør- og vestlendingen til å stemme sentrumspartia og skapt kjerneområde for Kristeleg Folkeparti.

\section{Bedehuskulturen som rural religiøs kultur (Jon Knudsen)}

Fleire forskarar har vore opptekne av at bedehuskulturen fekk sterkast nedslag i bygdene, og at det er trekk ved denne kulturen som ser ut til å høve særleg godt i bygdesamfunn (Ropeid, 1986). Samfunnsgeografen Jon Knudsen har samanlikna utbreiinga av «frikirkelighet» med utbreiinga av bedehuskristendom og finn at den frikyrkjelege vekkingskristendomen slo sterkast gjennom i byane, medan vekkingskristendomen som ikkje braut med statskyrkja, fekk mest rotfeste i bygdene (Knudsen, 1986). Han finn også ein skilnad mellom næringar der bedehuskristendomen har sterkast oppslutning frå personar i primærnæringane, og mindre frå sekundær- og tertiærnæringar.

\section{Faktorar som gav grobotn for bedehuskristendom}

Ulike faktorar er blitt nemnde for å forklare desse regionale religiøse skilnadane. Vi har alt vore inne på større egalitet på Vestlandet som ei 
mogeleg forklaring på at ein i ei bygd kunne samle seg om andre saker enn økonomisk kamp. Try set fram påstanden om at Vestlandet har meir av ein gamal einskapskultur som held lokalmiljøet saman og held vekkingsrørsla innanfor den statskyrkjelege ramma. Øidne nemner også geografisk plassering i forhold til kontakt med omverda, som ei forklaring på vekkingskristendomen si sterke stilling i kystområda på Vestlandet. Dei kystnære områda hadde mest oversjøisk kontakt med Storbritannia og USA, der vekkingskristendom stod sterkt. Det dreiar seg med andre ord om faktorar som migrasjon, ruralitet, egalitet, einskapskultur og kollektiv kyrkjeleg religiøsitet som var med og bestemte omfanget og forma på vekkingskristendomen i området.

\section{Sogn og Fjordane og «bibelbeltet»}

Korleis kan vi plassere Sogn og Fjordane i forhold til det vi har hevda er faktorar som gjev grunnlag for bedehuskulturen?

«Ruralitet»: Fleire forskarar har hevda at bedehuskulturen lettare får nedslag i bygd enn i byen. I så måte ligg tilhøva vel til rette i dette fylket, for Sogn og Fjordane har lenge skilt seg ut som eit av dei mest rurale fylka i Noreg. ${ }^{2}$ Fylket har i hovudsak bestått av mange små bygdesamfunn, få tettstader og ingen større by. Primærnæringar som jordbruk og fiske har hatt brei plass, industrialisering av vore avgrensa til nokre få tettstader, særleg basert på kraftkrevjande industri.

«Egalitet»: Gardane har som oftast vore små og nokså jamstore. Husmannsvesenet har vore lite utbreidd, bygdekulturen har vore prega av relativ egalitet som kan gje grunnlag for lokal samling om andre verdiar og interesser. Sentrumspartia har hatt stor oppslutning, arbeidarrørsla og Arbeiderpartiet har stått svakt.

«Motkulturar»: Fylket ligg innanfor ein region der «assosiasjonsånda» og foreiningskulturen har stått sterkt. Det gjeld ikkje berre lekmannsrørsla

https://www.ssb.no/184399/folkemengde-i-tettbygde-og-spredtbygde-strøk.fylke.1.januar 
(både Øidne og Try plasserer fylket innanfor bibelbeltet), men også dei andre motkulturane. Når det gjeld målsak, er vi i nynorsken sitt kjerneområde. Sogn og Fjordane er det store nynorskfylket der alle kommunane har hatt nynorsk som offisielt målføre. ${ }^{3}$ Dette er også truleg (saman med Møre og Romsdal) eit av dei fylka der den frilynde ungdomslagsrørsla har stått sterkast. Eit fylkeslagskart frå 1926 over frilynde ungdomslag viser 146 registrerte foreiningar i Sogn og Fjordane, mot til samanlikning 42 i Vest Agder (Dyrnes, Hals \& Kløvstad, 1986, s. 4). Oppslutninga om det nasjonale kjem også til uttrykk ved at dette fylket (saman med Nordland) er det fylket der bunader har vore er mest utbreidd. Høg oppslutning om alkoholforbod ved forbodsvala tyder på at fråhaldssaka har stått sterkt (Øidne, 1986, s. 45). Fråværet av bykultur med skjenkestader og polutsal har lenge truleg gjort at det har vore mindre tilgangen til alkohol.

«Migrasjon og kulturkontakt»: Sogn og Fjordane er eit fylke som strekker seg mellom kystbygder og det Øidne har kalla «Fjell- og Fjord-Noreg». Såleis skulle det gje grobotn for ekstern kontakt med pietistisk vekkingskristendom i kystområda og ein meir frilyndt og kulturopen kristendom $\mathrm{i}$ indre fjord- og fjellbygder.

Det finst ikkje nokon samla studie av vekkingar og bedehus i Sogn og Fjordane, men det ser ut til at fylket er prega av fleire av dei faktorane vi har sagt gjev grobotn for bedehuskultur. I eit av områda i fylket, Nordfjord, er desse forholda meir dokumentert og analysert (Tjomsland, 2018; Tjomsland, 2020). Det er også dette området eg kjenner best frå min eigen oppvekst. I fortsetjinga vil eg derfor fokusere på dette området, men det er viktig å presisere at Nordfjord på nokre dimensjonar skil seg frå resten av fylket. Når det gjeld organisering av misjonsarbeidet og forholdet mellom lekmannsrørsle og kyrkje, er det tydelege variasjonar i fylket. I Sogn og Sunnfjord er organisasjonsbiletet samansett med sterke innslag av dei kyrkjekritiske organisisjonane Indremisjonsforbundet og Misjonssambandet. Nordfjord er den delen av fylket som er mest prega av ei kyrkjepositiv lekmannsrørsle med Indremisjonsselskapet (seinare 
fusjonert i Normisjon) og Ungdomsforbundet. Den kyrkjepositive haldninga gjeld ikkje minst den bygda eg bruker som eksempel i det følgjande.

\section{Lokalt nærbilete: omvendingskristendom og kyrkjekristendom i ei fjordbygd på 1950- og 1960-talet}

\section{Ei fjordbygd i Nordfjord}

Frå den nasjonale og regionale drøftinga av vekkingskristendom går vi no ned på det lokale planet og til den bygda der spørsmålet om kven som var «kristeleg» blei reist. Korleis kan kjennskapen til religiøse kulturar nasjonalt bidra til å forstå det som skjedde lokalt? Og korleis kan dette lokale eksempelet bidra til å forstå forholdet mellom kyrkje, lekmannsrørsle og lokalsamfunn? Bygda vi skal til, er Vereide, ei lita fjordbygd i Nordfjord der eg vaks opp på 1950- og 1960-talet. Vereide var ei bondebygd, dei fleste levde av jordbruk og fruktdyrking. Fleire dreiv også med pelsdyravl. Det var ingen industri i bygda. Slik sett høvde bygda godt inn i det biletet vi har teikna av det rurale og relativt egalitære Vestlandet. Vereide var ein skolekrins med tredelt skole. Bygda hadde eit bakeri med butikk, og der låg også postkontor og telefonsentral. Næraste tettstad, som var kommunesenter og skolesenter med vidaregåande skole, låg sju kilometer unna. I bygda låg det også ein kristen folkehøgskole der far min var rektor.

\section{Kyrkjeleg religiøsitet og høgtidskristendom}

Vereide kyrkje er ei gamal steinkyrkje som ligg ved fjorden slik det var vanleg frå den tida sjøen var viktigaste ferdselsåra. Som i dei fleste andre vestlandsbygder på denne tida var oppslutninga om statskyrkja og kyrkja sine seremoniar massiv. Kameraten min hadde god dekning for å seie at «vi er no alle døypte». Han visste truleg også at om få år ville vi alle bli konfirmerte og gå til nattverd. Når det galdt konfirmasjon og nattverd var den kollektive kyrkjelege tradisjonen særleg sterk og varte lenger enn mange andre stader i landet. Då eg vart konfirmert i 1960, var det berre 
eitt alternativ, vi måtte love å «forsake Djevelen og alle hans gjerningar». Og måndagen etter konfirmasjonssøndagen var det «konfirmantaltergang» der det var forventa at alle konfirmantane skulle til nattverd saman med foreldra. Mange av foreldra hadde truleg ikkje gått til nattverd sidan dei sjølve var konfirmantar. Å bruke kyrkja sine ritual og seremoniar sjeldan og berre ved visse høve i livet er elles typisk for det vi har omtalt som den kollektive kyrkjelege tradisjonen. Eg hugsar også frå bygda at ein bonde følgde opp den gamle kyrkjeleg tradisjonen med å skrifte og gå til nattverd ein gong i året i påska, slik at nattverdsgang også fekk karakter av årsrite.

Andre kyrkjelege årsritar som hadde høg oppslutning, var kyrkjegang første juledag og 17. mai. På slike høgtidsdagar kunne soknepresten sjå ut over ei fullsett kyrkje og seie: «Kjære bygdefolk, kjære kristne», ei helsing som kunne oppfattast som ei stadfesting av at alle i bygda var kristne. På 17. mai kunne han sjå ut over ei bunadskledd forsamling, og det kunne han også på konfirmasjonssøndagen, for i dette «bunadsfylket» var det vanleg at jentene hadde bunad som konfirmasjonsdrakt. Når det galdt høgtidsgudstenesta på 17. mai, gjekk denne inn i den felles nasjonaldagsfeiringa, og det var tradisjon at også russen (dei som var i stand til det) deltok i gudstenesta ved å gå i prosesjon inn i kyrkja og sitje lengst framme.

\section{Skolen og «klokkar-læraren»}

At kyrkjekristendomen var ein del av felleskulturen i bygda, vart mellom anna stadfesta ved at skoledagen starta med at vi reiste oss og song eit salmevers. Det kom også fram ved at lærarrolla var ei rolle som, når det galdt religion, handla om noko meir enn læring av faktakunnskap. Til denne rolla var det forventningar om også utanom skoledagen å vere med og støtte opp om nasjonale og religiøse verdiar, slik det er blitt skildra i prosjektet «Vestlandslæraren» (Høydal, 1995). «Som målmenn, avholdsmenn og venstremenn - frilynte eller pietister - var lærerne folkeførere i sin tid» (Slagstad, 1998, s. 106). Som i mange andre bygder var kombinasjonen av å vere lærar og klokkar vanleg, både systera mi og eg hadde «klokkar-lærarar». 


\section{Kvinneforeiningar og «basarkalender»}

Vereide var ei bygd prega av «assosiasjonsånd» med eit rikt foreiningsliv. I dette foreiningslivet hadde misjonsforeiningane ein sentral plass, og misjonsforeiningar ville på denne tida i praksis seie kvinneforeiningar. På 1950- og 1960-talet var dei fleste kvinnene i denne bygda gardskoner eller heimeverande husmødrer, og når morgonarbeidet var ferdig i føøset og på kjøkkenet, kunne ein samlast til foreiningsmøte som gjekk på rundgang i heimane. Så godt som alle kvinnene i bygda var med i ei eller fleire foreiningar. På foreiningsmøta sydde og strikka ein gevinstar til den årlege basaren. Det var mange foreiningar så det blei det mange basarar å ta omsyn til, men kvar foreining hadde ein fast laurdag i året. (Sidan dette var før fjernsynet si tid, var det ikkje problem å ha basarane på laurdagen.) Det var også ein tradisjon for at ein skulle støtte basarar for foreiningar ein ikkje deltok i sjølv. Sidan det kunne bli mange basarar å gå på, var det tradisjon å sende loddpengar med andre når ein ikkje kunne gå sjølv.

\section{Ungdomshuset var bygda sitt forsamlingshus}

Basarane var i bygda sitt einaste forsamlingshus, «Haugtun», som tilhøyrde det frilynde ungdomslaget i bygda. «Haugtun» var eit tradisjonelt ungdomshus med ein sal med scene. Huset hadde eit inngangsparti med garderobe med luke inn til salen, fordi garderoben også fungerte som maskinrom for Bygdekinoen når den kom på vitjing. Frå gangen gjekk trapp opp til galleriet og ned til matsal og kjøkken. Bygningsmessig var huset berre ein arena. Men sidan huset, som bygda sitt einaste forsamlingshus, hadde mange ulike brukarar og bruksmåtar, kan ein også seie at det blei eit hus med mange «kulturarenaer»; frå dansesal og kinosal til juletrefestsal og basarsal. Basarane famna også over ein vid skala kulturelt og religiøst; frå den «verdslege» Redningsselskaps-basaren (med film) til ytre- og indremisjons-basarar (sjeldan med film, men med forkynnande talar). Ungdomshuset blei, som bygda sitt forsamlingshus, eit hus dit så godt som alle gjekk. Det var bygda si storstove, eller «bygdefolket sin pub», som ein av prestane uttrykte det. Men folket i bygda brukte det på ulike måtar, alt var ikkje like legitimt 
for alle å delta på. Slik blei også huset eit symbol på spenningar i bygdekulturen og på det som skilde. Hadde dei omvendingskristne stått for ein sektstrategi, ville dei ikkje ha delteke på arrangement i eit hus som inneheldt aktivitetar som var i strid med deira lære (som dans og kino). Men dei valde ikkje denne reaksjonen. Dei valde heller det ein kan kalle eit kompromiss mellom inklusivitet og eksklusivitet, ved at ein deltok på mykje av det som skjedde på huset, men ikkje på dei arrangementa og aktivitetane som stridde mot deira overtyding. Å gå på basar på ungdomshuset var rett, å gå på dans på ungdomshuset var urett og synd.

\section{Folkehøgskolen med både omvendingskristendom og kulturkristendom}

Sjølv om ungdomshuset, i tillegg til kyrkja, var bygda sitt einaste forsamlingshus, fanst det også andre lokale som kunne brukast til foreiningsog møteverksemd. Eit av dei var skolehuset der skolehuskjellaren vart brukt til dei vekkingskristne sine oppbyggingsmøte og til kristent barneog ungdomsarbeid, som søndagsskole og «Yngres». I tillegg var Nordfjord Indremisjon sin kristne folkehøgskole (kalla «Ljosborg») lokalisert i bygda, og her kunne det vere møte og stemne som også folk frå bygda kunne gå på. Skolen låg i «religiøse» omgjevnader med gravhaugar og prestegard som naboar og kyrkja berre nokre hundre meter unna. Som skole eigd av det «kyrkjepositive» Indremisjonsselskapet hadde skolen eit positivt forhold til kyrkjekristendomen. Rektor og lærarar gjekk ofte i kyrkja og oppfordra elevane til å gjere det same. Ved store stemne vart det gjerne også lagt gudstenester til kyrkja. Eksempel på dette er dei årlege haustmøta då ein hadde nattverdsgudsteneste i kyrkja på laurdagskvelden. Til desse stemna kunne det på 1950- og 1960-talet kome opptil 800 «misjonsvener» frå heile Nordfjorden (Tjomsland, 2018; Tjomsland, 2020). Dette var ei tid då det var heller uvanleg å reise ut av bygda, og for mange kunne dette vere årets «utflukt». På denne tida var også skolen eit utdanningsalternativ for mange ungdomar frå Nordfjord, enten som eit alternativ til gymnas/vidaregåande utdanning, eller som ei førebuing til vidare skolegang. 
Skolen stod klårt i ein vekkingskristen tradisjon der å vere kristen var å bli ein personleg og vedkjennande kristen. Dette vart formidla gjennom andaktar, forkynning frå talarar som kom på vitjing, og gjennom skolen sine faste vitnemøte. Tjomsland har omtalt skolen som ein slags regional vekkingsinstitusjon der misjonsfolket prøvde å få ungdomen til å ta eit «år på Ljosborg», med også den baktanken at dei gjennom dette året kunne bli personleg kristne (Tjomsland, 2018; Tjomsland, 2020). Mange elevar kunne også fortelje i ettertid at skoleåret vart eit vendepunkt for dei religiøst. Men samstundes var skolen ikkje ein «rein bibelskole». Den var også ein skole som sette allmenn teoretisk og praktisk kunnskap høgt, og som underviste i norsk, rekning, husstell, veving, sying, sløyd og metallsløyd. I tillegg til vekkingskristendom var skolen også prega av det ein kan kalle «kulturkristendom» og eit vidare danningsideal der den nasjonale kulturarven i litteratur og musikk blei verdsett. Denne verdsettinga av kulturarv hadde samstundes mykje av vekkingskristendomen sin tradisjonelle skepsis mot «underhaldningskulturen». Dans var synd; det blir fortalt at når elevane fekk høyre på Ønskjekonserten på måndagskvelden, var det saman med ein lærar som skulle passe på at dei ikkje dansa. Kortspel var ikkje lov, kortstokkar vart beslaglagde. Teater og film var heller ikkje bra, filmunderhaldning vart avgrensa til filmar med kristen tematikk, dyre- og naturfilmar eller idrettsfilmar. Som Tjomsland har påpeikt, vart denne kontrollerande «filmpolitikken» vanskeleg å handheve ut over på 1960-talet når fjernsynet kom og det vart vanleg (også hjå skolen sine tilsette) å ha fjernsyn i heimane.

\section{Bygd utan bedehus og vekking}

Ein måte å skilje ut kven som er «kristeleg» på, har ofte vore å sjå kven som går på bedehuset. I tette bygdesamfunn er dette eit synleg kjenneteikn som gjer at det nærmast er eit offentleg faktum kven som er bedehusfolk og tilhøyrer dei «kristelege» (Aagedal, 2003 s. 361-362). Ein faktor som gjorde det vanskelegare å skilje ut dei «kristelege» i denne bygda, var at bygda ikkje hadde bedehus. Mangel på bedehus kan både forståast som ein konsekvens av ein «einskapsprega» religiøs bygdekultur, og som ein faktor som bidrog til å oppretthalde denne kulturen. Ambivalensen 
mellom religiøs inklusivitet og eksklusivitet viste seg ved at ideen om å bygge bedehus fanst, men aldri blei realisert. Ideen kom til uttrykk gjennom ei av dei kvinneforeiningane som mor vår var med i og som kalla seg «bedehusforeininga». Denne foreininga arrangerte årleg basar til inntekt for reising av bedehus. Men dette bedehuset blei aldri bygd, det blei eit «bedehus på bankbok». Det er nærliggande å oppfatte dette som eit uttrykk for ein vekkingskristen kultur i bygda, som ikkje hadde nok støtte til å realisere prosjektet. Det kunne vere fordi det ikkje hadde brei nok støtte i bygda, og kanskje også fordi dei «omvendingskristne» var i tvil om kor nødvendig og riktig det var å satse på bedehus i denne bygda. Dette kan igjen ha samanheng med ein sterk kollektiv kyrkjeleg tradisjon. I artikkelen «Bygda som ikkje fekk bedehus» har eg vist korleis bedehusplanar i ei bygd med ein dominerande folkekyrkjeleg kultur aldri blei realiserte, men i staden slusa inn i eit kyrkjeleg byggeprosjekt (Aagedal, 1986, s. 75-87).

Eit anna kjenneteikn ved denne bygda som truleg bidrog til å gjere skilje mellom dei kristelege og resten av bygda mindre synleg, er at det, så langt eg kjenner til, ikkje skjedde noko vekking i bygda i min oppvekst. Heller ikkje Tjomsland, som har laga ein oversikt over vekkingar i Nordfjord, har registrert noko vekking i bygda. Dermed blir dette bygda med «vekkingskristne» og «bedeshuskristne», men utan vekking og bedehus. Når det gjeld forholdet mellom vekking og bedehus, er det litt som høna og egget når det gjeld kva som kjem først: Vekking kan vere utgangspunkt for bedehusbygging, og eit bedehus kan vere arena for vekking. På den eine sida kan dette registrerast som ein mangel og som eit handikap for vekkingskristendomen. På den andre sida kan det registrerast som ein kontekst som mogeleggjorde eit samspel og ein syntese mellom vekkingskristendom, kollektiv kyrkjekristendom og lokal kultur på 1950- og 1960-talet.

\section{Indremisjonsfolket mangla kontrollnøkkelen}

At denne bygda berre hadde eitt forsamlingshus og at dette var eit ungdomshus, var truleg med og prega det religiøse samspelet i bygda. Hadde indremisjonsfolket hatt sitt eige forsamlingshus, slik som ungdomslagsrørsla, 
hadde truleg treffpunkta med resten av bygdefolket blitt færre. Og hadde bedehuset vore det einaste forsamlingshuset, slik det ikkje var uvanleg i mange bygder, hadde det endra maktfordelinga i bygda. Det hadde gjeve dei omvendingskristne nøkkelen til å kontrollere moral og samværsformer på ein viktig offentleg arena.

Ein konflikt frå min oppvekst kan illustrere noko av dette. Nokon i bygda hadde teke initiativ til eit kurs i folkeviseleik for barna i bygda. Songdans var vel omtykt i bygdemiljøet og i ungdomslagsrørsla, men dette skapte uro hjå dei omvendingskristne ut frå ein utbreidd tankegang i desse miljøa om kva dette i neste omgang kunne føre til. Ein av dei ringte rundt i bygda og åtvara foreldra mot å sende barna på kurset, men sidan bygda sitt forsamlingshus var eit ungdomshus og ikkje eit bedehus, mangla dei omvendingskristne makt til å stoppe det. Dessutan hadde dei eit problem i tillegg: Folkeviseleiken hadde godkjenningsstempel frå skolen og dei kyrkjekristne ved at prestedottera og «klokkar-lærar-sonen» skulle vere med på leiken. Og det var ikkje aktuelt å boikotte verken skolen eller kyrkja av den grunn.

\section{Konklusjon. «Fjordingssyntesen»: inklusiv eksklusivitet, både kristen og kristeleg}

Det er tid for å vende tilbake til spørsmålet og svaret frå samtalen som innleidde denne artikkelen. Spørsmålet var «er du kristeleg?» og svaret frå ein kamerat: «Kristne er vi no alle, vi er no døypte». Kva fortel spørsmålet og svaret om det «religiøse landskapet» dei spring ut av?

For det første fortel spørsmålet at det finst ulike oppfatningar i bygda om kva det ville seie å vere kristen. Dette var ei bygd med ein sterk kollektiv kyrkjeleg tradisjon med allmenn oppslutning om kyrkja sine seremoniar der bygdefolk fekk bekrefta at dei var kristne når dei slutta opp om desse. Men samstundes hadde også ungar i bygda oppfatta at nokon var kristne på ein litt spesiell måte, annleis eller meir enn andre; og spørsmålet var om eg var ein av dei spesielle. Når eg opplevde spørsmålet som ubehageleg, var det nok fordi eg opplevde at det i forlenginga av dette låg spørsmålet: «Er du eigentleg ein av oss, tilhøyrer vi same fellesskap?». Grunnen til at eg var under mistanke var truleg at eg kom 
frå ein indremisjonsfamilie med ein far som var rektor på ein kristeleg folkehøgskole i bygda. Og mistanken var ikkje utan grunn. Mine omvendingskristne foreldre hadde lært meg ei anna oppfatning av kva det var å vere kristen enn det som låg i den kollektive kyrkjelege tradisjonen. Far min likte ikkje når presten første juledag helsa kyrkjelyden med: «Kjære bygdefolk! Kjære kristne!». Han meinte at det gav bygda falsk tryggleik om at dei var på den rette veg. Men samstundes deltok han, og dei andre i det kyrkjelojale indremisjonsfolket, i den kollektive kristendomen sine ritual: dåp, høgtidskyrkjegong, konfirmasjon og nattverd. Dei utfordra sjeldan direkte den kollektive kristendomstradisjonen i bygda ved å kritisere eller trekke seg ut av desse. Bygdefolk på si side var også truleg interessert i å gjennom ord og handling oppretthalde ein religiøs kultur som skapte «eit kristent vi» som inkluderte både dei sjølve og dei kristelege eller omvendingskristne. Det raske svaret frå kameraten min på vegne av meg om at «kristne det er vi no alle» kan tolkast som eit uttrykk for eit ønskje om å ikkje splitte fellesskapet på grunn av religion.

Eg vil kalle denne måten å handtere religiøse skilnader for «inklusiv eksklusivitet». Begge partar erkjenner at det finst skilnader som plasserer dei i ulike, og i potensielt motsetningsfylte, roller og identitetar. For dei omvendingskristne dreia det seg om ei overtyding om at dei kollektiv kyrkjekristne ikkje var «skikkeleg kristne», for dei kyrkjekristne dreia det seg om å kunne verne sin identitet som «kristne nok». Men i eit tett bygdesamfunn har begge partar ei felles interesse i å framleis kunne omgåast kvarandre. Difor unngår ein gjerne ord og handlingar som ekskluderer den andre på ein måte som gjer vidare samhandling vanskeleg. Kameraten min «glatta over» spenninga ved å seie at vi alle var kristne, noko han sikkert også hadde lært og meinte. Og at det var han som sa det, og ikkje eg, hjelpte meg ut av ein lojalitetskonflikt mellom mine kameratar og mine foreldre som hadde motstridande svar på kven som var kristne.

Den «inklusive eksklusiviteten» som eg seier prega det religiøse samspelet i oppvekstbygda mi, på var neppe representativ for det religiøse Vestlandet; og truleg heller ikkje for «Fjordingar» sitt forhold til kyrkje og bedehus. Det var fleire trekk ved denne bygda som gjorde den spesiell kulturelt og religiøst (sterk kollektiv kyrkjeleg tradisjon, ikkje bedehus eller vekking, ungdomshuset som einaste forsamlingshuset med meir). 
Kanskje må vi heller snakke om den som eit ekstremtilfelle. Men samstundes meiner eg bygda er eit eksempel som viser nokre interessante trekk ved «Fjordingen» sin religiøse kultur: kombinasjonen av kollektiv kyrkjekristendom, kyrkjelojal lekmannsrørsle og frilynt norskdomsrørsle i små egalitære bygdesamfunn.

\section{Litteratur}

Aagedal, O. (1986). Bygda som ikkje fekk bedehus. I O. Aagedal (Red.), Bedehuset. Rørsla, bygda, folket (s. 75-86). Oslo: Samlaget.

Aagedal, O. (2003). Bedehusfolket. Ein studie av bedehuskultur i tre bygder på 1980-og 1990-talet. Trondheim: Tapir.

Dyrnes, L. E., Hals, G. \& Kløvstad, J. (Red.) (1986). Ungdomshuset. Eit kultursenter $i$ Bygde-Noreg. Oslo: Samlaget.

Grimstad, I. (1986). Bedehushumoren. I O. Aagedal (Red.), Bedehuset. Rørsla, bygda, folket (s. 215-225). Oslo: Samlaget.

Høydal, R. (Red.) (1995). Nasjon - region - profesjon. Vestlandsloeraren 1840-1940. KULTs skriftserie nr.45. Oslo: Noregs forskingsråd.

Knudsen, J. P. (1986). Frikirkene - bedehuset for byene. I O. Aagedal (Red.), Bedehuset. Rørsla, bygda, folket (s. 155-172). Oslo: Samlaget.

Rokkan, s. (1987). Stat, nasjon, klasse. Essays i politisk sosiologi. Oslo: Universitetsforlaget.

Ropeid, A. (1984). Misjon og bedehus. I I. Semingsen, N. K. Monsen, S. TschudiMadsen \& Y. Ustvedt (Red.), Det gjenfødte Norge. Norges kulturhistorie (bind 4, s. 195-218). Oslo: H. Aschehoug \& Co.

Ropeid, A. (1986). Bedehuset og bygda. I O. Aagedal (Red.), Bedehuset. Rørsla, bygda, folket (s. 114-124). Oslo: Samlaget.

Sandvik, B. (1998). Det store nattverdfallet. Trondheim: Tapir.

Seland, B. \& Aagedal, O. (2008). Vekkelsesvind, den norske vekkingskristendomen. Oslo: Samlaget.

Seland, B. (2020). Det norske bibelbeltet: geografiske og kulturhistoriske perspektiv. Historisk tidsskrift (under publisering).

Slagstad, R. (1998). De nasjonale strateger. Oslo: Pax Forlag.

Tjomsland, A. (2018). Bedehusarvingar - Nordfjord Indremisjon 1970-200o. Masteroppgåve, Høgskolen i Volda.

Tjomsland, A. (2020). Frå indremisjon til mindre misjon. Nordfjord indremisjon 1970-200o. I B. Løvlie, P. Halse \& K. Hatlebrekke (Red.), Tru på Vestlandet. Tradisjonar i endring. Oslo: Cappelen Damm Akademisk. 
Try, H. (1986). Lekmannsrørsle og assosiasjonsånd ca. 1820-188o. I O. Aagedal (Red.), Bedehuset. Rørsla, bygda, folket (s. 15-39). Oslo: Samlaget.

Øidne, G. (1986). Litt om motsetninga mellom Austlandet og Vestlandet. I O. Aagedal (Red.), Bedehuset. Rørsla, bygda, folket (s. 40-58). Oslo: Samlaget. Årbok for Den norske kirke 1974. Oslo: Kirkens informasjonstjeneste. 



\title{
KAPITTEL 5
}

\section{Lesing som protestantisk utfordring}

\author{
Arne Apelseth \\ Høgskulen i Volda
}

\begin{abstract}
Samandrag: Mindre enn hundre år etter Gutenberg var trykkpressa blitt eit nøkkelelement i det som nokre har framstilt som ein «endringsmekanisme» som skapte «kommunikasjonsrevolusjon». Andre har heller sett trykkpressa som ein teknologi for å konsolidere institusjonell makt og dermed også grepet om samfunn og innbyggjarar. Relasjonar mellom statsmakt og prentemediet skapte nye standardar for personretta kontroll. Samstundes medverka protestantismen med hjelp av prenta medium sterkt til å gje skriftkultur tilnærma allmenn relevans, især ved å endre trongen for bøker og ved å forme vilkår for bruken. Ein vesentleg grunn låg i protestantismens personreligiøsitet, dvs. i vektlegginga av det særeigne forholdet mellom den einskilde og guddomen. Grunnlaget var Luthers fem maksimar, som vart omgjort til ein praktisk handlingsregel om at lekfolk ved sjølvsyn skulle kome til sann erkjenning gjennom individualisert bibellesing.
\end{abstract}

Nøkkelord: protestantisme og skriftkultur, lesekunne, lekfolkslesing, prentekultur, literacy, individ og samfunn

$\AA$ vere ein moderne, funksjonell utøvar av lese- og skrivekompetanse medfører også å vere historisk og kulturelt situert i ein samfunnstype der utveksling av skriftlege symbol og samhandling ved hjelp av skriftleg kommunikasjon har vore ein berande premiss i fleire hundre år. Det inneber å vere sosialt og kulturelt innlemma i eit samfunn med normer og verdiar som skriv seg frå ei fortid med overgang frå munnleg til skriftleg. Slike kommunikative overgangar har forma samfunnets

Sitering av denne artikkelen: Apelseth, A. (2020). Lesing som protestantisk utfordring. I B. Løvlie, P. Halse \& K. Hatlebrekke (Red.), Tru på Vestlandet. Tradisjonar i endring (Kap. 5, s. 83-126). Oslo: Cappelen Damm Akademisk. https://doi.org/10.23865/noasp.104.ch5

Lisens: CC BY-ND 4.o. 
historisk-kulturelle utvikling, skapt oppfatningar om meistringsstandardar og gjeve oss oppfatningar om (akseptable) minstemål. Dei har skapt og påverka kulturelle preferansar, gjeve religiøse referansepunkt og verka inn på individuelle liv og livsløp. Enno i dag ligg slike historiske røynsler nedfelt i kvardagslivets verdiar, haldningar, dugleikar og praksisar.

\section{Del I Når bisp og bønder kjem i same båt}

På ei visitasreise på Nordvestlandet i 1788 fekk Ole Irgens, bisp i Bergen stift frå 1779 til 1803, eit spørsmål frå nokre skyssbønder som tydelegvis har oppteke han. I alle fall tok spørsmålet vegen inn i visitasrapporten, og det er gjennom den nedskrivinga det har overlevd og kome ettertida for auga. Spørsmålet var, i den utforminga som Irgens gav det, om «noget nyt i vor Troeslærdom var opfundet eller noget af det gamle virkeligen var urigtig». Resten av Irgens visitasrapport går slik:

Paa Rejsen er jeg af skydsende Bønder bleven spurgt, om vor Catechismus skulle forandres, om noget nyt $\mathrm{i}$ vor Troes Lærdom var opfundet eller noget af det gamle virkeligen var urigtigt. Præster have beklaget, at blant Bønder saadan harmeligen fortælles med nogles Biefald de Indvendinger mod Treenighed, Syndefaldet, Fordrivelsens Evighed m.m. som de i Kiøbsteder eller ved Skibsfart have hørt af de, som agtes for Kloge. Skrivt-seden helst i det theologiske er og bliver unegteligen Aarsag til dette og meer Ont, med Fritænken selv forestille sig. Den Læremaade at skye ere Bibelske ved forklaring forstaaelige Metaphorer og indføren [af] et nyt meer uforstaaeligt Billed-Sprog. Hindrer grundig Kundskab. Blot menneskelig Talekonst med mange Ord at fremsette faa Sandheden allene for at bevæge uden at overbeviise, virke aldrig sand og varig Bædring, men heller Mistanke om det, som sminkes. Det som i Begyndelsen kan kildre nysgirriged Øren blie ved en uundgaaelig Gjentagelse omsider kiedsommeligt og medlydeligt. Sandheds Kierlighed og Bevaning beroe allene paa den grundige og tydelige Lærdemaade, til hvilken jeg ideligen muntrer og formaner, thi det Pralerie med nye Ord og Talemaader, som forvirre og forvildre Mengden, yttre sig ogsaa her 
hos unge Prædikanter. Gud naadeligen afværge, at disse og andre nye vaarlige

Moder skulle faae fremgang!

Bergen d. 18de Decbri 1788 Irgens. ${ }^{1}$

Lauskopla frå mogelege kontekstar kan spørsmålet verke pussig og blåøygd, jamvel vankunnig. I alle fall stadfester det avstand mellom vår(e) spørjehorisont(ar) og den eller dei som omgav bispen og dei skyssande bøndene for over 200 år sidan. Likevel er innføringa til Irgens er ein grei stad å starte eit resonnement om tenking, tekst og samfunn sist på 170o-talet. Vi veit ikkje eksakt kvar eller i kva for samanheng spørsmålet kom i, kven spørjaren var, om bispen hadde fått fleire spørsmål av denne typen, om orda fall akkurat slik som Irgens gav dei att, eller om det er tale om relativt fri utforming frå bispens side. Utsegna kan truleg takast for pålydande likevel. Det verkar ikkje urimeleg at det vart stilt slike spørsmål og brukt slike ordsamanstillingar.

I snever forstand viser spørsmålet, som nedskrivinga av det, til ei religiøs brytingstid i Norden, ein periode der streng og bokstavtru lutheranisme vart utfordra av ein teologi av meir rasjonalistisk type. Utdraget indikerer vidare at debatt om teologiske spørsmål ikkje berre var avgrensa til lærde forum, men hadde ein viss sosial distribusjon. Lekfolket i Danmark-Noreg var oppteken av teologirelaterte emne, om enn ikkje på same vis som embetsstanden var det. Nett $k v a$ lekfolk tenkte om religiøse emne, er lite tilgjengeleg for oss i dag. Det finst få autentiske kjelder som eignar seg til undersøking. Mest alt er andrehandsopplysningar som dette. Derimot viser protokollutdraget at det vart tenkt, og i nokon grad gjev det ein peikepinn på korleis. Merknaden viser kanskje mest til spennet i tenkingas sosiale dimensjon i andre halvdel av 1700-talet, at kulturelle og religiøse omgjevnader forma tankesett hos alle samfunnslag og at den oppfatta røynda organiserte sosial åtferd og nedfelte seg $\mathrm{i}$ spesifikke samhandlingsformer.

Pro Memoria I-II. Visitasmerknad med følgjeskriv frå Ole Irgens for året 1788. Generalinspeksjonens arkiv, Riksarkivet. Eit utdrag frå visitasrapporten er drøfta i Johs. Buset: «Frå sunnmørsk skulesoge 1742-1827. II. Borgund prestegjeld», Tidsskrift for Sunnmøre historielag, Ålesund 1945. 
På meir enn eit rudimentært plan kjenner vi ikkje Irgens' motiv for å føre inn merknaden, men sitatet gjev visse leietrådar. Spørsmåla som bispen fekk, peikar helst mot teksttradisjonen attende til Luthers tid, især den status og dei funksjonar som Luthers vesle katekisme hadde hatt til langt opp på 1700-talet for å definere røyndom. Bispens kommentar var meir orientert mot teologiske utfordringar frå samtida. Vidare kan vi heller ikkje sjå bort frå at teksten viser til trekk ved Irgens' eigen person og hans tilknyting til stand og embetsnormer.

Det er problematisk om vi vil kople slike embetsmannsutsegner til moderne kategoriar, for det vi har, er i røynda berre ein versjon. For ei rekonstruerande ettertid står ein likevel i fare for å skape retorisk og metodisk intimitet mellom ytring då og ytring no, nettopp fordi ein skriftleggjort kultur vil leggje større vekt på det skrivne enn det fortalde. I dette tilfellet ser vi embetsmannens tankar om sin eigen person og kva kyrkja hadde av utfordringar, og vi greier nok òg å lese ut korleis bispen tenkte om skyssbønders lesekunne og tolkingsevner i teologirelaterte spørsmål. Likevel lèt ikkje denne teksten seg utan vidare kople til vår måte å tenke om slike forhold. Det er berre tilsynelatande at utdraget er ei konstatering av det enklare slaget, dvs. enkelt dersom vi aksepterer Irgens' perspektiv og kontekst. Det avgjerande er om påstandane kan godtakast og gjerast til tolkingsobjekt utan andre støttepunkt enn Irgens' eigen tekst. Det kan dei truleg ikkje. Tekstutdraget er markert språkbruk. Sagt på ein annan måte: Utdraget er «danningshistorisk koda» og sosialt og historisk situert mellom embetsbrør. Teksten er også farga av det politiske og administrative systemet han var utferda i. I rolla som bisp i Bergen stift var Irgens eksponent for eit normsterkt danningsprogram med forventningar om «sivilisatorisk progresjon».

Teksten er òg kopla til generelle tekstdiskursar, der han tangerer både eit inklusivt og eit eksklusivt krinslaup, dvs. kyrkjesanksjonert litteratur og den litteraturen som følgde normene i eit kommersielt krinslaup. Såleis er merknaden til Irgens inngangsportal til eit medie- og kunnskapsunivers som på vesentlege område skil seg frå vår tid, men som nettopp via den doble litterære krinslauptilknytinga vanskeleg kan oppfattast som å vere fundamentalt forskjellig.

Visitasmerknaden er i dobbel forstand ein metatekst. Alt ved første blikk gjer han det klart at dette er språk om språkskapt og tekstrelatert 
røynd. Men overflata seier ikkje berre at det er språk om språk og tekst om tekst. Deskriptive metatekstar som dette, især om dei vart forma av personar med tilsyn for allmugedanning og ansvar for oppseding - og Irgens hadde nettopp ei slik stilling - kommuniserer også profesjonalitet, autoritet og standsdanning. Slike tekstar trekte skilje i samfunnet og dei skapte kulturelle distinksjonar.

Valet står gjerne mellom to tolkingsstrategiar når vi kjem over slike merknader. Situasjonsspesifikt kan samtalen med skyssbøndene naturlegvis knytast til det seine 1700-talets freistnader på å skifte ut Pontoppidans katekismeforklaring med Peder Saxtorph: Udtog af Dr. Erik Pontoppidans Forklaring, til de Eenfoldiges Nytte uddraget. Dette skapte oppstyr og mobilisering i fleire tiår, ikkje minst på Sunnmøre (Fet, 1995, s. 168f.). ${ }^{2}$ Første utgåve kom i 1771. Fleire følgde på 1700-talet og i hundreåret etter. ${ }^{3}$ Eit anna alternativ vil vere å vise til teksttradisjonen, for med mindre Irgens misforstod, er det lite sannsynleg at det var val av katekismeforklaring som vart nemnt av skyssbøndene. Truleg var det heller ikkje den andre utfordringa han nemner, allslags religiøst «hearsay» som lekfolk hadde snappa opp «i Kiøbsteder eller ved Skibsfart». ${ }^{4}$

180o-talet kom til å vise tydelegare kor kontroversielt det var å byte lærebok i religionsopplæringa. Episoden som Irgens refererer, kan kanskje lesast som ein forløpar for forklaringsstriden som stod i første del av 180o-talet. Ein kongeleg resolusjon 7.10.1852 roa striden, mellom anna fordi det blei slått fast at det ikkje skulle vere «Hinder for at i de Menigheder, hvor derom ytres et Almindelig Ønske, de sammesteds tidligere brugte Utgaver af de anordnede Lærebøger fremdeles benyttes». (Elseth, 1999, s. 105).

3 Om Irgens' eiga forklaring, Kort Underviisning om Saliggiørende Lordomme, hvilke af alle bør vides, troes og efterleves (1764, nytt opplag i 1767), var involvert i meiningsutvekslinga er ikkje kjent, men boka fanst som alternativ - om enn lite utbreidd. Jostein Fet har ikkje funne eit einaste eksemplar av boka i dei over 16 ooo skifta han har undersøkt frå Sunnmøre, Romsdal, Nordmøre og Telemark. Ludvig Selmer kjende til boka. Han karakteriserer ho som velforma og kort, og at ho nøye har utelate innslag av pietistisk tenking, men følgde Pontoppidans «Sandhed» i disposisjonen (Selmer, 1934, s. 531).

4 Problemet med import av uønskte tankar og tekstar var større tidlegare, og kyrkja vakta òg sitt ideologiske territorium meir nidkjært på 160o-talet enn det ho gjorde fram mot år 180o. Især hadde det vore åtvara mot kalvinistisk og sekterisk litteratur, og frå rettsprotokollar veit ein også at slike bøker vart konfiskerte i byar og hamner som vart frekventerte av utanlandske fartøy. Christian den femtes norske Lov (1687) var den sentrale rettesnora. Det heitte om religiøse bøker i 3. bok (avd.), kapittel 20, paragraf 3, "Om Bøger og Almanaker», at:

«Ej heller maa nogle Bøger i Tysk Sprog, som handle om fremmet Religion, eller andet, som nogen Tvistighed, eller Skrupel i den uforandrede Augsburgiske Confessions Tro og Religion kunde eragtis at foraarsage, uden Kongens sær Tilladelse, i Kongens Riger og Lande indføris, sælgis eller fal holdis (...)». 
Det ligg nærare å tolke utsegna som at det var sjølve fundamentet for offentleg religionsutøving det vart spurt om, og at skyssbøndene med «vor Catechismus» ikkje sikta til noko anna enn Luthers vesle katekisme. I 1788 hadde boka innpå 250 års resepsjonshistorie i Noreg, intimt knytt som ho var til kyrkje og stat. Boka kan langt på veg oppfattast som eit komprimert uttrykk for det tankelivet som rådde i «den lutherske staten» før 1814, for å parafrasere ein tittel frå nyare idehistorie (Gilje \& Rasmussen, 2002). Den vesle katekisma var ikkje berre ein sentral periodetekst, men òg ein tekst med vidtfemnande verknadshistorie. I tillegg kom at store mengder av litteratur, i fleire sjangrar, bygde ut den protestantiske tekstdiskursen, og mot slutten av 1700-talet femna denne tallause lesarar av både leke og lærde.

Samfunns- og røyndomsforståinga som skyssbøndene gav uttrykk for, var knytt til katekisma. Det var gjennom den teksten at det verkelege og sanne hadde ontologisk identitet, om vi skal tru bispen. Det var òg med denne boka dei hadde fått si viktigaste innføring i skriftkultur. Katekisma var òg plattform for den abstrakte kunnskapen om samfunnsorden og teologisk orden som periodens lekfolk fekk inn via katekismeforklaringa. Bispens vitnemål er vanskeleg å forstå på anna vis enn at personane kunne lese, og at dei også hadde forstått det dei las. Indirekte slår teksten fast at det ikkje var slakteblod, kaffigrut, stjerner eller andre potensielle tolkingsobjekt allmugen reflekterte over. Spørsmålet galdt sivilisasjon og skrift(kultur), danningsmidla tekst og bok og det protestantiske statssamfunnet som omgav bruk og tolking. Med det har bispen kommunisert at han føreset at mottakaren har kjennskap til det stendig utbygde nettverket av autorisert skrift- og tekstdanning frå reformasjonstida og fram til der bispen møtte skyssbøndene.

Utan omsyn til desse 250 åra med sterk offentleg styring av tekstsosialisering og tekstdisiplinering blir merknaden hengande i lause lufta. Det synest såleis relevant å sjå episoden med skyssbøndene i forhold til eit utvida sett med tekstar og tekstskapte diskursar som personar og særleg rolleutøving var omgjevne av. Det er avgjerande for val av tolkingsstrategiar er om vi reknar hendinga for ein einskildepisode. Her er ho ikkje vurdert slik. Snarare er ho oppfatta som ein glytt frå eit tema og ei samhandlingsform som vart aktualisert mange gonger og mange stader i andre delen av 1700-talet. 
Likevel speglar merknaden til Irgens først og fremst kjeldeskaparens verd. Såleis er merknaden korkje ideologisk autonom eller ubunden av historisk og samtidig kontekst. Korkje språkbruk eller situasjon kan sjåast presentisk, som at personane ter seg meir eller mindre som menneske av i dag - berre iført pudderparykk eller tresko. Både protokollinnføringa og det tidlegare spørsmålet var omgjevne av forhold som definerte og presiserte tolkingsrommet for deltakarane. Ein vil korrumpere teksten om ikkje tolkinga inkluderer desse. Kontekstforankringa kan presiserast vidare, og visitasmerknaden kan brukast til det. For det første viser teksten til ei fokusert hending. Hendinga (hendingane) gjekk føre seg i eit avgrensa område og i eit avgrensa tidsrom. Situasjonen i tid og rom gjev ei fysisk og situasjonsbestemt ramme. Kring hendinga kan det vidare trekkjast (minst) tre andre kontekstar som ein kanskje kan rekne med ville innverke på tekstutforming og teksttolking. Samhandlingsrelasjonen mellom bisp og skyssbønder er éin kontekst. Den relasjonen er så «nær» at han kan visualiserast, men tolkinga blir vanskeleg utan internaliserte, men abstrakte, føringar som den konkrete stoda var regulert av. I visitastilfellet har vi òg å gjere med ei formalisert institusjonell ramme. Det ritualiserte utgjorde ein ekstratekstuell instans, ikkje minst fordi tekstmerknaden vart skapt av den konteksten. Kombinasjonen av alle åtferdsføreskrivande kontekstar, formelle som uformelle, utgjorde såleis tekstens sosio-historiske ramme.

Det er ingenting som tyder på at Ole Irgens ikkje kom greitt frå utspørjinga. Men vi kjenner frå Hans Nielsen Hauges penn at ein skulle lyde Gud meir enn menneske, i praksis ei flytting av autoritet frå kyrkjeleiing og over på skriftstader som hadde status som Guds ord direkte, dvs. var utan teologiske omskrivingar. Om slik tenking kom direkte til uttrykk her, får vi ikkje vite, men Irgens var den som både såg og høyrde, og det var han som ved protokollinnføring lét rykte, observasjonar, vurderingar og tolkingar kome ettertida for auge.

\section{Del II Ein «plogmann»}

Frå merknaden går det fram at han som førte pennen, i eige medvit, i det minste, men òg av dei som seinare har tolka teksten, var vesensulik 
skyssbøndene. Tekstutdraget talar om eit fenomen som skal vere å finne på den andre sida av eit faktisk eller antesipert danningsskilje. Teksten er ei figurering av «den andre». Om han enn er ulik, anonym og ein stad utanfor eller bortanfor, så får han likevel ein danningsidentitet ved denne innføringa.

Ein av dei «skydsende Bønder» kan - i teorien, i det minste - ha vore min tipp-tipp-tipp-tipp-oldefar. Han heitte Jon Rasmusson og var ved denne tid om lag 43 år gammal. Jon budde på garden Apalset, om lag midt på nordsida av Stadlandet, og med Vanylvsfjorden som næraste ferdselsåre. Truleg var han ikkje aktuell som skyssbonde ved dette høvet, men han kunne ha vore det om kyrkjene i Selje og Vanylven hadde lege annleis til. Som med bønder flest langs viktige kyststrekningar låg det også på han plikt til å skysse ein embetsmann dersom omstenda gjorde det nødvendig. Saman med kona Ragnhild (Ragnilde) var Jon på Apalset frå 1764 til begge døydde over 30 år seinare med få månaders mellomrom. Det var nok ho som i praksis var gardbrukaren. Han var fiskarbonde. Det medførte at han lange periodar var fråverande grunna fiske og frakt. Korkje Jon eller Ragnhild vart langliva. Begge døydde sommaren 1795; ho 30. mai og han 19. august. Attlevande born (tre av seks) var ugifte og umyndige. Dei to jentene må seiast å ha vore godt vaksne. Marthe var 28 år og Ragnhild var 22. Sonen Mons, som arva odelen, var derimot berre 16 år gammal.

Ein grunn til å ta Jon fram her er at vi faktisk greier å finne ut litt om mann og tid frå det arveskiftet som var halde etter han. I og med at ektefellane døydde om lag samstundes, vart det halde eit felles skifte etter dei. Det ser ut til at verdiane var haldne samla til buet vart taksert og fordelt slik arvelova føreskreiv. ${ }^{5}$ Likeins ser det ut til at sorenskrivarens arbeid med skiftet var styrt av etiske normer om plikt og profesjonalitet snarare enn av omsynet til kva han sjølv kunne oppnå. Skiftet har eit oversiktleg

Det var i så fall i motsetning til tidlegare skifte på Apalset, som klart gjev inntrykk av at det rådde mistillit mellom stat og lokalsamfunn, og der sorenskrivarens innsats snautt strekte seg lenger enn til ein offentleg konfiskasjon av restverdiar. Tidleg på 1700-talet var ikkje tilliten til statens mann større enn at dødsbu vart delt opp og verdiar spreidde i slekta i god tid før sorenskrivar og takstmenn kom inn i biletet. I minst eitt tilfelle nekta sorenskrivaren å signere. I dette tilfellet torer arvelatarens tillit til statsmakta å ha vore monaleg større, nærast eit praktisk døme på Jesu ord om at ein pliktar å gje keisaren det keisaren skal ha og Gud det Gud skal ha. 
og ryddig preg og er lett å ta seg fram i sjølv så lenge etter. Gjenstandar er gjevne klar beskriving, til dømes i den detaljerte utlegginga av utsjånaden på dyra. Identiteten til buets sjøbruk og andre verdiar verkar udiskutabel.

Skiftet vart opna den 14. juni 1795, kort tid etter at Ragnhild var død, og fullført den 19. september same året. Den første delen av skiftet var etter Ragnhild, men det er rettast å sjå det som eit samla arveoppgjer etter begge. Jon Rasmusson døydde i august, og truleg har han hatt eit ord med i laget då første del kom i stand. Han kan ha lege på det siste då det skjedde. Det ser ut som om sorenskrivaren hadde sett av plass i juni til å fullføre litt seinare. Buet verkar fullstendig, og det gav også utslag på bruttoen. Samla verdi (busold) var 249 riksdalar, 4 ort og 14 skilling. Truleg kan dette skifteoppgjeret reknast som nokså representativt for kva fiskarbønder på ein middels gard på Nordvestlandet hadde av jordisk gods. Her var ingen prangande eignelutar. Skiftet etterlét helst inntrykk av nøktern soliditet. I lista til sorenskrivaren vart det ført opp nærare 200 gjenstandar, reiskapar og husdyr, til dømes 15 «Qvæg» (kyr, kviger og kalvar). Vidare var det hest, ni geiter og 15 sauer. Buet hadde elles fem gjenstandar i sølv, tinn og messing og ein koparkjel. Det fanst ein del smedreiskapar og hus- og kjøkenreiskapar i jern. Meir spesielt var at mange trearbeid vart rekna å vere av så god kvalitet at dei vart takserte. Oppstillinga av skiftet verkar grei. Gjeld var det ikkje. Etter fråtrekk for skiftekostnader stod det verdiar att å dele for litt over 210 riksdalar. Sonen Mons hadde full arvelott og fekk dermed halve verdien i buet. Gardsverdien var då inkludert. Dei to systrene hadde etter lova halv arvelott. Dei fekk dermed verdiar for ein fjerdedel kvar.

Brutto

Fråtrekk for skiftekostnader

Nettoverdi til deling

Til sonen Mons

Til dottera Marte

Til dottera Ragnhild

$$
\begin{array}{r}
249-4-14 \\
39-0-0 \\
210-4-14 \\
105-2-3 \\
52-4-1^{1 / 2} \\
52-4-1^{1 / 2}
\end{array}
$$

Når ein les gjennom eit meir enn 200 år gammalt skifte og funderer over gjenstandane i det, korleis dei har vorte samla eller skapte gjennom 
mange år, dannar det seg også eit bilete av folket og korleis dei levde. Personar kjem nokså nær innpå når ein til og med kan finne fram til kva namn dei gav kvar av kyrne på garden. Det var ingen uoppgjorde forhold som var melde inn frå grannar og slekt, og det var heller ikkje uteståande gjeld eller andre hefte på garden. Skiftet tyder på at dette har vore praktisk retta folk som levde i fred med omgjevnadene og prioriterte eit jamt liv utan kvasse kantar. Eignelutane viser at det var kvalitet i mange små ting. Det at sorenskrivaren fann grunn til å taksere mange trereiskapar, peiker mot det same. Det skil seg noko frå tidlegare tiders skifte der det tydelegvis var viktig å brikje med ein og annan kostbar ting i sølv, tinn, messing eller kopar. Arveskiftet hevda at både dyr og sjøbruk var i god stand. Garden verkar å ha vore på stell i Jon og Ragnhilds tid. Alle verdiar, utanom skiftekostnadene, gjekk beinveges til neste generasjon. Det inntrykket som fester seg av Jon og Ragnhild på Apalset, er at dei var eit par trottige og gudfryktige menneske som innretta liva sine etter eit kristeleg normsett.

Eit utdrag av skiftet, under overskrifta «Söe Reedskab», viser av kva dødsbuet hadde av eignalutar som var relaterte til fiske og frakt. Utvalet av båtar, båtpartar, notpartar, garn, tauverk og anna vegn på garden var dei mest verdfulle delane i skiftet. Samla vart alt sjøbruket taksert til kring 75 riksdalar. Summen oversteig klart verdien på den sjølveigde jorda. Taksten på garden var tilsvarande 1 våg fisk. Her vart taksten sett til 50 riksdalar.

Den eigneluten som hadde høgst verdi, var «1 Firroddnings Baad med Seyl» (truleg ein åttring) som stod til ein verdi av 13 rd., « ${ }^{1 /}$ Part udi 1 Sildenod» vart taksert til $10 \mathrm{rd}$. og « ${ }_{4}^{1 /}$ Part udi 1 Byebaad» (dvs. ei jekt) til $17 \mathrm{rd}$.

Jekta var truleg ei bygdefarsjekt, dvs. felleseige hos fiskarbønder i nærområdet. Ut ifrå skifteverdien kan vi kanskje tenke oss at jekteparten har vore i ei mellomstor, litt tilårskomen jekt. Om jekta skulle runde Stad, har nok storleiken minimum vore kring 15-18 meter og med lasteevne på 150-175 tønner (dvs. 12-14 lester). Jon hadde slekt i Selje, så jekta kan ha hatt tilhaldet sitt der også.

Det går fram av skifteopplysningane at felleseige, sambruk, parteigarskap og anna risikospreiing var vanleg. Det var også ein måte å organisere 
arbeid og økonomi på 170o-talet som i nokon grad var samordna med føringar frå religiøst liv. Såleis ser vi i skiftet konturar av ein investeringsmentalitet, ein rasjonalitet som på grunnplanet gjorde at overskot ikkje vart forbrukt, men «pløygd attende», for å låne ein velkjend metafor. Overskot kunne heller ikkje setjast i spekulasjonsøkonomi. Snarare var det vesle som fanst, nytta til å byggje ut den lokale kvardagsramma. Rimelegvis var det viktigaste å trygge næringstilgangen. I dette tilfellet har det resultert i samdrift med innlagd risikospreiing, dvs. luteige og partar i notbruk og fraktefartøy.

Eit alternativ til reinvestering i jordisk gods kunne vere å kjøpe bøker, og då helst av det kristelege slaget. Det har tydelegvis også vore gjort. Bøkene kan dessutan peike mot at den eine eller helst begge hadde ei pietistisk gudstru, ei oppfatning om at plikt, truskap, nøysemd, hardt arbeid etc. skulle ein gjere til Guds ære. Forbruk og pengesløsing var styggedom og synd. Ideologien som går fram av litteraturen, synest å passe med det inntrykket frå skifteoversynet. Her verkar det som om tanke, tru og handling har gått i same lei, og at det kan vere ei forklaring til dei verdiar som hadde samla seg på Apalset i 1790-åra.

I skiftet er det ført opp til saman seks bøker. Etter Jostein Fets oversyn var alle vanlege i allmugeheimar i siste del av 1700-talet, men det vart altså investert bra mykje pengar i litteratur. Bruktverdien på bøkene var nær sju riksdalar, og for det var det mogeleg å få kjøpt to gode kyr i 179oåra. Prisen hos ein bokhandlar i Bergen var kanskje kring det doble av verdien som brukt.

Familien hadde nok meir litteratur, men ikkje av ein slik type eller kvalitet at bøkene vart takserte ved skifte. Ved skiftet registrerte ein den materielle verdien på ting, slik at dei bøkene som finst oppført, var «skikkelege bøker», dvs. bøker med hard innbinding og stor slitestyrke. Mangel på hard innbinding kunne også medføre at heller ikkje biblar, nytestamente og katekismebøker vart registrerte. Vi ser at arveskiftet ikkje har ei einaste av desse sjangrane, men dei seks andre bøkene som er oppførte på lista, indikerer at hushaldet også hadde dei protestantiske grunnbøkene. Truleg har det vore billegutgåver eller at bøkene var i skral forfatning, dvs. så slitne at dei ikkje kunne tildelast takseringsverdi. Såkalla folkebøker, almanakkar og andre populære småtrykk i bokformat hadde 
normalt berre enkelt kartongomslag, og i mange tilfelle ikkje det eingong. Skillingsviser og liknande småskrifter var endå enklare, dvs. berre einskildark. Følgja var at denne typen litteratur berre unntaksvis kunne registrerast i skifta. Skriftene vart som regel «brukt opp» innanfor kvar generasjon.

Den første av bøkene på denne lista er ein huspostill, ei tjukk bok på over 1300 sider. Namnet var Henrich Müller: Evangeliske Hierte-Speyl, som indeholder en Forklaring over alle Søndagenes og Festernes Evangelier, og ni af den sal. Mands Prakener over Passionen eller Christi Lidelse. Müllers postill kom først ut i 1704. Deretter finn vi han i mengder av opplag utetter 1700-talet. Postillen var nokså dyr i kjøp, men oversynet hos Jostein Fet viser at han var populær på Nordvestlandet. Vi ser at sorenskrivaren takserte boka til heile 4 riksdalar i skiftet, altså meir enn det ei god ku vart verdsett til.

Bok nummer to på lista er kalla «Fattigmands Huusbog». Dette var sannsynlegvis En Fattig Mands Huus-Bog Loerende Hvorledis mand skal blive En sand Christen, Hvorledis mand skal leve En sand Christen, Hvorledis mand skal døe En sand Christen (1715), den 600 sider store danske utgåva av Richard Baxter: The Poor Man's Family Book (1674). ${ }^{6}$ Boka kan kanskje lesast som ein prosaisk parallell til John Bunyans samtidige allegori, The Pilgrim's Progress from This World, to That Which Is to Come. Denne vart omsett til dansk om lag samstundes med Baxters bok.

Bok nummer tre var den minste i denne samlinga. Det var ei songbok som den danske presten Lauritz Beich gav ut i 1726, kalla Himmerige paa Jorden, og med ein undertittel på nærare ei halv side som forklarar bruken. Boka inneheldt 40 songar i Kingo-tradisjonen, og var elles solid forankra i dansk-norsk statspietisme.

Den fjerde oppføringa var ei svært vanleg bønebok på 1700-talet, Hans Jacobsen Hvalsøe: De Bedendis aandelige Kioede af 41. Led, eller: Christendommens Articler sammensancket, Guds Hellige Navn til Ære og Dyrkelse.

6 Tittelen «Fattigmands Huusbog» kan også vise til ein snedig tittel som bokhandlarar på 17ootalet sette på Johann Arndts gamle oppbyggingsbok (frå tidleg 16oo-tal), Lyset i Mørket, eller fire Bøger om den Sande Christendom. 
Som tittelen også peikar på, var det ei bok som plasserte seg midt i den protestantiske dogmatikken og som òg skulle lesast mot denne. Det var ei relativt tjukk bok. Utgåver frå 1700-talet var gjerne på 600-700 sider. Populariteten grunna seg nok på at ho hadde eit vidt spekter av bøner tilpassa vanlege folks kvardagsliv. Boka kom ut i år 1700 og hadde 20 nye opplag alt før 1770. I alt vart boka prenta opp att kring 35 gonger - seinast i 1905 .

Bok nummer fem var Kragerø-presten Samuel Olsen Bruuns songsamling Dend siungende Tids-Fordrif, eller Korsets Frugt. Indeholder en Deel gudelige Psalmer og Sange, At bruge til Aandelig Forlystelse og Gudelig Tids-Fordriv som paa alle Tider, saa og $i$ alle Tilfoclde ere enfoldig componerede frå 1694. Boka var på kring 200 sider, altså om lag det doble av Beichs songbok. I tillegg til songane var det sett inn ein del notar. Lengst bak følgde det andaktstekstar. Også denne boka vart prenta opp att mange gonger fram til siste del av 1800 -talet.

I den siste boktittelen på lista står det «1 Ord. Kirke PS: Bog». Tittelen viser truleg til Thomas Kingos Den Forordnede Nye Kirke-Psalme-Boog (1699). Salmeboka hadde stor autoritet, var innretta etter kyrkjeåret og var nok den vanlegaste i mylderet av salmebøker før Landstads kom i bruk i siste del av 180o-talet. Førsteutgåva frå 1699 var diger og vanskeleg å bruke. Ho ser ut som ein uhandterleg kloss på over 600 sider. Seinare opptrykk eller redigerte utgåver fekk betre typografi og papir, og ikkje minst ei fornuftig innbinding som tok omsyn til bruken. Frå 1720-åra og frametter vart «Den Forordnede» slanka ned til eit bruksvenleg format med ca. 350 sider.

Samla representerte desse bøkene eit volum på mellom 3000 og 3500 tekstsider, og det var slett ingen litteratur som eigna seg til hurtiglesing. Det er tunge passasjar både syntaktisk og innhaldsmessig, og truleg kravde den langsame lesinga ekstra lesestoggar og periodar med refleksjon undervegs. Ein skal heller ikkje sjå bort frå at oppmodingar om å samtale over teksten vart følgde. Sjølv om bøkene var av det vanlege sortimentet, verkar det ikkje som om dei har hamna der tilfeldig. Bøkene høyrer til sentrale religiøse sjangrar, men ein kan òg sjå dei som katalogar over dygder og formaningar. Alle fikserer individet i formidlinga av moralske formaningar om sjølvtukt og sjølvdisiplin - like ned til rigide 
krav om kontroll med eigen svevn. Lina kom kanskje klarast til uttrykk i eit detaljert register lengst bak i «Fattigmands Huusbog», den danske utgåva av The Poor Man's Family Book.

Fleire, mellom anna Max Weber og Talcott Parsons, har sett slik moralsterk og allmugeretta litteratur på 160o- og 1700-talet som ei nøkkelkopling mellom religion og samfunnsutvikling, der påboda om å vere årvaken, flittig, ha sjølvtukt etc. resulterer i ei rørsle mot gradvis auka sosial sjølvkontroll og styrkt samfunnsdisiplin. I Den protestantiske etikk og kapitalismens ånd vrimlar det med referansar til Richard Baxter, og Weber såg nettopp Baxter som den fremste litterære eksponenten for puritansk pliktetikk. (Weber 1995, s. 96ff.) Om slike kvalitetar kan kallast modernitet per se, er eit omdiskutert spørsmål, men ein kan vanskeleg sjå bort frå at slike trekk ved samfunnet disponerer for (fasettar ved) teknologisk og industriell modernitet. Hos den engelske historikaren E. P. Thompson, som også resonnerer kring Baxter og puritansk etikk, blir ein sterk individuell og kollektiv (sjølv-)disiplin sett som ein nødvendig rekvisitt for å utvikle den industrielle tidsalderens etos i England på 1800talet (Thompson, 1966, jf. Thompson, 1967).

I engelsk forskingslitteratur går lesarar som følgde protestantismens tekstlege gjennombrot under namnet «protestant readers». Det vert sikta til ein sterkt normstyrt fellesskap av religiøst orienterte tekstbrukarar, primært i nordlege delar av Europa, seinare også i Amerika. Innleiingsvis var nok leke lesarar temmeleg ulike med omsyn til lesekunne og tolkingsevner, og vi kjenner mange døme på at tekstar ikkje alltid vart lesne og forstått slik dei var tenkte. Utetter 1600- og 1700-talet auka talet på lesekunnige i laggare samfunnslag, dels som følgje av bokprentets ekspansjon og boklesingas sterkare status og dels som følgje av kyrkjas mangsidige intervensjon i lekfolks kvardagsliv. Ei rad utspel frå 1500-talet til 180o-talet, og både konfirmasjon og skuleordningar inngår, hadde som mål å fremje grunnleggjande lesedugleik og å få etablert akseptable minstenivå i tolking av kristendomskunnskap. Truleg vart lesinga smått om senn meir kompetent, mest av alt ved at konvensjonar for tolking vart fanga opp og lesing og lesarar gjort meir einskaplege.

Mest av alt vart det fleire av denne typen lesarar. Det finst ikkje talfestingar på det forholdet mellom leseformasjonane, men truleg femna 
«protestant readers» alt tidleg fleire enn dei som sokna til dei tradisjonelle «lettered readers». Ikkje minst har boktrykkets ekspansjon samanheng med den store auken av ordinære, religiøst innretta morsmålslesarar og omsetjingsauke av protestantiske tekstar. Det store volumet av kristelege bøker gjekk ikkje upåakta forbi på 170o-talet, heller ikkje i DanmarkNoreg. I Epistola 447 («Levnetsbrev» nr. 4) reflekterte ein aldrande Holberg over forfattarskapen sin, især over manglande lønsemd og korleis det hadde samanheng med fleire variantar av «einfaldige» bokkjøparar. Mellom anna meinte han at to bøker som vi kjenner att frå arveskiftet i 1795, kvar for seg, hadde gjeve større inntekter enn det Holberg hadde hatt for heile forfattarskapen sin: «Ja jeg tør sige, at en eeneste liden Bog kaldet den Bedende Kiæde og Müllers Postill have givet flere Renter end alle mine Skrifter» (Holberg, 1754, jf. også Billeskov Jansen, 1963).

Skilnaden mellom lesekategoriane er relevant. Frå reformasjonen til siste del av 180o-talet var det vesentlege ulikskapar mellom dei to litterære systema. Den protestantiske lesaren las utan unntak tekstar på morsmålet. Ein slik lesar laut internalisere eit nokså rigid system av reglar, strategiar og konvensjonar for tolking - og som òg måtte stå til rette for eigen lesepraksis. Samstundes var den indre fellesskapen kopla til ein ytre gjennom eit kontrollerande sett av normer som sanksjonerte tenking, oppfatning, handling og samhandling. Tilsvarande ville den utdanna lesaren lese latin (ev. latinprega tekstar) eller morsmålstekstar med klassiskretorisk innretting. Det som kanskje mest skilde kristelege tekstar frå det lærde systemet, var gjerne at samanhengen mellom tekstar oftare vart uttrykt som fellesskap om tekstar (eller teksten) snarare enn som individuell forming, danning, påverknad og inspirasjon. Ein lærd eller borgarleg-intellektuell lesar ville nok ha eit retorisk system som «overnorm» for lesing og ei standsrelevant norm for boklege vanar. Derimot ville ein slik lesar berre i svært avgrensa grad måtte svare for lesemetode og tekstleg praksis. Begge system utvikla estetiske preferansar, separate litterære fellesskapar med tilhøyrande boklege krinslaup. Summen kan likne ein oppbygd «forventningshorisont» (Jauss, 1996), ein immateriell struktur som via bestemte kodar og konvensjonar frå samtid og fortid er i stand til å organisere korleis ein mottakar både skal avkode, forstå, verdsetje - og jamvel hylle - ein tekst. 


\section{Del III Lesande lekfolk som trope}

Eit gjengangarmotiv i europeisk biletkunst er den leke lesaren, dvs. tekstleg orienterte og tekstleg interesserte menneske utanfor tradisjonelt lærde sirklar. I ein innleiande fase vart motivet kanskje best visualisert ved at kvinner vart framstilte med bok, gjerne einskildvis og utan å vise aktiv lesing. Bøkene var lukka, og dei skapte assosiasjonane går i retning av andre fasar av lectio divina, særleg bønestunder som skulle følgje lesinga. I biletkunst frå europeisk renessanse og reformasjon ser ein oftare opne bøker når kvinner er nærverande. Sandro Botticellis Madonna del Libro frå kring 1480 viser ei kvinne og eit barn, gestalta som Maria som held barnet Jesus på fanget. Kvinna les, og barnet ser på moras andlet. Omgjevnadene er truleg nokså kvardagslege hos velståande i samtida. Auga til kvinna er vende mot den opne boka, og den høgre handa held blada i ro. Den opne boka på bordet er ei tjukk og vakkert innbunden bok. Det kan ha vore ei tidebok (book of hours). Det var ein sjanger som kom i velståande lekfolks eige i seinmellomalderen. Også frå bokhistoria er det kjent bokeigande kvinner. Ofte er det tale om kvinner frå rike familiar som eigde forseggjorde tidebøker og eksklusive samleband med bønelitteratur. Hans Holbein den yngres portrett av ein velståande handelsmann i London, hanseaten Georg Giese, viser at bøker, rekneskapar, kundelister, navigasjonskunnskap, ja, dei fleste former for skriftkultur, var relevant i kvardagsaktivitetane til ein framståande «Burgher» anno 1532.

I det neste hundreåret blei omtrent alle sider ved bøker og lesing sosialt utvida. Den privilegerte og eksklusive dåmen ved skriftkultur forsvann ikkje, men kom meir i bakgrunnen. Derimot fekk allmenn religiøs lesing, dels også dei kommersielle og funksjonelle sidene ved skriftkultur, meir dominerande posisjon. Etter reformasjonen, og med nederlandske område som sentrum, vart lesande lekfolk og kvardagslivets tekstbruk brodert ut i tallause variantar. Den store mengda av målarstykke av lesande lekfolk gjev inntrykk av at slike motiv vart konvensjonalisert til nærast å bli ein trope i biletkunst i løpet av 160o-talet. Trope er eit retorisk omgrep, avleidd frå å snu, som i vår samanheng gjerne bør forståast som motivanalogiar, dvs. at eit etablert motiv blir snudd og vendt på, kasta lys over eller fokusert slik at det vert mogeleg å oppleve fleire sider ved det. 
Malarar som Rembrandt og Vermeer viser repeterte døme på vendinga. Den leke lesaren har gradvis erstatta tidlegare roller, som primært var å vise fram religiøs emosjonalitet (sjåar av lys, fromt bedande etc.). Rembrandts og Vermeers bokorienterte og lesande personar har alt passert ein kommunikativ terskel ved å bli lesarar, og er gjerne på veg til å bli individuelle utøvarar av fleire slag tekstrelaterte handlingar. Vi ser at spennet i 1600-talsbileta går frå eldre lesarar, som omstendeleg «slit» seg gjennom tjukke bøker som bibel og postill, til relativt unge personar som var så inkorporerte i skriftkultur at dei både var penneføre og brevskrivande. Den siste kategorien viser handlingar som tradisjonelt er blitt forbundne med gryande individualitet og verdslege former for rasjonalitet.

Medan studiar av lesemotiv i målarkunsten helst fortel om ei omlegging som tok fleire hundre år, stig ein ny type av lesarar meir brått fram i bokhistorisk forsking. Især har kombinasjonen av Gutenbergs trykketeknikk og Martin Luthers program-reformatoriske skrifter skapt institusjonelle verknader. I den innleiande fasen var det mindre klart kva ein forenkla trykketeknikk kunne leie til, og endringane vart helst rekna i kvantitetar. Med masseprentet opplevde Europa ei «flood of printed books», er det hevda (Burke, 1978, s. 250). Overslag har vist at volumauken etter Gutenbergs tid må ha vore stor, men òg at auken kom brått. Elizabeth Eisensteins overslag indikerer kring åtte millionar bøker og skrifter alt ved utgangen av 1400-talet (Eisenstein, 1993, s. 45). Volumauken i det neste hundreåret var ikkje mindre formidabel. To franske historikarar, Lucien Febvre og Henri-Jean Martin, har rekna med at det kom ut omtrent 150 000-200 ooo utgåver i eit samla opplag på 150-200 millionar i løpet av 1500-talet (Febvre \& Martin, 1984, s. 262). Teoretikarar med større interesse for dei lange linene i europeisk modernitet har helst poengtert eit varig endringsmønster som følgde den prenta boka, mellom anna at Europa etter 1500-talet har blitt eksponert for ein vedvarande og stendig veksande volumauke. Det rår ikkje semje om kor stor volumauken har vore, eller om han femna om sentrum og periferi på same vis. Heller ikkje kan omfang og endringstempo slåast eksakt fast. Anthony Giddens refererer ein påstand om at volumet av trykksaker har fordobla seg omtrent kvart 15. år sidan Gutenbergs tid (Giddens, 1997, s. 37). Det kan kanskje stemme om ein tek alle atterhalda som ligg i ordet «omtrent». 
I europeisk idéhistorie har det ofte vore peikt på at ei ny kunnskapsorientering kom om lag samtidig med at ein ny type individualitet manifesterte seg. Begge var relatert til periodens endra strukturar i kommunikasjon, feidar som reformasjon og mot-reformasjon og ei viss renessanseinteresse for det fortidige mellom dei best utdanna. For breiare samfunnslag fekk især ekspansiv kontakt med område utanfor Europa kunnskapsmessige konsekvensar. Handel, kolonisering og imperiebygging medførte nærkontakt med andre kulturkrinsar, og vanlege europearar kunne, ved sjølvsyn, oppleve fenomen som ein tradert, dogmefast kunnskapskultur ikkje hadde gode nok svar på. Likevel, og i alle praktiske samanhengar, innretta lek og lærd i Europa seg på at kunnskap var ei guddommeleg frukt, dvs. at kunnskap kom gjennom utvalde (heilage) bøker eller vart overført gjennom kyrkja og via religiøse autoritetar. Unntaket var gjerne slikt som kom frå antikke kjelder. Det var det ikkje mange som visste kva var, anten det var tale om politisk filosofi, navigasjon eller alkymi. Følgja var at mest all kunnskap som strekte seg ut over det kvardagslege som galdt «dagen og vegen», var ein uhyre knapp ressurs som berre eit lite fåtal fekk tilgang til.

Utetter 1500- og 1600-talet kom det gamle kunnskapsuniverset i rørsle. Endringar kom ikkje brått, men snarare via tallause små steg, som for ettertida kan avlesast som gradvise reorienteringar i språk- og tekstbruk. Den traderte kunnskapen frå mellomalderen fekk gradvis svekt status, om enn det sjeldan gjekk så langt som i tilfellet med overleverte kart og reisebeskrivingar. Der vart eldre kunnskapsformer tidleg trekte eksplisitt i tvil - især om det fanst målingar som støtta opp under observasjonar. Parallelt med at tradisjonen fekk redusert sitt truverd, vart den eller dei som hadde observert eller opplevd noko, i større grad oppfatta som kjelde til kunnskap. Det å ha erfart noko, reflektert over ein sjølvopplevd, men unik situasjon eller ha sett noko spesielt ved sjølvsyn, og deretter oppleve å møte respekt og aksept for det som var sett og opplevd, er ein nokså unik fase i menneskets historie. Thomas Mores Utopia frå 1516 er eit godt døme frå ein innleiande fase, og mengder av observasjonar, reiseskildringar og rapportar frå eksotiske opplevingar følgde i dei neste hundreåra.

I artikkelen «The Concept of the Individual and the Idea(l) of Method in Seventeenth-Century Natural Philosophy» (2000) hevdar filosofen 
Peter Machamer at den svekka autoriteten til tradert kunnskap også kjenneteiknar det at folk tok til å tenke om seg sjølve som individ. Ein heller diffus individualitet var i emning tidlegare, kanskje frå 1200-talet av (Machamer, 200o, sjå noten s. 98). Hovudpoenget til Machamer er at individualiteten tok nye former på 1500- og 1600-talet. Han knyter det til periodens mangfaldige strev med å utvikle strategiar og metodar, for på intellektuelt og tidhøveleg vis å kunne fortolke og å forstå alt det nye som Europa vart konfrontert med. Det låg i sakas natur at fortid og dogmatikk ikkje kunne få diktere korleis spørsmål og erkjenningsstrategiar skulle formast.

Obviously the method by which this world of novel discoveries could be explored could not be dictated by traditional or a priori assumptions about the substance and character of what would be found, or about ideas concerning regularities in nature. A method was needed to give some sense about the reliability of inquiry or, minimally, to reassure that knowledge was possible and all was not chaos. A strategy was needed for approaching the novel, and for resolving any disputes and controversies that might arise. (Machamer, 2000, s. 89)

Machamer har føreslege at den individualiteten som grodde fram etter renessansen, bør oppfattast som å ha ulike, men innbyrdes relaterte fasettar. Især dreg han eit skilje mellom det han kallar eit «epistemic I» og eit «entrepreneurial I» (Machamer, 2000, s. 82f.). Det første, ein individualitet med erfaringsbasert kunnskapsorientering, vil i det vesentlege svare til typen som er skildra ovanfor. Den andre, som især merker seg ut som handlande subjekt, skal vi følgje vidare. Grunnen er at det først og fremst er den individualiteten som kan påvisast i kjelder. Dei to individualitetane finst, etter Machamers skjønn, veldokumentert hos ein del naturfilosofisk orienterte tenkarar på 160o-talet, tydelegast hos dei som kjente seg kalla til å erstatte diskrediterte kunnskapskjelder med tankesystem som dei utvikla sjølve. Desse tok eit markert sprang frå tenking og over til handling, dvs. skriving, der nettopp iscenesetjing av sjølvet som det kunnande, vitande og undervisande subjektet står i sentrum. Hos desse vil ein finne talrike freistnader på å krinse inn eller å formulere ein «metode», dvs. ein universelt funksjonell måte for skaffe seg og å forvalte ein sikker kunnskap: 
Method generally means a way of proceeding. Structurally, methods can be based on substantive claims and distinctions or on procedural rules. I contend that the new scientific method of the seventeenth century was essentially and inevitably a procedural method designed to gain adherents to and train initiates in natural philosophy, and to halt disputes and controversies. (Machamer, 2000, s. 89)

Machamer viser her til Bacon, Galilei, Descartes og Hobbes, og freistnader på å etablere prosedyrar som var anvendelege på ulike fenomen, og som dessutan var mogeleg å lære. Idealet var også at dei skulle skapast konsensus rundt «metoden» (i bunden form), men sidan det var mange kandidatar på same marknad, var kontroversar vanskelege å unngå. Ein einskapleg metode som alle kunne semjast om, var det slett ikkje råd å kome fram til.

No galdt dette eit lite utval av Europas fremste intellektuelle og forhold som især kjenneteikna deira tekstlege individualitet, men frå periodens biletkunst og tidleg-moderne bokhistorie veit vi at det også var ein lek omgang med tekst som utvikla seg i same tidsrom. Også denne kunne rekne ei fortid attende til siste del av mellomalderen. Ein 160o-talstekst som Pilgrim's Progress var sannsynlegvis ein av dei meir sentrale tekstane som formidla den nye måten å tenke om individet på, men det er viktig å understreke at formuleringar og reformuleringar av den nye individualiteten skjedde i ein spesifikt religiøs kontekst. Bunyans verk viser likevel mengder av døme på det Machamer kallar «epistemic I» og «entrepreneurial I». På sett og vis låg det til sjangeren (dvs. visjonsdikting) å ytre seg via markert framheving av subjektet og hans/hennar røynsler, men i det etter-reformatoriske Europa fekk denne individualiteten eit ekstra feste både i religiøse og meir verdslege samanhengar.

Det var òg gjennom sjølvhevdande språkbruk at eit «entrepreneurial I» kunne skilje seg ut i forhold til tidlegare individualitet. Denne «gestalten» henta verbal og annan autoritet (draumar, erfaringar etc.) hos seg sjølv, og han merkte seg ut språkleg ved å vere særleg raus med 1. persons pronomenbruk både i eintal (det forteljande eg) og fleirtal (vi, dvs. andre som er samd med den skrivande) og tilhøyrande verbformer.

One hallmark of this I is the increasing use of the first-person personal pronoun in the writings of the new methodologists. All of them indulge in first-person 
narratives, often accompanied by strong claims about their humility. One common rhetorical form in which the entrepreneurial I occurs is as a biographical tale about a narrator who is telling a story about himself or his experiences. The story is really meant as a parable about every person. Anyone can follow the same procedure or have the same experiences, if that person is properly trained in the method discovered by the narrator. Sometimes, the anti-authoritarian nature of the age comes through in such stories by way of assertions that people must freely choose to follow this path. (Machamer, 2000, s. 85)

Viktig er også at i denne perioden skil protestantisk litteratur seg aktivt ut og frå det mangfaldet som kjenneteikna renessansens tekstar. For denne litteraturen, som den tilhøyrande lesartypen, ville det meste vere innretta på frelsa og korleis ho kunne vinnast for den einskilde. For ein protestantisk lesar ville ein tekst som utelukkande var knytt til morskap, rekreasjon og tidtrøyte knapt ha verdi. Ein slik tekst representerte helst bortkasta tid og tap av overordna perspektiv. For protestantiske lesarar var tekstar å rekne som «instrument» eller «reiskapar» for å oppnå noko meir, kanskje ikkje ulikt den status som tekstar hadde for periodens vitskapsmenn. Difor måtte ein forfattar som inngjekk i den protestantiske diskursen underkaste seg denne diskursens sett av reglar og dermed "prove» at han som forfattar stod i Guds teneste, og likeins at emnet som han skreiv om, var i samsvar med (rette) protestantiske røynsler.

Litteraturvitaren Barbara Johnson har granska Pilgrim's Progress mot ein slik bakgrunn, mellom anna med formål å skilje ut komponentar som ho vurderer som viktige for å etablere ein protestantisk lesefellesskap. Ho nyttar lite av omgrepssettet som Machamer tok i bruk, men legg i det vesentlege vekt på liknande forhold som det han gjorde. Johnson òg fann iscenesetjing av eit skrivande sjølv som kunnande, vitande og undervisande. Likeins har Bunyan ei framstillingsform som kan føre tanken i retning av «metode», dvs. framheving av ein universelt gyldig og funksjonell måte som individet kan skaffe seg sikker kunnskap på. Dette er langt på veg også bokas organiserande narrativ. Johnson viser til aksentueringa av eit subjektivt «I» i opninga av Bunyans forteljing. På dansk går iscenesetjinga av allegoriens forteljande eg-person slik, og her er det lånt formuleringa frå den eldste omsetjinga frå tidleg 1700-tal: «Jeg drømte at jeg saae ...» (Bunyan [Bunian], 1704-07, s. 1 [26]). 
I Reading Piers Plowman and the Pilgrim's Progress. Reception and the Protestant Reader (1992) har Johnson identifisert tekstlege konstituentar i Bunyans allegoriske tekst som intertekstuelt knyter teksten til Bibelen, men som òg forankrar boka i ein engelsk tradisjon. Ho viser især til lesetradisjon rundt og etter det engelske diktet Piers Plowman frå siste del av 1300-talet. Johnson peiker òg på skilnader, skilnader som primært har utgangspunkt i reformasjonens maksimar, og det er via desse at Pilgrim's Progress både vidarefører og presiserer ein protestantisk lesefellesskap, ein protestantisk lesartype og ein protestantisk lesemåte. I Johnsons utlegging blir denne boka ein mønstertekst i ein ekspanderande protestantisk estetikk, der narrativ, struktur og språkkonvensjonar er organiseriserte i forhold til protestantismens maksimar, sjangrar og lesarar. Som døme er det vist til den velkjende metaforen pløying (plowing), og korleis denne får funksjon som eit bindeledd mellom forfattar, bok, lesar og fellesskap. Ho meiner Bunyans bok har bygd ut og styrkt denne metaforen i tre tydingar. For det første viser ho at verbet er brukt aktivt for å kople Bunyans tekst til Bibelen og til gjenkjenning av profetisk tale. Dinest blir det vist korleis Bunyan har kopla pløying med formaning, og at han med det kunne underbyggje ein ønskt autoritet og funksjon. Endeleg får pløye-metaforen representere dagleglivet i kroppsleg og åndeleg vånde og uvissa i strevet etter sanning (Johnson, 1992, s. 188). Skrifta, dvs. protestantisk forståing av Bibelen, blir i Bunyans utlegging ei linse (lupe) med dobbel funksjon. Linsa evnar både å gjere tydeleg kva guddomens vilje er, og kan likeins føre lesaren mot ei klarare forståing av sjølvet (op.cit., s. 205f.).

Barbara Johnson var ikkje den første litteraturvitaren som skreiv om Bunyan og Pilgrims Progress. Trass i verkets religiøse karakter inngår det i engelsk-amerikansk litteraturforsking, og då på eit anna vis enn liknande tekstar gjer hos oss. Johnson uttrykkjer eksplisitt interesse i lesemåtars kontinuitet, og teoretisk følgjer ho ein kombinasjon av bokhistorie og tysk resepsjonsestetikk. Tekstar er i denne tradisjonen kjenneteikna av å stå i ein mellomposisjon mellom noko ytre («røyndom») og lesarens

7 Resonnementa ligg nær dei vi kan finne hos Iser og Jauss, men utan å gå vidare inn på omgrep som Isers «implisitt lesar» og Jauss' «forventningshorisont». Tilsvarande held ho, utan vidare grunngjeving, lesemåtar som vi mellom anna kjenner frå Stanley Fish’ Bunyan-studiar, på trygg avstand. 
røyndomserfaringar. Men sjølv om vi seier at tekstar er kontekstuelt situerte eller at dei er blitt indre situerte hos ein lesar, så er ikkje det nokon garanti for at forståinga av teksten er presis (eller «god»). Teksten kan jamvel vere fullstendig misforstått. Spørsmålet er kva slags lesing denne teksten er blitt utsett for, men også kva slags tekst det er tale om og i kva ideologisert kontekst lesinga skjer i. For hermeneutisk orienterte teoretikarar tenderer mot å oppfatte tekstmottakaren som eit individ $i$ ein valsituasjon. I alle samanhengar kan ein lesar velje å følgje eigne lesenormer, med dei konsekvensar det har, eller vedkomande kan prøve å tolke teksten etter sosiale, tekstlingvistiske og retoriske kodar som ligg nedfelt i han. Om lesaren vel å satse på første eller andre alternativ (vi gjer sjølvsagt begge delar, alt etter kva som er situasjonen), er i det minste utgangsposisjonen lik. Lesaren blir involvert $i$ kamp med teksten (mediet). Det blir han i den forstand at det fleirtydige i tekstens bodskap(ar) må avkodast fortløpande og i neste omgang bli inkludert i eit rammeverk som er kognitivt overkomeleg («forståeleg») for den personen det gjeld.

Det er altså ikkje berre bodskapen, teksten i seg sjølv, vi forstår, men at teksten gjennom ei trinnvis leseakt gradvis vil stå fram som meiningsfull og meiningsberande for oss. Leseprosessen (tileigninga) er rekonstruerande på det viset at det semiotiske objektet (teksten, mediet) skifter gradvis karakter etter kvart som vi les og kombinerer nye og gamle innsikter:

In applying a code to the text, we may find that it undergoes revision and transformation in the reading process; continuing to read with this same code, we discover that it now produces a 'different' text, which in turn modifies the code by which we are reading it, and so on. This dialectical process is in principle infinite; and if this is so then it undermines any assumption that once we have identified the proper codes for the text our task is finished. Literary texts are 'code-productive' and 'code-transgressive' as well as 'code-confirming': they may teach us new ways of reading, not just reinforce the ones with which we come equipped. (Eagleton, 1983, s. 125)

Duellen eller det permanente samspelet mellom tekst og lesar understrekar lesarrolla sin dynamiske karakter, og slike møte opnar for eit mangfald av lesemåtar. Men spørsmålet om all lesing er adekvat eller gyldig, eventuelt om bestemte lesemåtar kan (eller skal) gjerast gyldige i møtet med ein 
konkret tekst, valdar større problem. I nesten alle større tekstar lèt det seg gjere å analysere seg fram til ein lesartype lesar som det konkrete verket synest intendert for. Ein konstruert (implisert) lesar er ein skapt storleik som frå forfattarens side blir utrusta med former for språkmeistring, tekstkompetanse og realkunnskap. Dels blir kompetanse føresett og dels skapt gjennom eit kontraktsforhold som blir etablert undervegs.

Resonnement om lesaren finn vi langt bak i tid, til dømes i Bibelen, men særleg frå reformasjonen og frametter. Eit kjent døme er Miltons resonnering kring «the fit reader». ${ }^{8}$ Den konstruerte lesaren er ein tekstskapingsstrategi, dvs. ein tekstbunden, kommunikativ instans som er lineært til stades. ${ }^{9}$ Ein verkeleg lesar kan leggje seg nokså nær den konstruerte (impliserte) lesaren, og dermed bli noko nær ein ideal lesar. Likevel er den verkelege lesaren fri, dvs. fri i prinsippet, i det minste, og kan gjere med teksten som han vil. Normalt vil ein verkeleg lesar prøve å skape ein kontekst for å tolke teksten, og der det kan skje at ny meining vert skapt for lesaren sjølv og den lesefellesskapen han høyrer til i. Eg tek med dette fordi tidleg-moderne protestantisk lesing og eit fleirtal av tekstane frå denne perioden eksisterte i eit intenst spenningsfelt mellom «questions of truth» og «questions of virtue». Etikettane er utvikla av Michael McKeon, og siktar til ei gjennomgåande epistemologisk krise, kjenneteikna av tydelege inkonsistensar mot ulike former for realitet og status. Særleg utslagsgjevande var at det i ein periode på kring 150 år skjedde ei sterk destabilisering og reorganisering av kategoriar for «sant» og «godt». Prosessen utløyste imperativ for handling ut ifrå opplevingar av «relative deprivation». Ordet relativ er meir sentralt enn deprivering i denne samanhengen, for det er ikkje tale om noko absolutt

8 Ludvig Holberg streifar innom både fiktive og røynlege lesarar mange stader, og jamvel ein James Joyce hadde idear om ein «ideal reader» for Finnegans Wake. Dei mest kjende lesarkonstruksjonane finn vi i tekstteoretiske arbeid - især frå 1970-talet. Wolfgang Iser skreiv om «implisitt lesar». Umberto Ecos omgrep var «modellesar». Stanley Fish’ bygde dels på Milton i omgrepet den «informerte lesar». Andre nemningar som har vore brukt, er «average reader» og «super reader» (Michael Riffaterre), «ideal reader» (Jonathan Culler), «intended reader» (Erwin Wolff), «mature listener/reader» (Ronald Wardhaugh), «the narratee» (Gerald Prince), og det er sikkert fleire òg.

9 Dette er ei tekstleg tilrettelegging som vi kan rekonstruere gjennom kompleksitet (tematisk, terminologisk og i organisering), omfang av redundans, forhold mellom setningstypar og setningsstrukturar, problemstillingar, vinklingar, haldningar etc. Tilpassing til ein tenkt lesar (ei tenkt lesargruppe) ser vi nok lettast i barnelitteratur. 
ved deprivering, seier McKeon (McKeon, 1988, s. 172f.). Derimot utløyste inkonsistens av status og destabilisering av «det gode» og «det sanne» ei kjensle av at sjølve fundamentet for «det verkelege», «det sanne», «det gode» og «det verdfulle» var i endring, og følgt av otte for endring.

For McKeon fungerer motsetningsparet som eit forklaringsprinsipp for sjangeretableringar frå tidleg på 1600-talet til om lag midt på 1700-talet, især for etableringa av den engelske romanen. McKeon ser denne (nye) sjangeren som ein sjangerrespons til ein grunnleggjande ustabilitet både $\mathrm{i}$ litterære og sosiale forhold, han vurderer det slik at romanen vart utvikla og oppstod med det formålet å gå inn dei kriseprega epistemologiske og sosiale forhold, altså ikkje ulikt det forgjengarar hadde gjort innanfor utprega "protestantiske sjangrar». Det er i denne stamtavla for prosaiske sjangrar vi vil kunne finne Richard Baxters The Poor Man's Family Book (1677) og John Bunyans The Pilgrim's Progress from This World to That Which Is to Come (I 1678 og II 1684).

Spenningar mellom «questions of truth» og «questions of virtue» kan sporast både i arveskiftet frå 1795 og kanskje særleg i spørsmålet som bispen fekk frå skyssbøndene. Dei lesande er likevel ikkje einsarta på andre vis enn at dei alle høyrer inn under normativiteten i det protestantiske språk- og tekstsynet. Innanfor det universet kunne protestantiske lesarar vere både tekstreflekterande og samstundes differensierte med omsyn til skriftrøynsler, bok- og tekstpreferansar. Ein kategori som «protestantisk lesar» bør oppfattast som ein storleik med variasjon. Såleis viser Jostein Fets studiar at fleire livområde var både tekststyrte og bokleg avleidde alt før 180o-talet, og jamvel at dei lenge hadde vore det. Endeleg opnar slike samansette lesepraksisar, i det minste dei som Fet påviser på 1700-talet og frametter, for å omtale også slike utøvarar av lesing og skriving som publikum, dvs. ei gruppe som har utvikla eit kvalitativt differensiert mottaksapparat for tekstlege normer.

\section{Del IV Haugianarane - ein protestantisk tekstfellesskap}

Om ein skal vurdere reformasjonens verknader på den allmenne bokdanninga i Noreg, kjem ein før eller seinare innom Hans Nielsen Hauge 
og folkerørsla som han blei opphavsmann til. Ein vesentleg grunn til posisjonen Hauge-rørsla har i norsk kultur- og utdanningshistorie, ja, kanskje den aller viktigaste, ligg i rørsla si reaktualisering eller revitalisering av trekk frå reformasjonskristendommen. Hauge-rørsla vart ein katalysator for slike oppfatningar, og som organisator og skribent sørgde Hauge for at både Luthers femdelte sola-prinsipp og den yngre pietismens person religiøsitet nådde breie lag av lekfolk. Eit anna forhold ligg i Haugerørslas historiske rolle som kommunikasjonsfellesskap, det at rørsla makta å skape ei sjølvorganisert gruppering av lesande og skrivande lekfolk som både kunne kommunisere effektivt internt og var i stand til å stå utanfor tradisjonell kontroll. Eit tredje viktig forhold i samanhengar som dette er at Hauge-rørsla, i motsetnad til mest all anna allmuge-aktivitet frå denne tida, faktisk er grundig dokumentert. ${ }^{10}$

Nettopp dokumentasjonen gjer denne lekmannsrørsla til omtrent best tenkelege inngang for å seie noko om reformasjonen lukkast i å forme «ein protestantisk lesartype». Mellom anna viser studiar av haugianarane rimeleg godt kva som var bokstatus og faktisk lesekunnskap i breie samfunnsgrupper i tida rundt den norske statsdanninga. Vidare skal det leggjast vekt på at det var moderniserande trekk ved Hauge og hans folk. ${ }^{11}$ Det gjeld ikkje så mykje Hauges initiering av saltkoking, papirmøller og liknande, men heller innovative trekk som følgde av rørsla si skriftforståing og tekstlege organisering. Så, i staden for å vektleggje haugianarane sin skriftlege korrespondanse, bruk av bøker og bruk av andre former for prenta skrift som eigenarta eller eit vesentleg avvik frå det som var

Alt Andreas Aarflots doktoravhandling frå 1969 viser til meir enn 500 ulike artiklar og verk om Hauge, Hauge-rørsla og haugianismen. Oversynet til Hauge-biografen Dag Kullerud og artiklar etter århundreskiftet viser at tilveksten dei siste 40 åra har vore vesentleg (Aarflot, 1969, jf. Kullerud, 1996).

11 Ikkje minst av den grunn har kyrkjehistoriske Hauge-studiar blitt supplert frå andre fagmiljø. Både sosiologar, filosofar og historikarar har i nyare tid (etter ca. 1990) levert bidrag. Samla gjer denne sekundærlitteraturen Hauge-resepsjonen mangfaldig og interessant. Endeleg høyrer det med at Hauge også var ein særs produktiv skribent som etterlét ein stor tekstmasse. I Betragtning over Verdens Daarlighed (1796) sa Hauge at han rekna seg for ein «lidet forsøgt og mindre Skriftlærd Dreng», men mannen bak smålætet gav faktisk ut 33 bøker og skrifter i åra 1796-1824. I tillegg kjem brevvekslinga han var involvert i. I samleutgåva til N. H. Ording (1947-1954) fyller Hauges eigne skrifter åtte band, og legg ein til alle Hauge-breva som Ingolf Kvamen har samla, er forfattarskapen på tolv band. Hauge [H.N.H Ording] (1947-1954), Hauge [Kvamen] (1971-1976). 
vanleg, er det heller vurdert slik at Hans Nielsen Hauge og hans folk faktisk var relativt tidstypiske i tru som i åtferd.

Haugianarane etablerte samhandlande nettverk og strukturar, mobiliserte kapital og grunnla nye næringsvegar, og dei flytta og forserte tradisjonelle stands- og næringsgrenser ved dette.

Mentalitetshistorisk kan nok Hauge-rørsla reknast som ein kombinasjon av sosialt og religiøst oppbrot. Viktig her er at det som batt Haugerørsla saman, ja, det som i mangt gjorde ho til ei rørsle, var tekst og litteratur, især den heilage skrifta. Samlingspunkta var sjølvsagt forankra i religiøse tekstar, men dei kommunikative strukturane til rørsla var i høg grad tekstlege, dei òg. Både Hauge og andre la stor vekt på talen og det personlege møtet, og det har skugga noko for at både den førestilte fellesskapen og dei omfattande nettverka vart bygde opp og haldne ved like ved indirekte samhandling, dvs. brevkorrespondanse og bokdistribusjon.

Massefenomenet er understreka på fleire måtar. Ei jamføring av det haugianske nettverket med det vi veit om opplag og distribusjon av Hauges 33 skrifter, vil nok gje mest informasjon. Det er ikkje kjent i absolutte tal kor mange haugianarar det fanst. Sjølv rekna Hauge med tusenvis, og nyare overslag vil nok gje han mykje rett. Det går fram av avtaket for Hauge-publikasjonar. Det er helst på det området at rørsla sin karakter av å vere massefenomen eller folkerørsle kom tydelegast fram. Haugebiografen Dag Kullerud viste til at Hauge meinte det var 200 ooo eksemplar som vart selde eller delte ut berre i løpet av seks år, frå 1796 og fram til at Hauge vart arrestert i 1804 (Kullerud, 1996, s. 273). Nils Gilje har sett sannsynleg opplag på Hauge-skrifter til 250 ooo før 1850 (Gilje, 1996, s. 19). Berge Furre har litt under halvparten, vel 120 ooo, men hos han er ikkje perioden presisert. Det er vel rimeleg å tru at talet 120 ooo kan sikte til opplag i Hauges levetid (før 1824) eller eit endå kortare tidsrom. Furre slår fast at Hauge må ha vore «førre hundreårs mest lesne forfattar» (Furre, 1997, s. 141).

Påstanden til Furre kan knapt dragast i tvil. Snarare vert han styrkt når ein tek omsyn til lesepraksis og sirkulasjonsmønster, til dømes tradisjonen med høgtlesing og at bøker ofte gjekk på rundgang i slekta og grendelaget. Begge lesemåtane var innarbeidde, der målet var både å spreie bodskapen og å styrke litterær tileigning. Det som i alle tilfelle 
er klart, er at det er tale om ei formidabel omsetjing av Hauge-skrifter, særleg når bokkonsumet skjedde i eit land med berre om lag 883600 innbyggjarar i 1801 . Hauge-rørsla var såleis eit ektefødd barn av skriftkulturens samhandlingsformer, og kommunikativt hadde rørsla også klart moderne trekk.

Hauge-rørsla har ofte vorte karakterisert gjennom den tidlegkapitalistiske aktiviteten, ein aktivitet som òg fall saman med økonomisk nøysemd, sparsemd og heller nøktern livsførsel. Om vi koplar mot trusgrunnlaget, lesepraksisar og kommunikativt repertoar, ser vi òg konturane av den rasjonaliteten som organiserte handlingar og verksemd. Motsett predestinasjonslæra som motiverte kalvinistane til timeleg innsats, er det rimeleg å rekne reformasjonskristendommens hushaldartanke som grunnstein bak Hauge-rørslas rasjonalitet.

Den kristne skulle betrakte seg som forvalter av livets goder. Hans overordnete kall er å være Guds husholder på jorden. Som gode husholdere må de kristne planlegge for fremtiden og økonomisere så Herren får det største utbyttet. Derfor blir flid og sparsomhet en viktig del av menneskets lydighetsplikt overfor Gud. Den gode husholder søker heller ikke egen vinning, men Guds kapitalakkumulasjon. (Gilje, 1996, s. 21)

Giljes tolking synest gyldig, særleg om ein ser ho i forhold til argument som statsmakta sjølv hadde teke i bruk for å spore allmugen til innsats gjennom heile siste del av 1700-talet, eller som det heiter hos Henrik Horstbøll: «Pietismens (..) dannelsesforestillinger blev i samtiden modsvaret af verdslige oplysningsteoretiske og kameralistiske ideer om samfundsnytten af personlig ansvarlighed og kundskabernes vækst» (Horstbøll, 1999, s. 157). Tankegangen stod sterkt hos leiande pietistar som Erik Pontoppidan.

Opplagstala på Hauge-skrifter, den interne skriftkommunikasjonen i Hauges venesamfunn og den samordnande rasjonaliteten står i kontrast til gamle og innarbeidde oppfatningar om lesekunne og bokbruk i same tidsrom. Det er vanskeleg å sjå korleis den allmugen som kulturhistoria refererer til, og det er då mest sikta til korleis han syner att i skulehistorie eller folkeminnevitskap, evna å ta unna slike mengder. Ei alternativ tolking kunne sjølvsagt vere at haugiansk lesing var eksepsjonell for si 
tid eller at det vart produsert, agitert for og omsett store mengder bøker som aldri fekk lesarar. Slike resonnement har eg aldri sett, og eg ser heller ingen grunn til å følgje ideen vidare.

Overslaga høver rett og slett dårleg med idear om ei semi-alfabetisert befolkning, at berre ein temmeleg avgrensa del av den norske allmugen var i stand til å lese tekstar som ikkje var kjende frå før. Problemet står seg sjølv om ein reduserer opplagstala på Hauges skrifter sterkt, aukar overslag på gode og middels gode lesarar og reduserer omfanget av den funksjonelle analfabetismen i perioden. Storleikane vil framleis gjere det vanskeleg å forstå korleis eit fåtal gode allmugelesarar i ei befolkning på under millionen absorberte slike mengder frå éin forfattarskap åleine. Reknestykket vert endå verre dersom ein tek omsyn til at Hans Nielsen Hauge var periodens mest kontroversielle forfattarar, ein som ikkje i det heile hadde appell til etablert litterær smak eller til lesevanar utanfor allmugens rekkjer. Derimot er det velkjent korleis rettsvesenet handterte forfattaren og at omtrent alt av Hauges forfattarskap vart systematisk motarbeidd. Skriftene oppnådde å bli offentleg idiot- og kjeltringforklart, jamvel i lange tider etter at statens tenestemenn stogga rettsforfølginga av Hauge.

Opplagstala som det er vist til ovanfor er høge, gjerne oppsiktsvekkande høge, men sjølv slike opplag lèt seg samordne med nyare nordiske inntak til den historiske lesekunna, i Sverige ved Egil Johansson (1981 og 2007), i Danmark ved Henrik Horstbøll (1999) og Charlotte Appel (2001) og her til lands ved Jostein Fet (især Fet 1995). Deira framstillingar opnar, på ulikt vis, for at overslag på omsette Hauge-skrifter viser til vanleg omgang med skriftkultur i lågare samfunnslag både på 180o-talet og tidlegare. Ei intensivering av leseopplæring kom nokre tiår inn på 1700-talet. Denne fall i tid saman med skule- og konfirmasjonsordningane. Ordningane var røynlege resultat av ei pietistisk vekking tidleg på 170o-talet som, til skilnad frå dei fleste religiøse bølgjer, også råka øvrigheita. Kongar, hoff og det geistlege hierarkiet i DanmarkNoreg vart dregne med, og det heile stod faktisk på i fleire tiår. Via skulens tekstar, konfirmasjon og pietismens klart intensiverte kyrkjetukt var det òg at allmugen i Noreg fekk djupare kjennskap til individualreligiøsitet og danningsidear. 


\section{Del V Sola scriptura og den ville lesinga}

Pietismen representerte ein meir nidkjær praksis på mange område. Han slo ikkje berre ut i planar for eit restrukturert skule- og konfirmasjonsprogram, men òg i grundigare systematikk i oppfølginga. Såleis er det frå denne tida det kom påbod om at rett kristeleg lesnad skulle vere både rimeleg og finnast tilgjengeleg så å seie over alt: «mængden af katekismeog bønnebogstryk fra denne tid dokumenterer da også, at den pietistiske bølge pumpede religiøs læsning på markedet i et hittil uset omfang» (Horstbøll, 1999, s. 157, jf. 436ff.). Det teologiske bakteppet er innfløkt og skal ikkje gjerast til noka hovudsak her, men må søkjast i prinsippet om sola scriptura og Luthers oppfatning av ei gresk-kristen språktenking som knytte reformasjonstid og renessanse til ein eldre språkfilosofisk tradisjon. Denne går via Augustins tenking om verbum, og derifrå attende til Platons dialogar om språk (særleg Timaios) og på den andre sida til tenkinga om Guds mektige ord i den kristne skapingsforteljinga. Her har Charles Taylor freista formulere denne smeltedigelen av antikke språkførestillingar:

Her oppstår en innlysende analogi som Augustin gjorde eksplisitt: Slik tanken finner sin ytre kledning i ordene, slik realiseres Guds tanke eller logos Augustins verbum - på en ekstern måte i skapelsen. Skapelsen er så å si Guds tale. Dette er grunnen til at alt er tegn, så sant vi evner å se det. (Taylor, 2007, s. 184)

Vi merker oss den doble premissen i siste setning hos Taylor, nemleg at alt er teikn, til dømes som bokstavar og tekst, men berre dersom vi evnar å sjå det. Ved å sjå skapinga som Guds tale har ein også lagt til grunn ein språkmodell (eit språkparadigme) for menneskesamfunnets måte å bruke ord på. Som Guds skapningar openberrar og lekamleggjer vi Guds tanke, og når alt er teikn, finst det heller ingen ytre eller referensiell relasjon som er meir grunnleggjande. Orda har berre referensiell meining dersom dei refererer til noko som $i k k j e$ er ord eller teikn. Ideen om at alt er teikn, gjev berre meining i eit ekspressivt perspektiv bygd på ei sterk og tydeleg førestilling om kva som eksisterer og kva slags former for eksistens som finst (ontologisk grunnlag). 
Augustin og hans etterfølgere forfektet altså en ekspressiv meningsteori med et ontologisk grunnlag. Den opprinnelige skaperen av mening, Gud, er ekspressivist. Dette setter rammen for middelalderens og den tidlige renessansens teorier, det vi kan kalle semiologiske ontologier hvor verden ble forstått som en meningsfull orden eller tekst. Dette verdensbildet er fremherskende helt opp det syttende århundret, da det ble lagt i grus av den vitenskapelige revolusjonen. (op.cit., s. 185)

I utdanningshistorisk perspektiv er dette ikkje kva som helst prinsipp. I røynda er det ei komprimert utlegging av fleire av protestantismens maksimar som er omgjort til ein praktisk handlingsregel om at lekfolket ved sjølvsyn skulle kome til ei sann erkjenning gjennom individualisert bibellesing.

Korleis no Martin Luther meinte dette, og om han fullt ut forstod dei samfunnsmessige og politiske verknadene som følgde av synspunktet, har det stått strid om sidan reformasjonen og fram til vår tid. Luther har vore teken til inntekt for dei fleste oppfatningar om dette spørsmålet:

Biblen alene, sola scriptura. I almindelighed er denne skriftopfattelse eller som man også har benævnt det: formalprincippet (at sandheden kun kan hentes i Skriften) blevet opfattet således at den enkelte kristne havde direkte og umiddelbar adgang til Biblen. Forståelsen skulle være en sag mellem teksten og dens læser og ingen andre skulle indblandes. Man kunne springe alle historiske og dogmatiske mellemregninger og formidlinger over. Enhver kunne så at sige blive direkte øyenvidne til, hvad Biblen beretter om. (Lindhardt, 1989, s. 112f.)

Heilt bokstaveleg kan ein likevel ikkje tolke det, seier Jan Lindhardt. ${ }^{12}$ Likevel var det via ytringar som dette, og i eit langtidsperspektiv, at allmugen vart tenkt inn (formalintegrert) i den protestantiske skriftinstitusjonen alt frå 1500-talet av. Ein grunn til reservasjon er at allmugen slett ikkje vart tenkt inn som fullverdig brukar av skrivekunst eller eit retorisk kommunikasjonsrepertoar. Alt på 1500-talet kom idear om at målet var

12 «Det er ikke sikkert at Luther mente dette. Men det var en fremherskende opfattelse i pietisme og også i meget af det 19. århundredes kristendom (...) Luthers princip om sola scriptura har været brugt som underlag for (...) traditionsbekæmpende læsemåder; den personligt oplevelsesmæssige, den fundamentalistiske og den historisk-kritiske. Alle har betragtet ham som sin forløber for deres eget syn og har læst sig selv ind i ham.» (Lindhardt, 1983, s. 112f.) 
å få forma den delen av befolkninga i den passiviserte rolla som mottakar, dvs. eit objekt for protestantisk tukt, informasjon og oppseding. Rolla skulle vidare utviklast gjennom sterkt normativ leseopplæring og kristendomsundervisning, mellom anna ved tilrettelegging av «god» og «rett» kristeleg litteratur. For stordelen av befolkninga var skrift- og kristendomsopplæring to sider av same sak i fleire hundre år. Vi må kanskje så langt fram som til andre halvdel av 180o-talet før kombinasjonen ikkje lenger var like sjølvsagd. Vidare sørgde trykkesensuren for at allmugen lenge hadde avgrensa kontakt med ikkje-autoriserte skrifter. Allmugen vart med andre ord styrt inn mot eit tekstunivers som kyrkja sanksjonerte, og der kyrkja markerte dette ved å åtvare i lov- og reskriptform om kva ho ville tole og ikkje tole.

Den glidande tildelinga av forrang til skrifta, og ein einsrettande bruk av prentemediet i kyrkja og staten si teneste, har systematikkens preg over seg, men gjekk slett ikkje utan problem og atterslag. 1500-talets statsmakt gjorde også den urovekkande oppdaginga at det kunne vere himmelvid skilnad på det som var tenkt av skrivaren (eventuelt autoriteten bak han) og det ein mottakar og lesar av det same skriftstykket tenkte. ${ }^{13}$

Problematikken melde seg i Danmark-Noreg samstundes. Også 1500-talets dansk-norske autoritetar såg med stor uro på at med det ekspanderande masseprentet kom det også ein fleire kategoriar av lesarar. Desse hadde ikkje den tradisjonelle elitens tolkingsapparat og vart oppfatta som lesarar på sjølvstyr. Problemet vart i første omgang ikkje formulert som mangel på lesekunne, men heller som det motsette. Det fanst ulike slag lesekunne, at dei lesekunnige las på kvart sitt vis, og med kommersialiseringa av prentet vart det opna for at kjøparen kunne velje sjølv kva han eller ho ville lese.

Fra 1500-tallet og frem finder man forskellige og dog sammenlignelige pædagogiske og dannelsespolitiske bekymringer vedrørende ungdommens, menigmands, almuens eller folkets læsning. Det er bemoerkelsesvoerdigt, at det ikke

13 Ei framifrå eksemplifisering av dette motsetningsforholdet finst i Carlo Ginzburgs dokumentasjon av liv, lesing og verdsbilete hos Menocchio, ein vanleg mylnar frå Friuli i Italia. Han vart truleg avretta av inkvisjonen kring 1601 på grunn av tekstskapte førestillingar som han hadde utvikla, og som han, trass i fleire åtvaringar frå inkvisisjonen, ikkje ville gje seg på (Ginzburg, 1980). 
drejer sig om at få almindelige folk til at loese. Det er i højere grad målet at få dem til at loese noget andet end det, de loeser. (Horstbøll, 1999, s. 25, min utheving)

Spenningstilhøvet mellom faktisk lesing, reelt eksisterande litteratur og tekstskapte gjeremål på ei side og det statlege og kyrkjelege autoritetar ønskte av lesing, tekstar og handlingar på den andre er såleis på ingen måte av ny dato. Konflikten mellom det faktiske og det ideelle har følgt tekstmediet like frå Gutenbergs og Luthers tid. Likeins var medvitet om trugsmåla frå ukontrollert lesing av den uønskte litteraturen uttrykt av lovgjevarar og skulereformatorar samanhengande frå Den danske kyrkjeordinansen frå 1539 (jf. innleiing, «Om Børneskoler») via Christian den Femtis Danske Lov frå 1683 (jf. 2. bok, kap. 18. «Om Skolerne») og fram til retningsliner for konfirmasjon og allmugeskule vart utarbeidde $i$ 1730- og 1740-åra. For Noreg galdt Christian den femtes norske Lov (1687). I denne lovboka fanst det ein eigen bolk som kunngjorde og klargjorde statsmakta sitt syn på skriftkultur, og i 3. bok (avdeling) kapittel 20, «Om Bøger og Almanaker», spesifiserte statsmakta skriftsensuren. Det omtalte trykking, import og reaksjonsmåtar òg. Mellom det kuriøse i lova var paragrafane 3 og 6. Dei gjekk beint på bokleg innhald, og dei gjev eit inntrykk av kva type litteratur statsmakta frykta og ville reagere mot. I paragraf 6 heitte det om almanakkar, men paragrafen viser truleg òg til nokre av dei minst omtykte folkebøkene, at «Ingen Spaa-Calender maa her i Riget sammenskrivis og trykkis, ej heller nogen Spaadom om Krig, dyr Tid, Pestilentze, eller andre saadanne Tilfælde, derudi indføris». ${ }^{14}$

I Kort og eenfoldig Underviisning for Skoleholderne, som Erik Pontoppidan skreiv medan han var bisp i Bergen, vart slik litteratur berre indirekte reflektert. Derimot var han tydeleg på kva undergravande makt som låg i den «andre» litteraturen i Sandhed til Gudfrygtighed (1739), især i spørsmål 215 og 225 med tilhøyrande svar:

14 Eg har her og i det vidare nytta søkbare tekstar på fulltekstbasen til Danmarks Pædagogiske Bibliotek på http://library.au.dk/materialer/saersamlinger/skolelove/ Tilvisinga til lovverket er «Kong Christian den femtes Norske Lov 15de april 1687 med Kongeloven 1665», lagt til rette for prosjekt for nettbaserte hovudfagsstudiar (PNH) på grunnlag av ISBN 82-00-05555-8, Universitetsforlaget 1982, og etter løyve frå Universitetsforlaget. http://www.hf.uio.no/iakh/forskning/ prosjekter/tingbok/kilder/chr5web/ 
(..) Hvad er Horerie i Ord? (215) (..) Hvad er der mere, som kan friste til Ukydskhed? (225)

(..) Al liderlig og ubluferdig Tale, liderlige Bøger, Romæner, Viser og Sange, Giekkerie og Narrerie, som gaar ud paa Utugt, eller i det mindste strider imod ret christen Alvorlighed. (215) (..) Ørkesløshed, liderligt Selskab, Romæner og løsagtige Elskovsbøger eller Billeder, letfærdige Lege, Dands, SkueSpil, og alt det, som føder Øyenslyst, Kiøds-Lyst og et overdaadigt Levnet. (225) $)^{15}$

Det var ikkje berre i København at det fanst «Skrifter, som er efter Pøbelens Smag», som Holberg formulerte det. Alt på slutten av 16oo-talet hadde Petter Dass åtvara mot å velje «Marcolphum til Frænde», ein indikasjon på at dei «Romæner» som Pontoppidan sikta til, både hadde nådd fram til, og blitt upopulær, mellom prestane, jamvel på Helgeland i rikets periferi. Likevel var det først nokre tiår seinare på 170o-talet, og i forsøka på å utvikle og normere ein borgarleg-litterær estetikk, at renessansens mange folkebøker, som historia om Marcolfus tilhøyrde, vart kollektivt avskrivne som smusslitteratur og som uttrykk for dårleg smak. Ludvig Holberg omtalte fenomenet i fleire av sine epistlar, kanskje mest eksplisitt i Epistola LXIII frå 1748-1754. Her fekk skribentar, omsetjarar, distributørar og lesarar av slik kommersiell lurveprosa så hatten passa, kollektivt kopla som dei vart til sivilisasjons- eller danningsforfall. Skarpast lut brukte han mot bokhandlarane. Han meinte dei hadde forvandla «boglige Konster» til «Kram-Vahre», og fordi dei låg under for skillingen vart dei også som yrkesgruppe dominert av «Pøbelens Smag»:

Boghandlere maa rette sig efter den gemeene Almue, som udi alle Lande er tallrigest, og som nu over alt haver faaet Lyst til Læsning; thi, hvis Næringen skal komme i Drift, og deres Gryder, som man siger, skal kaage, maa de være betænkte paa Skrifter, som er efter Pøbelens Smag, det er saadanne, hvorved skiønsomme Folk væmmes. (Holberg, 1748, s. 271f.)

Kor vanlege «Skrifter, som er efter Pøbelens Smag» var i den norske periferien, får vi beskjed om i «Syv trondhjemske Præsters Bønskrifter til

15 Utdraga frå Sandhed til Gudfrygtighed er frå Pontoppidans originaltekst, Pontoppidan (1739), s. $58 \mathrm{ff}$. 
Kirkestyrelsen om Skjærpelse i Kirketugten og Oprettelse af en Kirkeret» (1714). Dette sentrale innleiingsskrivet til dansk-norsk pietisme frå prestane i Romsdal og på Nordmøre var mest uroa over litteraturkvaliteten og minst over lesekunna:

Efterdi og dette Land er saa fattig paa gudelige Bøger, da maatte Theologi Hafniensis bære nogen yderligere Omsorg derfor, at Landet aldrig fattedes saadan aandelig Forraad. Mangen fattig Mand vilde gjerne kjøbe en Bibel, en Postil \&c., men kan ikke bekomme den, uden meget vanskeligt og betalt i dyreste Maader. Lucidarius, Sibyllæ Spørgsmaalsbog, Patriarchernes Testamente, Planetbogen, Munkesladder, danske Romaner og letfærdige Horeviser \&c., hvilke ufeilbarlig uden Facultatis theologicæ Vidende blive trykte (...) føres overflødig af Bogførere og kjøbes for let Priis af de Enfoldige til deres store Forargelse. I den Sted burde der vel saa laves at, at fattige Folk for taalelig Priis sig en Bibel kunde tilhandle. Vi har nu fast i to samfulde Aar begjært 600 Exemplarer af Bibelen til vore Menigheders Fornøielse. («Syvstjernen» 1714, i Ebbestad Hansen (red.) 1999, s. 244)

Skrivet frå dei sju prestane synest å ha teke vegen inn i lovverket, og i 1726 kom det jamvel ein lovheimel som hadde til sikte å hindre omførslehandel med «skarvebøker» nordafjells. I eit reskript frå 27. september det året heitte det at

Ingen forargelige og forfængelige Bøger og trykt Tant, saasom St. Peders Rejse, Sybillæ Spaadom, Lucidarius, Skjemt og Alvor, og flere andre deslige Digte, samt forfængelige Viser og Legender maa henføres eller forhandles i Nordlandene, Finnmarken, og Trondhjems Amt, under Confiscation og Straf, som Loven over forargelige Bøgers Forhandling foresiger. (Fet, 1995, s. 161)

Særleg verknad synest korkje forarging eller forbod å ha oppnått. Denne litteraturen fanst, og det heldt han fram med å gjere hundreåret ut. Eit halvt hundreår etter Holberg var soknepresten Claus Frimann i Davik i Nordfjord ute i same ærend. Bakgrunnen var at han ville gje ut ei songbok og der meinige lesarar var målgruppe. Formålet var å få avløyst det «litterære rasket» som han hadde sett kringom i heimane. Som Holberg sparte heller ikkje Frimann på konfekten i omtalen av den vanlege folkelesnaden. I «Forerindring» til Almuens Sanger (1790) finst det ei konkret 
grunngjeving for boka. Tidsbiletet, eller like gjerne utsynet til bokvariasjon i ytre Nordfjord, dekkjer truleg tidsrommet 1778-1790:

Hvor slet Bønder, eller Land-Almuen, paa de fleste Steder her i Landet, ere forsynede med saadan Læsning, som kan tiene dem til nogen nyttig Tidsfordriv, skulde neppe nogen anden troe, end den, der kommer i deres Huse. I det Historiske Fag ere Ugelspegel, Ugelspegels Overmand, Pilati Historie, Griseldis, Apollonius, Holger Danske, og fleere af samme Suurdei, heel kostelige Sager i deres Øine. Men jeg vil nu kun tale om de Poetiske Skrifter blant dem. Naar man da undtager Psalmebogen, samt nogle andre smaa gudelige Sange, (en Deel usle nok) tillige med Peder Dasses Skrifter, hvad har da Almuen at synge, uden nogle tossede Drikke- og Elskovs-Viiser, som i Byerne sammensmedes, eller og nogle hiemmegiorte, som en og anden halvforrykt Skoleholder har villet udmærke sig ved? I de fleeste ere verken sund Sands eller Sammenhæng at finde, og just de allerdaarligste og latterligste kiøbes helst, ja synges af Fruentimmerne med Taarer i Øinene. De gamle Kiæmpeviiser af Syv og Vedel, ere nu overmaade rare blant Bønder, som vel er; thi den megen Troldom og Diævelskab, som i disse er indvævet, fæste alt for dybe Rødder hos de Enfoldige, til at man burde ønske dem almindelige. Saadant er da hvad Almuen har at synge. (Frimann, 1790, s. IIIf.)

Småskrifter (som folkebøkene) var populære, men dei hadde òg eit tydeleg preg av å vere ei vare som skulle produserast så billeg som råd. Skriftene kom i ei mengd utgåver frå slutten av 1400-talet og fram til slutten av 1800 -talet. Karakteriserande var at bokutstyret berre vart ringare og ringare. Bøkene vart utslitne innanfor ein generasjon, og det er svært få som kan finnast i dag. Dei siste opptrykka kom i tiåra etter 1850. I den første tida var dette ein felleskultur, ein lektyre for både høg og låg, men i løpet av 1700-talet kom det eit skilje. Det lesande borgarskapet vart lært opp til å forakte desse småhistoriene, og etiketten røvarromanar er gjerne eit resultat frå estetisk polering. Moralsk og estetisk fordøming er også ein grunn til at dei så vanskeleg lèt seg etterspore i kjeldene òg.

\section{Del VI Timeleg og åndeleg litteratur}

Eit formål med denne gjennomgangen har vore å få fram at det totale utbodet av skriftkultur var langt større enn dei bøkene som folk møtte 
gjennom kyrkje og skule. Av omtalane framfor går det også fram at det var til dels stor skilnad mellom teksttypane. Kva fanst det så av litteratur i det tidleg-moderne samfunnet, og kva slags lesing(ar) opna han for? Sitata ovanfor indikerer at allmugens omgang med skrift og tekst var mangslungen, også før 180o-talet, men at dannande lesing i moderne borgarleg tyding var den minst viktige. Lesing til «Salighed», til praktiske føremål eller morskapslesing kom først. Det gamle samfunnet var grundig prega av den lutherske to-regimentslæra. Det fanst klare skilje mellom det timelege og det åndelege, og det viste att i tekstmassen. Likeins kunne både verdsleg og religiøs litteratur delast inn etter «lødigheit».

I det religiøse feltet omfatta lødig litteratur dei kyrkjeautoriserte bøkene, først og fremst Luthers vesle katekisme, Bibelen og salmebøker. Det var nøkkelverk i «hustavlestaten». Huspostillar, bøne- og oppbyggingsbøker utgjorde ein mellomkategori. Sterkare enn dei første kunne slike få mindre verdi ved skiftande teologiretningar. Når vi kjem fram til 1700-talet, er det tydeleg at ein del prestar ikkje tykte særleg om at allmugen tviheldt på gamle postillar og bønebøker, der ortodokst og reformatorisk innhald kunne tenkast å blokkere for pietistisk eller rasjonalistisk gudstru. Dei såg gjerne at allmugen hadde bøker i desse sjangrane, men av nyare type. Mest mislikt var bøker med endå eldre opphav, gjerne slike som kom i førsteutgåve i seinmellomalderen eller i tidleg reformasjonstid. Tre slike var Jesu Barndoms Bog, Lucidarius og En liden Aandelig Spørgsmaals Bog. Den siste var nok mest kjend under eit anna namn, nemleg «Prestepina».

Verdsleg litteratur kan delast inn omtrent på same måte. Lovbøkene under kongane Christian 4. og Christian 5. var verdslege parallellar til Bibelen. Dei òg var nøkkelverk i den staten som vart forma på 160otalet. Bøkene var store og dyre, og slett ikkje vanlege i kvar manns bokhylle. Lovbøkene synest å ha vore sjeldne samanlikna med dei kristelege bøkene. Slik bokeige høyrde rimelegvis til i eit bestemt segment lagrettemennene, dei som representerte norske lokalsamfunn i møtet med statsmakta. I ein mellomkategori fanst mellom anna formularbøker, almanakkar, bondepraktikkar og kalendrar. Til same kategori kan også reknast opplysningsskrifter av praktisk art (dokterbøker, reknebøker etc.). 
Alt frå slutten av 1500-talet finst det forfattarar som kommersielt utnytta det segmentet, og kanskje med Niels Heldvad (1564-1634) som den mest kjende av dei. ${ }^{16}$ Astronomi, i si moderne utforming, tilhøyrer vitskapar som er vanskelege å popularisere. Slik var det ikkje på 1600talet. Skrifter som på den tid prøvde å forklare fenomena for større lesegrupper, skilde ikkje mellom astronomi og astrologi, og hadde klare koplingar til ein teologisk forklart verdsorden. Det mønsteret går att mange stader, og 1600-talets populærlitteratur, til dømes flygeblada og skrifter om anger, bot og sjølvtukt (pønitens), speglar for notidsblikket ein røyndom som verkar nærast eventyraktig eller fortrolla, prega som han er av eit periodespesifikt symbolsystem som skulle kople saman mennesket og den verda som omgav det. Skriftene skulle gje nøklar til å avkode Guds vilje, og gjennom lesing fekk ein tilgang. Teologen Peder Mortensen Brincks «En ny Vise om en underlig Fødsel som er sket i Væ i Skaane den 7. Maij Aar 1581» var ei symbolsk fortolking av utsjånaden på misfoster, og poengterer kvar nøklane låg i strofe to: «De tegn Gudz søn for dommen spaar/i skrifften findes obenbar» (Brinck, 1581, i Kvideland, 1976, s. 92, jf. 142f.).

Slike skrifter kunne tilhøyre både det høge og låge sortimentet. Det var helst eit spørsmål om kven som var forfattar. Definitivt lågast status hadde folkeleg morskapslitteratur og trykte einskildark - skillingstrykka. Delvis galdt dette dei såkalla folkebøkene òg. Namnet vart skapt av tysk romantikk kring år 1800 og etter at denne litteraturen hadde mista sin breie appell. Folkebøkene er mest av alt litterære minne frå før-barokk eller tidleg-moderne litteratur. Opphavet til tekstane er gammalt og ofte ukjent. Mange av dei eksisterte som småforteljingar i munnleg form før dei vart samla og trykte om lag i overgangen mellom mellomalder og

16 Heldvads forfattarskap dekkjer langt på veg spennet i denne mellomlitteraturen. Frå 1591 tok han til med almanakkar på tysk og dansk. Dei var utstyrte med praktiske opplysningar og horoskop, og i tillegg "prognostica astrologica», spådommar om vêrlaget, landeplager, farsottar og meir. Alt bygde på innbyrdes posisjonar til himmellekamar. Eksakt kva kjøparar som absorberte litteraturen, er ikkje godt å vite i dag, men Heldvad fanst på bondebygda (Jostedal) ved midten av 160o-talet og jamvel så seint som kring midten av 1700-talet. Sett frå statleg synsstad var det nok av grunnar til å ville regulere den litterære marknaden. 
tidleg reformasjonstid. Dei første folkebøker på dansk kom om lag samstundes med at prentet slo gjennom, altså kring år 1500.

Som vi ser av Heldvads og Brincks skrifter, er litteraturen frå denne tida vanskeleg å plassere etter innhald. Slik var det òg med skillingstrykka og endå simplare flygeskrifter. Dei handla i bokstaveleg forstand om alt mellom himmel og jord og - sett frå vår synsstad - blanda forfattarar (kompilatorar) i hop alt saman til ei salig røre. «Himmelbrev», dvs. brev frå Jesus, gjekk hand i hand med verdslege orienteringsskrifter, opprop mot katastrofar og nyhendeviser, ofte med «gruelig» og «forskrecklig» på ei barokt utforma tittelside. Det sensasjonelle og oppsiktsvekkande skulle fange merksemda, og titlane fortel om tidleg marknadstilpassing og litterær smaksdanning i breiare samfunnslag.

\section{Sluttord}

Av uvisse grunnar synest norsk skule- og kulturhistorie å ville styre utanom rolla til bokprentet $\mathrm{i}$ den lange alfabetiseringprosessen. Det same gjeld tidleg-moderne tekst- og lesevariasjon som ikkje var beinveges relatert til skulens tekstsosialisering. Mykje av det same gjeld for formidlinga av det nye meiningsuniverset som kom med reformasjonen og Luthers syn på skrift og tekst. Begge delar fekk stor spreiing på grunn av ekspanderande prenteverksdrift. Fleire har drøfta Martin Luthers syn på språk som formidlingsform, oppfatningar av tekst som medium og hans vurdering av meinige lesarar som primærmottakarar av tekst. Derimot er det heller få vurderingar av akkumulerte verknader. Ein tilsvarande mangel gjeld òg for analysar av bokbruk, boktileigning, lesemåtar og lesefellesskapar.

Dette gjer at ein ofte kjem til kort i å forklare korleis lesing, seinare også skriving og rekning, vart instituerte som allmenne kunnskapsfelt og danningsdomene alt i tidleg-moderne tid. Det er såleis eit paradoks at ein, i eit land der organisert lekmannsaktivitet har funnest sidan 1700-talet, og som også har sett ettertrykkeleg spor etter seg, kunne tenke at det var mogeleg med bønder i ein ubroten mellomaldertradisjon så seint som på 18oo-talet. Slike førestillingar målber romantiske idéar om «kulturreservat», skjerma for verknader av auka lesekunne og det ekspanderande 
bokprentet. Det Marshall McLuhan (1962) kalla «Gutenberg-galaksen», dvs. ei samanfatning av kor avhengige og kor tvers igjennom prega vestlege samfunn var blitt av oppfinninga til Johann Gutenberg, blir i norsk samanheng ofte ein metafor som manglar referent - og som dermed også blir som å vere utan relevans. Følgja er at kulturhistoriske oversyn mister deskripsjonsfylde og forklaringskraft på område der gamle kunnskapsgrenser vart overskridne relativt tidleg - til dømes lesing. Å stille spørsmål om folk flest kunne lese på 170o-talet, eller om skrift- og tekstkultur var vanleg i kristendomsutøvinga eller om bokleg tankegods spelte ei rolle i kvardagen til Per og Ola, blir ein altfor uinformert måte å nærme seg emnet på. Når ein løfter fram prentereguleringar, bok- og lesehistoriske registreringar og liknande arkivstykke for gransking, vil ein i ikkje få tilfelle måtte konstatere at ein er ført grundig på villspor fordi anekdotar har vorte generaliserte. Førestillingar om dei einskaplege, stilleståande og konservativt regulerte samfunna før 180o-talet dukkar opp omtrent kvar gong norsk identitet skal diskuterast.

Lite av dette mytekomplekset held mål i møte med det som finst av tilgjengeleg dokumentasjon, men det er ikkje til hinder for at mytane får leve vidare som urbane forteljingar om særnorsk provinsialitet frå 180o-talet. Tenlege er dei knapt for nokon, og dei blokkerer for drøftingar av nøkkelelement i den lange moderniseringa mellom reformasjon og nasjonalstat. Det som manglar er langtidsverknader av bøker og lesing, drøfting av meiningsuniverset, handlingsarenaer og alternativ for dei handlingar som omgav menneska i dette samfunnet, og som haugianarane viser gode og varierte døme på. I sum er det på ingen måte uproblematisk å ikkje ta med følgjer av at det kommersielle masseprentet fekk ei enorm utbreiing. Utan det vil ein òg ignorere prentets teknologi, skriftbruk og tekstlesing som aktivt samfunnsregulerande krefter. Eksisterande kjelder gjer det dessutan uråd å akseptere oppfatningar som relevante, valide og pålitelege om dei, trass i bokhistorisk og litteratursosiologisk kritikk, framleis vil utelate dei former for lesing som ikkje hadde skulestova som primær arena. Det same gjeld for ei tenking som neglisjerer hustavlestatens kvardagsregulering av protestantisk moral, og dermed også etiske verknader av tvangsinnlemming i kristeleg litteratur i fleire hundre år etter reformasjonen. 


\section{Litteratur og kjelder}

Apelseth, A. (2004). Den låge danninga. Skriftmeistring, diskursintegrering og tekstlege deltakingsformer 1760-1840. Avhandling (dr.art.). Bergen: Universitetet i Bergen, Det historisk-filosofisk fakultet, Nordisk institutt.

Apelseth, A. (2007). Tvang til skrift og vilje til tekst. Lesehistoria som problemfelt. I Årbok for norsk utdanningshistorie, nr. 24 (s. 126-167). Bergen: Bymuseet i Bergen.

Appel, C. (2001). Loesning og bogmarked i 16oo-tallets Danmark I-II. Danish humanist texts and studies, vol. 23. Avhandling (dr. fil.) Københavns Universitet, 200o. København: Museum Tusculanum.

Baxter, R. (1717). En fattig Mands Huus-Bog. Lorende hvorledis mand skal blive en sand Christen, hvorledis mand skal leve en sand Christen, hvorledis mand skal døe en sand Christen. København: Pet. Nørwig.

Bunyan, J. (1704). En Pillegrims Fremgang fra denne Verden, til den Tilkommende. Fremsat under en Lignelse af een Drøm, hvor udi er aabenbaret hans Udgangs Maade, hans farlige Reyse, og trygge Hiemkomst til det begierte Land / Første Part [1704]. København: Jens Godsen.

Burke, P. (1978). Popular culture in early modern Europe. London: Temple Smith.

Buset, J. (1945). Frå sunnmørsk skulesoge 1742-1827. II. Borgund prestegjeld. Tidsskrift for Sunnmøre historielag, Ålesund, 1-22.

Eagleton, T. (1983). Literary theory. An introduction. Oxford: Basil Blackwell.

Eisenstein, E. L. (1993). The printing revolution in early modern Europe. Cambridge: Cambridge University Press.

Eco, U. (1990). The limits of interpretation. Bloomington: Indiana University Press. Eco, U. (1992). Interpretation and overinterpretation. Cambridge: Cambridge University Press.

Eco, U. (1996). Læserens rolle. I M. Olsen \& G. Kelstrup (Red.), Voerk og leser. En antologi om receptionsforskning (s. 178-20o). København: Borgen/Basis.

Eco, U., Rorty, R., Culler, J., Brooke-Rose, C. \& Collini, S. (1995). Fortolkning og overfortolkning. Etterord av Svend Erik Larsen. Systime's studieserie. Herning: Systime.

Elseth, E. (1999). Wilhelm Andreas Wexels: «Dyret i Aabenbaringen»? Oslo: Luther forlag.

Febvre, L. \& Martin, H.-J. (1984). The coming of the book: The impact of printing 1450-180o. London: Verso.

Fet, J. (1995). Skrivande bønder: Skriftkultur på Nord-Vestlandet 160o-1850. Oslo: Samlaget.

Fish, s. (1972). Self-consuming artifacts: The experience of seventeenth-century literature. Berkeley: University of California Press.

Ebbestad Hansen, J. E. (Red.) (1999). Norsk tro og tanke I-II (Utvalg og presentasjon). Oslo: Tano Aschehoug. 
Frimann, C. (1790). Almuens Sanger. Kiøbenhavn: Gyldendals Forlag.

Furre, B. (1996). Hans Nielsen Hauge og det moderne Noreg. I S. Aa. Christoffersen (Red.), Hans Nielsen Hauge og det moderne Norge (KULTs skriftserie nr. 48). Oslo: Norges forskningsråd.

Furre, B. (1997). Hans Nielsen Hauge, kyrkja og embetsstaten. Tidsskrift for kirke, religion og samfunn, 2, 141-151.

Giddens, A. (1997). Modernitetens konsekvenser. Oslo: Pax Forlag A/S.

Gilje, N. (1996). Hans Nielsen Hauge - en radikal ildprofet fra Tune. I S. Aa. Christoffersen (Red.), Hans Nielsen Hauge og det moderne Norge (KULTs skriftserie nr. 48) (s. 15-29). Oslo: Norges forskningsråd.

Gilje, N. \& Rasmussen, T. (Red.) (2002). Norsk idéhistorie, bd. 2. Tankeliv i den lutherske stat. Oslo: Aschehoug.

Ginzburg, C. (1980). The cheese and the worms. The cosmos of a sixteenth-century miller. London: Routledge and Kegan Paul.

Hauge, H. N. (1947 [1796]). Løbebanen. I den Hellige Treenigheds navn Gud Fader, Søn og den Hellig Aands! Amen. IHans Nielsen Hauges skrifter. Samlet utgave ved Hans N. H. Ording. Bd. 1. Oslo: Andaktsbokselskapet. s. 108-118.

Hauge, H. N. (1947-1954). Hans Nielsen Hauges skrifter. Samlet utgave ved Hans N. H. Ording. 1-8. Oslo: Andaktsbokselskapet.

Hauge, H. N. (1971-1976). Brev frå Hans Nielsen Hauge. Ved Ingolf Kvamen. 1-4. Oslo: Lutherstiftelsen.

Holberg, L. (1748). Epistola 63. I Lud. Holbergs Epistler, Befattende Adskillige historiske, politiske, metaphysiske, moralske, philosophiske, Item Skiemtsomme Materier. Tomus I (Ep. 1-81). (s. 341-345). Kiøbenhavn.

Holberg, L. (1754). Epistola 447. I Lud. Holbergs Epistler, Befattende Adskillige historiske, politiske, metaphysiske, moralske, philosophiske, Item Skiemtsomme Materier. Tomus V, (Ep. 447-539) (s. 12-132). Kiøbenhavn. (Epistola 447 er også publisert i Billeskov Jansen, F. J., Memoirer. Kommenteret af F. J. Billeskov Jansen, 1963.)

Horstbøll, H. (1999). Menigmands medie. Det folkelige bogtryk i Danmark 1500-1840. En kulturhistorisk undersøgelse. I serien Danish humanist texts and studies. Volume 19. Forfatterens avhandling (doktorgrad) Aarhus universitet 1998. København: Det kongelige bibliotek/Museum Tusculanums forlag.

Iser, W. (1974). The implied reader. Patterns of communication in prose fiction from Bunyan to Beckett. London: Johns Hopkins University Press.

Iser, W. (1996). Tekstens appelstruktur. I M. Olsen \& G. Kelstrup (Red.), Veerk og loeser. En antologi om rceptionsforskning (s. 102-133). København: Borgens forlag. Jauss, H. R. (1996). Litteraturhistorie som utfordring til litteraturvidenskaben. I M. Olsen \& G. Kelstrup (Red.), Voerk og loeser. En antologi om rceptionsforskning (s. 56-101). København: Borgens forlag. 
Johansson, E. (1981). Den kyrkliga lästraditionen i Sverige - en konturteckning. I M. Jokipii \& I. Nummela (Red.), Läskunnighet och folkbildning före folkskolväsendet. Ur nordisk kulturhistoria. Mötesrapport. 18. Nordiska historikermötet. Studia historica Jyväskyläensia 22. Band 3 (s. 193-224). Jyväskylä: Jyväskylä Ylipisto.

Johansson, E. (2007). The history of literacy in Sweden. I H. J. Graff (Red.), Literacy and historical development. A reader (s. 238-271). Carbondale: Southern Illinois University Press.

Johnson, B. (1992). Reading Piers Plowman and the Pilgrim's Progress. Reception and the Protestant reader. Carbondale: Southern Illinois University Press.

Kullerud, D. (1996). Hans Nielsen Hauge - Mannen som vekket Norge. Oslo: Forum Aschehoug.

Kvideland, R. (1976). 160o-talsviser. Eit handskrift frå Røldal. Norsk folkeminnelags skrifter, 118. Bergen: Norsk folkeminnelag.

Lindhardt, J. (1989). Tale og skrift. To kulturer. København: Munksgaard.

Machamer, P. (2000). The concept of the individual and the idea(l) of method in seventeenth-century natural philosophy. I P. Machamer, M. Pera \& A. Baltas (Red.), Scientific controversies: Philosophical and historical perspectives (s. 81-99). Oxford: Oxford University Press.

McKeon, M. (1988). The origins of the English novel, 1600-1740. Baltimore: Johns Hopkins University Press.

McLuhan, M. (1962). The Gutenberg galaxy. The making of typographic man. Toronto: University of Toronto Press.

Selmer, L. (1934). Irgens, Ole. I Norsk biografisk leksikon, bd. VI (s. 531-532). Oslo: Aschehoug.

Taylor, C. (2007). Språket og menneskets natur. I Agora (s 176-211). Oslo: Aschehoug.

Thompson, E. P. (1966). The making of the English working class. New York: Vintage Books.

Thompson, E. P. (1967). Time, work-discipline, and industrial capitalism. Past \& Present, 38, 56-97.

Weber, M. (1995). Den protestantiske etikk og kapitalismens ånd. Oslo: Pax Forlag.

Weber, M. (1973). Den protestantiske etikk og kapitalismens ånd. Gyldendals studiefakkel. Oslo: Gyldendal.

Aarflot, A. (1969). Tro og lydighet. Hans Nielsen Hauges kristendomsforståelse. Avh. (dr. theol.) - Universitetet i Oslo. Oslo: Universitetsforlaget.

\section{Arkivkjelder}

«Pro Memoria I-II.» Visitasmerknad med følgjeskriv frå Ole Irgens for året 1788.

Generalinspeksjonens arkiv, Riksarkivet. Kopi hos forfattar (AA). 


\section{Nettkjelder}

Skiftet på Apalset i 1795, i Statsarkivet i Bergen (SAB), Nordfjord Sorenskriveri, 04/o4a/Loo19b, Skifteprotokollar 1790-1795, s. 645b-646a. Lesen 25. januar 2020.

Brukslenke for sidevisning: https://www.digitalarkivet.no/sk20081201650653

Permanent bildelenke: http://urn.digitalarkivet.no/URN:NBN:no-a1450sk20081201650653.jpg

«Skolelove», ved fulltekstbasen til Danmarks Pædagogiske Bibliotek. Lenker lesne 5.2.2020. http://library.au.dk/materialer/saersamlinger/skolelove/ «Kong Christian den femtes Norske Lov 15de april 1687 med Kongeloven 1665», lagt til rette ved UiO, Institutt for arkeologi, konservering og historie og Det humanistiske fakultet for prosjekt for nettbaserte hovudfagsstudiar ( $\mathrm{PNH}$ ) på grunnlag av ISBN 82-00-05555-8, Universitetsforlaget 1982, og etter løyve frå Universitetsforlaget. Lenker lesne 5.2.2020. http://www.hf.uio.no/iakh/forskning/ prosjekter/tingbok/kilder/chr5web/

Utdraget frå Sandhed til Gudfrygtighed er frå originalteksten, (Pontoppidan 1738, s. 58ff.) Lenka ser ut til å vere broten pr. 5.2.2020, men gjekk pr. 2015 til ein skanna fulltekst under Arkivverket, digitalarkivet: http://da2.uib.no/cgi-win/ WebBok.exe?slag=lesbok\&bokid=pontoppidan 


\title{
Vestlandsk kyrkjesyn: Med Johs. Solem som orienteringspunkt
}

\author{
Jan Ove Ulstein
}

Høgskulen i Volda

Samandrag: Artikkelen undersøkjer synet på forsamlinga i lekmannsrørsla på Vestlandet. Med indremisjonshovdingen Johs. Solem som dreiepunkt vil artikkelen vise korleis han og andre oppfatta vennesamfunnet på bedehuset som sjølve «menigheten». Utgangspunktet er 1890-talet, men med framhald heilt fram til våre dagar. Det er historia om korleis ei vekkingsrørsle etablerer eit radikalt sjølvstende overfor statskyrkja, basert på teologien omkring det allmenne prestedømet. Artikkelen drøftar korleis idealet om vennesamfunnet får sine utfordringar under vekslande kontekstar, med kyrkje- og forsamlingsdanning, med spørsmål om kvinner også kan ha alle tenester i det allmenne prestedømet. Kan ein i ei bedehusforsamling tenkje seg det allmenne forstandardømet? Om ikkje - kva røper det om synet på det allmenne prestedømet?

Nøkkelord: forsamling, kyrkjesyn, vestlandsk religiøsitet, kvinne og organisasjon, allment prestedøme

\section{Introduksjon}

Denne artikkelen skal handle om synet på forsamlinga i vestlandsk indremisjon, med innsteg i 1890-åra. Det står i ein historisk samanheng: lekmannsrørsla sitt eige arbeid i forhold til Den norske kyrkja. Den historiske bakgrunnen for vestlandsk lekmannskristendom har Birger Løvlie gitt i føregåande artikkel, også for min hovudperson, Johannes (Johs.) Solem. Vi ser der brytingane mellom aust og vest, mellom Gisle Johnson/ Lutherstiftelsen og dei meir radikale i vest, mellom samarbeid med

Sitering av denne artikkelen: Ulstein, J. O. (2020). Vestlandsk kyrkjesyn: Med Johs. Solem som orienteringspunkt. I B. Løvlie, P. Halse \& K. Hatlebrekke (Red.), Tru på Vestlandet. Tradisjonar i endring (Kap. 6, s. 127-161). Oslo: Cappelen Damm Akademisk. https://doi.org/10.23865/noasp.104.ch6

Lisens: CC BY-ND 4.0. 
presten og fullstendig sjølvstende, mellom forsøk på kyrkjeleg reformarbeid og oppbrot. ${ }^{1}$

Sparringpartnar er heile tida den offisielle norske lutherske statskyrkja, både i sin teologi og sin institusjon. Teologien er Confessio Augustana (CA), særleg artikkel 7, med kjenneteikn på kyrkja som ei forsamling av truande der evangeliet blir forkynt reint og sakramenta forvalta rett. Institusjonen er Den norske (stats)kyrkja. Det første kjenneteiknet seier noko om forkynninga om synd og nåde, lov og evangelium ${ }^{2}$ - som er hjartepunktet både i luthersk teologi og i den pietistiske omvendingsforkynninga. I tillegg kjem Martin Luthers vektlegging av det allmenne prestedømet - som også blir den teologiske legitimeringa av eit sjølvstende for lekfolk. Det forklarar også at lekmannsrørsle og demokratisk rørsle var to sider av same sak frå tidleg 180o-talet av. 'Lek' er ikkje berre eit ord i motsetning til 'lærd', men også til 'ordinert', det vil seie presten og presteembetet. Presten var både lærd og «retteleg kalla» (CA 14), og i tillegg statens embetsmann. Det forsterkar samanfallet av demokratisk rørsle og lekmannsrørsle - med embetsmannsstaten og embetspresten som motpart.

Det forsterkar også dei teologiske brytingane og gir dei sin kontekst. Lekmannsrørsla vil vere luthersk, og det adjektivet går inn i namnet på landsorganisasjonane. Det går heile tida føre seg ei drøfting av teologi, praksis og strategi. Desse drøftingane vi ser både på landsplan og lokalt, er uttrykk for teologi; det er teologiske spørsmål dei drøftar til dømes i striden i Sunnmøre Indremisjon på 1950-talet. Spørsmål var om einingane kunne bruke predikantar som ikkje stod på det lutherske i eitt og alt. Drøftingane var nødvendige for å avklare praksis. Var det nok at dei var lojale og aldri snakka om sitt avvikande syn på dåpen, eller kunne dei grunngi sitt syn om dei vart spurde?3 Det er døme på teologi knytt til eit praksisfelt, det er kontekstuell teologi driven av lekfolk, utan at fagteologar tok del i brytingane. Luthersk sett er ein slik aktivitet i pakt

\footnotetext{
For denne prosessen med kyrkjeleg reformarbeid over tid, sjå Løvlie, 1996.

Carl Fr. Wisløff ville heller seie Lov - Evangelium enn Synd - Nåde. Sjå Sjåstad, 2016, s. 200-201, 212-215.

3 Ordets folk, 1998, s. 234-239. Også like etter starten var det litt avvikande syn i Det Vestlandske Indremisjonsforbund, DVI, i reformert retning, t.d. i nattverdsspørsmålet Andreas Lavik, sjå Fossum, 1987, s. 49, 66.
} 
med vekta på det allmenne prestedømet. Helge Aarflot (1973) peikar på at teologien i middelalderen var utført av dei verkeleg profesjonelle, i klostera, der lekfolk ikkje vart rekna med. Luther braut med dette, og teologien fekk to løp. Han fekk sin lærde stad ved universiteta, ikkje lenger i klostera. I tillegg blir teologien også demokratisert. Begge delar er likevel retta mot kyrkjeleg praksis. ${ }^{4}$ Luther stod for ein folkeleg teologi, han «opp-teologiserte» lekfolket.5

Det allmenne prestedømet rører også ved det andre kjenneteiknet på forsamlinga, det institusjonelle. Det andre kjenneteiknet i CA 7 er administreringa av sakramenta. Det er eit stikkord for ei institusjonell organisering; ei forvalting krev meir enn spontanitet. Og her stod Den norske kyrkja for ei gjennom-institusjonalisert forvalting, samanvevd med ei statsform og ein kyrkjerett. Ei vekkingsrørsle må nødvendigvis finne si form. ${ }^{6}$ Det skjedde som aktiv deltakar i den foreiningsdanninga som var viktig del av sjølve tidsånda på 180o-talet, Associations-aanden. 7 Det er ei organisering, ikkje ei institusjonalisering. Ein landsorganisasjon er generelt sett ei samanslutning av foreiningar til felles beste, for å fremje sine formål, ikkje ei samanslutning av forsamlingar til eit kyrkjesamfunn.

Organisering av foreiningane på landsplan skjedde ved misjonsorganisasjonane, først Det Norske Misjonsselskap i 1842. Lutherstiftelsen kom først i indremisjonen (1868), og utvida frå Kristiania. Dei dreiv arbeidet i samarbeid med «embetet» - av Gisle Johnson oppfatta som nødvendig ut ifrå CA 5 og 7 . Han var luthersk vekkingsorientert statspietist. Men eit meir «radikalt» syn vann fram. 'Radikal' blir her målt på forholdet til kyrkja, eit sjølvstende i forhold til prest og kyrkjeinstitusjon. Grunnleggande spørsmålsstilling i denne artikkelen er då, med Johs. Solem som orienteringspunkt: Kva kyrkjesyn kan grunngi eit radikalt sjølvstende, og kva kontekst krev det? Kva skjer ved skifte av kontekst?

4 Opprettinga av Menighetsfakultetet (1908) er lett å sjå i dette perspektivet: ein kombinasjon av universitets- og lekmannsteologi, eller: lekmannsteologiens behov for å føre ein teologisk kamp i universitetsfeltet. Begge delar: fordi teologi er ein viktig refleksjon omkring frelse og sant kristenliv, med praktiske konsekvensar for forkynning, formaning og praksis.

Aarflot, 1973, s. 90-91.

Med kyrkjevekstterminologi: movement si neste fase er machinery (Ralph Winter).

Try, 1985 . 
Eg går først innom 1890-talet for å gi eit signalement på den pietistiske vestlendingen sitt forhold til organisering. Det var tida då fleire organisasjonar vart stifta på Vestlandet. ${ }^{8}$

Så går eg utførleg inn på to småskrifter av Johannes Solem, begge haldne på årsmøte i Det Vestlandske Indremisjonsforbund (DVI) på 1930-talet, og trykte opp att i 1995. Eg vil gi han ordet til ein grundig gjennomgang av synet på historia i lekmannsrørsla si store forteljing i hans versjon, og synet hans på kva den bibelske forsamling eigentleg er. Dette blir tyngdepunktet i artikkelen, med kontekst.

Eit noko lettare tyngdepunkt blir på 1990-talet, der DVI er i ein fase for klargjering av sin organisasjon. Eg går inn i debatten om kvinners plass i forsamlinga - fram-provosert ved eit framlegg frå styret om at kvinner kunne veljast inn i Forbundsstyret. Det vart avvist av Landsmøtet. Høyrde ikkje kvinnene med til det allmenne prestedømet? Dette spørsmålet heng saman med synet på forsamlinga på den tida i rørsla. ${ }^{9}$

Siste stopp blir eit riss av utviklinga sidan, med formell danning av kyrkjesamfunn. Kyrkjemøtet 2016 opna for vigsel av likekjønna i kyrkja. Det auka avstanden til kyrkja.

Vi kan føregripe utviklinga ved å markere nokre faktiske utviklingslinjer. I 1890-åra var spørsmålet om lekmannsforkynning for lengst avklara. Konventikkelplakaten var oppheva i lovverket (1842), og lekmannsorganisasjonane var samstemte på denne sjølvstendige retten (frå 1891). Det store spørsmålet frå den tid var om lekfolket også kunne administrere nattverden, som «fri» nattverd, dvs. på bedehusa utan prest, i kraft av at alle er prestar. Den retten vart lovfest i 1913, etter ein lengre prosess. Praksis var likevel ikkje eintydig. Først etter 2000 kom dei første forsamlingane ${ }^{10}$ der dei også praktiserte dåp, og vart registrerte som sjølvstendig kyrkjesamfunn. Det forstyrra i realiteten ordenen på bedehuset, der ein før kunne vere medlem i fleire organisasjonar og samtidig stå i statskyrkja. Skilnaden mellom foreining og forsamling viser seg tydelegare. Den

\footnotetext{
Gundersen (1996) gir ei god oversikt over framveksten av dei kristelege organisasjonane.

Ulstein, 2001.

Sunnmørskirka hadde sitt første møte 15. januar 2006, legitimert av kretsstyret. http://sambaandet.no/2005/11/29/oppstart-for-sunnm\%C3\%B8rskirka/. Dei hadde få medlemmer dei første åra.
} 
nye statusen førte med seg retten til og ansvaret for ekteskapsinngåing og gravferd, med lokal «hyrde» eller forsamlingsleiar (forstandar) og ikkje berre tilreisande emissær. Då snakkar vi om ein gryande kyrkjeinstitusjon, ikkje ein organisasjon.

\section{0-talet og Solem}

I 1891 forlét Lutherstiftelsen «nødsprinsippet», ${ }^{11}$ men heldt fram med ei samarbeidslinje med kyrkja. På denne tida vart det arbeidd mykje med å slå saman indremisjonen på Vestlandet og Austlandet. Det var fleire møte om det, der dei fleste av «hovdingane» gjekk inn for det. På eit møte i Bergen 1891, og Stavanger i 1892, var ålesundaren Erik Solem den einaste «stribukken» som tala alle midt imot. ${ }^{12}$ Han ville ikkje ha samanslåing av vestland og austland i indremisjonen. Seks år seinare vart Det Vestlandske Indremisjonsforbund (DVI) skipa i Bergen, 1898, med ein meir radikal kurs, dvs. klart sjølvstende i forhold til kyrkja og eit arbeid uavhengig av presten, men ikkje heilt imot samarbeid med kyrkja. Litt paradoksalt er det at presten Ole Kristian Grimnes hadde vore pådrivar og vart første formann. Andreas Lavik vart nestformann og redaktør av bladet Sambåndet. ${ }^{13}$ Både Erik og Johs. Solem var med i oppstarten.

Johs. Solem var fødd i Ålesund i 1968, son av den markante lekmannsleiaren Erik Solem. Han vaks opp i ein heim der folk gjekk ut og inn, og der samtalane ofte gjekk om kristendom. Han fekk eit kristeleg gjennombrot under konfirmasjonsundervisninga til Grimnes og tok eit aktivt religiøst standpunkt. Turen gjekk til ingeniørstudiar i Trondheim. Der kom han i kontakt med Marius Giverholt, som hadde eit stort søndagsskulearbeid i gang. Giverholt er kjend for å ha eit syn på kyrkja som er strengt

\footnotetext{
11 Sjå t.d. Løvlie, 2020.

12 Karakteristikken kjem frå sonen, Johs. Solem, og er ein hyllest. Sjå også Fossum (1987, s. 39-40) om Erik Solems rolle i kritikken av hovudstadsindremisjonen. Frå 1913 tok organisasjonane til å arbeide for ei samanslåing eller nærare samarbeid mellom dei. Det vart det arbeidd med til 1936, då dei gav opp. Om «Geilosammenslutningen», sjå Fossum 1987. Johs. Solem representerte Kinamisjonsforbundet før dei og DVI gjekk ut i 1919. Etter den tida var han likevel med i arbeidsutvalet $\mathrm{i}$ «sammenslutningen».

13 Solem, 1938/1995. Kortversjon om stiftinga: https://imf.no/om-oss/historien/. Lengre: Ordets folk, 1998, s. 49-62.
} 
kongregasjonalistisk, dvs. at den enkelte forsamlinga er heilt sjølvstendig. Han praktiserte fri nattverd i heimen. ${ }^{14}$

Johs. Solem kom tilbake til Ålesund 1890 og hadde med seg eit meir radikalt kyrkje- og kristendomssyn. Han vart seinare borgarmeister i Ålesund og ein respektert mann. Han var med i leiarskapet i DVI allereie i starten i $1898 .{ }^{15}$ Innsteget på 189o-talet er ikkje tilfeldig. Her ser vi demonstrert i organisatorisk form eit skilje mellom vestlendingane og austlendingane i indremisjonsarbeidet, ikkje minst forholdet til «ebetet». Sjølv der presten var med i flokken, var det i Ålesund lagt opp til møte i kyrkjetida. Presten Grimnes var sjølv med på det! Det skjedde før kampen mot liberal teologi fekk sine parolar på Calmeyergate-møtet i 1920. Her er det presten som prest, og ikkje som liberal teolog, som er i fokus.

På 1890-talet vart også Norsk Luthersk Kinamisjonsforbund skipa (1891), med Johannes Brandtzæg som motor. Han blir også av Solem rekna som ein på same linje. Begge desse to organisasjonane representerer det radikale lekfolket på Vestlandet. Solem var med i begge. Kinamisjonsforbundet hadde på denne tid hovudsetet i Bergen, seinare på Framnes, for så å flytte til Oslo. Medan Kinamisjonsforbundet (seinare Misjonssambandet) gjekk i retning av ein sterk landsorganisasjon, så markerte DVI allereie i starten at hovudvekta låg på det enkelte vennesamfunnet. Det er markert i grunnreglane.

De enkelte Foreninger eller Fellesforeninger beholder fremdeles sin fullkomne Frihet og selvstendighet i alle sine Anliggender, ogsaa naar det gjelder virkemaaten og virkemidlene. ${ }^{16}$

14 Om Solems biografi, sjå Handeland, 1966, s. 272-278. Fri nattverd praktiserte Giverholt frå 1888. Ludvig Hope er den mest kjende forkjempar for den saka. Han heldt eit føredrag om det på eit lekmannsmøte i 1906. I 1913 vart det lovleg. Det kan oppfattast som ei klargjering etter oppheving av Konventikkelplakaten i 1842. Lekfolk fekk no rett til å forrette fri nattverd utan prest, ifylgje norsk lov.

15 Ordets folk, 1998, s. 354. Han var formann 1907-1909, i forbundsstyret 1898-1910 og frå 1919 til 1935.

16 Sitert etter Fossum, 1987, s. 41. Fossum protesterer mot den vanlege tolkinga at dette dreia seg berre om eit kyrkjesyn. Det var i høg grad eit anti-autoritetært syn på både samfunn og kyrkje. Det betyr at tidsånd og teologi samverka til utforming av posisjonen. Til kampen for sjølvstende, sjå også Bernhard Eide i Det Vestlandske Indremisjonsforbund gjennom 50 år (s. 55-90). 
Skulle vi oppsummere maktstrukturen i Vestlandske Indremisjonsforbund på 190o-talet, så ligg vekta på den enkelte foreininga, dernest på det regionale leddet (kretsen) og sist på det nasjonale (Bergen). Sjølvstendet til foreiningane slo ut i ulikskapar lokalt. Der var svært stor skilnad i profilen mellom indremisjonane i Ørsta og på Valderøya.

\section{Dreiepunkt Solem}

Johs. Solem vart beden om å halde foredrag på årsmøtet i 1934 om forholdet til statskyrkja. ${ }^{17}$ I 1938 hadde han (på 40-årsjubileet) foredrag om Det frie lekmannsarbeidet i kommende dage. Begge desse foredraga vart trykte, og i 1995 publiserte Sambåndet Forlag begge samla som opptrykk. ${ }^{18}$ Det er like før noko nytt tek til å skje i forbundet. Organiseringa på bedehuset endra seg på 9o-talet. Generalsekretær i perioden, Karl Johan Hallaråker, vedgjekk at hyrde var nærast «framandord» på bedehuset. ${ }^{19}$ Brytinga omkring kvinna som læreansvarleg avspegla endringane. Det er for oss interessant at Solem sine foredrag blir trykt opp då. Det kan bety at vi har ei forholdsvis konsistent linje i desse spørsmåla til då, i alle fall blir ein hovdings tale prenta på nytt.

Eg låner briller av Solem ved dei to foredraga, og kommenterer. Så ser eg vidare på kva som skjer frå slutten av 1900-talet og vidare. Etter hundre år kan vilkåra og konteksten ha endra seg - kva skjer så med indremisjonsarbeidet og foreiningane? Som vi skal sjå, er det sjølvstendige syn ute og går mellom «vestlendingane». Eg vil bruke Solems syn som ein type. Det er ikkje sikkert at han er representativ, han var ikkje for ei konform linje. Men han meislar ut eit syn som verkar å vere nær noko erketypisk for vestlendingen. Det uttrykkjer ein bestemt teologi. ${ }^{20}$

\footnotetext{
17 Sjå Løvlie (2020) om hans foredrag om same tema på lekmannsmøtet i Ålesund 1893, Statskirken og de troendes forhold til samme, 1893.

18 Begge desse skrifta ligg ute digitalt i Nasjonalbiblioteket. Det er same paginering i opptrykket som i originalane. Dei kom ut i Jubileumsserien. https://www.nb.no/items/48b58e $7 f_{323}$ c2ffocde5194egf 4 ac674? page $=53$ \&searchText $=$ johs. $\% 2$ osolem

19 Hallaråker, 1997.

20 Eg refererer desse småskrifta ganske mykje. Det er også for å gi eit direkte inntrykk av orienteringa nær hans eigne uttrykk og tankeføring.
} 


\section{Solem om indremisjonshistoria}

Solem startar foredraget i 1938 (på årsmøtet og ved feiringa av 40-årsjubileet) med å dra indremisjonshistoria frå Hans Nielsen Hauge av. For oss er det av mest interesse å sjå kva han legg vekt på i denne historieframstillinga. Ei forteljing seier mykje om den som fortel. Ho profilerer her ei rørsle og ein teologi ved sitt narrativ. Når eg ikkje markerer anna, er det referat av Solems framstilling. Han vel ut og tolkar.

Hauge hadde ingen ytre organisasjon for arbeidet. Han hadde ein «indre organisasjon» i venneflokken. I sitt berømte «testamente» rekna han dei truande som «menigheten» med valde «eldste» til å styre og leie. Solem held denne måten å organisere på «i det store og hele», noko som svara til Det nye testamentet. Han legg til at Hauge også oppmoda vennene om å halde seg til «statens religion», høyre på prestane og ta imot sakramenta av dei. Solem forklarar det ved at han var «barn av sin tid, og bundet av tidens autoritetstro». ${ }^{21}$

Konventikkelplakaten vart oppheva av Stortinget i 1842. Etter den tid var lekmannsforkynning lovleg. Motstand mot den var der framleis. Det endra seg noko ved professor Gisle Johnsons «prestevekkelse» frå midten av århundret. For «de troende prestene han sendte utover landet stilte seg som regel i et helt andet forhold til den haugianske vekkelse». Dette «utbrudd av åndelig liv blant prestene hilste haugianerne med glede.» ${ }^{22}$

Desse prestane fekk innverknad på arbeidet, særleg på Austlandet. Dette representerte samtidig ein fare. For det frie lekmannsarbeidet var det kanskje farlegare enn «forhånelse og forfølgelse». Å vere avhengig av presten og kyrkja førde til tap av det åndelege sjølvstendet som var vilkåret for å kunne vere lys og salt blant folket. Professor Johnson var også tilhengar av «nødsprinsippet». Fordi det var stor naud mellom folket trass i statskyrkja, så måtte ein tole lekmannsverksemda, med Solems ord: «som en foreløbig foranstaltning, inntil kirken selv kunne overta all åndelig forpleining. ${ }^{23}$

\footnotetext{
21 Solem, 1938/1995, s. 4-6; Solem, 1934/1996. Her har vi ein Hauge-kritikk. Litt paradoksalt er det at Hauge blir skulda for å ligge under for autoritetstruskap. Solem er m.a.o. sterkt usamd med Hauge her.

Solems tolking, Solem, 1938/1995, s. 8. Sjå også Aalesund Indremisjon (s. 16) om embetet.
} 
På dette nødsprinsippet vart det første indremisjonsselskap stifta i 1868, Lutherstiftelsen, med foreiningar frå Austlandet, med lekmenn sendt ut over landet. På Vestlandet var det annleis, kanskje takka vere herrnhutane. ${ }^{24}$ Dei var pionerar for heidningemisjon og ei rekke andre tiltak. I 1864 vart det også stifta ei fellesforeining (indremisjon) for Hardanger og Voss. ${ }^{25}$

Johnson skreiv til leiarane på Vestlandet og ville ha dei med i Lutherstiftelsen. Det vart blankt avvist. Dei kjende seg på trygg bibelsk grunn ved å praktisere det allmenne prestedømet og utfalde nådegåvene, i samsvar med Luther. Vestlandske lekfolk stod saman om å ikkje vere underbruk under kyrkja. Deira rolle i Guds rike kravde ei fri stilling. ${ }^{26}$

Presten Jakob Sverdrup støtta også vestlendingane si radikale linje. Han prøvde å gjere Bergen til hovudstad for lekmannsrørsla i Norge, men mislukkast. Det vart halde to møte om å lage ein landsorganisasjon på 1880-talet, utan resultat. Lutherstiftelsen skjønte at om dei skulle samle indremisjonen i landet til eitt selskap, så måtte dei la nødsprinsippet fare. Det skjedde i Drammen 1891, saman med namneendring til Det norsk-lutherske Indremisjonsselskap. ${ }^{27}$

Men tilslutninga frå Vestlandet gjekk ikkje så glatt, trass i at dei aller fleste leiarane gjekk sterkt inn for det. Erik Solems opposisjon er nemnd. Ein annan, «kandidat Brandtzæg», meinte leiarane hadde svikta den vestlandske lekmannskristendommen. Denne «unge mann» vart sterkt irettesett av Jakob Sverdrup. Likevel greidde ikkje hovdingane å få til ein slik organisasjon. Dei var ikkje på linje med lokalforeiningane. Den konfliktfylte historia på 1890-talet førte til slutt til skipinga av DVI. ${ }^{28}$

Pådrivar her var presten O. K. Grimnes. Han hadde «kommet til liv i Gud» ved ein lekpredikant i Skiens-området. Han vart den første formann. Hans biografi spelar ei viktig rolle hos Solem. Grimnes var prest i Ålesund

\footnotetext{
24 Solem nemner dei. Sjå om deira betydning i denne fasen på Vestlandet i Vestavind, Løvlie, 2002. Solem nemner dei også frå si tid i Trondheim, Aalesund Indremisjon (s. 14-17). Hauge i sitt testamente organiserte ingen ytre organisasjon, hevdar Solem. Det var herrnhutane, brødrevennene, som innførde det samfunnsbyggjande elementet i sine societé (brorskap) - med foreiningane. Solem,1938/1995, s. 8-10.

Solem, 1938/1995, s. 10. Til desse forsøka på å organisere indremisjonen i ein organisasjon, sjå Fossum, 1987, s. 34-40.

Solem, 1938/1995, s. 11.

Solem, 1938/1995, s. 12-13.
} 
frå 1878 til 1893, så i Bergen. Han fann med ein gong fram til venneflokken og stod i ei stor vekking på slutten av 188o-talet. Ei hending viser kor han stod last og brast med det radikale lekfolket på Sunnmøre. I 1888 vart Ålesund truleg den første byen som la formiddagsmøte på søndag samtidig med gudstenesta i kyrkja. Og: Det vart støtta av byens to prestar! Dei fekk refs av biskopen, men Grimnes formulerer noko som vi kan kalle eit strategisk prinsipp: «Innfør formiddagsmøte nu mens dere har troende prester. Ti har dere først fått dem, så kan de ikke godt ta dem fra dere igjen, når dere får andre prester. $\mathrm{Og}$ da kan dere trenge det vel så godt. $\aleph^{29}$

Solem er også kritisk til Indremisjonsselskapet og Ole Hallesby. Endå dei i eit vedtak frå 1914 strauk bestemmelsen om at dei skulle vere forplikta på å arbeide i tilslutning til «det kirkelige embete», så viser praksis noko anna. Hallesby forkynner sterk tilslutning til kyrkja, endå han burde ha halde seg til det han var med på å formulere i (Calmeyergate)møtet i Oslo i 1920 - at viktigaste middel kampen mot den liberale teologien er organisasjonane sitt byggjande arbeid. Der var det tale om å «selvstendiggjøre og styrke disse». Og, er Solems spørsmål, kva skulle dei sjølvstendiggjerast og styrkast overfor - om ikkje kyrkja? Men Hallesby ser ut til å vere påverka av den kyrkjelege ånd ved Menighetsfakultetet. Det er DVI og Kinamisjonsforbundet som sterkast hevdar den frie lekmannslinja - fordi dei først og fremst tek omsyn til «den levende menighet ... i forlikelsens tjeneste ... Og kun så langt kirken og dens prester står oss bi i dette arbeidet, kan vi samarbeide med dem».30

\section{Om Hauge, Johnson, Hallesby}

Vi ser at Solem i framstillinga reduserer Hauges sjølvstende overfor autoritetane, i «testamentet». Det er ikkje autoritetstru Hauge er mest kjent for. Men han kan ha noko rett i sin kritikk. Også Oddvar Jensen (2012) oppfattar Hauges testamente som ein tilpassande strategi, men som nødvendig i forhold til lovverket. Det kan bety at Hauge ikkje berre var barn av si tid og dermed slavisk autoritetstru, men realist i si tid og

Solem, 1938/1995, s. 14-16. Om Grimnes, sjå også Aalesund Indremisjon, s. 26, 87. Det var på den tid overveldande kyrkjesøking til Grimnes' og Aslaksens gudstenester. Formiddagmøte samtidig tok vekk køa utanfor kyrkjedøra. 
i sin strategi. Jensen viser til det tidlege Hitra-brevet frå Hauge (1802). Der framstiller Hauge seg med apostolisk fullmakt i kraft av sitt kall, og han peikar ut eldste i dei ulike vennesamfunna - også kvinner. ${ }^{31}$ Når Solem identifiserer vennesamfunnet med «den levende menighet», så er det på linje med Hauge. For Solem gjeld det å ta avstand frå samarbeid med «det kirkelige embetet», slik «nødsprinsippet» hos Gisle Johnson var uttrykk for. Johnsons kyrkjesyn tilsa at presten hadde ansvar for å forkynne evangeliet og forvalte sakramenta etter CA 7. Statskyrkja er kyrkje hos han. Lekmannsarbeidet blir eit viktig supplement han i sin pietistiske teologi arbeidde for. Det er truande prestar Johnson sender ut. Solem legg vekta på det første leddet i CA 7, på at «menigheten» er forsamlinga av dei truande, altså vennesamfunnet. Der er kyrkja, og ikkje i statskyrkja. Både hos Solem og hos Hope (sjå seinare) er dei kristne det same som dei omvende. Det er då ein får «liv i Gud».

Hans refs av Hallesby viser same radikale synet. Hallesby burde gjere lekmannsarbeidet meir sjølvstendig - overfor (stats)kyrkja. No kan ein peike på at Solems tolking av den siterte ordlyden ikkje er heilt patent. Det går an å ha eit svært sjølvstendig lekmannsarbeid og samtidig sjå det i samsyn med det lokale kyrkja og presten. Ungdomsforbundet gjorde det. Vi ser her ein skilnad mellom aust og vest. Generalsekretær Wisløff i Indremisjonsselskapet gjekk inn for å «fylle institusjonene», dvs. gå inn i dei nye sokneråda (etter 1920) og prege dei.

Det radikale ligg altså i forholdet til statskyrkja. Vi ser no på korleis han legg det til rette i foredraget av 1934. Det er same tema som han tok føre seg dryge 40 år tidlegare. Løvlie (2020) oppsummerer det slik:

Foredragets budskap kan samles i to punkter. Kirkeordningen innebar en organisering av «verden» inn i Jesu Kristi kirke, og kirkens møte med folket produserte fortløpende hykleri, ved at ugudelige mennesker ble tatt inn i kirkens handlinger og ble tiltalt som «kjære kristne». Solem konkluderte med at statskirken verken var bibelsk eller luthersk.

31 Jensen, 2012. Om den tidlege Hauge, med si rørsle, sjå også Trygve Riiser Gundersen «Stemme utenfra», Bokmagasinet, Klassekampen, 23.11.2019, s. 4-6. Kvinner er med på like fot. Dei profeterte, men dei «bringes til taushet». I «testamentet» er Hauge meir tilbakehalden: «Kvinder holde ikke tale, hvor der er Vantroe saman, men kun i Stilhed med enkelte, eller hvor en del troende er sammen.» Kanskje har Solem noko rett i at Hauge bøygde av for tidsånda. 


\section{Solem om forholdet til statskyrkja}

Solem startar med eit døme han finn typisk. Ein prest åtvarar predikanten Paul Gerhard Sand mot å kome til bygda hans, for her var det fred og ro. Sand sa at han kom, om han vart kalla. Kalla vart han, og vekking kom. Solem held dette for å vere typisk for den offisielle kyrkja utan åndeleg liv. Der har ein det godt med sitt embete og sine institusjonar. Men det er «kirkegaardens fred». Når det kjem vekking og liv, vekkjer Anden folk opp frå syndesøvnen så dei opplever personleg frelse ved evangeliet. Då kjem også kallet til åndeleg presteskap etter Peters og Luthers ord. Nest etter rettferdiggjering ved tru åleine var det det allmenne prestedømet Luther heldt for å vere viktigast. Saman med 1 Kor 12 om nådegåvene er 1 Pet 2,9 grunnlaget for lekfolkets rett til å arbeide for Guds rike. Luther var klar på at ytre seremoniar gjer ingen til prest. Men han vann ikkje fram med å gjennomføre det allmenne prestedømet reint organisatorisk, hevdar Solem. ${ }^{32}$

Når det tok til å bli åndeleg liv i kyrkja, med Hauge, var enno Konventikkelplakaten der og forbaud forkynning ved lekfolk. Først i 1842 vart han oppheva, etter tredje gongs handsaming. Det var den verdslege styresmakta som gav lekfolk lovleg rett til å forkynne. Men først i 1888 (med Jakob Sverdrup som minister) vart det lovleg for dei å preike i kyrkjene frå kordøra (Solems utheving). I 1906 rådde lovverket til at lekfolk preika frå preikestolen. I 1920 kom lova om sokneråd/menighetsråd. Desse råda tok over ansvaret for tilsynet med kyrkjene. Også etter dette vart predikantar nekta å preike i kyrkjene, til dømes kandidat Brandtzæg i Trondheim. Han var ikkje kyrkjeleg nok..$^{33}$

Lova om menighetsråd frå 1920 får så ein drepande kritikk av Solem.

Det skal veljast av manntalet, minus dissenterane - det mest verdslege manntalet i landet. Og der er ingen garanti for at det er truande som blir valde inn. Anna kan ein ikkje vente av ei statskyrkje som alle dagar har vore «riket av denne verden», og som alltid vil vere det. Og i lova står det at rådet kan sette i gang og leie kristeleg verksemd. Solem heldt dette «kan» for å vere ei ulukke. Og han siterer pastor Skagestad (frå 1909), der

\footnotetext{
32 Solem, $1934 / 1995$, s. 3-5.

33 Solem, 1934/1995, s. 6-10. I nattverdstriden like etter århundreskiftet vart mange nekta å preike i kyrkjene, t.d. Ludvig Hope, Fossum, 1987, s. 66-67.
} 
han åtvarar mot at råda skal overta ansvaret for arbeidet $\mathrm{i}$ «menigheten». Då ville «livet bli lagt i dødens arme».34 Solem siterer også sokneprest Grimnes. Etter 1920 hevda han at den som arbeider for den nye ordninga fylgjer «den flokken som hev forædaren Judas til førar». Solem tykte først at Grimnes tok vel sterkt i. Men om desse råda «opptrer i konkurranse med det kristelige brorskaps sammenslutninger og deres arbeide», då blir dei farlege, det skjer «i dødens armer». Lekmannsrøsla må stå i kampstilling (Solems utheving) overfor kyrkjelege institusjonar. ${ }^{35}$

Neste steg for frigjering av lekmannsrørsla i lovverket var at den frie nattverd vart lovleg. Det var i 1913 at Stortinget gav denne gåva til «den levende menighet» (Solems utheving. ${ }^{36}$

Forsamlinga har ein bibelsk rett til å forvalte nattverden. Solem siterer CA 7, begge ledd. Han argumenterer (med Pontoppidan) at forsamlinga av dei truande er kyrkja, sakramenta er (berre) kjenneteikn på kyrkja. Hans logikk er at då kan forsamlinga også bruke sakramenta fritt. Hans Nielsen Hauge kom berre halvveges dit. Han brukte «menighet» om vennesamfunnet, men gjekk til kyrkja for sakramenta, til rasjonalistiske prestar. Dette har lekmannsrørsla seinare korrigert. Allereie i 1877 hevda skoleinspektør Irgens på eit stiftsmøte i Bergen at det einaste konsekvente var at indremisjonsforeiningane kunne forvalte sakramenta - når dei kunne forkynne Guds ord. ${ }^{37}$

Der er meir krut hos denne vestlandske lekmannshovdingen. No gjeld det eit stort frivillig landsmøte i Oslo 1920, mest kjent som Calmeyergatemøtet, den store mobiliseringa mot liberal teologi. I striden mot den nyrasjonalistiske liberale teologien var det nødvendig med eit styrkt og sjølvstendiggjort kristeleg organisasjonsarbeid, heitte det. Det gjeld å ikkje bruke tida til innbyrdes strid. Dette tolkar Solem som ei sjølvstendiggjering overfor kyrkja. Han viser til ei formulering som tyder på det:

Solem, 1934/1995, s.13f. Skagestad vart seinare praktikumsrektor på MF. Solem seier ganske sarkastisk at han neppe stod for «det bibelske menighetsbegrep han den gang hevdet» (s. 14). Den «kirkelige vind» hadde drive han bort frå det. Også Hope brukar mykje plass på Skagestads endring. Han siterer i sin heilskap Skagestads angrep på seg sjølv. Brytinga går nettopp på kyrkjesynet. Hope, 1923/1969, s. 79-86.

Solem, 1934/1995, s. 17-20. 
«Hvor menigheten har prester, der vitterlig ikke forkynner det bibelske evangelium, hevder vi den levende menighets rett til på andre lovlige veier å betjene sig med Guds ord, dåp og nadverd.» Det var 472 stemmer for og 334 imot denne formuleringa. Det kan synest å vere eit knapt fleirtal. Men Solem gir grunnar for å tolke det slik at mindretalet ville krevje denne retten om så det skjedde ulovleg. Som Hans Nielsen Hauge. Har ei levande menigheit denne retten, så har dei han sjølv om presten ikkje er liberal. Men då er det desto større grunn til å nytte han..$^{8}$ Solem er samd med Ludvig Hope om at ein ikkje treng stridast om spørsmålet innbyrdes. Ein kvar må fylgje sitt eige samvit om ein vil ta imot nattverden i kyrkja eller på bedehuset..$^{39}$

Det siste Solem vil understreke, er at vennesamfunnet på bedehuset er sjølve samfunnet. Her siterer han grundig generalsekretær Wisløff frå 1930 i bladet For Fattig og for Rik. Han vil «Gi kirkens hvad kirkens er, og bedehuset hvad bedehusets er». Wisløff formanar indremisjonsfolk til å vere «passelig kirkelige», og truande prestar til å leve saman med truande på bedehuset, og la indremisjonen vere vennesamfunnet for kyrkja. Indremisjonen er ikke berre ei foreining, men sjølve samfunnet..$^{\circ}$

Dette er Solem heilt og fullt samd i. Derfor held han det for rart at Wisløff ikkje dreg den konklusjonen at nattverden høyrer heime der. Han ser at noko har endra seg. På Geilo-møtet ${ }^{41}$ i 1919 vedtok dei sju punkt som skulle fremje eit godt forhold mellom dei frie organisasjonane. Det siste gjekk på synet på fri nattverd. Om det spørsmålet heiter det «at enten man nyter Herrens nadverd i kirken eller utenfor kirken, så bør ikke dette

\footnotetext{
38 Solem, 1934/1995, s. 21-24.

39 Solem, 1934/1995, s. 25. Han siterer elles aldri Hope i kyrkjesynet. Også seinare generalsekretær i Misjonssambandet, Tormod Vågen, vil gi evangelisk fridom til å gå til nattverd på bedehuset eller i kyrkja, eller begge delar, sitert i Veien fram, 1977, s. 274. Dette tyder på at der er ulike kyrkjesyn i indremisjonen, slik også konstatert av Solem i Aalesund Indremisjon: 42. Ei brei framstilling hos Bernhard Eide i Det Vestlandske Indremisjonsforbund gjennom 50 år, s. 162-185, dokumenterer dei store spenningane.

Solem, 1934/1995, s. 26-27. Wisløffs posisjon kan verke sjølvmotstridande, men var det neppe. Han gjekk inn for å «fylle institusjonene», men i ein strategi for å nøytralisere dei, for å få full kontroll frå innsida. «... lekmannsbevegelsens målsetting måtte være å besette de statskirkelige institusjonene og sørge for at de ikke fikk utrettet stort. Det var de kristelige organisasjonene som skulle være kjernen i den fremtidige kristelige virksomhet.» Fossum, 1978, s. 109. 
brukes som grunnlag for mistenkeliggjørelse eller angrep på kristne brødre og deres arbeid for Gud.» På Geilo-møtet 1930 strauk dei dette siste punktet. Det tolkar Solem som signal om ei endring i nattverdsynet i kyrkjeleg retning. Og han tilskriv dette den nye «kirkelige vind» frå Menighetsfakultet. Også truande prestar vil ikkje ha nattverd utanfor kyrkja. Denne vinden blæs frå ei kyrkje der professor professor Odland har sagt «at som system betraktet - er den ubibelsk og hedensk helt igjennom». ${ }^{22}$

Solem kritiserer kyrkja for å gjere sine ritual og reglar til ei lov ein skal lystre meir enn Guds ord. Når sokneråda skal stå for denne kyrkjelege retninga, ser han dårlege kår for "den levende menighet» her i landet. ${ }^{43}$

\section{Solem og Hope}

Vi merkar oss her ei vedvarande understreking av at vennesamfunnet er sjølve samfunnet av dei heilage. I prinsippet bør dei då kunne ha alle sakramenta, også dåp. Det siste skjer det lite av, og fri nattverd er det delt syn på i vennesamfunnet - slik det kjem fram ovanfor. Det betyr at konsekvensen av dette synet ikkje blir trekt når det gjeld dåp. ${ }^{44}$ Grunnen til det heiter nok Ludvig Hope, og det gjeld heile kyrkjesynet. ${ }^{45}$

Der er to trekk å merke seg når det gjeld organisering og forholdet til statskyrkja.

For det første er det frå slutten av 180o-talet av ein sterk uvilje mot bandet mellom stat og kyrkje. ${ }^{46}$ Forfattarane av Ordets folk ${ }^{47}$ viser ei utvikling frå sterk statskyrkjekritikk til å akseptere kyrkjeordninga som eit gode, også i forhold til «menigheten» av dei vekte. Solem var ein av dei som tidleg meinte at det måtte kome eit skilje mellom stat og kyrkje, til dømes på lekmannsmøtet i Ålesund 1893. Han endra etter kvart syn.

Solem, 1934/1995, s. 28. Sjå utdraget av Odland som Hope publiserer i Kyrkja og Guds folk, Hope, 1969, s. 137-140.

43 Solem, 1934/1995, s. 30.

44 Ein grunn hos Solem kan vere at sakramenta berre er kjenneteikn, og derfor ikkje grunnleggande nødvendige. Det gjeld særleg dåp. Men omvendinga har erstatta dåpen som viktigaste middel for atterføding. Dåpen må ikkje vere ei «sovepute», var refrenget i vestlandsk bedehustradisjon. Krav om dåp på bedehuset verka då meir som prinsipp enn behov.

45 Ordets folk, 1998, s. 106.

46 Til dømes lekmannsmøtet i Ålesund 1893, Løvlie, 2020.

47 Ordets folk, 1998, s. 102-106. 
Då DVI hadde fleirtalsvedtak på årsmøtet i 1906 for frikyrkje, vart det problematisert av Ludvig Hope, fordi då ville indremisjonen «blive mer og mer en hel menighedsorganisasjon", noko ein ikkje burde kaste bort kreftene på. Der går Johs. Solem til rette med det synet. Det er nettopp indremisjonsfolket som bør engasjere seg i kyrkjelege spørsmål, ikkje (underforstått: som Hope) la vere å bry seg om «hvad Guds ord lærer os om en rett menighedsordning», så lenge ein får preike til omvending. Indremisjonen skal vere «sammenslutningen av de levende kristne innen menigheden» - «selvfølgelig de geografiske statskirke-menigheder». ${ }^{48}$

I same periode (fram mot 1910) var der store prosessar omkring statskyrkjeordninga. Taranger-utvalet (1908) ville ha ei fri folkekyrkje. Denne folkekyrkjetanken var Solem sterkt usamd i. Ho er like ubibelsk som statskyrkja, og utan den åndsfridommen som statskyrkja gir. Men han ville heller ikkje inn i Frikyrkja. Dei fleste var så lite medvitne i kyrkjesyn at dei ville bli verande i statskyrkja uansett - og då ville det vere urett å forlate dei. Han tenkjer seg heller ei masseutmelding - når tida er inne. ${ }^{49}$

Skilnaden mellom Hope og Solem her kan vere at Hope ville «organisera og styrkja indremisjonen», og såg for seg ei «indre samling av heile det frie kristne arbeidet»,50 medan Solem var strengare på dei nytestamentlege ideala og orienterte seg lokalt, kritisk også til fri folkekyrkje.

I tida då Hope skreiv Kyrkja og Guds folk, var det ein sterk diskusjon om å ta også dåpen inn på bedehuset. ${ }^{11}$ Hope sitt foredrag (1922) og fylgjande bok (1923) gjorde den aksjonen mindre aktuell. Han hadde vore i Amerika og sett dei mange frikyrkjene, og dei hadde alle den same veikskapen som kyrkja heime, med same vanekristendom. Hope brukar sterke ord og mange døme på kvifor det var eit villspor. Samtidig grunngav han eit

48 Fossum, 1987, s. 63-65. Dette tyder på eit sterkare syn på nytestamentleg menighetsordning enn Hope. Men deira ideal er ganske nære kvarandre. Fossum ser ei motsetning i syn mellom desse to $\mathrm{i} 1906$. en mot ytre organisering så kan dette tyde på eit ideal nær Hauge sitt nettverk. på denne tida, for å regulere det i forhold til kyrkja. Det vart ikkje fremja. 
absolutt sjølvstende i forhold til kyrkjeorganisasjonen. Sluttordet i boka er den kjende parolen: $I$ kyrkja, men ikkje under kyrkja.52

Fordelen Hope ser med å vere i kyrkja, er ikkje liten. Det er knytt til skule og kunnskap i kristendom. Kyrkja er slik eit viktig grunnlag for vekkinga..$^{3}$ Dei fleste har sin heim nummer to i kyrkja, men dei aller fleste er ikkje omvende. ${ }^{54}$ Med andre ord: Kyrkja er ei vel førebudd misjonsmark.

For det andre grunngir Hope ein nærast ekstrem form for organiseringskritikk. Ei ytre form kveler fort sjølve livet. Også i frikyrkjene i USA var mange med som ikkje var truande. Han kvir seg ikkje for å bruke same kritiske målestokk på organisasjonane her heime. Han ser ei krise i lekmannsarbeidet, med altfor omfattande organisasjon og profesjonalisering..$^{5}$

Hope brukar konsekvent ordet kristne om dei omvende. Han motseier Skagestads omdreiing, snudd av ein «kyrkjeleg vind», utan å gå inn i argumentasjon..$^{56}$ For Skagestad er kyrkja eit gudsfolk. For Hope er gudsfolket i vennesamfunnet. Men han ser problem med frikyrkjedanning for vennesamfunnet. I USA måtte Haugevennene lage sin eigen indremisjon,

Både Hope og Solem talar imot at lekmannsarbeidet skal bli leia av presten, for presten er ein som MÅ preike, preike, preike - han misser si kraft og dei kristne tørkar opp. «Nådegåvene vert ikkje tekne i bruk. Ansvaret, plikta og signinga som fylgjer med arbeidet og ansvaret, vert teke ifrå dei kristne.// Embetet druknar nådegåva.» Hope, 1969, s. 55. Men same fare trugar også dei samfunna som vil byggje på berre ekte materiale. Dei store kyrkjene druknar i den verdslege mengda, «i kyrkjestrev, vanekristendom og hyklarskap», Hope, 1969, s. 55-56.

Slik også (general)sekretær Gustav Ballestad: «Er det noe i veien med Gudskunnskapen, med kristenkunnskapen, så er det med en gang et avgjørende hinder for vekkelsen.» Ordets folk, 1998, s. 18.

Hope, 1969, s. 57 .

55 Etter den store suksessen i foreinings- og organisasjonsarbeid ser Hope ei krise i lekmannsarbeidet. No dett same folket frå kvarandre i mange organisasjonar, sjølve organisasjonstrongen har sprunge løpsk, med emissæren som må ut og samle pengar og rekruttere folk til å lage foreiningar. Her kan ein ete kvarandre opp. Leiarane må få tak i emissærar, og emissærane blir ein stand som driv på heile året - utan den pausen det var å reise heim for å drive kroppsarbeid. Då slapp ein å bli trøytt og tom. Talekunst kjem i staden for åndsmakt. Det er ikkje lenger nok med enkelt vitnemål om synd og frelse. Verst: dei trøytte går til presten og gudstenesta, der er meir ro. Det siste røper at ein har gløymt at kristenliv ikkje berre er vekking og bønemøte for dei ufrelste, det krev kvild. I grunnen er det greitt at kyrkja dreg lekfolk til seg, også ho kan trenge folkehjelp. Men når avskallinga er ferdig, kjem ein ny og stor arbeidsdag. Hope, 1969, s. 44-49.

Same Skagestad-sitat som Solem viser til. Hope trykkjer eit større innlegg der Skagestad gjer greie for sitt kyrkjesyn, med angrep på Hope. Hope, 1969, s. 79-86. 
noko som vart svært dårleg motteke av kyrkjeleiinga.57 Sjølve livet ville finne sine former, etter Hope. Derfor: Lat stillaset stå medan vi byggjer Guds rike, men, må vi legge til: ved hjelp av stillaset. Med Grundtvig rekna Hope kyrkje som ei borgarleg ordning med ein «himmelsk gjest». ${ }^{58}$

Solem brukar ikkje uttrykk om statskyrkja som stillas. Det er det mest siterte uttrykket av Hope. ${ }^{59}$ I Hope sitt kyrkjesyn vil i sin konsekvens all organisering vere «stillas», heller ikkje indremisjonsorganisasjonane vil kunne vere «sjølve livet». ${ }^{60}$ Det ville heller ikkje den organisasjonen han sjølv ein periode vart generalsekretær for (NLM), vere. For Hope vil livet sjølv ta seg av organiseringa, det «reinskar seg sjølv, så det kan stige fram att i ny kraft.» ${ }^{61}$ Det peikar i same retning som hos Solem: det lokale vennesamfunnet med sine nådegåver, hos Hope med ei likesæle grensande til aversjon overfor organisasjonsspørsmål, men med ein rett til å styre i eige hus. ${ }^{62} \mathrm{Og}$ dette huset bør ikkje vere for stort. Liknande aversjon har vi nok hos Solem, men han tenkjer meir i nytestamentlege ideal og har sterkare meining om «stillaset». For Hope var lekpredikanten ein del av

57 Hope gir plass til omtale av «Hauges lutherske indremisjonsforbund». Han siterer Peder Fostervold. Der kjem det fram, utan motsegn frå Hope, at dette forbundet ikkje skal ta plassen frå dei enkelte foreiningane. Forbundet gjer berre eit fellesarbeid, utan å vere noko overstyre. Fostervold siterer artikkel 6 i lovene: «De enkelte foreninger beholder fremdeles sin fulle frihet og selvstendighet $\mathrm{i}$ alle sine egne anliggender - også når det gjelder virkemåten og virkemidlene.» Hope, 1969, s. 69. Det er om lag identisk med DVI sine vedtekter.

Av Carl Fr. Wisløff referert til med sympati for stillas-tenkinga. Sjåstad, 2016, s. 230.

59 Det er vanskeleg å finne det i Kyrkja og Guds folk. I eit foredrag 1922, som utgangspunkt for Kyrkja og Guds folk, 1923, brukar han det. I sistnemnde brukar Hope heller ulike uttrykk for ytre form og «kyrkjestrev». I eit foredrag i 1932, «Kyrkja og lekmannsarbeidet» (trykt i Veien fram, Hope, 1977, s. 228-245). Der brukar han ordet stillas. Han understrekar at den sanne kyrkja er både i statskyrkja, i frikyrkjene og i organisasjonane. Men også i organisasjonane er det mange som står utanom «menigheten», fordi der er «svimling i kveiten» overalt. Kyrkja er Guds folk! Alle stillas er då borte. Sjå også Hope, 1969, s. 156-157. Der er kyrkje(organisasjon) noko «ved sida av menigheten, noko nytt som Bibelen ikkje kjenner til». Sjå neste note.

6o Kyrkjehistorikaren Rudolph Sohm gir han tilslutning til, dvs. eit spiritualistisk kyrkjesyn der kyrkjerett ikkje har nokon vesentleg plass, og der idealet er den første forsamling før noka organisering. Hope, 1969, s. 140-145. Sohm utviklar eit syn på nådegåvene som suverene, utan at dei har noko læreembete, «deres gjerninger er det som legitimerer dem og gir dem rett til å kreve kjærlighetens lydighet av menigheten». Og «menigheten velger dem, det er kun at den anerkjenner det valg som er gjort av Gud». Men «Liksom enhver kristen i menighetens forsamling kan ta ordet til tale (preken), således kan enhver kristen meddele gyldig dåp og lede gyldig nattverdhandling. I denne alle troendes like kristelige handledyktighet består den i sannhet apostoliske kristelige tros alminnelige prestedømme.» (143). Same i Veien fram, 1977, s. 258-260.

61 Hope, 1969, s. 45.

62 «Ein truande lekmann har same rett og same plikt i Guds rike som ein truande prest.» Hope, 1932/1977, s. 236. 
strukturen i kyrkjetenkinga, han hadde si fullmakt frå Gud og utøvde den i forkynning og sjelesorg. ${ }^{63}$ Der er kanskje Solem ikkje heilt på linje, han tenkjer svært lokalt. Det er heller ikkje sikkert at han vil oppfatte den aktuelle kyrkjeorganisasjonen som noko stillas for vennesamfunnet. Vårt spørsmål vidare er kor kongregasjonalistisk Solem tenkjer. ${ }^{64}$

\section{Solem som strateg}

Som strateg ser Solem utelukkande bakover.

I andre del av foredraget frå 1938 set han søkelyset på notidssituasjonen, og han er kritisk.

Først er han kritisk til den store skaren av løna lekpredikantar. Det blir eit levebrød i staden for tillegg til eit vanleg yrke. Dei kan fortrenge lekmannen. Dei kan passivisere den lokale foreininga når ho overlèt alt oppbyggeleg til den tilreisande. Verst er at det frivillige lekmannsarbeidet er i ferd med å forsvinne. Slik forsvinn også den personlege sjelesorga, nådegåvene blir forsømde og den vanlege kristne blir ein benkeslitar. Vi får «predikantkristne» i staden for samfunnskristne, og det er «siste sort». Vi treng ikkje fleire slike kristne. Vi må få tilbake dei samfunnskristne og kvardagskristne. Solem dreg parallellen til synet på ein truande prest i gamle dagar. Dei var farlegare enn andre prestar når dei trudde seg å ha alle nådegåver og ikkje trong lekfolket. Han vil ha ei fornying tilbake til det opphavlege. ${ }^{65}$

Den neste kritikken gjeld storstemna.

Desse stemna skulle gi ei åndeleg fornying som skulle gi betre kvardagskristne og samfunnskristne. Gjer dei det? Han tenkjer tilbake på småmøta og husmøta tiår tidlegare. Dei var oppbyggelege. Der var det lett å gi personleg sjelesorg. På småmøta skal ein byggje kvarandre opp

\footnotetext{
63 Oddvar Jensen tolkar Hope i den retning, som ei vidareføring av den apostoliske fullmakta Hauge meinte seg å ha fått. Jensen, 2012, s. 67-68. Sjå også notane ovanfor.

64 Lekmannsrørsla har eit funksjonalistisk embetssyn, også kalla lågkyrkjeleg. Det vil seie at dei ser på funksjonen å forkynne, døype og forvalte nattverden - utan å knyte det til ein fast person. Det dreier seg så om utfalding av nådegåver. Lekpredikanten har sitt kall direkte frå Gud. Jensen, 2012, s. 68. Solem, 1938/1995, s. 22-29.
} 
ved bønemøte og vitnemål. Desse småmøta bør tilreisande predikantar vere med på. Det er der det skjer. ${ }^{66}$

Så sender Solem ei drepande salve mot underhaldningskristendom. Den kom frå venner i Amerika, og er noko skrap (Solems uttrykk). Det einaste dei har igjen av kristendom mange stader, er namnet. «Men skinnet uten kraften er som bekjendt kirkens verste pest.» Ein finn på mange merkelege ting for å få folk til å kome dit Guds ord blir forkynt, særleg ved song og musikk. Det er ikkje nok å vogge folk inn i ei religiøs stemning. Slike lukkar hjarta for Guds nåde. Solem tilkjenner likevel songen ein viss plass, som ei nådegåve i lokalforsamlinga til velsigning og oppbygging. Han skal berre støtte og inderleggjere forkynninga av evangeliet. Ikkje noko meir. Berre det einfaldige evangeliet om synd og nåde er Guds kraft til frelse. ${ }^{67}$

Solem avsluttar foredraget med ein hyllest til forkynninga. Det er ei einfaldig forkynning av Guds ord til syndaren. «Profetåndens kraft» var over Hauge og medarbeidarar, endå dei i kunnskap stod langt under dagens lekpredikant. Vi må be om at denne spontane profetånda kan kvile over vår tids lekfolk, med «vitnesbyrdes ånd», skriv han. Eit slikt evangelium blir ikkje populært. Populært blir heller lovforkynning og sjølvrettferdiggjering. ${ }^{68}$

Foredraget til Solem skapte spenning på årsmøtet i 1938. Formann Nils Lavik seier at «det vart mykje sjø um Solems foredrag». ${ }^{69}$ Det var ein gammal hovding som slik gav forbundet sitt testamente. ${ }^{\circ}$

Vi må legge noko til innleiinga til dette underkapittelet - at som strateg ser Solem bakover. Det må rettast til innover, til småmøtet utan store fakter - utan påfunn for å trekkje folk, til det frivillige arbeidet med alle involvert, med bønemøte og frie vitnemål, til kvardagskristendom. Slik det var før. Det kan også rettast bakover mot eit bibelsk ideal.

\footnotetext{
66 Solem, 1938/1995, s. 29-32.

67 Solem, 1938/1995, s. 32-35. Næraste parallell seinare er «misjonsfolkets professor» Carl Fr. Wisløffs syn på drama til bruk i forkynninga på slutten av 70-talet. Ein «når» ikkje folk slik, hevda han, det spelar på underhaldning for å gjere bodskapen attraktiv, med drama som verkemiddel. Om moderne song uttalte han i 1995: «Den moderne sangen og musikken er blitt et av de viktigste virkemidler til å bryte ned Guds ord». Sjåstad, 2016, s. 358-359.

68 Solem, 1938/1995, s. 35-37.

69 Ordets folk, 1998, s. 159. Jubileumsskriftet refererer ankepunkta.

70 Ordets folk, 1998, s. 160. 
Vi ser at idealet er ein streng kongregasjonalisme, heilt og fullt lekmannsstyrt, helst utan profesjonelle predikantar eller uniformerande storstemne med tvilsame verkemiddel. Det enkle evangeliet om synd og nåde er nok, i eit fellesskap av bøn og vitnemål og gjensidig sjelesorg. Ein kan på denne bakgrunnen forstå at det er lokalnivået som er foreininga med mynde, slik dei motsette seg hovdingane sine freistnader til samanslåing med austlendingane i samarbeid med kyrkja. Slik låg vekta i lokallaga i DVI, ikkje i topporgana. Dei er samarbeidsorgan, ikkje meir toppstyring som i Misjonssambandet. ${ }^{71}$ Dette kan kallast eit spiritualistisk kyrkjesyn. Mange gjer det. Eg vil heller kalle det personalistisk, som første del i CA 7. Det er ei forsamling, «samfunnet av dei heilage», av dei truande, dei sant truande. Det kan likne Luther si vekt på lokalforsamlinga som grunnleggande. Der var kyrkja - i, med og under den synlege forsamlinga. Men organisasjonsapparatet, inkludert presteskap eller «emissærskap», er her asketisk. Alle er prestar på like fot. Her må Anden styre og dele ut roller etter nådegåve, også når det gjeld leiarar. I mangel på personalt embetssyn kan ein ty til bibelske nemningar for funksjonane, som til dømes «eldste». Det er litt i slekt med det reformerte synet på tenestene, der dei hentar mønster direkte frå Bibelen, men treng ikkje her vere eit absolutt mønster.

Ein kunne undre seg over at denne kongregasjonalisten med det asketiske organisasjonsidealet var med på å danne langsorganisasjonar. Truleg ligg det i det sterke sjølvstendet som lokalforeininga har, DVI hadde same ideal som Hauge-foreininga i Midt-Vesten (eller omvendt), organisasjonen er berre til støtte. DVI skulle ikkje vere eit kyrkjesamfunn nasjonalt, berre samfunnet lokalt. Generalsekretær eller kretssekretær kan då ikkje opptre som biskop eller tilsynsmann. Men dei kan vere til hjelp.

\section{Vennesamfunnet som ur-type}

Jakta på eit vestlandsk kyrkjesyn kan her summerast opp med funnet av eit ganske tydeleg ideal. Det er den enkelte forsamling av omvende som er

71 Hope gjekk dit som generalsekretær. Eg har ikkje gått inn på drøfting av hans syn i forhold til seinare status. Hans periode vart kort. 
sjølve «samfunnet av dei heilage». Heller ikkje den konkrete forsamlinga på bedehuset er identisk med den. Solem meiner at predikant-kristne er «siste sort». Og Hope ser fram til ei avskalling, for når «avskallinga er ferdig, kjem ein ny og stor arbeidsdag. $\rangle^{72}$ Det er småmøtet med frie vitnemål og felles bøn og utøving av nådegåver som er ur-typen av ei forsamling for Solem, eit verkeleg vennesamfunn. Det same idealet har Hope. Vekkingane vil også kome ved predikantar som er kalla til det, men dei skal helst ha eit arbeid ved sida av som dei kan trekkje seg tilbake til. Emissærar skal ikkje vere ein eigen stand som må halde oppe eit organisasjonsarbeid og ein organisasjonsøkonomi i konkurranse med andre organisasjonar. Dei må søkje fellesskap med dei truande på småmøta. For Hope er predikanten sjølve den grunnleggande tenesta (Jensen 2012), men også han har kritiske ord til emissæren. Idealet for lekpredikanten er den som er kalla av Gud direkte, og som blir brukt til vekking og oppbygging. Han er nødvendigvis ikkje den lokale leiaren, den eldste, det er nådegåvestyrt. ${ }^{73}$

Kor luthersk er så lekmannsarbeidet her?

Dette idealet kan argumenterast for som ei oppfylling av Luthers grunnleggande kongregasjonalisme, med vekta på den lokale kyrkjelyden/forsamlinga - men her utan at dei heng saman på annan måte enn ved ytre og lause band, med andre ord slik stiftarane av DVI tenkte det. Det u-lutherske kan ligge i synet på nattverden, eller at eit symbolsk syn på nattverden var til stades ${ }^{74}$ ikkje nødvendigvis $i$ at ein vil ha hand om han $i$ lekmannsregi. Det siste kan vere ei ordna administrering. Det er då spørsmål om embetssyn og ordning som er radikal i forhold til aktuell orden i statskyrkja, men likevel innan ein luthersk diskurs. Litt verre er det med eit symbolsk syn på nattverden til stades. ${ }^{75}$ Men: Både når ein ikkje vil dele nattverden i kyrkjene for ikkje å knele saman med nokon som ikkje er truande, eller når dei feira nattverden berre mellom dei sanne truande

\footnotetext{
Hope, 1969, s. 49.

Jensen, 2012.

Andreas Lavik gjekk i den retning, Fossum, 1987, s. 49, 66.

Ser ein stort på det, kan ein sjå at nattverden skaper det han skal, sjølv med eit feil syn på nattverdsteologien - om innstiftingsorda lyder. Men der er mange i rørsla som hevda eit luthersk syn på nattverden, og ville ha same orden som i kyrkja (Det Vestlandske Indremisjonsforbund gjennom 50 år).
} 
på bedehuset, ${ }^{76}$ då er ein direkte i brot med CA 8, som markerer det felleskristne oppgjeret med donatistane. Nattverden (sakramentet) er gyldig om han blir forretta av «hyklarar og vonde». Draumen om det reine nattverdbordet må i luthersk samanheng kallast sekterisk. Det er draumen om den reine «menighet», der ein kan skilje ut "dei ureine». Då er det ikkje lenger berre eit spørsmål om synd og nåde, men svært sterke krav til åndeleg kvalitet hos dei som ved vekking og omvending har funne nåde at det er ei sann omvending i fellesskap med andre som er sant omvende. Det stiller nettopp slike krav til vennesamfunnet som Solem gjer seg til talsmann for - at nådegåvene er i bruk på ein gjennomgripande måte. Det er eit bibelsk ideal som kan dragast i sekterisk retning.

Kva skjer så når denne asketiske kongregasjonalismen møter andre kontekstuelle vilkår? Når DVI ikkje vil vere eit kyrkjesamfunn, men går i den retning likevel? Og når spørsmålet om åndeleg leiarskap kan utelukke halvparten av det allmenne prestedømet frå slik teneste? Det siste er meir radikalt enn erkjent. Om alle er prestar - slik at alle kan ha sokneprestens funksjonar, så ligg det ikkje noko kjønnssegregerande i det. Det er sett opp mot (sokne)presten, og er innlegg i ein embetsdebatt. Funksjonane skulle i prinsippet kunne takast vare på av alle truande. Ulike nådegåver kjem så til og fordeler oppgåvene (1 Kor 12). Presten i statskyrkja var alltid mann. Det var kulturelt sjølvsagt. Er det også teologisk sjølvsagt? Kvinneprestdebatten viste at det ikkje var tilfellet. Men eigentleg var det ein debatt på bortebane.

\section{DVI, kvinnene og organisasjonen}

1999 hadde DVI landsmøte. Der låg føre eit framlegg frå Forbundsstyret om at kvinner kunne veljast inn i dette høgste organet. Det hadde vore utgreidd, og der var fleirtal for det i høyringane. ${ }^{77}$ Men motstandarane hadde mobilisert via einingane (representantar), og forslaget vart nedstemt, med eit stort mindretal. ${ }^{78}$ Sjølve spørsmålet om kvinna si rolle i

\footnotetext{
76 Jensen, 2012; Lerheim, 2008.

77 Hallaråker, 1999.

78 Sjå nærare om prosess og bakgrunn i Ulstein, 2001.
} 
vennesamfunna hadde vore vekslande i tradisjonen. ${ }^{79}$ Ved stiftinga av DVI kan det registrerast ein inkonsekvens. Til det allmenne prestedømet høyrde også kvinnene - vi er alle prestar. Kvinnelege lekpredikantar hadde det ikkje vore mange av, men dei fanst. Hauge brukte kvinner i ei slik rolle, også som «forstander» i venneflokken. ${ }^{80}$ Organisasjonen opna frå første stund generalforsamlinga for kvinner, men lukka likevel tilgangen til landsstyret. Ordets folk ${ }^{81}$ ser tilbake på det ikkje som ein inkonsekvens, men som ein balanse mellom to omsyn: det allmenne prestedømet og tenestedelinga mellom mann og kvinne (lære- og hyrdeansvaret). I så fall var der forventingar om læreansvar i forbundsstyret, trass i hovudvekta på einingane.

Synet på kvinna si rolle i lekmannsrørsla var varierande, ${ }^{82}$ og mannsdominansen sterk, som elles i samfunnet. Den kyrkjelege tradisjonen hadde vore bastant avvisande til kvinner som prestar, så det vesle som hadde vore i lekmannsrørsla, var unntak. Vekta på det allmenne prestedømet peika også i slik retning. Opninga for kvinners stemmerett var avgjort radikalt i 1898, medan avgrensinga mot styredeltaking viste at det fanst grenser. I DVI var det ulikt syn på kvinnelege evangelistar. Andreas Lavik arbeidde for større rom for kvinnene. ${ }^{83}$ Han blir i 1917 av formannen (B. A. Lindeland) mint om at «vi har ikke endnu løst det principielle ved spørsmålet om kvindelige evangelister». ${ }^{84}$ Det betyr også at det i DVI har gått føre seg ein diskusjon om organisering i bedehusforsamlinga, der tesen om det allmenne prestedømet for begge kjønn med utfalding av dei nådegåver som blir gitt, blir fremja, men også korrigert og innskrenka

79 Klokkersund, 1986; Svalastog, 1983. Ordets folk, 1998.

80 Hitra-brevet nemner kvinner mellom desse, sjå Jensen, 2012, s. 66-67. Sjå også posisjonen til Andreas Lavik hos Løvlie, 2020.

81 Ordets Folk, 1998, s. 262.

82 Fri til teneste, s. 16-21, rissar opp eit bilete frå bruk av kvinner i leiing og tale, men med avgrensande tendens fram mot 1850 (di meir offentleg, di mindre kvinne, 1856). På 1880-90-talet var tanken om kvinner som prestar komplett latterleg.

83 Sjå Løvlie, 2020. Klokkersund, 1986, s. 37-50 gir ei grundig framstilling av situasjonen. Sonen, Johannes, skreiv på leiarplass i Dagen i 1920 at det ikkje var teologisk grunnlag for å nekte kvinnelege prestar.

84 Ordets folk, 1998, s. 262. Forfattaren av Ordets folk viser til at kvinnelege evangelistar ikkje skal forståast under forsamlinga si lære- eller hyrdeteneste. Kommentaren er skriven etter kvinneprestdebatten. Det blir tolka av Johannes Kleppa (medforfattar i Ordet folk) slik det er formulert i framhaldet. Kleppa var leiar i det utvalet som skreiv Fri til teneste (1982). Der er kjønnsrollene utdelte etter eit evig mønster (s. 38). 
av bibelord. Det allmenne prestedømet tek ut til sine leiarar og lærarar menn med nådegåveutrustning til oppgåva eller funksjonen, er tolkinga då. Det inneber at Gud ikkje gir kvinner slike nådegåver. «Kvinner som trur dei har kall og nådegåver til slike funksjonar, har difor anten misforstått eller fornektar medvite Guds ord på dette punktet. Tilsvarande gjeld også for menn som går inn for kvinner i desse funksjonane.» ${ }^{85}$

På denne bakgrunnen er forslaget og hendinga i 1999 tvitydig. Organisasjonen (inkludert styret) ville sleppe kvinnene til i forbundsstyret. Om det betydde at dei kunne ha læreansvar, eller om einingane visste at det hadde forbundsstyret eigentleg ikkje, verkar uklart. Det kan røpe ei dreiing i retning av å akseptere kvinneleg leiarskap, med eller utan læreansvar. Mobiliseringa må tolkast som ei kampsak der ein rekna med læreansvar i forbundsstyret.

Solems ideal var under press i tida etter. Den liberale teologien var bortimot overvunnen i kyrkja etter 1920 og med MF-prestane, var synet. ${ }^{86}$ Det gav ein pause når det gjaldt statskyrkjespørsmålet - for kyrkja (og organisasjonane) var då veleigna stillas. Men spørsmålet om kvinnelege prestar gav (vrang)lærespørsmålet ei ny omdreiing. Då gjeld det lydnad mot Guds ord ikkje berre i trusvedkjenninga, men også i ordningsspørsmål - for synet på presten går inn i ein ordningsteologisk debatt, ikkje ein dogmatisk om jomfrufødsel og oppstode. Forbundsstyret sette ned eit utval til å greie ut spørsmålet. Boka Fri til teneste var i overraskande grad ordningsteologisk orientert, og blir kritisert for det. Innstillinga vart ikkje vedteken. ${ }^{87}$

85 Slik Fri til teneste, 1982, s. 74.

86 Denne vurderinga stogga iveren etter å få lovfesta bedehusdåp (1922). Ordets folk, 1998, s. 134137.

87 Med sterke ordelag, "Uklåre kyrkjesynsutsegner», men at det finst ei ordna teneste berre menn skal ha tilgang til - med sterke og sprikande reaksjonar i etterkant. Ordets folk, 1998, s. 333-335. Fri til teneste, 1982, s. 25 understrekar at ordningane er Guds ordningar, og avspeglar den orden som er i Gud. Her målber dei ein tidlaus ordningsteologi, ikkje eit veleigna stillas. Sjå heile kapittel 3 om kva det betyr på ulike område. Grunnleggande ser dei over/underordningsforholdet mellom mann og kvinna grunna i sjølve mysteriet i frelseslæra og fastsett for æva (s. 38 ). Kvinnerolla er definert ut ifrå mors- og omsorgsrolle - noko som gjeld i heim og kyrkje. Så gir ein nokre argument for at det same ikkje gjeld i samfunnet, t.d. kvinnelege ordførarar. Altså: Underordninga gjeld i heim og kyrkje, men ikkje i samfunnet. Det første er guddommeleg mønster, det andre er felles kulturoppdrag. 
Kvinneprestdebatten i kyrkja blir ein viktig bakgrunn. Den blir kopla på bibelsynet og blir eit vedkjenningsspørsmål for mange. Den heng ikkje på eit funksjonalistisk embetssyn i DVI, men rører heller ved ein patriarkalsk tendens. Kvinneprestmotstanden vart ei konservativ kampsak for bibelsynet på denne tida (etter 1970), mot liberal teologi, no også på Menighetsfakultetet. ${ }^{88}$ Kvinneprestane måtte kome i same posisjon som liberale prestar, med same boikott. For lekmannsrørsla dreia det seg teologisk sett om å kunne plassere ei forståing av kvinnetekster i Bibelen i forhold til sitt hovudprinsipp om allment prestedøme. Det er bibelsynet og ei bestemt tolking som skaper bry. Ved å tolke kvinnetekstene som eit gudsord for alle tider kjem ein i trongsteg. Om ein vil grunngi det restriktive synet som eit bibelsk prinsipp, utan forklaring, noko som skjer, så fører det likevel eit mønster med seg som er ordningsteologisk. Då må ein ty til ei «tenestedeling» mellom kjønna, som stikkordet vart. Det må leggast til rette innan tenestestrukturen, og då snakkar vi om organisering grunna i kyrkjesyn, der det allmenne prestedømet gjeld fullt ut berre for menn.

Dette synet står ikkje åleine. Forarbeida til landsmøtet viser at ein framleis er klar over at forbundsstyret ikkje kan diktere. Generalsekretær Hallaråker sitt notat av 1999 held forbundsstyret for å vere foreiningane sitt tenande fellesorgan. DVI er eit forbund av sjølvstendige foreiningar. ${ }^{89}$ Det har ikkje overordna læreansvar. Han avviser at berre menn har læreansvar, men medgir at dette er eit uklart punkt i historia..$^{\circ}$ I oppsummeringa om åndeleg leiarskap (1997) drøftar han ulike modellar for

88 Ordets folk, 1998, s. 261. Ordets folk knyter det til Carl Fr. Wisløffs avgang frå MF som 67-åring til kritikk av bibelsynet ved MF. Der refererer Ordets folk med tilslutning Jens Rognsvågs kommentar om at kvinnelege prestar er ikkje eit spørsmål om kvinnesak eller ordning, men er eit bibelsk prinsipp.

Ordets folk, 1998, s. 273 stadfester denne sjølvstendelinja.

Også mellom dei som gjekk mot kvinner med hyrde- eller læreansvar, var det semje om at kyrkjesynet grunna seg i det allmenne prestedømet, og det same gjeld evangelisk tenkjemåte når det gjeld embetet (Fri til teneste). Dette blir Aksel Valen-Sendstad teke til vitne på. Det er fundamentet for å forstå den kristne tenesta, s. 43-44. (Aksel V-S var til liks med sin far, Olav, for kvinnelege prestar). Dei meiner at kvinner har del i den tenesta som ligg til det allmenne prestedømet, det er uavhengig av dei fleste variablar, også kjønn. Men dei vil ikkje sette ordningar og bibelord ut av kraft (s. 46). 
organisering, og rår frå eit læreråd på bedehuset. Men det er berre råd. Han er klar over si rolle. ${ }^{91}$

Kva stod det om?

Avvisinga av lovforslaget kan kallast ei symbolsak. Men det gjorde noko med forståinga av indremisjonsarbeidet, både av forbundsstyret og av foreininga. Forbundsstyret kunne tilleggast eit overordna læreansvar (i praksis truleg berre om foreiningane var samde). Og ein stor (?) del av rørsla gav menn ansvar for lærespørsmål og utelukka halvparten av dei allmenne prestane frå å utøve sitt prestedøme - for det var nettopp erstatninga av (sokne)presten og hans kall som var kampsaka. ${ }^{92} \mathrm{Vi}$ har sett at Solem oppfatta vennesamfunnet som sjølve samfunnet i ekklesiologisk forstand. Men han var lidenskapleg kongregasjonalist og tilhengar av å praktisere dei nådegåver Anden gir. Det vi her ser konturane av eit "presteskap» som ikkje er allment. Om Solem ville ha gått imot kvinneleg leiaransvar lokalt, har eg ikkje informasjon om, men det bryt avgjort med ei kongregasjonalistisk linje med læretukt frå toppen av organisasjonen.

\section{Frå foreining til forsamling til kyrkje?}

Der er ulike syn på leiing av foreininga i indremisjonen. I Ålesund endra dei styresamansetjing i 1937 frå åtte menn i styret til seks menn og tre kvinner. ${ }^{93}$ Det skjer noko med forsamlingane i tida fram mot tusenårsskiftet. I 1997 opna Bergen Indremisjon styret for kvinner, men oppretta samtidig eit lære- og hyrderåd med det øvste åndelege ansvaret for forsamlinga. Det blir også strid om bruk av forstandartittel i indremisjonsforsamlinga på Nestun. ${ }^{94}$ Det skjer tydelegvis ei endring i syn i denne

91 Seinare blir dette likevel etablert, også på landsplan. Ved arbeidet fram imot bedehusforsamlingar vart det oppretta eit sentralt ImFs Lære- og tilsynsråd. Dei gir i juni 2014 ei rettleiing til forsamlingane om å ha slike hyrderåd, og ikkje ha kvinner med der. Dei gir ei kortfatta, men nyansert rettleiing. Her er det sentraldominansen som har overteke. https://www.imf.no/ wp-content/blogs.dir/44/files/2018/o2/Veiledning-fra-ImF-om-menn-og-kvinners-tjeneste.pdf. Nedlasta november 2019.

92 Her er fleire måtar å forstå det allmenne prestedømet hos Paulus og Luther på, som sacerdos og ikkje hierevs. Men det ville vere å gå inn på eit anna syn på presten, som kunne gå vekk frå utfordringa av prestemonopol på forkynning og sakramentforvalting. Vi er alle prestar, men ikkje alle er sokneprestar (Melanchthon).

93 Aalesund Indremisjon, s. 61. Det var etter at Johs. Solem hadde forlate byen.

94 Ordets folk, 1998, s. 335, 337. 
tida. Framleis målber styret og generalsekretær at dei berre gir råd til einingane, og at ordet hyrde er eit framandord på bedehuset. Men Johannes Kleppa i Ordets folk ser tilbake og seier at hyrde- og læreansvar frå starten av har vore for menn. Han er ein av forfattarane bak innstillinga Fri til teneste - som altså ikkje vart vedteken i forbundet. ${ }^{95}$

På 200o-talet skjer det ei endring i retning av kyrkje. Sunnmørskirka blir til i 2006. Denne kyrkja kjem ikkje etter initiativ frå grasrota, frå Ålesund Indremisjon, men frå krinsen og sentrale personar. Ho samla folk frå litt ulike foreiningar, somme av dei er utmelde av statskyrkja. ${ }^{96}$ Prosessen går vidare, og i 2009 opprettar Indremisjonsforbundet (det nye namnet, 1999) eit formelt kyrkjesamfunn. ${ }^{97}$ Det har eit landsstyre og forstandarar i dei like bedehusforsamlingane, alle med vigselrett nasjonalt. No er alt «under eitt tak» ${ }^{98}$ og nasjonalt koordinert saman med bedehusarbeidet elles i forbundet. Spørsmål om medlemskap er pragmatisk, og det viser overgangen frå tidlegare foreiningar som også har fungert som forsamling. Dei har også fungert som andre foreiningar på bedehuset, der ein kunne vere medlem av fleire. Dei nye forsamlingane står til teneste for alle indremisjonsfolk utan å krevje utmelding og innmelding - det siste er nødvendig med tanke på offentleg støtte.

Oddvar Jensen (2011) undrar seg over at dette ikkje har kome før. Han viser til den delen av den haugianske arven som vart dempa av Hauges testamente - Hitra-brevet. Med forkynning, dåp og nattverd har ein allereie dei ekklesiologiske kjenneteikna som CA 7 talar om. Birgitte Lerheim (2008) spør om endringane ikkje berre viser tit eit nytt sjølvstende overfor kyrkja, og ny kyrkjekritikk, men også ein kritikk av indremisjonshistoria. Ein ny generasjon vil bli meir kyrkje, det skjer ei «kyrkjeleggjering». Vi kan legge til ein skilnad i kontekst frå (gryande) modernitet

95 Fri til teneste, 1982, s. 171 konkluderer med at også møteleiing høyrer med til hyrde- og læreansvaret. «Ved møte for den samla kyrkjelyden (same kva hus, kva dag, kva klokkeslett denne samlast) skal mannen ha det overordna ansvaret for møtet. ... Er det ein kvinneleg misjonsarbeidar, må det vere ein mannleg møteleiar som har det overordna ansvaret i møtet -». Om Kleppas syn var ei tolking eller bygd på dokument frå 1898, har eg ikkje undersøkt.

Det blir i dag presentert slik: https://www.imf.no/forsamling/

Om eit av dei viktigaste omsyna i seinare tid for fleire organisasjonar, sjå Birkedal, 2018. 
(der bedehuset var samlingsstad for bygda) til postmodernitet, med nye sosiale behov og mønster, ny mobilitet, ny kontekst.

Foreiningane si tid er definitivt forbi - som folkerørsle. Den teologiske situasjonen i folkekyrkja er også sterkt endra. Seinare års utvikling har ført til ein dominans for meir «mjuk» og liberal kristendom. ${ }^{99}$ Det er ikkje lenger slik at det konservative lekfolket har dominansen. Dei mest radikale - i forhold til kyrkjeinstitusjonen - har også vorte meir fråverande i kyrkja. Den nye kyrkjelege aktiviteten tok frå dei dominansen i det frivillige arbeidet tidlegare. ${ }^{100}$ Utviklinga i ordningsspørsmål (kvinnelege prestar) og samlivsspørsmål (homofilt samliv) utvidar konflikten i forhold til den hundre år gamle Calmeyergate-linja. No er liberal ikkje lenger knytt til jomfrufødsel, under og oppstode - altså dogmatiske spørsmål, men til etiske spørsmål. Ein skulle tru at ei slik restriktiv linje kunne ha vore praktisert også i ein ny situasjon. ${ }^{101}$ Samtidig var det klart at freding av statskyrkja ikkje var utan vilkår.

Vi ser altså ein utvikling i retning av frikyrkje for Indremisjonsforbundet, ImF. Det skjer i ein organisatorisk overgangsfase med to strukturar side om side. Vi skal sjå det i lengdeperspektiv.

\section{Solem, Hope og kyrkjesynet i Indremisjonsforbundet}

Den teologiske motstanden mot Den norske kyrkja hadde to hovudtrekk. Det var først og fremst ei sjølvstendiggjering på grunnlag av det allmenne prestedømet. Vekkinga sitt folk var sjølve Samfunnet. ${ }^{102}$ Det andre er eit tilhøyrande funksjonalistisk embetssyn, også kalla lågkyrkjeleg, der i

\footnotetext{
99 Henriksen \& Repstad, 2005.

100 Stor mobilisering mot og konflikt på 6o-talet, m.a. med eit lekmannsmøte i Bergen 1965. Sjå Sjåstad, 2016, s. 195-197. Sjå også Ordets folk, 1998, s. 251-252. På 9o-talet registrerer også Harald Hegstad at forholdet bedehus-kyrkje, vennesamfunn-geografisk forsamling har flytta inn i kyrkja i utviklinga frå bedehus til arbeidskyrkje. Hegstad, 1994, s. 16-17.

101 Odd Sverre Hove tok til orde for det i debatten etter vedtak på Kyrkjemøtet om vigsel av likekjønna (Vårt Land, 22.04.16: «Vil bruke læretukt mot kirkemøtevedtaket»).

102 For mange bedehusfolk var nok vennesamfunnet nettopp eit vennesamfunn som supplement til det kyrkjelege fellesskapet. Vi kan ikkje rekne med uniformering i tankegang i bedehusfolket, sjølv ikkje i den radikale delen.
} 
prinsippet alle truande kunne ha alle (sokne)prestens funksjonar, der Gud gav nådegåvene og kalla til funksjonen.

Her kan ein spørje om reformasjonens skjelning mellom (offer)prest og sokneprest hadde slått heilt inn. Retorikken seier det motsette. Då er det ei indre motsetning når ein i neste omgang ikkje vil gi kvinna hyrde- eller læreansvar. Ein kvar kristen kan etter læra ha sokneprestens funksjonar, vart det hevda. Ingenting i ein slik lågkyrkjeleg embetsteologi grunngir innsnevring av det. Ei avgrensing vil bety at ikkje alle er prestar.

Denne avvisinga blir for mange grunngitt i eit bibelsyn, eit prinsipp gitt i bibelord, der prinsippet likevel reint faktisk skaper ein ordningsteologi av forpliktande karakter ${ }^{103}$ omkring leiing i ei foreining som skal vere forsamling. ${ }^{104}$ Leiing i ei foreining har sin tradisjonelle organisasjonslogikk, vel gjennomført i organisasjonane. Leiing av ei forsamling kan kalle på definerte roller etter anna mønster - der hyrde- og læreansvar kan plasserast.

Då er vi over i ein ordnings- og embetsteologi av prinsipiell karakter. Ordningsspørsmål er nettopp ikkje faste, dei er i rørsla tolka som adiafora, som vanleg i lutherdommen, og kan skiftast ut etter denne tankegangen. Solem og Hope vil knapt nemne dei. For Hope er ordningsspørsmål øydeleggande for «livet sjølv» med sitt «kyrkjestrev». Hope såg sanne truande både i statskyrkje og frikyrkjer - og i organisasjonane. ${ }^{105}$ Men desse stillasa er ikkje sjølve kyrkja. Solem strippar det heile til den nytestamentlege forsamlinga med sin spontane nådegåvekarakter og er skeptisk til predikantkristne. Hope er langt på veg på linje. Hope held all

103 Her er det fleire syn ute og går. Til den lutherske adiaforon-problematikken gjeld ordningar som tidsbestemte, dei er ikkje evige, dei kan skifte med situasjonen. Legg ein ordningsteologi av prinsipiell karakter til grunn, så er ordninga mellom mann og kvinne ei ordning i Gud, for æva. Fri til teneste, 1982, s. 38 . I rettleiinga av 2014 vil det sentrale ImFs Lære- og tilsynsråd dempe uttrykket «overordna» og viser til nytestamentlege ideal. Dei prøver heller ikkje å trekkje i tvil kvinners nådegåve, gjerne eit hyrdesinn, men det er berre menn som er skikka og kalla til eit spesielt ansvar. For å unngå problem med restriksjonar på kvinneroller i samfunnet viser dei til den lutherske toregimentslæra. https:/www.imf.no/wp-content/blogs.dir/44/files/2018/o2/ Veiledning-fra-ImF-om-menn-og-kvinners-tjeneste.pdf.

104 «Forsamling» er stikkord som her dekkjer kyrkjelyd og menigheit. Det er brukt som omsetjing av ekklesia i Bibel 2011. Studerer ein dokumenta omkring IMF kyrkjesamfunn, så ser ein korleis det ikkje er heilt lett å navigere mellom foreining og forsamling, mellom organisasjon og kyrkjeinstitusjon. 
organisering for å vere stillas. «Stillas» er faktisk ein effektiv metafor for slike adiafora-spørsmål. Hope brukar det litt vidare. Han held skule, kyrkje og organisasjon for å vere gode stillas. No er dei to første ikkje det dei var, dei gir ikkje lenger den sterke bakgrunnen som vekkingsforkynninga kunne spele på. No må ein satse på kristen oppseding av eigne born, og andre, i heim og fri-skular for å mogne dei for omvending. ${ }^{106} \mathrm{Og}$ organisasjonane har ikkje lenger den sterke medvinden som identitetsskapande sosial konstruksjon. Forpliktande medlemskap er ingen trend, derimot er nære grupper det meir. Det kan forsterke behovet for å ha alt på éin stad for heile familien. ${ }^{107}$

Ein annan konsekvens av synet på prest og "prest» er overtydeleg. Finst det eit preste- eller forstandarembete berre for menn, så ryk føresetnaden om at lekfolk kan ha alle (sokne)prestens funksjonar, og ein må halde seg med eit embetssyn der ein vigsla/innsett person har hyrde- og læreansvar. Då har ein det allereie, på luthersk, i den geografiske forsamlinga. Eller så må ein bryte med same kyrkje og bli eige kyrkjesamfunn og vigsle/innsette "prest», same kva tittelen er. Det er i ein slik ordningsog embetsteologi Fri til teneste grunngir avvisinga av kvinneleg prest/ hyrde/lærar, noko som då vart avvist. Men i den nye kyrkjeinstitusjonen i ImF er der både landsstyre (ikkje identisk med forbundsstyre, men mogleg overlapping) og forstandarar i dei nye bedehusforsamlingane (ikkje identisk med leiar i bedehusforeininga). Brukar vi same logikken som i opposisjonen mot kyrkjepresten, så vil det seie at vi er alle prestar, og derfor i prinsippet kan ha alle funksjonane som forstandaren (som teologisk sett er i same posisjon som soknepresten) har. Vi er alle forstandarar/ forsamlingsleiarar, vil då tydinga vere - i det allmenne forstandardømet. I prinsippet kan ein kvar truande forrette fri nattverd uavhengig av forstandaren og lage eiga nattverdforeining. For å kome unna ei openberr indre og praktisk motsetjing må ein anten gi ein fundamental kritikk

\footnotetext{
106 Det var dei kristelege organisasjonane som stod bak stiftinga av IKO i 1945. Det betydde at eit meir ope syn på oppsedingskristendom hadde vunne plass. Det er eit trekk som får meir vekt etter kvart.

107 Husmøte- og kyrkjevekstteologi har slått inn, ifylgje Lerheim, 2008 og Jensen, 2011, delvis karismatiske ideal for kyrkjedanning. Sjå også Birkedal \& Lannem, 2019 om situasjonen i dag.
} 
av indremisjonshistoria på dette området - eller vedkjenne seg ein ordningsteologi av anten biblisistisk eller luthersk karakter.

ImF har luthersk vedkjenning. Det betyr at ei eller anna tolking av lutherdom er med i identiteten. Det kan også bety kritikk av adiaforaperspektivet på alle ordningar, og den kritikken kan med luthersk legitimitet kome frå bibeltolking. Nils Alstrup Dahl kom med nokre eksegetiske merknader som viser noko normativt i dei nytestamentlege «menighetsformer», særleg der dei er i nærkontakt med det sentrale i trua. ${ }^{108}$ Men avstanden er stor til dei tolkingane Solem og Hope la til grunn. Dei kunne til gjengjeld kallast noko naive når det gjeld realismen i å unngå ordningar og organisering i ei forsamling og rørsle. ${ }^{109}$ Det kjem av det som er hjartepunktet i synet deira, livet sjølv, det som gir liv. Det kan aldri vere nokon ytre organisasjon! Alt slikt er stillas. Det indre livet i forsamlinga vil likevel med nødvendigheit ha sine strukturar, vil ein sosiolog hevde som sjølvsagt. Det syter Gud for, vil Hope seie, og Solem ville sjå etter nokre mønster i den nytestamentlege forsamlinga det er nærliggande å gripe til. ${ }^{110}$

Nerven i teologien til desse hovdingane er vennesamfunnet som tett kongregasjonalistisk fellesskap. Og den kan det så langt ikkje innvendast imot frå luthersk teologi. Lokalforsamlinga er der sjølve grunneininga. Det er der det blir forkynt og kome til tru, og i forsamlinga skal det også levast eit trusliv. Kyrkja er i Det nye testamentet Kristi kropp, og ho må vise seg som kropp i verda - om ein då ikkje har eit så spiritualistisk kyrkjesyn at kroppen, i sin sosialitet, ikkje er synleg. Idealet hos Solem og Hope er dei sant omvende. ${ }^{111}$ Sikraste stad å finne dei er i vennesamfunnet med praktisering av nådegåver. Kyrkjesynet er då personalistisk.

\footnotetext{
108 Dahl, 1970.

109 Også 1 Kor 12 gir eit mønster for eit ordna liv i ei forsamling, men er enno ikkje institusjonalisert.

110 Slik Hope ville i 1907 nærme seg den første kristne forsamling i indremisjonen og ikkje i organiserte kyrkjesamfunn, kanskje som parallell menighetsorganisasjon. Grundtvigs kyrkjesyn kan vere med her. Solem hevda at indremisjonen bør vere oppteken av «ret menighetsordning» etter Guds ord. Indremisjonen bør vere samanslutninga av levande kristne innan den geografiske statskyrkjemenigheten. Han vil på det tidspunktet (1907) vere med i drøftinga av «De kirkelige spørgsmaal». Konteksten var reformarbeidet i statskyrkja. Sjå Fossum, 1987, s. 63-66.

111 Og her kan ei luthersk innvending kome mot eit for einsidig syn på kva som fører til tru. Omvending som erstatning for dåpen som nådemiddel er ei innvending. Likeeins eit syn på eit større mangfald i vegar til aktivt trusliv. Lerheim, 2008; Jensen, 2011.
} 
Kongregasjonalismen kan uttrykkje det lokalt. Det kan då eksistere fleire slike forsamlingar side om side i ulike lutherske kyrkjesamfunn, utan ei forpliktande overbygning verken lokalt eller nasjonalt. Men ei nasjonal organisering over lokalforsamlinga skjer no i ImF med ein ordningsteologi. ${ }^{112}$

Det skjer mykje i dei mest radikale lekmannsorganisasjonane for tida når det gjeld kyrkjedanning, samtidig som dei er organisasjonar. ${ }^{113}$ For ImF sitt vedkomande har vi sett skifte i perspektiv og praksis, samtidig som gammal struktur står ved lag. I forhold til dei radikale kyrkjesyna til Solem og Hope har det skjedd eit oppbrot. Ein kunne då seie at Hope ser ut til å få rett - når han åtvarar mot å danne frikyrkjer: «Dei små samfunna vert for mykje innestengde hjå seg sjølv. Dei store kyrkjene har organisert seg inn $i$ verda. Dei små har organisert seg $u$ t or verda. $\|^{114}$ Då kan ein hamne i isolerte grupper utan større stillas. Men, som Solem hevda på lekmannsmøtet i Ålesund 1893: ein kan stå og arbeide for reformer - til det å bli ståande blir ei synd. ${ }^{115}$ For mange utmelde er det eit samvitsspørsmål. Og dei samlar seg lokalt saman med folk i organisasjonen. Vi får ei blanding av kongregasjonalisme og landsorganisasjon i eit hybrid kyrkjesyn. Det er to stillas med heilt ulik struktur i ein postmoderne installasjon. ${ }^{116}$

\section{Litteratur}

Birkedal, E. (2018). «Alt under ett tak». En empirisk undersøkelse av menigheter under Normisjon. Tidsskrift for Praktisk Teologi, 35(1), 35-46.

Birkedal, E. \& Lannem, T. S. (2019). Kirkelandskapet i Norge i endring. Norsk Tidsskrift for Misjonsvitenskap, 73(1),8-22.

\footnotetext{
112 Eg viser igjen til rettleiinga frå 2014, https://www.imf.no/wp-content/blogs.dir/44/files/2018/o2/ Veiledning-fra-ImF-om-menn-og-kvinners-tjeneste.pdf

113 Sjå Lerheim, 2008 og Jensen, 2011. Meir har skjedd etter deira arbeid, ikkje minst etter kyrkjemøtetvedtaket 2016 om vigsel av likekjønna. Sjå Birkedal \& Lannem, 2019. Denne artikkelen vil avslutte med utviklinga i ImF, sett på bakgrunn av deira historie.

114 Hope, 1969, s. 55-56.

115 Referert etter Løvlie, 2020.

116 No blir det arbeidd for ein fusjon av trussamfunna i ImF og NLM - ikkje av organisasjonen. Det er styret i Ims som har vedteke å slå seg saman med andre evangelisk-lutherske trussamfunn, i første rekke NLM. Det kan bli avgjort først ved dei neste generalforsamlingane. "Vil slå seg sammen med NLM». Vårt Land 11.11.2019, s. 6.
} 
Dahl, N. A. (1970). Gis det noe normativt i de nytestamentlige menighetsformer? Luthersk Kirketidende, 105(19), 434-441.

Danielsen, L. J., Kleppa, J., Landro, M. \& Sæle, F. J. (1982). Fri til teneste. Om kvinna sin plass og funksjon i kyrkjelyden. Oslo: Luther Forlag.

Det Vestlandske Indremisjonsforbund gjennom 50 år. (1948). «Forbundet» av Bernhard Eide. «Bibelskolen» av S. Anker-Goli. «Finnmarksmisjonen» av A. Ellingsgård. Bergen: Det Vestlandske Indremisjonsforbund.

Fossum, R. R. (1987). "fra nu av er broderstrid umulig!». Geilosammenslutningen, Lekmannsbevegelsen organisert til topps? Forsøket på å organisere de frivillige organisasjonene til én samlet enhet $i$ årene 1913 til 1936. Hovedoppgave i historie, Universitetet i Bergen.

Gundersen, K. (1996). Visjon og vekst. Framveksten av de frivillige kristelige organisasjonene 1814-1940 (Tillegghefte nr. 3). Tidsskrift for Kirke, Religion og Samfunn. Volda: Møreforsking, Høgskulen i Volda, TKRS.

Hallaråker, K. J. (1981). Bedehuset - heim og misjonsstasjon. Om lekmannsrørsla sine ideal og Vestlandske indremisjonsforbund sin profil. Bergen: Vestlandske indremisjonsforbund.

Hallaråker, K. J. (1990). I truskap mot framtida. I K. T. Gundersen (Red.), Organsisasjonane ved korsvegen? (s. 77-85). Volda: MRDH.

Hallaråker, K. J. (1997). Åndeleg leiarskap og den truande forsamlinga på bedehuset. Straume: Vestlandske indremisjonsforbund.

Hallaråker, K. J. (1999). Notat om menn/kvinner i Forbundsstyret 16.04.99. Henta 2001 frå www.dvi.no/sambaandet/default.asp

Handeland, O. (1966). Vårløysing. Band II. Andre utgåva. Bergen: A. S. Lunde \& co.s forlag.

Hegstad, H. (1994). Kirkevirkelighet og kirkeforskning. Ung Teologi, 31(4), 9-18.

Henriksen, J.-O. \& Repstad, P. (Red.) (2005). Mykere kristendom? Sørlandsreligion $i$ endring. Bergen: Fagbokforlaget.

Hope, L. (1923/1969). Kyrkja og Guds folk. 3. opplag. Oslo: Lunde.

Hope, L. (1932/1977). Kyrkja og lekmannsarbeidet. Veien fram, 1977, 228-245.

Jensen, O. (2012). Lekpredikanten og kirken. De nye forsamlingers ekklesiologi. I Kirke Kultur Politikk. Festskrift til professor dr. theol. Bernt T. Oftestad på 70-årsdagen (s. 61-71).Trondheim: Tapir Akademisk Forlag.

Kleppa, J. \& Odland, P. (1998). Ordets folk. Det Vestlandske Indremisjonsforbund 1898-1998. Bergen: Sambåndet forlag.

Klokkersund, R. (1986). «... Hjemmet først og fremst, men det andet ikke forsømmes...», Kirkas kvinnesyn belyst med utgangspunkt $i$ debatten om kvinners adgang til presteembetet i perioden 1891-1912. Hovedoppgave i historie, Universitetet i Bergen.

Knudsen, J. P. (1984). Urbanisering og sosial endring. Kirke og Kultur, 89(4), 245-253. 
Lerheim, B. (2008). Frå lekmannsforsamling til kyrkjelyd - endringar i kyrkjesyn og kyrkjepraksis i tre lutherske lekmannsorganisasjonar på 1990- og 2000-talet. Norsk Tidsskrift for Misjonsvitenskap, 62(1), 22-42.

Løvlie, B. (1996). Kirke, stat og folk i en etterkrigstid. Kirkeordningsarbeid i Den norske kirke 1945-1984 i et strategisk perspektiv. Oslo: Luther Forlag.

Løvlie, B. (2002). Vestavind. 1870-årenes debatt om kristenliv og kirkeordning under innflytelse fra Skottland. Trondheim: Tapir.

Løvlie, B. (2020). Bedehus, vekkelse og bevegelse. I Tru på Vestlandet. Kyrkjefag Profil. Oslo: Cappelen Damm Akademisk.

Oftestad, B. T. (1986). Ole Hallesby og Ludvig Hope som kirkelige strateger. Kirke og Kultur, 215-229.

Sjaastad, E. (2016). Carl Fr. Wisløff. Presten som ble misjonsfolkets professor. Kyrkjefag Profil 27. Kristiansand: Portal forlag.

Solem, J. (1934/1995). Den frie lekmannsbevegelsens rett innen statskirken. Foredrag av borgermester Johs. Solem holdt på Det Vestlandske Indremisjonsforbunds årsmøte 6. oktober 1934. Straume: Sambåndet Forlag.

Solem, J. (1938/1995). Det frie lekmannsarbeidet $i$ kommende dage. Foredrag holdt på Det Vestlandske Indremisjonsforbunds årsmøte i Bergen 23. september 1938. Straume: Sambåndet Forlag. Henta frå https://www.nb.no/ items $/ 48$ b 58 e $7 f_{323}$ c2ffocde 5194egf 4 ac674? page $=53$ \&searchText $=$ johs. $\% 20$ solem

Svalastog, O. A. (1983). Frå kvinnelege predikantar til kvinnelege prestar eller berre bibelkvinner. Nokre teologiske synspunkt på kvinna og det allmenne prestedømet ifrå Hans Nielsen Hauge til Kleppa-innstillinga. Hovudoppgåve i kristendomskunnskap, Menighetsfakultetet.

Try, H. (1985). Associationsaand og foreningsvekst i Norge. Forskningsoversyn og perspektiv. Øvre Ervik: Alvheim \& Eide.

Ulstein, J. O. (2001). Indremisjonskvinna på Vestlandet - frå fortropp til baktropp? Om bibelsyn og prestedøme, organisasjonskultur og plausibilitetsstruktur i Indremisjonsforbundet/DVI. Norsk Teologisk Tidsskrift, 102(3), 154-167.

Statskirken og de troendes forhold til samme. Referat af forhandlingerne paa det kirkelige loegmandsmøde i Aalesund den gde og 1ode November 1893. Aalesund: «Søndmøre Folkeblad»s Trykkerie.

Veien fram. Grunnsyn og arbeidsmåter i Norsk Luthersk Misjonssamband. Oslo: Lunde Forlag og Bokhandel 1977.

Wisløff, C. F. (1971). Norsk kirkehistorie. Bind III. Oslo: Lutherstiftelsen.

Aalesund Indremisjon. 100 års festskrift 1868-1968. Utarbeidet av borgermester Johs. Solem og red.sekr. OlavAlmås. Ålesund: Sunnmørspostens trykkeri.

Aarflot, H. (1973). Teologiens Sitz im Leben som vitenskaps- og religionssosiologisk problem for teologien. Tidsskrift for Teologi og Kirke, 44(2), 81-125. 



\title{
KAPITTEL 7
}

\section{Bedehus, vekkelse og bevegelse}

\author{
Birger Løvlie \\ Høgskulen i Volda
}

\begin{abstract}
Sammendrag: I andre halvdel av 1800-tallet ble Vestlandet kirkelig sett preget av en voksende lekmannsbevegelse. Bevegelsen vokste parallelt med andre bevegelser, og tok opp i seg kampen for nynorsk målføre. Forbindelsen til den vestnorske reformbevegelsen er også tydelig, noe som kom til syne på et lekmannsmøte i Ålesund i 1893. I Volda kom det til konflikt mellom radikale lekfolk og stedets sokneprest. Konflikten viser at lekfolket fikk kulturell makt i allianse med blant annet forkjemperne for nynorsk.
\end{abstract}

Nøkkelord: lekmannsbevegelse, reformbevegelse, indremisjon statskirkekritikk, nattverdsstrid, målsak

\section{Innledning}

I det Herrens år 1893 gjæret det blant kristenfolket på Sunnmøre. Lekfolkets retter og plikter i Den norske kirke ble gjenstand for debatt. Et viktig spørsmål handlet om retten til å praktisere nattverd uten medvirkning av prest. Noen steder ble det markert at bedehuset ikke skulle slippe til talere som deltok i privat nattverd. Slike vedtak vitner om at deler av lekfolket på Vestlandet trådte varsomt i forhold til embetet, samtidig som vestlendingene i det store og hele hadde avvist diverse forsøk på å legge vestnorsk indremisjon inn under den såkalte Lutherstiftelsen, stiftet i 1868 i den hensikt å sammenfatte alt indremisjonsarbeid i Norge. Det ville ha medført en viss kontroll fra presten over virksomheten. Dette 
mønsteret kjente de fra Lutherstiftelsens grunnregler, ${ }^{1}$ og var tydelige på at de ville gå $i$ en annen retning. Hvilken vei, eller med andre ord: Hvor stor selvstendighet skulle lekfolket og deres forsamlinger ha, og hvordan argumenterte det vestnorske lekfolket for deres frihet? Svaret på disse spørsmålene kan klargjøre deres forhold til Den norske kirke, både ordningsmessig og konfesjonelt, i ei tid da andre trossamfunn drev inn mot kysten.

To store bevegelser som berørte kirkelivet, utviklet seg parallelt i andre halvdel av 180o-tallet. Det gjelder reformbevegelsens kamp for å endre kirkeordningen, og det gjelder vekkelsesbevegelsen som grep om seg slik at statskirkens ansikt utad ble radikalt endret. Begge bevegelsene har vært gjenstand for mange studier, slik at vi vet mye om begge, men sammenhengen mellom bevegelsene er det grunn til å se nærmere på. Når sammenhengen undersøkes, må en ta hensyn til en viss ulikhet. Vekkelsesbevegelsen var et indrekirkelig fenomen. Reformbevegelsen var i større grad en bevegelse som hadde søkelys på et politisk problem. Den arbeidde for større frihet for kirken, i en nær allianse med venstresida i norsk politikk, og det gir grunn til å undersøke i hvilken grad vekkelsesmiljøet beveget seg i samme retning.

På Sunnmøre ble sammenhengen mellom vekkelseskristendom og reformbevegelsen satt på dagsorden på et lekmannsmøte høsten 1893. Menn som åndelig sett var en frukt av vekkelser, møtte opp sammen med menn som var engasjert i krav om kirkereformer. I og med at det ble utgitt et fyldig referat fra møtet, har vi tilgang til en nyttig kilde for å besvare spørsmålene ovenfor, ikke minst en kilde til å finne ute hvordan sunnmørske representanter for lekmannsbevegelsen debatterte og prøvde å stake ut veier videre. En annen kilde har vært Jakob Straumes upubliserte manuskript Vekkingslivi Volda, en framstilling fra en insider. Ole Hovdhaugens upubliserte dokumentsamling ${ }^{2}$ har vært svært nyttig i den delen av artikkelen som handler om Volda og Ørsta. Jeg benytter meg selvsagt også av de ulike framstillinger av vestnorsk indremisjonshistorie

Gundersen, 1996, s. 46, 54ff.

Hovdhaugen, 2018. 
som finnes. Disse er ikke minst nyttige for den som vil ha et riss av forhistorien.

\section{Framveksten av en vestnorsk indremisjon}

Lekmannsbevegelse, bedehus og vekkelse er sentrale begrep i denne historien, ei historie som foregår i en periode som kan beskrives med ord som nasjonsbygging og demokratisering. Bedehus er vel det mest «kristelige» av disse begrepene, og vekkelse det mest allmennkulturelle. Et eksempel på det siste er at da en samling intellektuelle stiftet «Selskapet for Folkeopplysningens fremme», i 1851, var formålet å «virke til Folkets Oplysning med særlig Hensyn til Folkeåndens Vækkelse, Udvikling og Forædling».3 Omtrent samtidig begynte den kirkepolitiske reformbevegelsen å bli en del av lekmannsbevegelsen, særlig på Vestlandet, inspirert av demokratiserende tendenser, som for eksempel formannskapslovene av $1837 .{ }^{4}$ Det var ikke lang vei derfra til krav om menighetsråd.

Det første forsamlingshuset som ble kalt bedehus, ble bygd i Skien i 1850, men haugianske forsamlingshus fantes i flere byer og bygder før det. Noen ble bygd allerede omkring 1840, de fleste i vest. Noen steder ble huset bygd som følge av en vekkelse, andre steder ble huset bygd til oppbyggelig formål, som igjen kunne føre til vekkelse. Bedehus kunne altså bli bygd fordi det hadde vært vekkelse, men også for at den skulle komme. Fenomenet vekkelse kan fra en kultursosiologisk synsvinkel defineres som en prosess der en heller stor flokk mennesker mer eller mindre samtidig opplever en omveltning som gir ny mening i tilværelsen.5 Teologen Georg Sverdrup ${ }^{6}$ (1848-1907) skildret i en selvbiografi vekkelsene han hadde opplevd som ung i noe mer kristelige vendinger. Han opplevde vekkelsene som «en frisk og skarp luftning» over landet.

Sitert etter Slagstad, 1998, s. 93.

4 Reformbevegelsens start er ikke enkel å tidfeste, men Stavanger Amtsformannskaps henvendelse til Stortinget om å vurdere en mer demokratisk kirkeordning, fra 1850 er nok det første innspillet fra ikke-geistlig hold.

5 Seland \& Aagedal, 2008, s. 15.

6 Georg Sverdrup var sønn av presten og politikeren Harald Ulrik Sverdrup, nevø av Johan Sverdrup og bror av Jakob Sverdrup. Etter teologisk embetseksamen dro han til USA i 1874, som professor ved Augsburg Seminar. Som student ga han ut en serie traktater om kirkelige forhold, sammen med sin bror og Georg Schielderup. Løvlie, 2002, s. 62-65, jf. Hamre, 1986. 
De hadde satt skille mellom mennesker, et skille som måtte til for å gi folket en bevissthet om kristendommens evighetstunge alvor, som krever en avgjørelse for eller imot, helt med Jesus eller helt imot ham. Med et uttrykk fra Søren Kierkegaard skrev Sverdrup om vekkelsens «enteneller», enten født på ny eller evig fortapt.? Dette evighetstunge alvoret ble knyttet til tro på endring. Vekkelsesfolket trodde at et menneske, ung, voksen eller gammel, kunne få sitt liv endret, brått og varig i et møte med Gud, og det la ikke bare grunnlag et myndig menneske, det motiverte også for samfunnsendringer.

I 1957 skrev geografen Gabriel Øidne en artikkel med en talende tittel: «Litt om motsetninga mellom Austlandet og Vestlandet». ${ }^{8}$ Noen år senere kom sosiologen Gunnar Teiglands artikkel med en like talende tittel: «Embetsmakt mot folkevilje».9 I begge artiklene er lekfolket en del av motsetningene, som forfatterne ser på som avgjørende for å forstå utviklingen av lekmannsbevegelsen i andre halvdel av 180o-tallet, særlig organisatorisk. Før det, det vil si de første tiåra etter Hans Nielsen Hauges tid, gikk kristenlivet i Norge, både i øst og vest, i én retning, mot større innflytelse for lekfolket, innenfor og utenfor en kirke som i Grunnloven var definert som statens offentlige religion, håndhevet av «religionens lærere» som en del av statens maktutøvelse. Retningen har vært den samme, i korrelasjon med nasjonsbygging og demokratisering, men tempoet har vært noe ulikt, og viljen til å gjennomføre prosessen kan ha hatt ulik styrke.

Viljen til reformer seiret avgjørende i 1842 med opphevelsen av Konventikkelplakaten, men det var en politisk seier, ikke primært teologisk. Teologene hadde sitt eget problem, nemlig Den augsburgske bekjennelse, artikkel 14, som sa at den som skulle lære offentlig eller forvalte sakramentene, måtte være rett kalt. Det betydde å være utnevnt av ham som siden eneveldet hadde vært kirkens øverste biskop og forvaltet retten til å kalle prester, nemlig kongen. Rett prest var å være «ansatt og innsatt av den øverste kirkestyrelse under h.m. kongens presidium». ${ }^{10}$

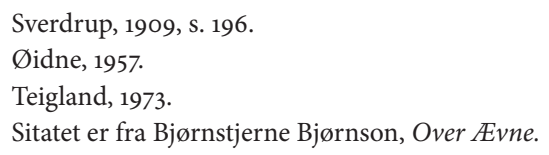


Lekmannsforkynnelse var derfor et kirkerettslig problem, som ble løst med henvisning til at det var så stor mangel på forkynnelse at det eksisterte en nødssituasjon. For å bedre på denne nødssituasjonen ble Lutherstiftelsen ble opprettet, etter initiativ av en gruppe med professor Gisle Johnson (1822-1894) ${ }^{11}$ i spissen. Der ble det gitt adgang for lekfolk til å forkynne når de fikk tillatelse fra stedets prest, men det normale oppdraget for Lutherstiftelsens utsendinger var utdeling av traktater. Til den slags virksomhet «kunde jeg like gjerne sende min pige!», utbrøt læreren og emissæren Lars Goderstad fra Tvedestrand. ${ }^{12}$

Det ble gjort forsøk på å få Vestlandet med i Lutherstiftelsen, men det lyktes ikke. Det vestnorske lekfolket ble ikke organisert fullt og helt før i 1898, selv om en krets hadde eksistert siden 1864, nemlig Sunnhordland, Hardanger og Voss Indremisjonssamskipnad. Den kretsen ble stiftet uten at Gisle Johnson ble spurt til råds. Da Johnson noen år senere oppfordret Samskipnaden til å bli med i Lutherstiftelsen, var svaret nei. ${ }^{13}$ Lutherstiftelsen ga ikke lekfolket den friheten som var så viktig for folk som identifiserte seg med Hauge. Lutherstiftelsens og Gisle Johnsons reservasjoner overfor lekmannsforkynnelsen ble et sentralt element i motsetningen mellom Østlandet og Vestlandet. ${ }^{14}$ Den friheten vestlendingene slo ring om, var en forsamlingsfrihet under predikanter og ledere som hadde vunnet seg tillit, slik Hauge anbefalte i sitt testamente. På 1870-tallet ble det mer og mer klart at reformbevegelsens folk ikke delte Johnsons konservative og lite demokratiske statskirkelighet. Etter at Johnson tok initiativet til oppropet «Til Christendommens venner i vort Land» (1883), var tilliten nærmest borte i lekmannskretser. I kampen for og mot den politiske liberalismen som Johan Sverdrup representerte, var avstanden stor. ${ }^{15}$

11 Gisle Johnson var professor i teologi ved universitetet i Christiania. I 1855 var han med på å starte Christiania Indremissionsforening og samtidig var han virksom som predikant. Det førte til en vekkelse som ofte er omtalt som Johnson-vekkelsen. Mange av hans studenter var så sterkt preget av hans teologi og forkynnelse at de er blitt kalt de johnsonske prestene. Ousland 1950. Av nyere forsking vises til Hallgeir Elstad (2000), som har konsentrert sin studie til prester som ble ordinert i Kristiania.

Hamre, 1964, s. 37.

Øidne, 1957.

Wisløff, 1961. 
En ny samling av lokale foreninger til en indremisjonskrets kom i stand på Sunnmøre i 1882. Her var foregangsmenn som Erik Solem og Andreas Grytnes. Solem var radikal lekmann, mens læreren og klokkeren Grytnes sto for et nærere samarbeid med prestene. Stiftelsesmøtet foregikk uten Solem, som var syk, og dermed fikk geistlige utsendinger inn i grunnreglene at det skulle være to geistlige medlemmer i styret. Paragraf 2 sa at fellesforeningen skulle stå i et støttende forhold til det «kirkelige embede». Dermed var det åpenbart at fellesforeningen bygde på ulike forutsetninger.

Prosessen som førte fram til stiftelsen av Det Vestlandske Indremisjonforbund startet med et indremisjonsmøte i Stavanger i oktober $1890 .{ }^{16}$ Lars Oftedal (1838-1900), ${ }^{17}$ den viktigste drivkrafta i vekkelsene i $1870-$ og 8o-åra, ${ }^{18}$ var dirigent, og den nyutnevnte soknepresten i Korskirken i Bergen, Jakob Sverdrup, holdt foredrag om det som var møtets tema, nemlig spørsmålet om landets indremisjonsforeninger skulle samles i en organisasjon. Han tok utgangspunkt i det uttalte ønsket fra en prest som skrev: «Vi ønsker en Sammenslutning af de spredte kræfter til en organisme i Lighed med Det Norske Misjonsselskap». ${ }^{19}$ Sverdrup hevdet at det var avgjørende forskjeller. NMS begynte med organisasjon, mens en sammenslutning av indremisjonsarbeidet måtte bli et forbund av foreninger, som bevarte sin selvstendighet. Sverdrup argumenterte som luthersk kongregasjonalist, og hans idéer ble videreført i arbeidet som førte til at forbundet ble opprettet i 1898 som en sammenslutning av selvstendige foreninger.

Lekfolkets program startet lokalt, der det skulle arbeides for å vekke og nære et sant kristelig liv. Etter hvert bygde de bedehus, og ledere med talegaver ble invitert til å tale i og utenfor sin egen forening. Disse lederne var ofte menn med en posisjon i lokalsamfunnet, som bønder, entreprenører

16 Luthersk Kirketidende, 1890 II, s. 299-302.

17 Lars Oftedal var fra Stavanger og etter endt teologisk utdanning var han sjømannsprest i Cardiff (1866-68. Deretter var han emissær i Bergen indremisjon en tid før han ble stiftskapellan i Agder. Fra 1874 av var han prest i Stavanger, først i Hetland og deretter St. Petri. Der la han ned en stor innsats som sosial reformator, bygde bedehus, skoler og barnehjem. På Stortinget, 1883-1885 og 1889-1891, støttet han Sverdrups Venstre.

18 Døssland, 1975, s. 6.

19 Luthersk Kirketidende, 1890 II, s. 167. 
eller lensmenn, og de hadde tillitsverv som ordførere eller tingmenn. Framfor alt var en ny gruppe i ferd med å vinne posisjoner, nemlig lærerne. Lærerne hadde faktisk et kirkelig kall til å arbeide i den kristne skolen, og i praksis forberedte de barna på konfirmasjonen. I deres arbeid skulle de hellige Guds navn ved å lære Guds ord rent og klart, slik Den lille katekisme forklarte den første bønn i Fader vår. Noe annet syn på det kirkelige embetet enn katekismens ord om forkynnelsen hadde de neppe; de hadde heller ikke bruk for mer. ${ }^{20}$ Gjennom tidsskrift som Folkevennen og Norsk Skoletidende var de blitt vant til debatt og selvstendig vurdering av spørsmål som angikk både deres yrke og deres livssyn. De utgjorde etter hvert en elite som sto nærmere folket enn det presten gjorde, og de ivaretok den statspietistiske tradisjonens styrke, som besto i at de ga nye generasjoner en basis av kristen kunnskap, som vekkelsene kunne høste av. Men lærernes innflytelse var ikke avgrenset til skolen, de ble også lekfolkets ledere. ${ }^{21}$

Lekfolket var organisert rundt ledere, små og store høvdinger. De var predikanter, og vant seg tillit, både ved å «stå i vekkelse» og ved å være sjelesørgere som ledet folk til trosvisshet. I tillegg var de ideologer, som kjempet for åndelig, sosial og politisk frihet. «Frihed er tidens løsen, Frihed paa det politiske og på det kirkelige Feldt», skrev redaktøren N. J. Laache i For fattig og rik, i en artikkelserie som ble lest og sitert om og om igjen, blant annet på lekmannsmøtet i Ålesund. De returnerte innbydelsen til å undertegne oppropet «Til Christendommens Venner i vort Land», som regel uten underskrift, ${ }^{22}$ og gikk i stedet hen og stemte på Johan Sverdrup. Han kunne ikke ha vunnet uten «bønefolket». ${ }^{23}$ Dette skapte selvsagt spenninger. Sokneprest, senere biskop J. C. Heuch, skrev om at vanviddets dager var kommet, mens Luthersk Kirketidende så sent

\footnotetext{
20 Goderstad, 1914, s. 17ff.

21 Lærernes sentrale rolle i foreningslivet gjaldt ikke bare i den religiøse sektoren. Hans Try omtaler lærerne som en «foreningselite-gruppe» som litt etter litt overtok prestens rolle, i takt med «bedre utdanning, større sjølvkjensle og sterkare gruppekjensle» (Try, 1985, s. 62). Wisløff, 1961, s. 99ff. Oppropet ble sendt ut i 1883, fra en komité med Gisle Johnson i spissen, som en sterk oppfordring til kristenfolket om å stemme konservativt. 
som i 1894 skrev at det å gi allmenn stemmerett til «et raat og barnaktig folk» var av det onde. ${ }^{24}$

Lederskap var viktig, ikke minst teologisk. Overfor en dominerende, geistlig religion måtte det utvikles en alternativ kirkeforståelse. Den kom til uttrykk fra en voksende reformbevegelse, som hadde kjempet, især etter 1850, for en friere kirkeordning med særlig vekt på å få innført valg av menighetsråd. De mest radikale i bevegelsen var vestlendinger og gikk under navnet «de bergenske reformvenner», og deres engasjement var bensin til indremisjonsbålet. ${ }^{25}$ Begge miljøene hadde samme utgangspunkt, nemlig den nytestamentlige tanken om de troendes allmenne prestedømme. Når lekfolk skrev eller talte om denne saka, var det primært lekmannens rett til å forkynne Guds ord som skulle begrunnes, mens reformbevegelsens talsmenn på Vestlandet gikk noe lenger og skrev om det allmenne prestedømme som basis for hele deres kirketenkning. Unge teologer som Georg Schielderup og brødrene Jakob og Georg Sverdrup publiserte en rekke Kirkelige Traktater med dette lavkirkelige utgangspunktet. Jakob Sverdrup var for øvrig kirkeminister da det ble gitt lov til at en lekpredikant kunne preke fra prekestolen i kirkene i 1897.

Jakob Liv Rosted Sverdrup (1845-1899) ${ }^{26}$ knyttet for alvor reformbevegelse og vestnorsk indremisjon sammen. Med ham kom folkehøgskoletanken på plass. Som ung teolog dro han til Danmark, der han studerte og ble engasjert av Grundtvigs folkelige og pedagogiske idéer, før han vendte tilbake og startet Sogndal folkehøgskule. Han bygde på det han hadde lært av Grundtvig, uten å kopiere. Til det var Grundtvigs folkelige idéer for nasjonalistiske, og det typisk danske passet ikke for vestlendingene, som hadde sitt eget kristelige og folkelige særpreg. ${ }^{27} \mathrm{Da}$ han holdt sitt foredrag i Stavanger, i 189o, var han, som nevnt, nettopp blitt sokneprest

\footnotetext{
24 Luthersk Kirketidende, 1894 II, s. 161.

25 Løvlie, 2002, s. $69 f f$.

26 Jakob Sverdrup tok teologisk embetseksamen i 1869. I 1877 ble han sokneprest i Leikanger, og samme år ble han valgt inn på Stortinget. Gjenvalgt flere ganger, etter 1892 representerte han Moderate Venstre. Han var også i flere omganger kirkeminister i Johan Sverdrups regjeringer og kjempet for kirkelige reformer som valgfri borgerlig ekteskapsinngåelse og menighetsråd. Teologisk var han påvirket av Gisle Johnson, men samtidig sto han i markant opposisjon til Johnsons statskirkelige konservatisme. Han startet og redigerte bladet Ny Luthersk Kirketidende (1877-1881), der han argumenterte for kirkefrihet, se Løvlie, 2002, s. 73-79.

Sverdrup, 1870 .
} 
i Korskirken i Bergen. I 1899 ble han utnevnt til biskop i Bjørgvin, men døde før han kunne tiltre. I en Wikipedia-artikkel er han omtalt som teologisk konservativ og pietist, som inspirert av Grundtvig, og som liberal venstrepolitiker. ${ }^{28}$ Det er vanskelig å finne en klar sammenheng i slike karakteristikker, men hvis vi fokuserer på hans betydning for vestnorsk indremisjon, så sto han fram som en lavkirkelig og politisk liberal lutheraner som framfor alt plantet tanken om kristelig opplysning blant lekfolket. Sammenhengen kan beskrives som en korrelasjon; Jakob Sverdrups vektlegging av det allmenne prestedømme utviklet seg parallelt med hans liberalpolitiske, demokratiske, idealer, og både det allmenne prestedømmet og det politiske demokratiet var avhengig av økt kunnskap. Hadde Jakob Sverdrup lest Luthers viktigste skrift om det allmenne prestedømme (og det hadde han nok), ville han vite at det var der Luther satte fram sine krav om undervisning av barna, til og med for jentene.

Hvor stor innflytelse hadde unge menn og teologer som Schielderup og brødrene Sverdrup på det vestnorske lekfolket? De rakk ikke å påvirke startfasen, for da de kom på banen, var Bergens indremisjon allerede stiftet. Vedtektene den gang var omtrent som i Lutherstiftelsen, det vil si at nødsprinsippet lå til grunn. Arbeiderne skulle være kolportører. De unge menns engasjement gikk i en friere retning. Jacob Sverdrups radikale forståelse av det legitime i lekmannsforkynnelsen kom til uttrykk da han var utsending til Lutherstiftelsens årsmøte i 1878. Der foreslo han en endring i grunnreglene slik at stiftelsens utsendinger skulle få adgang til «at forkynde Ordet i større forsamlinger», uten å oppnå stor oppslutning. ${ }^{29}$ Samme år skrev han en artikkelserie, der han avsluttet med å definere Bergen som indremisjonens midtpunkt, slik Stavanger var det for hedningmisjonen..$^{\circ}$ I kampen for lekmannens frihet til å forkynne fikk han avgjørende støtte fra ham som gjerne omtales som den som fikk mest å bety for indremisjonen på Vestlandet: Jacob Traasdahl.

\footnotetext{
28 Hentet 03.07.2019 fra https://no.wikipedia.org/wiki/Jakob_Sverdrup.

29 Ny Luthersk kirketidende, 1878, s. 269.

30 Ibid., s. 394.
} 
Jacob Traasdahl (1838-1903) $)^{31}$ ble avgjørende for at den rosenianske vendingen slo gjennom på Vestlandet. ${ }^{22}$ I Göteborg kom han i kontakt med Carl Olof Rosenius (1816-1868) og Oscar Ahnfeldt (1813-1882), som besøkte Norge flere ganger. ${ }^{33}$ Han virket en kort periode i Kristiansund, der han til slutt ble nektet å bruke bedehuset på grunn av sin forkynnelse, som etter de eldre kristnes mening brøt for mye med den haugianske tradisjonen. I Bergen fikk hans rosenianske forkynnelse større gjennomslag. Kort sagt virket den rosenianske forkynnelsen som en frigjøring fra et ensidig negativt menneskesyn som både den haugianske vekkelsen og Gisle Johnsons teologi presenterte som sann lutherdom. Den rosenianske troende var nok pietist i livsstil og fromhet, i likhet med haugianerne, men var samtidig i større grad et frigjort menneske i sin samvittighet. Det er grunn til å tro at Traasdahl hadde med seg påvirkning fra sin fortid i metodismen med et mer optimistisk syn på det nye livet i Kristus. Det var litt skummelt i en tid da prester var svært vaktsomme overfor metodistene, som etablerte menigheter over hele landet, blant annet $\mathrm{i}$ Sogndal og Ålesund, der også baptistene hadde fått en menighet. ${ }^{34}$

I arbeidet med å organisere et indremisjonsforbund hadde Traasdahl mange medspillere, en av dem var Andreas Lavik (1854-1918). ${ }^{35}$ Som sekretær og redaktør var Lavik de første tjue åra «eitt med Forbundet». ${ }^{36}$ Han var radikal og uredd; som redaktør av Sambaandet førte han en på mange måter åpen linje. På Stortinget hadde han gjort seg bemerket som en forsvarer av kvinnelig stemmerett. Dette ble for radikalt, selv for venstrefolk. Både på grunn av denne saka, og av andre årsaker, ble han ikke gjenvalgt.

31 Jacob Traasdahl vokste opp i en haugianerfamilie på Lesja, og kom til bevisst tro i en metodistforsamling i Fredrikstad, der han gikk i malerlære. Etter 1870 holdt han til i Bergen, som predikant, redaktør og forfatter. Han omtales som den som hadde størst innflytelse på profilen til Det Vestlandske Indremisjonsforbund. Kleppa \& Odland, 1998, s. 57.

32 Kleppa, 2013.

33 Løvlie, 2002, s. 51, jf. Eide, 1950, s. 44. Ahnfeldt ble omtalt som en sangevangelist av samme betydning som Ira Sankey, Luthersk Kirketidende, 1894 I, s. 279-283.

34 Rosenianisme, slik både jeg og andre bruker ordet, gjør det nærliggende å tenke seg en forkynnelse som i det store og hele er knyttet til Rosenius. Det er opplagt en forenkling. Ikke minst hadde herrnhuternes etablering av Brødremenigheter med betydelig påvirkning i Oslo, Stavanger og Trondheim vært med på å berede grunnen for den rosenianske dreiningen i forkynnelsen. Andreas Lavik var bonde fra Eksingedalen i Nordhordland. Ansatt i Bergens Indremisjon fra 1878, og representerte Venstre på Stortinget 1889-91. Sekretær i DVI 1898-1918 og redaktør av Sambåndet det meste av perioden. 
I flere år ble han heller ikke brukt som forkynner i indremisjonen, men var tilbake tidsnok til å bli redaktør, en talerstol som kunne brukes til å forme en profil. I 1911 publiserte han en artikkel om kvinnens plass i det oppbyggelige arbeidet. Den var skrevet av Henny Dons (1874-1966), en av grunnleggerne av Lærerinnenes Misjonsforbund i 1902, der hun var formann til 1946. Hennes budskap var at det å forkynne evangeliet er en menneskerett, ikke en mannsrett. ${ }^{37}$ Noe senere skrev Lavik heftet Vort folk $i$ dag, der han også argumenterte for kvinners rett til å forkynne Guds ord.$^{3}$ I likhet med Dons argumenterte han teologisk. For ham var kvinnen som mor en myndighetsperson med rettigheter i borgersamfunnet. Lavik var i så måte en sann disippel av Jakob Sverdrup.

Jakob Traasdahl var et skrivende menneske. Han ga ut tre forskjellige blad, barnebladet Duen, Familievennen og Fredsbudet. I blada skrev han fortellinger som senere kom ut i bokform. Han skrev også et tobinds verk med gjennomgang av tekstrekkene, i samarbeid med en annen som fikk stor innflytelse, nemlig Paul Gerhard Sand (1848-1911)..$^{39}$ Han var en ekte rosenianer. Både i Ålesund og på bygdene omkring var han sentral i en vekkelse som gjerne ble omtalt som «Sandstormen».40 Vi nærmer oss Sunnmøre.

\section{Vekkelsesforkynnelsen}

Hva lærte de, og hva siktet de mot? Forkynnelsen i vekkelsene var som så mye annet under endring. Volda-presten Halvdan Møller var tydelig på at det vekkelsesmiljøet han levde i, hadde brutt med den haugianske forkynnelsen som altfor lovisk, og som gjorde at trosvisshet var avhengig av at gjenfødelsens frukter var synlige. Møller sto fram som fullblods rosenianer, men han avgrenset seg mot det som gjerne ble kalt nyevangelismen, som forkynte en subjektiv forsoningslære og tenderte mot å ikke ta Guds

\footnotetext{
37 Sambaandet, 10.11.1911.

38 Kleppa \& Odland, 1998, s. 62.

39 Paul Gerhard Sand var østlending, født i Øvre Eiker, men bosatte seg på Biri. Han var utdannet lærer, men viet seg til forkynnelse og virket som predikant på Sunnmøre i perioder fra 1887 til 1992.

Handeland, 1966; Skorgevik, 1974.
} 
hellighet og vrede alvorlig nok. ${ }^{41}$ Nyevangelismens talsmenn, den svenske predikanten P. P. Waldenstrøm og hans disipler, hadde gjort mange innhogg i de sørlige deler av landet, mens Vestlandet hadde stort sett gått fri, mente Møller. Avsondringen fra resten av landet hadde altså sine fordeler. Her lød den troens forkynnelse som virket et sunt kristenliv:

Tro på den Herre Jesus, slik som du er nu, og slik som du har det nu, syndig som du er og bunden som du ser deg! Kom som en ugudelig og fortapt til ham, der retfærdiggjør den ugudelige og frelser det fortapte! Syndsforlatelsens nåde er ferdig til at annammes som fri Gave. Vår frelser, Jesus Kristus, har allerede brakt det fullkomne offer, en gang for alle. Derfor har han en full og ferdig nåde for syndere, og han gir den til hver den som kommer til ham og tar imot. ${ }^{42}$

Dette lød ganske annerledes, og mye enklere, enn den «saliggjørelsens orden» som haugianerne la til grunn for omvendelsen. Den startet med at en ble vakt og gikk steg for steg i erkjennelse av synd, før man kunne ta imot nåden. Frelsesvisshet var omtrent umulig, og i alle fall avhengig av at gjenfødelsens frukter ble synlige. ${ }^{43}$

Møller la stor vekt på at vekkelsesforkynnelsen hadde et samfunnsbyggende siktemål. Der det er vekkelse, vokser et bevisst og sterkt samfunnsliv blant de troende til en rett menighetsdannelse. En avgjørende faktor for dette er at presten har syn og sans for denne prosessen. Han mener at det fantes prester, også på Vestlandet, som ikke hadde det, og i stedet opptrådte som et meningspoliti, men i det store og hele var man «velsignet med et stort og enigt Samarbeide i retning af samfundsliv og Menighedsdannelse på Troens Grund», og med det mente han blant annet et vekstmiljø for nådegavene. Lederskapet var de nådegavene Gud skjenket forsamlingen, og det ble det nye embetssynet. Basert på «de av HelligAanden skjenkede Naadegaver» skulle lederskapet framfor alt framelske et kristelig fellesskap av mennesker som slutter seg til av personlig overbevisning.

Det Møller skrev, lyder nesten som et ekko av synspunkter fra han som var hovedlæreren på praktikum på Møllers tid der, Gustav Margerth

\footnotetext{
41 Wisløff, 1971, s. 52ff.

42 Luthersk Kirketidende, 1890 I, s. 221.

43 Ousland, 1978, s. 18-33.
} 
Jensen (1845-1922). Som ung prest skrev han en lang artikkel om statskirken som en autoritetskirke som sto foran en utvikling i retning av en frivillighetskirke. ${ }^{44} \mathrm{I}$ sine forelesninger på praktikum noen år senere beskrev han menighetene som et sørgelig skue, en likegyldig mengde som tok del i kirkens skikker av treg vane:

En saadan Menighedsskikkelse efterlader dybe og væsentlige Savn; den tilfredsstiller ikke kristne Menneskerss Trang til et indbyrdes Samfund, hvori Personerne kan komme hverandre nær og styrkes, glædes og opbygges af hverandre $(\ldots)^{45}$

Folkekirken har sin styrke i dens oppdragende oppgave overfor folket, men den prest som vil forme et menighetsfellesskap, vil først og fremst personlig omvendte mennesker. Ikke all kraft skal brukes på den kristne oppdragelsen; presten må med alvor søke oppdragelsens frukt, personlige, levende kristne. ${ }^{46}$

Gustav Jensens anliggende var (selvsagt) ikke å avskaffe den statskirkelige orden; han ville reparere dens mangler og formet et program for «en myndig og virkekraftig Menighed». Som prest tenkte, praktiserte og skrev Halvdan Møller som sin lærer.

En av vekkelsespredikantene, den nevnte Paul Gerhard Sand, har etterlatt seg vitnesbyrd om det han anså som helt avgjørende i forkynnelsen. Midt i hans virksomhet på Sunnmøre, i 1889, ga han ut ei lita bok med tittelen Vink og Raad for Logpredikanter. Her kom blodmystikken til uttrykk: Forkynn syndenes forlatelse i Kristi blod, forkynn for hele verden at der er renselse i dette blod for den urene synder. ${ }^{47}$

Vekkelsespredikanten hadde sine metoder. Herman Hundére, i mange år bibelbud i Lutherstiftelsen, deretter pastor i Frikirken på Moss i 1877, forteller fra et oppbyggelsesmøte i Sogndal, der han vokste opp. Haugianeren Nils Optun holdt møter på gården Vikum i 1837 (fem år før Konventikkelplakaten falt!), da Hundére var ti år gammel:

\footnotetext{
44 Luthersk Kirketidende, 1877.

45 Jensen, 1887 , s. 210.

46 Ibid., s. 225.

47 Her sitert etter Skorgevik, 1974, s. 28.
} 
Efter at nævnte Opbyggelse paa Vikum var afsluttet, begynte Nils til Eftermøde, med at gaa sagte over Gulvet og snakke privat, som det kaldtes, med Denne og Hin som han kunde faa at tale med, og En af de første var mig, som sad saa ganske i hans Vei. Med sin Haand lagt paa mit Hoved spurgte han om jeg vilde blive et Guds Barn, hvilket Spørgsmaal kun blev besvaret med Graad og han bad Herren velsigne mig, en Bøn jeg haaber Herren har hørt. Jeg har ofte tenkt at jeg da fik min første Indvielse. At den da begyndte Bevægelse havde store Virkninger til Vækkelse blant Folk, fremgaar især deraf at fra den Tid fremstod mange Brødre som virkede stadig med Opbyggelse. ${ }^{48}$

Ettermøte, med individuell tiltale og forbønn, var altså ikke noe som kom senere, fra amerikanske vekkelsesbevegelser. ${ }^{49}$ Hundére opplevde dette i en ekte haugiansk kontekst, og han opplevde det som skjedde, som en ordinasjon til sin tjeneste.

Lekmannsforkynnelsens sterke vektlegging av det personlige valg var ikke noe nytt, det var en del av arven etter Hauge, og i samsvar med pietismens fromhetsideal. Det nye var at det personlige gudsforholdet ble lagt til grunn for kirkesynet. Kirken var ikke et embetsverk som ble overtatt fra fedrene, den var et samfunn som ble til i brorskapet mellom troende og gjenfødte. Dette var vekkelsesforkynnelsens samfunnsbyggende effekt. Den la et grunnlag for den vestnorske utgaven av drømmen om den frie folkekirke, men den kunne også fungere som en religiøs legitimering av den egalitet og motkulturell bevissthet som vestlendingene var preget av..$^{50}$

\section{Prest og lekmann i vekkelsestider}

Den prestegenerasjonen som inntok embeter i 1850-åra, var i betydelig grad påvirket og formet av professor Gisle Johnson. Det skyldtes både hans undervisning og hans virksomhet som predikant i Kristiania. Som predikant påvirket han med hele sin personlighet, slik at det ble sagt at de nye prestene talte som Johnson, ba som Johnson og sukket som Johnson.

\footnotetext{
48 Brev til H. G. Heggtveit, 21.07.1902. Heggtveitsamlingen, Menighetsfakultetet.

49 Seland, 2016, s. 176; Furre, 1990, s. 177ff.

50 Teigland, 1973. 
Johnsons glanstid som predikant og professor i systematisk teologi ble forholdsvis kort. Han var på høyden i 1850-60-åra, men da han midt på 1870-tallet overtok kirkehistorien, var hans innflytelse som foreleser forbi, skriver Godvin Ousland..$^{51}$ Enkelte av Johnsons studenter har tegnet et bilde som viser at de ikke var blinde for hans svake sider. Georg Sverdrup beklaget at Johnson hadde latt seg fange av et politisk engasjement som fortrengte det som var det viktigste. Sverdrup hevder at den mest varige virkningen av Johnsons virksomhet var at prestene kom i et nærere forhold til lekfolket, men la til at det selvsagt ikke bare skyldtes Johnson. Tidene forandret seg, og geistlighetens opphøyde stilling forsvant. Presten var nå til for menigheten, ikke omvendt. . $^{52}$ Sagt med andre ord: Mot slutten av 180o-tallet var det ikke Johnsons teologi så mye som en egalitær tidsånd som preget vekkelsesmiljøet på Vestlandet.

Vekkelsene skapte et nytt klima, med mye lys, men også med en mulighet for storm. En grov skisse kan se slik ut: Som representant for tradisjonen sto statskirkens prester med sitt hegemoni på forvaltning av sakramentene og utførelsen av lovfestede ritualer som konfirmasjon, vielse og gravferd. På den andre siden sto vekkelsens ledere med en ny kristendomsforståelse, der personlig omvendelse førte mennesker til friheten i Kristus, og der det allmenne prestedømmet konkurrerte med det geistlige embetet som grunnlag for kirkens virksomhet.

Så enkelt var det selvsagt ikke. Mange prestestillinger var besatt og betjent av teologer som hadde tilegnet seg et positivt syn på lekfolket. Mye tyder på at roseniansk forkynnelse i det store og hele var i samsvar med Johnsons vekkelsesforkynnelse..$^{53}$ Disse prestene ønsket vekkelsen velkommen, og de kunne selv være vekkelsespredikanter, med stor respekt for indremisjonsfolket. Barstad i Volda var en av dem, Grimnes i Ålesund var en annen, og på samme tid var en av dem som omtales som «johnsonsk prest» i virksomhet i Nordfjord. ${ }^{44}$ Bedehusfolket hadde nok i det store og hele en tradisjonell respekt for og tillit til «en troende prest». I Volda førte det til et samarbeid mellom presten og indremisjonen, der

\footnotetext{
Ousland, 1950, s. 40.

Sverdrup, 1909, s. $193 \mathrm{ff}$.

Ousland, 1978, s. 69ff.

Tjomsland, 2018.
} 
vekkelsens frukter skulle bevares i et samspill. Soknet ble inndelt i kretser med valgte ledere som gikk under betegnelsen diakoner, en videreføring av en kretsinndeling som ble til på sokneprest Wraamanns tid da det ble etablert foreninger til støtte for Det Norske Misjonsselskap.55 Dessuten ville vekkelsesfolket være lutherske i forhold til sakramentene. Men med deres vekt på det allmenne prestedømmet kom mange av dem til den konklusjonen at de hadde rett til å samles til nattverd uten prestens medvirkning. I og for seg var det en naturlig følge av at det ble talt så mye om blodet i lekmannsforkynnelsen, men i spørsmålet om nattverdsforvaltningen var presten bundet av norsk lov. Da lekfolket gjorde som de ville, ble et jordskjelv utløst. Episenteret var i Volda, og et kraftig etterskjelv kom i Ålesund i 1893.

\section{Vekkelse i by og bygd}

Ålesund fikk tidlig sin indremisjonsforening allerede i 1868. Primus motor var trønderen Erik Solem (1833-1895).56 Som mange andre steder fikk statuttene en paragraf som slo fast at foreningen skulle virke «i et understøttende forhold til det offentlige embede i kirken. $\aleph^{57}$ Det nære forholdet vokste seg sterkt da Ole Kristian Grimnes (1849-1932) ble tilsatt som residerende kapellan i byen i $1878 .^{58}$ Det sies at kirkesøkningen i Ålesund var på sitt høyeste i Grimnes’ tid som prest der. ${ }^{59}$ Vekkelsen kom for alvor da Paul Gerhard Sand virket der i fire måneder i 1887.

Ålesund var et handelssentrum på Sunnmøre, en by som var i rivende utvikling, og som betjente et stort distrikt. Nå ble også predikanter sendt

\footnotetext{
55 Straume, u.årst., s. 34.

56 Erik Solem var rørlegger og kom til Ålesund for å bygge vannverk. Han ble værende der, som bestyrer av vannverket, samtidig som han var brannsjef. Han hadde haugiansk bakgrunn, men beveget seg i roseniansk retning under påvirkning fra Jacob Traasdahl. Handeland, 1966; Hagesæter, 1982.

57 Hagesæter, 1982, s. 64.

58 O. K. Grimnes var fra Aust-Agder, født i Vestre Moland. Han var en tid lærer før han kom til Ålesund. I 1893 ble han sokneprest i Sandviken i Bergen. Fra 1898 til 1905 var han formann i DVI. I 1908 ble han sokneprest i Skedsmo. Han støttet lekmannsvirksomheten, til og med da indremisjonen vedtok å ha møter søndag formiddag. Kleppa \& Odland, 1998, jf. Hagesæter, 1982. Hagesæter, 1982 s. 64.
} 
til distriktet, og i november 1887 kom Paul Gerhard Sand til Ørsta og Volda. «Sandstormen» brøt løs.

Volda og Ørsta var bygder som fikk varige impulser fra Hans Nielsen Hauges besøk i 1799. Det førte til at han fikk sin venn Vebjørn Svendsen til å kjøpe og slå seg ned på sentrumsgården Ørstavik. Han hadde ei tjenestejente fra Romsdal, bare kjent som Torborg, og hun holdt vekkelsesmøter i huset til Svendsen, omkring 1820. Senere ble Berthe Kanutte Aarflot en ledende skikkelse, på linje med Sjur Velsvik og Sjur Koppen, to aktive haugianere som satte sitt preg på bygdene.

Haugianerne var selvsagt ikke alene. Skolebygda Volda trakk til seg mange med radikale meninger. Trekløveret Synnøve og Per Riste og Rasmus Steinsvik drev kurs i landsmålet og startet avisa Vestmannen, som ble talerør for det «rene venstre», og «utfordra både bygdearistokratiet, bedehusrørsla og presteskapet». ${ }^{60}$ Denne utfordringen handlet ikke minst om språket. Frilynte radikalere kjempet for gjennomslag for nynorsken, og prestene Møller og Barstad viste forståelse for det prosjektet. Fra 1889 begynte Barstad å gi ut bladet Stille stunder, på landsmålet, som det het den gang, som ei motvekt til det stemplet nynorsk hadde fått som «fritenkerspråk». ${ }^{61}$ Bladet ble godt mottatt, og Volda ble et sentrum for motkulturelle strømninger som bredte seg. Den som en gang har lest den unge Matias Orheims opplevelse da han for første gang hørte forkynnelse på nynorsk dialekt fra prekestolen i Stårheim kirke, skjønner at målsak og vekkelse kunne være to sider av samme sak, «i djup harmoni med sjølve naturen».62 Det tok nok si tid for folk flest å venne seg til nynorsk på bedehuset, men kulturbevisste predikanter legitimerte målsaka. I Volda fikk de en støttespiller i Henrik Kaarstad, nordfjordingen som kom til Volda i 1886, 21 år gammel, for å være styrer ved Voldens høiere Almueskole. Sammen med prestene Barstad og Møller gikk han på kurs for å lære seg å skrive nynorsk, og han ble en aktiv medarbeider i Stille Stunder. Sammen med en annen skolemann, Aage Stabell, startet han opp Voldens

\footnotetext{
60 Halse, 2007 , s. 62.

61 Halse, 2011, s. $213 \mathrm{ff}$

62 Orheim, 1954, s. 92.
} 
privatseminarium i 1895, et sted for å fremme en syntese av norskdom og kristendom. ${ }^{63}$

Jeg har ovenfor brukt legitimering om effekten av 180o-tallets vekkelseskristendom, og det bør utdypes noe. Den norske stat hadde sin makt legitimert, ikke bare ved sin faktiske politikk, men også religiøst ved sin binding til den lutherske bekjennelse. Vestlendingene søkte kulturell og politisk makt, ikke minst i kampen for nynorsken, mot alkoholen, for opplysning og mot en embetsmakt som legitimerte en konfesjonell stat. De valgte bevisst å legitimere folkemakt, ${ }^{64}$ og gjorde det blant annet ved å slutte opp om kampen for nynorsken. Berge Furre hevder at fotfolkets angst for «fritenkjarmålet» ikke hindret lekfolkets ledere i å ta i bruk «bygdemål», først muntlig, men nokså snart skriftlig. Furre nevner Matias Orheim og Ludvig Hope, men allerede i 1868 var den første formannen i Bergens Indremisjon, dampskipsekspeditør Olav Paulson, med på å stifte Vestmannalaget, det eldste mållaget i Norge. Den legitimering som fant sted, var (selvsagt) av en annen karakter enn den som statens offentlige religion sto for. Lekmannsbevegelsens vektlegging av individuell omvendelse, tro og overbevisning bidro til en subjektiv visshet om å være i opposisjon til noe. Historikeren Harold Perkin hevder i sin framstilling av 1800-tallets England at det var de frikirkelige retningene i England som la på plass «a pattern for the new society», ${ }^{65} \mathrm{og}$ ble fødselshjelper (midwife) for en klassebevissthet, en frigjøring fra det gamle avhengighetssystem, og som kanaliserte opposisjonen inn i frivillige, ikke-voldelige organisasjoner. Slik også med lekfolkets oppslutning om venstrepolitikken mot slutten av 180o-tallet. Når oppslutningen ble uttrykt i bruk av nynorsk, var det noe mer enn språkpolitisk støtte; det var nasjonsbyggende, et bidrag til framveksten av en vestnorsk nasjonal identitet. ${ }^{66}$

Omkring 1890 rådde det noe som det er fristende å bruke ord som kirkelig anarki om i Volda sokn, men akkurat det kunne sies om svært

\footnotetext{
63 Høydal, 1995, s. 56 f.

64 Teigland, 1973. Se til dette også Holme, 1981.

65 Perkin, 1969, s. 196.

66 Burgess, 2003, s. 110: «En 'nasjon' er en samling av enkeltdeler som deler ett og samme opphav, og som kommer fra ett og samme språk».
} 
mange steder. Ekstatiske elementer forekom og ble viet stor oppmerksomhet i by og bygd, slik at den kirkelige orden ble utfordret og rokket nærmest daglig. Mye av dette var randfenomener i det store bildet, men som fikk så pass stor innflytelse på det troende lekfolket i Volda at tiltak ble ansett som nødvendig. Presteskapet nøt tillit og utøvde et aktivt lederskap for å føre nyomvendte inn på trygg luthersk grunn. Sokneprest August Weenaas og kapellan Johannes Barstad ledet samlinger for de omlag 40 diakonene som ledet hver sin krets av Volda indremisjon. ${ }^{67} \mathrm{I}$ 1890 overlot Barstad formannsvervet i Volda indremisjon til den erfarne læreren Nikolai Molvik, og i 1891 ledet de to innvielsen av Ørsta bedehus. Samme år ble det stiftet ungdomsforening i Volda, med lekmannen Åge Stabell som formann og Weenaas som nestformann. Alt tyder på et tillitsfullt forhold, men det meste raknet vesentlig på grunn av nattverdsspørsmålet. I mai 1892 kom det til rettssak mot dem som hadde ledet an i fri nattverd, Knut Bjørkedal og Ole G. Clausen, og i juli samme år gikk sokneprest Weenaas til skolestyret og fikk gjennom et vedtak om å avsette to lærere som hadde deltatt i fri nattverd. De to var Wilhelm Grytten og Nikolai Molvik. Vedtaket gjort med åtte mot fem stemmer, og ble godkjent av biskop Hvoslef. Molvik måtte også si fra seg formannsvervet i Volda indremisjon. I ettertid er Grytten og Molvik blitt gjort ansvarlige for en selvtekt som bredte seg raskt, men mye tyder på at Ørsta-mannen Paul Myklebust kan ha vært den egentlige initiativtakeren. Straume mener han hadde med seg idéen fra et opphold på bibelskole i Sverige, og som medlem av skolestyret kjempet han med nebb og penn mot avsettelsen av hans to venner. ${ }^{68}$

Ved å komme sammen til oppbyggelige samlinger med nattverd som ble ledet av lekmenn, gikk indremisjonsfolket i Volda inn i en praksis som var i ferd med å bre seg ut over landet. I februar 1889 skrev biskopen i Kristiania, C. P. Essendrop, til kirkedepartementet for å få en vurdering av hvordan denne praksisen forholdt seg til den kirkelige lovgivningen. Statsråden, Jacob Aall Bonnevie, svarte i desember samme år. ${ }^{69}$ Han startet med å opplyse om at et tilfelle av privat nattverd var blitt behandlet

\footnotetext{
67 Luthersk Kirketidende, 1890, s. 226.

68 Straume, u.årst., s. 43.

69 Ibid., s. 24-32.
} 
i rettsapparatet. Det gjaldt ingen ringere enn folkehøgskolemannen og stortingsrepresentanten Viggo Ullmann. Han ble dømt, men dommen ble opphevet av Høyesterett, og statsråden antydet at behandlingen i høyeste rettsinstans kunne ha medvirket til utbredelsen av såkalte nattverdsforeninger. Statsråden hadde satt seg grundig inn i saka, og kunne beskrive utførlig hvordan slike samlinger ble gjennomført. Han konkluderte med at det dreide seg om mer enn et vanlig måltid; for de forsamlede handlet det om å ta nattverdsforvaltningen bort fra den vanlige gudstjenesten og fra det prestelige embete. Departementets vurdering kan samles i tre punkter: Praksisen var kirkesplittende, i den forstand at de som deltok ville skille seg ut. Den var dessuten i strid med Den augsburgske bekjennelse, artikkel 5, 8 og 14. Det avgjørende var imidlertid at denne praksisen var lovstridig. Det ble vist både til Kirkeritualet av 1685 (kap. V) og til Christian V's norske lov (2-5-1 og 2). Statsråden tok også fram et reskript fra 1741 som innskjerpet loven med å presisere at nattverd utenfor gudstjenesten var ulovlig også for presten, bortsett fra ved nattverd for de syke. Statsrådens konklusjon var departemental: Biskopen ble pålagt å instruere prestene til å advare sine får på det sterkeste mot deres ukirkelige og lovstridige adferd, under trussel om at de kunne miste adgang til kirkelige goder, men prestene måtte også instrueres om at de ikke skulle gripe til andre midler enn til å rapportere til sin biskop om hva som foregikk..$^{\circ} \mathrm{Da}$ dette rådet ikke ble fulgt i Volda, var harmonien brutt.

Åsa Thorstvedt ${ }^{11}$ har på overbevisende måte vist at for Weenaas handlet denne saka om troskap både mot bekjennelsen og kirkens orden, som han var forpliktet på som embetsmann. Han betraktet motpartens handlinger som et brudd med Den norske kirke, og hadde skoleloven av 1889 på sin side, for så vidt som dissentere ikke hadde adgang til å være lærere. Problemet var at motparten ikke kunne eller ville være med på at de to lærerne hadde gjort noe som var i strid med bekjennelsen eller norsk lov. Særlig provoserende var det at en biskop hadde latt departementet avgjøre hva som var rett og urett i denne saka. Det var et «skræmeskot»

\footnotetext{
$70 \quad$ Først ved Lov av 25. juli 1913 ble straffebestemmelser som kunne ramme lekfolk som forrettet nattverd opphevet. På det tidspunktet var læreren Aasulv Bryggesaa kirkeminister.

Thorstvedt, 2020.
} 
som de møtte med passende sitat av Luther. ${ }^{22}$ Nå ville lekfolket diskutere statskirkesystemet, og samlet seg i Ålesund.

\section{Lekmannsmøtet i Ålesund}

Gjæringen førte til at det ble kalt sammen til et lekmannsmøte i Ålesund, i november samme år som spenningen toppet seg i Volda. ${ }^{73}$ Johannes Solem (1868-1948) ${ }^{74}$ distribuerte innbydelsen, som han undertegnet sammen med Nikolai Molvik og Paul Myklebust fra Ørsta. Med direkte henvisning til innflytelsen fra Marius Giverholt ble Solem karakterisert som «den største drivende kraft i kyrkjelivet på Sunnmøre den komande mannsalderen».75 Solem ble kjent som brannmester da Ålesund brant i 1904. I 1891 var han aktivt medvirkende til at Kinamisjonsforbundet ble stiftet.

Møtet skulle svare på to spørsmål:

1. Er statskirkens menighetsordning i overensstemmelse med Guds ord og apostlenes anordninger?

2. Hvis ikke, er da de kristne forpliktet til å gjøre noe for å oppnå en med Guds ord overensstemmende menighetsordning, og kan man ha grunnet håp om å få en sådan gjennomført?

Solem holdt også det første foredraget, og skulle dermed innlede diskusjonen om det første spørsmålet. Foredraget innledet med en oversikt over de mange vekkelsene som foregikk. Solem mente at vekkelsene hadde skapt et klima for uro omkring kirkeordningen. Han startet nokså friskt

\footnotetext{
72 Ørstavik, 1996, s. 11.

73 Referatet fra møtet er gjengitt i sin helhet i Hovdhaugen, 2018, s. 77-95.

74 Johannes Solem var sønn av Erik Solem og vokste opp i Ålesund. Etter fire år i Trondheim kom han tilbake til Ålesund som ingeniør. I Trondheim knyttet han seg til miljøet rundt Marius Giverholt, en teolog og predikant av roseniansk støpning. Giverholt hadde startet en luthersk frimenighet i Kristiansand, men forlot denne da menigheten sluttet seg til Den Evangelisk Lutherske Frikirke. Hovedgrunnen var at Giverholt var overbevist kongregasjonalist, og krevde at lokalmenigheten skulle være uavhengig av en synode. Dette synet kom til å prege vestnorsk indremisjon. Etter noen år i Halden flyttet Solem tilbake til Ålesund i 1918, der han var borgermester fram til 1935 .

Handeland, 1966, s. 275.
} 
med å sitere et foredrag på et stiftsmøte i Bergen i 1877. Statskirken er ved flere av sine lover og anordninger i åpenbar strid med Guds ord og kan ikke oppfylle sine plikter overfor medlemmene. Eneste tvingende grunn til å bli stående var broderkjærligheten, en plikt som binder inntil det er klart at det er synd å bli stående, men det eneste holdbare er å bli stående i virksomt arbeid for reformer.

Reformkravene rettet seg mot fadderordningen ved dåp og mot obligatorisk konfirmasjon, der han kunne sitere biskop Laache, ${ }^{76}$ som kalte konfirmasjonen «et spilfekteri, et utvortes vesen, et apespill og en menneskesats uten sannhet». Solem angrep også sammenkoplingen av absolusjon og nattverd, og manglende kirketukt. Dermed berørte han reformbevegelsens store nederlag i 1888. Som kirkeminister fremmet Jakob Sverdrup forslag til ny lov om menighetsråd og prestevalg, der det var tatt med krav til stemmerett som medførte at personer kunne nektes kirkelig stemmerett på grunn av offentlig forargelse i liv og lære. ${ }^{77}$ Forslaget ble angrepet av radikale venstrefolk, som et forsøk på å «øre inn kyrkjetukt bakvegen». ${ }^{78}$ Det falt og ble en av årsakene til splittelsen i Venstre. Den mest konservative fløyen dannet Moderate Venstre, med Jakob Sverdrup og Lars Oftedal som sentrale ledere. Både Solem og andre deltakere viste at reformnederlaget hadde medført økt skepsis til kirkestyret

Solem tok også for seg det territoriale ved statskirken, fra Kapp til Lindesnes, mens kirken etter sitt vesen er Kristi legeme. Solem siterte kirkehistorikeren Merle d'Aubignés bok To konger og to kongeriker, ei bok som ble oversatt av sokneprest Eckhoff i Sunnylven noen år tidligere. ${ }^{79}$ Poenget var at kirken skulle være underordnet Kristi kongelige embete, et velkjent begrep for alle som hadde lest Pontoppidans forklaring til katekismen, og la til Jesu ord om at hans rike ikke er av denne verden (Joh 18, 36). Solems viktigste bibelsitat til støtte for sitt syn var likevel Paulus' ord om Kristus som hode for sin kirke (Ef. 5, 24).

76 Solem var ikke helt presis. Sitatet er fra et foredrag som Andreas Grimelund holdt i 186o, like før han ble biskop i Trondheim. Foredraget ble publisert i Ny Luthersk Kirketidende, 1878, s. 241-252.

77 Sverdrup videreførte med dette et krav som hadde vært grundig drøftet på det frivillige kirkelige landsmøtet få år tidligere, se Forhandlinger, 1886.

78 Nerbøvik, 1996, s. 178, jf. Mjeldheim, 1984, s. 176f.

Løvlie, 2001. 
Solems foredrag viser hvordan både problemene, argumentasjonen og skytset går igjen i denne tida. Ikke bare Merle d'Aubigné, men også biskop Grimelund, redaktør Laache og sokneprest Høyer siteres underveis i møtet. Foredragets budskap kan samles i to punkter. Kirkeordningen innebar en organisering av «verden» inn i Jesu Kristi kirke, og kirkens møte med folket produserte fortløpende hykleri, ved at ugudelige mennesker ble tatt inn i kirkens handlinger og ble tiltalt som «kjære kristne». Solem konkluderte med at statskirken verken var bibelsk eller luthersk.

Neste innleder var kirkesanger Andreas Grytnes, som skulle svare på spørsmål nummer to. Også han sto fram som en tilhenger av reformbevegelsen, og hadde knyttet sitt håp til Jacob Sverdrups forslag til kirkelov. Men Stortinget hadde for lengst gjort slutt på ethvert håp om forbedring, og nå burde ikke de troende bruke kreftene på reformer. Jesus gikk ikke ut av den jødiske folkekirken, sa Grytnes, og han ba heller ikke sine disipler om å gjøre det.

Grytnes hadde ikke bare mistet håpet om reformer; han var blitt skeptisk til reformenes effekt. Han trodde ikke en fri kirke ville gi lekfolket den friheten man strevde for å få. På sett og vis var enkelte av de mest utålmodige enige med ham, men Myklebust trakk en annen konsekvens, han ville melde seg ut. Det samme ville Molvik, som takket for foredraget, men som nok ikke var enig med taleren. Han uttrykte som sitt syn at om sunnmøringene mente at tida ikke var inne til å gå ut, så ville det likevel bli utfallet. Han la vekt på at når noe var i uoverensstemmelse med Guds ord, hadde de troende ikke bare rett, men også plikt til å si fra.

Møtet vedtok til slutt en resolusjon i fem punkter. Den slo fast at statskirkens ordning ikke stemte med Guds ord og bekjennelsen. Forsamlingen erkjente at reformer ikke kunne oppnå det de ønsket seg av kirken. Møtedeltakerne kunne ikke tilrå en rask utmelding, men forpliktet seg til å arbeide for å øke bevisstheten om at den bestående ordning var uholdbar. De som mente at det var synd å bli stående i statskirken, fikk råd om å følge sin samvittighet, men i siste punkt i resolusjonen ble det vedtatt at inntil videre kunne de troende benytte seg av sine rettigheter i statskirken.

På litt sikt fikk Molvik (dirigenten) rett i at det ville komme til brudd. De ulike deltakerne reiste heim, og snart etter hadde 150 meldt seg ut av 
kirken i Volda og Ørsta. De første tilfeller av «gjendåp» kom i 1896, noe som kan leses som at Grytnes hadde rett på møtet i Ålesund da han mente at de som sterkest kritiserte dåpspraksisen, egentlig ville avskaffe barnedåpen. Rett nok sa han det til feil mann, Paul Myklebust, som kunne sin katekisme, men andre var nok på vei over i et annet dåpssyn allerede i 1893 .

Innbydelsen til lekmannsmøtet i 1893 viser at det var forholdet til statskirkesystemet som var hovedsaka på møtet, noe Solem markerte i starten på sitt foredrag. Årsaka til at reformkravene var så sterke, var etter hans syn at det var vekkelsene som hadde åpnet øynene hos folk for å se at Jesu Kristi kirke var noe mer enn en statlig og kommunal innretning. Det var vekkelser som ble utløst av den lekmannsforkynnelsen som vokste etter at Konventikkelplakaten ble opphevet, som det ble referert til. Det er likevel påfallende at Hans Nielsen Hauge ikke er nevnt i referatet; den eneste vekkelsespredikanten som det refereres til, er Rosenius (1816-1868). Han er nevnt fordi han ble oppfattet som en som advarte mot å bryte med statskirken. Derimot er det ikke nevnt noe om at Hauge i sitt testamente hadde bedt sine tilhengere om å bruke kirken i alt som hørte til god orden. Men det var det som langt på vei ble konklusjonen.

Det var altså den mer evangelisk frigjørende rosenianismens representanter som holdt møte i Ålesund. Skjønt frigjørende, de var livsstilspietister som var blitt omvendt fra et liv som etter deres framstilling besto av dans, drikk og kortspill. Og i dette ugudelige livet hadde de vært ansett som verdige nattverdsgjester. Dette førte til at noen trakk den slutningen at statskirken produserte hykleri. Det vekkelseslivet de representerte, hadde gjort dem til lesere, først og fremst av Bibelen og oppbyggelige skrifter. I Bibelen fant de at kirken skulle være underordnet Kristus som konge, og at menigheten var en samling av prester. I oppbyggelige skrifter fant de sitater av Luther, og de ble brukt i kirkedebatten for alt de var verdt.

Vekkelsene innebar en kulturell endring, som kan beskrives som en myndiggjøring av lekfolket, som var kommet til et nivå der de ikke lot seg by hva som helst. Politisk ga det seg utslag i at det var venstrefolk som møttes, mens kristelig sett var det en salig blanding. Det var enighet blant deltakerne om at statskirken ikke svarte til bibelske standarder, og 
i stor grad mente de at den heller ikke holdt mål i forhold til den lutherske bekjennelse. Etter hvert viste det seg at ikke alle var like opptatt av at kirken skulle være luthersk, men de fleste viste seg å ha en luthersk ballast knyttet til CA VII. De følte seg forpliktet på broderkjærlighet til ikke å bryte, med mindre de oppfattet det som synd å bli stående, noe som ikke er enkelt å avgjøre i en setting der «former og ceremonier» ikke hører med til salighetens grunnvoll.

Referatet fra lekmannsmøtet vitner om stor uenighet om retningsvalg, og ikke så liten usikkerhet og oppgitthet. Johannes Solem oppsummerte sitt inntrykk slik: Møtet skulle svare på to spørsmål, først om hvorvidt statskirkens menighetsordning er i overensstemmelse med Guds ord og apostlenes anordninger. Hans inntrykk var at svaret var et enstemmig nei. Andre spørsmålet var om de troende skulle gjøre noe for å oppnå en menighetsordning i overensstemmelse med Guds ord og den lutherske bekjennelse. Noe oppgitt og kanskje også litt sarkastisk konstaterte han at møtet hadde besluttet at intet skulle gjøres. Det kunne det selvsagt ironiseres over, og det skjedde også. En geistlig observatør mente å kunne konstatere at «Konsekvense og Klarhed og Handlekraft er ikke de søndmørske "Separatisters" sterke side». Derfor regnet ikke innsenderen med at det ville bli noen større uttredelse fra statskirken: «Om nogle faa aar vil den hele Bevægelse sygne hen». ${ }^{80}$ Profetien er ennå ikke oppfylt.

\section{Veier videre}

Sunnmøre indremisjon fulgte en stø kurs. Snart etter (1898) sluttet fellesforeningen seg til stiftelsen av Det Vestlandske Indremisjonsforbund. Egentlig var det sunnmøringene som ivret mest for et slik forbund. Erik Solem ivret sterkt for tanken, og hadde støtte fra Ålesunds-presten Ole Kristian Grimnes. I 1893 flyttet Grimnes til Bergen som prest i Sandviken. I Ålesund hadde han vært med på å vedta at indremisjonen skulle begynne med møter søndag formiddag (1889), og da forbundet ble stiftet, ble han valgt til formann. Da hadde han gjort forarbeidet til sammenslutningen, i en komité sammen med Jacob Traasdahl og Andreas Lavik. 
De hadde utarbeidet et forslag til retningslinjer. Første punktet handlet om å bevare indremisjonsarbeidets frihet og uavhengighet. Neste punkt slo fast at sammenslutningen ikke på noen måte skulle gripe inn i de enkelte foreningers frihet. Det ble altså slått fast et uavhengighetsprinsipp. Et annet punkt vakte debatt. Det handlet om at forbundet anbefalte at virksomheten skulle stille seg støttende og samarbeidende i forhold til det kirkelige embete. Punktet ble til sist vedtatt i en endret form, med en tilføyelse «så langt som mulig».

Noen valgte en annen vei. Både Paul Myklebust og andre hadde nok bestemt seg på forhand. Det hadde nok bakgrunn i den behandlingen hans venn Nikolai Molvik fikk, men også i at han hadde landet på et prinsipp om den sekulære stat, gjerne formulert i slagord som «en fri kirke i en fri stat». Deres vei ble en som Solem hadde vist at han kjente godt til, nemlig en luthersk frikirke. I 1896 ble en luthersk frimenighet stiftet i Ørsta med Paul Myklebust som forstander, og med en medlemsmasse der flertallet var «heller radikale venstrefolk» ${ }^{81}$ Det var en vei som Solem \& co i og for seg ikke hadde prinsipielle motforestillinger mot, men de fleste sluttet seg i så måte til parolen om å vente til det kunne bli en masseuttredelse.

\section{Avrunding}

Innledningsvis spurte jeg om hvilke veivalg som ble gjort, og presiserte at spørsmålet dreide seg om hvordan det vestnorske lekfolket argumenterte for den frihet de mente de trengte innenfor statskirken. Det enkle svaret på disse spørsmålene er at de talte og argumenterte som reformbevegelsen. Det handlet om en kirke som ble bygd nedenfra, med basis i rettighetene til de troendes allmenne prestedømme, rettigheter som skulle ivaretas i kraft av nådegaver som Helligånden gir til menigheten. Samtidig ble dette synet omsatt i en strategi som ikke var avhengig av kirkelige reformer. I den prosessen jeg har skildret, ser vi at vekkelsens ild og begeistring førte vestnorsk kristenliv i en retning som best kan

\footnotetext{
81 Grøvik, 1973, s. 348.
} 
beskrives med slagordet «i kirken, men ikke under kirken». De valgte den veien som siden er blitt kalt det haugianske vennesamfunnets linje.

På den annen side var de jo ikke haugianere. De hyllet Hauge som foregangsmannen for lekfolkets frihet, men i forkynnelsen var det Rosenius som var idealet. Den samme dobbeltheten kan sees også i deres forhold til pietismen. Lekmannsbevegelsen etter 1880 var preget av noe helt annet enn Gisle Johnsons statspietistiske tankegods. Johnson ble aldri demokrat, og en årsak var nok, som Jens Arup Seip antydet, teologiens tendens til å søke ondets rot i mennesket selv, noe som ikke motiverte for politisk og sosiale reformer. ${ }^{82}$ Det hindret likevel ikke en grunnleggende respekt for og tillit til prester som fulgte Johnsons vekt på å vekke til kristelig liv.

Vekkelsesfolket ble faktisk en politisk faktor. Med deres nære forhold til reformivrige krefter som dominerte Sør- og Vestlandet var det nærmest et kall for vekkelsesfolket, eller leserne, å følge opp krav om sosiale reformer, språklig likestilling og ikke minst en bedre skole. I så måte lot de seg inspirere av Grundtvig. De bygde folkehøgskoler, sørget for et utdanningstilbud til «Muldets Frænde» og bidro til en noe forsinket opplysningstid.

Det miljøet jeg har prøvd å skildre, var fram for alt en bevegelse. Det som knyttet de ulike aktørene sammen, var det som bidro til endring, men også det de ikke godtok. Kampen for endringer forutsatte makt, og den måtte ha religiøs legitimitet. Det ble vekkelseskristendommens bidrag til avgjørende politiske og kulturelle endringer i det norske samfunnet ved overgangen til 1900-tallet.

\section{Litteratur}

Burgess, J. P. (2003). Den opplyste romantikken og den romantiske opplysningen. Aasen med Witoszek. I J. P. Burgess (Red.), Den norske pastorale opplysning. Nye perspektiver på norsk nasjonsbygging på 180o-tallet. Oslo: Abstrakt forlag.

Døssland, A. (1975). Den organiserte lekmannsrørsla i eit vestnorsk bygdesamfunn frå ca. 189o-1945. Ei gransking frå Kvinnherad kommune. Hovudfagsoppgåve i historie ved Universitetet i Trondheim. 
Eide, B., Anker-Goli, S. \& Ellingsgård, A. (1950). Det Vestlandske Indremisjonsforbund gjennom 50 år. Bergen: Det Vestlandske Indremisjonsforbund.

Elstad, H. (2000). «-en Kraft og et Salt i Menigheden-»: ein studie av dei såkalla «johnsonske prestane» $i$ siste halvpart av 180o-talet $i$ Noreg. Oslo: Unipub forlag.

Forhandlinger $i$ det fra 15 de til 29 de Oktober 1885 i Kristiania forsamlede frivillie kirkelige Landsmøde. (1886). Kristiania: Lutherstiftelsen.

Furre, B. (1990). Soga om Lars Oftedal. Oslo: Samlaget.

Goderstad, L. (1914). To Slags Prester. Fremstillet i Bibelens og Kirkehistoriens Lys (Et principielt Indloeg i Kirkereformsagen). Bergen: Lunde \& Co Forlag.

Grøvik, I. (1973). Vekking for ånd og hand. Syn og segn.

Gundersen, K. (1996). Visjon og vekst. Framveksten av de frivillige kristelige organisasjonene 1816-1940. Volda: Møreforsking Volda.

Hagesæter, J. (1982). Sunnmøre Indremisjon 100 år. Ålesund: Sunnmørsposten A/S.

Hamre, A. (1964)). Haugiansk frukt. Sunnhordland, Hardanger og Voss Indremisjonssamskipnad gjennom 100 år. Bergen: Sunnhordland, Hardanger og Voss Indremisjonssamskipnad.

Hamre, J. (1986). Georg Sverdrup. Educator, Theologian, Churchman. Northfield: The Norwegian-American Historical Association.

Halse, P. (2007). Profet på heimstaden? Nokre sider or soga om Johannes Barstad og prestetida hans i Volda. I Voldaminne. Årsskrift. Volda sogelag.

Halse, P. (2011). Gudsord og folkespråk. Då nynorsk vart kyrkjemål. Trondheim: Tapir. Handeland, O. (1966). Vårløysing. Band II. Bergen: A. S. Lunde \& co forlag.

Holme, I. M. (1981). De captivitate norwegiae - ein analyse av kyrkje-statforholdet $i$ historisk og aktuell samanheng. Hovedoppgave i statsvitenskap, Universitetet $\mathrm{i}$ Oslo.

Hovdhaugen, O. (2018). Kristenliv gjennom tidene, sett fra Volda og Ørsta. Upublisert manus.

Høydal, R. (1995). Det kulturradikale trugsmålet - eit tildriv til etableringa av Voldens Privatseminarium? I Bergem (Red.), Forkynning fellesskap forsking. Volda loerarskule 1895-1995. Volda: Høgskulen i Volda.

Jensen, G. (1887). Afhandlinger om Gudstjeneste og Menighedsliv. Kristiania: Grøndahl.

Kleppa, J. \& Odland, P. (1998). Ordets folk. Det Vestlandske Indremisjon 1898-1998. Straume: Sambåndet.

Kleppa, J. (2013). Jacob Traasdahl - kristendomsforståinga og kyrkjesynet. I Bråten \& Myrseth (Red.), Motstand og tilbedelse. Festskrift til Roald Nkolai Flemestad. Oslo: Arken.

Løvlie, B. (2001). I klørne på Heuch. Synnulvspresten Eckhoffs bidrag til statkirkedebatten på 1870-tallet. I Ulstein \& Aadnanes (Red.), «Jeg gikk meg over sjø og land...». Festskrift til Ottar Berge på 65-årsdagen. Trondheim: Tapir. 
Løvlie, B. (2002). Vestavind. 1870-årenes debatt om kristenliv og kirkeordning under innflytelse fra Skottland. Trondheim: Tapir.

Løvlie, B. (2016). Lekmanns- og misjonsbevegelsene som demokratiseringsagenter. I Dørum \& Sødal (Red.), Mellom gammelt og nytt. Kristendom i Norge på 180o- og 190o-tallet. Bergen: Vigmostad og Bjørke.

Mjeldheim, L. (1984). Folkerørsla som vart parti. Venstre frå 1880-åra til 1905. Oslo: Universitetsforlaget.

Nerbøvik, J. (1996). Norsk historie 1870-1905. Oslo: Samlaget.

Orheim, O. (1954). Livet sjølv. Ungdomsutgåva av skrifter i samling I. Bergen.

Ousland, G. (1950). En kirkehøvding. Professor Gisle Johnson som teolog og kirkemann. Oslo: Lutherstiftelsens forlag.

Ousland, G. (1978). Vekkelsesretninger i Norsk kirkeliv. Hva de loerte og hva de siktet på. Oslo: Luther.

Perkin, H. (1969). The origins of modern English society 1780-1880. London and Henley: Routledge \& Kegan Paul.

Sand, P. G. (1889). Vink og Raad for unge Loegprcedikanter. Biri: Paul Gerhard Sand i kommisjon hos $\mathrm{H}$. Hauge.

Seip, J. A. (1945). Et regime foran undergangen. Fredrik Stang- Ole Jacob Broch. Oslo: Johan Grundt Tanum.

Seland, B. (2016). Revolusjon i bygda - vekkingskristendommen som endringsprosjekt. I Dørum \& Sødal (Red.), Mellom gammelt og nytt. Kristendom i Norge på 180o- og 190o-tallet. Bergen: Vigmostad og Bjørke.

Seland, B. \& Aagedal, O. (2008). Vekkelsesvind. Den norske vekkingskristendommen. Oslo: Samlaget.

Skorgevik, K. (1974). «Sandstormen». Trekk fra det religiøse liv på Sunnmøre i åra 1880-1900. Hovedfagsoppgave i kristendomskunnskap ved Universitetet i Oslo.

Slagstad, R. (1998). De nasjonale strateger. Oslo: Pax.

Straume, J. Vekkingsliv over Volda. Upublisert manus.

Sverdrup, G. (1909). Samlede Skrifter i Udvalg. Udgivne ved Andreas Helland. Første Bind. Minneapolis: Frikirkens Boghandels Forlag.

Sverdrup, J. (1870). Grundtvig og de danske Folkehøiskoler. Folkevennen.

Teigland, G. (1973). Embetsmakt mot folkevilje. Syn og segn.

Thorstvedt, Å. (2020). «I kjølvannet av varme vinder. Weenaas og vekkelsen», i: Løvlie, Halse og Hatlebrekke: Tru på Vestlandet. Tradisjonar i endring. Oslo: Cappelen Damm Akademisk.

Try, H. (1985). Assosiasjonsånd og foreningsvekst $i$ Norge. Forskningsoversyn og prespektiv. Øvre Ervik: Alvheim og Eide.

Tjomsland, A. (2018). Bedehusarvingar - indremisjonsrørsla i Nordfjord 1970-200o. Masteroppgåve ved Høgskulen i Volda 2018. 
Weenaas, A. (1935). Livserindringer fra Norge og Amerika. Bergen: A. S. Lunde \& co Forlag.

Wisløff, C. F. (1961). Politikk og kristendom. En studie omkring oppropet «Til

Christendommens Venner i vort Land. Bergen: A. S. Lunde \& co forlag.

Øidne, G. (1957). Litt om motsetninga mellom Austlandet og Vestlandet. Syn og Segn.

Ørstavik, R. (1996). Ørsta frikyrkje 1896-1996. Ørsta: Møre-Nytt. 


\title{
Frå indremisjon til mindre misjon: Nordfjord indremisjon 1970-2000
}

\author{
Andreas Tjomsland \\ Høgskulen i Volda
}

\begin{abstract}
Samandrag: Nordfjord indremisjon var ein lågkyrkjeleg lekmannsorganisasjon som eksisterte frå 1879 til 2000. Artikkelen fokuserer på dei siste tretti åra, frå 1970 til 2000, ein periode då mange lågkyrkjelege organisasjonar møtte motgang. I Nordfjord var indremisjonen framleis ei verkeleg folkerørsle utover 1970-talet, og mykje nytt arbeid blei sett i gang. Men utover 1990-talet peika pilene for gåveinntekt og rekruttering nedover, og ungdom som vaks opp i rørsla, tok ikkje over stafettpinnen etter dei eldre. Flytting, utdanningsauke og konkurranse var viktige faktorar. I indremisjonen var det tidlegare vekkingslivet blitt institusjonalisert, med dei tette småfellesskapa på bedehusa som grunnstein. Desse hadde fått eit fokus på ansvar og offer som appellerte lite til ungdom og samfunnet rundt, og forynga seg lite. Lojale indremisjonsfolk sleit seg ut på å gjere stadig fleire oppgåver, og resultatet blei mindre misjon utover 1990-talet.
\end{abstract}

Nøkkelord: indremisjon, bedehus, Nordfjord, lågkyrkjeleg kristendom, bygdekultur, Vestlandet

\section{Innleiing}

Misjon er eit ord som for mange er synonymt med lysbilete frå misjonsmarka på Madagaskar, eller innsamlingar for fattige i andre land. Men norsk misjon har òg hatt ein heimefront, indremisjonen. Denne har fătt liten plass i den lokale og regionale historieskrivinga, trass i at han har hatt stor innverknad på mange liv og lokalsamfunn. I denne misjonsgreina handla det om å føre naboar og slektningar til omvending. Dette var grunnlaget for dei mange lokale indremisjonsforeiningane, slik som dei i distriktet Nordfjord, heilt nord i noverande Vestland. I 1879 blei det skipa

Sitering av denne artikkelen: Tjomsland, A. (2020). Frå indremisjon til mindre misjon: Nordfjord indremisjon 1970-2000. I B. Løvlie, P. Halse \& K. Hatlebrekke (Red.), Tru på Vestlandet. Tradisjonar i endring (Kap. 8, s. 193-215). Oslo: Cappelen Damm Akademisk. https://doi.org/10.23865/noasp.104.ch8 Lisens: CC BY-ND 4.0. 
ei felles regional foreining her, med formål om «paa den evang. luth. Kirkes Bekjendelses Grundvold at vække og nære et sandt kristeligt Liv i vort kirkelige Samfund» i distriktet. ${ }^{1}$ Nordford indremisjon blei ein del av Indremisjonsselskapet, ein misjonsorganisasjon som jobba noko tettare saman med Den norske kyrkje, enn det Vestlandske indremisjon og NLM gjorde.

I dei hundre åra frå 1870 til 1970 var indremisjonen og bedehusa ein betydeleg aktør i mange lokalsamfunn, og bar preg av å vere ei brei folkerørsle. ${ }^{2}$ Indremisjonen sin framvekst og identitet kan ikkje forklarast utan å forstå vekkinga si sentrale rolle. Sosiologisk sett kan ei vekking definerast som «... ein prosess der ein heller stor flokk menneske nokolunde samtidig opplever ei omvending som gjev ny meining i tilveret.» ${ }^{3}$ Men kva skjedde med lekfolket, organisasjonen, innsatsvilja og lojaliteten når vekkingane ikkje kom som før i tida? Mot slutten av 1900-talet blei det stadig færre lokallag i dei store misjonsorganisasjonane, og bakom ligg komplekse og samverkande mekanismar. For å forstå meir av utviklinga etter 1970 kan det dermed vere fruktbart å ta for seg ein avgrensa organisasjon, som Nordfjord indremisjon.

Ved å undersøkje både gåveinntektene frå Nordfjord indremisjon sine rekneskapar og informasjon frå det interne misjonsbladet Ljosstrålar, og deretter kople dette mot utviklingstrekk i samfunnet på lokalt, regionalt og nasjonalt plan, kan vi seie noko om korleis dei store samfunnsendringane i denne perioden verka inn på indremisjonen sitt arbeid. $\mathrm{Og}$ samstundes kan dette bladet fortelje noko om korleis interne kulturtrekk i rørsla utvikla seg, eller ikkje utvikla seg, i denne tida. Ljosstrålar hadde eit opplag på kring 1450 i 1983, ned til kring 1000 ved tusenårsskiftet. Mykje av stoffet er eigenprodusert, men bladet trykte òg utdrag frå talar, bøker og andre blad, som ein med det må rekne med at redaktøren gjekk god for. Redaktøransvaret var knytt til stillinga som krinssekretær i Nordfjord indremisjon fram til 1988, og styraren eller ein utpeikt lærar ved Nordfjord folkehøgskule hadde ansvar for «sin» del av bladet, «Ljosborgteigen», fram til 1993. Frå 1988 var redaktøransvaret ikkje lenger så

Wergeland, 1979, s. 22 - Statuttar for «Nordfjords Fællesforening for den Indre Mission». Ljosstrålar (november 1937) fortel til dømes om det regionale haustmøtet på Vereide, som samla 800 menneske innomhus. Over tusen deltakar på friluftsstemner var heller ikkje uvanleg. Seland \& Aagedal, 2008, s. 15. 
tett knytt opp mot sekretærstillinga, og tonen i bladet blei samstundes merkbart meir sjølvgranskande og kritisk. ${ }^{4}$

\section{Vekkingar og bedehusbygging}

Indremisjonen står i ein vekkingstradisjon tilbake til Hans Nielsen Hauge (1771-1824), men som ikkje kan forklarast utan å ta med den tyskimporterte pietismen som kom før den tid. Haugiansk vekkingsliv var prega av ei spesiell blanding av at folk skulle kome til djup syndserkjenning og gjennomgå ei omvending, og ei økonomisk gründerånd som omforma det norske samfunnet på 18oo-talet. Vekkingsstraumane frå Carl Olof Rosenius (1816-1868) og gjennom prestane som blei undervist av Gisle Johnsson (1882-1894), som kom seinare på 180o-talet, dvelte mindre ved syndefordervet, og blei det meir direkte startskotet for den organiserte indremisjonsrørsla. I indremisjonstradisjonen i Sunnfjord var predikantane Anders Nilsen Haave (1809-1867) og Mads Wefring (1819-1894) sentrale eksponentar for den same dreiinga mot større vekt på nådebodskapen, det same gjaldt Arne Linde (1822-1914) i Nordfjord. . Predikantar eller emisscerar $^{6}$ som Linde stod i sentrum for det dramaet som kunne utspele seg under vekkinga. Forkynninga til ein av dei som verka i Nordfjord, blei hugsa som «..eit friskt vårvêr, lik elva i vårflaumen» som dei stundom var redd for at skulle gå over sine breidder, men som til slutt likna på «vårsola som smiler over liv som gror.» I indremisjonstradisjonen blei vekkingane gjerne omtala slik, med naturlikningar som mildvêr, vårløysing eller bløming. Dette var noko bønder og fiskarar kunne kjenne att.

Nordfjord indremisjon hadde eigne tilsette emissærar, som i starten var løna berre vinterstid, seinare på heiltid. ${ }^{8}$ Indremisjonen organiserte òg

$4 \quad$ I 1988 var det vanskeleg å skaffe krinssekretær, og bladstyraransvaret gjekk til ein merittert forkynnar i Nordfjord indremisjon. Ein annan tok over i 1993, saman med rektor for folkehøgskulen. Samtidig var det slutt på den skarpe todelinga mellom krinsstoff og skulestoff i bladet. Ein journalist med erfaring frå regionale og lokale aviser bidrog òg mykje til bladet utover 1990-talet. Wergeland (1979, s. 20) fortel om korleis Linde si forkynning var full av «varme, hjartelag og medkjensle».

6 Aagedal (2003, s. 50) bruker «emissær» som tittel på det «yrket» som oppstod då dei omreisande predikantane blei løna av organisasjonane frå rundt $1900 \mathrm{og}$ framover, til skilnad frå ubetalte «reisende brødre» fram til 1860 og Lutherstiftelsen sine deltidsarbeidande «bibelbod» mellom 1860 og 1891 .

7 Knut Myrstad om vekkingsforkynninga til Johs. G. Holsen i Ljosstrålar (oktober 1964).

8 Wergeland, 1979, s. 31 . 
omreisande talarar gjennom sentralorganisasjonen i Oslo, og andre organisasjonar hadde sine talarar som slapp til på bedehusa. Slike tilreisande predikantar kom gjerne til ei bygd, tok inn hos ein av «venene» og heldt møte i nokre dagar. Men dersom det var teikn til vekking, kunne dei bli lenger. Emissærane kunne tale inn i ei felles røyndomsoppfatning der det var allment akseptert at livet hadde to moglege utgangar. Ofte var retorikken basert på valet mellom frelse og fortaping. Dette la eit alvorleg bakteppe for vekkingsforkynninga, både for dei som «kom med» og dei som ikkje gjorde det.

I lokalsamfunna blei vekkingane gjerne opplevd som dramatiske hendingar, som snudde opp ned på relasjonar og familiar. Det var ingen stader å gøyme seg for vekkinga i små bygder, og det kunne opplevast som at "Gud va' øve' alt». ${ }^{9}$ Vekkingane gjorde at trauste bønder fekk sterke kjensleutbrot, og det gav verkeleg dramatiske omslag i folk sine liv. Ofte blei heile bygder forandra, frå å vere prega av «banning, rå tale, drikk og sedløysa», ${ }^{10}$ til bygder der vekkingskristendomen fekk definere dei sosiale spelereglane, eller i alle fall kva det ville seie å vere kristen.

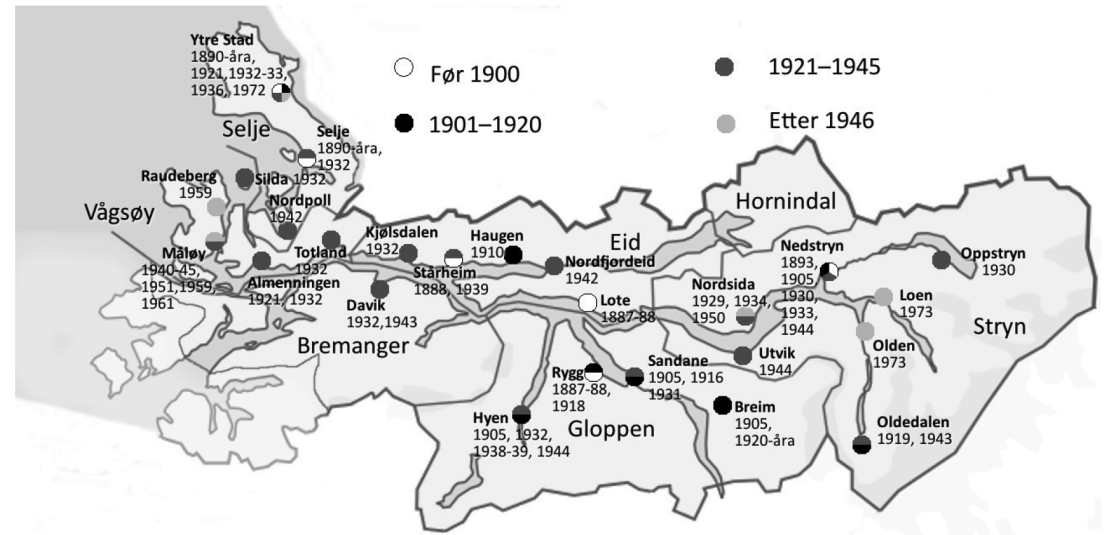

Figur 1. Vekkingar i Nordfjord. (Grunnkartet er hentet fra Wikimedia Commons: https://commons. wikimedia.org/wiki/File:Norway_Sogn_og_Fjordane_-_Sogndal.svg. Lisens CC BY-SA 3.0. Alle tilpasninger er gjort av forfatteren.)

Kartet i Figur 1 viser dei vekkingane som indremisjonsfolket rekna opp ved 100-års-jubileet i 1979. ${ }^{11}$ Nokre stader i Nordfjord kom vekkingane fleire

Seland, 2006, s. 136.

Slik beskriv Wergeland (1979, s. 21) situasjonen før vekkingane.

Wergeland (1979, s. 61-73) om vekkingane i Nordfjord. Vekking er eit uspesifikt omgrep, og dei som her er oppførte, er altså dei som indremisjonsfolk i Nordfjord på 1970-talet mintest som 
gonger, som på Stadlandet, på Sandane og i Stryn. Andre plassar hende det berre éin gong, gjerne i byrjinga av 30-åra. Så skipa dei «vakte» eit såkalla venesamfunn, og i mange tilfelle levde dei vidare på dei hendingane som hadde vore så skjelsettande for dei. Dei bad og arbeidde for at akkurat det same skulle hende på nytt i bygda. Vekkinga blei det sentrale referansepunktet for dei som kalla seg "veneflokken», ${ }^{12}$ og ho var grunnen til at flokken, som etter kvart organiserte seg i den lokale misjonsforeininga, eksisterte. Håpet om nye vekkingar var grunnen til at dei heldt oppe arbeidet.

Dermed blei det også eit eksistensielt problem for rørsla at ikkje dei store vekkingane kom attende i etterkrigstida. I Ljosstrålar frå 1951 kan vi lese at det var tungt å gå og arbeide utan at det kom vekking. Misjonsfolket visste likevel kva dei venta på. Rett nok kunne vekkinga si art og ytre form skifte med tid og miljø. Men dersom det var Guds verk, ville resultatet vere syndserkjenning og omvending. ${ }^{13}$ Arva frå den tyske pietismen innebar at prosessen burde skje i denne rekkefølgja.

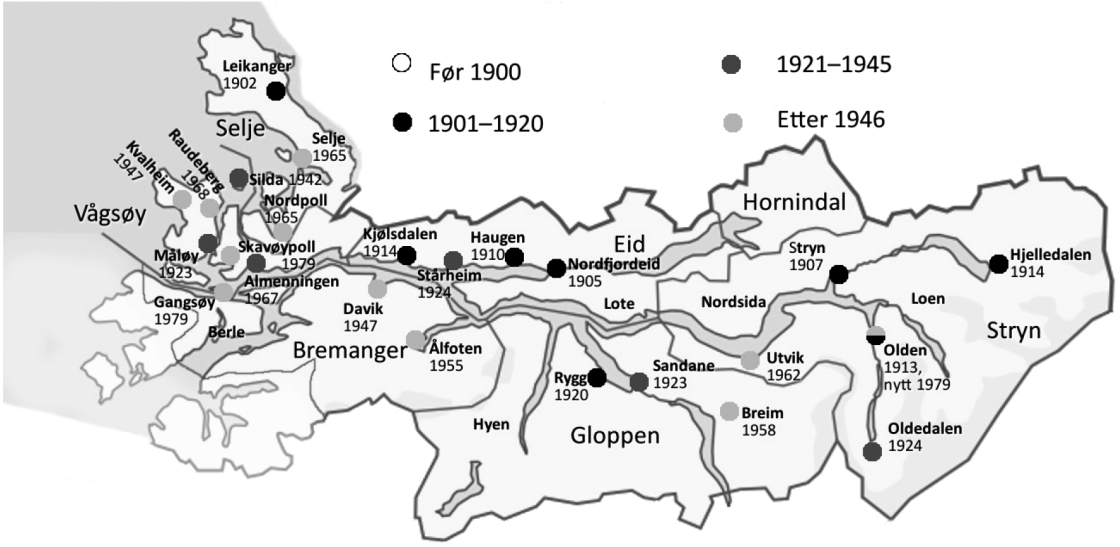

Figur 2. Bedehus i Nordfjord. (Grunnkartet er hentet fra Wikimedia Commons: https://commons. wikimedia.org/wiki/File:Norway_Sogn_og_Fjordane_-_Sogndal.svg. Lisens CC BY-SA 3.0. Alle tilpasninger er gjort av forfatteren.)

viktige hendingar. Vekkingar i regi av pinserørsla eller andre organisasjonar vil ikkje nødvendigvis vere med. Den søraustlege delen av Bremanger kommune er ikkje med, fordi denne «høyrde til» DVI. Kommunane er inndelte som dei var frå 1977. Wergeland (1979, s. 61) beskriv vekkingane som «sjølve livsnerven, utgangspunktet og grunnlaget for den oppgåva indremisjonen har fått i folket vårt.»

13 Referat frå Vestlandske Indremisjon sitt årsmøte, vidareformidla i Ljosstrålar (september 1951). 
Figur 2 viser oss at bedehusa ofte blei bygde i etterkant av vekkingane. Vi ser at medan vekkingane hadde ein topp i mellomkrigstida, så var det $\mathrm{i}$ etterkrigstida det blei bygd flest bedehus i Nordfjord. Nokre stader, som på Eid, var det ikkje nokon klar samanheng mellom vekking og bedehusbygging. Husa blei gjerne reiste på det som då var sentrale stader i bygdene. I bedehusa blei dramaturgien og dramatikken i vekkinga institusjonalisert, og det blei vanleg at omreisande talarar «talte til vekking», sjølv om faktiske vekkingar var ganske sjeldne. Vekkinga var utover 1960- og 70-talet framleis det store målet for alt arbeidet som blei lagt ned på bedehuset.

Ved starten av 1970-talet stod Nordfjord indremisjon på mange vis fram som ei vital rørsle. Særleg verkar vekkingane i 1972 og 1973, først på Stadlandet og så i Olden, å ha «kveika» misjonsfolket. Særleg inspirerande var det for dei trufaste støttespelarane at mange ungdomar «kom med», som det heitte. Kor mange av desse som var oppvaksne i indremisjonen og kor mange som kom til utanfrå miljøet, er vanskeleg å seie noko $\mathrm{om}$. Men desse vekkingane eller fornyingane heldt likevel liv $\mathrm{i}$ håpet om ei vekking av den gamle gode sorten.

Og om det potensielt kunne fungere, var det kanskje ikkje stor grunn til å endre på vinnaroppskrifta. Likevel kom det ikkje fleire store vekkingar i Nordfjord. I 1983 blei det rapportert om at mange var «fornya», i ein møteserie som varte lenger enn planlagt i Innvik. Det er verdt å merke seg at i begge desse oppslaga var soknepresten djupt involvert i det som skjedde og det fortel oss om ein indremisjon som jobba tett på Den norske kyrkja.

Hovudinntrykket i Ljosstrålar utover 1980-talet er ein viss resignasjon med tanke på vekking. I staden for å ha vekkinga i fokus, flytta bladet merksemda over på kor bra det var å jobbe på, jamt og trutt, og kor viktig det var å ikkje gje opp. ${ }^{14}$

\section{Institusjonalisert vekkingsliv}

Vekta på syndserkjenning og omvending i rett rekkefølgje var problematisk for arbeid som kunne føre til at unge berre vaks stilt og roleg inn

14 Ljosstrålar (april 1984) trøystar med at «Det jevne vedvarende arbeid forteller at de som arbeider
har tro på arbeidet, derfor fortsetter de selv om det til sine tider kan være tungt.» 198 
i trua. ${ }^{15}$ Slikt blei kalla "oppdragingskristendom», og var lenge eit fyord i indremisjonen. ${ }^{16}$ Det måtte ei omvending til, og det var klare forventingar til korleis ho skulle sjå ut. Men utover etterkrigstida blei det meir akseptert å snakke om ein "stille» variant av vekking. ${ }^{17}$

Den generasjonen som opplevde vekkingane på tidleg 1900-tal, hadde gjerne sett konsekvensane av fyll og hasardspel for heile familiar. Dei var fullt medvetne om kva dei omvendte seg bort frå. Men dette skjemaet for omvending blei så ført vidare til dei neste generasjonane. Å vakse opp som ein del av bedehusrørsla var trygt, men fullt av forventingar. Ein skulle halde seg unna kortspel, dans og svir, men på den andre sida skulle ein på eit tidspunkt omvende seg, «kome til klårleik», ta eit standpunkt for å verkeleg bli rekna med i flokken. Når desse ungdomane skulle ta avstand frå det ville livet dei $i k k j e$ hadde levd, stod dei overfor eit visst dilemma.

Løysinga for indremisjonsfamiliane i Nordfjord var folkehøgskulen. Nordfjord ungdomsskule (no folkehøgskule) blei innvigd i 1923. Indremisjonen stod i spissen for å få oppretta skulen, som kravde ein dugnadsog gjevarinnsats som i seg sjølv fortel oss at indremisjonen var ei brei folkerørsle.

I mange indremisjonsslekter var det forventa av ungdomane at dei skulle ta ein vinter på «Ljosborg», som skulen på Vereide i Gloppen blei kalla. Her var det ei tydeleg forventing frå gamalt av, om at skuleåret skulle bidra til ei slags omvending eller gjennombrot. Ein tidlegare elev, som hadde om lag 100 (!) temmeleg nære slektningar som hadde gått på skulen, sa det slik i eit intervju: «Elevåret var avgjerande. Kristentrua braut for alvor igjennom til utadvendt liv. Eg vart frimodigare». ${ }^{18} \mathrm{Vi}$ kan sjå folkehøgskulen som eit kompromiss mellom oppdragingskristendomen, som var realiteten for indremisjonsungdomane, og omvendingskristendomen, som var idealet

\footnotetext{
15 I Nordfjord førte desse to ulike måtane å forstå vegen til frelse på at samarbeidet mellom indremisjonen og NKUF (KFUK/KFUM) blei vanskeleg. Felles leirarbeid blei avslutta i 1961.

16 Seland (2006, s. 121) refererer til indremisjonsselskapets predikant Alfred Hagnor som i 1937 forkynte at «selv om du har levd med ham op gjennem barneårene, må det komme et personlig gjennembrudd med dig. Det går an å bli en opdragelseskristen, som ikke lenger eier livet i Gud.»

17 Wergeland (1979, s. 61) anerkjenner til dømes «den stille vekkinga eller vekst som også er ei frukt av det jamne arbeidet». 
for dei vaksne. Lenge såg dette mønsteret ut til å fungere. Når det kom rapport frå skulen om vekkingar, eller når kristentrua «braut gjennom» hos unge, så var det med på å legitimere skulen overfor dei trufaste støttespelarane i fjorden. Ønsket om ei ordna form for vekkingsoppleving for ungdomane var altså det eine beinet skulen stod på.

Det andre var å tilby arbeidsretta eller studieretta skulegang til bygdeungdomen. Men når først den offentlege ungdomsskulen blei allmenn og obligatorisk, og deretter vidaregåande skule blei tilgjengeleg for dei fleste, blei folkehøgskulen hengande litt i lause lufta. Via nysatsingar som EDB og sosialliner, som låg i grenseland mellom nyttig og moro, så enda dei fleste folkehøgskulane opp med liner som meir var eit slags friår, før dei unge tok fatt på arbeidsliv eller høgare utdanning.

Då blei det raskt attraktivt å ta «friåret» sitt andre stader i landet, og det blei eit gjentakande refreng i Ljosstrålar at ungdomen frå Nordfjord, særleg frå indremisjonsheimane, måtte søkje seg til Ljosborg, som etter kvart fekk få elevar frå nærområdet. Mykje av den tradisjonelle koplinga mellom indremisjonsfamiliane og skulen, og dermed den institusjonaliserte vekkingsforma, forsvann i denne prosessen.

\section{Bilar, bortebuarar og bustadfelt}

Nordfjordungdomen reiste i stadig større grad bort frå Nordfjord, ikkje berre for eit «friår», men òg for studie og arbeid. Vi ser ut frå folketeljinga i 2001 at folketalet for heile Nordfjord ikkje hadde gått særleg mykje ned sidan 1970. Men det var blitt over 2000 færre barn i distriktet, og over 2000 av ungdomane studerte no ein annan plass enn i heimkommunen. Ein klar effekt av dette var færre barn og unge til å fylle korvettlag, yngresforeiningar og indremisjons-ungdomslag. ${ }^{19}$

Reint bortsett frå at ungane flytta vekk for ein periode eller for godt, så hadde utdanninga òg ein annan konsekvens for indremisjonen. I Nordford, som elles i landet, kom det ei enorm endring i utdanningsnivået $\mathrm{i}$

19 Ljosstrålar (oktober 1993) beskriv effekten av bortreiste ungdomar for bedehusa: «Det merkast i miljøet når kanskje fem av ei gruppe på ti blir borte i eit jafs. Gruppa i alderen 15-30 manglar i mange bedehusmiljø». 
denne perioden. I 1970 hadde tre av fire nordfjordingar berre grunnskuleutdanning. I 2000 hadde over fire femdelar vidaregåande eller meir. Desse tala gjaldt heile befolkninga, dei unge fekk raskt høgare utdanningsnivå enn dei eldre. Utdanningsauka kom sterkare og tidlegare i Gloppen og Eid, enn i Selje og Bremanger.

Dei bedehusungdomane som tok høgare utdanning, for så å kome tilbake til Nordfjord, må nødvendigvis ha sett bedehusarbeidet $\mathrm{i}$ eit nytt lys. ${ }^{20}$ Sosiologen Peter Berger sitt uttrykk plausibilitetsstrukturar beskriv nettverk av sosial samhandling som er med på å gjere ein religiøs tradisjon truverdig for individet. Berger argumenterer for at individualiseringa av religiøse val gjorde at religiøse grupperingar ikkje lenger kunne ramme inn og forklare «heile verda», berre delar av ho. ${ }^{21}$ I dei tradisjonelle bygdesamfunna ville lekfolket sine aktivitetar halde ved like den pietistiske plausibilitetsstrukturen, og gjere at denne kristendomsforma blei opplevd som noko rimeleg eller sjølvsagt. Men i byane og på studiestadane stod gjerne indremisjonsungdomen meir for seg sjølv i møte med eit meir pluralistisk miljø, og dei møtte fleire kritiske innvendingar på nedarva tradisjonar enn dei var vande med. I første omgang kunne dette kunne føre til religiøs passivisering, eller i det minste ein endra religiøsitet.

Ulike sider ved det tradisjonelle bedehusarbeidet blei kritiserte i storsamfunnet, men òg «innanfrå», som i Erling Utnem sitt føredrag «Visitas på Bedehuset» frå 1966. Mellom anna tok Utnem tak i sjølve forståinga av «venesamfunnet», og sa «at noen mellom oss opptrer som om de var ansatt som sorteringsmannskap i Vår Herres folkeregister» og åtvara mot at vegen var for kort til kameraderi, indre-sirkel-mentalitet og fariseisme. ${ }^{22}$ Det er lite teikn i materialet frå Nordford indremisjon til at slikt blei diskutert i organisasjonen før utpå 1990-talet.

I bedehuset i Stavanger var det 20-25 medlemmer att i 1979. Utover 80- og 9o-talet forlét dei ellipsemodellen, altså tanken om at ein skulle gå i kyrkja på føremiddagen og deretter på bedehuset om kvelden. Dei men òg kunne ruste studentane betre til å møte kritikk mot trusbakgrunnen deira. 
begynte å kalle seg «IMI-kirken» og tilbaud nattverd og dåp. Indremisjonsselskapet sitt «by-bedehus», Storsalen i Oslo, starta opp gudstenester i 1989, og Salem i Trondheim følgde på. ${ }^{23}$ Endringa frå foreining til forsamling var tydeleg i byane gjennom heile siste tredelen av 1900-talet, og indremisjonsfolket her opplevde at denne satsinga gav vekst. Indremisjonsungdomen som flytta tilbake til Nordfjord, eller aktive kristne tilflyttarar, hadde dermed gjerne med seg eit heilt anna bilete av kva som fungerte, enn det som framleis gjaldt i Nordfjord. ${ }^{24}$ For i Nordfjord indremisjon var «ellipsemodellen» ikkje oppe til diskusjon. Gjennom 50 årgangar av Ljosstrålar er det berre éin artikkel som på noko vis tematiserer at det kunne vere vanskeleg å engasjere seg både i kyrkja og på bedehuset. ${ }^{25}$ Dette todelte engasjementet var sjølvsagt for indremisjonsfolket i Nordfjord, men det må ha vore framandgjerande for både tilbakeflyttarar og innflyttarar. Dermed stod dei unge overfor valet mellom å halde kontakten med det gamle miljøet på studentstaden, halde seg passive eller å endre eller nyutvikle lokalt kristent arbeid. ${ }^{26}$ Dersom dei valde det siste, kunne det vere freistande å berre styre fullstending utanom indremisjonssystemet. ${ }^{27} \mathrm{Og}$ om det blei starta opp nye tiltak, så måtte ein forsikre om at det berre skulle vere supplement til alt det andre indremisjonen og kyrkja dreiv med, slik som når det blei starta opp «unge vaksne»på Sandane eller lovsongskveldar på Eid..$^{28}$

Knut Myrstad (1913-2001) var mellom dei store «høvdingane» i Nordfjord indremisjon. Han var krinssekretær frå 1948 til 1965 og seinare stortingsmann for KrF frå 1965 til 1977. Myrstad var tidleg ute med å tale for ei samanslåing av dei kristne organisasjonane, ${ }^{29}$ og var på mange vis ein

Granerud, 2017.

Aagedal (1988, s. 240) beskriv tilbakeflyttarane som spesielt godt eigna til å kunne tilpasse «det nye» til dei lokale forholda, og nokon som potensielt kunne skape «ny bedehusteologi» og nye praksisar.

I Ljosstrålar (desember 1995) skriv formannen at det kunne verke som «Vestlandske» og NLM med si sjølvstendige line opp mot Den norske kyrkja var betre rusta til å bygge «fullverdige fellesskap». Aagedal (1988, s. 34) presenterer desse tre vala som dei «bykristne» har i møte med bygdebedehuset. Desse alternativa gjeld like mykje for tilbakeflyttarar som for tilflyttarar. Ljosstrålar (mars 1995) fortel om korleis mange grupper ønskjer å «operere fritt» utan å koordinere med bedehuset. 
visjonær mann. Men han var nok representativ for Nordfjord indremisjon i si vurdering av «framande» møteformer i 1979: «Metodar som vert

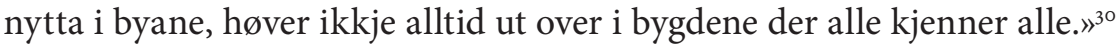
Nordfjord indremisjon heldt fast på biletet dei hadde av regionen sin som ei samling av egalitære grender som låg tungvint til, ei slags roleg øy i eit hav av endringar. Akkurat denne førestillinga styrte mange av strategivala. Men utanfor bedehusveggane endra verkelegheita seg raskt.

Fram til 196o-talet var kommunikasjonane i distriktet baserte på fjordtransport med rutebåt. Turen frå Selje til Sandane tok 18 timar i byrjinga av 6o-åra. Men i 1968 opna ferjesambandet Anda-Lote og Lotetunnelen, og med privatbil gjekk reisetida på same strekninga ned til to timar i slutten av tiåret..$^{31}$ I 1975 stod flyplassen på Anda klar, og heilårsvegen over Strynefjellet blei opna i 1977. Dette gjorde at det no var mogleg å kome seg mykje raskare til andre delar av landet, særleg austover. Dei betra kommunikasjonane gav store endringar i rammevilkåra for det tradisjonelle grendebaserte bedehusarbeidet.

Skavøypoll bedehus kan illustrere effekten dette hadde for bedehusa. I 1954 blei det danna eige indremisjonslag her, og i 1965 stod tomta klar. Leiaren for det lokale indremisjonslaget kunne fortelje om «sterk trong for eit slikt hus« i dette området. I 1974 opna Måløybrua, og dermed var det fem minutt å køyre til Måløy, som alt hadde eige bedehus. Frå før hadde det vore fem minutt å køyre til Almenning bedehus andre vegen. Så då bedehuset blei innvigd i 1979, høyrde det på eit vis allereie heime i ei tid som var over. Dei innsamla midla frå Skavøypoll var høgast i starten av 8o-talet, og dalte så sakte, men ujamt, utover perioden. I 2013 hadde den lokale indremisjonen 12 medlemmer, mest eldre damer. ${ }^{32}$

Den gamle grendementaliteten blei oppheva eller utvatna i dei sentrumsnære strøka. Folk reiste til kommunesentera både i arbeidstida og fritida og tenkte på seg sjølve som «måløyværingar» eller «eidarar». Så stod bedehuset, ungdomshuset og gjerne det lokale idrettslaget att, som uttrykk for ein måte å tenkje samfunn på som blei borte med

\footnotetext{
Wergeland, 1979, s. 142.

Knut Myrstad fortel om denne skilnaden i reisetid i Wergeland (1979, s. 139-140).

Kleppa, 2013.
} 
biltransporten. Småbygdene blei til «drabantbygder» ${ }^{33}$ Nokre stader der indremisjonen hadde stått sterkt, blei rett og slett fråflytta, og der blei det naturleg nok vanskeleg å drive indremisjon. Men det finst døme frå Nordfjord, som Hennøystranda i Bremanger, der det blei halde misjonsbasar så lenge det budde ei handfull folk der fast. Øya Silda hadde eige bedehus, og var i 1955 den staden i noverande Vågsøy kommune som samla inn mest pengar til indremisjonen. Ved folketeljinga i 1960 hadde Silda 178 innbyggjarar, i 1980 var der 114 att, og i 2001 berre 38, ingen av dei under 15 år. Talet på lokalsamfunn i Nordfjord med indremisjonsaktivitet gjekk ned frå 72 i 1965 til 31 i 2000.

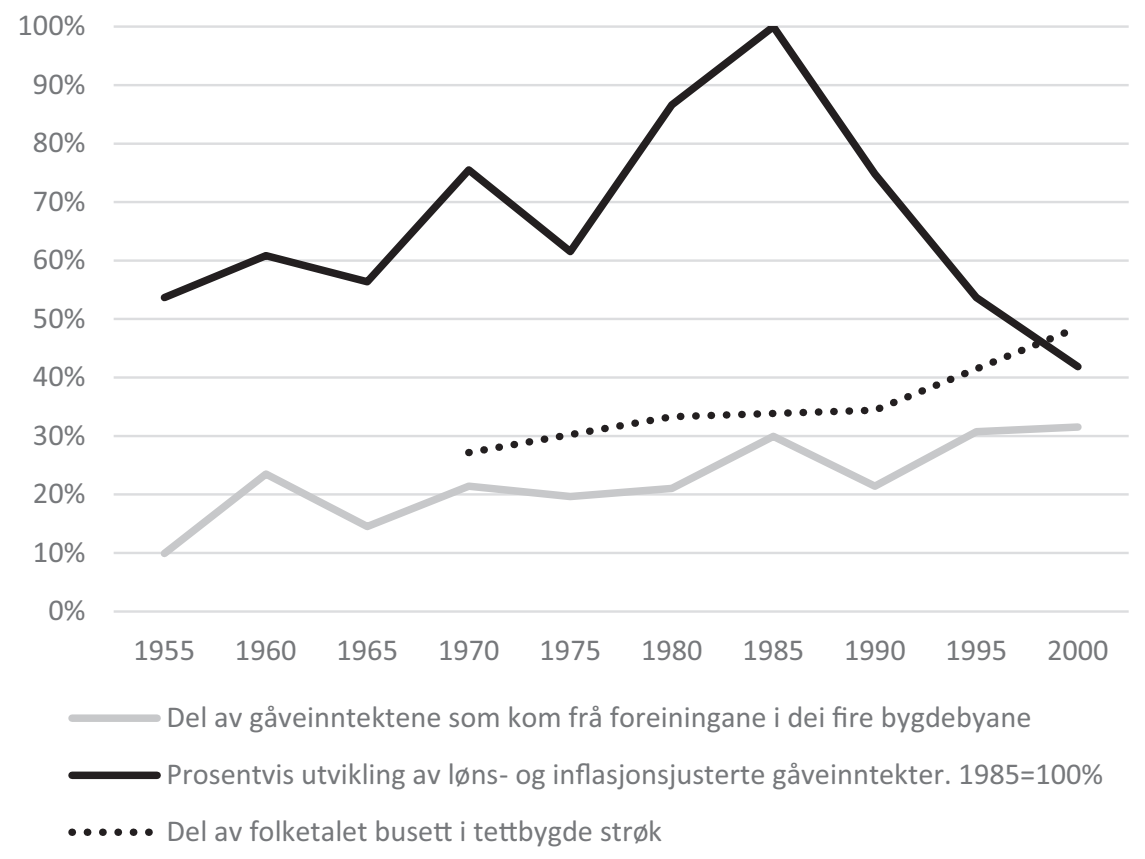

Figur 3. Sentralisering og gåveinntekter til Nordfjord indremisjon.

Figur 3 viser korleis om lag halvparten av nordfjordingane, ifølgje folketeljingane, budde i tettbygde strøk i 2001. Det gjorde berre rett over ein

33 Aagedal (1988, s. 22) brukar ordet «drabantbygd» om ein kommune der pendlinga inn til byen gjer at koplinga mellom bustad og arbeidsstad blir mindre, samtidig som den spreidde busetnaden og "grendemønsteret» lever side om side med bustadfelta. Betra kommunikasjonar gjorde at store delar av Nordfjord etter 1970 likna stadig meir på «drabantbygder» enn på stabile «bondebygder», sjølv utan noko stort urbant sentrum i nærleiken. 
fjerdedel av dei i 1970. I tillegg gjorde altså biltransporten at bygdesentera blei lettare tilgjengeleg for folk som framleis budde i utkanten. I Bremanger kommune gjekk folketalet drastisk nedover, og Selje og Vågsøy hadde òg etter kvart negativ folkevekst. Gloppen stod ganske stilt, medan særleg Eid og delvis Stryn kommunar hadde ei positiv folketalsutvikling. Men dei kommunale tala dekker over ei intern flytting inn mot dei nye kommunesentera.

Særleg Stryn, Sandane og Eid sentrum vaks mykje utover 70- og 8o-talet, og busetnaden i Måløy blei tettare, sjølv om ikkje folketalet vaks så mykje. Nordfjord fekk fire ganske jamstore bygdebyar. Men som vi ser av figuren, vaks ikkje delen av gåveinntektene til indremisjonen som kom frå Eid, Stryn, Måøy og Sandane i same tempo. Eid sentrum, som vaks mest, var ikkje prega av vekkingskristendomen på same måte som mange av dei bygdene folk flytta frå. Folkevekst i sentrumsområda gav ikkje automatisk vekst i bedehusarbeidet i dei same områda, ${ }^{34}$ og det er ein medverkande årsak til at dei løns- og inflasjonsjusterte gåveinntektene til Nordfjord indremisjon blei nær halverte frå 1970 til 2000.

\section{Bedehuskultur i endring}

Indremisjonen og bedehusa kom frå, og fungerte i, ein kulturell kontekst der verdiar som nøysemd, dugnad, fråhald, offervilje, tradisjonell moral og egalitet var viktige. Desse verdiane var under sterkt press dei siste 30 åra av 190o-talet, og rundt om på bedehusa blei denne endringa tolka som del av «sekulariseringa» eller «avkristninga». Spørjeundersøkingar frå Norsk Monitor viser oss likevel at talet på nordmenn som svarte at dei betrakta seg som «personleg kristne», ikkje gjekk ned mellom 1985 og $1995,{ }^{35}$ men verdiane til folk flest var likevel i endring. Rett nok var det ei viss dreiing i retning materialistiske verdiar hos folk, men hos dei som heldt fast på ein idealistisk måte å tenkje på, tapte dei tradisjonelle idealistane terreng for meir moderne idealistar. ${ }^{36}$

\footnotetext{
34 Aagedal (2003, s. 167) observerte korleis bedehusa i ein annan kommune med folkevekst i denne perioden, «drabantbygda», heller ikkje klarte å fange opp dei som flytta til.

35 Hellevik, 1996, s. 18-19 og 55.

36 Hellevik, 1996, s. 24-30 og 84 .
} 
Knut Myrstad kan stå som eit døme på den tradisjonelle måten å tenkje idealisme på. Ein grunn til at han i si tid valde å reise som emissær i eige heimdistrikt, fortalde han, i staden for å ta ein tilsvarande jobb i Langesunds-området, var at løna berre var rundt ein fjerdedel heime i Nordfjord: «Ein måtte vere villig til å yte eit offer. Og eit offer blei det». ${ }^{37}$ Typisk for dei meir moderne idealistane frå 1968 og framover var individualitet og autoritetsskepsis. Dei ønskte å oppleve meistring, i staden for at offeret var eit stort poeng i seg sjølv. Kort fortald blei det viktigare for dei å gjere sitt eige val om å vere med på noko som «fungerte». I stor grad ville slike verdiar gjere det vanskeleg å engasjere seg på det lokale bedehuset, både for «vanlege» ungdomar og dei som var frå indremisjonsheimar. Miljøvern, politisk frigjeringskamp eller religiøsitet i form av rørsler som «Jesusvekkinga» eller den karismatiske «trusrørsla» korresponderte betre med den nye måten å tenkje idealisme på. Men det var ikkje utan vidare rom for slikt $\mathrm{i}$ indremisjonen. ${ }^{38}$

Dei kulturelle skilnadane på bedehusfolket og andre var spesielt synlege i spørsmål om såkalla adiafora. Dette er handlingar som verken kan kallast moralsk gode eller fullstendig forkastelege, og som dermed var opne for forhandling. Tradisjonelt hadde til dømes indremisjonen vore mot film og kino som ikkje hadde eksplisitt kristeleg innhald. Dersom ein heldt seg unna bygdekinoen, som av og til blei sett opp rundt omkring, så var det lenge ganske enkelt for indremisjonsfolket å halde ungdomane sine på den rette sti akkurat på dette feltet. Men etter at fjernsynet kom, blei alt mykje vanskelegare. «Det vil fullkomment ødelegge oppdragelse og moral hos den kommende generasjonen", blei det åtvara om televisjonen gjennom Ljosstrålar i $1965 .{ }^{39}$ Men fem år seinare kan vi lese ein liten notis i same blad at elevlaget hadde samla inn pengar for å handle inn TV-apparat på jenteinternatet på folkehøgskulen. ${ }^{40}$ Synet på kva som var akseptabelt endra seg ganske fort. Folkehøgskulen var meir i dagleg kontakt med ungdomstrendane, enn det bedehusa etter kvart var. Derfor låg nok folkehøgskulen

\footnotetext{
37 Wergeland, 1979, s. 137.

38 Sørbø (1985, s. 34-35) beskriv til dømes korleis «blomsterbarna» i det karismatiske Ung Visjon i Molde ikkje fekk plass innanfor Romsdals indremisjon under «Jesusvekkinga».

39 Ljosstrålar, februar 1965.

40 Ljosstrålar, januar 1970. 
framfor resten av indremisjonen i å skape rom for både TV, drama, nye musikkformer og etter kvart dans.

Folkehøgskulen hadde òg ei anna tilnærming enn resten av rørsla til idrett, som gjennom heile etterkrigstida blir omtala som triveleg og morosamt i rapportar frå skulen. Den tradisjonelle haldninga i indremisjonen var, derimot, at kristne ikkje skulle drive idrett, og då spesielt ikkje konkurranseidrett. Dette var likevel eit spørsmål som var ope for debatt i indremisjonen, og allereie på 1950-talet blei det argumentert mot dei tradisjonelle haldningane i Ljosstrålar. ${ }^{41}$ Fleire av forkynnarane i indremisjonen var aktive konkurranseidrettsmenn. ${ }^{42}$ Likevel hang motstanden, særleg mot konkurransar på søndagen, lenge i. Det var jo kanskje ikkje så rart at indremisjonsfolket var skeptiske til dette. For det hjelpte jo ikkje at konkurransearrangøren unngjekk kyrkjetida, når bedehusfolket skulle møte opp i kyrkja på føremiddagen, og så på bedehuset på ettermiddagen.

\section{Kvar var ungdomen?}

Det største løftet Nordfjord indremisjon gjennomførte i 1960- og -70-åra, var bygginga av eit eige ungdomssenter ved Bryggja i Vågsøy. Allereie på slutten av 1960-talet såg krinssekretæren teikn til at folkehøgskulen ikkje nødvendigvis hadde ei framtid som det samlande elementet for indremisjonsungdomen. Meininga var at ungdomssenteret skulle ta over stafettpinnen. ${ }^{43}$ Fjordly, som leirstaden blei kalla, blei fylt med mykje ulik aktivitet frå starten, på ein måte som kan minne om slik grendebedehusa hadde vore brukt før i tida. ${ }^{44}$ Allereie frå første heile driftsåret i 1974 blei det fortald om korleis Fjordly var blitt eit kraftsenter i fjorden og ein

\footnotetext{
41 Ljosstrålar, oktober 1953.

42 I Ljosstrålar (september 1997) fortel ein veteranidrettsmann og forkynnar om korleis han har opplevd det som ein frigjeringsprosess at synet på idrett har gått frå syndestempel til aksept for livsutfalding.

43 Ljosstrålar, mars 1971.

44 Aagedal (2003, s. 336) viser til korleis bedehusa i «Bondebygda» pleidde å ha arrangement av mange typar for bygdefolket, men no var blitt meir «reine» bedehus. Fjordly blei arena for barne-, ungdoms- og konfirmantleirar, møte for andre organisasjonar, politiske og kulturelle konferansar, lærarlagsmøte og prostimøte. Foreiningar, klubbar, pensjonistlag og skuleklassar besøkte bygget, det blei brukt til bryllaup og gravferder, og bygdefolket skipa til festar og basarar der.
} 
åndeleg heim for ungdomane. ${ }^{45}$ Leirstaden fungerte frå starten av som ein stad der ungdomen fekk skape sitt eige uttrykk, der det blei snakk om å praktisere nådegåver, og der impulsane frå karismatisk kristendom slo sterkare inn enn på bedehusa. Her blei dei unge følgd opp av nokon dei stolte på, og dei fekk tillit og veksande ansvar. ${ }^{46} \mathrm{I}$ leirsamanheng begynte det å bli aksept for «unge som i det stille har vakse fram til ei personleg tru», som altså ikkje hadde gått skjematisk gjennom syndserkjenning og omvending. ${ }^{47}$ I materialet frå Ljosstrålar blir soga om ungdomssenteret presentert som eit stort lyspunkt for rørsla, og tala frå årsrapportane fortel den same historia. I 1972 hadde indremisjonen ei leirdeltaking som svara til $4 \%$ av talet på barn og unge i Nordfjord. I 1997 svara deltakinga til om lag $11 \%$ av barna og ungdomen.

Men dersom leirstaden var den åndelege heimen, så ville jo ikkje ungdomane vere «åndeleg heime» på sitt lokale bedehus. Unge leirdeltakarar strøymde i alle fall ikkje til bedehuset til dømes i Stryn, sjølv om det var nyoppussa og alt. ${ }^{8}$ Nokre stader i landet blei bedehusa det vi kan kalle «aktivitetsbedehus», med omfattande korarbeid, eller ulike aktivitetsgrupper som var opne for deltaking for bygdefolk flest. Dette ser ikkje ut til å ha skjedd i Nordfjord. Idealet på bedehusa i Nordfjord, som til dømes kjem til uttrykk etter vekkinga i 1972, var i staden at dei som var blitt omvende eller «kome til klårleik», tok del i det etablerte venesamfunnet. ${ }^{49}$ Forventinga der var at ein skulle ta del i dei såkalla småmøta, som var tette, personlege møte med bibellesing og bøn..$^{50}$ Men som religionssosiologen Ida Marie Høeg har påvist, er det ikkje slik at jo eldre ein blir, jo meir innstilt blir ein på å ta vare på tradisjonell tru og praksis. I staden er det den haldninga og praksisen dei unge startar opp med, som blir avgjerande for utviklinga framover. ${ }^{51}$ Samanhengen mellom leirarbeidet og småmøta på grendebedehuset var sjølvinnlysande for det vaksne

\footnotetext{
45 Årsmelding for Nordford indremisjon, 1974, s. 8-10.

46 Ljosstrålar (april 1998) fortel om ei som starta som vanleg deltakar, og sidan «gjekk gradene» via kjøkenhjelp til leiaroppgåver.

47 Ljosstrålar, august 1968, rapport frå leirarbeidet.

48 Ljosstrålar, mai 1995.

49 Ljosstrålar, mars 1973. Ungdomssekretæren skreiv: «Og til dykk unge vil eg seia: Finn din plass i venesamfunnet. Lat ikkje din plass stå tom når dei kristne, der dei bur, samlast til bønemøte».

50 Ljosstrålar, mai 1995.

51 Høeg,2010, s. 336. 
misjonsfolket, som hadde finansiert leirane, men ikkje like sjølvsagt for dei som vaks opp med leirstaden som «åndeleg heim».

Mykje tyder på at Fjordly og bedehusa fungerte som ulike sosiale felt der det var nokre former for kulturell kapital som blei verdsett på ungdomssenteret, og heilt andre typar kapital som gjaldt heime på bedehuset. ${ }^{52}$ Mange ungdomar kjende seg heime på leirstaden, der dei forstod dei kulturelle kodane. Der kunne dei bli anerkjende til dømes for revynummer, karismatiske trusuttrykk, dugleik i idrett eller rytmisk musikk. Dette var former for «kapital» som ungdomen ville få liten gevinst for på bedehuset heime, der den tradisjonelle idealismen rådde. På bedehuset var det i større grad fråhald frå alkohol, trufast oppmøte, jamt og trutt arbeid og offervilje som gav anerkjenning.

På Stadlandet var gjennomsnittsalderen i indremisjonslaget passert 60 år i 1994. Men løysinga som leiaren såg for seg, var at det kom tilsig av nye krefter, altså at ungdomane på nytt skulle strøyme inn på bedehuset. Måten det skulle skje på, var at det skulle bli ei ny vekking, som den dei hadde hatt i 1972.53 Vekkingane på 1930-talet ser ut til å ha verka konserverande på indremisjonen sin kultur og strategi utover etterkrigstida, som eit bilete på noko som ein gong fungerte. På same måten verkar det kanskje utover 1990-talet som om minnet om vekkinga i 1972 var blitt ein grunn til å halde på vinnaroppskrifta frå for tjue år sidan.

\section{Supplere-ikkje fjerne}

Tida mellom 1970 og 1985 viste på overflata få teikn til å vere nedgangstid for Nordfjord indremisjon. I staden ekspanderte arbeidet i mange retningar. Indremisjonen satsa på bygging og drift av ungdomssenter og barnehagar, hotelldrift i storskala i Innvik, omreisande evangeliseringsteam, manns- og kvinnehelger, arrangement for innsamlingsgruppa ansvarsringen, bibelkurs og mini-bibelskular, pensjonisttreff og bibelcamping. I tillegg kom ei stor utbygging av internat på folkehøgskulen og nybygg og renovering av eit par bedehus. Dei tilsette var fleire enn før, reiste meir 
rundt, og økonomien gjekk i rett retning. Men rundt 1990 byrja inntektene å gå synleg ned, og mangelen på nyrekruttering på bedehusa og mangelen på både frivillige og betalte arbeidarar var synleg for alle. I denne situasjonen var det nettopp diskusjon rundt nye utbyggingsplanar for retreatsenter som fekk usemje og misnøye til overflata i organisasjonen. ${ }^{54}$ Dette skjedde både i lesarinnlegg i Ljosstrålar, på årsmøte og i meir private forum. ${ }^{55}$

Det er lett å tenkje at problemet var at indremisjonsfolket var for konservative. Men hovudtanken med konservatisme er jo at ein må forandre for å bevare, altså vil ein konservativ ønskje ei jamn utvikling, med respekt for tradisjonane. I staden ser vi på 9o-talet at bedehusfolket heller ville skape nye ekstratiltak for, sekundært, å lokke folk inn til dei «vanlege» møta. Og gjennom ganske opne meiningsutvekslingar, som blei refererte i bladet, får vi innblikk i ein indremisjon som ikkje hadde særleg tru på desse vanlege bedehusmøta, som var sjølve ryggmergen i arbeidet. Dette resulterte i ein ambivalens som kunne kome tydeleg til uttrykk i Ljosstrålar. Overskrifta på referatet frå ein strategikonferanse i 1995 var at ein skulle gå «Ut med glede i Nordfjord». Men sjølvkritikken i oppsummeringa rett under, med overskrifta «Fast i gamle spor», var beisk: Misjonsfolket var redde for å ta på seg oppgåver, sat fast i gamle tradisjonar, såg ikkje pliktene sine i Den norske kyrkja, hadde for mange konfliktar, programma var for trøytte og fargelause, mange forsamlingar var for lukka og mange miljø utan evne eller vilje til å ta imot nye menneske. Ikkje gjekk dei på besøk til sjuke og einsame heller, eller tok seg tid til å lese Guds ord. ${ }^{56}$ Denne situasjonsbeskrivinga gjekk altså ut i over tusen postkassar til det trufaste misjonsfolket i Nordfjord.

Etter at dei hadde fordøydd dette lesestoffet, kom kanskje telefonen: «Vil du ta på deg leiaroppgåver i denne organisasjonen?» Dei som fekk jobben med å ringe rundt, hadde vanskelege arbeidsvilkår. Folk sa nei.57 Utover 1990-talet var det vanskeleg å skaffe folk til både frivillige oppgåver og til løna stillingar. Leiarane som trakk seg, var tydelege på at det var

\footnotetext{
54 Ljosstrålar (juni 1990) inneheld eit kritisk innlegg om ressursbruken.

55 Styreprotokollane gjev innblikk i fleire konfliktar som måtte handterast tidleg på 9o-talet.

56 Ljosstrålar, mars 1995.

57 Ljosstrålar, mai 1997, under overskrifta «Hundrevis av telefonar». 
altfor mange saker å handtere, og for lite tid til det dei ønskte å fokusere på.58 Samtidig, og sjølvsagt ikkje utan samanheng med dette, gjekk økonomien raskt i feil retning. I reine tal stod inntektene stille, men justert for lønsvekst og inflasjon stupte dei utover 1990-talet. Figur 3 viste korleis inntektene i 2000 berre var $42 \%$ av det dei var i 1985. Særleg minka inntektene frå lokalforeiningane, som forsvann ei etter ei.

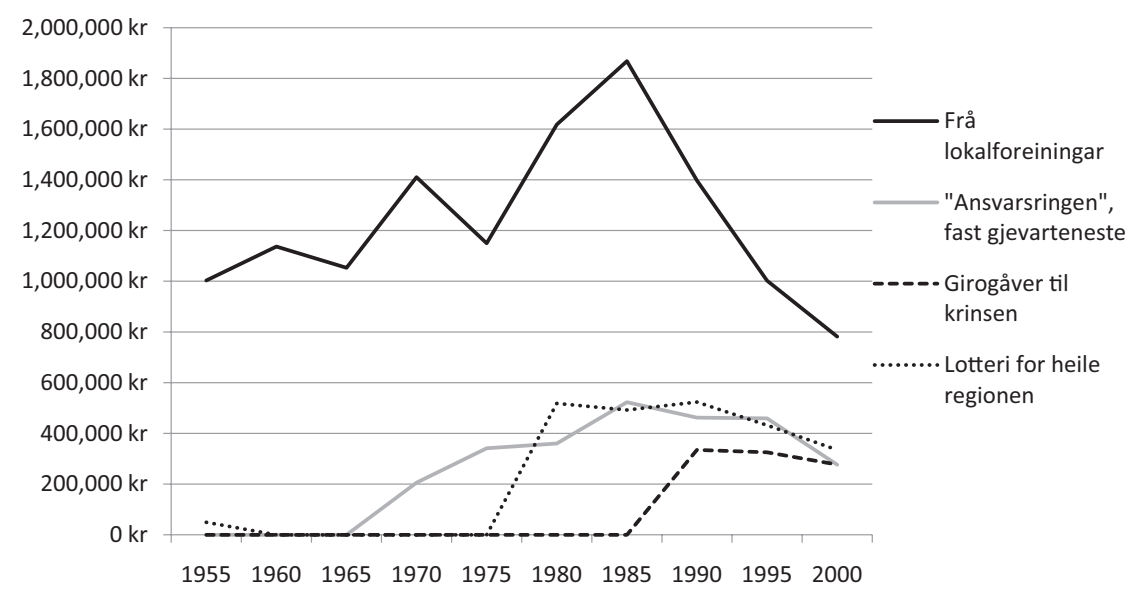

Figur 4. Fire gåvekjelder til Nordfjord krins av Indremisjonsselskapet, justert for inflasjon og lønsvekst.

Figur 4 viser korleis gåvene til krinsen frå lokalforeiningane gjekk ned frå 1985, og korleis nye måtar å få inn pengar på ikkje hjelpte nok til å vege opp. I 1965 hadde indremisjonen inntektsbringande aktivitet i 72 lokalsamfunn i Nordfjord, i 2000 var det aktivitet berre på 31 stader. Situasjonen etter 1985 var altså at det blei stadig færre aktive, på stadig færre stader, og stadig minkande inntekter. Indremisjonen sin reaksjon på dette var å finne på nye tiltak som skulle setjast i verk. Etter ein prosess som blei sett i gong sentralt i Indremisjonsselskapet blei det heldt regionale strategikonferansar frå 1990. Konferansen for Nordfjord i 1995 resulterte i heile 17 ulike tiltak som skulle gjennomførast. Det er altså forståeleg om leiarane kjente at dei hadde mange saker å følgje opp. For mange involverte blei det nok opplevd som om heile indremisjonen sitt arbeid var oppe til

58 Ljosstrålar (april 1997) gjev att formannen si grunngjeving for å trekkje seg, under overskrifta «Mange saker - lite misjon». 
vurdering på denne tida. Men i stor grad konsentrerte evalueringa seg om dei ytre formene, slik som til dømes måten ein organiserte stolane på.59 Mange viktige underliggjande faktorar verkar ikkje å ha blitt særleg problematisert. Dette gjaldt til dømes lojaliteten til Den norske kyrkja, innsats i denne i tillegg til på bedehuset, takhøgda for ulike bibeltolkingar, avhengigheit av eksterne predikantar, kjønnsroller, gjennomføring av tradisjonsrike tilstellingar, den totale arbeidsbelastninga for misjonsfolket, forståinga av «venesamfunnet», fråhaldskravet og ideala om nøysemd og offer. Det store biletet er at organisasjonen ikkje satsa på eller makta å utvikle dei nære fellesskapa som var sjølve ryggrada i arbeidet. I staden brukte dei energien på å starte nye tiltak på mange kantar. «Supplere ikkje fjerne» var overskrifta på ein artikkel i Ljosstrålar om nytenking på Sandane bedehus. ${ }^{60}$ Dette høver godt som hovudoverskrift over den strategien organisasjonen la seg på. Ikkje berre var organisasjonen tydeleg på at dei var eit supplement til Den norske kyrkja, men òg at nye tiltak skulle supplere, ikkje erstatte, dei eksisterande. Alle desse supplerande tiltaka skulle så fyllast med frivillige, som skulle kome frå dei foreiningane som var i ferd med å døy ut. ${ }^{61}$ Dette var eit reknestykke som ikkje gjekk opp.

Midt oppe i alle dei andre utfordringane var det mykje diskusjon i organisasjonen når det gjaldt om ein skulle slå seg saman med andre. Styret i Nordfjord indremisjon arbeidde for ein fusjon med Sunnford indremisjon, men mange i Nordfjord var redde for at dette kunne føre til mindre nærleik til det lokale arbeidet. ${ }^{62}$ Til slutt stemte generalforsamlinga i Nordfjord indremisjon nei til ei samanslåing med Sunnfjord indremisjon, men ja til samanslåing med ytremisjonsorganisasjonen Santalmisjonen..$^{63}$ Uansett rulla prosessane vidare nasjonalt, og heile Indremisjonsselskapet og Santalmisjonen blei slått saman til Normisjon frå 2001. Då var det heller ikkje krefter att til å kjempe mot samanslåinga med Sunnfjord indremisjon og Santalmisjonen. Nordfjord indremisjon

\footnotetext{
59 Ljosstrålar, mars 1998, under overskrifta «Ikkje i buss på bedehuset».

60 Ljosstrålar, mars 1998.

61 Langhelle (2006, s. 143) observerer at «kring tusenårsskiftet var det gamle venesamfunnet, basis og ryggmarg for alt det andre, i ferd med å bli sterkt svekt og mange stader i ferd med å døy ut.»

62 Ljosstrålar, desember 1998.

63 Ljosstrålar, mai 1999.
} 
avslutta 122 år som som eigen organisasjon i 2001, og gjekk inn i Normisjon Sogn og Fjordane. ${ }^{64}$

\section{Avslutning}

Årsakene til at den breie folkerørsla Nordford indremisjon enda opp som små grupper av trufaste, er mange, og dei er fleire og meir samansette enn denne artikkelen har rom for. Å skulde på fenomen som «sekularisering» eller «avkristning» blir fort uklart og uspesifikt. Men dei store samfunnsendringane frå 1960-talet var heilt klart ein viktig faktor. Biltransporten og samlinga av servicefunksjonar i kommunesentera rokka ved det gamle grendefellesskapet, men indremisjonen heldt fast på møteformer og organisasjonsformer som hadde fungert då avstandane var mindre og alle visste kven alle var. Indremisjonsarbeidet i meir sentrale strøk vaks ikkje i takt med innbyggartalet der. Den aukande mobiliteten og tilgangen til utdanning gjorde òg at mange reiste bort for vidaregåande, høgskule- eller universitetsutdanning. Mange kom ikkje tilbake til Nordfjord, eller dei valde bort trua, eller den varianten av tru som dei hadde vakse opp med. Det fanst sjeldan noko i byane som svara heilt til indremisjonskulturen i Nordfjord. Dermed ville mange potensielle indremisjonsarvtakarar, dei som både heldt på trua og vende heim til Nordfjord, ha fått ei endra forståing av kva kristendom var og korleis kristent arbeid kunne fungere.

Indremisjonen sin grunnleggjande «forretningsidé» var å skape tette, kristne fellesskap rundt i bygdene, som i sin tur kunne vere basis for nye vekkingar. Historia om tilbakegangen for indremisjonen i Nordfjord er derfor i all hovudsak historia om manglande rekruttering og utvikling i desse grunncellene. Av lojalitet til det som hadde fungert under tidlegare vekkingar, blei ikkje formene, språket, ideala eller arbeidsmetodane på lokalplan endra i særleg grad. Av lojalitet til Den norske kyrkja var det uaktuelt å vidareutvikle lokalforeiningane til forsamlingar som likna dei

64 Ljosstrålar, april 2000. Krinsbladet fortel at heile dette historiske møtet blei gjort unna på 20 minutt. Dette blir forklart som harmoni. Resignasjon er vel kanskje ei vel så god forklaring. Evenshaug (2019, s. 95) beskriv mismot og kjensle av toppstyrt prosess som årsaker til at indremisjonsfolk ikkje stemte mot fusjonen. 
i byane. Nytenking blei kanalisert inn i tiltak på sida av foreiningane, ofte på regionalt plan.

Den generasjonen som begynte å bli gamle midt på 1980-talet, heldt gjerne fast på offeret som ein viktig bit av sin idealisme. Dei hadde opplevd vekkingane, dei hadde tru på at det same skulle skje på nytt, og dei gav så det monna av både tid og pengar. Generasjonane som kom etter, var meir pragmatiske idealistar. Dei var i aukande grad på jakt etter noko som fungerte, og det dei gjerne kunne sjå at fungerte av kristeleg arbeid i byane, fann dei ikkje att $\mathrm{i}$ indremisjonen.

Dermed kunne inntekter og aktivitetsnivået til Nordfjord indremisjon vere på topp rundt 1985, men derfrå gjekk det nedover. Etter kvart som utfordringane blei tydelege, reagerte indremisjonen med å setje i gang mange tiltak som låg litt i randsona av det dei hadde drive med før. Men rekrutteringa av frivillige til nye tiltak skulle skje frå dei foreiningane som ikkje fornya seg, verken i form, tal eller i alderssamansetning. Utover 1990talet var dermed krava til nokon som ville engasjere seg i indremisjonen at ein, i tillegg til å møte opp på småmøte og vanlege bedehusmøte, burde vere engasjert i kyrkja, gjerne gjennom soknerådsarbeid, i ulike indremisjonstiltak som leirarbeid, fotballcup eller retreatsamlingar, og gjerne i styrearbeid både på lokalt og regionalt plan. Å vere kristen på indremisjonsvis blei å ta ansvar, og ansvarsbyrden på kvar enkelt auka etter kvart som det blei færre att. Med den nye vekta på fritid som vaks fram gjennom 1980- og 1990-talet, blei dermed terskelen for å engasjere seg i indremisjonen stadig høgare. Det hjelpte nok ikkje at indremisjonen var prega internt av krisestemning når det gjaldt både mannskap og økonomi.

Nordfjord indremisjon var fullstendig avhengig av gåver og frivillig innsats frå privatpersonar for å drive. Dermed blir spørsmålet om kvifor det blei så mykje mindre indremisjon, til sjuande og sist om vi kan forstå prioriteringane til den jamne nordfjordingen i arbeidsfør alder utover 1980- og 90-talet. Stadig fleire av desse hadde vore ute og sett seg om i verda, skaffa seg utdanning og nye hobbyar, eller slått seg ned i eitt av dei nye sentrale byggefelta, slik at berre etternamnet fortalde om heimgrenda der barndomens bedehus stod. Og, som vi har sett, fanst det mange grunnar til at folk i desse situasjonane var mindre interesserte i å gje pengar og tid til indremisjonen enn før. 


\section{Bibliografi}

Berger, P. L. (1967). The sacred canopy - elements of a sociological theory of religion. New York: Anchor Books /Random House.

Evenshaug, O. (2019). Fra indremisjon til Normisjon: Et kritisk blikk på en fusjon. Drammen: Gunnerius forlag.

Granerud, S. (2017). Forsamlinger og menigheter. I K. Jørgensen, T. Seierstad, S. Granerud \& D.-H. Eriksen, Misjon i bevegelse (s. 74-87). Oslo: Luther.

Hellevik, O. (1996). Nordmenn og det gode liv: Norsk monitor 198-1995. Oslo: Universitetsforlaget.

Høeg, I. M. (2010). Religion og alder. Kirke og Kultur, 4, 331-337.

Kleppa, H. (2013). Intervju om Skavøypoll bedehus. (24.9.2018) Fylkesarkivet i Sogn og Fjordane, Kulturhistorisk leksikon. Henta frå: https://leksikon.fylkesarkivet.no/ article/bdcb5a9c-3572-426b-a13e-a215ao8f91f8/

Langhelle, S. I. (2006). Frå religiøst fellesskap til personlege val. I K. Helle (Red.), Vestlandets historie, bind 3 - Kultur (s. 106-145). Bergen: Vigmostad \& Bjørke.

Nordfjord indremisjon. (1937-2000). Ljosstrålar - organ for Nordfjord krins av Det norske lutherske indremisjonsselskap og Nordfjord folkehøgskule. Selje/Sandane: Nordfjord krins av Det norske lutherske indremisjonsselskap og Nordfjord folkehøgskule.

Nordfjord indremisjon. (1950-2000). Årsmelding for Nordford krins av Det norske lutherske indremisjonsselskap. Sandane: Nordfjord krins av Det norske lutherske indremisjonsselskap

Nordfjord indremisjon. (1987-1994). Protokoll for krinsstyret.

Redse, A. (2015). Kultur og kulturanalyse - trusfridom og dialog. Volda: Høgskulen i Volda.

Repstad, P. (1984). Fra ilden til asken - en studie i religiøs passivisering. Oslo: Universitetsforlaget.

Seland, B. (2006). Religion på det frie marked - folkelig pietisme og bedehuskultur. Bergen: Høyskoleforlaget.

Seland, B. \& Aagedal, O. (2008). Vekkelsesvind, den norske vekkingskristendommen. Oslo: Samlaget.

Sørbø, J. I. (1985). Blomsterbarn i kyrkja. Oslo: Det norske Samlaget

Tjomsland, A. (2018). Bedehusarvingar - Nordford indremisjon 1970-20oo. Masteroppgåve: Høgskulen i Volda.

Utnem, E. (1966). Visitas på bedehuset. Oslo: Vårt Lands Forlag.

Wergeland, N. (Red.) (1979). Nordfjord indremisjon 100 år, bakgrunn og framvokster 1879-1979. Sandane: Nordfjord Indremisjon.

Aagedal, O. (1988). Rapport frå Bedehusland. Oslo: Samlaget.

Aagedal, O. (2003). Bedehusfolket - Ein studie av bedehuskultur i tre bygder på 1980og 1990-talet. Trondheim: Tapir. 



\title{
KAPITTEL 9
}

\section{I kjølvannet av varme vinder - Weenaas og vekkelsen}

\author{
Åsa Thorstvedt
}

Klepp frikyrkje

Sammendrag: I 1889 ble August Weenaas sokneprest i Volda, der han ble en av hovedpersonene i en konflikt som nådde sitt toppunkt når to lærere ble oppsagt på grunn av at de hadde deltatt i fri nattverd. Weenaas var blitt påvirket av haugiansk vekkelse i tidlig ungdom, og studerte teologi under professor Gisle Johnson. I mange år arbeidet han med utdanning av prester for norske kirker i USA. I Volda prøvde Weenaas å få kontroll over en vekkelsesbevegelse, men tapte til slutt slaget. Artikkelen drøfter Weenaas' handlingsmønster og motiver i lys av hans tidligere erfaringer og av hans teologiske kompromissløse overbevisning.

Nøkkelord: Haugiansk, roseniansk, vekkelse, USA, sokneprest, konflikt, Volda

\section{Innledning}

I løpet av det siste årtiet av 180o-tallet meldte over 200 mennesker seg ut av statskirken i Ørsta og Volda (Handeland, 1966, s. 241f.). Det er et oppsiktsvekkende høyt tall, og i hendelsenes sentrum står blant annet presten August Weenaas og hans handlingsmønster overfor deltakere i fri nattverd. Flere hendelser kan forklare årsaken til det store mengden utmeldinger, men nattverdsstriden initierte nok i høy grad det som så ville komme.

I ettertid har August Weenaas blitt beskrevet i både mer fordelaktige og i mindre flatterende ordelag. Han er også blitt tillagt både motiver

Sitering av denne artikkelen: Thorstvedt, Å. (2020). I kjølvannet av varme vinder - Weenaas og vekkelsen. I B. Løvlie, P. Halse \& K. Hatlebrekke (Red.), Tru på Vestlandet. Tradisjonar i endring (Kap. 9, s. 217-230). Oslo: Cappelen Damm Akademisk. https://doi.org/10.23865/noasp.104.ch9

Lisens: CC BY-ND 4.0. 
og holdninger som ikke harmonerer med verken hans bakgrunn eller personlige overbevisning. På den ene siden beskriver kristendomshistorikeren Oscar Handeland ham både som en markant luthersk teolog og som et pliktmenneske, sterk og stø (Handeland, 1966, s. 217), og skolehistorikeren Peder Bergem omtaler ham som en lærd mann (Bergem, 1998, s. 82). I Kjell Skorgeviks studie av det religiøse livet på Sunnmøre 1880-190o er Weenaas framstilt som en teolog med solid forståelse for det som preget lekmannsforkynnelsen i dette tidsrommet, men med en vaktsom holdning overfor separatistiske tendenser, som han mente hadde utspring i antinomisme (Skorgevik, 1974, s. 60). Samtidig er Weenaas også blitt beskrevet med mer negative penselstrøk, som «den stiveste av alle statskirkeprester, den personifiserte lekmanns-motstanderen» (Handeland, 1966, s. 218), og dette er nok også det ettermælet som henger igjen i lokalsamfunnet i dag (Bergem, 1998, s. 82), kanskje særlig i de frikirkelige miljøene. Et skrift av to lokale forfattere tillegger f.eks. Weenaas en «personlig aggresjon» (Rusten \& Hovdhaugen, 2016, s. 26) som motiv for måten han møtte dem som ønsket fritak fra skriftemål før nattverd. To så ulike vurderinger kan ha mange årsaker, men én viktig forskjell består i ulikt utgangspunkt: den positive framstillingen av Weenaas framhever hans teologiske innsikt og fasthet, mens den negative er av mer psykologisk eller relasjonell art, med vekt på hans konfronterende handlingsferd i en konfliktsituasjon.

Konflikten som Weenaas ble involvert i mens han var sokneprest i Volda, nådde et høydepunkt da to lærere der ble sagt opp i 1892 på grunn av deres deltakelse i fri nattverd. Denne historien er også sentral i et annet kapittel i denne boka (Løvlie, 2020), men med tanke på den rollen som Weenaas spilte, er det grunn til å undersøke hvilke teologiske og erfaringsbaserte motiver som skapte den overbevisningen han møtte vekkelsen med. Det er dette denne artikkelen vil svare på.

For å kunne svare på hvem Weenaas var og hvordan vi skal kunne forstå hans forhold til og handlingsmotiv på konkrete uttrykk av vekkelsens vinder, vil artikkelen både ta for seg Weenaas' teologiske ståsted, hans utvikling i studietida og hans erfaringer fra tjenesteåra i Amerika. De stridsspørsmålene han levde med der, blir belyst både ut fra hans egne og hans motparts skrifter. Artikkelen vil videre skildre nattverdsstriden på 
bakgrunn av dette. Artikkelen er delt i to: Weenaas sitt møte med vekkelsen og Vekkelsens møte med Weenaas.

\section{Weenaas sitt møte med vekkelsen}

August Weenaas ble født i 1835 og hadde sine leveår gjennom alle de store omveltningene Norge gikk igjennom særlig under andre halvdel av det 19. århundre. Weenaas studerte under professor Gisle Johnson, som underviste i systematisk teologi ved Universitetet i Kristiania. Gjennom Johnsons virke som predikant møtte Weenaas vekkelsen på nært hold og opplevde en personlig omvendelse som endret hele hans måte å tenke og leve på. Han virket som prest og prestelærer i et Amerika som tok imot hundretusentalls nordmenn som søkte lykke, rikdom og frihet - og der prestens rolle var helt annerledes enn i hjemlandet. Weenaas måtte stå $\mathrm{i}$ harde konfrontasjoner og $\mathrm{i}$ åpne konflikter - først i Amerika - så i Norge. Han mistet sin store kjærlighet og mange av barna sine på veien. Og så avslutter han yrkeslivet sitt på et lite sted hvor han karakteriserer dagene sine som Det gik sin joevne, rolige Gang. Historien om Weenaas er historien om en mann som aldri gikk på akkord med sin samvittighet, uansett prisen han måtte betale.

\section{Hva skjer' a i Skjeberg?}

Som ung mann bodde og arbeidet Weenaas på en prestegård i Skjeberg som privatlærer i to perioder. Begge oppholdene ble av livsavgjørende betydning. Første gang resulterte besøket i beslutningen om å studere teologi, som igjen førte ham videre inn i et livsvarig prestekall (Weenaas, 1935, s. 32ff.). I den andre arbeidsperioden møtte Weenaas vekkelsen på nært hold gjennom «De Vakte». De var etter hans hjerte. Weenaas skriver selv at han følte han manglet noe når han så på denne skaren og det de eide; glede, kjærlighet og fred. En vårdag ble han selv møtt av Gud, og etter den skjellsettende opplevelsen var han helt forandret. Weenaas definerer selv dette som sin omvendelse der hele hans tankesett ble snudd opp ned. Han fikk en ny vennekrets og hans ønske og fokus ble dette ene; sjelenes frelse og fred med Gud (Weenaas, 1935, s. 43ff.). 


\section{Teologi og nytt liv}

Tilbake på teologistudiet var Weenaas en ny mann. Han tilbrakte all ledig tid til studier, bønn og annen oppbyggelig aktivitet. Han hadde alltid likt undervisningen til professorene Gisle Johnson og Carl Paul Caspari, og nå opplevde han at den var full av Guds Ånd. Den store vekkelsen som gikk over Kristiania i 1850-åra, er gjerne omtalt som den johnsonske vekkelsen, og mange kommende prester ble en del av bevegelsen som fulgte (Elstad, 2000; Løvlie, 2020). Etter hvert som studentene ble uteksaminert, spredte vekkelsen seg til det ganske land godt fundamentert i Skriften og bekjennelsen.

Gjennom sitt arbeid i et kristent blad kom Weenaas også i kontakt med svensk oppbyggelseslitteratur og ble gjennom den kjent med Rosenius og hans teologi. Weenaas anerkjente Rosenius' lære i høy grad, men var kritisk til Rosenius' manglende vekt på sakramentenes plass og hvordan den subjektive erfaringen, ifølge Weenaas, ble tillagt større vekt enn det objektive fundamentet.

Mot slutten av studietida ser vi enda en konsekvens av Weenaas omvendelse; alvoret og det tunge ansvaret det lå over prestegjerningen. Han følte seg altfor ung og umoden til å gå inn i en så viktig rolle, og dette resulterte i en utsettelse av inntredelse i presteyrket (Weenaas, 1935, S. 50 ff.).

\section{Gisle Johnson og Gisle Johnson}

Gisle Johnson var uten tvil et stort forbilde for August Weenaas. De hadde det samme teologiske grunnsynet og Weenaas velger, som Johnsen, å reise på en lengre studietur til Erlangen. Weenaas var også svært begeistret over Johnsens undervisning (han skriver faktisk at ingen andre professorer kan måle seg med denne) og brukte også notatene fra Johnsons undervisning da han selv ble professor ved presteseminaret Augustana Seminary (Weenaas, 1890, s. 15, 25). Johnsons teologi var preget av en pietistisk grunnholdning der den personlige omvendelsen var et sentralt element. Johnson ønsket lekmannsbevegelsen velkommen samtidig som han mente at en vekkelse må skje innenfor kirkens murer. Det var nettopp dette som skjedde i den johnsonske vekkelsen: personlige omvendelse, 
oppreisning av lekfolket, innenfor kirkens vegger. Som et kuriosum kan også nevnes at Weenaas høye aktelse for Johnson også gjenspeilet seg i hans eget hjem; han navnga sønnen sin Gisle Johnson (Weenaas, 1935, s. 164; Haanes, 2003, s. 105).

\section{Nød bryter alle lover}

For å forstå Weenaas og hans tilknytning til Johnsons teologi må vi også kjenne til opprettelsen av Lutherstiftelsen og utarbeidingen av nødsprinsippet. Gisle Johnsen var Lutherstiftelsens første formann. Organisasjonens hovedoppgave var å spre kristen oppbyggelig litteratur, og dette skjedde oftest ved at utvalgte menn, kalt bibelbud eller kolportører, reiste rundt og solgte bøker. I anledning besøkene hadde de gjerne egne samlinger. For at disse samlingene ikke skulle komme på kollisjonskurs med prestens jurisdiksjon, ble «nødsprinsippet» utformet med en argumentasjon at mangel på forkynnelse hadde skapt en nødssituasjon i kirken (Molland, 1979, s. 247ff.). Det ble en måte å finne en både praktisk og akseptabel løsning på lekmannsforkynnelsen uten å samtidig utfordre embetets posisjon og autoritet. Nødsprinsippet ga lekfolket en mulighet til å virke som forkynnere, samtidig som det var tydelig definerte premisser for denne ordningen. Det ble en måte for kirken å organisere lekfolket på, og derfor også i praksis en måte å kontrollere dem på. ${ }^{1}$

\section{Møtet mellom det gamle og det nye}

Før Weenaas flyttet til Amerika for første gang, tjenestegjorde han blant annet som lærer i Ålesund. Allerede her kom Weenaas i sin første konflikt. Han opplevde at den lokale presten var fiendtlig innstilt til den johnsonske vekkelsen, og Weenaas karakteriserer hans prekener som tomme, ikke-oppbyggelige og dermed utilfredsstillende. Weenaas omgangskrets besto av lekfolk fra indremisjonen, og når han oppdaget at mange

Det spente forholdet mellom Gisle Johnson og den radikale lekmannsbevegelsen blir utdypet i Løvlie (2020). 
mennesker ikke hadde mulighet til å komme seg til kirken startet han opp bønnemøter på fattighuset. Disse søndagsmøtene ble svært populære og det drøyde ikke lenge før presten sendte politiet for å stenge bygningen. Bønnemøtene fortsatte da i et privat lokale. Men siden de besøkende bare $ø$ ket i antall, ble det besluttet å bygge et bedehus hvor Weenaas ble formann. Bedehuset virket samlende for de kristne i området og tilskyndet til samarbeid mellom lekfolket og kirken. For Weenaas var det også et viktig anliggende at samarbeidet bidro til å holde de ikke-lutherske forsamlingene borte (Weenaas, 1935, s. 65).

\section{Erfaringer fra frihetslandet}

Weenaas første periode i Amerika var åtte år med gleder, engasjement, flytting og grunnleggelse av et presteseminar. Men det var også åtte år med sorger, anklagelser, åpne konflikter og indre og ytre splid. På grunn av den store norske emigrasjonen til Amerika meldte det seg etter hvert et stort behov for prester - og videre prestelærere for å kunne utdanne sine egne prester. Det var ikke ett norsk luthersk kirkesamfunn, men flere, og de var nokså uenige både i teologi og uttrykk. De var også uenige innad i de ulike kirkesamfunnene, eller synodene som de kalte seg, og de delte seg etter hvert i flere og flere synoder.

Weenaas ble først ansatt som lærer ved Augustana-synodens presteseminar i Marshall, Wisconsin. Han hadde tidligere fătt tilbud om å jobbe for Den norske synode, men det hadde vært helt uaktuelt (Weenaas, 1935, s. 98). Dem var han grundig uenig med, både i slaverispørsmålet og i synet på lekmannens plass og rolle (Weenaas, 189o, s. 3 ff.). Augustana-synoden var et svensk-norsk samarbeid, men kort tid etter hans ankomst fikk de norske studentene eget presteseminar. Videre skulle selve synoden også separeres slik at det ble en ren norsk synode (Helland, 1920, s. 25f.). Dette skjedde ikke uten dramatikk og endte med at det ble opprettet to nye norske synoder, der Weenaas ble en del av Konferentsen. Lokalene til presteseminaret ble overtatt av den andre grupperingen, og derfor sto nå Weenaas plutselig uten lokaler. De fant en midlertidig løsning, samtidig som de arbeidet for å kjøpe en ny eiendom. I 1872 var et nytt presteseminar på plass i nye lokaler i Minneapolis, med Weenaas som eneste 
lærer. Han rekrutterte først Svein Oftedal, og ikke lenger etter rekrutterte de sammen Georg Sverdrup og Sven Gunnersen (Hamre, 1986, s. 42f; Weenaas, 189o, s. 29ff, 54, 61). Dette var Weenaas svært fornøyd med i starten, men det tok ikke lang tid før det begynte å skurre både teologisk og relasjonelt mellom Weenaas og hans ny kollegaer.

Weenaas fortsatte også sin kamp mot Den norske synode. Sammen med Oftedal skrev han en uttalelse hvor de sammen redegjorde for sine synspunkter angående Den norske synode, Aaben erkloring der de legger fram «wisconsinismen» som de mente at Den norske synode sto for. Erklæringen konkluderer med at de like lite kan forsones med Den norske synode som Kristus kan forsones med Belial (Weenaas \& Oftedal, 1894, s. 3ff.). Denne uttalelsen gikk ikke upåaktet hen i fedrelandet Norge. Men til Weenaas store sorg fikk han ikke støtte i sin argumentasjon. I stedet for å legge vekt på de anliggender som han og Oftedal la fram, fikk de heller kritikk i hjemlandet for å skape splid mellom de norske lutherske kirkesamfunn i Amerika (Schielderup, 1875; Preus, 1875; Schielderup, 1875). Weenaas kjente seg nok misforstått og skrev derfor en ny redegjørelse som ble trykt to år senere, Wisconsinismen belyst ved historiske Kjendsgjerninger. I denne utgivelsen prøvde han å skrive sitt anliggende på en mildere måte, samtidig som han fortsatt var tydelig på hva han anså som åpenbart ubibelsk i læren til Den norske synode. Håpet om at det teologiske miljøet i Norge nå både ville se og forstå, ble ikke innfridd (Weenaas, 1876; Weenaas, 1935, s. 154). Ny debatter ble skapt, og nye utgivelser med motargument ble trykket (Muus, 1879). Ryktet han skapte gjennom denne kampen, bar han med seg når han så flyttet hjem til Norge igjen.

Gjennom Weenaas' første åtte år i Amerika fikk han store og dyrekjøpte erfaringer av teologisk uenighet, personlige konflikter og trusler om kirkelige splittelser. Det er også viktig å være klar over at menighetsforståelsen som Weenaas møtte, var vokst fram i et land der religiøs og politisk frihet var høyt aktede verdier og der lekfolket hadde måttet grunnlegge og styre menighetene uten hjelp av et geistlig overhode. I dette nye landet hadde presten liten eller ingen formell innflytelse i samfunnet, og i den lokale menigheten møtte han et myndiggjort lekfolk. Dette var noe Weenaas oppmuntret, og et av hovedpoengene i hans kritikk av Den 
norske synode var jo nettopp deres undertrykkelse av lekfolket. Weenaas sa eksplisitt at det var ingen han kunne være mer uenig med i verden enn Den norske synode, og om det var noe han virkelig kunne tenke seg å bruke livet på, så var det å kjempe imot denne synoden (Weenaas, 1890, s. 4).

Mens Weenaas første gangen reiste til Amerika for å arbeide i en synode han gav sin teologiske tilslutning til og som han ønsket både å kjempe for å bevare, var hans anliggende i den andre perioden helt annerledes; han bar nå en visjon om å arbeide for en forent norsk-amerikansk luthersk synode. Dette var noe fullstendig annet enn tilnærmingen han hadde i sin første periode. Weenaas var blitt kalt av den haugianske synoden som han i utgangspunkt var noe teologisk uenig med, både i deres overdimensjonerte fokus på den subjektive opplevelsen og deres mangel på kirkeritualer. Men dette var for ham underordnet et viktigere og høyere mål: enhet. Etter seks år i Norge var han nå klar for å reise tilbake til det landet som hadde gitt ham så mange stridssår. Dessverre varte ikke oppholdet så lenge. Weenaas fant tidlig ut at kirkelederne ikke hadde den samme lidenskapen som han når det kom til å arbeide for å forene de ulike norsk-amerikanske kirkene (Weenaas, 1935, s. 18off.). I sine memoarer skriver han at lederne mente at saltet kun kan bevare sin kraft i en lukket krukke (Weenaas, 1935, s. 200). Grunnlaget for oppholdet var ikke lenger til stede, og Weenaas returnerte hjem til Norge for andre gang.

\section{Vekkelsens møte med Weenaas}

Samtidig, i Volda på Sunnmøre, blåste en sterk åndelig vind. Kapellan Johannes Barstad, som også hadde opplevd den johnsonske vekkelsen, ble en del av denne bevegelsen. Barstad beskriver hvordan mennesker i hopetall ble fylt av entusiasme og lidenskap og som med glede møttes til gudstjenester og bønnemøter. Vekkelsen økte i styrke etter at bygda, og kirken, fikk besøk av den rosenianske predikanten Paul Gerhard Sand i 1887. Som en konsekvens av den økte kirkelige aktiviteten tok også Barstad initiativ til å dele inn soknet i tolv områder hvor hvert enkelt område hadde egne møter og dessuten tok ansvar for gamle og syke. Lederne for hvert område, diakonene, møttes til felles bønnemøte med sang og 
bibellesning hver måned (Handeland, 1966, s, 177ff.). Vekkelsesbevegelsen besto ikke av en ensartet gruppe, og etter hvert oppsto det spenninger mellom de forskjellige grupperingene og disse kom til syne under et av diakonmøtene. Dette resulterte i at en av lederne, en klokker, sendte et brev til departementet og ba dem kalle August Weenaas til å tjenestegjøre i Volda i den ledige prostestillingen. August Weenaas var nå tilbake i Norge og må ha vært kjent for voldingene, for i brevet motiverer klokkeren valget med at Weenaas både hadde erfaring med kirkekonflikter og hadde god teologisk kunnskap og fundament (Handeland, 1966, s. 216).

Weenaas takket ja til kallet og kom til Volda i 1889. Den haugianske vekkelsen hadde sveipt over området noen tiår før, men det som møtte Weenaas nå, opplevde han som nyevangelisme. Selv om Weenaas ikke tilsluttet seg alt haugianerne sto for, hadde de i alle fall det samme fundamentet i bekjennelsen som ham. Denne nye bevegelsen hadde ifølge Weenaas ikke dette grunnlaget, men var fundert på subjektivitet og følelser. Til hans store sorg tok kapellanen del i disse aktivitetene (Weenaas, 1935, s. 220f.). I begynnelsen deltok Weenaas på de månedlige diakonmøtene, men det tok ikke lang tid før det avtok (Handeland, 1966, s. 218). Skillet ble nok for stort, både i innhold og form. Uansett var dette bare småplukk å regne, i forhold til det som skulle komme.

\section{Nattverdsstriden}

Ole G. Clausen var en omreisende predikant for indremisjonen og god venn av kapellan Barstad. Gjennom sin bror hadde han blitt kjent med fri nattverd, og i romjula 1891 samlet han noen venner og de delte nattverd sammen. Selv om dette var et lukket møte, spredte ryktet seg til både avis og prost (Handeland, 1966, s. 222f.). Da tok Weenaas affære. Ifølge et skriv fra biskopen fra året før var fri nattverd ulovlig i dobbel forstand. For det første var det i strid mot både kirkeloven og bekjennelsen, og for det andre var det i strid med straffeloven fordi du ved å innstifte nattverden opererte som statlig embetsmann. Samtidig presiserte skrivet at det ikke var ønskelig med rettssak, men at en først gjør nattverdsbryterne klar over at det de gjør er ulovlig og videre ekskluderer dem fra nattverdbordet. Politianmeldelse måtte være siste utvei (Handeland, 1966, s. 225). 
Allikevel velger Weenaas å politianmelde Clausen sammen med en annen, Knut Bjørkedal. Men siden det ikke kunne bevises at de hadde opptrådt som embetsmenn, de hadde bare sendt brød og vin videre til sidemannen, ble ingen av dem siktet. Det andre de hadde kunnet bli dømt for, var om noen hadde blitt lokket inn i det. Heller ikke dette var tilfelle. Rettssaken fikk ingen avskrekkende virkning verken på de to anmeldte eller på skaren rundt dem. De fortsatte åpenlyst å praktisere fri nattverd (Handeland, 1966, s. 225ff.).

En av dem som deltok i samlingene var lærer Nikolai Molvik. Dette fikk Weenaas til å se rødt. Det var én ting at en lekmann deltok i fri nattverd, men at en skolelærer gikk rett imot den lutherske bekjennelsen, det var svært alvorlig. Samtidig hadde en annen lærer, Wilhelm Grytten, angivelig snakket nedlatende om kirken. På spørsmålet om hvorfor de gjenfødte hadde sluttet å gå i kirken, svarte han: «Guds born kan ikkje vera nøgde med svinemask, dei må ha mat for sjelane sine.» (Handeland, 1966, s. 231f.).

\section{Tiden etter striden}

Weenaas, som leder av skolestyret, åpnet da skolesak mot de to lærerne. Barstad prøvde å snakke med Weenaas, men han var urokkelig, og det endte med at begge lærerne ble sagt opp (Handeland, 1966, s. 233ff.). Men også denne gangen ble det tap for Weenaas i epilogen. Et år etter oppsigelsene fikk lærerne oppreisning gjennom en godtgjørelse fra Stortinget. Det hadde kommet en distriktslege flyttende til Volda som tok saken opp politisk. Molvik var død, men hans enke fikk enkepensjon og Grytten fikk vartpenger etter anbefaling fra kirkenemnden hvor flere av medlemmene betvilte lovligheten i oppsigelsene (Handeland, 1966, s. 236).

Samtidig øket trykket blant lekfolket. Det ble arrangert et stort lekmannsmøte i Ålesund i november 1893 der de blant annet reiste spørsmål om det nå var på tide å forlate statskirken, og om statskirkens nattverdsordning egentlig var bibelsk (Handeland, 1966, s. 237f.; Løvlie, 2020). Weenaas selv så på utviklingen med sorg og tilla opprørene kirkefiendtlige motiver: 
Bevægelsen voxte med rivende Fart omkring 1892-1893 og bragte en Række af Ubehageligeder, Bekymringer og Sorger for mig som Sogneprest i Volden. Det artede sig overordenlig brutal og hensymsløs og skjulte ikke det aandelige Hovmod, forenet med Uvidenhedens Fanatisme, som var Bevægelsens inderste Drivkraft. Der blev i Løbet af en Vinter bygget 6 Bedehuse til udelukkende Brug for Bebægelsen og Dissentere, som vankede om i Menighederne. Det Hele var aabenbart anlagt paa at ødelægge vore Menigheder og gjøre vore Kirker tomme. Dette lykkedes dog slet... (Weenaas, 1935, s. 223)

Året etter forlot Weenaas stillingen i Volda. Hans siste del av livet gik sin jovne rolige Gang (Weenaas, 1935, s. 227), som han selv oppsummerte det, og han opplevde å blitt møtt på sitt nye virkested med Imødekommenhed og Venlighed (Weenaas, 1935, s. 228). Tida med konflikter, splid og nederlag var forbi, men ikke glemt. Bitre minner fra tida i Volda er fortsatt tydelig til stede når han skriver: Jeg forlod Volden i Høsten 1895, og et Par Aar efter havde Bevoegelsen raset ud. Flere var blevne Gjendøbere, de fleste var faldne tilbage til det gamle verdslige Voesen, og deres Bedehuse stod tomme, forladte og gjolbundne (Weenaas, 1935, s. 224).

Mer enn å beskrive sannheten om den åndelige situasjonen i området han forlot, tegner denne påstanden et bilde av en både skuffet og såret mann med dyrekjøpte erfaringer. Det ser allikevel ikke ut til at han angrer. Fordi for ham var det et samvittighetsspørsmål.

\section{Konklusjon}

I innledningen løftet jeg fram ulike vurderinger av Weenaas som prest $\mathrm{i}$ Volda, og reiste spørsmålet: Hvem var egentlig Weenaas, og hvordan kan vi forklare hans måte å håndtere en dyptgripende konflikt på?

Jeg har prøvd å tegne en linje gjennom hans liv og i hans bakgrunn. Jeg har pekt på haugiansk påvirkning og hans tilslutning til den johnsonske teologien og vekkelsen. Jeg har videre vist hvordan årene i møte med norsk-amerikansk kirkeliv ga ham erfaringer på godt og vondt og utviklet en lengsel etter, og arbeid for, enhet. Weenaas var pliktoppfyllende og samvittighetsfull. Han var kompromissløs og konfronterende og det satte ham i stadig nye konflikter. 
Det er ingen grunn til å tvile på at Weenaas sin omvendelse i ungdommen både var ekte og dyptgripende. For ham var tro absolutt en hjertesak, og han hadde en sterk overbevisning om et myndiggjort lekfolk og respekt for dem som hadde andre uttrykksformer enn ham. Han ønsket lekmannsbevegelsen velkommen og uttrykte også begeistring over den. Men bevegelsen måtte styres, og det var prestens oppgave i kraft av den myndighet han var blitt gitt. Dette var helt i tråd med Johnsons tenkemåte, men enda viktigere: for Weenaas var det også helt i samsvar med Skriften og bekjennelsen. Og for Weenaas gikk dette foran alt. Han målte alt han gjorde og mente opp imot dette. Han gikk til både Skriften, til Gisle Johnson, til Pontoppidan og til kirkeritualene før han gikk til det skrittet å anmelde de såkalte nattverdsbryterne (Handeland, 1966, s. 224).

Weenaas var ansvarsbevisst og han gikk aldri på akkord med sin overbevisning. Han ønsket vekkelsen velkommen med samme agenda som fra dag én: sjelenes frelse og fred med Gud (Weenaas, 1935, s. 47f.). Selv nyevangelismen med sitt, ifølge Weenaas, altfor sterke fokus på den subjektive opplevelsen lot han passere. Han må ha sett hjertet til den enkelte. Og han hadde smertelige erfaringer av hva indre splittelse kunne føre til. Likevel er det den veien han velger, fordi han var overbevist om at bevegelsens motiv var å skape splid. Som jeg siterte ovenfor: Det Hele var aabenbart anlagt paa at ødeloegge vore Menigheder og gjøre vore Kirker tomme (Weenaas, 1935, s. 223). Og for at det subjektive, det enkelte individs overbevisning, aldri kan heve seg over Ordet, eller bekjennelsen. Og selv om han flere ganger beskrev statskirkeordningen i negative ordelag, de stive statskirkelige Forholde med de store og døde Massemenigheder (Weenaas, 1935, s. 160), så mente han at så lenge stat og kirke var forent, måtte en ta konsekvensene av det og til en viss grad sette religionsfriheten til side.

Dette var også veien kapellanen Johannes Barstad til slutt måtte velge. Også for ham ble prisen høy. Både Clausen og de andre som praktiserte fri nattverd, var hans venner, og vekkelsen hadde forandret ham dypt. Og selv om han mente at fri nattverd i utgangspunktet var i tråd med Skriften, tok han avstand fra praksisen fordi det var ulovlig og dermed splittende. Dette kostet ham vennekretsen. For dem var han en forræder. 
Weenaas var en johnsoniansk prest. Han mente at kristentroen måtte springe ut fra en personlig omvendelse og bygge på et personlig standpunkt. På dette grunnlaget kommuniserte han også godt med det haugianske samfunnet i Amerika. Men mens hans motiv for sin andre Amerika-reise var å bygge kirke, også i økumenisk forstand, ble oppgaven når han kom tilbake til Norge noe helt annet. Her møtte han en statskirke med gryende reformarbeid og en voksende lekmannsbevegelse som ikke ville underlegge seg prestens autoritet $\mathrm{i}$ kraft av hans embete. Vi ser en mann som desperat prøver å effektuere både en teologi og en praksis som tilhørte tidligere tider. Å være en del av det haugianske kirkelivet i Amerika hadde vært et kall for Weenaas, mens det umulige i å finne en felles plattform og enighet med tilhengerne av vekkelsen med utspring $\mathrm{i}$ det haugianske i Volda kanskje ble hans største nederlag. Han fortsatte dog hele livet å utfordre sine sognebarn til å bli sanne disipler med en personlig tro. Med Bibelen og bekjennelsen som et absolutt fundament.

\section{Litteraturliste}

Bergem, P. (1998). Henrik Kaarstad og Volda loerarskule. Volda: Møreforsking. Elstad, H. (2000). «en Kraft og et Salt i Menigheden»: ein studie av dei såkalla «johnsonske prestane» $i$ siste halvpart av 180o-talet $i$ Noreg. Oslo: Unipub forlag.

Hamre, J. (1986). Georg Sverdrup. Educator, theologian, churchman. Northfield: Norwegian-American Historical Association.

Handeland, O. (1966). Vårløysning bind II. Bergen: A.S Lunde \& Co.s forlag. Helland, A. (1920). Augsburg Seminar gjennem femti aar 1869-1919. Minneapolis, Minnesota: Folkebladet Publishing Companys Trykkeri.

Haanes, V. (2003). Pastors for the congregations: Transatlantic impulses. I T. W. Nichol (Red), Crossings. Norwegian-American Lutheranism as a transatlantic tradition (s. 93-118). Northfield: The Norwegian-American Historical Association.

Løvlie, B. (2020). Bedehus, vekkelse og bevegelse. I Løvlie, Halse \& Hatlebrekke (Red.), Tru på Vestlandet. Tradisjonar i endring. Oslo: Cappelen Damm Akademisk.

Molland, E. (1979). Norges kirkehistorie i det 19. århundre bind I. Oslo: Gyldendal Norsk Forlag.

Muus, B. J. (1879). Falskt Vidnesbyrd. Decorah, Iowa.

Preus, A. C. (1875). Den "aabne Erklæring", Kritikken derover i "Luth. Kirketidende" og Hr. Pastor G. Schielderup. Luthersk kirketidende, 12(17), 17-24. 
Rusten, H. \& Hovdhaugen. (2016, 1. julli). Men Gud gjorde ingen feil - Det frie kristenliv i Volda og Ørsta frå 1893 til 1983. Sauluspaulus.no. Hentet fra https:// www.sauluspaulus.no/mengudgjordeingenfeil.pdf

Schielderup, G. (1875). Nogle Modbemerkninger til Provst Preus. Luthersk kirketidende, 12(22), 27-32.

Schielderup, G. (1875). Professorerne Oftedals og Weenaas's "aabne Erklæring". Luthersk kirketidende, 12(12), 12-18.

Skorgevik, K. (1974). «Sandstormen». Trekk fra det religiøse liv på Sunnmøre i åra 1880-190o. Hovedfagsoppgave i kristendomskunnskap ved Universitetet i Oslo.

Weenaas, A. \& Oftedal, S. (1894). Aaben Erkloering. Minneapolis: Folkebladets trykkeri.

Weenaas, A. (1935). Livserindringer fra Norge og Amerika. Bergen: A. S. Lunde \& Co.s forlag.

Weenaas, A. (1890). Mindeblade eller Otte Aar i Amerika. Volden: R. P. Hjelles Forlag.

Weenaas, A. (1876). Wisconsinismen belyst ved historiske Kjendsgjerninger. Chicago: Skandinavens Bog- Og Accidens Trykkeri. 


\section{KAPITTEL 10}

\section{Det kulturkristne Hareid i det pietistiske Sunnmøre}

\section{Leidulv Øyvind Grimstad}

Møre bispedømme

Samandrag: Artikkelen presenterer Hareid-samfunnet si utvikling innan kristenog kulturlivet frå 1850-åra, som tok ei anna retning enn elles på Sunnmøre. Der var det den pietistiske lekmannsrørsla som var dominerande. I Hareid vart den grundtvigianske retninga førande: Menneske først - så kristen. Ein av dei som bidrog til denne utviklinga var Lars Hareide (1828-1900), som i 1857 tok til i Hareid som skulemeister. Han hadde gått på Stord lærarskule og var inspirert av Grundtvig si kristendomsforståing og pedagogikk. Etter kvart kom det to lærarar til med same ideologi. Desse, saman med prost Anker (1848-1921), fekk avgjerande betyding for utviklinga av kristen- og kulturlivet i bygda.

Nøkkelord: pietisme, kulturkristen, grundtvigiansk, kor

\section{Innleiing}

«Dokke frå Hareid er ikkje personlege kristne, men kulturkristne!» Denne utsegna blei eg møtt med i møte med det kristne skulelagsmiljøet då eg kom til Volda på gymnas i 1970.

Kva som eigentleg låg i desse omgrepa var for meg uklart. Personleg kristen og kulturkristen, to variantar av kristent livssyn, på mange måtar ein kulturkonflikt mellom ei pietistisk retning med vekt på personleg omvending og strenge reglar for livsstil, og ein meir kulturopen 
grundtvigiansk retning i våre bygder. ${ }^{1}$ Eg fann det difor interessant å finne ut meir ut emnet. Denne utsegna om personleg kristen og kulturkristen har eg belyst i mi masteroppgåve: Det kulturkristne Hareid i det pietistiske Sunnmøre. ${ }^{2}$

Kjeldematerialet har vore protokollar for ulike lag heilt frå $1847 \mathrm{og}$ fram til i dag. Også bygdebøker, jubileumsskrift og samtalar med eldre folk er kjelder. Masterarbeidet har avdekt at kristenlivet i Hareid skil seg ut $\mathrm{i}$ hve til dei andre bygdene rundt på Sunnmøre.

Ein av dei tinga som mellom anna forbausa meg då eg som elev kom ut $i$ verda, var forbodet mot sketsj på indremisjonen sitt bedehus i Volda. Og eg hugsa at vaksne folk forlét bedehuset på Vatne under ein programkveld som skulelagskoret Vårvon ${ }^{3}$ i Volda hadde der. Då spelte eg i ein sketsj. Eg hadde no «vakse opp» på bedehuset på Hareid. Her hadde vi alltid underhaldning med sketsj og anna moro, i tillegg til forkynning, og meinte meg både som ein bedehusgut og personleg kristen.

I denne artikkelen vil eg leggje fram moment som har ført til begrepet Det kulturkristne Hareid, og korleis utviklinga frå midten av 1850-åra og fram til vår tid har vore. Eg vil særleg sjå etter kven som har vore sentrale i utviklinga av lekmannskristendommen i Hareid og deira bidrag til det som vart særpreget her. Derfor vil eg presentere personar i Hareid som har vore sentrale i forminga av kyrkje- og kulturliv i bygda. Vidare vil eg sjå på ulike lag og organisasjonar og deira bidrag til det kulturkristne Hareid.

\section{Arven etter Gamleklokkaren og hans medhjelpar}

Kristenlivet i Hareid har heilt sidan 1857 vore prega av ei grundtvigiansk kristendomsforståing. Det klassiske slagordet for Grundtvig; Menneske først, så kristen, har vore tonegivande i bygda.

Det kan vere vanskeleg å bestemme ein start på historia. I mitt arbeid går eg tilbake til om lag midten av 180o-talet. I 1828 blei Lars Fredrik

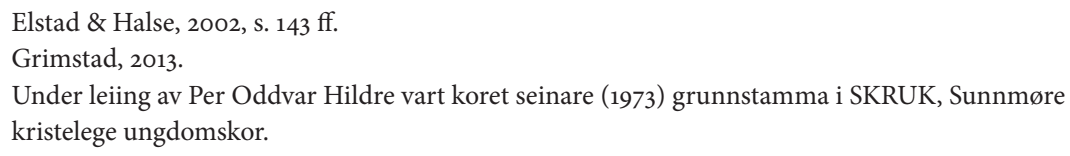


Hansson Hareide fødd. Han gjekk på Stord Lærarskule i 1855-57. Der fekk han syn for Grundtvig si kristendomsforståing og hans pedagogikk. Han kom tilbake til Hareid i 1857 og blei tilsett som lærar, klokkar og kyrkjesongar i Nedre Hareidsdalen. I tillegg fekk han mange andre verv, både frivillige og offentlege. Etter sin død fekk han heiderstittelen Gamleklokkaren.

Lærarane hadde i den tida ei særskild stilling i bygdesamfunna, og var ofte nest etter presten. Lars Hareide var ikkje noko unntak. Han hadde ei djup forankring i si kristne tru, var ein varm forkynnar og nær knytt til kyrkja.

Om lag samstundes med at Hareide blei tilsett som lærar i Hareid, var presten Carl Anton Madsen (1811-1902) sokneprest i Ulstein prestegjeld i 1855-1874. Han òg var grundtvigianar. Med den felles grundtvigianske kristendomsforståinga er det truleg at dei arbeidde godt saman.

Lars Hareide vart ein representant for det som seinare kom til å bli eit omgrep: vestlandslæraren, ${ }^{4}$ men han skilde seg likevel ut på eit felt. Magnulv Bjørndal (1913-200o) omtalar han som teologisk ortodoks med eit konservativt politisk kyrkjesyn: Han likte ikkje den store lekmannsvekkinga med det rosenianske og nyevangeliske synet som til dømes vekkingspredikant Paul Gerhard Sand (1848-1911) hadde rundt om på Sunnmøre i 1880-189o, den såkalla Sandstormen. Denne vekkinga fekk heller ikkje så stor innverknad i Hareid.5 At kristenlivet i Hareid ikkje utvikla seg slik som i dei andre bygdene på Sunnmøre, meiner eg har å gjere med kven som kom i sentrale posisjonar i bygda. Klokkar og kyrkjesongar Lars Hareide var eit godt døme på det. Han hadde eit godt samarbeid med presteskapet, og i 1881 tok han saman med prost Anker, som eg vil presentere seinare, initiativ til indremisjonsforeining i Hareid. Lars Hareide utarbeidde lovutkast til ei slik foreining som vart stifta i

4 Grundtvigianismen prega pedagogikken ved lærarskulane i andre halvdel av 180o-talet. Til dømes arbeidde lærarskulen i Volda etter denne pedagogikken med norskdom, målsak og fråhaldssak. Skulen hadde blant anna eigen IOGT-losje og mållag. Rekrutteringa til lærarskulane i slutten av 1890-åra kom mykje frå Nordvestlandet. Lærarar frå denne skulen fekk mykje å seie i dei bygdene dei kom til med kristendom, målsak og fråhaldssak i ballasten. Dei gjekk aktiv inn i kulturlivet på staden. Omtalen av vestlandslæraren var: kyrkjesongar, målmann, fråhaldsmann og vestremann på Tinget. Grundtvigs tankar og filosofi førte til oppstart av folkehøgskulen, både frilynte og kristne. Første folkehøgskule i Noreg blei starta i 1864 på Sagatun på Hamar.

Bjørndal, 1983, s. 11. 
1883 med prost Anker som formann og Lars Hareide som nestformann. Lærarane skulle på den tida vere presten sin undergjevne hjelpar. Lars Hareide var den førande både i skulestellet og i det kristelege arbeidet i bygda. Og gjennom dette samarbeidet stilte indremisjonen seg understøttande til det kirkelige embetet. Det braut med den tradisjonelle linja for lekmannsrørsla. ${ }^{6}$ J. Straume skriv i eit festskrift for Norsk Luthersk Misjonssamband, Kristenlivet på Sunnmøre og i Romsdal, følgjande.

Men her på Hareid var det ingen Erik Solem (1833-1895) som kunne halde på lekmannslina. Indremisjonen her fekk ein heller høgkirkeleg profil. Kristenlivet var stivt og høgkirkeleg. ${ }^{7}$

Lekmannsrørsla generelt markerte seg med å ta avstand til embetskyrkja. Men i Hareid blei det ikkje i lekmannsrørsla i nokon opposisjon mot kyrkja, då som følgje av desse åndshovdingane, (sjå under) og gode, kloke prestar og lekmenn.

Ser ein til dømes til Ulstein, tok kristenlivet ei anna retning. Her vart det òg stifta indremisjonsforeining, men i Ulstein hadde lekfolket den dugande lågkyrkjelege, leiaren Johannes P. Skeide. Han kom med etter ei vekking som presten Christian Herman Wisløff (1836-1927) heldt i Skeide skulehus. Skeide var sterkt gripen av Rosenius sin vekkingsteologi. Som dei fleste skolerte ungdomane var på den tida, var han i opposisjon til embetsmennene. Han gjorde opptakta til fråhaldsarbeidet og det meste av det som finst av kristeleg arbeid i Ulstein i dag. Skeide blei ein dyktig lekmannshøvding med sterk inspirasjon frå haugerørsla og rosenianismen. ${ }^{8}$

Det kom etter kvart to lærarar til, Elan Rasofiel Rise i 1862 og A. C. Riise i 1895, også dei inspirert av grundtvigianismen. Desse har på kvar sine måtar prega hareidssamfunnet innan kristendommen og kulturen.

6 Lekmannslinja viser til at dei frivillige misjonsorganisasjonane var frie organisasjonar i kyrkja, men ikkje under kyrkjeleg mynde.

7 Straume, 1950, s. 131.

8 Roseanismen: Carl Olof Rosenius, svensk lekpredikant og salmediktar. Han sto i spissen for ei åndsbølge med fornying av pietismen rundt 1860 i Sverige og Noreg. Rosenius er grunnleggaren av den såkalla nyevangelismen som frå Sverige breia seg til lekmannskretsar i Danmark og Norge. «Ny-evangelismen» var ei luthersk nådeforkynning («Kom som du er») med forsiktig formulering av etiske krav. (Store Norske Leksikon) 
Felles for dei tre nemnde lærarane var at dei levde samstundes ein periode, dei var grundtvigianarar, nær knytte til kyrkja og vart etter kvart med i dei same organisasjonane. Fleirstemming song og kyrkjesong var også sentrale faktorar i deira liv. Dei var òg opptekne av den nasjonale kulturen som braut fram i denne tida, og sist, men ikkje minst: målsaka.

I 1880 gjekk to ungdomar frå Hareid på Sparbu folkehøgskule hos grundtvigianaren Matias Skard og kom tilbake til Hareid med den grundtvigianske kristendomsforståinga. Dei var òg inspirerte av målsaka, fråhaldssaka, song og den nasjonale kulturen. Desse to ungdomane, Gullik Grimstad (1853-1951) og Gullik Nesset (1855-1937), vart nære samarbeidspartnarar for Lars Hareide.

Alle dei fem personane, Lars Hareide, Elan Rasofiel Rise, A. C. Riise, Gullik Grimstad og Gullik Nesset, vart i ettertida kalla åndshovdingar, og i ulike kombinasjonar var dei med på å etablere og sette sitt preg på heile organisasjonslivet i Hareid i ein periode frå 1857 til 1930 og var alle i si tid sterkt interesserte i nasjonalt liv og arbeid. Åndshovdingane med Lars Hareide i spissen peika ut ei retning både kulturelt og religiøst for komande generasjonar. Dei gav ettertida ein symbolsk kapital: kristendom, norskdom, fråhaldsak, målsak og song. For eit særtrekk i hareidskulturen er folkesongen, kyrkjesongen og korsongen som har gått hand $\mathrm{i}$ hand fram til i dag, det har vore ei gjensidig forståing om at det eine ikkje utelèt det andre. Dette kjem tydeleg til syne med den firstemte fellessongen under Hareidsstemna. I 1962 fekk korsongen sitt eige stemne og har årleg feira seg sjølv og bygda i 57 år.

\section{Personar i Hareid som har vore sentrale i utforminga av Hareid-kulturen}

Kan einskildpersonar vere med på å prege ei bygd, ein kultur over fleire generasjonar? Svaret mitt er: Ja. Og eg tenkjer då mest på Gamleklokkaren. Han tok i bruk ei av stovene sine til skulestove. Her samla han òg ungdomen til songøving og utlån av bøker. Han var truleg den første på Sunnmøre som starta med fleirstemmig song, rundt 1857-1858. ${ }^{9}$

Bjåstad \& Waage, 1985, s 527. 
Som politikar var han medlem av heradstyret og formannskapet, ordførar, varaordførar, valmann og skyldsetjingsmann. I den tida med mangel på bygdedoktor og bygdeveterinær var han det òg. Alt dette i tillegg til å vere gardbrukar og bas for kastenot.

Lars Hareide hadde eit fabelaktig organisasjonstalent: Han var stiftar og første nestformann for Hareid forening for indremission 1883, stiftar og første formann i Hareide ungdomsforening, ${ }^{10} 1886$, stiftar av Hareide diskusjonsforening 1895, stiftar av Hareide Sokn hedningsmissionsforening, stiftar og forstandar for søndagsskulen 1895. Då IOGT-losjen «Losje Dag over Land $»^{11}$ blei stifta i 1887 , gjekk han inn som medlem; han ville vise samfunnsansvar, sjølv om han personleg var svært glad i øl. Sundmøre kreds af ynglinge- og ungdomsdomsforeninger vart skipa i 1891. Han blei med i styret som rekneskapsførar og var einaste lekmann i styret. $^{12}$

Han hadde òg kontakt med kulturmiljøet elles på Sunnmøre. Det syner seg ved at Anders Hovden (1860-1943) var gjest hos han. ${ }^{13}$ Og han sjølv gjesta Ivar Aasen (1813-1896) i Oslo. ${ }^{14}$

Gamleklokkaren var, som det ligg i namnet, kyrkja sin mann. På ymse preikelause søndagar heldt Lars Hareide overhøyringar i Hareid kyrkje med postillesing og katekisering. Ofte med mykje folk til stades. Det var solid og god lutherdom borna fekk med seg. Han var ein varmhjarta og djupt kristeleg forkynnar og hadde stor tillit mellom bygdefolk..$^{15}$ Lars Hareide døydde i 1900.

Gamleklokkaren var oppteken av fellesskapen. Og det «grodde» rundt han. Lærarane Elan Rasofiel Rise og A. C. Riise vidareførte arven etter Hareide. Dei var aktive både innan organisasjonslivet, kyrkja og korsongen. Det Elan Rasofiel Rise er mest kjend for, er korsongen. Då han kom som lærar i 1862, lét Hareide Rise ta over korarbeidet. Han starta då med korsong for vaksne. Dermed var grunnlaget lagt for korsongen i Hareid. Eit

\footnotetext{
10 Foreininga har skifta namn over tid, Hareid kristelege ungdomslag, Hareid KFUK-KFUM, Hareid KM. I artikkelen brukar eg Ungdomsforeininga (KM).

IOGT-Norge, 2013; Grimstad, 2013, s. 37.

Orten \& Brungot, 1991, s. 19.

Hovden, 1913, 1996 (3. utgåva), s. 103.

Djupedal, 1960.

Måseide, 1986, s. 9. 
kulturmerke som har prega bygda og organisasjonane fram til i dag. Rise hadde eit mål med dette arbeidet: god folkesong og kyrkjesong som alle kunne vere med på. 52 kor har vore i drift i Hareid i løpet av desse 157 åra, både kristelege og frilynte kor. Målet var å få flest med på å syngje, og han såg det som si fremste oppgåve å få fram folkesongen og den gode kyrkjesongen. For Rise var det viktig å få alle med i koret, ikkje berre dei flinkaste. Han øvde inn firstemmig salmesong i kyrkja, og han leidde kyrkjesongen i over 50 år. I 1872 skifte Hareid kyrkjelyd salmebok. I 1877 kom Lindemanns koralbok til Landstads salmebok. Målet hans vart då at alle songane i koralbok skulle lærast firstemmig. Ikkje alle likte den firstemmige songen i kyrkja. Han kom nesten i mål før Hareid kyrkje fekk orgel i 1919. Men han likte ikkje at kyrkja skulle få orgel, «då vil det bli slutt på kyrkjesangen», meinte han. Orgelet var ei gåve frå skipper Peter S. Brandal (1870-1933). I høve innviinga av orgelet uttalte biskop Peter Hognestad (1866-1931): "De har ikkje bruk for orgel i Hareid kyrkje.»

Målet og songen vekte folks nasjonale sans. Då Blix-salmar kom, øvde han inn nokre i kyrkjekoret. Han bad då presten og kyrkjetilsynet om lov til å syngje ein eller to av Blix-salmane etter gudstenesta. Det fekk han lov til, men første gongen dei song, tok nokre i protest hatten sin og gjekk: «Slikt skulle dei ikkje ha noko av.» ${ }^{16}$ Blix-salmar vart innførte i Hareid i 1901, etter forslag frå indremisjonen, men allereie i $1898^{17}$ gav presten løyve til at ein kunne syngje Blix-salmar ved gudsteneste i Hareid kyrkje. I 1904 vart det vedteke i Ulstein. ${ }^{18}$

A. C. Riise hadde òg teke utdanning på Stord lærarskule. Han vart tilsett som lærar i Hareid då Gamleklokkaren slutta i 1895. Han tok over tenesta som klokkar og kyrkjesongar i 1895 og hadde den til 1932. Det vert sagt om han at han hadde ei formidlingsevne utanom det vanlege når det galdt litteratur og poesi, som han ofte tok i bruk i klasserommet. Han la grunnsteinen til diktlesingstradisjonen i Hareid. ${ }^{19}$ Som tenåring tok han til som korleiar og dirigent, og var det i over 60 år. Han skipa barnekor

\footnotetext{
16 Måseide, 1986, s. 172.

17 I mars 1892 blei Nokre Salmar av Elias Blix (1836-1902) autorisert til bruk ved den offentlege gudstenesta, og desse landsmålssalmane blei trykte bak i Landstads kirkesalmebog som nr. 635-784.

Halse, 2009, s. 373 .

På festar og i lagsarbeid er det nesten alltid med diktlesing. Gjerne då dikt som vert lesne utanboks.
} 
med over 70-80 born, blandakor, mannskor og vart rekna som ei usedvanleg dyktig kordirigent.

Eg har tidlegare nemnt dei to ungdomane som gjekk på folkehøgskule i Sparbu i 188o. Der vart dei inspirerte av grundtvigianismen, målsaka, norskdom, opplysning- og fråhaldssaka. Etter dette året kom dei tilbake og gjekk ivrige inn i det mangslungne kulturelle og kristne i arbeidet $\mathrm{i}$ heimbygda..$^{20}$ Dei engasjerte seg i den kristelege ungdomsforeininga, $i$ indremisjonen, losje, som søndagsskulelærarar, bibliotekarar og kommunepolitikarar. ${ }^{21}$

Under folkehøgskuletida hadde dei fått blodskrekk; dei likte ikkje forkynninga om Kristi forsoning på ein blodig kross. Dei hadde lite glede av blodteologien som var så sentral i den rosenianske vekkingsrørsla. ${ }^{22}$

Dei kom tilbake frå folkehøgskulen med «høge hugmål». Dei ville heller tale om

Kristus i kvardagslivet; «Kristus i kvardagslivet var gode greier for store idealistar», skriv Jakob Straume (1894-1978) ironisk. ${ }^{23}$

Lars Hareide delte dette nye synet til dei to Gullik-ane, og sidan han var ein åndeleg førar i bygda, fekk kristendomssynet deira stort gjennomslag.

I denne avgjerande tida for Hareid, hadde vi presten Nils Christian Anker. ${ }^{24}$ Han var sokneprest i Ulstein/Hareid 1881-1895, og prost frå 1885 i Søre Sunnmøre prosti. Han var konservativ teologisk, men stod på god fot med lekfolket. Han vart første krinsformann i Sunnmøre krins av NKUF (Ungdomsforbundet) 1891-1895, og i hans periode var det ein eksplosiv auke i foreiningar, 18 nye. På Sunnmøre var han foreiningsentreprenøren framfor nokon. "Jeg har villet, at menigheterne skulde vore arbeidende menigheter ... arbeide for Guds riges fremme i den kjorlighet som er kristentroens frukt». ${ }^{25}$ Som organisasjonsmann gjorde han opptakta til Hareid Indremisjonsforeining, var initiativtakar til oppstart av

\footnotetext{
20 Halse 2009: 148.

21 Bjåstad \& Waage 1985: 537.

22 Straume, 1950, s. 131.

23 Straume, 1950, s. 131

24 I Ulstein var han sokneprest, men blei seinare prost på Søre Sunnmøre. Til dagleg vert han omtala som prost Anker, og ei gate i Ulsteinvik er kalla opp etter han.

Orten \& Brungot 1991. 
Ulstein Ynglingeforening (Kristeleg ungdomslag) i 1882 og Hareide ungdomsforening i 1886.

Andre sentrale personar i Hareid som følgde i Gamleklokkaren sine fotspor, var bonde Arne I. Grimstad (1865-1957), lærar J. P. Måseide (1877-1966), lærar Torvald Rise (1901-1973), fiskebåtreiar Einar Hareide (1899-1983), sokneprest Otto Bernhard Holmås (1898-1987), bonde Ludvig Anton Holstad (1885-1968), bonde Peter Brekke (1890-1972), lærar Ingolv Hareid (1898-1981), postopnar Ruth Hovden Hareide (1906-1997), skomakar Karl I. Røyset (1909-1996). Desse personane har på ulikt vis sett sitt preg på kristen- og kulturlivet i Hareid.

\section{Utviklinga i Hareid frå 1850-åra og framover}

I 1840-åra omfatta Ulstein prestegjeld både Hareid og Ulstein sokn. Presten budde i Ulsteinvik, heitte Nils Nicolai Wraamann (1806-1861) og var på den tida ein tradisjonell prest, men også stri og rådriken. Men etter at kona døydde, vart han ein heilt annan. Han var gripen av den johnsonske vekkinga blant prestan ${ }^{26}$ og blei ein forkynnar det gjekk gjetord om. Hans forkynning kveikte nytt liv i haugianarmiljøet i Ørsta og Volda og i det meir spreidde miljøet i Ulstein prestegjeld. Han var leiar i den første større vekkinga i nyare tid. ${ }^{27}$ Han var òg svært vyrk for heidningmisjonen og stifta i Ulstein prestegjeld den første misjonsforeininga på Sunnmøre i $1846 .{ }^{28}$ Her teikna det seg 174 medlemar frå Hareid medrekna Vartdal, og 189 i Ulstein. Medlemsteikninga vaks så fort at ved det første offisielle møtet i Ulstein kyrkje 6. januar 1847, hadde 454 teikna seg. I 1850 vart det vedteke å dele foreininga i to, ei for Hareid og ei for Ulstein. Det skjedde i $1852 .{ }^{29}$

Seinare i 1891 vart ei ny foreining stifta, Hareide Sogn Hedningsmissions-Forening. Lars Hareide og kretsen rundt han var med i «bestyrelsen». Og som elles i lags- og organisasjonslivet i Hareid er det mange av dei same personane som er medlemar her også. Etter kvart blei fleire

\footnotetext{
26 Johnson si kristendomsforståing gjekk ut på å ha ei personleg trusvisse og truserfaring.

27 Bjåstad, 1977 , s. 377.

28 Bjåstad, 1977 , s. 377.

29 Bjåstad, 1977 , s. 378.
} 
foreiningar stifta. Misjonsorganisasjonane har tradisjonelt vore knytte til lekmannsrørsla. I Hareid var dei dermed også knytte til kyrkja.

Men ikkje alle prestar var johnsonske. Etter Wraamann fekk vi grundtvigianaren Carl Anton Madsen (1811-1902). Eg meiner at han har vore med og leggje grunnen til rette for det grundtvigianske miljøet som utvikla seg i Hareid, då saman med Lars Hareide.

Indremisjonane i Hareid og Ulstein gjekk i noko ulik lei etter som tida gjekk. ${ }^{\circ}$ Ein kan seie at i Ulstein var det eit sterkare lavkyrkjelege, pietistisk preg enn i Hareid. I slutten av 1890 -åra var det pietistiske indremisjonsarbeidet nede i ein bølgjedal. Det hadde vore presteskifte, Carsten Balthasar Hansteen (1856-1923) erstatta Anker, og følgde i hans fotspor. Men det var søndagsskulen som stod Hansteen sitt hjarte nærmast. Gamleklokkaren slutta som lærar, og idealisten og grundtvigianaren A. C. Riise tok då over som lærar, klokkar og kyrkjesongar. I tillegg var dette ein nasjonal og politisk tidsperiode. Riise gjekk inn i Ungdomsforeininga(KM), og saman med Gullik-ane dreiv dei eit idealistisk ungdomsarbeid som har sett merke etter seg i Hareid heilt fram til våre dagar. Dette, saman med den politiske situasjonen og den kulturelle framveksten, gjorde nok at Indremisjonen hadde magre kår. ${ }^{31}$

\section{Samarbeid mellom dei ulike organisasjonane i Hareid}

Samarbeidet mellom organisasjonane i Hareid, Indremisjonen, Hareid kristelege ungdomsforeining, Den Indre sjømannsmisjon, Det Norske Misjonsselskap, Norsk Luthersk Misjonssamband og fråhaldslosjen har i alle år vore godt. Var det vekkingar og rørsle i eitt lag, innstilte gjerne dei andre si verksemd i den tida det gjekk føre seg. Det har aldri vore halde kristelege møte på bedehuset samstundes med gudsteneste i kyrkja.

Hareid indremisjon sitt tilhøve til kyrkja har alltid vore ukomplisert. Bedehusfolket har vore mellom dei mest trufaste kyrkjegjengarane, og ingen har søkt til nattverdsbordet oftare. Samarbeidet med prestane

\footnotetext{
30 Bjørndal, 1983, s. 6.

31 Bjørndal, 1983, s. 13.
} 
har òg vore godt, og i 10o-årsskriftet for Hareid indremisjon vert prost Anker, sokneprest Hansteen (1856-1923) og sokneprest Holmås spesielt framheva. Samarbeidet mellom kyrkje og indremisjon har begge tent på. ${ }^{22}$ Eit anna særtrekk med Hareid indremisjon er det nære samarbeidet som var med fråhaldsrørsla, og då spesielt losje «Dag og Land». Og igjen vil eg meine at det hadde å gjere med kva leiarar laga hadde. Eg finn blant anna i protokollane at når Hareid indremisjon har hatt ungdomsveker, har dei bode inn dei andre laga: ungdomslaget, idrettslaget, saniteten, husmorlaget, alle misjonsforeiningane, speidarane, Hareid mannskor og hornmusikken.

\section{Eit myndig lekfolk}

Ein ny epoke tok til då Ingolv Hareid blei tilsett som lærar etter A. C. Riise i 1929. Han blei ein førar og myndig lekmann i alt kristenliv i Hareid. Han var kritisk til den linja Sunnmøre indremisjon hadde lagt seg på i spørsmålet om nattverd. I Vestlandske indremisjonsforbund hadde det vorte opna for at foreiningane kunne ha fri nattverd utan prest til stades. Det blei opplevd som radikalt. På den bakgrunnen tok Hareid indremisjon opp spørsmålet om å melde seg ut av Sunnmøre indremisjon:

Formannen tok fram ymse døme på kor indremisjonen på Sunnmøre av prinsipp, arbeider mot kyrkja, sjølv mot dei truande prestar. ${ }^{33}$

Styret for Hareid indremisjon opplevde at gjennom 1920-åra hadde Sunnmøre indremisjon sine leiarar og arbeidarar framstilt sitt arbeid som det einaste rette kristelege arbeid. Dei fordømte også andre kristelege arbeidsgreiner og dømte ofte leiarane frie for liv $i$ Gud..$^{34}$ Det gjekk ganske hardt føre seg med brevvekslingar mellom Hareid og Sunnmøre indremisjon, der Hareid indremisjon trua med å melde seg ut. Eg finn ikkje at Hareid indremisjon gjorde alvor av det, men i 100-års jubileumsboka for Sunnmøre indremisjon skriv Johannes Hagesæther (1905-1992):

\footnotetext{
32 Bjørndal, 1983, s. 29.

33 Sitat frå styreprotokollen til Hareid indremisjon 9.11.1930.

34 Dei hadde ikkje den rette tru eller tru i det heile.
} 
at Hareid indremisjon ikkje var tilfreds med haldninga til Sunnmøre indremisjon og var utmeld i tidsrommet 1929-1932. ${ }^{35}$

Sekretær Lars Lid ivra mykje for at alle indremisjonsforeiningar på Sunnmøre skulle ha eigne ungdomsforeiningar (IUF). Dette skapte mykje strid og kløyving i dei kristne ungdomsflokkane, slik også i Ulstein..$^{36}$ Det vert fortalt at Lid også ville starte ungdomsforeining på Hareid. Men då sette formannen Ingolv Hareid ned foten: «Vi har ei foreining som driv det kristne ungdomsarbeidet, og vi skal ikkje ha noko splitting i den flokken!» Lid stod på sitt, men til slutt bøygde han av, då formannen truga med å melde Hareid indremisjonsforeining ut av Sunnmøre Indremisjon. Trusselen var reell, det hadde Lid fått erfart tidlegare.

Såra etter feiden med Sunnmøre Indremisjon vart ikkje så snart lækte. Seinare, då sokneprest Holmås slutta i Hareid, heldt Ingolv Hareid takketale til han på vegne av søndagsskulen og indremisjonen. Hareid vart oppmoda om å sende utdrag av talen til Heimen, Sunnmøre Indremisjons sitt blad. Men redaktøren for bladet, Lars Lid, nekta å ta inn stykket; han meinte at det var for personleg og at det ville kome motinnlegg mot stykket. Denne saka er grundig dokumentert i styreprotokollen frå 9. juli 1939. Dermed kom det til brot mellom Hareid indremisjon og Sunnmøre Indremisjon, då Ingolv Hareid melde ut Hareid indremisjon i tidsrommet 1939-1943. I denne tida sende ikkje Hareid tilskot til Sunnmøre indremisjon, og Hareid fekk heller ikkje talarar derifrå. Men emissærar frå andre organisasjonar kom, særleg frå Det Norske Misjonsselskap.37

\section{Hareide ungdomsforening - Ungdomsforeininga - Hareid KFUK-KFUM}

Etter at dei to Gullik-ane kom heim frå folkehøgskule, var dei opptekne avå gi ungdomen innsyn i kva dei hadde fătt lært, og starta opp med lagsverksemnd. I Ulstein vart det skipa ei ynglingeforening i 1882. No ville soknepresten, prost Anker, at det skulle lagast til noko for hareidsungdomen

\footnotetext{
Hagesæter, 1982, s. 155.

Hatlebrekke, 1983, s. 31.

Bjørndal, 1983, s. 22.
} 
òg. Ein komité vart nedsett, og her var Gamleklokkaren sjølvskriven, i lag med Hans O. Gjerde (1852-1889) og Gullik Grimstad. Dei tok på seg å leggje fram eit utkast til lover.

Den 12. desember 1886 i Bigset skulehus vart Hareide ungdomsforening stifta. Lars Hareide blei vald til formann. På dette møtet melde over 50 menn og kvinner seg inn i foreininga. Program var det i den første tida så som så med:

Songkoret indøvede et par lovsongar og derefter oplæsedes fortælingen om Jaampa på ski efter ulven..$^{38}$

Etter kvart som møtestrukturen gjekk seg til, blei det vanleg med innleiingar og samtalar med referat. Ein gong Lars Hareide innleidde om emnet Vaart himmelske og jordiske kald, blei referatet på vel 16 sider i protokollen. Frå eit anna møte er det eit referat på vel 30 sider.

Alle møta opna med bøn og salmesong, så vart det foredrag eller opplesing. Her var det emne frå historia og naturkunna i tillegg til kristeleg litteratur. Mange av dei emna som blei tekne opp til drøfting og diskusjon, omhandla dagleglivet og kva ungdomen dreiv på med.

I den første tida var Hareide ungdomsforening eigentleg å rekne som eit kristeleg akademi. Det tok opp i seg det som rørte seg i samfunnet og bygda, både av kristeleg og frilynde straumdrag. I løpet av dei første 25 åra til foreininga vart det haldne 224 foredrag. ${ }^{39}$ I 1887 vart det lufta om ikkje ein skulle setje i gong med ein «Haandgjernings- eller Husflidsskole»? Her ser ein samfunnsengasjementet i foreininga. Den 9. april i 1899 var emnet på møtet skogplanting. Lensmann Moldenes hadde eit innleiingsforedrag, og resultatet vart at det blei starta ei skogplantingsforeining med 25 menn og 30 kvinner. Dei hadde fleire dugnadar med å plante skog.

Ungdomsforeininga(KM) tok opp mange emne til diskusjon. I ei spørsmålskasse kunne alle få stille spørsmål, og den 9. februar i 1896 var eit av spørsmåla:

\footnotetext{
38 Ungdomsforening, 1886.

39 Lars Hareid 19, A. C. Riise 36, Arne I. Grimstad 17, Gullik Grimstad 34, J. P. Måseide 24, Gullik Nesset 27, Severin Hovlid (1868-1945) 27, Elling Bjåstad (1874-1952) 9, Elan Rasofiel Rise 20, Edvard Kvammen (1869-1948) 6 og Hans Rise (1861-1939) 5 foredrag.
} 
Er det heldig at kvinden stilles ved siden af manden inden for foreningen? Taber hun ikke noget af sin kvindelighet?

Lars Hareide meinte at -

«hun burde have taleplikt saalænge man fik det ind i bevidstheden at man havde frihed til at tale». ${ }^{40}$

Av andre saker som Hareid kristelege ungdomsforeining engasjerte seg i, var målsaka. Den 28. januar i 1900 var det tema på eit møte, og konklusjonen var at det vart skipa eit mållag i foreininga, og dei to første vintrane etterpå vart det halde opplæring over 13 kveldar i å skrive nynorsk. Lærarar var J. P. Måseide og Elan Rasofiel Rise. I foreininga hadde dei òg eiga boksamling med både profan og kristeleg litteratur. Men i lovene for laget står det at litteratur må vere luthersk.

Ein viktig kulturinstitusjon i foreininga var Kameraten ${ }^{41}$, det handskrivne bladet. Ein starta med det i 1889. Her fekk mange prøve ut sine meiningar og tankar. Bladstyrar gjekk på omgong, og det vart opplesing frå bladet på kvart møte.

Ungdomsforeininga(KM) starta opp med bibeltimar i 1893, og det har vore ein tradisjon meir eller mindre ubroten fram til våre dagar. Dei første åra var bibeltimemøta uregelmessige, men då J. P. Måseide kom til bygda i 1903, vart dei meir regelmessigd. Seinare vart bibeltimenemnda samansett av ein representant for Ungdomsforeininga(KM), ein frå indremisjonen og ein frå kyrkja, oftast presten. Torsdag har vore bibeltimedag. Søndagsskulesaka låg også foreininga på hjartet, og på haustparten i 1895 blei foreldre invitert til eit møte og søndagsskulen skipa.

Dei fem nemnte åndshovdingane var opptekne av at den oppveksande generasjonen skulle få god og rett kristendomsforståing. I protokollar frå denne tida vert det understreka at samlingane hadde andakter og

\footnotetext{
40 Måseide, 1986, s. 21.

41 Handskrivne blad: «Kameraten» Hareid kristelege ungdomsforeining, «Nyebrot» losje Dag over Land, «Fram» Hareide frilynte ungdomslag. Det var vanleg at organisasjonane hadde handskrivne blad. Eit handskrive blad var ei bok som gjekk på omgang der medlemane fekk ansvar for å skrive inn meiningar, dikt, refleksjonar m.m. som blei opplesne på lagsmøta. Men eg finn ikkje at misjonsforeiningane hadde slike.
} 
skriftlesing. Denne arven vidareførte lekmennene som kom som leiarar utover 1900-talet. Og heile tida var målet å samle, ikkje skape, stridar.

Korsongen i bygda stod sterkt i 189o-åra. Skulle ein ha kvalitetssong eller folkesong? Det skapte spenningar, då Elan Rasofiel Rise og A. C. Riise hadde ulikt syn på korsong. Frontane var harde, og Arne I. Grimstad kom med følgjande resolusjonsforslag på eit lagsmøte 26.04.1896:

Ongdomsforeiningi med fleire uttalar, at kyrkjesangen er den fyrste song. Synest det burde vere ungdomen ei hjertesak og æresak å møtest på dei songøvingane der salmesongen lærest. ${ }^{42}$

Seinare, då Ten Sing-rørsla kom på 1970-talet, var det motstand i enkelte kretsar mot band og slagverk. Denne motstanden botna meir i musikksmak og kultursyn enn i religiøse grunnar.

Ungdomsforeininga(KM) vart driven i ei grundtvigiansk ånd. Lærar J. P. Måseide kom til Hareid frå Mauseidvågen. Han hadde indremisjonsbakgrunn. Då han tok over leiinga i Ungdomsforeininga(KM), førte han foreininga inn ei meir konservativ retning. Han ville ha rekkefølgja: kristendom og norskdom, ikkje omvendt. Dette førte til at nokre syntest at arbeidet i Ungdomsforeininga(KM) vart vel pietistisk og indremisjonsprega. Det kulminerte under vekkinga i 1909. Då braut ein flokk ut og skipa Hareid frilynte ungdomslag. Stiftinga av dette nye laget skapte spenning blant ungdomen i bygda. I møteprotokollen for Hareide frilynde ungdomslag av 8. april 1909 står det at ein kunne ikkje stå som medlem i begge laga, og at ein måtte velje kva lag ein ville høyre til i.

Det frilynde laget dreiv regelmessig møteverksemd med det handskrivne bladet Fram, opplesingar, ordskifte, teaterverksemnd, ${ }^{43}$ song og leik til slutt. Dette laget var i arbeid i 4 år, Men ein arbeidde med tankar om eige hus, og i 1920 stod eit nytt hus på Holstad med namnet Trudvang klart. Då laget gjekk inn i 1929, tok Hareid mannskor, Hareid Songarlag, som stod det frilynde ungdomslaget nær, over huset. Seinare, i 1939, starta ein opp med kinodrift på Trudvang, og kinodrifta gjekk fram til 6. mai 1984.

\footnotetext{
42 Ungdomsforening, 1886.

43 Norleif Holstad, son til Ludvig Anton Peder, var leiar i Hareid amatørteaterlag.
} 
Splittinga gjekk inn på ungdomen, og på ein «spursmaalkveld» $\mathrm{i}$ Hareide ungdomsforening den 20. januar 1909 var følgjande stilt:

Kva er skilnad millom frisinna og kristeleg ungdom?

Kvifor skal me ha to ungdomsforeiningar?

Kvifor kan ikkje ungdommen faa leika ${ }^{44}$ etter møta no? (Det hadde dei gjort heilt frå oppstarten i 1886.)

Korleis kan ein ungdom bevare eit reint kristenliv?

Kvifor skal det nett no vere tid til å skipa frilynt ungdomslag?

Opprettinga av Hareid frilynte ungdomslag i 1909 var eit oppgjer med pietismen. Laget sine statuttar og medlemar stod framleis trygt på det kulturkristne fundamentet som var i Hareid, der kyrkja var sentrum. Til dømes var den første formannen ein trufast kyrkjegjengar heile livet. Hareid frilynde ungdomslag var med på å forsterke grunnlaget for det kulturkristne Hareid som voks fram. Det kjem tydeleg fram i vedtektene for laget: kristendom, norskdom, fråhaldsaka, målsaka og song. Desse fem markørane kan leggjast på både den kristne ungdomsforeininga, losjen og indremisjonen. Det viser homogeniteten i bygda der ein har eit felles verdigrunnlag. At her kunne vere nyansar, er oppstarten av det frilynte laget eit teikn på. Men dette laget fekk berre i førstninga ein aktiv periode på om lag fire-fem år. ${ }^{45}$ Når eg ser i protokollane over kven som er med i Hareide frilynte ungdomslag, går fleire igjen i både det kristelege ungdomslaget, losjen og indremisjonen. Den spenninga som kunne sjå ut til å kløyve ungdomsflokken då laget vart etablert, ser ut til å forsvinne raskt.

Allereie i 1908 føreslo Gullik Nesset at foreininga skulle starte eige arbeid blant gutar. Etter nokre år, i 1914, kom det i gong eit gutespeidararbeid. Men det ein kjenner som speidararbeidet i Hareid, tok til i 1939.

Eg har tidlegare skrive om Gamleklokkaren, Lars Hareide, og hans arbeid som kan sjåast som ein forløpar til søndagsskulen. Det var det

\footnotetext{
44 Folkeviseleikar og stevleikar.

45 Koret som A. C. Riise «tok» med seg frå den kristne ungdomsforeininga inn i det nystifta laget, blei etter kvart eit sjølvstendig kor, Riise-koret. Det var i aktivitet fram til 1944. Eg ser her at korrørsla i Hareid stadig manifesterer seg som det etter kvart sterkaste kulturuttrykket saman med kyrkja.
} 
første kristne barnearbeidet eg veit om i Hareid. Det låg også sterkt på hjartet blant prestane at borna skulle lære om Jesus. Sokneprest Hansteen, som kom etter prost Anker i 1894, hadde si store interesse i søndagsskulearbeidet. Og at borna vart prioriterte, syner seg ved at det den 31. august 1924 vart halden den første barnegudstenesta i Hareid kyrkje ved sokneprest Hoem. Sokneprest Holmås heldt seinare kurs for søndagsskulelærarar i Ulstein og Hareid i 1935, og innprenta dei fire punkt:

- Ver små.

- Unngå formalisme.

- Sky latskap.

- Be uavlateleg. ${ }^{46}$

Søndagsskulen heldt til i Grimstad bedehus, men frå 1930 vart han flytta over til kyrkja. Ikkje alle likte det, skepsisen var stor:

Kanskje fordi ungane då ikkje ville gå til kyrkje seinare ...? Men røynsla var at dei flittigaste søndagsskuleborna vart dei flittigaste kyrkjegjengarane som vaksne. ${ }^{47}$

Det var til tider vanskeleg å rekruttere nye søndagsskulelærarar. Men i kjølvatnet av vekkinga som sokneprest Holmås leia i 1931, kom det til mange nyomvende, og det hjelpte på rekrutteringa til søndagsskulelærarar.

Under årsmøtet for Sunnmøre søndagsskulen i Stordal i 1931 var der eigen båt frå Hareid. Holmås skipa eit kor på reisa, og berre to timar gamalt song koret på festen til stor fagnad. Her syner det seg kva kormiljøet i Hareid hadde å seie.

Søndagsskulen har vore eit stykke av Hareids kyrkjesoge, om han ikkje alltid har fătt den omtalen han er verd. Dette arbeidet i bygda har vore ein viktig del av forminga av mange barnesinn. Her vart det sådd kristne verdiar som blei avgjerande for val seinare i livet.

Men tek vi bort søndagsskulen i Hareid dei neste 50 åra, vil det snart visna i kristenlivet $i$ bygda, avsluttar utgivarane av jubileumstidsskriftet i 1945.

\footnotetext{
46 Holt, 1998, s. 101.

47 Flø, Hareide \& Hareide, s. 1945.
} 


\section{Fråhaldsarbeid}

Fram til 1880 var øl og brennevin sett på som ei gåve frå Gud, og det var straffbart ikkje å brygge. Men som ei motvekt til drikkeskikkane og den forbanninga som spesielt brennevinet førte med seg, vart det etter kvart stor oppslutning om fråhaldsarbeidet. I assosiasjonstida, organisasjonstida, var det ei oppblomstring av ulike fråhaldslag på Sunnmøre.

Fråhaldslosjen IOGT sin ideologi var likeverdstanken; alle medlemar var ein stor søskenflokk. Dermed var menn og kvinner likestilte i alle organisasjonsledd. Då losjen i Hareid vart skipa den 13. november i 1897, var chartermedlemane, det vil seie dei som fekk fullmakt til å stifte lokal losje, åtte kvinner og ti menn. Som andre organisasjonar har også losjen hatt eit handskrive blad, Nyebrot.

Slik den kristenkulturelle situasjonen var i Hareid, fekk losjen stor oppslutning. ${ }^{48}$ Ein ser av medlems- og møtebøker at det i stor grad var dei same folka som var med i losjen, i den kristelege ungdomsforeininga og indremisjonen. Igjen ser ein fruktene av samhaldet i bygda.

Både i Hareid og elles på Søre Sunnmøre finn eg at dei mest framståande menn og kvinner i bygdene var medlemar i losjen. Fråhaldsrørsla si stordomstid var i tiåret 1910-1920. Då hadde Søre Sunnmøre distriktslosje 39 losjar i arbeid med 3234 medlemar. Losje Dag over Land i Hareid var då den største losjen utanfor byane i Noreg med 274 medlemar registrerte i 1919, altså 16,5 \% av den vaksne befolkninga. ${ }^{49}$

Losjen var samfunnsengasjert, og i tillegg til sitt kulturelle bidrag var arbeidet mot rusdrykk og hjelp til dei som var råka av følgjene av det sentralt. Då det kom til folkeavrøysting om brennevinsforbod i 1919, vart losjen sterkt engasjert i saka. Seinare, i 1947, var det 2334 medlemar på Søre Sunnmøre, der Hareid hadde 303 medlemar, 14,9 \% av den vaksne befolkninga, losje Tru i Ulsteinvik med 109 medlemar, 3,1 \% av befolkninga..$^{50}$

48 Då Pål-Gustav (Gustav K. Hareide, 1883-1975) var 90 år, fortalde han denne historia til sonen Johannes G. Hareide (1922): Det var vanleg med ølbrygging på gardane i Hareid den tida, ein skulle ha med leskande øl i torvspadinga. Men på Pålhaugane, Hareid gnr. 13, budde kona til Gustav, Johanne Karoline Hareide (1880-1962). Ho melde seg inn i losjen i 1898, og dermed vart det for ettertida servert kaffi i staden for øl. Det fekk konsekvensar for heile huslyden, og «det året surna ølet $i$ kjellaren på Pålhaugane, og sidan har det aldri vorte brygga øl der» (Nyebrot, 1973). 
IOGT Noreg bygger på eit kristent grunnlag og har som valspråk: Tru, Von og Kjorleik. Kyrkja og losjen har hatt eit godt samarbeid heile tida. Når det gjeld tilhøve til andre kristne organisasjonar, har det vore litt ymist, når ein då ser bort frå Hareid.

Under vekkingane på 30-talet kom det frå fleire av dei tonegjevande i misjonsorganisasjonane både fordekt og open motstand mot fråhaldsarbeidet. Forkynninga gjekk ut på at losjen ikkje var kristeleg nok, og at losjearbeidet kunne tyne kristenlivet. Det førte til at losjar vart nedlagde. Bjarne Rabben siterer ein kristenførar:

«Eg har vore med i eit fråhaldslag, men då eg vart ein kristen, gjekk eg ut. Eg treivst der ikkje. Fråhaldsarbeid høver ikkje for ein vedkjennande kristen». Eit argument var at «ein drikkar hadde lettare for å sjå si synd enn den pyntlege fråhaldsmannen.» ${ }^{51}$

I bygder rundt om på Sunnmøre var det ein viss motstand frå pietistisk hald mot fråhaldsrørsla generelt og losjen spesielt. Men ikkje i Hareid, tvert imot. Heilt frå starten i 1883 har samarbeidet med indremisjonen og ungdomslaget vore det beste. Leiarane her var òg medlemar i losjen. Og då det nye bedehuset i Hareid stod ferdig i 1955, var det naturleg at losjen følgde med som leigar.

\section{Hareidsdalens bedehus - Grimstad bedehus ${ }^{52}$}

I forlenginga av store vekkingar på 1880- og 1890-talet vart det bygd mange bedehus i Noreg. Tanken på eit eige forsamlingshus i tillegg til kyrkja og skulen melde seg også i Hareid i slutten av 1880-åra. Det førte til at Hans I. Grimstad (1844-1935) gav tomt til eit bedehus som blei bygd på dugnad.

Det var folk frå heile kommunen som reiste huset: Brandal, Hareid, Bigset og

Snipsøyrdalen, med unntak av Hjørungavåg som allereie hadde sitt eige hus. ${ }^{53}$

\footnotetext{
51 Rabben, Indresøvde \& Torset, 1983, s. 19.

52 Hareidsdalens bedehus og Grimstad bedehus - namn på same huset som blei bygd på Grimstad. I dei ulike protokollane blir namna brukte om kvarandre.

Furnes, 2003, s. 43.
} 
Huset vart reist av bygdefolket, men av praktiske grunnar tok indremisjonen og ungdomslaget (KM) seg mynde til å disponere huset ved eit valt styre. Dette var uproblematisk, då det var same folket.

30. des. 1891 holdt indremisjonsforeningen den første Fæst i Hareidsdalens bedehus, og siste møte før overføring til det nye Hareid bedehus var den 28. september 1955, då det var eit møte i ungdomslaget. ${ }^{54}$

Bedehuset vart eit inkluderande bygdebedehus som mange lag gjorde seg nytte av: losjen, songkor, misjonsforeiningar, det frilynte ungdomslaget, farande talarar og andre. Bedehuset på Grimstad var det einaste forsamlingshuset i Hareid, og det blei derfor også brukt til verdslege syslar som kommunestyremøte og møte i likningsnemna.55

\section{Bedehuset på Hareid}

I 1935 kom spørsmål om nytt bedehus i Hareid opp for første gong. Dette huset burde då ligge sentralt i Hareid og måtte ta omsyn til både Indre og Ytre Hareid. Eit arbeidsutval for nytt bedehus i Hareid nedsett i 1936 med medlemar frå Indremisjonen og Ungdomsforeininga(KM). Det var viktig for initiativtakarane at denne prosessen med å bygge nytt bedehus ikkje måtte bli til «strid millom dei truande i krinsane». Tanken var i førstninga å flytte Grimstad bedehus til Hareid og sett på murar i full høgde.

Arbeidet vart sett i gang i 1952, men sjølve bygginga starta først i 1953. Då var det blitt fritt sal av tømmer ${ }^{56} \mathrm{og}$ lettare på byggefronten. Dermed la ein vekk planen med å flytte huset frå Grimstad til Hareid. Bedehuset på Grimstad vart i 1956 flytta til Bjåstad/Bigset. Med innsamla middel, blant anna etter rike vintersildefiskesesongar, og ei pantegjeld på kr 50 ooo vart Hareid bedehus innvigd under festen den 18. desember 1955, eit hus på 975 kvadratmeter, fordelt på to høgder.

Det var naturleg at då nytt bedehus skulle byggast, var det Indremisjonen og Ungdomsforeininga(KM) som stod som byggherrar. Det

Måseide, 1986, s. 85 .

Bjørndal, 1983, s. 36 .

Etter den andre verdskrig var det i nokre år mangel på byggemateriale og dermed restriksjonar på tildeling av slikt materiell. 
særmerkte ved det er at det er Noregs kristelege ungdomsforbund og Vestlandske indremisjonsforbund som er felleseigarar og samarbeidspartnarar. Det åndelege klimaet som hadde vore i bygda sidan 188o-åra, gjorde at desse to organisasjonane samarbeidde om å reise det nye bedehuset. Eg har ikkje funne andre stadar i landet med liknande konstellasjon. Ein kan vel trygt seie at dette er dei to organisasjonane som ligg lengst frå kvar andre på den lutherske organisasjonsskalaen.

Fleire aviser skreiv om innviingsfesten. Vikebladet skreiv at huset skal vere eit tempel for kristen tru og kultur, og Sunnmørsposten slo fast at Hareid hadde vigsla vakraste bedehus på Sunnmøre, eit hus der alt godt og byggjande åndsarbeid skal ha sin plass. Sunnmøre Arbeideravis slo til med overskrifta: «Eit tempel for kristen tru og kultur», og omtalte det nye bygget som eit hus for vidt og fritt kristensyn og kulturelt arbeid.

Dei to kristelege dagsavisene Vårt Land og Dagen hadde litt ulike oppslag. Vårt Land poengterte at både Indremisjonen og Hareid kristelege ungdomsforeining var eigarar av huset, medan det er interessant å merke seg at den kristenkonservative avisa Dagen ikkje hadde med at det var eit fellesprosjekt for heile bygda og felleseige mellom Det vestlandske indremisjonsforbund og Noregs kristelige ungdomsforbund.

Drifta av bedehuset vart organisert med eige styre, tre frå Indremisjonen og tre frå Ungdomsforeininga(KM). Leigetakarar det første året var Hareid kristelege ungdomsforeining, Losje «Dag over Land», Hareid indremisjon, Det Norske Misjonsselskap, Norsk Luthersk Misjonssamband, Santalmisjonen, Indre Sjømannsmisjon, Finnemisjonen, Ungdomsmisjonen og Ytre Sjømannsmisjon. I tillegg kjem det fleire enkeltarrangement. Etter kvart kom fleire til som faste leigarar; Søndagsskulen, Hareid kristelege mannskor, Hareid Godtemplarkor, Husmorlaget, Saniteten, Muhammedanarmisjonen og Israelsmisjonen.

I dag, over 60 år etter innviinga, har styret framleis ei samansetning med tre representantar frå Hareid kristelege ungdomsforeining og tre frå Hareid indremisjon. Saman med losjen kan ein kan seie at desse organisasjonane var som ein trekløver; om ein var medlem i den eine, var ein oftast også medlem i dei to andre.

I 2020 er indremisjonsarbeidet innstilt, og KFUK-KFUM Hareid har ikkje muligheiter til å drive bedehuset åleine. Derfor har desse to 
foreiningane gjeve Hareid sokn huset som gåve. Hareid sokne vil drive huset som kyrkjelydshus vidare, og det er i Gamleklokkaren si ånd.

\section{Sketsj på bedehuset}

Eg kan ikkje finne noko forbod mot skodespel i lovene eller protokollane for bedehuset på Grimstad, og seinare for Hareid bedehus. På songarfestar i bedehuset vart til dømes skodespel av Ivar Aasen framførte, Ervingen i 1904 og Til sceters i 1906.

Det var mykje vakker song i desse spelestykka, og bygdefolket tykte det var overlag gilde festar. ${ }^{57}$

Men etter vekkinga i 1909 med kløyving i ungdomsflokken blei det reist spørsmål frå ungdomen på eit møte i Ungdomsforeininga(KM) den 21. januar 1914:

Er bedehuset vorte meir heilagt no enn fyrr - sidan med ikkje for hava der skodespel eller stevleik?

Seinare er sketsjar igjen ein del av programinnslaga på festar. I protokollane for Ungdomslaget finn eg at det ikkje var noko motførestillingar mot leik (folkeviseleik) når ungdomen møttest, men dans var ikkje aktuelt.

Barnelosjen «Lys og Liv», som heldt til på bedehuset, var no ein «opplæringsanstalt» $\mathrm{i}$ både formell møteleiing og underhaldning. I mi tid var der sketsjar på kvart einaste møte. Og desse unge skodespelarane fann ein att seinare i Hareid amatørteater. På AVGD-festar (All verdens gutars dag) i speidaren vart det framført sketsjar og opptrinn. På lagsmøte i Ungdomsforeininga(KM), på festar og klubbkveldar var sketsjar oftast ein del av underhaldninga.

\section{Vekkingar}

Siste del av 180o-talet var ei oppvakningstid, også på våre kantar. Assosiasjonstida var på sitt høgste, og nye organisasjonar, lag og foreiningar

57 Brekke, 1962, s. 13. 
vart etablerte. Spesielt blei indremisjonsforeiningar etablerte rundt 188otalet. Og med det fekk ein eit apparat som kunne organisere tilreisande vekkingspredikantar.

Den største vekkinga på Sunnmøre i dette tidsrommet var det som blir kalla «Sandstormen». Lærar og forkynnar Paul Gerhard Sand verka her frå 1881 til 1891, mest mot slutten av 188o-åra. Sand si teologiske forankring var i blodteologien. Han preika forlating for syndene i Kristi blod..$^{8}$ Han fekk preike både i kyrkjer og bedehus og hadde stor tillit blant lekfolket.

Vekkingane som Paul Gerhard Sand si forkynning skapte, spreidde seg på Sunnmøre, men ikkje alle plassar skapte det ro og harmoni. Tvert imot, verksemda til P. G. Sand førte til splitting blant dei truande mange stadar på Sunnmøre. I Volda og Sykkylven var det knapt nokon heim som ikkje var involvert i vekkinga, og når prestar som August Weenaas og Peter Jesper Selmer Østby fordømte Sand si lære, førte dette til kyrkjesplitting i bygda..$^{59}$

«Sandstormen» var sterkt dominerande i Herøy, og i Ulstein vart det ei djuptgripande vekking. Der blei det til dømes bygd to bedehus med 405 meter mellom dei.

Vekkingane på denne tida kunne altså føre til steile frontar. Lekpredikantane på Sunnmøre ville ikkje nøye seg med å forkynne når presten gav løyve til det. Sunnmøringane ville ha full fridom til å forkynne Guds ord, uavhengig av presteskapet. Det var med på å profilere indremisjonen som ein lågkyrkjeleg organisasjon. ${ }^{60} \mathrm{Og}$ her var ålesundarane Erik og Johannes Solem dei mest markante leiarane. Dei hevda at det er ein plikt og ei plikt for kristne å forkynne og vitne om sin frelsar, i kraft av det ålmenne prestedømmet som kvar kristen var ein del av. ${ }^{61}$

Vekkingane førte til at det på Sunnmøre i denne perioden vart ei stordomstid for indremisjonsarbeidet og lekmannsrørsla. Men her finn eg igjen Hareid som eit unntak. I Hareid blei Sandstormen ikkje så sterk, kanskje berre ein svak bris. Grundtvigianaren Lars Hareide, med sitt

\footnotetext{
58 Skorgevik, 1974, s. $28 \mathrm{ff}$.

59 Skorgevik, 1974, s. 20, 89 ff.

60 Sunnmøre indremisjon oppmoda til skiping av Det vestlandske indremisjonsforbundet i 1897, og i 1898 blei det ein realitet. Skorgevik, 1974, s. 83 .

61

Skorgevik, 1974, s. 79.
} 
strengt kyrkjeleg syn, hadde stor påverknad inn i indremisjonen og Ungdomsforeininga(KM). Åndshovdingane her hadde vore sterkt påverka av grundtvigianismen, og dei var no leiarar i kristenlivet i Hareid.

Eg har peika på grunnar til dette med dei sterke og markerte åndelege leiarane vi hadde. Hareid låg mellom Ålesund og Volda/Ørsta med sterke haugianske, og etter kvart rosenianske, miljø. Eg finn heller ikkje dissentarverksemd i Hareid i motsetning til Volda, der vekkingane etter kvart vart grobotn for fleire retningar: Den evangeliske lutherske frikyrkje, pinsevennar, frie evangeliske forsamling, clausianarane, frelsesarmeen, frifrie (jublarane) med fleire. Sjølv i dag er det berre éin kyrkjelyd i Hareid, ein kyrkjelyd med djup forankring i folket.

\section{Vekkingar lokalt}

Den første vekkinga eg kjenner til, var som tidlegare nemnt ved presten Wraamann på 1840-50-talet. Han var gripen av Gisle Johnson (18221893) si vekking mellom prestane. Haugerørsla tykkjest derimot å ha hatt liten innverknad i Hareid/Ulstein. Magnulv Bjørndal konkluderar med at Hauge følgde postvegen over Hellesylt-Stranda-Ørskog-Vestnes og ikkje kom utover til Hareidlandet. Men kanskje var det like mykje at futen budde i Brandal, prosten i Dimnasund og skrivaren i Haugsholmen, som var årsaka til det. Hauge og embetsmenn gjekk ikkje så godt saman.

I 1875 var det vekking i Ulstein ved presten Wisløff. I Ulstein fekk dei ein dugande lekmannsførar, Johannes P. Skeide. Han var sterkt gripen av Rosenius sin teologi om den frie nåden. Han blei seinare ein dyktig lekmannshøvding i Ulstein. ${ }^{62}$

I 1881 kom Anker som ny sokneprest i Ulstein. Han hadde gått i skule med Gisle Jonsson og var oppteken av organisasjonsbygging. Han var gripen av indremisjonstankane om nødsprinsippet; ${ }^{63}$ kyrkja skulle vere leiar og presten hyrde.

Då Hareid indremisjon blei skipa i 1883 etter opptakt av sokneprest Anker og «Gammelklokkaren» Lars Hareide, fekk laget same lover som

\footnotetext{
62 Bjørndal, 1983, s. 6.

63 Løvlie, 2020.
} 
i Ålesund. Det skulle stille seg understøttande til det kyrkjelege embetet. Men her på Hareide var det ingen Erik Solem som kunne halde på lekmannslinja, skreiv Straume. ${ }^{64}$ Indremisjonen fekk eit høgkyrkjeleg preg her, hevda han. I Ulstein vart indremisjonen leia av den lågkyrkjelege Johannes P. Skeide. Såleis gjekk dei to indremisjonsforeiningane i kvar si lei.

Frå protokollen for Hareid Indremisjon finn eg at Paul Gerhard Sand talte i Hareid berre fire gongar ${ }^{65}$. Hans vekking var sterkt farga av det rosenianske og nyevangeliske synet, og det var ikkje etter Gamleklokkaren, Lars Hareide, sitt sinn og syn. Den fekk derfor heller liten påverknad. Likevel finn eg spor etter vekking i Hareid i denne tida. Føraren i flokken av dei verdslege ungdomane, Sacharias Røyset (1866-1893), blei omvendt, og det verka som eit «lynnedslag». Han fekk mykje å seie åndeleg sett, og han blei den første lekmannen som heldt oppbyggingsmøte i Hareid utanom prest, skulemeistrar og omreisande lekpredikantar. Han kom inn i styret for Indremisjonen og hadde fleire verv i det kristne arbeidet i bygda, men han døydde tidleg. ${ }^{66}$

Det var vekkingar her i byrjinga av 1900-talet. Men først i vekkinga i 1909, ved emissær Ole Alme (1880-1942) frå Volda, vart det uro. Han reiste for Indremisjonen og Misjonssambandet og hadde eit fritt evangelisk syn. Alme forkynte Kristus i oss, eit levande liv ved trua i hjarto, Kristus var einaste grunnlaget for kristenlivet. Konsekvensen av denne forkynninga var at mange ungdomar syntest at det vart for mykje pietisme og indremisjon i Ungdomsforeininga(KM). Og denne vekkinga var medverkande til at Hareid frilynte ungdomslag vart skipa.

Ei vekking i 1915 var ved frikykjeforstandar Johannes G. Jensen (18791948) i Ålesund. Det skapte uro hos presten, då nokre personar i Hareid leigde fiskebåten Tampen for å reise til Ålesund på møte i Ålesund Frikyrkje. Men ingen melde seg ut av statskyrkja på grunn av denne vekkinga.

Vekkinga i 1921 var ei av dei største i Hareid. Det var ved Bernt Fauske (1896-1980), som representerte Ungdomsforbundet. Den fekk stor verknad

\footnotetext{
64 Straume, 1950, s. 13.

65 Protokoll for Indremisjon, 1883, s. 29.

66 Måseide, 1977, s. 85.
} 
i lang tid. Men noko skjedde under vekkinga i 1921. Då gjekk nokre av dei beste songarane ut av koret til A. C. Riise, av samvitsgrunnar. Då sa Riise:

Eg forstår, at der kan vere delte meiningar om songarbeidet vårt religiøst sett, må aldri høyrast eit vondt ord for det, korkje frå meg eller dei øvrige songarane. ${ }^{67}$

I Ungdomsforeininga(KM) vart det starta eit songkor i kjølvatnet av denne vekkinga. Eg vil tru at dei som gjekk ut av Riise-koret, gjekk inn i dette koret.

Samstundes var det vekking i Ulstein. Men der fekk ho litt andre konsekvensar. Mange av emissærane reiste rundt og forkynte at dei omvende måtte gå ut av songkor om dei tok trua si alvorleg, elles ville dei falle ifrå. Under denne vekkinga vart det i Ulstein lagt ned fleire gode kor, fordi det var ikkje kristeleg nok å vere med i kor og syngje innøvd fleirstemmig song. ${ }^{68}$ Men å syngje overstemmer og understemmer i musikklag var greitt, for der kom stemmene impulsivt idet ein song; songen var meir åndsinspirert då, meinte dei.

Den vekkinga som kanskje har betydd mest i Hareid, var i 30-åra ved sokneprest Holmås. Han hadde bakgrunn som reisesekretær i NKUF før han blei sokneprest i Ulstein/Hareid. I to veker før påske i 1931 heldt han bibeltimar i Grimstad bedehus. Ei vekking byrja og blei ei av dei djupaste og mest omseggripande i Hareid. Holmås og evangelist Andreas O. Eidsaa (1872-1958), i Sunnmøre krins av NKUF, arbeidde saman. Stor einskap rådde mellom dei kristne, og prest og lekfolk hadde full og heil gjensidig tillit, ikkje strid og partiånd. ${ }^{69}$ I soknerådsprotokollen for Hareid står det:

Holmås er ein fødd talar og uvanleg klår i tanken, på same tid som han er ei eldsjel som ikkje sparer noko når det gjeld å hjelpe folk over frå åndeleg død til liv i Gud..$^{70}$

Tema for møta var: Vakt - Omvend. I perioden 23. mars til ut mai køyrde han 50 gongar over til Hareid til møte, samtalar og rådgjeving. Vekkinga

\footnotetext{
67 Hareide kristelege ungdomsforeining, protokoll 1922.

68 Hatlebrekke, 1983, s. 30.

69 Måseide, 1977, s. 43.

70 Bjørndal, 1983, s. 60. 
ved Holmås heldt fram i 1932. I denne vekkinga kom det med folk i sin beste alder: det var no alle skipperane kom med,,$^{71}$ fortel Elida Hareid (1897-1993). ${ }^{72}$ Grunnen til at denne vekkinga fekk varig verd, var at Holmås var prest her, og såleis kunne grunnfeste dei som var komne med. I andre vekkingar var det ofte emissærar som skapte glød ei tid, men når dei reiste, svana det ofte der det svall. Holmås heldt fram i 1935, og då la han møteserien til Trudvang, huset til det frilynte ungdomslaget, som då var det største forsamlingshuset i Hareid utanom kyrkja. Dette er den vekkinga som har sett mest varige spor etter seg i Hareid. Han reiste ikkje vidare til neste bygd, han budde her og følgde opp dei som hadde vendt om.

I 1940 kom neste større vekking, og særleg mange ungdomar gav seg over til Gud. Sokneprest i Grytten, Hallvard Jendem (1908-1988), stod for denne. Hareid kristelege mannskor blei stifta i etterkant av denne vekkinga. ${ }^{73}$ Siste større vekking var i 1956 - i Hareid ved Arthur Birkeland (1914-1958), utsendt frå indremisjonen.

Vekkingar kjem ofte i samband med ulike reisande predikantar. Og uansett kva organisasjon predikanten kom frå, reduserte dei andre laga i Hareid i solidaritet si eiga møteverksemd så lenge vekkingane stod på.

Alle vanlege misjonslag er i arbeid i Hjørungavåg no. Det vert ikkje halde kristelege møte i kollisjon med kyrkja. ${ }^{74}$

Det går igjen i mange skrifter at vekkingar øydelegg kulturlivet i bygdene og skaper splitting i kristenflokken. Det har vi ikkje hatt i Hareid, snarare det motsette. Iver O. Røyset, losjehovdingen, meinte at vekkingane hadde god verknad for losjen. Rett nok vart det fåe møte medan dei stod på, men så auka medlemstalet etterpå.

I kjølvatnet av vekkingar blir det ofte splitting, slik som under vekkingane ved Arthur Birkeland i 1956. Då måtte nokre velje om dei ville vere

\footnotetext{
71 I 1969 fekk Hareid kyrkje to nye klokker i gåve. På den eine står det: GITT AV ELDRE SKIPPERAR I HAREID SOKN, med ei seglskute i relieff. På hi sida: GUDS ORD DET ER VÅR FEDREARV TIL SØNER SKAL DET GANGA, og eit anker i relieff. På den andre klokka: GITT AV HAREID SPAREBANK, med Kristusmonogrammet chiro i relieff, og på den andre sida: HØYR MINE MALMAR DEI TONAR OG KVED: HERREN ER FRELSAR I HONOM DEG GLED og Olav V sin vignett. Verset er dikta av Johan H. Grimstad. Måseide, 1977, s. 19.

Måseide, 1977, s. 81.
} 
personleg vedkjennande kristne og ta konsekvensane av det. Det fekk Hareid Godtemplarkor merke. ${ }^{55}$ Også idrettslaget merka at nokre ikkje lenger kunne vere med der av samvitsgrunnar.

Vekkingane skapte ikkje kløyvingar mellom indremisjonen og Ungdomsforeininga(KM). Ein av grunnane er at vi har hatt kloke leiarar. Gamleklokkaren, Lars Hareide, var leiar i begge laga i mange år og nøytraliserte såleis eventuell motstand, konkluderer Peder Måseide (19072002): ${ }^{76}$ Han var ein sterk og myndig åndeleg leiar i bygda, og han hadde eit strengt kyrkjeleg syn som han tok med seg inn i både indremisjonen og ungdomslaget. Derfor vart ikkje vekkingslinja med den rosenianske forkynninga den rådande i bygda. ${ }^{77}$

Leiarane, lekmennene, i Hareid har vore for det meste lærarar. Dei fleste har vore frå Hareid og har vakse opp i hareidskulturen. I tillegg til si lærargjerning og organisasjonsdeltaking har fleire vore klokkarar i kyrkja i årstider, ${ }^{78}$ fire klokkarar i ein tidsperiode på 120 år, og dei stod for stabiliteten. I same tidsrommet hadde ein 12 presteskifte.

Det er ikkje uvanleg å høyre om ungdom som måtte velje mellom bedehuset eller det frilynte ungdomshuset, der det blant anna var dans og kino. I Hareid hadde vi bedehuset og Trudvang. Men vala var ikkje eit anten-eller. Når presten Holmås leigde Trudvang til vekkingsmøte, kunne ikkje huset vere så «farleg», og kino i seg sjølv var ikkje synd.

\section{Korsongen i Hareid}

I jubileumsåret i 1962 kom det ut ei bok med tittelen: Korsangen $i$ Hareid gjennom 100 år. ${ }^{79}$ Her skriv Brekke at pastor Peter Thams Buschmann

75 «No hender det Godtemplarkoret, som det har hendt kor før her i Hareid under vekkingsri: Der er songarar som ikkje kan vere med i eit såkalla verdsleg kor, og går ut av koret. Sume har vel vanskeleg for å skjøne dette, men kvar må fylgja sitt samvit, og her har aldri vore bandtvang i kora på Hareid i så måte. Trass i litt misstemning og ujamne øvingar og synging, så held koret seg bra oppe, og nye songarar kjem til etter kvart. Brekke, 1962, s. 53.

76 Måseide, 1986, s. 89.

77 Måseide, 1977 , s. 85 .

78 Klokkarar: 1857-1895 Lars Hareide (Gamleklokkaren), 1895-1932 A. C. Riise, 1932-1964 Torvald H. Rise, 1964-1977 Magnulv J. Bjørndal, alle lærarar. Bjørndal, 1983, s. 77.

Brekke, 1962. 
(1762-1845) var svært oppteken av god song i kyrkja, og han lærte klokkar Olavius (Nevstad) Kaldhol (1798-1857) noteskrift og øvde inn rytme med han. Klokkarane i Hareid var lærarar og kyrkjesongarar, så songen i Hareid har stått sterkt gjennom lange tider. Det var Lars Hareide, Gamleklokkaren, som tok til med fleirstemmig song. Han øvde inn fleirstemmig song med skuleborna, og dei song ved gudstenester. Dette var noko nytt, men ikkje alle var like begeistra. Ei herme etter nokre vartdalstrandingar som ikkje likte grovloetine, lydde: Dette er for gale, no har hareidsdølingane teke til å syngje grovt i kyrkja.

I 1862 tok Elan Rasofiel Rise over arbeidet med korsongen, og han blir rekna som korsongen sin far i Hareid. Han starta alltid øvingane med dagens bibeltekst, og han følgde kyrkjeåret i salmevalet. Ut frå sitt kristelege, nasjonale grunnsyn, med inspirasjon frå grundtvigianismen og folkehøgskulerørsla, øvde han inn nasjonale songar og fedrelandssongar.

I 1872 kom Landstads salmebok, og i 1877 Lindemans koralbok. Rise brukte desse bøkene til å lære inn salmesongen i kyrkja firstemmig. Det førte til at songen i Hareidskyrkja vart vidt kjent. Lars Hareide sa i eit ordskifte i Hareide ungdomsforening i 1896: «Kyrkjesangen i Hareid stend no på eit høgt trin, og eg kan aldri gløyme den songen, som var framførd $i$ kyrkja, då når nyekyrkja var innvigd i 1877». I gudstenesta i Hareidskyrkja under Sunnmøre krins av NKUF sitt krinsungdomsstemnet jonsok i 1962 var biskop Per Juvkam (1907-2003) her. Der blei salmen Deg vore oere sungen. I Sunnmørsposten sitt referat frå dette stemnet vart biskopen sitert

Av alle dei minne eg har med meg på livsvegen, så vil minnet om denne gudstenesta, og den songen eg her vart møtt med, stå som eit av dei mest lysande.

Denne salmen og songen gjorde eit djupt inntrykk på meg òg. Eg var i kyrkja denne søndagen, og eg minnest kvar i kyrkja eg var: ved sida av orgelet på galleriet.

Ein gong fekk Rasofiel nokre gutar med på å stå fram i koret i kyrkja og syngje saman med presten, medan dei andre stod på lemen og song tilsvar. Dette var òg noko nytt, og prost Johannes Barstad (1857-1931) sa det slik: "Nei, noko så vakkert har eg aldri høyrt».

A. C. Riise tok over klokkar- og lærartenesta etter Gamleklokkaren. Han starta då Hareid blandakor, knytt til Hareide ungdomsforening, og 
med det kom ein ny giv inn i songen i bygda. Av repertoaret kan nemnast: Noreg, Noreg blånende op, Hvem banker så silde på klosterts port, Valdresvisa, På solen jeg ser, Jeg har båret lerkens vingar, Noregs beste, vern og fest, Sølvet, Gud signe vårt dyre fedreland, Seterjentens søndag. Dette har vorte tradisjonssongar som vert sungne firstemmig i lyd og lag fram til dags dato. ${ }^{80}$

Dei ulike laga i Hareid hadde songkor, og desse var alltid med på festar og samlingar. I ei lita kommune som Hareid er kortradisjonen sterk. Eg finn ikkje tradisjonell musikklagsverksemnd ${ }^{81}$ i Hareid i denne tida. Musikklagstradisjonen er ofte knytt til den pietistiske lekmannsrørsla. Mi forklaring på den sterke kortradisjonen har å gjere med det kulturgrunnlaget som vart lagt av dei første pionerane, åndshovdingane. Ein kan ikkje syngje dei nasjonale songane med gitarakkompagnement: Når fjordene blåner, Noregs fjelde, Brudeforden i Hardanger, I storm og stridSunnmøre. Her må det firstemmig korsong til for å gi songane løft.

\section{Disharmoni i harmonien}

Sjølv om det var ulikt politisk syn i Hareid-samfunnet i åra rundt 1900, var det harmoni mellom organisasjonane. Langt på veg var alle dei sentrale personane med i alt. Eg har gått gjennom lagsprotokollar for Hareide Indremisjon, Hareide kristelege ungdomsforening, Losje «Dag over Land», Hareide diskusjonsforening, Hareide Frilynde ungdomsforeining, Hareid søndagsskule, kyrkjetilsynsnemnda, Hareide Sogns Hedningemissionsforening og formannskapsprotokollar for tidsrommet 1880 til 1920. Her har eg notert opp dei som er nemnde i ulike verv og komitear, til saman 450 namn. Eg finn då at både kvinner og menn har hatt opptil sju verv i ulike lag i kombinasjonar: indremisjon/søndagsskule, kristeleg ungdomsforeining/losje, frilynte ungdomslag/losje,

\footnotetext{
8o Oversikt over nokre av songane som blei innøvd firstemmig, og der fleire «lever» enno i dag, finn ein i minneskissa om A. C. Riise. Grimstad, 1995.

81 Magnulv Bjørndal skriv i jubileumsskriftet for Hareid indremisjon om tida rundt 1920: I denne tida var der og eit musikklag i sving, men denne musikkforma har aldri slått gjennom i Hareid. I Bigset derimot, har der vore eit lite musikklag i gang gjennom lange tider. Det går godt i dag og (Bjørndal, 1983). Rundt 1993 vart dette nedlagt, og Hareid Musikklag starta opp og er i aktivitet $\mathrm{i}$ dag, 2019.
} 
indremisjon/kristeleg ungdomsforeining, medlemar av kommunale verv osv. Tala tilseier at mange var medlemar i fleire lag.

Den første disharmonien mellom organisasjonane eg finn, kom i 1909 som eit resultat av ei vekking, då nokre ungdomar gjekk ut av den kristelege ungdomsforeininga og starta eit eige lag, sjølv om dei hadde dei same måla. Denne første splittinga gjekk ikkje så djupt og varte ikkje lenge.

Under vekkingane som Fauske hadde i 1920-1921, vart frontane igjen markerte. Eit av emna som blei teke opp, var Vakta dykk for dei falske profetane. Kunne ein vere med i lag som ikkje hadde ei klar kristen forankring? ${ }^{82}$

Kanskje den sterkaste splittinga som har vore i Hareid-samfunnet kom i forlenginga av denne vekkinga. Det førte til at det blei arrangert to festar 17. mai både i 1921 og 1922. Den eine på bedehuset og den andre på Trudvang. Igjen sitat frå ungdomslagsprotokollen:

Me vilde koma saman til ein heilt kristeleg fest til avslutning paa dagen. Me vilde takka Gud for kva han har gjort for oss ... difor fann me det tenelegast å ha ein eigen fest og ikkje vere avhengig av nokon annan. Det skal me ogso for ettertidi gjera til vaar regel. Me hadde fulle hus endå det var to festar.

I protokollen for det frilynte ungdomslaget står deira 17. maifest nemnt, men ikkje nokon brodd mot andre. Seinare finn eg ikkje omtalar av slike parallelle festar.

Harmonien blei gjenoppretta. I seinare protokollar finn eg at i 1922 var Ungdomsforeininga(KM) og det frilynte ungdomslaget saman om eit skriv, der dei bad heradstyret vende seg til styresmaktene: Me vil med dette uppmoda det vyrde heradstyret um venda seg til styresmaktene med eit sterkt krav um faa alle offentlege skriv og skjema på landsmålet.

82 I Hareide ungdomsforening sin protokoll står det: På dette møtet bad formannen i den frilynde foreiningi um ordet. Han vilde tilbakevise den mistanken bygdafolket - helst dei kristne - viste for arbeidet til foreiningi deira. Han meinte at dei som bekjenner seg som kristne, kunde med godt samvit arbeida saman med deim.

Dette vart klart motsagt med det at ein av dei nyomvende som fyrr hadde arbeidt i den frilynte foreiningi, reiste seg og avla eit klart vitnemål um sin Frelsar, og heldt fram at sidan han hadde vorte umvend, kunde han paa ingen maate finna seg til rette i den frilynde foreiningi. Han takka for seg der og då. 


\section{Oppsummering}

Kulturmøtet eller kulturkrasjet eg opplevde i Volda for 50 år sidan, har eg kome tilbake til med jamne mellomrom. I arbeidet mitt med masterarbeidet har eg kome fram til mitt svar på spørsmålet:

Hareid er ei bygd der Grundtvig sitt kristendomssyn og hans pedagogiske idear fekk rotfeste i ei sentral tid. Dei fem store åndshovdingane Lars Hareide, Elan Rasofiel Rise, A. C Riise, Gullik Grimstad og Gullik Nesset blei sentrale personane for desse ideane. Ei samansetning av grundtvigiansk kristendomssyn, kyrkjeleg tilhøyrsle, norskdom, målsak, fråhaldssak, idealisme, korsong og organisasjonsbygging har vore med på å forme Hareids-kulturen og gjort Hareid til ei bygd prega av ei kulturopen kristendomsform. Ein grunn til som eg vil peike på, er at frå 1886 og fram til dags dato har Ungdomsforbundet (KM) hatt kontinuerleg arbeid. Det er eit av dei einaste laga i Noreg med så langt kontinuerleg arbeid blant barn og unge. KM sitt motto og med sin Trekant: Ånd, sjel og lekam, har òg vore i Grundtvigs ånd.

Samarbeidet innanfor bedehuset har vore det beste, samarbeidet med dei andre misjonsorganisasjonane like eins, og ikkje minst samarbeidet med kyrkja. Hareid bedehus kan vel langt på veg også kallast eit kyrkjelydshus med stor takhøgd. Bedehuset og kyrkja har ikkje hatt konkurrerande møteverksemnd etter det eg kjenner til. Men i nabobygda Ulstein er det nattverdsmøte søndag føremiddag på bedehuset, samstundes som det i i kyrkja, som ligg like ved, er nattverdsgudsteneste. Noko slikt kunne ikkje ha skjedd i Hareid. Her er det ikkje andre kyrkjelydar, og heller ikkje grunnlag for andre kyrkjelyder, enn den som er knytt til Den norske kyrkje.

Mi oppleving er at det stort sett ikkje var noko skilje mellom kulturane i dei ulike kristne organisasjonane i Hareid: Vi var no alle bedehusfolk, trudde eg. Derfor vart møtet med bedehusfolket $i$ Volda eit kulturkrasj.

\section{Litteraturliste}

Bjåstad, I. \& Waage, A. (1985). Bygdebok for Ulstein og Hareid, band V Gardar og folk (Vol. Gnr. 52 - gnr. 51 Røyset) Hareid og Ulstein: Hareid og Ulstein kommune. 
Bjåstad, I. (1977). Soga om Hareid og Ulstein bind II. Hareid og Ulstein: Sogenemnda for Hareid og Ulstein.

Bjørndal, M. (1983). Hareid Indremisjon 1883-1983. Glimt frå kristenlivet og bedehus $i$ Hareid - ei hundreårssoge. Hareid: Hareid Indremisjon.

Brekke, P. (1962). KORSONGEN I HAREID GJENNOM 100 ÅR. HAREID.

Djupedal, R. (1960). Ivar Aasen Dagbøker. Bank 3 Dagbøker 1830-1896. Oslo: Det Norske Samlaget.

Elstad, H. \& Halse, P. (2002). Illustrert norsk kristendomshistorie. Bergen: Fagbokforlaget.

Flø, K., Hareide, J. R. \& Hareide, I. (1945). Hareid sundagsskule 1895-1945. Vårt motto: Borna for Kristus. Ørstavik: Stiftstyret for søndagsskulen.

Furnes, K. (2003). Sunnmørsk Bedehusland. Ålesund/Giske: SI-Senteret A/S Bokhandel.

Grimstad, L. Ø. (2013). Det kulturkristne Hareid i det pietetiske Sunnmøre. Masteroppgåve ved Høgskulen i Volda.

Hagesæter, J. (1982). Sunnmøre Indremisjon 100 år. Ålesund: Styret for Sunnmøre Indremisjon.

Halse, P. (2009). Gudsord og folkemål. Framveksten av nynorsk kyrkjespråk 1859-1908. Oslo: Det teologiske fakultet, Universitetet i Oslo.

Hatlebrekke, K. U. (1983). Ulstein Indremisjon 1883-1983. Ulsteinvik: Ulstein Indremisjon.

Holt, K. (1998). Søndagsskuleliv på Sunnmøre. Sunnmøre søndagsskulekrins 1897-1997. Ålesund: Sunnmøre søndagsskulekrins.

Hovden, A. (1913/1996). Ivar Aasen i kvardagslaget (3. utgåva). Oslo: Det Norske Samlaget.

Løvlie, B. (2020). Vekkelse, bevegelse, bedehus. I B. Løvlie, P. Halse \& K. Hatlebrekke (Red.), Tru på Vestlandet. Tradisjonar i endring. Oslo: Cappelen Damm Akademisk. Måseide, P. (1977). Hareid kyrkje gjennom 100 år. Hareid: Hareid sokneråd.

Måseide, P. (1986). UNDER TREKANTEN I 100 ÅR. Hareid kristelege ungdomsforeining 1886-1986. Hareid: Eige forlag.

Rabben, B., Indresøvde, E., \& Torset, O. (1983). KULTURKAMP GJENNOM $75 \AA ̊ R$. Søre Sunnmøre distriktslosje 1907-1982. Volda: Søre Sunnmøre distriktslosje.

Orten, Ø., \& Brungot, H. P. (1991). Guds gamle bodskap finn nye vegar. Noregs KFUKKFUM Sunnmøre krins 1891-1991. Ulsteinvik: Noregs KFUK-KFUM, Sunnmøre krins.

Skorgevik, K. (1974). «Sandstormen». Trekk fra det religiøse liv på Sunnmøre i års 1880-1900. Oslo: Universitetet i Oslo, Hovudfagsoppgåve i kristendom.

Straume, J. (1950). Kristenlivet på Sunnmøre og Romsdal. Eit festskrift. Oslo.

Thorstvedt, Å. (2020). I kjølvannet av varme vinder. Weenaas og vekkelsen. I B. Løvlie, P. Halse \& K. Hatlebrekke (Red.), Tru på Vestlandet. Tradisjonar i endring. Oslo: Cappelen Damm Akademisk. 
Ulstein, J. O. (2020). Vestlandsk kyrkjesyn. I B. Løvlie, P. Halse \& K. Hatlebrekke (Red.), Tru på Vestlandet. Tradisjonar i endring. Oslo: Cappelen Damm Akademisk.

\section{Elektroniske kjelder}

Store norske leksikon.

\section{Utrykte kjelder}

Hareid frilynte ungdomslag - sekretær, H. f. 1909. Møtebok 1909-1929. Brev til Sunnmøre ungdomssamlag ved Olav Myklebust.

Hareid kristelege ungdomsforeining - sekretær, H. k. Frå 1923. Protokoll for Hareide kristelige ungdomsforening. Hareid.

Hareid kristelege ungdomslag og Hareid indremisjon, H. k., \& indremisjon, H. 1958. Lover for Hareid bedehus.

Hareide Indremisjon, S. H. 1883. Protokoll for Hareids forening for indre misjon stiftet den 18. april 1883. Hareid.

Hareide ungdomsforening - sekretær, R. i. H. k. Frå 1886. Protokoll for Hareid kristelege ungdomsforening.

Hareide Sogn Hedningemissions-Forening - sekretær, S. f. H. S. 1891. Hareide Sogn Hedningemissions-Forening - Protokoll. Hareid.

Losje Dag over Land - sekretær, L. D. o. L. s. 1897-1901. Møteprotokoll for losje Dag over Land. Hareid.

Syskjebandet. 1947. Artikkel vedr. medlemsstatistikk. Medlemsblad for Søre Sunnmøre Distriktslosje. 


\title{
Læraren i skulefolkets
} stordomstid: Om ein einskild lærar sitt forhold til presten og til skuledemokratiet

\author{
Kristin Hatlebrekke \\ Høgskulen i Volda
}

Samandrag: Slutten på 1800-talet vert ofte karakterisert som skulefolkets stordomstid og folkeskulelærarane sin gullalder. Særleg har lærarane på bygdene i etterkant fått titlar som periferiens nasjonsbyggarar, bygdehovdingar og bygdematadorar, merkelappar som kan leie tanken i retning høg status. Som følgje av dette trur ein gjerne at dei hadde lett spel når det kom til kven som skulle ha autoritet i klasseromet. Med utgangspunkt i dagbøker frå ein lærar i ei lita bygd drøfter denne artikkelen kor lett dette eigentleg var i ei tid då det var store spenningar i samfunnet, og då fleire enn lærarane fekk auka sjølvmedvit.

Nøkkelord: skulehistorie, lærarhistorie, skulen på 1800-talet, skuledemokrati, skulefolkets stordomstid

\section{Innleiing}

Det er skrive mykje og mangt om læraren og lærarrolla i notid og fortid, nokon prøver seg jamvel på framtidsvisjonar. Denne artikkelen skal handle om fortida. Hovudpersonen er læraren Jakob Hatlebrekke, fødd i 1857, som skula i heimkommunen Sande på Sunnmøre frå 1878

Sitering av denne artikkelen: Hatlebrekke, K. (2020). Læraren i skulefolkets stordomstid: Om ein einskild lærar sitt forhold til presten og til skuledemokratiet. I B. Løvlie, P. Halse \& K. Hatlebrekke (Red.), Tru på Vestlandet. Tradisjonar i endring (Kap. 11, s. 265-288). Oslo: Cappelen Damm Akademisk. https://doi. org/10.23865/noasp.104.ch11

Lisens: CC BY-ND 4.0. 
og til han døydde i januar $1905 .{ }^{1}$ Dette er ein viktig periode i norsk skulehistorie då "hovudstammen i det norske skolesystem» (Slagstad, 1998, s. 96) vart utvikla, og ein epoke som også er kalla «skolefolkets storhetstid» (Ekspertgruppa, 2016, s. 45). Når det gjeld læraren, som på mange måtar var den lekamleggjorde skulen på denne tida, skriv Ivar Frønes at den lærarrolla som då vart skapt, er «av sentral betydning for å forstå lærernes senere posisjon»(Frønes, 1989, s. 21). Det kan altså vere ein samanheng mellom forteljinga om ein landsens lærar frå 18oo-talet og dagens tolking av og forhandling om rolla og mandatet.

Det har vore forska ein heil del på skulen på 18oo-talet, og lærarane frå denne tida har fått merkelappar som bygdematadorar, folkeførarar og nasjonsbyggarar, alle meint som heiderstitlar, vil eg tru. Så har vi nemninga vestlandslærar, som er ei meir tvitydig nemning. Ho viser særleg til lærarar som kom frå lærarutdanningsinstitusjonane på Stord og i Volda frå denne tida, og peikar mot idealisten som i og utanfor klasserommet fremja målsak, kristendom, norskdom og fråhaldssak. Dagens lærarar blir ikkje sjeldan målt mot desse stødige og trygge fortidsheltane, suverene både bak kateteret og i lokalsamfunnet. I Aftenposten frå 2015 kan vi i ein redaksjonell artikkel om dagens læraryrke for eksempel lese dette nostalgiske tilbakeblikket, truleg med referanse til læraren rundt førre århundreskifte: «En gang var læreren autoriteten i samfunnet, en som folk så opp til, som hadde status, en som mange drømte om å bli. I dag er ikke læreryrket lenger oppe i toppsjiktet av statusyrker [...]» (Braathen, Sjøberg \& Brønmo, 2015).

På bakgrunn av dette glansbildet vil eg sjå nærare på realitetane i eitt konkret lærarliv. Eg er i denne samanhengen ikkje ute etter å stadfeste honnørorda, det har andre gjort både når det gjeld Jakob Hatlebrekke (Rabben, 1979, s. 283-284) og lærarstanden i alminnelegheit frå denne tida (Hodne, 2010, s. 111-119). Men Jakob Hatlebrekke skreiv dagbøker, og i desse tekstane finst det også passasjar som fortel om «fortredeligheter og gjenvordigheter» i lærarlivet. Desse er ofte knytte til elevane, det må vere eit tidlaust element i lærarens liv. Men like ofte er det skulekommisjon,

1 Jakob Hatlebrekke var oldefar min. 
skulestyre, tilsynsutval og jamvel presten som er kjelde til frustrasjonane. Dei demokratiske organa som kom til utetter 180o-talet, åt seg skulelov for skulelov inn på det som hadde vore presten som embetsmann og kyrkja sitt domene, og i staden for presten kom kommunens folkevalde inn i styringa av skulen. I små lokalsamfunn ville det seie sambygdingar frå same sosiale lag som læraren. Som artikkelen vil vise, kunne dette innebere utfordringar.

I tillegg til det administrative og styringsmessige skiftet vart også fagkrinsen og målsetjinga for skulen si opplæring forandra gjennom skulelovene. Desse peika mot at skulen skulle gi den opplæringa folket, ved sine representantar i ulike organ, meinte tente dei best for å kunne vere deltakande borgarar i eit folkestyrt land. Dette var nytt både når det gjaldt mål og innhald samanlikna med den gamle kyrkjeskulen som hadde lagt meir vekt på sitt fag, kristendomskunnskap og si målsetjing, konfirmasjon.

Desse reformene skjedde samtidig med andre, store forandringar i Noreg. Slutten av 180o-talet var ei konfliktfylt tid då makt vart flytta frå embetsmannsstanden til den jamne mann og kvinne. Ikkje alle var nøgde med denne utviklinga, og læraren, med utdanning og stigande sjølvtillit og status, men som sjølv frå fødselen av ofte høyrte til allmugen, kunne lett kome i skvis mellom gamalt og nytt. Det var ein situasjon som det kunne krevje sin pedagog å stå i.

I denne artikkelen vil eg løfte fram kva Hatlebrekke, som praktiserte i denne tida som også er kalla folkeskulelærarane sin «gullalder» (Haugland, 1995, s. 92), skreiv i dagbøkene sine om press og forventningar frå bygdefolk, foreldre, prest, biskop og representantar for dei ulike organa som utgjorde skuledemokratiet. Følte han seg som representant for ei stordomstid for yrket sitt? Med tekstane hans som utgangspunkt vil eg kaste lys over korleis skulelovene frå 1860 og 1889 verka inn på yrkesutøvinga til læraren i denne spenningsfulle tida med store omleggingar i samfunnet, ikkje minst når det gjaldt kven som skulle styre skulen. Det som her kjem fram, vil eg sjå på i lys av tre forskingsarbeid om læraren og lærarrolla på denne tida, og vidare spørje om det er sider ved posisjonen til læraren frå denne perioden som kan vere underkommunisert i forskingslitteraturen. 


\section{Metode og kjelde}

Spørsmålet om kva som er viktig historisk kunnskap, eller kva som er historie, melder seg når ein skal skrive om eit menneske som var ein av mange, ein i massen. I den nasjonale historia har Jakob Hatlebrekke ingen framskoten plass. Noregshistoria på makronivå ville vore den same utan han. Men lokalhistorisk, i siste boka i den fem bands sterke Soga om Sande og Rovde (Rabben, 1979) frå 70-talet, er Hatlebrekke nemnt blant lærarane som var i sving i kommunen etter skulelova av 1860 (Rabben, 1979, s. 43-52). Her har han altså også ein plass blant fleire, men forfattarane til lokalhistoria forsvarar å nemne alle lærarane i kommunen $\mathrm{i}$ dette tidsrommet med at dei var aktive i ein epoke som var svært viktig for utbygginga av skulestellet (Rabben, 1979, s. 44). Dei utgjorde det første lærarkorpset med formell seminarutdanning, og dei var dei første som underviste i faste skulehus og ikkje som omgangsskulelærarar. Slik gjorde dei ein pionerinnsats både som pedagogar i skuletida og som premissleverandørar for korleis skulen og skulehuset skulle vere integrert i lokalmiljøet.

Med utgangspunkt i dette, og i definisjonen på lokalhistorie som «lokalt avgrensa studiar av menneske i samfunn sett i tidsperspektiv» (Tretvik, 2004, s. 16), kunne ein forsvare merkelappen lokalhistorie på denne artikkelen. Hatlebrekke, gjennom dagboka, ville då tene som eit eksempel som stadfesta forteljinga om læraren som bygdehovding. Den etablerte forståinga ville kunne diktere eller legge sterke føringar for forståinga av det einskilde tilfellet som blir løfta fram.

For å unngå dette, og fordi eg trur dagboknotata har potensial til å belyse noko anna enn den etablerte forteljinga om sjølve Læraren, vil eg knyte meg opp mot ei anna retning innan historievitskapen som kallast mikrohistorie. Dette er ei forholdsvis ny grein av fagfeltet, og Arnfinn Kjelland har i ein artikkel gått igjennom nokre diskusjonar rundt denne måten å forske på (Kjelland, 20). Ein av diskusjonane handlar om korleis mikrohistorie skil seg frå lokalhistorie, der det, som Kjelland skriv, lenge har vore vanleg å kaste lys over allmenne emne med «konkret lokalhistorisk empiri» (Kjelland, 2009, s. 244). Om noko skal kallast mikrohistorie, understrekar han, «må forskingsprosessen i prinsippet ha gått den andre vegen» (Kjelland, 2009, s. 244). Det vil seie at den mikrohistoriske eininga 
ein studerer, skal brukast til å få fram eller belyse nye problemstillingar. Dette er dei svenske forskarane Jonas Lindström og Karin Hassan Jansson samde i. Dei seier at mikrohistoria sitt potensial og vitskaplege legitimitet ligg i å diskutere «det almänna i (det nya) ljuset av det enskilda» (Lindström \& Jansson, 2017, s. 358).

I artikkelen Pigan i fadersväldet: Regler, undantag och mikrohistoriska möjligheter (Lindström \& Jansson, 2017) skisserer Lindström og Jansson ein metode til bruk om ein vil utføre det dei kallar ei mikrohistorisk undersøking. For det første meiner dei at undersøkinga bør «utgå från det enskilda» (Lindström \& Jansson, 2017, s. 353). Utgangspunktet skal altså vere eit konkret tilfelle, då dette er sjølve kjernen i mikrohistorisk forsking. Dernest er kontekstualisering viktig for å gi lesaren relevant historisk kunnskap om samanhengen og bakgrunnssituasjonen mikroeininga blir sett i lys av. Til kontekst høyrer også tidlegare forsking og eventuelt «den store forteljinga $»^{2}$ om emnet. Til forskjell frå kontekst som bakgrunnssituasjon, den vil vere upåverka av den aktuelle mikrohistoriske undersøkinga, vil ein her gjere greie for eit spesifikt tilfelle av forskingssituasjonen på feltet som «åtminstone i idealfallet» (Lindström \& Jansson, 2017, s. 361) vil kunne gå i dialog med undersøkinga, skriv Lindsström og Jansson. Det ein vil finne fram til her, er dermed om det finst noko i den store forteljinga som eventuelt treng å bli modifisert av den vesle.

Her vil det reise seg eit spørsmål om ein kan forandre ei stor forteljing på basis av ei lita, med andre ord gjeld det generalisering. Om dette skriv Lindström og Jansson at spørsmål av typen «är dette representativt/typiskt/generaliserbart» (Lindström \& Jansson, 2017, s. 375) ikkje skal rettast til den mikrohistoriske undersøkinga, fordi eit slikt spørsmål til denne adressaten ville innebere å misoppfatte både utgangspunktet og resultatet. Spørsmålet skal heller stillast til «framtida studier» (Lindström \& Jansson, 2017, s. 375).

Mitt prosjekt vert følgjeleg å løfte fram sider ved eitt einskild lærarliv slik det kjem fram i dagbøkene, og for det eine setje dette i samanheng

2 I artikkelen brukar eg «stor forteljing» som nemning på ein dominerande diskurs, og «den lille forteljinga» som nemning på ei einskildforteljing. 
med den historiske konteksten og for det andre undersøke korleis det som kjem fram, korresponderer med anna forskingslitteratur om emnet.

\section{Om dagboka og Jakob Hatlebrekke}

I denne artikkelen er dagbøkene til Jakob Hatlebrekke (1879-1904) den viktigaste kjelda. Der har han skrive nesten kvar dag frå nyttårsdag 1879 til midten av desember 1904. Desse heimelaga hefta har blitt tekne vare på, og dei er no på Statsarkivet i Bergen. Som kjelde for denne artikkelen brukar eg ei avskrift som lokalhistorikaren Bjarne Rabben laga i 1975. I denne prosessen forkorta han tekstane noko. Det som er utelate, er ifølgje han sjølv vêrobservasjonar, notat om gardsarbeid, småfiske, sterkt personlege opplysningar og notat om kontroversar med skuleborna og «somt anna» (Rabben, 1975, i forordet til Hatlebrekke, 1879). Det er altså mogleg at det finst materiale i dei originale dagbøkene som hadde vore av interesse for denne artikkelen.

Som kjelde vert dagbøker tilordna kategorien egodokument (Baggerman \& Dekker, 2019). Dagbøkene til Hatlebrekke er eit tydeleg partsinnlegg i forteljinga om lærar, skule og lokaldemokrati i Sande kommune på slutten av 180o-talet. I dei daglege notisane finst det både djupt private sukk, passasjar som liknar på forsvarsskrift for han sjølv, og avsnitt som tyder på at han ser for seg at andre vil kome til å lese dette seinare. Dermed reiser det seg eit spørsmål om den intenderte lesar, og om han (også), skaper seg sjølv og set seg i scene gjennom desse tekstane. Det får vi ikkje vite. Hadde vi hatt dagboka til ein forelder, eller til formannen i tilsynsutvalet, var det temmeleg sannsynleg at dei konkrete hendingane Hatlebrekke viser til, ville bli fortalt på ein annan måte. Og når dagbøkene vert kopla til skulehistorie og til store forteljingar om læraren på slutten av 1800 -talet, vert det gjort ei tolking av kva dette handlar om av meg som skriv.

Jakob Hatlebrekke var fødd på garden Hatlebrekke på Kvamsøya i Sande kommune i 1857. Foreldra var typiske sunnmørske fiskarbønder. Han var elev ved Voldens høiere Almueskole og Lærerskole og fekk eksamen i 1878. Denne skulen kom i gong frå 1861 under namnet Voldens høiere Almueskole med annecteret Dannelsesanstalt for Almueskolelærere 
og var i drift til 1880. Skulen hadde, likt arvtakaren Voldens Privatseminarium som vart skipa i 1895 med Henrik Kaarstad som rektor, ein tydeleg ideologisk profil, skriv Jostein Nerbøvik og nemner særleg den nasjonaldemokratiske bodskapen som ein samanbindande historisk faktor. Berre namnelista over dei som tok lærareksamen i Volda mellom 1861 og 1880 er ei «fortetta kulturhistorie» (Nerbøvik, 1995, s. 39), skriv han vidare, og stadfestar at mange av elevane frå denne tida hadde stor innverknad på samfunna dei seinare vart ein del av som lærarar.

I 1881 fekk Hatlebrekke fast stilling i skulekrinsane Gjerdsvika og Haugsbygda på Gurskøya i Sande kommune. Dagbøkene teiknar eit bilde av ein entusiastisk, allsidig og driftig lærar og fiskarbonde med ei hand med i mykje av det som skjedde i begge skulekrinsane også utanfor skulen. Dette ville ikkje vore mogleg om ikkje tonen mellom læraren og gamal og ung i bygdene på det jamne var god. Han var aktiv både på det kulturelle og det religiøse området, og var med på å setje i gong mange foreiningar utover åtti- og nittitalet. Lokalhistorikaren Bjarne Rabben skriv om Hatlebrekke sin innsats slik: «Når ein av dagboka hans ser alt han var med på i desse to bygdene og kor fullpakka dagane hans var med skulearbeid, gardsarbeid, ungdomsmøte, songmøte, fråhaldsmøte, oppbyggingsmøte, festar, basarar og møte om bygdespørsmål, så kan ein undrast på korleis han kunne greie det.» (Rabben, 1979, s. 283-284). Når det kjem til det politiske, etterlèt dagbøkene ingen tvil om at læraren i Gjerdsvika og Haugsbygda var venstremann.

Samla sett kan altså Hatlebrekke ha vore ein typisk representant, kanskje sjølve inkarnasjonen, av ein vestlandslærar, iallfall om ein ser bort frå målsaka, som ikkje kan ha appellert særleg til han. I dagbøkene skriv han bokmål/riksmål heilt til det siste, men innimellom, og meir etter som åra går, finst det eksempel på både dialektbruk og nynorsk. Men lågkyrkjeleg kristendom kombinert med trufast kyrkjegang og ei ganske kulturopen innstilling, fråhaldssak og nasjonsbygging på lokalplannivå finn ein rikeleg omtala i dagbøkene. Denne sida av lærarportrettet, aktiv på mange frontar og høgt respektert, er også godt kjend frå både forsking og skjønnlitteratur. 


\section{Læraren frå slutten av 1800-talet i forskinga}

Frå forskingslitteraturen om lærarane på slutten av 180o-talet presenterer eg her tre arbeid som eg vil sjå dagboknotatane til Hatlebrekke i lys av. Det første er frå folkeminnegranskar Ørnulf Hodne, det andre er ein artikkel frå Kjell Haugland, og det tredje er frå Reidun Høydal og er ein del av vestlandslærarprosjektet (Høydal, 1995, s. 1). På kvart sitt vis bidreg desse arbeida til bildet av læraren på slutten av 180o-talet som ein klippe i lokalsamfunnet, ein autoritet som resten av bygda både støtta seg til og støtta opp om.

Folkeminnegranskar Ørnulf Hodne har undersøkt korleis «den gamle lærargenerasjonen», dei som var aktive mellom 1885 og 1925, blir hugsa av dei som opplevde desse lærarane bak kateteret (Hodne, 1987). Han har også skrive det han sjølv kallar «en annerledes skolehistorie» (Hodne, 2010), der han tek utgangspunkt i folkeminnet. Det er få overraskingar i dei portretta som blir teikna der. Han legg ikkje skjul på at det også då fanst lærarar som var upopulære (Hodne, 2010, s. 116) og kanskje lite eigna til oppgåva (Hodne, 1987, s. 85-86). Men hovudbodskapen er at læraren, særleg bygdelæraren, var den personifiserte skulen og den kallsmedvitne oppsedaren. Folk hadde høge tankar om lærargjerninga, og dette viser seg ved at elevane var positive til læraren også når han var streng. Han er hovdingen og primus motor i mykje organisasjonsarbeid, éin informant seier beint ut at det var ei uskriven lov at læraren skulle vere aktiv i slikt arbeid i den bygda der ein heldt skule (Hodne, 2010, s. 113). Materialet til Hodne teiknar bildet av ei kulturberande og verdiskapande yrkesgruppe. Men det vert også poengtert at det var viktig at læraren ikkje var kontroversiell i politiske og religiøse spørsmål. Var det mistanke om vranglære, fritenkeri eller fanatisme, kunne det hende at kristendomstimane vart overhøyrt av høgare makter (Hodne, 1987, s. 83).

Oppsummert seier Hodne at læraren av den gode, gamle sorten var «romslig, folkelig og ubyråkratisk - og sterkt individualistisk» (Hodne, 1987, s. 86).

Kjell Haugland tonar ned det individualistiske når han gjer greie for rolla på slutten av 180o-talet. Tvert om meiner han at dei sterke forventningane til korleis ein lærar skulle te seg, skapte mindre armslag for denne yrkesgruppa enn for mange andre (Haugland, 1995, s. 92). Elles er 
han oppteken av læraren som nasjonsbyggar i bygdene. Som nasjonsbyggarar med norskdom, målsak, fråhaldssak og lekmannskristendom på agendaen, utfordra lærarane maktposisjonen til den gamle eliten, skriv Haugland. Nasjonsbygging handla om å skape ein norsk identitet, og når denne identiteten vart ein del av den politisk-sosiale maktkampen mellom periferi og sentrum, bønder og overklasse, hadde læraren lett spel, meiner Haugland. Men han nemner eit viktig vilkår: Læraren må sjølv velje rett side i kampen mellom overklassen og bondestanden. Ein avgjerande føresetnad for å kunne ha tillitsforhold og leiarposisjon i bygdene var at læraren «identifiserte seg med bondekulturen og valde ei primus inter pares-rolle», skriv han (Haugland, 1995, s. 97).

Reidun Høydal har i hovudoppgåva si i historie undersøkt det ho kallar myten om vestlandslæraren; den samfunnsengasjerte leiaren i bygdene som også er fråhaldsmann, målmann og lågkyrkjeleg kristen. Denne myten, seier ho i innleiinga til oppgåva, kan bygge på trekk ved einskildlærarar som har blitt generalisert og som har fått stå uproblematisert, og som dermed har blitt ein stereotypi. For å forklare korleis denne eventuelt reelle lærartypen vaks fram, og om mogleg deaktivere myten, undersøkte Høydal lærarutdanninga i Volda, bakgrunnen til mange av elevane og om det var noko ved denne kombinasjonen som skapte lærarar av eit visst kaliber. Konklusjonen hennar når det gjeld det mytiske, vart at Voldalærarane faktisk hadde mange av dei kjenneteikna ein vestlandslærar var sagt å ha. Det var «ein mann som var oppteken av og engasjert i målsak, fråhaldssak og kristeleg arbeid, han var politisk aktiv og aspirerte til ei leiarrolle i bygdesamfunnet» (Høydal, 1995, s. 339). Med andre ord ser det ut til at Høydal stadfestar at det var hald i myten, og at denne lærartypen både var ein realitet og eit ideal.

\section{Den historiske konteksten. Skulelovene frå 1860 og 1889}

Tiden krever «at der vides meget», skal Hartvig Nissen, ein av arkitektane bak fleire av skulereformene i siste halvpart av 180o-talet, ha sagt (sitat henta frå Slagstad, 1998, s. 185). Det han hadde i tankane, var nok ikkje erfaringskunnskap om torskens veg i havet, men såkalla bokleg 
lærdom. Demokratiseringa av Noreg som fann stad på denne tida med innføringa av parlamentarisme i 1884 og med forskyving av makt frå ein klasse til ein annan i lokaldemokratiske organ som for eksempel skulestyra, kravde eit utdanna folk. Dermed var det også behov for ein skule som kunne utdanne borgarar som kunne setjast inn i slike verv og skjøtte dei til gagn for samfunnet. Og for å realisere ein slik skule trong ein velutdanna lærarar, meinte Nissen (Bergem, 1995, s. 22).

Parallelt med utviklinga i skulen forandra samfunnet seg på gjennomgripande vis. Både på det politiske, sosiale, økonomiske og det kulturelle området var forandringane så radikale at tida og prosessane har fått namnet «det store hamskiftet». Ein snakkar også om «det moderne gjennombrotet» og om overgangen frå embetsmannsstat til venstrestat. «Venstrestat» er her ei tilvising til overgang til parlamentarisme og ein meir reell folkesuverenitet enn det som vart sett i verk dei første tiåra etter 1814 .

Jostein Nerbøvik skriv om desse endringane (Nerbøvik, 1999, s. 171-191), og viser korleis det kom til syne mellom anna gjennom kvinnerørsla, lekmannsrørsla, folkehøgskulerørsla, målsaka og fråhaldsrørsla. Også i diskusjonane rundt norskdom og nasjonalisme ser ein spor av eit Noreg i forandring. Desse forandringane var ikkje vitskapelege paradigmeskifte som primært interesserte ein liten krins innan statsstyring og forsking. Tvert imot, dei store folkelege rørslene fekk kanskje større betyding for kvinna på fjøskrakken enn for mannen i departementet.

Store forandringar inneber gjerne store spenningar. Temperaturen i det folkelege engasjementet kan ein lese ut av oppslutninga om politiske val. Heilt fram til 1880 låg deltakinga blant dei røysteføre på under femti prosent, men så stig engasjementet markant, og i 1894 er ein er oppe i $90 \%$ valdeltaking. Og det endå ein betydeleg større del av folket hadde røysterett (Dokka, 2017).

Skulen og lærarane hadde sin plass i denne prosessen gjennom det skulehistorikarane Alfred Oftedal Telhaug og Odd Asbjørn Mediås kallar skulen sitt statsborgarlege prosjekt (Telhaug \& Mediås, 2003, s. 59). Den som skulle vere borgar og ta del i ansvaret for utviklinga i samfunnet, trong opplysning til dette formålet. Hartvig Nissen var ikkje aleine om å meine at det var viktig å vite, og utetter 180o-talet auka talet på skuledagar for born, og i tillegg vart det det sett i gong kveldsskular i mange 
skulekrinsar slik at vaksne menneske kunne få del i kunnskap deira eigen skulegang ikkje hadde gitt dei.

Sjølv om det hadde kome til nokre endringar av skulelovene dei første tiåra av 180o-talet, var desse ifølgje skulehistorikarane Alfred Oftedal Telhaug og Odd Asbjørn Mediås «av mindre format» (Telhaug \& Mediås, 2003, s. 54). Dei store endringane på skulefronten skjedde mot slutten av 180o-talet, og særleg var Loven om allmueskolen på landet frå 1860 og Lova om folkeskulen frå 1889 viktige, då dei innebar store reformer som både vedkom innhaldet i skulen og styringa av den.

Når det gjeld Loven om allmueskolen på landet frå 186o, var ei viktig side ved denne lova at folket fekk sterkare innverknad på det som skjedde i skulen ved at skulen skulle styrast av ein kommunal kommisjon, seinare kalla skulestyret, som vart oppnemnd av kommunestyret. Framleis var presten sjølvskriven formann (Myhre, 1982, s. 45), han var statleg embetsmann, og å styre skulen hadde vore ein del av stillingsinstruksen så lenge det hadde vore offentleg skule i landet, men det var teke eit steg i retning av å gi folket makt. I tillegg til skulekommisjonen var det også oppretta ei frivillig ordning med tilsynsutval for kva einskild skule. Dette utvalet sitt mandat var å passe på sjølve skulehuset og å føre tilsyn med drifta, men òg å ta opp ting ein meinte var viktig i skulekvardagen. Foreldra til elevane var representerte i dette utvalet (Dokka, 1988, s. 80). Både skulekommisjonen og tilsynsutvalet innebar at prest og kyrkje fekk mindre formell makt over skulen, og som vi skal sjå, følte også læraren at desse organa greip inn i den faglege og pedagogiske autonomien hans.

1860-lova innebar at det vart lagt meir vekt enn tidlegare på såkalla borgarleg opplysning, noko som igjen betydde at kristendomskunnskap, som var kyrkja sitt domene, vart svekka på timeplanane. Sekulariseringa av skulen tok for alvor til.

Neste skulelov kom i 1889. Denne gongen vart namnet allmugeskule erstatta med folkeskule. Dette kan ha vore eit viktig politisk signal om ein ny status for både høg og lav i samfunnet. Allmugen er eit omgrep som har sin motpart i dei høgare klassene, som borgarskapet og embetsmannsklassen. Folket kan forståast som heile folket. Men namneskiftet annonserte også at skulen skulle vere styrt av folket, og med denne lova fekk lokaldemokratiet større innverknad på skulen enn det har hatt 
nokon gong, skriv Reidar Myhre (1982, s. 49). Tilsynsutvalet vart obligatorisk, dei borgarlege faga vart ytterlegare styrkt, og skulestyret fekk no rett til å lage undervisningsplan og fordele timetalet mellom faga. Dette var ikkje berre enkelt, særleg ikkje med tanke på statusen til skulens eldste fag. Kristendomen si stilling var på ingen måte udiskutabel på slutten av 18oo-talet, verken innanfor eller utanfor skulen. Positivistisk kulturradikalisme hadde vind i segla, og spørsmålet om det var skulen si oppgåve å gi religionsundervisning var ikkje ukjent, og svaret var heller ikkje opplagt (Myhre, 1982, s. 39). Kyrkja, også den ein representant for store deler av folket, engasjerte seg i saka. I ein skulediskusjon med Johan Sverdrup sa biskop J. C. Heuch at «I enhver kulturkamp, vil det være om Skolen, at Hovedslaget kommer til at staa, thi det er gjennom Skolen, at en kulturretning gjennemtrenger den hele Slægt og gjennem de oppvoxende Generationer bereder sig en Fremtid hos Folket.» (sitert frå Myhre, 1982, s. 39).

Løysinga i denne saka vart at formålet for kristendomsfaget vart nedfelt i skulelova, men talet på timar i faget fekk skulestyret bestemme. Når det gjaldt tilsynet med undervisninga, fekk prost og biskop bevare ansvaret for kristendomskunnskapen, men resten tok skuledirektøren over.

Slik Hartvig Nissen ville, vart det også sett i verk tiltak for å auke kompetansen og dermed statusen til lærarane. Det var ikkje lenger nok å ha oversikt over Pontoppidans 750 spørsmål og svar for å vere kvalifisert for å arbeide i klasserommet. Med lova om Allmugeskule på Landet av 1860 kravde staten lærarutdanning og kompetanse innan fleire fagområde, og dette vart det også lagt til rette for ved at det vart oppretta offentlege lærarseminar i tillegg til dei private. Lova innebar altså eit lærarløft. Men løna var låg heilt fram mot 1890-talet. Og tilsetjingsmyndet skulle heilt og fullt ligge hos lokale myndigheiter utan at det var rom for å anke til ein sentral instans. Blant lærarar vart ikkje dette sett på som bidrag til å auke statusen til yrkesgruppa (Dokka, 1988, s. 80).

Skulelovene på slutten av hundreåret innebar altså reformer på fleire felt, og det gjekk ikkje berre stille for seg. «Det gamle skoleregimet ble nedkjempet med en voldsom kraft i kjølvannet av embedsmannsstatens politiske sammenbrudd» (Slagstad, 1998, s. 96), og den som kanskje meir enn nokon stod midt i dette og følte rivningane på kroppen, var læraren. 


\section{Dagboknotat}

I det følgjande vil eg løfte fram sitat frå dagboka der Hatlebrekke fortel om korleis det var å vere lærar i eit lite bygdesamfunn på slutten av 180otalet. Som nemnt i innleiinga er fokuset retta mot forholdet til dei lokale representantane for arbeidsgivar, i første omgang presten, så i aukande grad skulestyret og tilsynsutvalet. Det er særleg dei problematiske sidene ved dette i eit lite bygdesamfunn, som ofte har med vanskelege sider i samspelet med elevar og foreldre å gjere, eg trekker fram her.

Dagboknotata ser eg i lys av sider ved dei skulepolitiske føringane i lovverket som endra seg radikalt i løpet av andre halvdel av 180o-talet.

\section{Læraren og presten, representanten for det gamle embetsmannsveldet}

Til langt inn på 180o-talet var det vanleg at den som ville bli lærar fekk eit kurs hos den lokale presten. Slik låg sertifiseringsmyndet for skulen hos kyrkja, og hierarkiet mellom yrkesgruppene var dermed gitt. Etter kvart kom det lærarskular i sving, men desse hadde liten kapasitet med omsyn til opptak, og dei danka ikkje ut behovet for presten sin kompetanse. I skulelova frå 1860, derimot, kravde staten lærarutdanning og kompetanse innan eit breiare fagområde for å få sleppe til bak kateteret. Dette vart det lagt til rette for ved at lærarutdanninga vart styrkt med omsyn til innhald og kapasitet (Myhre, 1982, s. 51). Lova innebar altså eit lærarløft og ei heving av læraren sin status. Slik nærma han seg presten.

Det var likevel langt att til at prest og lærar var jambyrdige, noko tituleringa av presten og den refererte dialogen i eit av Hatlebrekke sine dagboknotat frå 1885 tydeleg viser: Hatlebrekke skriv om korleis han og ein annan ung lærar i kommunen skulle innom prestegarden for å revidere årsrekneskap og levere søknad om alderstillegg i lønna. Dei hadde gledd seg til «en lun passiar» med presten. Denne tilnærminga gjekk ikkje heilt som dei håpte: «Men omforladelse, han spurgte kun: 'finder I nu trykkerten?' og da forstod vi det derhen: 'der er døren.' Og hvem vil så uleilige prestefar?» (Hatlebrekke, 1885, 6. mars). 
I tillegg til å styrke læraren sin posisjon andsynes presten med omsyn til utdanning vart det kristelege og det borgarlege formålet med skulen sidestilt med lova av 186o. Fagområde som historie, geografi og naturfag vart obligatoriske, og det vart dermed mindre tid til kristendomskunnskap. Kyrkja sitt kunnskapsområde var på retrett i skulen, og også som følgje av dette vart læraren sitt forhold til dei geistlege eit anna.

Likevel hadde presten framleis så vel rett som plikt til å visitere undervisninga og vurdere kunnskapar og ferdigheiter til både lærarar og elevar i alle fagområde. Prest og bisp var autoritetar, også på undervisning. Hatlebrekke kommenterer i dagboka 3. juli 1885 etter ein eksamen der presten har vore til stades: «Iår gik det godt - å det kom av at eg spurde sjølv». Kanskje anar vi ein kime til profesjonsstrid her, eller markering av revir. Eit par år seinare ser vi at presten T. A. H. Berger (1848-1925) og Hatlebrekke har delt faga mellom seg når elevane skulle eksaminerast: «Berger hørte børnene i religion og læsning. Eg havde derefter regning, geografi og sang.» (Hatlebrekke, 1887, 6. juli).

Når bispen kom til soknet, var det duka for visitas. Dette arrangementet var framleis ikkje ein visitt der likeverdige yrkesutøvarar møttest i kvar si rolle, her var det tydeleg ubalanse i maktforholdet, det ser vi frå ein dagboknotis frå 1887. Hatlebrekke skriv at han har vore på Larsnes, der bispen $^{3}$ har overhøyrt han og iallfall to andre lærarar i katekeseoppgåver. Etter kva han skriv, var bispen denne gongen fornøgd med to av lærarane, han sjølv inkludert, medan tredjemann fekk kritikk for manglande klarheit i tankegangen og for å ha for mange ja- og nei-spørsmål «hvilket er for let, da det ikke bringer børnene til at tænke». Elles får vi vite at bispen har rost songkvaliteten, kritisert «bogstavernes stilling» og dessutan kommentert at det mangla eit par fødselsår og datoar i protokollen (Hatlebrekke, 1887, 16. juli). Ingenting i dagboka tyder på at Hatlebrekke opponerer mot bispen, slik ein kan få inntrykk av at han gjorde mot presten når han skriv at det gjekk betre med elevane når han sjølv stod for eksamineringa.

3 Denne biskopen var Fredrik Waldemar Hvoslef (1825-1906). Han hadde vore prest i Kautokeino under opprøret der i 1852, og vart seinare styrar for lærarseminaret i Tromsø. I 1881 vart han utnemnd til biskop i Bergen og hadde denne stillinga til han gjekk av med pensjon i 1898. I mellomtida var han tilbode å bli kyrkjeminister i 1884 . 
Kven som skulle kunne tilsetjast som lærar var eit viktig spørsmål på slutten av 18oo-talet, og lova frå 1860 sa også noko om dette (Dokka, 1988, s. 50). Hans-Jørgen Dokka skriv at først skulle ledige postar utlysast. Så skulle skulekommisjonen innstille, og til slutt skulle stiftsdireksjonen tilsette. Men saka var ikkje utdebattert med dette vedtaket. I diskusjonane fram mot 1889-lova ville mange at skulekommisjonen skule få uinnskrenka rett til å bestemme kven som skulle tilsetjast (Dokka, 1988, s. 75). Lærarane og konservative politikarar vegra seg mot dette, og meinte det ville opne for tilfeldige og skiftande sympatiar i lokalsamfunnet, noko som ikkje trygga lærarane si stilling. Venstre, derimot, meinte at dette ville vere eit vedtak i liberalismens og åndsfridomens teikn. Åndsfridom var eit viktig stikkord her, for parallelt med diskusjonen om kven som skulle tilsetje lærarar, gjekk ein debatt om kva krav ein skulle stille til lærarane når det kom til religion. I 1883 hadde konservative krinsar gått ut med «Opraabet til Christendommens venner i vort Land $»^{4}$, der dei argumenterte for at ikkje berre kristendomslærarane, men alle lærarar måtte høyre til i statskyrkja, noko Venstre var imot.

Eit ekko av denne diskusjonen finn vi nok i Hatlebrekke si dagbok når han i 1887 kommenterer ei tilsetjingssak i Sande kommune. Han fortel at Per Riste, heimehøyrande i kommunen og seinare kjend som dugande lærar, ihuga målmann og norskdomsforkjempar i Volda, ikkje har fått post, han har ikkje eingong vore i betraktning. Det kunne sjå partisk ut, skriv Hatlebrekke, «men der vare foretagne 2 stemmegivninger, og udfallet vare det same. Rygtet om at han er løs i sine anskuelser om religionen har vist kastet ham. Der er ingen anden grund. Gud fri oss fra et ondt rygte» (Hatlebrekke, 1887, 11. november, og Runde, 2008, s. 91). Eit par dagar tidlegare viser dagboka at han har hatt møte i Ynglingeforeningen, og der har dei snakka om den skadelege og den gagnlege litteraturen og «Om faren ved at læse fritenkerske bøger og blade» (Hatlebrekke, 1887, 8. november).

Her kan altså kyrkje og skuledemokrati ha vore på same side, og ikkje ville tolerere moglege uortodokse oppfatningar på livssynsområdet, slik

4 Oppropet gjaldt ikkje berre innhaldet og styringa av skulen, men var eit innspel i den kraftige kulturkampen som gjaldt mange område i Noreg på 1880-talet. 
Hodne skriv (1987, s. 83). Hatlebrekke, som sjølv var uttalt venstremann, kan sjå ut til å vere delt i synet på den manglande tilsetjinga av Riste. På en eine sida stadfestar han at Riste er ein god nok lærar, kanskje også at han er ein truande mann, slik det kjem fram i biografien om den felles venen Bernt Støylen (Runde, 2008, s. 91). På den andre sida står ikkje Hatlebrekke opp for åndsfridom og liberale idear, men åtvarar ungdomen mot fritenkeri. Ein kan ane konturane av eit kyrkjeleg meiningsmonopol, og om nokon vert sagt å opponere, omtalast dette som «et ondt rygte».

Men dagbøkene viser også at det skjer ei utvikling i forholdet til presten og kyrkja sin autoritet mellom folk. Dette gjeld ikkje berre relasjonen mellom lærar og prest, men også korleis allmugen eller kyrkjelyden definerer sin posisjon andsynes embetsmannen og denne sin definisjonsmakt på det religiøse området. Utfordringa kjem ikkje frå liberalt, religionskritisk hald, men frå vekkingskristendomen. På seinvinteren 1888, i ein periode med store vekkingar også på ytre søre Sunnmøre, skriv Hatlebrekke om ein potensiell konflikt i samband med eit oppbyggeleg søndagsmøte som ikkje var i regi av kyrkja. Då gudstenesta var over, vart det tillyst oppbyggeleg møte i skulehuset ikkje så langt unna kyrkja. «Men ein og annan murrad då, at det var ingjen meining i å lysa mæte der uppe for heile meinigheiti, samt at det var då meiningslaust å forlate kyrkja. Me åtte ho sjølve. Lat deim nægte os kyrkja lenge nok, me tæk ho.» (Hatlebrekke, 1888, 11. mars). Dette enda med at ein mann gjekk bort på kyrkjegardsmuren og ropte ut at møtet skulle haldast i kyrkja om ei stund. Då presten (Berger) fekk høyre dette, lo han, skriv Hatlebrekke, og legg til at han ikkje kunne tyde låtten. Men han trur at den signaliserte medhald. Om han hadde rett i dette, ser vi kanskje her eit teikn på at ikkje berre fotfolket si sjølvforståing var i endring, men at også presten definerte seg sjølv og rolla si på ein ny måte.

\section{Læraren, skulestyret og tilsynsutvalet}

Skulelovene frå 1860 og 1889 innebar ei demokratisering og desentralisering av skulen. Som nemnt meiner Myhre at lokaldemokratiet aldri har hatt større innverknad på den norske skulen enn under særleg folkeskulelova av 1889 (Myhre, 1982, s. 49). 
Når det gjaldt styret av skulen, var det ikkje lenger sjølvsagt at presten skulle vere formann i skulestyret, og følgjeleg vart relasjonen mellom prest og lærar nok ein gong ein annan. Men lærarane var heller ikkje nøgde med at lagnaden deira no heilt og fullt låg i hendene på lokaldemokratiet (Dokka, 1988, s. 80). Det ser ikkje ut til at skulekommisjonen i Sande heller hadde sans for denne lova, iallfall ikkje ved første augekast. Hatlebrekke refererer 24. september1888 til eit møte der den viktigaste saka var forslag til ny skulelov. Hatlebrekke skriv ikkje meir om forslaget enn at det vart forkasta.

Då lova tredde i kraft, vart den tidlegare skulekommisjonen omdøypt til skulestyre og fekk vide fullmakter. Dei fekk for det første rett til å både tilsetje og seie opp lærarar. Ankeinstans var ikkje i nokon av tilfella eit statleg organ, men kommunestyret (Dokka, 1988, s. 80). For det andre skulle skulestyret også utarbeide undervisningsplanar, med mål, innhald og timefordeling. Samansetjinga av dette rådet vart dermed viktig. Kyrkja fekk inn den lokale presten, men han var altså ikkje lenger sjølvskriven som formann. Ordføraren skulle vere med, og lærarane fekk også ein representant. Resten av medlemane var det kommunestyret som peika ut (Myhre, 1982, s. 50).

I og med denne lova vart det tidlegare frivillige tilsynsutvalet obligatorisk. Hatlebrekke skriv mykje om dette. Utvalet var knytt til den einskilde skulekrins, og lærar og utvalsmedlemer var dermed sambygdingar og naboar. Ofte gir dagboka innblikk i gemyttleg stemning og godt samarbeid på same lag for skulens og elevane sitt beste. For eksempel skriv Hatlebrekke ein novemberdag i 1891 om eit møte der dei har samtala om skuleruta, og tilsynsutvalet har delegert oppgåva til lærarane. Etterpå går dei over til å snakke om «kristentro, videntro og hjertetro» (Hatlebrekke, 1891, 19. november) og avsluttar møtet klokka halv tolv om kvelden. Seinare fortel han om song og spel i prestegarden der mange tilsynsutval og lærarar frå kommunen deltek etter å ha hatt felles møte om skuleruta (Hatlebrekke, 1892, 18. januar).

Ut frå det Hatlebrekke skriv, kan det sjå ut til at tilsynsutvalet særleg var aktive når det gjaldt spørsmål om oppmøtet til undervisninga og i spørsmål om disiplin. Læraren melder for eksempel til utvalet når det er mykje fråvær frå skulen, då er det medlemene si plikt å stramme opp 
foreldra. Ved fleire høve rapporterer dagboka om elevar som ikkje kjem fordi dei tek del i arbeidet på garden og i båten. Tilsynsutvalet kan også sjølv vedta skulestans slik dei gjer i Gjerdsvika 11. mars 1891 når silda kjem (Hatlebrekke, 1891, 11. mars). Då skal store og små i båtane, og det er ikkje tid til undervisning. Og dersom Hatlebrekke sjølv får lyst til å «prøve efter silden» (Hatlebrekke, 1896, 2. desember) når det går rykte om god fangst, innvilgar tilsynsutvalet det. Men det hender også at medlemer av tilsynsutvalet heilt på eiga hand oppfordrar einskilde foreldre til å halde barn heime frå skulen for eksempel for å få potetene opp av jorda. «En pen skoletilsynsmann!», skriv Hatlebrekke ved eit høve når han har høyrt om slikt (Hatlebrekke, 1900, 28. mai).

Straff og disiplinære tiltak var også ein del av tilsynsutvalet sitt verkeområde. Dagboka fortel at fjerde januar 1890 troppar tilsynsutvalet opp på skulen, og ein far er med dei. Denne faren vil ikkje at borna hans skal bli slått av læraren, og har samla tilsynsutvalet, sannsynlegvis for å få medhald, trur Hatlebrekke. Men representantane for lokaldemokratiet, derimot, «vil strængt pålegge mig at give børnene ris for ulydighed både hvad lækser og opførsel angår» (Hatlebrekke, 189o, 4. januar). Den aktuelle faren ville heller ikkje ha noko av pålegg om at borna skal lære å lese før dei begynner på skulen, for hans born skulle ikkje berre lese, men også arbeide, hadde han sagt (Hatlebrekke, 1890, 14. januar). På det punktet har utvalet inga meining, iallfall skriv ikkje Hatlebrekke om det. Men elles viser dagbøkene at dei er til stades som tilhøyrarar ved eksamen, og at dei også har høve til å kome innom skulen og observere undervisninga. Det gjer dei ikkje så altfor ofte, skriv Hatlebrekke.

Men det ser også ut til at tilsynsutvalet ved fleire høve har vore ei direkte utfordring for Hatlebrekke. Dei definerer mandatet til ikkje berre å passe at bygda og foreldra gjorde plikta si andsynes skulen, men også til å ha tilsyn med læraren. Hausten 1891 ser vi spor av ein lesetidsdebatt, der folk i bygda har finrekna og kome til at han eit år har undervist tre timar for lite. «Å du verden!!!!!», skriv Hatlebrekke (1891, 12. oktober), og minner seg sjølv på at han i mange år har skula 36 timar for mykje og aldri fătt verken ros eller lønn for det. Tilsynsutvalet hissar seg likevel ikkje opp over dei tre timane i manko, men kjem på at når elevane har blitt teke med for å synge på bispevisitasen, og dette har 
blitt rekna som skuletid, er det verre, sjølv om læraren hevdar at dette var innanfor avtalen.

Kanskje var det ikkje alltid lett å vere tilsynsutval heller. Også medlemene der kunne oppleve kontroversar om skulen som belastande. Dette viser ein samtale med eit utvalsmedlem som Hatlebrekke refererer i dagboka. Mannen seier at han gler seg til å slutte til nyttår, og grunngir dette slik: «Det er farligt at snakke til både børn og forældre om deres pligter; man kan da ikke være sikker på liv og hus» (Hatlebrekke, 189o, 1. oktober).

Når tilsynsutvalet ikkje klarar å ordne opp i ei sak, kjem skulestyret på banen. Det ser vi hausten 1890, når det er tydeleg at det er misnøye med Hatlebrekke i den eine skulekretsen hans, der han ikkje bur. Først vert tilsynsutvalet kopla inn. Første gong han skriv om dette, fredag 5 . september, fortel han om ein utriveleg dag i skulestova. Han har sendt ein elev på gangen på grunn av juks og trass. Dette utløyser fornærming og vrede blant elevane, og Hatlebrekke kommenterer i dagboka at det «er besynderligt, nu skal en lærer ikke en gang have ret til at vise ut en ulydig gut» (Hatlebrekke, 1890, 5. september). Vidare skriv han at å bruke munn når ein blir refsa, ikkje er uvanleg blant gutane på skulen. Tysdagen derpå kjenner han seg «sjælesyk» og skriv at grunnen til dette er «at man her i bygden er så misfornøiet med mig.» Tilsynsutvalet har vore på skulen og snakka med han om episoden fredagen før. Det «ble talt vidt og bredt» og «efter megen ventileren» var det bestemt at klagene skulle leggast ved protokollen. Hatlebrekke vinn ikkje fram med sanninga, skriv han, og han må innrømme at han har handla urett og må be foreldre og barn om tilgiving. Søndagen etter får han vite at to menn i bygda har sendt inn klage til skolestyret. «O, hvor tungt det er at være hadet», skriv Hatlebrekke (1890, 21. september) etter at han har oppsøkt klagarane og prøvd å snakke med dei. Det går fram at klagarane også meiner at læraren går for ofte heim, og at han les og førebur seg for lite. Hatlebrekke kommenterer i dagboka at dette skuldast misunning for at han utanfor skuletida kan «få den forfriskelse at udrette noget forskjellig arbeid». Saka går vidare til presten, og så til skulestyret etter å ha vore innom ein tur til i tilsynsutvalet for om mogleg å kome til forlik. Saka vil ingen ende ta, og 10. november er det kretsmøte der læraren skal møte kritikarane sine 
med presten til stades som møteleiar. I mellomtida har partane skrive forklaringar til presten, og kritikarane frå bygda krev å få innsyn i kva Hatlebrekke har skrive. Då dette var gjort, og alle kunne høyre at læraren ikkje hadde skrive noko ufordelaktig om skulekrinsen, vart enden på visa at dei som har noko imot å tilgi læraren, blir bedne om å reise seg i møtet. Alle blir sitjande. Ein knapp månad seinare kommenterer Hatlebrekke at ein skulegut kjem med eit kalvelår som gåve. «De må ville forsone hvad de har fornærmet mig», skriv han (Hatlebrekke, 1890, 5. desember).

Skolestyret hadde altså det øvste myndet. Dagboka viser at Hatlebrekke ved fleire høve var nokså kritisk til dette organet, sjølv om det er fjernare enn tilsynsutvalet reint geografisk, og han derfor har mindre med det å gjere. Men når det er snakk om løn, kostgodtgjersle, kva bøker han skal bruke i undervisninga, eksamensordningar og talet på skuledagar, er det «herrerne» i skolestyret som bestemmer. Ved eitt høve kommenterer Hatlebrekke samansetjinga etter at ein mann i kommunestyret etter Hatlebrekke si oppfatning har hjelpt bror sin inn i posisjonen som skulestyremedlem: «Enhver som er kjendt i Haugsbygden vil vide at om bygdens opsiddere blev delt i 5 klasser, så vilde P.R. på ingen måde komme høiere end 4. klasse hvad hans fremsyn for skolen andgår. Han kan vel være frisindet nok, men det er et skadeligt frisind disværre.» (Hatlebrekke, 1893, 19. november). Kva dette frisinnet gjeld, er ikkje uttrykkeleg sagt.

Etter at skulelova frå 1889 hadde forandra forholdet mellom skule og kyrkje, hadde biskop Johan Christian Heuch (1838-1904) i Kristiansand teke til orde for at visitasordninga måtte forandrast (Aarflot, 1967, s. 445). Før hadde visitasen primært vore ein skulevisitas, sa han, no måtte fokuset flyttast til kyrkjelyden. Men skulen vart ikkje flytta heilt ut av det kyrkjelege synsfeltet, framleis skulle bispen overhøyre læraren i katekisasjon. Men no skulle dette flyttast frå kyrkja til skulen, som var heimebanen til lærar og elevar. I 1894 fortel Hatlebrekke i dagboka om eit lærarmøte i Sande kommune der den nye visitasordninga var blitt diskutert med presten til stades. Møtet fatta ein resolusjon som protesterte mot ei omlegging av visitasordninga og grunngav dette med at resultatet ville bli at skulen vart lausrive frå kyrkja, og at landet ville bli avkristna. Hatlebrekke og to andre lærarar som ikkje var til stades på møtet, var blitt presentert for resolusjonen i etterkant og bedne om å skrive under. Men 
for Hatlebrekke var det ikkje spesielt viktig at elevane kom til kyrkja, han kan «ikke erkjende så store farer, om biskop, prost og prest kom og hørte på undervisningen i skolerne» (Hatlebrekke, 1894, 1. september). Følgjeleg signerer han ikkje. Men dagen etter er han til gudsteneste der det også skulle vere avstemming om bededags- og visitatsspørsmålet. Ifølgje dagboka var det ikkje opplyst om kva saka gjaldt før kyrkjelyden skulle stemme. Hatlebrekke kommenterer slik: «Det er bemærkelsesværdigt hvorledes også en ellers bra prest kan henrives af politikken, som også af Høire søges indlagt i dette spørgsmål.» (Hatlebrekke, 1894, 2. september).

\section{Lett spel?}

Kva fortel desse utdraga frå dagboka om lærarlivet til Hatlebrekke i skulefolkets stordomstid? Hadde han som lærar lett spel, som Haugland meiner, eller er her sider ved organiseringa og styringa av skulen som kunne gjere kvardagen alt anna enn lett?

I denne teksten har eg løfta fram dagboknotat som eg trur viser til kompliserte sider ved livet som lærar i ei bygd i ei tid då dei samfunnsmessige forandringane var store. Som ei følgje av dette var heller ikkje skulen som før, og som kanskje endå verre var sett frå nokre foreldre sitt perspektiv - skulen var sjølv drivkraft i nokre av endringane.

I prosessen med nasjonsbygging og å forme om landet til eit reelt folkestyre og innbyggarane til demokratiets borgarar i staden for kongens undersåttar hadde skulen fått sin plass gjennom skulelovene som vart kjempa fram på Stortinget. På det lokale, konkrete nivået, mellom born som gjekk på yrkesskule heime hos foreldra og lærte korleis dei skulle skaffe seg ein leveveg der, var det læraren som fekk oppgåva å realisere store ideal og å motivere elevar og foreldre for nye idear på skulefronten, som for eksempel fleire skuledagar i året og nytt faginnhald. Til dette knytte deg seg utfordringar som lett kunne bli personlege.

Læraren, som den personifiserte skulen, vart i nokon sine auge den som underminerte gammal skikk der born og vaksne arbeidde i lag med heilt nødvendig matauk. Dette vart ein strid mellom naboar og sambygdingar, og dei som skulle hjelpe, som for eksempel tilsynsutvalet, var ikkje alltid på skulen sitt lag, slik læraren såg det. Det var sjølvsagt ikkje alltid 
elevane heller, slik har det visst vore sidan Sokrates si tid. Ein dag fortrur Hatlebrekke seg til dagboka slik: «I dag har eg opplevet noget som ikke har hændt før i skolen. I middagsstunden kastede etpar eller flere gutter sten efter mig da jeg stod i døren for at holde opsigt med dem.» (Hatlebrekke, 1893, 12. april).

Når Hatlebrekke fortel at gutane ler hånleg av spørsmåla om noregshistorie i staden for å svare (Hatlebrekke, 1883, 29. juli), kan dette sjølvsagt vere uttrykk for akutt negativitet som kan skuldast nær sagt kva som helst i relasjonen mellom lærar og elev. Men notisen kan òg vise til at ikkje alle i bygda følte seg om ein del av det statsborgarlege prosjektet eller identifiserte seg med målsetjingar om nasjonsbygging. Seinare skriv Hatlebrekke om eit lærarmøte der ein lærarar skal halde foredrag om historieundervisninga si betyding for oppsedinga og ein annan lærar om naturfaga si betyding for det same (Hatlebrekke, 1885, 4. juni). Foredraget skal gå for opne dører, sjølv om dette er eit lærarmøte. Kan dette vere eit motivasjonstiltak mynta på alle vaksne i skulekrinsen for skulen si store sak?

Det er, slik eg ser det, ikkje tvil om at Hatlebrekke både sikta mot ein leiarposisjon i bygda og hadde denne posisjonen. Slik var han både vestlandslærar og bygdehovding, slik at Høydal og Hodne skildrar desse lærartypane. Men hadde han lett spel, som Haugland seier? Ikkje alltid, ser det ut til. Å identifisere seg med bondekulturen, eller fiskarbondekulturen for Hatlebrekke sin del, var neppe vanskeleg når det var der ein høyrde til.

Men å vere den fremste blant likemenn er ikkje enkelt i ei tid med store spenningar og forandringar der fleire enn læraren skaffar seg innsikt i aktuelle problemstillingar. Ein må rekne med at aktiviteten i dei mange folkelege rørslene fungerte som vaksenopplæring på fleire felt, og at fiskarbøndene gjennom desse styrkte posisjonen sin og sjølvkjensla si andsynes gamle autoritetar som prestar og lensmenn, men også i møte med lærarane, om dei aldri så mykje aspirerte til ei primus inter pares-rolle.

Interessemotsetnadane kunne vere smertefullt reelle med omsyn til borna sin skulegang, og å velje rett side var ikkje enkelt når det var mange spel langs mange aksar på gang. Skuledemokratiet med skulestyre 
og særleg tilsynsutval opna for godt samarbeid, men òg for at læraren sin autoritet i klasseromet kunne svekkast. Når dette moglege samarbeidet gjekk i stå og motsetnadane tilspissa seg, viser dagboka at den gamle autoriteten i bygdesamfunnet, presten, kunne vere god å ha. I tillegg til sjølve embetet kunne han støtte seg på embetet sin tradisjon som både statleg embetsmann og "prestefar». Læraryrket sin tradisjon var av eit anna merke, og ikkje noko å lene seg mot. Hatlebrekke fortel for eksempel om regelrett skjenn frå ein forelder som meiner han er for sein med å begynne skuledagen. Hatlebrekke avviser ikkje refsinga, men forsvarar seg så godt han kan, ser det ut til, men på utfordraren sine premissar (Hatlebrekke, 1889, 21. november). Læraren måtte altså sjølv skape statusen. I denne samanhengen kan det vere interessant at Hatlebrekke for det aller meste skriv bokmål eller riksmål, det gamle regimet sitt språk.

Når ein les lærar Hatlebrekke sine hjartesukk, hans sjølvforsvar og vurderingar av dei han tidvis opplevde som motstandarane eller utfordrarane sine, er det lett å sjå at det kunne vere einsamt å vere lærar i ei lita bygd i den såkalla gullalderen for læraren. Spelet var alt anna enn lett.

\section{Litteraturliste}

Baggerman, A. \& Dekker, R. (2019). Center for the study of egodocuments and history. Center for the Study of Egodocuments and History. Henta frå http://www. egodocument.net/egodocument/index.html

Bergem, P. (Red.) (1995). Forkynning fellesskap forsking: Volda loerarskule 1895-1995. Volda: Høgskulen i Volda.

Braathen, F., Brønmo, H. \& Sjøberg, J. (2019, 10. oktober). Yrket som falt frå statustoppen. Aftenposten. Henta frå https://web.retriever-info.com/services/ archive/search

Dokka, Å. G. (2019). Laber val-entusiasme etter 1814. I Store Norske Leksikon. Henta frå https://www.ssb.no/valg/artikler-og-publikasjoner/laber-valg-entusiasmeetter-1814

Dokka, H.-J. (1988). En skole gjennom 250 år. NKS-forlaget.

Ekspertgruppa om lærerrollen. (2016). Om loererrollen: Et kunnskapsgrunnlag. Bergen: Fagbokforlaget.

Frønes, I. (1989). Lærer for livet. Et essay om samfunn, skole og lærerrolle. I K. Ø. Jordell \& P. O. Aamodt (Red.), Loreren fra kall til lønnskamp: 250 års skolehistorie (s. 20-42). Oslo: Tano. 
Hatlebrekke, J. (1879-1904). Dagbøker. Bergen: Statsarkivet.

Haugland, K. (1995). Unge seminaristar søkjer kulturell identitet og sosial posisjon bygder i hamskifte søkjer leiarar og strategiar. Ein studie med to innfallsvinklar. I R. Høydal (Red.), Nasjon - region - profesjon: Vestlandsloeraren 1840-1940 (s. 91-109). Oslo: Noregs forskingsråd.

Hodne, Ø. (2010). Folkeskolen i folkeminnet: En annerledes skolehistorie. Oslo: Cappelen Damm.

Hodne, Ø. (1987). Skolen i gamle dager. Oslo: Universitetsforlaget.

Kjelland, A. (2009). Norsk lokalhistorie og «nyare» mikrohistorie. Heimen 46(3), 237-254.

Kjelland, A. (2009). Mikrohistorie: «gammal og sur vin i nye krukker» - eller ei teoretisk nyorientering i historiefaget? (Notat 4/2009). Volda: Høgskulen.

Lindström, J. \& Jansson, K. H. (2017). Pigan i fadersväldet: Regler, undantag och mikrohistoriska möjligheter. Historisk Tidsskrift, 137(3).

Myhre, R. (1982). Den norske skoles utvikling: Ide og virkelighet. Oslo: Gyldendal Akademisk.

Nerbøvik, J. (1999). Norsk historie 1860-1914. Oslo: Det Norske Samlaget.

Nerbøvik, J. (1995). Voldens høiere Almueskole med annecteret Dannelsesanstalt for Almueskolelærere 1861-188o. I P. Bergem (Red.), Forkynning Fellesskap Forsking: Volda loerarskule 1895-1995 (s. 21-42). Volda: Høgskulen i Volda.

Rabben, B. (1979). Soga om Sande og Rovde. Bind V. Sande Sogenemnd.

Rabben, B. (1975). Forord. I J. Hatlebrekke (1879-1904), Dagbøker. Bergen: Statsarkivet.

Runde, O. S. (2008). Bernt Støylen. Oslo: Det Norske Samlaget.

Slagstad, R. (1998). De nasjonale strateger. Oslo: Pax Forlag.

Telhaug, A. O. \& Mediås, O. A. (2003). Grunnskolen som nasjonsbygger: Fra statspietisme til nyliberalisme. Oslo: Abstrakt forlag.

Tretvik, A. M. (2004). Lokal og regional historie. Oslo: Samlaget.

Aarflot, A. (1967). Norsk kirkehistorie. Bind II. Oslo: Lutherstiftelsen. 


\title{
KAPITTEL 12
}

\section{Levd hverdagsreligion}

\section{Hildegunn Valen Kleive}

\author{
Høgskulen i Volda
}

\begin{abstract}
Sammendrag: Denne artikkelen gir en innføring i perspektivet levd hverdagsreligion. I tillegg tematiseres perspektivets forhold til begrepet «folkelig religion» og tilnærmingens relevans for skolens religionsundervisning. I perspektivet levd hverdagsreligion inkluderes og vektlegges vanlige folks religiøse praksiser og erfaringer, som er både kroppslige, materielle og diskursive. Disse er lokalisert både i og utenfor religiøse organisasjoner og institusjoner. Perspektivet er preget av funksjonelle forståelser av religion, og forskningen på fenomenet er kjennetegnet av et sterkt innslag av etnografiske metoder. Artikkelen drøfter hvordan denne tilnærmingen til religion kan kaste lys over større samfunnsstrukturer, sosiale prosesser og bias i forskningen. Interessen for levd hverdagsreligion har vokst fram i flere fag, selv om bidrag fra religionssosiologien særlig framheves i denne artikkelen.
\end{abstract}

Nøkkelord: hverdagsreligion, lived religion, religiøs praksis, religionsfag

\section{Innledning}

Hensikten med denne artikkelen er å gi en innføring i perspektivet levd hverdagsreligion, særlig med tanke på lærerstudenter. Siden artikkelen står i en antologi som omhandler vestlands-religiøsitet, vil en del av eksemplene som brukes være relatert til denne konteksten.

I vanlige folks hverdager skapes og finnes noe vi kan betegne som levd hverdagsreligion, det er i grunnen ikke noe nytt. Likevel er det en $ø$ kende interesse for å forske på nettopp dette. Å forske på levd hverdagsreligion handler ikke om oppdage helt nye former for religion, det er heller å forstå som et supplement og et korrektiv til andre tilnærminger i 
religionsforskningen (Dessing mfl., 2013; Ammerman, 2007; McGuire, 2008). Og sentralt i den forbindelse er å gi flere enn de religiøse ekspertene mulighet til å skissere hva religion er, og hvor religion befinner seg. Perspektivet, eller tilnærmingen, levd hverdagsreligion mangler et spesifikt og eksklusivt begrepsapparat, men det finnes likevel en del fellestrekk i forskningslitteraturen på feltet. Og det er nettopp slike fellestrekk denne artikkelen ønsker å løfte fram.

I denne artikkelen vil jeg først kort gjøre rede for framveksten av forskningsfeltet levd hverdagsreligion, før jeg skisserer sentrale trekk ved perspektivet. Jeg vil videre diskutere hvordan levd hverdagsreligion relaterer seg til begrepet «folkelig religion», før jeg avrunder med å diskutere perspektivets plass i skolens religions- og livssynsfag.

\section{Et perspektiv med røtter i flere disipliner}

Bøkene til Ammerman (2007) og McGuire (2008) har hatt særlig stor betydning i etableringen og utbredelsen av perspektivet levd hverdagsreligion i religionssosiologien. Disse bøkene vokser ut av en vridning (eller «turn») i 1990-åra mot etnografiske metoder i religionssosiologien (Ammerman, 2016, s. 83). Sentralt i denne vridningen var å sette vanlige folks tenkning og praksis på agendaen. Dette uttrykte religionshistorikeren David Hall (1997) gjennom betegnelsen Lived religion. Meredith McGuire videreførte denne betegnelsen i religionssosiologien, mens Nancy Ammerman kalte samme fenomen Everyday religion. Woodhead (2013) syr disse termene sammen til Everyday lived religion. Levd hverdagsreligion er altså en norsk oversettelse av Woodheads begrepsfusjon.

Fokuset på levd hverdagsreligion, som i dag er en viktig trend i religionssosiologisk forskning (Repstad 2019a), har likevel røtter i flere vitenskapelige disipliner. Leonard Primiano, som har bakgrunn i folkloristikk og etnologi, finner det uheldig at det ikke er tilstrekkelig anerkjent at hans fagfelt i mange tiår har vært opptatt av levd hverdagsreligion før interessen for «lived religion» oppstod i (religionssosiologien) i Amerika på 1990-tallet (Primiano, 2012, s. 383). I tillegg til å ha sterke røtter i folkloristikk, etnologi og sosialantropologi anvendes og utvikles perspektivet levd hverdagsreligion også i disipliner som historie, samfunnsgeografi, 
teologi og i «religious studies» (Ammerman, 2016). Det er også viktig å merke seg at mange studier i praksis har fokus på levd hverdagsreligion uten nødvendigvis å bruke denne betegnelsen i sine tekster (Ammerman, 2016). Eksempler på bøker fra en norsk kontekst som eksplisitt er opptatt av levd hverdagsreligion, er Horsfjord (2017) og Kalvig og Solevåg (red.) (2015). Repstad (2019a) reflekterer også i stor grad en norsk kontekst, både i gjennomgangen av hverdagsreligion som teoretisk perspektiv og i utvalget av empiriske eksempelstudier som er tatt med i boka.

Parallelt med den økede interessen for etnografiske metoder i religionssosiologien fra 1990-tallet ble funksjonelle forståelser av religion mer vektlagt. Det innebærer å være opptatt av å analysere hva religion gjør og bidrar til, og hvordan religion påvirker og påvirkes av kontekst (Davie, 2013, s. 13). Dette utfordret de substansielle definisjonene av religion som ifølge Day (2011, s. 5) lenge hadde vært favorisert i religionssosiologien. Substansielle religionsdefinisjoner fokuserer på innhold, det vil si på å avklare hvilke trosoppfatninger og praksiser og hvilke, eventuelle, overnaturlige vesener som hører til hvor, og på basis av dette avgjøre hvor grensene mellom religiøse tradisjoner går.

Jeg vil nå fortsette med å peke på sentrale trekk ved perspektivet levd hverdagsreligion.

\section{Levd hverdagsreligion}

\section{Vanlige folk og større strukturer}

Et sentralt anliggende i perspektivet levd hverdagsreligion er hvem som har myndighet til å definere hva som teller som religion. Denne «avklaringsmyndigheten» har i vestlig kontekst ofte vært gitt, eller tatt, av privilegerte eksperter eller eliter. Disse har gjerne vært (er?) mannlige geistlige eller akademikere. De har fremmet hierarki, tekst og dogmatikk og har ofte stått i nær forbindelse med nasjonalstaten (Woodhead, 2013, s. 11). Denne privilegerte eliten har brukt sin makt og autoritet til å skissere hva som skal være å forstå som sann og autentisk religion, og har ofte forutsatt tydelige skiller mellom de religiøse tradisjonene. I levd hverdagsreligion-forskning blir denne autoriteten til å definere og skissere religion delt med vanlige folk ved at vanlige folks praksiser og forståelser 
av religion blir tatt på alvor og inkludert (McGuire, 2008, s. 12). Betegnelsen «vanlige folk» brukes gjerne for å understreke en ikke-ekspert/ikkeelitistisk posisjon i samfunnet. Å være oppmerksom på spenningen mellom «ekspertenes» religion og «vanlige folks» religion, og det å gi «vanlige folks» religion plass når religioner skal forstås og beskrives, er altså et hovedanliggende i tilnærmingen levd hverdagsreligion.

Friksjoner mellom eksperters religion og vanlige folks religion er kjent også fra den vestlandske konteksten som er rammen for den antologien denne artikkelen står i. Kristendomshistorisk forskning viser hvordan det å etablere religiøs selvstendighet for lekfolk i forhold til en kirkelig geistlighet har vært et viktig trekk i Vestlands-regionen allerede fra 180o-tallet (Løvlie, 2020; Ulstein, 2020). Dette innebar ikke nødvendigvis et brudd med kirke og geistlighet, men handlet om å skape mer rom for lekmenn til å forme og forkynne kristen tro og liv. «Lekfolk» tilsvarer i denne sammenhengen «vanlige folk». Lekmannskristendommen vektla gjerne hverdagen som viktig arena for levd religion. Dette kommer tydelig fram i multitalentet Matias Orheim sin salme «Ein kvardagskristen vil eg vera». Ifølge kristendomshistoriker Birger Løvlie er dette en «kvardagskristendom som det luktar jord av» (Løvlie, 2007, s. 141), blant annet fordi den anerkjenner og gleder seg over at også «arbeidet er ein integrert del av det å følgje Jesus» (Løvlie, 2007, s. 141). Religion er altså i denne forståelsen ikke avgrensa til enkelte hellige rom eller til enkelte tider i uka. At religion er levd hverdagsliv, har altså vanlige folk på Vestlandet visst lenge før den etnografiske vendinga kom i religionssosiologien på 1990-tallet.

$\AA$ inkludere vanlige folks praksiser og forståelser har mange konsekvenser. For det første ligger det i dette et potensial til å korrigere elitistiske bias i religionsforskning og religionsforståelse. For vanlige folks praksiser og forståelser vil ikke nødvendigvis reflektere de dogmatikkene eller systematiseringene av religion som skapes ved universiteter eller av religiøse ledere. For det andre kan det innebære at interessen i forskninga forskyver seg fra å studere «religion» og «tro» som abstrakte begreper til å studere hva folk gjør og erfarer (Primiano, 2012, s. 384). Det å inkludere vanlige folks stemmer gir dessuten et mer komplekst og dynamisk bilde av religioner enn det som ofte kommer fram $\mathrm{i}$ «offisielle» framstillinger 
av religioner. I tillegg til kan det også medføre utvidelser av hva som oppfattes som religion, fordi hva som teller som religion, er vanlige folk selv med på å bestemme. Et mye sitert eksempel på dette er hvordan noen opplever hagearbeid som en spirituell eller religiøs praksis (McGuire, 2008). Denne nedenfra-og-opp- eller grasrot-tilnærmingen til religion, der vanlige folks oppfatninger, erfaringer og praksiser anerkjennes, er følgelig på bølgelengde med mye postkolonial teori.

Som nevnt har religiøse eksperter ofte framstilt religioner som ganske klart avgrensa enheter, kan hende inspirert av en substansiell religionsforståelse. Men det forskere på levd hverdagsreligion gjerne oppdager, er at religion stadig endrer og tilpasser seg, og at den kan bestå av uventa sammensetninger og motsetninger (McGurie, 2008, s. 4). Dette gir innsikt $\mathrm{i}$ at religion hverken finnes $\mathrm{i}$ «ren form» eller alltid opptrer som klart avgrensa enheter (Primiano, 2012, s. 384, 388). Et trekk ved religion som tilnærminga levd hverdagsreligion bidrar til å få øye på, er altså at skillene mellom religioner og skillene mellom religiøse og sekulære praksiser er porøse (Repstad, 2019a; Ammerman, 2014). En kritisk innvending til denne utvida, mangfoldige og inkluderende tilnærmingen til religion er at selve religionsbegrepet kan miste mening, altså at hva som gjør noe til religion, kan bli så uklart at begrepet mister sin analytiske verdi. At begreper kan være så omfattende og omdiskuterte at den analytiske verdien står i fare, er ikke religion alene om, også begreper som kultur, samfunn og historie er i samme båt (Woodhead, 2011). En begrepskollaps er i grunnen alvorlig, for uten avklarte begreper blir forskning en endeløs rekke av beskrivelser. Det medfører forskning med liten forklaringskraft som gir lite grunnlag for økt forståelse, og som dessuten gjør komparasjon og generaliseringer vanskelig. En vei ut av dette kan være å beholde noen substansielle definisjoner av religiøse tradisjoner, men stadig diskutere hvor, hvorfor og hvordan grensene rundt disse tradisjonene opprettholdes eller tråkkes ned. Med andre ord: Substansielle og funksjonelle sider ved religion bør ses sammen.

At det vanlige, trivielle og rutinemessige i hverdagslivet kan gi glimt av, men også skape og reprodusere, større sosiale mønstre og strukturer (Scott, 2009; Neal \& Murji, 2015), er nok en av årsakene til den økte forskningsinteressen på hverdagsliv. En frokost er aldri bare en frokost, 
glorete julebelysning er aldri bare glorete julebelysning, en begravelse er aldri bare en begravelse (Rosaldo, 1993; Back, 2015; Munson, 2007) En frokost, en julebelysning og en begravelse handler ikke bare om å få i seg mat, pynte til jul eller ta farvel med en avdød, det er også hendelser der sosialt delte normer, konvensjoner, fortolkninger og ritualer kommer til uttrykk, skapes, omskapes eller protesteres mot. Det er særlig når slike «regler» eller strukturer blir bevisst eller ubevisst brutt, at man blir oppmerksom på hvordan strukturer eller sosial orden er vevd inn i hverdagslige samhandlingssituasjoner og praksiser. Analysen av julebelysning-pyntinga (Back, 2015) viste for eksempel at denne skapte og opprettholdt distinksjonen mellom sosiale klasser. Et eksempel fra den nordvestlandske konteksten på hvordan ungdommers hverdagslige praksiser kan gi glimt av større strukturer, kan hentes fra Hildegunn Valen Kleives arbeid om unge tamilhinduer (Kleive, 2017a). Her beskrives hvordan unge tamilhinduer i noen sammenhenger gjør religion synlig, gjennom for eksempel klær eller merke i panna, mens de i andre kontekster demper synlig religiøsitet. I det som oppfattes som tamilske kontekster, skaper synlig religiøsitet tilhørighet til den tamilske gruppa, mens ungdommene forteller at det å vise synlig religiøsitet i det som oppfattes som norske kontekster, har motsatt effekt. I norske kontekster senser altså ungdommene et sekulært skript, eller sekulære forestillinger og strukturer, som handler om at religion er en privatsak som ikke bør spilles ut i det som oppleves som norske offentlige kontekster. Dersom ungdommene skulle glemme å dempe religiøs synlighet når de entrer en norsk kontekst, for eksempel ved glemme å ta vekk pulveret i panna etter en pujaseremoni, opplever mange dette som flaut, som et brudd på en sosial «regel». At fokuset på hverdagsreligion har dette potensialet til å vise til noe større gjennom konkrete hverdagslige situasjoner, er kanskje blitt oversett. Repstad antyder hvert fall at hverdagsreligionsforskninga står i fare for å lide under en strukturell blindhet (Repstad, 2019b, s. 3). En vei ut av dette er ifølge Repstad å legge til rette for mer dialog mellom hverdagsreligionsforskere og forskere som studerer forholdet mellom religion og politikk (Repstad, 2019b, s. 3; Repstad, 2019c).

Jeg vil nå peke på hvordan fokus på praksis, erfaring og endring er sentrale trekk i forskningen på levd hverdagsreligion. I tillegg vil jeg 
understreke at levd hverdagsreligion uttrykkes og skapes både i og utenfor organiserte religiøse sammenhenger.

\section{Praksis}

Mens mye tidligere religionsforskning var opptatt av å beskrive religioner gjennom systematiserte troslærer, blir det å analysere praksis sentralt i en levd hverdagsreligion-tilnærming (Ammerman, 2007, s. 6). Religion oppfattes som noe som er vevd inn i hverdagslivets kroppslige, materielle og diskursive praksiser (Ammerman, 2016, s. 93), der det rutinemessige, repetitive og rytmiske er særlig i fokus (jf. Scott, 2009, s. 2). ${ }^{1}$

At praksis har med kropp å gjøre, kan jo synes åpenbart. Når man deltar i ritualer og rutiner bruker man jo kroppen. Man bøyer eller strekker seg, sitter, går, sanser, puster og opplever nærvær av andres kropper. Jeg vil her peke på to sider ved det kroppslige. Det første poenget er at kroppslige praksiser gjør noe. Kroppslig praksis studeres altså funksjonelt. Spørsmål som da kan dukke opp, er for eksempel: Hvordan skaper kroppslige praksiser relasjoner mellom folk og kontekster? På hvilken måte har deltakelse i praksiser noe å si for identitet? Hvordan nyskaper praksiser kontekster, og hvilke tilhørigheter bekreftes? Et eksempel på at kroppslig praksis skaper noe, ble beskrevet i forrige avsnitt, der det å dekorere kroppen med noe som oppfattes som religiøst betydningsfullt kan skape tilhørighet eller avstand til andre mennesker og grupper (Kleive, 2017a). Det andre poenget jeg vil peke på, er hvordan religiøse praksiser, som er kroppslige, kan uttrykke religionenes dennesidige relevans. For kroppslige religiøse praksiser knyttes ofte til helse og helbredelse. I tillegg blir slike praksiser ofte oppfattet som ressurser som kan gi styrke og løsninger i krevende hverdagssituasjoner. Denne siden ved levd hverdagsreligion korresponderer med beskrivelser av den pragmatiske og dennesidigorienterte samtidsreligiøsiteten som finnes i Vesten (McGuire, 2008, s. 106, 119). Når unge tamilhinduer på Nordvestlandet bruker religion til å takle (sky-)høye forventninger og krav til å gjøre det bra på skolen, eller når

Dette tangerer interessen mange religionsforsker har for ritualer (jf. Gilhus \& Mikaelson, 2007, s. 47-51). 
noen av dem forteller at grunnen til at de har det bra fysisk og mentalt, har med mer regelmessig utførte pujaritualer å gjøre (Kleive, 2017b), er det uttrykk for en kroppslig og mundant orientert hverdagsreligion.

Hverdagslivets materielle praksiser understreker at ting, og samhandling med ting, har betydning for religion. Man er ikke bare opptatt av hvordan ting symboliserer eller illustrerer religion, men også hvordan ting er og gjør religion. For igjen å hente et eksempel fra Kleive (2017a), beskrives der et armbånd som mange tamiler bærer. I utgangspunktet er dette armbåndet en form for amulett som skal beskytte og bringe bæreren lykke. Ungdommene var ikke veldig opptatte av denne amulettfunksjonen til armbåndet. Andre funksjoner ved armbåndet var vel så viktige for dem. Noen fortalte at det å bære dette armbåndet var den måten de nå var religiøse på, andre pekte på hvordan dette armbåndet var en bekreftelse av tamilsk identitet eller tilhørighet til spesifikke templer, andre igjen brukte armbåndet fordi de syntes det var tøft og fordi de hadde sett folk i tamilske filmer bruke dem. Altså, armbåndet gjør en rekke ting, blant annet er det religion for noen. I tillegg understreker denne materielle praksisen at religion endrer seg, og at religion handler om noe mer enn kun abstrakte forestillinger.

Praksiser kan også være diskursive. Da studerer man hvordan det snakkes, skrives, synges og fortelles (Ammerman, 2016, s. 90). I et levd hverdagsreligion-perspektiv er man ikke bare opptatt av den meningen eller tanken som ordene uttrykker, men også hva denne diskursive praksisen gjør i det sosiale liv. Man spør: Hva skjer når noe omtales på den eller den måten i den eller den settingen? Igjen understrekes det funksjonelle. Kleive (2017a) hevder at når de tamilske ungdommene betegner menstruasjonsfesten sin som konfirmasjon, er det en diskursiv praksis som skaper og bekrefter en likhet med norske venner. Antropologen Martin Stringer (2008) har utviklet noe han kaller for «a situational theory of belief», som beskriver vanlige folks religiøse diskursive praksiser. Han finner at folk bruker ulike, og ofte motstridende, «belief statements» avhengig av tid og sted de befinner seg. Dette gjøres fordi folk opplever at ulike situasjoner krever ulike ting. I én sammenheng kan det gi mening å anvende utsagn knytta til reinkarnasjon, i en annen kan det gi mening å snakke om en himmel. Stringer finner i sin empiri at folk kan ha løsere eller fastere 
emosjonell tilknytning til sine tros-utsagn, og det varierer med erfart situasjon når slike utsagn oppleves som verdifulle og viktige. For de unge tamilene i eksempelet ovenfor gir det altså mening å understreke likhet $\mathrm{i}$ noen sammenhenger, antakelig fordi det bekrefter et fellesskap. I tillegg understreker Stringer at tro ikke bare er ekte eller autentisk når den er inderlig opplevd, eller når de religiøse utsagnene man bruker, knytter seg til en kilde, det mener Stringer derimot er en protestantisk bias knytta til trosbegrepet som folks vanlige (hverdagslige) praksiser korrigerer.

\section{Erfaringer}

Vanlige og hverdagslige, men også ekstraordinære, erfaringer er sentrale utgangspunkt i levd hverdagslivsforskning. Erfaringer er nært knytta de kroppslige, materielle og diskursive praksisene som er diskutert ovenfor. Slike praksiser skaper jo erfaringer og opplevelser. Men kan erfaringer forskes på, eller er erfaring så særegne og individuelle opplevelser at de blir utilgjengelig for forskning? Kan man for eksempel tenke seg at erfaringer av et gudsnærvær eller en følelse av mening ikke går an å måle eller fange vitenskapelig? Bender (2007) mener religiøse erfaringer er forskbare siden erfaringer og opplevelser er situert i språk, forestillinger og symboler og derfor aldri utelukkende subjektive. Den som erfarer og opplever, gjør det ved hjelp av et i stor grad sosialt delt forestillingsapparat. I individuelle erfaringer er det sosiale implisert, derfor kan for eksempel religiøse erfaringer si noe om det sosiale. Det kan være verdt å merke seg at selv om individuelle erfaringer reflekterer sosialt delte forestillinger, er det brokker av disse, gjerne henta fra flere ulike kilder, som kommer til uttrykk i enkelterfaringene. Det interessante blir jo da å studere komposisjonen og utvalget av sosialt delte forestillinger som erfaringene er satt sammen av, og videre reflektere rundt hvorfor det er akkurat disse som kommer til uttrykk.

Videre er det å studere erfaringer viktig for å kunne forstå hvordan folk etablerer kunnskap. Inspirert av blant annet erfaringsrealisme ${ }^{2}$ understreker Woodhead (2013, s. 14) hvordan folk først forstår på et kroppslig

Jf. for eksempel Aase \& Fossåskaret, 2014, s. 54-59. 
og emosjonelt nivå. I tråd med dette hevder Morgan (2010, s. 5) at slike kroppslige erfaringer ligger til grunn for det vi tenker og mener. Oppfatningene våre er egentlig toppen av et isfjell av det vi gjennom livet har sanset, følt, hørt, luktet og sett. Altså, når mennesker i sine hverdager møter ting, symboler og steder, skapes det erfaringer og emosjoner som danner grunnlag for kunnskap og oppfatninger (Woodhead, 2013, s. 14). Også i disipliner som teologi, som tradisjonelt har hatt sin styrke i å systematisere trosforestillinger, finner vi nå en økende forståelse av å la erfaringer og empiriske forhold informere det teologiske arbeidet, og ikke utelukkende basere seg på tekster og fortolkningen av disse (Henriksen, 2019, s. 119). Erfaring kommer før dogmatikk (Henriksen, 2016).

\section{Hvor finner vi religion?}

På en måte er dette spørsmålet allerede besvart i og med at temaet for denne artikkelen er hverdagsreligion, altså religion slik den finnes, skapes, leves og uttrykkes i folks hverdager. Men alt er ikke sagt med det. Når religion oppfattes som noe som er vevd inn i hverdagslivets kroppslige, materielle og diskursive praksiser, medfører det blant annet at skillet mellom kultur og religion kan bli vanskeligere å dra, om det da noen gang har vært enkelt eller mulig. Fra et ikke-religiøst ståsted er jo all religion kulturelle produkter (Horsfjord, 2017, s. 41). Det å gjøre religion til noe enkelt avgrensbart, avskåret fra andre kulturelle uttrykk og arenaer, slik mye sekulariseringsteori har hatt en tendens til å gjøre, kan da bli vanskelig å opprettholde. Dette er i tråd med Ammerman (2007, s. 9), som hevder at det moderne livet ikke er så skarpt oppdelt som tidligere teoretikere har tenkt. Dette bidrar for det første til å løse opp i de skarpe skillelinjene mellom religion og ikke-religion, og for det andre innebærer det at religion kan komme til uttrykk i hverdagspraksiser utenfor organiserte religiøse samlinger og institusjoner. For det er ikke slik at religion bare forekommer til bestemte tider på bestemte steder. Begge disse to anliggendene har vært viktige bidrag levd hverdagsreligion-forskning har tilført religionsforskning generelt. Men det kan likevel hende at deler av forskninga på levd hverdagsreligion i for stor grad har ignorert de formene for religion som finner sted i organiserte eller institusjonaliserte 
sammenhenger. Et hverdagslivsperspektiv på religion bør fokusere på praksiser og erfaringer uavhengig av hvor de finner sted. Og når vanlige folk kommer til orde, viser det seg at mye av deres religiøsitet faktisk praktiseres i organiserte og institusjonaliserte rammer (Ammerman, 2014). Dessuten, om man inkluderer organisert institusjonalisert religiøsitet, vil det kunne bidra til en større helhetsforståelse og til å forstå makt- og makrostrukturer i en gitt kontekst (Ammerman, 2014; Repstad, 2019c). Det er dessuten viktig å merke seg at også geistlige og «religiøse eliter» lever ut sin religiøsitet i hverdagen. Samuels (2004) sin studie av buddhistiske munker og klosterliv illustrerer dette. Han hadde observert at munkene feiet gårdsplassen i klosteret jevnlig, men var nær ved å overse at dette ble ansett som en viktig religiøs praksis i hverdagen. Han ble først oppmerksom på dette da han ba munkene om å ta bilder av det de i sin hverdag oppfattet som religion.

Hvor finner man religion i en vestlandsk kontekst? Lekmannsengasjementet som historisk har vært et viktig trekk ved religiøsiteten på Vestlandet, kan ha gitt et inntrykk av at vanlige folks religiøsitet har flytta seg ut av de organiserte, geistlig dominerte sammenhengene. Fra en side sett stemmer det at lekmenn og -kvinner gjorde krav på en viss autonomitet $\mathrm{i}$ forhold til geistligheten. Likevel skjedde dette, som nevnt, ofte uten å kutte båndene til kirka helt av. Dessuten, noe av det som legitimerte et selvstendige lekfolk, og som ble sentralt i lekmannsteologien, var vektleggingen av det bibelske prinsippet om at alle egentlig er prester, i teologiens språk kalt «det allmenne prestedømmet»(Ulstein, 2020). I tillegg skapte lekmannstradisjonen sine egne organisatoriske rammer, først og fremst gjennom bedehus og misjonsforeninger (Løvlie, 2020). Forskning viser videre at Nordvestlandet er en region i Norge der folkekirkeligheten står sterkt (Botvar, Repstad Aagedal, 2012) ${ }^{3}$. Det ville derfor føre galt av sted om man forsket på hverdagsreligion på Vestlandet uten å trekke inn organisasjoner og institusjoner. Den kristelig orienterte majoritetsreligiøsiteten i denne regionen befinner seg nettopp i spenningsfeltet og i dialoger mellom kirke, bedehus og lekmannsautonomitet. Forskningen

3 Botvar mfl. (2012) kaller regionen for «Vestlandet ellers». Slik differensieres denne regionen fra Agder/Rogaland. 
til Kleive (2018) viser for øvrig hvordan religiøse institusjoner er viktige for videreføringen av en minoritets religiøse tradisjoner. Dessuten har kristne kirker og bedehus betydning for denne minoriteten. For i bygder på Vestlandet deltar minoritetsbarn- og ungdom i aktiviteter som kor og speider på bedehuset eller i kirka, og dessuten fungerer ofte bedehuset som et forsamlingshus på bygda der både 17. maifester og bursdagsfester blir arrangert.

\section{Stadige endringer}

Et trekk ved levd hverdagsreligion som ofte framheves, er at den stadig er i endring. Dette har blant annet å gjøre med hvordan individer selv er med på å forme sin religiøsitet. Individer står i relasjon til mange steder, tradisjoner, ting og mennesker, og i disse relasjonene forhandler individer fram sine religiøse praksiser og oppfatninger. I disse prosessene utvises stor grad av kreativitet og kompetanse (Primiano, 2012, s. 387). Denne forhandlings- og skapelsesprosessen pågår kontinuerlig, og dermed endrer levd religion seg stadig. Peggy Levitt (2009) viser hvordan slike prosesser er særlig tydelige blant transnasjonale ungdommer. Disse ungdommene forhandler daglig om hva de skal inkludere eller ikke av normer og praksiser i sine liv. Ungdommene lager ikke nødvendigvis helhetlige og koherente synteser av alle de religiøse og kulturelle elementene de forholder seg til. Isteden opparbeider ungdommene seg repertoarer de selektivt benytter i respons til muligheter og utfordringer de møter i hverdagen (Levitt, 2009, s. 1126). Dette illustrerer pragmatismen og kompleksiteten i levd hverdagsreligion. De stadige forhandlingene og endringene innebærer et ikke-essensialistisk syn på religion. Dette betyr videre at religionskunnskap er ferskvare. Kunnskap om hvordan religion praktiseres og hva som oppfattes som religion blant folk, må altså stadig oppdateres. Likevel må en religionsforsker være oppmerksom på at folk selv kan ha essensialistiske forståelser av sin egen (eller andres) religiøsitet. Noen kan være svært opptatte av at det finnes avgrensbare religioner, og at disse har faste og uforanderlige kjennetegn. Andre kan holde fast på etablert terminologi som «islam», «kristendom» eller «humanisme», selv om de er oppmerksomme på historiske og geografiske forskjeller og 
endringsprosesser. Dette kan ha å gjøre med at det å ha en kategori å forstå seg selv i lys av har identitetsmessige gevinster som folk verdsetter. Dette kan eksemplifiseres gjennom Abby Days forskning (2011), som viser at mange av dem som krysser av på «kristen» i store religionsundersøkelser, ikke gjør dette fordi de er opptatt av Jesus, bibel eller dogmatikk, men fordi «kristen» oppfattes som en betegnelse på en gruppe de ønsker tilhøre. I tillegg understreker Days forskning med dette hvordan skillet mellom religion og ikke-religion ikke alltid er empirisk fundert eller nyttig analytisk.

Videre er det verdt å merke seg at behovet for å standardisere, eller essensialisere, religion er ofte påtakelig i minoritets- eller diasporamiljøer. I en kontekst der mye er ukjent og majoriteten finner deg ukjent, kan behovet for å avklare hvem man er, hvilke praksiser man skal opprettholde og hva man skal mene, være stort. Ifølge Jacobsen (2018) kan slike standardiseringsbehov være influert av protestantisk kristendom, som jo er en religionsform som er kjent for å vektlegge (essensialistisk) systematisk troslære.

Vi har nå gjennomgått sentrale trekk ved levd hverdagsreligion. Jeg vil i neste avsnitt kommentere hvorvidt levd hverdagsreligion overlapper det allerede velkjente begrepet «folkelig religion».

\section{Er levd hverdagsreligion og «folkelig religion» synonymer?}

«Folkelig religion» er et kjent begrep i religionsforskninga. I likhet med levd hverdagsreligion er folkelig religion konsentrert rundt vanlige folks religion (McGuire, 2002, s. 113). Men mens levd hverdagsreligion, hvert fall ifølge Ammerman (2007, 2014, 2016) og Repstad (2019a), dekker religion som forekommer både i organiserte og ikke organiserte settinger, framhever folkelig religion den ikke-offisielle, ikke-organiserte, «nonexpert»-religionen. Men i tillegg til å bli sett på som det motsatte av «offisiell religion» (Primiano, 1995, s. 38) har merkelappen folkelig religion ofte en nedsettende klang. Dette i motsetning til den statusen vanlige folks religion tillegges i perspektivet levd hverdagsreligion, der det som tidligere nevnt er et hovedpoeng at vanlige folk har myndighet til å utvide 
hva som skal anerkjennes som religion. Folkelig religion har fra elitistisk hold ofte blitt ansett som synkretistisk, uren og kanskje til og med hedensk, altså som motsetningen til ren og autentisk religion (McGuire, 2002, s. 113). Ren, sann eller autentisk religion blir i denne sammenhengen gjerne forstått som en religion som er opptatt av det hinsidige og transcendente, og av hellige tekster som normgrunnlag. Og folkelig religion er blitt sett på som mer profan fordi den ofte er sentrert rundt hverdagslige, pragmatiske og kroppslige behov, som helse, fruktbarhet, beskyttelse og velstand (McGuire, 2002, s. 114; Geaves, 2007, s. 7). Et maktaspekt kommer til uttrykk ved at de som setter merkelappen «folkelig religion», sjelden setter den på seg selv, og de som får merkelappen «folkelig religion» på sine praksiser, er ofte fattige, minoriteter eller innfødte i tidligere kolonialiserte land (McGuire, 2002, s. 115).

Folkelig religion blir altså ofte forstått som en slags B-lagsreligion, mens offisiell, spesialist-/elite-definert religion en slags A-lagsreligion. For å forhindre en slik verdiladet differensiering kan religion beskrives mindre normativt ved å systematisere hva som motiverer for religiøs praksis (Geaves, 2007, s. 6). Ballard (2000), som forsket på religion i Punjab, gjorde dette ved å vise hvordan folk er opptatt av ulike dimensjoner ved religion. Noen er opptatt av spirituelle praksiser og spirituelle ledere (panthic dimension), andre ønsker å framheve religionenes sosiale og moralske sider (dharmic dimension). Noen bruker religion for å fremme sosiale, økonomiske eller politiske interesser (qaumic dimension), mens andre er mer opptatte av hvordan religiøse praksiser er handlingsstrategier for å snu skjebnen i positiv retning eller til å kunne håndtere det uforklarlige (kismetic dimension). Ballard tok i bruk empirinær terminologi for å oppnå at vanlige folk i størst mulig grad preget forståelsen og framstillingen av de religiøse praksisene han forsket på.

En annen måte å unngå å bli normativ på i beskrivelsen av vanlige folks religion, er å beskrive og forstå religiøsiteten i lys av hvilken kontekst den befinner seg i. Religionsforskerne Robert Jackson og Eleanor Nesbitt fra University of Warwick har vært sentrale for denne tilnærmingen til religion (jf. blant annet Jackson, 2008 og Nesbitt, 2010). Skoleforskeren Tove Nicolaisen bruker deres kontekstmodell ved å eksemplifisere hvordan en hindukvinnes morgenritual kan forstås på «det individuelle nivået $\mathrm{i}$ 
familiekonteksten, på gruppenivå og på et nivå som representerer den vide religiøse tradisjonen» (Nicolaisen, 2018, s. 22). Da beveger man seg mellom det å beskrive hva dette ritualet har å si for kvinnen selv og hennes familie, via hvordan ritualet bidrar til å ivare ta tradisjoner, identitet og fellesskap for en gruppe hinduer i diaspora, til å vise hvordan denne morgen-pujaen uttrykker trekk ved bhakti-bevegelsen.

Det kan også nevnes at også Ammerman (2014) søker å systematisere folks levde hverdagsreligion gjennom en typologi. Denne typologien er deskriptiv i den forstand at den kategoriserer hva folk er opptatt av som religion, og er ikke normativ i den forstand at den graderer hvilke av disse formene som er «best». Hun skiller mellom teistisk, ekstrateistisk og etisk spiritualitet. I teistisk spiritualitet dreier spiritualiteten seg om å utvikle en relasjon til Gud, og om møter med det mystiske/ uforklarlige. En er altså svært oppmerksom på guddommelige aktører. Den ekstra-teistiske spiritualiteten handler også om transcendente relasjoner, men ikke først og fremst til guddommer. Man er for eksempel opptatt av hvordan natur og skjønnhet kan gi ærefryktfølelser, og av individers individuelle (indre) meningssøking. Etisk spiritualitet, som kan gå litt på tvers av de to ovennevnte kategoriene, vektlegger moralsk godhet og den gylne regel (Ammerman, 2014, s. 23-55).

Jeg vil i siste del av denne artikkelen knytte levd hverdagsreligion til religions- og livssynsfaget i skolen. Kunnskap om levd religion mener jeg må med for å kunne oppfylle fagets intensjon, i tillegg til at det å integrere dette perspektivet er viktig for å lykkes med at elevene sitter igjen med en helhetlig forståelse av religion.

\section{Levd hverdagsreligion og skole}

Fagfornyelsen hevder at KRLE er et fag som er sentralt for at elevene skal kunne «forstå seg selv, andre og verden rundt seg»4. For å oppnå slike mål mener jeg det er avgjørende at levd hverdagsreligion er integrert i faget. Slike mål kan ikke oppnås uten å bevege seg inn i sin egen og andres hverdag og søke forstålse for de prosessene som finner sted der. Potensialet

4 https:/www.udir.no/lk2o/rleo1-03/om-faget/fagets-relevans-og-verdier 
for å gjøre dette ligger allerede i faget, i kompetansemål som vektlegger kunnskap om praksis, eller i kompetansemål der en skal ta utgangspunkt i aktuelle spørsmål en gitt gruppe er opptatt av. Dersom man skal kunne gå i dybden på kompetansemål som: «Elevene skal kunne sette seg inn i og formidle egne og andres tanker, følelser og erfaringer» ${ }^{5}$ forutsetter også det at man må være temmelig tett på folks liv. Lærebøker for faget, både i grunnskolen og i lærerutdanningene, har gjerne formidlet kunnskap om levd hverdagsreligion og religionenes innenfra-perspektiv ved å inkludere intervjuer med representanter for tradisjonene i sine bøker (jf. Eidhamar, 2004). Slike grep kan gjøre at elevene møter mer enn bare «offisielle» ekspertversjoner av de ulike tradisjonene. Men det dynamiske og foranderlige elementet ved levd hverdagsreligion er vanskelig å få fram i bøkenes statiske form. Når bøkene blir gamle, blir slike intervjuer også mer og mer foreldet. Til lærebøkene i grunnskolen er det gjerne tilknytta nettbaserte ressurser. Slike ressurser har potensial til å formidle oppdatert og aktuell kunnskap om religiøse praksiser og forståelser. Nødvendigheten av at kunnskap om religion og livssyn stadig oppdateres, kommer særlig fram i forskning på ungdom og religion. For eksempel viser forskning blant ungdom med hindu- og muslimsk bakgrunn i Norge en bevegelse mot at religion blir oppfattet mer og mer som et privat, indre og individuelt anliggende (Friberg, 2016; Sandberg mfl., 2018; Gupta, 2006). Dette er et trekk ved islam og hinduisme som nok ikke (enda) er innarbeidet i lærebøker og pensumbøker. Om ikke forlagene oppdaterer sine nettressurser, kan kanskje begrepet utforske, som er sentralt i Fagfornyelsen i skolen, inspirere til å framskaffe oppdatert og situert religionskunnskap i skolen. Utforske kan blant annet bety å undersøke hvordan religion uttrykkes på ulike institusjonelle, digitale og hverdagslige arenaer, eller å konsultere ny forskning. Dette kan gi elevene møter med fenomenet levd hverdagsreligion som kan utruste dem til å forstå samfunnet og kulturen utenfor klasserommet.

5 Kompetansemål etter 4. trinn https://www.udir.no/lk2o/rleo1-03/kompetansemaal-og-vurde-
ring/kv176 
Vektlegging av levd hverdagsreligion kan også bidra til å realisere et av KRLE-fagets nøkkelord, nemlig pluralistisk ${ }^{6}$. Begrepet pluralistisk kan knyttes til levd hverdagsreligions kritiske element, som handler om at flere, ikke bare eliten, har myndighet til å framstille hva en tradisjon innebærer. Ved å integrere perspektivet levd hverdagsreligion i skolen kan altså elevene bli bevisste på spenningene mellom ekspert-religion og vanlige folks religion, og også kunne se dem i sammenheng med hverandre. En slik undervisning, som fokuserer på mangfold og kompleksitet, er i praksis selvsagt svært krevende og forutsetter lærere med god fagkunnskap og metodiske ferdigheter. Mangfoldet og kompleksiteten i religionene kan lett forsvinne dersom man tviholder på klart definerte verdensreligionskategorier, som gjerne favoriserer standardiserte og offisielle framstillinger av tradisjonene. Verdensreligionskategoriene er i tillegg i stor grad vestlig konstruerte begreper, noe som kan medføre at forståelsen av religioner preges av vestlige og kristne tradisjoner og tankegods. Dette innebærer likevel ikke at man nødvendigvis må ta helt farvel med verdensreligionsbegrepet, for disse termene er, som tidligere nevnt i artikkelen, ofte viktige «identitetsknagger» for vanlige folk. Dessuten vil mange som definerer seg innen samme kategori, ofte dele en del oppfatninger, praksiser og fortellinger. Og det er like viktig å studere slike fellestrekk som det er å ta pluraliteten på alvor. Om man vil beholde verdensreligionskategoriene, må man altså være oppmerksom på at hva som ligger i betegnelsen islam, kristen, hindu osv. ikke alltid er gitt, og at skillene mellom religioner og mellom religion og det sekulære er uskarpe, porøse og noen ganger kunstige (Anker, 2017; Day, 2011; Nicolaisen, 2018).

Stabell-Kulø (2005) hevder at mange elever ikke får så mye ut av religions- og livssynsfaget fordi undervisninga preges av substansielle framstillinger av religioner. Det vil si at elevene møter en mengde faktaopplysninger og beskrivelser av tradisjoner, heller enn hva religion og livssyn bidrar til og gjør i enkeltmenneskers liv og i samfunnet. Med en elevgruppe som på grunn av sekularisering kan ha et distansert forhold til religion, kan et lass med substansielle beskrivelser av religion være vanskelig å finne mening i, og faget kan dermed framstå som uinteressant

6 https://www.udir.no/lk2o/rleo1-03/om-faget/fagets-relevans-og-verdier 
og irrelevant. Men ifølge Stabell-Kulø (2005) er det å introdusere elevene for funksjonelle sider ved religion og livssyn viktig før de blir overlesset med substansiell kunnskap. Det er fordi funksjonelle beskrivelser av religion kan skape «knagger» elevene kan henge den substansielle kunnskapen på. Med andre ord kan funksjonelle beskrivelser av religion bidra til å skape en kontekst som hjelper elevene til å finne mening i den substansielle kunnskapen om religion. Å gjøre elevene kjent med levd hverdagsreligion i undervisninga kan bidra til at den funksjonelle siden ved religionene og livssyna kommer tydeligere fram, og kan dermed bli viktig for elevenes videre læring om religion og livssyn.

\section{Konklusjon}

I denne artikkelen har jeg vist at levd hverdagsreligion handler om hvordan vanlige folk uttrykker, møter, skaper og deler noe som oppfattes som religion i sine hverdagskontekster. Fenomenet levd hverdagsreligion kommer til uttrykk gjennom kroppslige, materielle og diskursive praksiser og i folks erfaringer. Levd hverdagsreligion er dessuten noe som stadig endres, og individer har en stor rolle selv i utforminga av sin egen religion.

Levd hverdagsreligion er dessuten et perspektiv man kan gjenfinne i mange vitenskapelige disipliner, og et felles trekk er interessen for etnografiske metoder og vektleggingen av funksjonelle forståelser av religion. Perspektivet levd hverdagsreligion anerkjenner vanlige folks beskrivelser av hva religion innebærer. Dette medfører at religioners mangfold og kompleksitet kommer svært tydelig fram, og det vil ofte anskueliggjøre hvordan skiller mellom tradisjoner er porøse. Siden vanlige folk lever ut sin religiøsitet både i og utenfor organiserte eller institusjonaliserte settinger, bør forskning på levd hverdagsreligion gjenspeile begge disse arenaene. Denne tilnærmingen til religion, der man studerer små hverdagslige situasjoner og praksiser, har vist seg som gode portaler til å kunne si noe om hvordan religion er relatert til større sosiale mønstre og strukturer.

Levd hverdagsreligion ikke er et ukjent tema i skolens religions- og livssynsfag, men det er en side ved faget som hele tiden må oppdateres. Noen arbeidsmåter, for eksempel det å utforske, kan støtte opp om at 
elevene får oppdatert kunnskap om levd hverdagsreligion. Ved å mer bevisst inkludere funksjonelle religionsforståelser i undervisningen vil elevene kunne øke sin forståelse av hva religion kan bety for folk, og hva religion kan skape på lokalt og globalt nivå. Dessuten er vil det gi et godt utgangspunkt for videre læring. Å sette søkelyset på levd hverdagsreligion er altså nyttig for at elevene skal forstå det mangfoldige samfunnet de beveger seg i til daglig.

\section{Referanser}

Aase, T. H. \& Fossåskaret, E. (2014). Skapte virkeligheter: Om produksjon og tolkning av kvalitative data. Oslo: Universitetsforlaget.

Ammerman, N. (Red.) (2007). Everyday religion: Observing modern religious lives. Oxford: Oxford University Press.

Ammerman, N. (2014). Sacred stories, spiritual tribes: Finding religion in everyday life. New York: Oxford University Press.

Ammerman, N. (2016). Lived religion as an emerging field: An assessment of its contours and frontiers. Nordic Journal of Religion and Society, 29, 83-99.

Anker, T. (2017). På tide å si farvel til verdensreligionene? I M. Von Der Lippe \& S. Undheim, Religion i skolen (s. 25-34). Oslo: Universitetsforlaget.

Back, L. (2015). Why everyday life matters: Class, community and making life livable. Sociology, 49(5), 820-836.

Ballard, R. (2000). Panth, Kismet, Dharm te Qaum: Four dimensions in Punjabi religion. I P. a. T. Singh, Shinder (Red.), Punjabi Identity in a Global Context Delhi (s. 7-37). Oxford University Press.

Bender, C. J. (2007). Touching the transcendent: Rethinking religious experience in the sociological study of religion. I N. Ammerman (Red.), Everyday religion: Observing modern religious lives (s. 201-218). Oxford: Oxford University Press.

Botvar, P. K., Repstad, P. \& Aagedal, O. (2012). Regionaliseringen av norsk religiøsitet. I U. Schmidt \& P. K. Botvar (Red.), Religion i dagens Norge (s. 44-59). Oslo: Universitetsforlaget.

Davie, G. (2013). The sociology of religion: A critical agenda (2nd ed.). London: Sage. Day, A. (2011). Believing in belonging: Belief and social identity in the modern world. Oxford: Oxford University Press.

Dessing, N., Jeldtoft, N., Nielsen, J. \& Woodhead, L. (Red.) (2013). Everyday lived Islam in Europe. Farnham: Ashgate AHRC/ESRC religion and society series.

Eidhamar, L. G. (Red.) (2004). Religioner og livssyn. Kristiansand: Høyskoleforlaget. Friberg, J. H. (2016). Assimilering på norsk. FAFO-rapport: 43. 
Geaves, R. (2007). Saivism in the diaspora: Contemporary forms of Skanda worship. London: Equinox Pub.

Gilhus, I. S. \& Mikaelsson, L. (2007). Hva er religion. Oslo: Universitetsforlaget. Gupta, R. (2006). Being a Hindu in Oslo: Youth, change, and continuity (Vol. 121). Oslo: Novus.

Hall, D. (Red.) (1997). Lived religion in America. Princeton: Princeton University Press. Henriksen, J. O. (2016). Everyday religion as orientation and transformation: A challenge to theology. Nordic Journal of Religion and Society, 29(01), 36-51.

Henriksen, J. O. (2019). Empirically informed theology. On theology in an interdisciplinary context. I P. Repstad (Red.), Political religion, everydayr: Sociological trends: 119-125. Volume 33. International Studies in Religion and Society. Leiden/Boston: Brill.

Horsfjord, V. (2017). Religion i praksis. Oslo: Universitetsforlaget.

Jackson, R. (2008). Contextual religious education an the intepretitive approach. British Journal of Religious Education, 30(1), 13-24.

Jacobsen, K. A. (Red.) (2018). Verdensreligioner i Norge (4. utg.). Oslo: Universitetsforlaget.

Kalvig, A. \& Solevåg, A. R. (Red.) (2015). Levende religion. Globalt perspektiv - lokal praksis. Stavanger: Hertervig Akademisk.

Kleive, H. V. (2017a). Belonging and discomfort: Young Hindu Rreligiosity in rural Norway. Nordic Journal of Religion and Society, 30(01), 43-60.

Kleive, H. V. (2017b). Mestring og balanse. Prismet, (1-2), 27-41.

Kleive, H. V. (2018). Not that religious: A study of young Tamil religiosity in northwestern Norway. Phd- thesis. Oslo: Norwegian School of Theology, Religion and Society (MF).

Levitt, P. (2009). Roots and routes: Understanding the lives of the second generation transnationally. Journal of Ethnic and Migration Studies, 35(7), 1225-1242.

Løvlie, B. (2020). Bedehus, vekkelse og bevegelse. I B. Lovlie, P. Halse \& K. Hatlebrekke (Red.), Tru på Vestlandet. Tradisjonar i endring. Oslo: Cappelen Damm Akademisk.

Løvlie, B. (2007). Kor mykje stort... Matias Orheim, hans bidrag til vestnorsk kultur og kristenliv. Trondheim: Tapir Akademisk Forlag.

McGuire, M. (2002). Religion: The social context ( $5^{\text {th }}$ ed). Belmont, Calif: Wadsworth Thomson Learning.

McGuire, M. (2008). Lived religion: Faith and practice in everyday life. Oxford and New York: Oxford University Press.

Morgan, D. (2010). Introduction: The matter of belief. I D. Morgan (Red.), Religion and material cultur: The matter of belief (s. 1-17). London: Routledge.

Munson, Z. (2007). When a funeral isn't just a funeral: The layered meaning of everyday action. I N. Ammerman (Red.), Everyday religion: Observing modern religious lives (s. 121-135). Oxford: Oxford University Press. 
Neal, S. \& K. Murji (2015). Sociologies of everyday life: Editors' introduction to the special issue. Sociology, 49(5), 811-819.

Nesbitt, E. (2010). Intercultural education. Ethnograpich and religious approaches. Brighton: Sussex Academic Press.

Nicolaisen, T. (2018). Hinduer. Oslo: Universitetsforlaget.

Primiano, L. N. (1995). Vernacular religion and the search for method in religious folklife. Western Folklore (Reflexivity and the Study of Belief), 54(1), 37-56.

Primiano, L. N. (2012). Afterword: Manifestations of the religious vernacular: Ambiguity, power, and creativity. I M. Bowman \& Ü. Valk (Red.), Vernacular rReligion in everyday life: Expressions of belief (s. 382-394). Cambridge University Press.

Repstad, P. (Red.) (2019a). Political religion, everyday religion: Sociological trends. Volume 33. International Studies in Religion and Society. Leiden/Boston: Brill. Repstad, P. (2019b). Introduction. I P. Repstad (Red.), Political religion, everyday religion: Sociological trends: $1-7$. Volume 33. International Studies in Religion and Society. Leiden/Boston: Brill.

Repstad, P. (2019c). More dialogue between approaches: Everydal religion and political religion. I P. Repstad (Red.), Political religion, everyday religion: Sociological trends: 55-66. Volume 33. International Studies in Religion and Society. Leiden/Boston: Brill.

Rosaldo, R. (1993). Culture and truth: The remaking of social analysis. Boston, MA: Beacon Press.

Samuels, J. (2004). Breaking the ethnographer's frames: Refelections on the use of photo elicitation in understanding Sri Lankan monastic culture. American Behavioral Scientist, 47(12), 1528-1550.

Sandberg, S., Andersen, J., Gasser, T. L. U., Linge, M., Mohamed, I. A. A., Shokr, S. A. \& Tutenges, S. (2018). Unge muslimske stemmer. Om tro og ekstremisme. Oslo: Universitetsforlaget.

Scott, S. (2009). Making sense of everyday life. Cambridge: Polity.

Stabell-Kulø, A. (2005). Religioner i klasserommet. Innføring i religionsdidaktikk. Bergen: Fagbokforlaget.

Stringer, M. (2008). Contemporary Western ethnography and the definition of religion. Continuum Advances in Religious Studies. London: Continuum.

Ulstein, J. O. (2020). Vestlandsk kyrkjesyn. I B. Lovlie, P. Halse \& K. Hatlebrekke (Red.), Tru på Vestlandet. Tradisjonar i endring. Oslo: Cappelen Damm Akademisk.

Woodhead, L. (2011). Five concepts of religion. International Review of Sociology, 21(1), 121-143.

Woodhead, L. (2013). Tactical and strategic religion. I N. Dessing, N. Jeldtoft, J. Nielsen \& L. Woodhead (Red.), Everyday lived Islam in Europe (s. 9-22). Farnham: Ashgate AHRC/ESRC religion and society series. 



\title{
KAPITTEL 13
}

\section{Da katolisismen kom att til Nordvestlandet}

\section{Anders Aschim}

Høgskolen i Innlandet

\begin{abstract}
Samandrag: I løpet av eit knapt hundreår har Den katolske kyrkja gått frå å vere så godt som ikkje-eksisterande på Nordvestlandet til å bli den største religions- og livssynsminoriteten i regionen. Artikkelen dokumenterer og analyserer ei av dei mest markerte endringane i det religiøse feltet i regionen i nyare tid.
\end{abstract}

Nøkkelord: kyrkjehistorie, Den romersk-katolske kyrkja, Møre og Romsdal

\section{Innleiing}

Da den første katolske kyrkjelyden på Nordvestlandet etter reformasjonen blei grunnlagt i Molde i 1923, var det to katolikkar i byen, forutan dei «profesjonelle religiøse» som var komne utanfrå for å reetablere Den katolske kyrkja i området. Ved årsskiftet 2017-2018 hadde dei tre katolske sokna Ålesund, Molde og Kristiansund, som geografisk dekkjer heile Møre og Romsdal fylke, til saman 7557 registrerte medlemmer. Folketalet i fylket var 266 858. Registrerte katolikkar utgjorde altså 2,8 \% av befolkninga. På same tidspunkt hadde andre kristne trussamfunn utanfor Den norske kyrkja til saman 5700 medlemmer i fylket, eller 2,1\%. Ikkje-religiøse livssynsorganisasjonar hadde 2682 medlemmer, medan talet på registrerte muslimar var 2641, kvar av desse 1,0 \% av befolkninga. ${ }^{1}$

1 Statistiske opplysningar frå Trondheim katolske stift (e-post 04.07.2019), haldne saman med Statistisk sentralbyrå, Statistikkbanken, tabell 01222 og 08531.

Sitering av denne artikkelen: Aschim, A. (2020). Da katolisismen kom att til Nordvestlandet. I B. Løvlie, P. Halse \& K. Hatlebrekke (Red.), Tru på Vestlandet. Tradisjonar i endring (Kap. 13, s. 311-338). Oslo: Cappelen Damm Akademisk. https://doi.org/10.23865/noasp.104.ch13

Lisens: CC BY-ND 4.O. 
Med andre ord: I løpet av eit knapt hundreår har Den katolske kyrkja gått frå å vere så godt som ikkje-eksisterande på Nordvestlandet til å bli den største religions- og livssynsminoriteten i regionen. Det handlar om ei av dei tydelegaste endringane i det religiøse feltet på Nordvestlandet dei siste hundre åra. Korleis gjekk dette til? Kva for faktorar har medverka til denne utviklinga?

\section{Det religiøse feltet}

Med stikkordet «felt» har eg alt signalisert tilknyting til ein teoretisk tradisjon innan sosiologien, særleg knytt til Pierre Bourdieu. «I sterkt differensierte samfunn er det sosiale kosmos konstituert av eit sett av relativt sjølvstendige sosiale mikrokosmos», seier han. Det er desse som blir kalla «felt». Eit felt kan definerast som «eit nettverk, eller som det indre forholdet av objektive samband mellom posisjonar» (Bourdieu \& Wacquant, 1995, s. 82). Dette kan lyde nokså abstrakt. Litt meir konkret blir det når Bourdieu illustrerer empiriske studiar av til dømes det litterære eller det akademiske feltet med kart over posisjonane i slike sosiale rom og aktørane som inntar dei (Bourdieu, 1996, s. 111, 113; 2000, s. 191). Den enklaste tilgangen gir nok likevel spel-metaforen: På same måte som i spel finst det i eit sosialt felt visse reglar som spelarane er samde om, bestemte eigenskapar som blir rekna som ressursar eller «kapital», og ulike aktørar som konkurrerer om dei attraktive posisjonane og om den gevinsten som er rekna som attråverdig i nett dette spelet (Bourdieu \& Wacquant, 1995, s. 83-85).

No er Bourdieus modell etter mitt syn meir eigna til å forklare reproduksjon og stabilitet i sosiale felt enn endring, som er temaet i denne boka. Til dette føremålet vender eg meg til Neil Fligstein og Doug McAdams A Theory of Fields (2012). Deira innleiande definisjon av omgrepet «felt» er ganske lik Bourdieu sin, men når dei nyttar den talande nemninga «strategiske (handlings)felt», røper dette ei dynamisk og aktørorientert tilnærming til studiet av sosialt samspel:

A strategic action field is a constructed mesolevel social order in which actors (who can be individual or collective) are attuned to and interact with one another on the basis of shared (which is not to say consensual) understandings about the purposes of the field, relationships to others in the field (including 
who has power and why), and the rules governing legitimate action in the field.

(Fligstein \& McAdam, 2012, s. 9)

Teorien har omfattande forklaringsambisjonar. For vårt føremål kan vi nøye oss med å hente fram nokre nøkkelelement. For det første: Medan ein forskar som Bourdieu i regelen er opptatt av individuelle aktørar i sosiale felt, utvidar Fligstein og McAdam perspektivet med systematiske studiar av kollektive aktørar. Frå forsking på organisasjonar og folkelege rørsler hentar dei reiskapar for å forstå bakgrunnen for kollektiv handling, samarbeid og konkurranse (2012, s. 24-25).

For det andre: Medan andre teoretikarar gjerne fokuserer på dynamikken innan eitt avgrensa og sjølvstendig felt, insisterer Fligstein og McAdam på at felt er innleira i eit nettverk av felt, dei står alltid i forhold til andre felt. Relasjonane mellom felt kan vere av ulike slag. Dei kan vere nære og fjerne, sterke og svake. Felt kan vere uavhengige av kvarandre, dei kan stå i eit nokolunde likeverdig og gjensidig forhold til kvarandre, men dei kan òg vere avhengige av overordna og meir omfattande felt $\mathrm{i}$ ein hierarkisk struktur. Eit godt eksempel på det siste er nettopp den gjennomorganiserte katolske Kyrkja. Eit katolsk sokn kan analyserast som eit avgrensa felt. Samtidig er det, saman med andre sokn, innleira i eit bispedøme, som igjen berre er eitt av mange innan den store Kyrkja. Eit viktig skilje hos Fligstein og McAdam går endeleg mellom statlege og ikkje-statlege felt (2012, s. 18-19, 59-64).

For det tredje: Også i skildringa av dei ulike rollene - eller posisjonane, som Bourdieu seier - innan eit felt merkar ein det dynamiske elementet i teorien. Der Bourdieu sine felt er befolka av «dominerande» og «dominerte», er aktørane hos Fligstein og McAdam omtala som «etablerte» («incumbents») og «utfordrarar» («challengers»; 2012, s. 13-16). ${ }^{2}$ I historia som er tema for denne studien, gir det meining å analysere den kollektive aktøren Den katolske kyrkja som ein «utfordrar» i eit regionalt religiøst felt dominert av den «etablerte» og statsstøtta lutherske kyrkja, men der òg frikyrkjer og

2 Omsetjinga av «incumbents» er ei utfordring. Dette er eit etablert omgrep i engelskspråklege studiar av sosiale rørsler. I Fligstein og McAdams versjon handlar det om «those actors who wield disproportionate influence within a field and whose interests and views tend to be heavily reflected in the dominant organization of the strategic action field» $(2012$, s. 13). Omsetjinga «etablerte» låner eg frå Bjerke \& Halvorsen, 2018, s. 48. 
lutherske organisasjonar av ulik teologisk og sosiologisk farge er på banen og konkurrerer om posisjonar, tilhengarar og ideologisk hegemoni.

For det fjerde: Fligstein og McAdam legg stor vekt på ein bestemt type aktørar: «institusjonelle entreprenørar», individ med særlege «sosiale evner» («social skills», 2012, s. 16-18). Slike kan finnast både mellom etablerte og utfordrarar. Karakteristisk for desse er «a highly developed cognitive capacity for reading people and environments, framing lines of action, and mobilizing people in the service of broader conceptions of the world and of themselves» (2012, s. 17), evner som mellom anna under visse omstende kan gjere det mogleg å forme nye «politiske koalisjonar» innanfor feltet (2012, s. 15, 110).

For det femte: I sosiale felt finst det til eikvar tid lågmælt konkurranse om posisjonar som kan føre til mindre justeringar, men sjeldan til radikale endringar i maktbalansen. Her skil ikkje Fligstein og McAdam seg frå Bourdieu. Men eit særleg interessant trekk ved teorien deira er den tanken at meir grunnleggjande endringar i eit felt ofte skuldast påverknad frå omveltingar i andre felt, «eksterne sjokk» («exogenous shocks», 2012, s. 19-20).

Emnet for denne studien er historia til dei tre katolske sokna i Møre og Romsdal, fortolka ut frå den lokale katolske Kyrkja sin interaksjon med nære og fjerne sosiale felt. Eg er særleg opptatt av dei fasane der ein kan observere større endringar. Ut frå teorien til Fligstein og McAdam vil hovudhypotesen vere at slike endringar kan ha samanheng med endringar i andre, nære eller fjerntliggjande, felt.

\section{Kunnskapsstatus og kjelder}

Det finst omfattande dokumentasjon om utviklinga av Den katolske kyrkja i Noreg i Kyrkja sine eigne historieframstillingar (særleg Kjelstrup, 1942; Eidsvig, 1993; Nilsen, Oftestad \& Hegna, 2016), sjølv om desse til ein viss grad ber preg av institusjonens eigne interesser. Her er både materialrike og fagleg kompetente bidrag, men mykje har fokusert på den absolutt største eininga, Oslo katolske bispedøme. Møre og Romsdal høyrer til det mindre MidtNoreg stift. Ei gruppe aktørar som har vore inngåande studert, er ordenssøstrene (Nilsen, 1993; 2001; 2004; 2016a; Aukrust \& Nilsen, 1996; Poels, 2004; 2005; Kristvik [Risholm], 1996, 2000, 2010, 2013). Særleg verdifullt for 
denne studien er det betydelege kjeldearbeidet, inkludert intervju med søstrer, som er gjort av Poels og Kristvik om St. Carolus Borromeus-søstrene si verksemd nettopp i dei tre mørebyane. I lokalhistorisk litteratur er det den katolske kyrkjelyden og særleg det katolske sjukehuset i Molde som har sett sterkast spor (t. d. Kristvik, 2010; 2013; Gjendem, 2016).

Denne studien byggjer i hovudsak på desse og andre trykte kjelder. Bladet Kirkelig Tidende, som skal ha vore meldingsblad for dei katolske sokna i Midt-Noreg i perioden 1931-1940, har det ikkje lukkast meg å finne. Men blada Klippen, Broen og St. Olav formidla mykje lokal informasjon, lenge rett nok hovudsakleg frå prestane og kyrkjeleiinga sin synsvinkel. Aviser kan gi ein peikepinn om merksemd og reaksjonar i lokalsamfunna. Eg har vidare gjennomgått arkivalia frå Midt-Noreg stift. For Ålesunds del kan eg òg byggje på etnografisk arbeid (observasjon og intervju) i toårsperioden 2014-2016 i samband med prosjektet «Ora et labora. Katolske arbeidsinnvandrarar på Sunnmøre». ${ }^{3}$

\section{Utfordrar i det religiøse feltet}

\section{Etablering}

Fastbuande katolikkar var det få av da kyrkjelyden i Molde blei oppretta i 1923. Ekteparet Helga og Peter F. Dahll i Molde hadde konvertert nokre få år tidlegare. I Kristiansund budde franskfødde Lilly Werring; hennar førstefødde son var døypt katolsk, og det blei òg dei to ho fekk seinare. Alt frå starten av var altså både norske konvertittar og katolske innvandrarar og barna deira representerte i kyrkjelyden. Desse første katolikkane høyrde til den økonomiske og sosiale eliten i byane sine. Både Peter Dahll og Sigurd Werring, ektemannen til Lilly, hadde konsultitlar, noko som både vitnar om solid posisjon i næringslivet og om internasjonale kontaktar. Det handla mellom anna om klippfiskeksport, ikkje minst til katolske land. ${ }^{4}$

Ein sentral aktør i etableringa i Molde var den nyleg (1922) utnemnde apostoliske vikaren for Noreg, den nederlandske biskopen Johannes (Jan)

\footnotetext{
Eg takkar prestar og stiftsadministrasjon i Midt-Noreg for all hjelp og velvilje.

Grunnlegginga av kyrkjelyden i Molde er skildra mellom anna i Kjelstrup, 1942, s. 264-267; Eidsvig, 1993, s. 297. Om ekteparet Dahll, sjå mellom anna Austigard \& Jakobsen, 1997, s. 24-28; Lilly Werring, sjå Kristvik Risholm, 1996, s. 8; Sigurd Werring, sjå Hoffstad, 1939, s. 941.
} 
Olav Smit. For det katolske hierarkiet var Noreg misjonsmark, og Smit var misjonsmann. Han var nær knytt til landsmannen kardinal Willem van Rossum, som var prefekt for Propagandakongregasjonen, altså leiar for Vatikanets misjonsdepartement.

Smits motto var «Norge tilbake til moderkirken» (Nilsen, 2001, s. 221). Han delte visjonane og strategiane til forgjengaren, luxemburgaren Johannes Olav Fallize. Rekatolisering av Noreg var målet. Midlet var katolsk nærvær i norske lokalmiljø. Til dette høyrde kyrkje og prest, ordenssøstrer og katolsk helseinstitusjon, og - for Fallize, men i mindre grad for Smit - katolsk skole. Geografi var òg ein viktig strategisk faktor (Eidsvig, 1993, s. 288, 290). Det fanst inga katolsk kyrkje mellom Bergen og Trondheim. Molde var eit sentrum for turisttrafikken på Nordvestlandet, og Fallize hadde tatt til orde for katolsk etablering her.

Det blei Smit som sette visjonen i verk. Ekteparet Dahll gav i 1922 tomt til bygging av kyrkje. No skjedde ting fort. Smit sette i gang pengeinnsamling gjennom bladet St. Olav. I første omgang blei nybygg for kostbart, og i juni 1923 blei ein bygard i Molde sentrum innkjøpt for å tene som kapell, prestebustad og søsterkommunitet (Kjelstrup, 1942, s. 264; Romsdals Budstikke, 06.06.1923, s. 3). Den 14. juni 1923 kom den nederlandskfødde pastor Peter Breukel til byen som sokneprest for den nye St. Sunniva kyrkjelyd (Romsdals Budstikke, 13.06.1923, s. 3). Molde var den katolske etableringa som geografisk låg nærast Selja, den gamle heilagstaden knytt til den heilage Sunniva, så namnet var ikkje tilfeldig valt. Fire nederlandske ordenssøstrer frå St. Carolus Borromeus-ordenen kom til Molde 12. juli (Kristvik, 2010, s. 175). Presten og søstrene hadde hendene fulle med å setje huset og kapellet i stand. Alt 26. juli blei kapellet vigsla, og det av kardinal van Rossum sjølv, assistert av biskop Smit (Romsdals Budstikke, 28.07.1923, s. 2). Det var stor nasjonal interesse for noregsbesøket til van Rossum, det første kardinalbesøket i landet sidan 1247 (Eidsvig, 1993, s. 301-302).

Det katolske hierarkiet, representert ved biskopen, var altså, ikkje overraskande, eit felt med høgst aktiv påverknad på etableringsprosessen på Nordvestlandet. Svært viktig er òg den sentralkyrkjelege Propagandakongregasjonen, som i desse åra hadde store voner om framgang i Skandinavia. Meir uventa er kanskje den svært tydelege rolla til det nederlandske katolske feltet. Kardinalen, biskopen og den første soknepresten var alle 
nederlendarar. Dei appellerte sterkt til landsmennene sine og «knyttet den norske misjon til den nederlandske kirke» (Eidsvig, 1993, s. 289). Dette er utførleg drøfta av Vefie Poels (2004; 2005). Rollene til Smit og van Rossum blei seinare overtatt av menn med annan nasjonal bakgrunn. Viktigare på lang sikt blei dei nederlandske ordenssøstrene, som gjennom nesten sytti år skulle vere ein berebjelke i katolsk kyrkjeliv på Nordvestlandet. Og vanlege katolikkar i Nederland var viktige som moralske, åndelege og ikkje minst økonomiske støttespelarar. Katolikkar var ikkje i majoritet i Nederland, men dei var ein stor og medviten religiøs minoritet (Kristvik Risholm, 2000, s. 23-26; Poels, 2004, s. 192-194; Kristvik, 2010, s. 176-177). Misjonstanken stod sterkt. Det fanst til og med eit eige misjonsblad for Noreg, Uit het land van St. Olav, grunnlagt av biskop Smit i 1922 og utgitt heilt til 1975. Svært mange nederlandske ordenssøstrer kom til Noreg i teneste for den katolske misjonen (Poels, 2004, s. 194-197).

Karl Borromeus-søstrene, i heimlandet kjende som «Zusters onder de Bogen» etter moderhuset i Maastricht, var ein veletablert kongregasjon med karitativt arbeid som si særlege oppgåve. Mange var velutdanna og erfarne sjukepleiarar. Sjukepleie skulle òg vere oppgåva til dei fire som kom til Molde sommaren 1923 under leiing av moder Fulgentia (Nilsen, 1993, s. 223-224; Kristvik Risholm, 2000, s. 50-51; Poels, 2005, s. 265-269). Dermed kjem vi i kontakt med eit anna samfunnsfelt som var viktig i samband med den katolske etableringa, nemleg helsevesenet. Norsk helsevesen i mellomkrigstida var i utstrekt grad bygd på offentlegprivat samarbeid, og katolske institusjonar hadde alt i lang tid vore viktige element mange stader i landet (Schiøtz, 2003, s. 180). Søstrene i Molde etablerte raskt ein liten klinikk i lokala sine.

Kjelstrup (1942) omtalar konsekvent dei norske katolske etableringane som «misjonsstasjonar». Dette var kjende tonar for kristenfolk i Noreg. Slik sett var dei ikkje ulike dei stasjonane norske lutherske misjonsorganisasjonar hadde grunnlagt til dømes i Sør-Afrika (jf. Hovland, 2013) eller på Madagaskar (jf. Skeie, 2013). Også her høyrde kyrkje, skole og helseinstitusjonar med i den samla strategien.

I 1931 blei Den katolske kyrkja i Noreg reorganisert. Mellom-Noreg, det vil seie Møre og Romsdal og Trøndelag, blei skilt ut som eige «kyrkjedistrikt» med eigen overhyrding (Kjelstrup, 1942, s. 285-288; Eidsvig, 
1993, s. 320-321). Frå no av fekk ein tysk prestekongregasjon, dei såkalla Picpus-patrane, det geistlege ansvaret for Mellom-Noreg. Tyske prestar og nederlandske nonner fekk altså den store oppgåva å rekatolisere Nordvestlandet, med utgangspunkt i ei forsamling beståande av nokre få norske konvertittar og katolske innvandrarar.

Den direkte misjonen var prestane si oppgåve. Søstrene si misjonsoppgåve var meir indirekte. Gjennom kontakt med lokalbefolkninga og gode gjerningar skulle dei skape sympati og interesse for Den katolske kyrkja. Frå det rike intervjumaterialet til Poels, Kristvik, Aukrust og Nilsen går det fram at mange søstrer hadde eit ambivalent forhold til oppdraget. Ei sjukepleieutdanna søster med lang fartstid i Noreg kan stå som døme på den realitetsorienteringa mange opplevde:

På en måte opplevde jeg meg som misjonær. Vi fikk altså dette misjonskurset, og trodde nok at det var en slags misjonsmark vi kom til. Vi hadde ikke mye kjennskap til Norge. Jeg husker en gang på toget at en ung mann stilte følgende spørsmål: «Hva gjør dere her, vi er ikke hedninger.» Jeg svarte: «Vi er her for å hjelpe katolikkene.» Nordmenn kunne bli støtt, for de er jo ikke hedninger. (Aukrust \& Nilsen, 1996, s. 97)

Distriktet fekk oppgradert statusen sin til apostolisk prefektur i 1935, og til apostolisk vikariat med eigen biskop i 1953, i samband med 800årsjubileet for opprettinga av erkebispesetet i Nidaros i 1153, da Noreg blei eigen kyrkjeprovins i mellomalderen. Først i 1979 kom det ei ny oppgradering til sjølvstendig prelatur, eller «stift», som ein valde å kalle det i Noreg, uavhengig av Propagandakongregasjonen (Broen, 2/1979, s. 12). Midt-Noreg var altså ikkje meir å forstå som misjonsdistrikt.

Den første prefekten, pater Cyprian Witte, var alt sokneprest i Molde. Han valde å bli buande her og ikkje flytte til Trondheim, som var det naturlege senteret for kyrkjedistriktet. Noko av det første han gjorde, var å etablere Den katolske kyrkja i Kristiansund, først med eit lite kapell som anneks til Molde (1932), frå 1934 som eige sokn med fast prest. Kyrkjelyden fekk namnet St. Eystein. Fire Borromeus-søstrer etablerte samtidig klinikken «Stella Maris», som snart hovudsakleg blei fødeklinikk (Kjelstrup, 1942, s. 333-334; Kristvik Risholm, 1996, s. 11-13; 2000, s. 66-67). Private initiativ var kjærkomne i Kristiansund; kommunen hadde elendig økonomi 
i mellomkrigstida (Aass, 1991, s. 308-389). Slik fekk Lilly Werring oppfylt det store ønsket sitt om katolsk kyrkje i heimbyen. Framleis var familien hennar dei einaste lokale katolikkane (Kristvik Risholm, 1996, s. 20).

I Ålesund tok prosessen meir tid. Den første katolske kvinna skal ha slått seg ned i byen i 1933 (Klippen, 4/1954, s. 4). Fleire følgde, både i byen og i sunnmørsbygdene. I 1950 rapporterer bladet Klippen (2/1950, s. 3) om eit par katolske familiar som får besøk av Molde-presten annakvar veke. Første søndag i advent 1954 innvigde biskopen eit lite rom i ein privatbustad til katolsk kapell. I 1958 kjøpte Den katolske kyrkja eit hus i Nørvasundet, og tre Borromeus-søstrer etablerte «Mariaheimen», eit lite sjukehus, seinare pleieheim. Kyrkjelyden blei skipa året etter med 45 medlemmer (Vu Manh Hung, 2004).

\section{Konkurranse}

Attende til starten i Molde. Korleis endra den katolske etableringa det lokale religiøse feltet? Interessa for kardinalbesøket og vigslinga av kapellet i Molde var svært stor (Romsdals Budstikke, 24.07.1923, s. 1; 28.07.1923, s. 2). I eit intervju seinare på året med Aftenposten (01.12.1923, s. 6), som hadde lagt merke til den fornya katolske innsatsen i Noreg, fortalde pastor Breukel: «Kirken er altid fuld. Denne store tilslutning tilskriver jeg at en stor religiøs trang er tilstede.» Han meiner «at sympatien i Norge overfor vor kirke er storartet - men det maa indrømmes, at det er et langt skridt derfra til overgang til kirken».

Breukel hadde gode grunnar til å vere nøktern, konversjonane lét vente på seg. Men han var offensiv. Alt i august 1923 annonserte han eit kurs i katolsk truslære i avisa, under overskrifta «Nu er tiden inne» (Romsdals Budstikke, 25.08.1923, s. 3). Han fekk svar på tiltale i eit kort, men retorisk kraftig lesarinnlegg med same tittel av sokneprest Johan Nyhagen, den lokale forvaltaren av det lutherske statskyrkjelege hegemoniet. Soknepresten åtvara både mot intern splitting og mot «fremmede Lærdomme». Innlegget var slått opp på første side, saman med ein artikkel om «Romerkirken» som påstod at katolikkar blei nekta å lese Bibelen. Breukel imøtegjekk begge artiklane nokre dagar seinare, i same avisa som formidla kunngjeringa om at den sterkt omdiskuterte teologen Jens Gleditsch var blitt vigsla til biskop i statskyrkja 
(Romsdals Budstikke, 30.08.1923, s. 1; 03.09.1923, s. 2). Breukel såg eit konkurransefortrinn, Nyhagen ein fare, i den interne lutherske kyrkjestriden. Imot luthersk mangfald og usemje kunne Den katolske kyrkja marknadsførast som ein fast, stabil og tradisjonstru institusjon. Det hjelpte likevel lite. Om kardinal van Rossums besøk i Noreg hadde vekt stor interesse, stakk han sjølv kjeppar i hjula i etterkant ved å publisere eit lita bok om noregsferda som provoserte mange norske lutheranarar (Slotsvik, 2009, s. 59-61).

Også lekkatolikken Helga Dahll ytra seg offentleg. I innlegget «Hvor er Kristi kirke?» kontrasterte ho katolske og protestantiske misjonærar, til fordel for dei første. Både soknepresten og representantar for Det Norske Misjonsselskap tok til motmæle. Nyhagen omtala henne noko nedlatande som «en neppe fireårig proselyt» (Romsdals Budstikke, 12.01.1924, s. 1; 14.01.1924, s. 2; 25.-26.01.1924). Molde var ein by med høg grad av religiøs aktivitet. Den lokale indremisjonsforeininga høyrde til ein sterk lekmannsorganisasjon som stod på luthersk og statskyrkjeleg grunn, men kunne utfordre det geistlege hegemoniet. Både Frelsesarmeen og Metodistkyrkja var etablerte i byen (Abrahamsen, 1992, s. 330-333). Ved sida av katolisismen var adventismen ein annan ny utfordrar i det lokale religiøse feltet på 1920talet. Evangelist T. S. Valén tok for seg både den katolske og den lutherske soknepresten i ein møteannonse (Romsdals Budstikke, 06.05.1924, s. 3).5

Noka stor utfordring for statskyrkja blei den katolske misjonen likevel ikkje. Å kome inn i det lokale helsefeltet viste seg òg vanskeleg. Den vesle katolske klinikken fekk nesten ikkje pasientar det første året. Kristvik lanserer to moglege forklaringar på dette: at behovet for helsetenester i Molde alt var dekt, med to lokale sjukehus og primærhelseteneste både i kommunal og ideell regi, og/eller at det fanst ein religiøst begrunna skepsis mot katolsk nærvær (Kristvik Risholm, 2000, s. 51-52; Kristvik, 2010, s. 178-180). I 1926 ville leiinga for Karl Borromeus-søstrene i Nederland leggje ned verksemda i Molde på grunn av lokal motstand, for lite arbeid og manglande inntekter. Når dei likevel heldt fram, var det etter press frå hierarkiet. Biskop Smit skreiv til kardinal van Rossum at om søstrene forlét Molde, ville det bety misjonsstasjonens død, og van Rossum overtala kongregasjonen (Poels, 2004, s. 205; 2005, s. 278). Her kjem det til syne ei spenning mellom ulike

Om T. S. Valen (eller Valén), sjå Valen, 2000. 
felt innanfor den mangfaldige katolske kyrkjestrukturen. Ordenssamfunn og kongregasjonar er ikkje utan vidare underlagde biskopen; mange har sin eigen overnasjonale styringsstruktur. Samarbeid blir regulert gjennom avtalar. Biskop Fallize hadde hatt eit konfliktfylt forhold til somme søsterkongregasjonar han forsøkte å overstyre (Nilsen, 2001, s. 112-117, 126-142).

Søstrene viste seg svært tilpasningsdyktige til behova i helsefeltet. Samarbeidet med tuberkulosesjukehuset Reknes sanatorium frå 1928 blei ein nøkkel for den vidare utviklinga. I 1934 kunne søstrene opne det nybygde St. Carolus sjukehus, finansiert av moderhuset i Nederland, der moder Fulgentia no var blitt generalforstandarinne for heile kongregasjonen. Ho var ein tydeleg «institusjonell entreprenør» innan det katolske feltet, med ein klar strategi for søstrene sitt nærvær i distriktet: Sjølv om gjennomslaget for katolisismen var uteblitt, såg ho det som kongregasjonen si oppgåve å sørgje for at det fanst «mange tabernakel» i Noreg. Tabernaklet er den staden i katolske kyrkjer der den innvigde hostien, Kristi lekam, blir oppbevart, der Kristus sjølv etter katolsk sakramentsyn er til stades, til velsigning for nærmiljøet. Utan søstrer ville det ikkje vere prest, kyrkje og tabernakel på staden (Poels, 2005, s. 207-208).

Det høyrer med til historia at det etter debatt i Molde bystyre om konsesjon for sjukehuset ved fleirtalsvedtak blei lagt inn eit vilkår om at ein ikkje skulle leggje «hindringer i veien for at pasienter, som ønsker betjening av andre trossamfunds sjelesørgere, kan få det» (Abrahamsen, 1992, s. 293). Den katolske verksemda var altså omdiskutert og til dels mistenkeleggjort i byen. Det nye sjukehuset hadde 36 senger, og bustader og kapell for søstrene. Behovet for sengeplassar til tuberkulosepasientar gjekk opp og ned, men St. Carolus fann andre næringsvegar, dels i samarbeid med fylkessjukehuset, dels med private spesialistar. Det var verken auge- eller øyre/nase/hals-avdeling ved fylkessjukehuset, og St. Carolus blei ein viktig faktor i utviklinga av spesialisthelsetenesta i Møre og Romsdal (Kristvik Risholm, 2000, s. 54-58; Kristvik, 2010, s. 180-181; Gjendem, 2016, s. 13-21).

\section{Krig}

Andre verdskrig var ei endring i det verdspolitiske feltet med direkte og dramatiske konsekvensar også for dei små katolske kyrkjelydane i Molde 
og Kristiansund. Begge byane blei bomba og sette i brann i aprildagane 1940 (Abrahamsen, 1994, s. 30-50; Aass, 1991, s. 520-531). Dei katolske kapella gjekk med i bybrannane, men St. Carolus sjukehus og Stella Maris fødeklinikk var uskadde, og kapella til søstrene blei nytta som soknekyrkjer under krigen og dei første etterkrigsåra (Kristvik Risholm, 1996, s. 21; Kristvik, 2010, s. 182-183). Nesten alle dei katolske prestane i MellomNoreg var tyske, inkludert prefekt Cyprian Witte i Molde og sokneprest Pantaleon Stelzmann i Kristiansund. Dei hamna i ein delikat situasjon, ikkje berre på grunn av konflikten mellom opphavslandet og det nye landet deira, men òg fordi mange av dei tyske militære var katolikkar og søkte til den lokale kyrkja. I Molde blei løysinga ei separat messe for dei tyske soldatane (Kristvik Risholm, 2000, s. 56).

Ordenssøstrene, på si side, var nederlendarar, frå eit land som til liks med Noreg var okkupert. Ikkje berre kapella, men også institusjonene deira blei svært viktige under krigen, ikkje minst i Kristiansund, der store delar av infrastrukturen i byen var øydelagd. Mange katolske sjukehus rundt i landet var rekvirerte til krigslasarett av okkupasjonsmakta (Nilsen, 2004, s. 228-229; 2016a, s. 150-151). Det var planar om å gjere det same med Stella Maris, men dei blei skrinlagde etter protestar frå legane i byen fordi «klinikken var helt uerstattelig i den nedbrente by» (Kristvik Risholm, 1996, s. 14).

I det heile ser det ut til at Den katolske kyrkja kom gjennom krigen med auka respekt i lokalmiljøet. Pater Witte, som alt var norsk statsborgar, døydde plutseleg i april 1945, like før freden. Han fekk ein sympatisk nekrolog i Romsdals Budstikke (18.04.1945, s. 2). Pater Stelzmann fekk norsk statsborgarskap i 1948. «Før krigen inntok han en konsekvent holdning mot den tyske nazismen, og under okkupasjonen stilte han seg avgjort og uredd i opposisjon til okkupasjonsmakten», skreiv lokalavisa Tidens Krav (25.06.1948, s. 1).

Ryggdekninga frå det katolske hierarkiet spelte nok òg ei rolle for dei lokale kyrkjelydane. Rett nok har det vore stilt spørsmål ved pavestolen si haldning, særleg knytt til konkordata (avtalane) med Mussolini-regimet i 1929 og med Hitler-regimet i 1933. Men særleg frå og med den pavelege ensyklikaen «Mit brennender Sorge» (1937) posisjonerte Den katolske kyrkja internasjonalt seg som ein viktig kritikar av nazistisk ideologi. Jacob 
Mangers, den katolske biskopen i Oslo, markerte seg tydeleg i forhold til okkupasjonsmakta. Mellom anna gjorde han felles sak med Den norske kyrkja i kritikken av den obligatoriske ungdomstenesta som NS-regimet kunngjorde i 1942. Resultatet var trugsmål om utvising av alle utanlandske prestar og ordenssøstrer. Dette blei likevel ikkje sett i verk (Eidsvig, 1993, s. 348-352; Nilsen, 2004, s. 218-220).

Både lokalt og nasjonalt har altså Den katolske kyrkja solidarisert seg med dei okkuperte mot okkupasjonsmakta. I ei krisetid viser både biskop, prestar og søstrer seg som institusjonelle entreprenørar. Den felles kyrkjekampen ser ut til å ha bidratt til eit mildare klima og aukande gjensidig sympati i etterkrigsåra, og til å dempe inntrykket av Den katolske kyrkja som eit framandelement i det norske samfunnet.

\section{Bygging og barnehagar}

I løpet av desse første tiåra var Den katolske kyrkja blitt ein del av bybildet i Molde og Kristiansund, først og fremst gjennom helseinstitusjonane som søstrene dreiv. Men konversjonane som misjonsideologane hadde sett for seg, blei det ikkje mange av. I 1948 var det framleis ikkje meir enn om lag 35 medlemmer i kyrkjelyden i Molde (Kristvik, 2010, s. 183). I Kristiansund stod det enda magrare til. Da familien Werring flytta frå byen i 1945, var presten og søstrene dei einaste medlemmene. I 1948 tok ein langsam auke til med to belgiske menn som flytta til byen med familiane sine (Kristvik Risholm, 1996, s. 21-22). Også seinare var denne «vikariatets minste menighet» sårbar for mobilitet. Våren 1950 kunne sokneprest Hünen melde om «en aldri så liten blomstring» i kyrkjelyden. I tillegg til dei seks søstrene ved fødeklinikken «Stella Maris» var det 13 andre medlemmer. Av desse var åtte barn under sju år. Men alt same sommar flytta åtte av desse personane, to norske barnefamiliar, frå byen (Klippen, 1/1950, s. 3; 3/1950, s. 3).

Byggeverksemd var eit stort løft for heile samfunnet i gjenreisingstida etter krigen, også for dei katolske kyrkjelydane og for den nye overhyrden Johannes Rüth, som i 1953 blei vigsla til biskop (Eidsvig, 1993, s. 339-341; Müller, 2010, s. 37). No blei det endeleg høve til å byggje prestebustader og etter kvart kyrkjer, med biskopen både som pådrivar 
og som pengeinnsamlar i sitt heimland Tyskland. Men her var ein òg avhengig av det offentlege, statlege og kommunale, feltet: Å få byggeløyve til kyrkjer tok tid; bustadbehovet hadde prioritet i dei raserte byane, og Molde-kyrkjelyden fekk i første runde avslag på søknaden (Klippen, 4/1955, s. 4). St. Sunniva kyrkje kunne endeleg vigslast og takast i bruk i 1957, på den tomta som ekteparet Dahll hadde gitt til formålet 35 år tidlegare. Året etter var turen komen til Kristiansund og St. Eystein kyrkje. Kyrkjelydane kunne no flytte ut av kapella til søstrene og ta sine nybygde soknekyrkjer i bruk. Alt i 1960 stod Vår Frue kyrkje i Ålesund ferdig. I alle tre byar var det òg bygd prestebustader.

Søstrene og helseinstitusjonane deira - St. Carolus sjukehus i Molde, Stella Maris fødeklinikk i Kristiansund, og etter kvart Mariaheimen i Ålesund - var framleis ein nøkkelfaktor i Den katolske kyrkja si verksemd, både økonomisk, i praktisk kyrkjelydsarbeid og når det gjaldt kontaktflaten med lokalsamfunnet. Søstrene bidrog med eit større beløp til bygginga av St. Sunniva kyrkje i Molde, og i Kristiansund gav dei tomt til St. Eystein kyrkje og prestegard (Kristvik Risholm, 1996, s. 20; 2000, s. 59, 69). Endringar i feltet for helsetenester påverka den kyrkjelege verksemda. Det blei oppretta fødeavdeling ved det nybygde sjukehuset i Kristiansund i 1956 (Schiøtz, 2003, s. 323-324). Det førte til at Stella Maris blei nedlagt som fødeklinikk, for straks å gjenoppstå som pleieheim med nær tilknyting til det same sjukehuset (Klippen, 2/1956, s. 3; Kristvik Risholm, 1996, s. 15-16; 2000, s. 69).

Etter krigen fann søstrene dessutan eit nytt arbeidsområde og ein ny næringsveg, nemleg barnehagar. Dette var noko Borromeus-søstrene hadde erfaring med. Fleire var òg utdanna barnehagelærarar. Alt i 1940 hadde dei starta St. Torfinn barnehage på Hamar, den einaste staden der dei hadde verksemd i Noreg utanfor Møre og Romsdal. I 1951 starta søstrene i Molde ein liten barnehage under temmeleg enkle forhold, utan offentleg godkjenning. Da prestegarden stod ferdig i 1953, fekk dei nye lokale der og utvida verksemda. Eit avisoppslag om St. Sunniva barnehage førte til debatt i Molde menighetsblad og i lokalpressa. Nokre frykta katolsk påverknad på barna, men fleire var takknemlege for at søstrene bidrog til å dekkje eit reelt behov. I Kristiansund blei det bygd barnehage under meir ordna forhold. Stella Maris barnehage opna i 1955 og blei svært 
positivt mottatt i byen (Kristvik Risholm, 1996, s. 16-20; 2000, s. 80-85; Kristvik, 2010, s. 185-186; Poels, 2005, s. 455-460). Barnehagedrift kunne altså bli oppfatta som eit nytt utfordrande utspel i det religiøse feltet, men sette òg Den katolske kyrkja i kontakt med andre samfunnsfelt. Barnehagar var på denne tida stort sett drivne av private eller ideelle institusjonar, men området var i ferd med å bli sterkare regulert av det offentlege, i første omgang forstått som barnevernsinnretningar, først seinare som pedagogiske tiltak (Korsvold, 2005, s. 78-83).

\section{Konsil og reform}

På 1960-talet skjedde den største endringa i nyare tid i Den katolske kyrkja internasjonalt. Under Andre Vatikankonsil (1962-1965) bles ein reformvind over Kyrkja, sett i gang under pave Johannes 23. med slagord som «aggiornamento» - «oppdatering». Mellom oppdateringane var eit endra samtaleklima med andre kristne og ei rad liturgiske reformar.

Alt før konsilet kunne ein merke eit mildare klima mellom protestantar og katolikkar her på berget. Medan Antonius Deutsch, prefekten i dei første etterkrigsåra, framleis hadde som mål å «fortelje protestantane sanninga» og godt kunne ta ordet i Studentersamfunnet i Trondheim for å «rundjule protestantar» (Müller, 2010, s. 17), var tonen annleis hos etterfølgjaren som overhyrde i Midt-Noreg, biskop Johannes Rüth. Da han blei innbeden til 8oo-årsjubileet for Nidaros erkebispestol i 1953 i Erkebispegarden, nytta han dette bibelsitatet i talen til den lutherske kollegaen: «La det ikke være trette mellom meg og deg. Vi er jo brødre ... Drar du til venstre, vil jeg dra til høyre» (1 Mos 13, 8-9; Eidsvig, 1993, s. 341). Med denne invitasjonen til arbeidsdeling framfor konkurranse opptrer biskop Rüth tydeleg som institusjonell entreprenør. I Ålesund opplevde den nye katolske kyrkjelyden å få støtte av ein annan slik, nemleg den lutherske soknepresten Monrad Norderval, seinare biskop i Nord-Hålogaland (Klippen, 3/1961, s. 4).

Eit særleg konsekvensrikt resultat av konsilet var høvet til å feire liturgien på nasjonale språk i staden for på latin. Den liturgiske fornyinga førte òg med seg endringar i kyrkjerommet. Presten kunne no forrette messa ståande bak altaret, vend mot kyrkjelyden, ikkje med ryggen til. «Den nye posisjonen uttrykker fellesskap mellom prest og folk - i 
Kristus», skriv Oftestad (2016, s. 193). Prestane i mørebyane var ivrige i oppfølginga. I løpet av året 1966 hadde ein gjennomført endringar i koret i alle dei tre kyrkjene i Ålesund, Molde og Kristiansund (Klippen, 4/1966, s. 3-4; 1/1967, s. 3). Den musikalske pater Athanasius Kulbach i Levanger, seinare sokneprest i Molde, komponerte òg tonar til den norske messeliturgien og andre liturgiske songar. Det blei rett nok dominikanaren Thoralf Norheim sine messetonar som fekk størst gjennomslag til den norske liturgien, men pater Kulbach har framleis fleire liturgiske omkved i den katolske salmeboka Lov Herren. Det var forresten òg Kulbach som fekk den pedagogiske oppgåva å forklare at latin slett ikkje var avskaffa i den katolske gudstenesta, heller ikkje i Noreg (Klippen, 1/1977, s. 7-8). At det var naudsynt, viser at det ikkje har vore heilt fritt for intern uro rundt dei liturgiske endringane (jf. Oftestad, 2016, s. 194).

I åra under og etter konsilet opplevde Den katolske kyrkja i Europa ein markant nedgang i preste- og ordenskall. Denne «kallskrisa» råka òg dei kvinnelege kongregasjonane i Nederland, mellom dei Karl Borromeus-søstrene (Poels, 2004, s. 586). Nokre har oppfatta dette som ein direkte verknad av konsilet, andre har peikt på andre faktorar i samtida (Nilsen, 2012, s. 114-119). Resultatet var uansett at det blei vanskelegare å rekruttere ordenssøstrer til teneste i Noreg, noko som kom til å få konsekvensar også for dei katolske sokna på Nordvestlandet.

\section{Velferdsstat og kyrkje}

Under gjenreisningen etter krigen ble helsesektoren generelt utvidet og modernisert. Sykepleien ble mer profesjonalisert. De katolske sykehusene gjorde sitt beste for å følge med, og i 1960-årene foregikk ordenssøstrenes aktivitet og tjeneste stort sett i disse institusjonene. Ti år senere, i 1970-årene, var flertallet av de katolske sykehusene borte. (Nilsen, 2012, s. 114)

Etterkrigstida bar ikkje berre preg av gjenoppbygging, men òg av utbygginga av velferdsstaten. Dette førte til sterk utvikling og endring i feltet for helsetenester, ikkje minst når det gjaldt sjukehusstrukturen. Det handla om ny medisinsk kunnskap, om spesialisering og profesjonalisering, om modernisering av institusjonane, og om sterkare offentleg engasjement 
og styring. Etter mange års arbeid kom det ei sjukehuslov i 1969 som samordna sektoren (Seip, 1994, s. 313-356; Schiøtz, 2003, s. 309-347).

I Molde blei St. Carolus sjukehus selt til fylket i 1968. Fleire av søstrene heldt fram som tilsette ved sjukehuset. Pleieheimen Stella Maris i Kristiansund blei nedlagd i 1971 (Kristvik Risholm, 2000, s. 58, 69-70). Mariaheimen i Ålesund stengde òg ved utgangen av dette året. «Det var 2 faktorer som gjorde at styret for søstrenes kongregasjon bestemte seg for at Mariaheimen skulle stenge sine dører: Bestemmelser i den nye sykehusloven, og mangel på ordenskall», refererer Klippen (1/1972, s. 12). Dette er representativt for mange nedleggingar av katolske helseinstitusjonar i 1960- og 70-åra (Nilsen, 2012, s. 116-117). «Paradokset er at den velferdsstaten som søstrene bidro til å skape gjennom sine sykehus, til slutt gjorde disse institusjonene overflødige», oppsummerer Else-Britt Nilsen presist (2016b, s. 142).

Borromeus-søstrene la no ned kommunitetane i Ålesund og Kristiansund og konsentrerte seg om Molde og Austlandet. I Kristiansund blei Stella Maris barnehage seld til kommunen i 1971 fordi søstrene flytta frå byen (Kristvik Risholm, 2000, s. 85). I Molde dreiv søstrene St. Carolus barnehage heilt til 1986. Da overtok kommunen, men søster Hilde Geers heldt fram som styrar heilt til 1990, da søsterkommuniteten i Molde blei nedlagd (Kristvik, 2010, s. 185).

Også seinare har det vore ordensfolk i Molde, rett nok med andre og mindre utadretta oppgåver. Hausten 1991 kom augustinarkorherren Brian McNeil til Molde som sokneprest saman med ein medbror og skipa eit lite kloster. Det blei oppløyst etter få år (Broen, 5/1991, s. 10; 1/1995, s. 22). Men i 1999 oppretta tre filippinske søstrer frå The Missionary Servants of the Holy Trinity kommuniteten Stella Maris i Molde (Broen, 1/20oo, s. 1, 15). Den er der framleis, og søstrene har sentrale oppgåver i kyrkjelydsarbeidet.

Med helseinstitusjonane blei òg noko av det økonomiske grunnlaget for den kyrkjelege verksemda borte. Men samtidig skjedde ei viktig endring på eit anna felt, nemleg den norske statens religions- og livssynspolitikk. Lov om trudomssamfunn og ymist anna frå 1969 var eit viktig skritt på vegen mot jamstilling i religions- og livssynsfeltet. I $\$ 19$ fastsette lova at registrerte trus- og livssynssamfunn hadde krav på statleg og kommunal stønad pr. medlem tilsvarande løyvingane til Den norske kyrkja, som enno var statskyrkje. 
Frå 1970-talet auka òg dei økonomiske bidraga frå tyske katolske institusjonar til dei nordiske katolske kyrkjene (Eidsvig, 1993, s. 388). Ikkje minst har det kome store bidrag til bygge- og renoveringsarbeid, til dømes i Molde. Ombygginga av St. Carolus' hus, der søsterkommuniteten held til, og bygginga av nytt kyrkjelydslokale var i det vesentlege finansiert med midlar frå Tyskland (Broen, 3/2001, s. 27).

\section{Migrasjon og mangfald}

Mørebyane har alltid vore involverte i internasjonale nettverk gjennom handel, skipsfart og industri, noko som òg har ført katolske migrantar til Nordvestlandet. Migrasjon er den faktoren som har bidratt sterkast til medlemsvekst i dei katolske kyrkjelydane, og til dei største endringane i den demografiske samansetjinga deira. Her er sambandet med andre nære og fjerne felt særleg tydeleg. Det handlar om lokal og internasjonal arbeidsmarknad, om statleg innvandringspolitikk, og ikkje minst om fjerne politiske og militære kriser.

Migrasjon er òg den faktoren som har medført dei største endringane i det religiøse feltet i regionen samla sett. På den eine sida har den lutherske folkekyrkja mange stader vist seg mindre eigna til å inkludere kristne immigrantar enn frikyrkjer med meir oversiktlege og tettare fellesskap. På den andre sida gjer den overnasjonale karakteren til Den katolske kyrkja det naturleg for katolske immigrantar å oppsøkje ei lokal katolsk kyrkje. Migrasjon har bidratt til ei ny arbeidsdeling innan det religiøse feltet, og til vekst både innan frikyrkjer og innan Den katolske kyrkja.

Etter oppstanden i Ungarn i 1956 kom ungarske katolikkar til regionen som flyktningar. Også seinare har katolske flyktningar frå ulike delar av verda funne ei hamn på Nordvestlandet. Frå 1970-talet og utover kom ein del chilenarar og nokre vietnamesarar. Tamilar frå Sri Lanka blei eit markert innslag frå 1980-talet, særleg i Ålesund. Dei seinaste åra har det kome ein del eritreiske flyktningar til dei katolske kyrkjelydane. Gjennom åra har det òg kome eit mindre tal personar med flyktningbakgrunn frå Afrika, frå Midt-Austen og frå Balkan.

Frå 1980-talet og i mange år framover var personar med filippinsk bakgrunn den største gruppa i alle dei tre kyrkjelydane. Mellom filippinarane 
er kvinner i stort fleirtal. Ein god del har helsefagleg utdanning. Mange har gifta seg med norske menn. Det har òg vore mange yngre filippinske kvinner som har vore i distriktet ein periode som au pair. Innslaget av filippinske menn har vore lågare, men somme sjøfolk som har jobba på norske skip, har slått seg ned i Noreg (Henriksen, 2007, s. 158-165).

EU-utvidinga austover i 2004 og den opne arbeidsmarknaden innan EU/EØS-området har, saman med etterspurnad etter arbeidskraft innan industri, sjømatnæring og byggeverksemd, ført til stor arbeidsinnvandring særleg frå Polen og etter kvart frå Litauen. Dette er land der katolikkar utgjer ein majoritet. Denne plutselege tilstrøyminga var ei utfordring for Den katolske kyrkja. Alt før EU-utvidinga var det eit stort tal polske sesongarbeidarar på jordbærplukking om sommaren, særleg i Valldal. Dei fekk eit kyrkjeleg tilbod ved at ein polsk prest vikarierte for soknepresten i Ålesund under sommarferien. Under utbygginga av Ormen Lange-anlegget på Aukra (2004-2007) fungerte ein polsk katolsk prest og ein norsk luthersk prest som anleggsprestar. ${ }^{6}$ Det aukande behovet for polsk sjelesorg blei løyst gjennom avtalar med polske bispedøme som sender prestar til Noreg på åremålskontraktar. I dag utgjer polakkar fleirtalet av medlemsmassen i dei fleste katolske kyrkjelydar i Noreg, mellom anna i dei tre i Møre og Romsdal.

Å få til geistleg betening for den etter kvart store gruppa litauiske katolikkar har vore vanskelegare. Litauen har, ulikt Polen, ikkje overskot av prestar. Det er berre to litauiske prestar i Noreg, noko som betyr at dei fleste kyrkjelydar berre sporadisk kan gi tilbod om kyrkjelege tenester på litauisk. Det har vist seg vanskeleg for Den katolske kyrkja i Noreg å halde kontakt med dei litauiske migrantane. Likevel finn ein, særleg i Molde, at litauarar tar aktiv del i den kyrkjelege verksemda (Låver, 2019, s. 49).

\section{Det lokale katolske feltet}

Hovudperspektivet i denne studien har vore dei katolske kyrkjelydane i mørebyane sitt forhold til ulike sosiale felt: det regionale religiøse feltet; det katolske hierarkiet og ordensvesenet; nederlandsk, tysk og polsk

6 Opplysningar frå intervju med to ulike prestar. 
katolisisme spesielt; dei norske felta for helsetenester og omsorg for barn; det internasjonale og det norske politiske feltet (særleg helse-, migrasjonsog livssynspolitikk); den lokale og internasjonale arbeidsmarknaden. Vi har sett korleis endringar i både nære og fjerne felt har vore med på å påverke utviklinga av lokalt katolsk kyrkjeliv. Men ein katolsk kyrkjelyd har òg sin indre dynamikk og kan analyserast som eit sosialt felt i og for seg.

Heilt frå starten fann vi to grupper representerte i dei katolske kyrkjelydane i Møre og Romsdal: konvertittar og katolske migrantar. Kyrkja sine ambisjonar har vore klart misjonerande, særleg i den første tida. Likevel har Den katolske kyrkja på Nordvestlandet alltid vore talmessig dominert av medlemmer med migrantbakgrunn. For det meste av historia gjeld dette også nasjonalt i Noreg (Hovdelien, 2016, s. 89-91), men tendensen er enda tydelegare her. Det tyder ikkje at konvertittar har vore marginale. Tvert om, ofte har dei inntatt «etablerte» snarare enn «utfordrar»-posisjonar, for å bruke Fligsteins og McAdams terminologi. Kyrkjelydane har hatt og har mange ressurssterke konvertittar som har hatt formelle eller uformelle leiarposisjonar. Til dels har dei òg fungert som brubyggjarar mellom migrantane og det nye lokalsamfunnet deira. Bakgrunnane for konversjonane kan ha vore ulike. Somme har funne vegen til Den katolske kyrkja gjennom sin katolske ektefelle, andre har hatt sympatiske møte med Kyrkja gjennom katolsk verksemd i lokalmiljøet, atter andre har vore frustrerte over utviklingstrekk i Den norske (lutherske) kyrkja.

Forholdet mellom prestar, ordenssøstrer og lekfolk er viktig i katolske kyrkjelydar, ikkje minst under dei små forholda som lenge rådde på Nordvestlandet. I hovudsak ser tilhøvet lokalt ut til å ha vore harmonisk. Ser ein berre på den autoriteten katolsk kyrkjerett legg til biskop og sokneprest, kan ein kome til å overvurdere prestane sin maktposisjon i det lokale katolske feltet. Ordenssøstrene har spelt ei svært viktig og sjølvstendig rolle internt i kyrkjelydane. Prestane har vore heilt avhengige av deira praktiske og økonomiske støtte og hjelp (Kristvik Risholm, 1996, s. 20-22; Standal og Molka-Danielsen, 2002; 2003; Poels, 2004, s. 206). Den norskfødde Picpus-pater Olav Müller (mellom anna sokneprest i Ålesund 1967, Kristiansund 1968 og 1988-1998) har i anekdotiske glimt skildra forholdet mellom fattigdomen til prestane på 1950-talet, utan løn 
eller lommepengar, og den velordna økonomien i institusjonane til søstrene. «Det gjaldt derfor å holde seg på god fot med søstrene, særlig med moder priorinne» (2010, s. 40-41). Mange av søstrene var dyktige leiarar og må kunne karakteriserast som institusjonelle entreprenørar i Fligstein og McAdams forstand.

I Picpus-patrane si tid var det betydeleg grad av kontinuitet i den geistlege beteninga; nokre få prestar veksla på å ha ansvar for dei ulike sokna, gjerne i 8-10 år av gongen. Men denne prestekongregasjonen la ned verksemda i Midt-Noreg i år 2000 etter langvarige konfliktar med biskop Georg Müller, som sjølv høyrde til ordenen.? I seinare år har presteskapet vore meir samansett, og gjennomtrekken har vore høgare, særleg i Molde og Kristiansund. Samtidig har talet på katolikkar vist ein bratt auke, i takt med auka innvandring til Noreg og til regionen. Først i 1988/1989 passerte medlemstalet 100 personar i Kristiansund og Molde, samtidig med at den største kyrkjelyden, Ålesund, passerte 200. Alt i 2011 nærmar Molde seg 1000 medlemmer, medan Ålesund har passert 2500. I 2019 er medlemstala 4398 i Ålesund, 1620 i Molde og 1243 i Kristiansund. ${ }^{8}$

\section{Frå misjonsstasjon til sjømannskyrkje?}

Katolske migrantar kan finne ikkje berre eit religiøst, men òg eit sosialt og kulturelt fellesskap i ein katolsk kyrkjelyd (Giskeødegård \& Aschim, 2016; Halvorsen \& Aschim, 2016; 2017). Her kan ein møte likesinna, folk som snakkar same morsmål og har same kulturelle bakgrunn, og kanskje til og med få messa og andre kyrkjelege tenester på eins eige språk. Slik sett kan dei katolske kyrkjene i Noreg i dag minne meir om norske

7 Det var offentleg kjent, også frå avisene, at det i årevis var høgt konfliktnivå rundt Georg Müller, som i 2009 gjekk av som biskop av heilt andre grunnar, nemleg ei overgrepssak. Pater HeinzJosef Catrein (sokneprest i Ålesund og sokneadministrator i Molde 1995-200o, frå 2009 provinsial for Picpuspatrane sin tyske provins) har gitt ei openhjartig framstilling av sitt samansette forhold til Müller i Baumberger \& Meland, 2017.

8 Medlemstala for 2019 er rapportert pr. e-post frå sokneprestane. Eldre statistiske opplysningar i Tande, 1994; 2008; 2010; 2012; 2014; Statistikk, 1994; 2001; jf. http://www.katolsk.no/organisasjon/norge/statistikk. Dei nyaste tala i dei publiserte statistikkane er noko usikre. Oslo katolske bispedøme blei felt ved dom i Oslo tingrett 08.12.2017 for ulovleg medlemsregistreringspraksis i perioden 2011-2014, og denne problematikken råkar truleg òg Midt-Noreg stift. 2019-tala er korrekte etter opprydding i medlemsstatistikken. 
sjømannskyrkjer i utlandet enn om misjonsstasjonar (Tjørhom, 2014, s. 232; Mæland, 2016, s. 56, 238).

Ei slik samanlikning har noko for seg, særleg når det gjeld dei største innvandrargruppene i Kyrkja, som filippinarar og polakkar. Om kommuniteten frå Missionary Servants of the Holy Trinity i Molde skreiv biskopen: «Søstrenes oppgave i Midt-Norge, i tillegg til [å undervise i Den katolske tro], er å være støtte for filippinere som er bosatt i området» (Müller, 2004). Den store veksten i polsktalande medlemmer har ført til at Den katolske kyrkja i Noreg har gjort avtalar med bispedøme i Polen om geistleg betening (Mæland, 2016, s. 156-163; Erdal, 2016). I alle kyrkjelydane på Nordvestlandet er det tilbod om messe på polsk kvar søndag.

Likevel haltar samanlikninga med sjømannskyrkja, av tre grunnar: For det eine er det ikkje mogleg i kyrkjelydar med små ressursar å gi tilbod på mange ulike språk, slik tilfellet er i storbyar som Oslo, Bergen og Stavanger. I mørebyane er det berre regelmessig tilbod om messe på norsk og polsk, og noko sjeldnare på engelsk. Katolikkar som talar litauisk, tagalog (Filippinane), tamil (Sri Lanka), tigrinja (Eritrea), spansk (inkludert Latin-Amerika) eller fransk (inkludert store delar av Afrika) for å nemne nokre av dei største gruppene i området - får sjeldan eller aldri messe på sine språk. For det andre blir det lagt vekt på å utvikle ein stadeigen norsk katolisisme i konglomeratet av språk og kulturar, ikkje minst gjennom liturgi og salmesong på norsk. Og for det tredje er nettopp vektlegginga av Kyrkja sin katolisitet, som verdsomspennande institusjon med ein tydeleg og felles organisasjonsstruktur og ideologi, eit berande element. «I andre kyrkjer blir immigrantar møtt med ønsket 'velkomen til vår kyrkje'. Hos oss kan vi seie 'velkomen til di kyrkje'», lyder ei karakteristisk utsegn frå ein sentral lekperson i ein av kyrkjelydane, ein norsk konvertitt (Giskeødegård \& Aschim, 2016, s. 126).

\section{Frå «éi heilag katolsk Kyrkje» til parallelle kyrkjelydar?}

Trass i dei ideologiske føringane i retning av ein universell katolisisme med stadeigen norsk farge er spørsmålet i tittelen på Sidsel Mælands 
doktoravhandling velgrunna: «Hva har vi felles?» (2016, s. 8, 239). Utsegna er eit sitat frå ein informant og siktar både til det breie kulturelle mangfaldet i Den katolske kyrkja og til den organiserte oppdelinga i nasjonale grupper, gjerne knytt til nasjonalspråklege prestar og messefeiringar. Kyrkja har faktisk plikt til å gi kyrkjelege tenester til migrantar på deira eige språk, om nødvendig. Dette er organisert under den såkalla innvandrarsjelesorga (Mæland, 2016, s. 30-31; Oslo katolske bispedøme, 2014).

Spørsmålet er om denne multikulturelle strategien likevel fører til den situasjonen ein har kalla "parallellkyrkjelydar», der to eller fleire separate fellesskap deler dei same lokala, men elles har lite eller inkje med kvarandre å gjere (Erdal, 2016, s. 263-264; Hovdelien, 2016, s. 97). No er situasjonen av reint praktiske og ressursmessige grunnar annleis utanfor dei store byane. I sokna på Nordvestlandet er det eigentleg berre den store polske gruppa som har høve til å forme eit slikt separat fellesskap, sjølv om dei engelske messene, i alle fall i Ålesund, får eit tydeleg filippinsk preg gjennom frammøte, musikkval og andre uttrykk. Langt på veg er det mogleg for polakkane å leve i eit reint polsk fellesskap rundt den polske presten og den polske messa. Polsk katolisisme kan slik sett opplevast som ein utfordrar til den etablerte norske katolisismen, på liknande vis som Marta Trzebiatowska har vist for Skottland (2010).

Likevel er det mange trekk som motseier dette bildet. I ei spørjeundersøking blant polske kyrkjegjengarar i Ålesund våren 2015 oppgav heile $43 \%$ at dei også gjekk til norskspråkleg messe, ikkje berre til polsk. Kor ofte seier ikkje svara noko om, men funnet er likevel interessant. Om ein legg til ei betydeleg polsk investering i form av dugnad og annan innsats for kyrkjene (Aschim \& Giskeødegård, 2017), og fellestiltak for heile kyrkjelyden som den store Corpus Christi-prosesjonen i Ålesund, høver kanskje uttrykket «felles sokn» («shared parish», Hoover, 2014) betre enn «parallellkyrkjelydar» som skildring av situasjonen. Sjølv om ein til dagleg opererer som separate felt - til dels av reint praktiske grunnar; kyrkjene har for liten plass i forhold til behovet -, er det likevel ein betydeleg grad av utveksling og samhandling mellom ulike grupper i kyrkjelyden. Her finst eit potensial for interne konfliktar mellom grupper i kyrkjelyden, ikkje minst om tid og rom, men òg eit stort og interessant spelerom for institusjonelle entreprenørar. I feltarbeid i Ålesund har vi registrert 
både prestar, norske konvertittar, innvandrarar med lang butid i Noreg og særleg aktive «nye» immigrantar i slike roller.

Eit interessant trekk i fleire av kyrkjelydane er det ein må kunne karakterisere som interne vekkingsrørsler. I Kristiansund har ein sidan 2006 hatt misjonærgrupper sende ut av den neokatekumenale rørsla, ei katolsk «indremisjonsrørsle». I Ålesund samlar gruppa «Stella Maris» eit stort tal engasjerte polske katolikkar til felles bøn og andre aktivitetar (jf. Giskeødegård \& Aschim, 2016, s. 132-134).

\section{Konklusjon}

Frå ein beskjeden start har Den katolske kyrkja i Møre og Romsdal vakse til å bli den største religions- og livssynsminoriteten i regionen. Den opphavlege visjonen om rekatolisering av Noreg gjennom intensiv misjonsinnsats viste seg rett nok raskt som urealistisk. Den katolske kyrkja blei aldri nokon reell utfordrar til det lutherske hegemoniet i det lokale religiøse feltet. Det katolske nærværet blei likevel halde ved lag, men med andre grunngivingar, dels for å støtte dei få lokale katolikkane som fanst, men tanken om at sjølve nærværet av Kyrkja og sakramentet var viktig for lokalsamfunnet, uavhengig av medlemstal, var òg eit argument. Ordenssøstrene og institusjonane deira hadde ei heilt avgjerande rolle i denne fasen.

Erfaringar frå Andre verdskrig og eit mildare økumenisk klima i etterkrigsåra fekk konsekvensar også for det lokale religiøse feltet. Ein kan nok ikkje tale om eit utstrekt samarbeid mellom Den katolske kyrkja og den lutherske folkekyrkja, men ei strategiendring frå konkurranse til arbeidsdeling er tydeleg. Medlemstalet i dei katolske kyrkjelydane har vakse i takt med den aukande innvandringa i etterkrigstida, særleg på 200o-talet. Den store veksten har altså kome etter avviklinga av ordenssøstrene sine kommunitetar og institusjonar. Men det var langt på veg desse som hadde skapt den infrastrukturen som gjorde veksten mogleg.

Denne lokale kyrkjehistoria i Møre og Romsdal er eit døme på korleis Den katolske kyrkja på den eine sida er ein stabil, gjennomorganisert og tradisjonstung institusjon, på den andre sida fleksibel og i stadig endring, i samspel med og påverka av ulike samfunnsmessige prosessar. 


\section{Kjelder og litteratur \\ Kjelder}

Klippen. Katolsk menighetsblad (1950-1978)

Broen (1979-2009; 2004-2009 på nett: http://www.katolsk.no/organisasjon/norge/ kirkebladet/broen)

St. Olav (2010- på nett: http://www.katolsk.no/organisasjon/norge/kirkebladet\# arkivhttp://www.katolsk.no/organisasjon/norge/kirkebladet\#arkiv) www.katolsk.no

Romsdals Budstikke, Molde

Sunnmørsposten, Ålesund

Tidens Krav, Kristiansund

Statistisk sentralbyrå

- Tabell 01222: Endringar i befolkninga i løpet av kvartalet, for kommunar, fylke og heile landet (K) $1997 \mathrm{~K}_{4}$ - 2019K1 https://www.ssb.no/statbank/table/o1222/

- Tabell 08531: Medlemmer i trus- og livssynssamfunn som mottek offentleg stønad og er utanfor Den norske kyrkja, etter religion/livssyn (F) 2010-2018 https://www.ssb.no/statbank/table/o8531

Trondheim katolske stift, arkiv

Intervju med katolske prestar og lekfolk i Ålesund sokn

\section{Litteratur}

Abrahamsen, O. A. (1992). Molde bys historie 3. 1916-1940. Fra brann til bombing. Molde: Molde kommune.

Abrahamsen, O. A. (1994). Molde bys historie 4. 1940-1964. Krig - gjenoppbygging vekst. Molde: Molde kommune.

Aschim, A. \& Giskeødegård, M. F. (2017). 'Vi gjer det for Gud ... og for oss sjølve'. Polske innvandrarar på dugnad. Kirke og kultur, 121(2), 203-218.

Aschim, A., Hovdelien, O. \& Sødal, H. K. (Red.) (2016). Kristne migranter i Norden. (Kyrkjefag Profil, 28.) Kristiansand: Portal.

Aukrust, K. \& Nilsen, E.-B. (1996). Bak klosterets port. Nonner i Norge forteller. Oslo: Solum.

Austigard, B. \& Jakobsen, S. (1997). Nøisomhed gjennom 200 år. Molde: Hakon Møre.

Baumberger, B. \& Meland, S. I. (2017, 14. januar). Biskopens siste vokter. Adresseavisen, Ukeadressa, s. 7-15.

Bjerke, P. \& Halvorsen, L. J. (2018). Kulturtidsskriftene. En analyse av kulturtidsskriftene i Norge. Bergen: Fagbokforlaget.

Bourdieu, P. (1996 (1984)). Homo academicus (Moderna franska tänkare, 27.)

Stockholm: Symposion. 
Bourdieu, P. (2000 (1992)). Konstens regler. Det litterära fältets uppkomst och struktur (Moderna franska tänkare, 31.). Stockholm: Symposion.

Bourdieu, P. \& Wacquant, L. J. D. (1995 (1991)). Den kritiske ettertanke. Grunnlag for samfunnsanalyse. Oslo: Samlaget.

Eidsvig, B. I. (1993). Den katolske kirke vender tilbake. I E. Gunnes, J. W. Gran \& L. R. Langslet (Red.), Den katolske kirke i Norge fra kristningen til idag (s. 143-426). Oslo: Aschehoug.

Erdal, M. B. (2016). 'When Poland became the main country of birth among Catholics in Norway'. Polish migrants' everyday narratives and Church responses to a demographic re-constitution. I D. Pasura \& M. B. Erdal (Red.), Migration, transnationalism and Catholicism: 259-289. London: Palgrave Macmillan.

Fligstein, N. \& McAdam, D. (2012). A theory of fields. Oxford: Oxford University Press. Giskeødegård, M. F. \& Aschim, A. (2016). «Da hadde jeg et stykke Polen her.» Den katolske kirke som transnasjonalt rom for fellesskap og tilhørighet. I A. Aschim, O. Hovdelien \& H. K. Sødal (Red.), Kristne migranter i Norden. (Kyrkjefag Profil, 28.) (s. 123-141). Kristiansand: Portal.

Gjendem, O. (2016). St. Carolus. Fra sykehus og kloster til moderne kontorbygg. Molde: Molde bymuseum.

Halvorsen, L. J. \& Aschim, A. (2016). Å ta del. Polske innvandrarar, Den katolske kyrkja og lokalsamfunnet. I A. Aschim, O. Hovdelien \& H. K. Sødal (Red.), Kristne migranter i Norden. (Kyrkjefag Profil, 28.) (s. 102-122). Kristiansand: Portal.

Halvorsen, L. J. \& Aschim, A. (2017). Religion som ressurs. Polske arbeidsmigrantar og Den katolske kyrkja på Sunnmøre. I J. R. Andersen, E. Bjørhusdal, T. Årethun \& J. G. Nesse (Red.). Immateriell kapital. Fjordantologien 2016 (s. 88-108). Oslo: Universitetsforlaget.

Henriksen, K. (2007). Fakta om 18 innvandrergrupper i Norge (Rapporter 2007/29). Oslo: Statistisk sentralbyrå.

Hoffstad, E. (1939). Hvem er hvem i noeringslivet? Merkantilt biografisk leksikon. Oslo: Halvorsen \& Larsen.

Hoover, B. C. (2014). The shared parish. Latinos, Anglos, and the future of U.S. Catholicism. New York: New York University Press.

Hovdelien, O. (2016). En verdenskirke i miniatyr. Ordenssøstre, prester og kirkelig ansatte om Den katolske kirke i Norge som migrantkirke. I A. Aschim, O. Hovdelien \& H. K. Sødal (Red.), Kristne migranter i Norden. (Kyrkjefag Profil, 28.) (s. 87-101). Kristiansand: Portal.

Hovland, I. (2013). Mission station Christianity. Norwegian missionaries in colonial Natal and Zululand, Southern Africa 1850-189o. (Studies in Christian Mission, 44.) Leiden: Brill.

Kjelstrup, K. (1942). Norvegia catholica. Moderkirkens gjenreisning i Norge. Et tilbakeblikk $i$ anledning av 10o-årsminnet for opprettelsen av St. Olavs menighet $i$ Oslo, 1843-1943. Oslo: Apostoliske vikariat. 
Korsvold, T. (2005). For alle barn! Barnehagens framvekst $i$ velferdsstaten (2. utg.). Oslo: Abstrakt.

Kristvik Risholm, J. (1996). Stella Maris. St. Carl Borromeus-søstrenes liv og virksomhet i Kristiansund, 1934-71. Årbok for Nordmøre, 5-30.

Kristvik Risholm, J. (2000). «For kirken og verden». Katolske ordenssøstres møte med det norske samfunn 1923-199o. Hovudoppgåve i historie. Trondheim: NTNU.

Kristvik, J. (2010). St. Carolus i Molde - katolske nonner i helsevesenet 1923-1990. «de hadde så mange rare forestillinger om den katolske kirke og nonner». Romsdalsmuseet. Årbok, 174-187.

Kristvik, J. (2013). St. Carolus og Borromeussøstrene. I G. Eldøen, K. E. Strømskag, T. A. Johnsen \& M. Langnes (Red.), Sjukehusbyen Molde 1713-2013 (s. 90-105). Molde: Romsdalsmuseet.

Låver, K. (2019). Fra drøm om måneferd til rosenes by. Min menighet: Molde. St. Olav, 131(2), 46-51.

Müller, G. (2004). Den katolske kirke i Midt-Norge. Manuskript. Midt-Norge stift, arkiv.

Müller, O. (2010). Pateren dypper pennen. Katolsk skjemt og alvor. Oslo: St. Olav.

Mæland, S. (2016). «Hva har vi felles?» En studie i kulturell kompleksitet og multikulturelle prosesser i Den katolske kirke i Norge. Dr. philos.-avhandling. Oslo: Universitetet i Oslo.

Nilsen, E.-B. (1993). Ordenssøstrenes virke i Norge - en oversikt. I E. Gunnes, J. W. Gran \& L. R. Langslet (Red.), Den katolske kirke i Norge fra kristningen til idag (s. 447-468). Oslo: Aschehoug.

Nilsen, E.-B. (2001). Nonner i storm og stille. Oslo: Solum.

Nilsen, E.-B. (2004). Religious identity and national loyalty. Women religious in Norway during the Second World War. I Y. M. Werner (Red.), Nuns and sisters in the Nordic countries after the reformation. A female counter-culture in modern society (s. 213-253) (Studia Missionalia Svecana, 89.). Uppsala: Swedish Institute of Mission Research.

Nilsen, E.-B. (2012). Ordenssøstre i Norge under dobbel ild? I B. Løvlie, K. Norseth \& J. Schumacher (Red.), Kirke kultur politikk. Festskrift til professor dr. theol. Bernt T. Oftestad på 7o-årsdagen (s. 111-120). Trondheim: Tapir akademisk.

Nilsen, E.-B. (2016a). Katolsk kirkeliv under krigen. I E.-B. Nilsen, B. T. Oftestad og L. Hegna (Red.), Katolsk kirkeliv i Norge gjennom 1000 år (s. 147-167). Oslo: St. Olav.

Nilsen, E.-B. (2016b). Nonner i Norge i nyere tid. I E.-B. Nilsen, B. T. Oftestad og L. Hegna (Red.), Katolsk kirkeliv i Norge gjennom 1000 år (s. 129-145). Oslo: St. Olav.

Nilsen, E.-B., Oftestad, B. T. \& Hegna, L. (Red.) (2016). Katolsk kirkeliv i Norge gjennom 1000 år. Oslo: St. Olav.

Oftestad, B. T. (2016). Nasjonal katolisisme og økumenisk konsil. I E.-B. Nilsen, B. T. Oftestad og L. Hegna (Red.), Katolsk kirkeliv i Norge gjennom 1000 år (s. 180-199). Oslo: St. Olav. 
Oslo katolske bispedømme (2014). Retningslinjer for innvandrersjelesorgen i Oslo katolske bispedømme. Henta frå http://www.katolsk.no/organisasjon/okb/ innvandrersjelesorg/retningslinjer-for-innvandrersjelesorgen-2014

Poels, V. (2004). Expanding the number of tabernacles. Dutch women religious in the Norwegian mission. I Y. M. Werner (Red.), Nuns and sisters in the Nordic countries after the reformation. A female counter-culture in modern society (s. 191-212) (Studia Missionalia Svecana, 89.). Uppsala: Swedish Institute of Mission Research..

Poels, V. (2005). Een roomse droom. Nederlandse katholieken en de Noorse missie, 1920-1975. Nijmegen: Valkhoff Pers.

Schiøtz, A. (2003). Folkets helse - landets styrke. 1850-2003. (Det offentlige helsevesen i Norge 1603-2003, 2.). Oslo: Universitetsforlaget.

Seip, A.-L. (1994). Veiene til velferdsstaten. Oslo: Gyldendal.

Skeie, K. H. (2013). Building god's kingdom. Norwegian missionaries in highland Madagascar, 1866-1903. Studies in Christian Mission, 42.

Slotsvik, T. N. (2009). «Alt for Norge. Ikke ogsaa for katoliker?» Den katolske minoriteten i Norge 1905-1930. Masteroppgåve i historie, Universitetet i Bergen.

Standal, B. \& Molka-Danielsen, J. (2002). Den katolske kirken og arbeidet i Molde. St. Sunniva Menighet i Molde. Manuskript. Midt-Norge stift, arkiv.

Standal, B. \& Molka-Danielsen, J. (2003). Våre menigheter. St. Sunniva - Molde. Broen, 45(5), 3.

Statistikk. (1994). Registrerte katolikker i Norge. Broen, 35(2), 24.

Statistikk. (2001). Katolikker i Norge, etter fødeland (2000). Broen, 42(1), 15-18.

Tande, C. (1994). Katolikker i Norge etter fødeland. Broen, 35(4), 16-19.

Tande, C. (2008). Den katolske kirke i Norge - en verdenskirke i miniatyr. Broen, $49(5), 14-17$.

Tande, C. (2010). Statistikk 2010. Katolsk i Norge. En innvandringspreget kirke i rask forandring. St. Olav, 122(2), 26-29.

Tande, C. (2012). Den katolske kirke i Norge - hvem er vi? En statistisk milepæl rundes. St. Olav, 124(3), 26-29.

Tande, C. (2014). Hvor bor katolikkene? St. Olav, 12-15.

Tjørhom, O. (2014). Fornyelsen som forsvant. Et kritisk blikk på Den katolske kirkes utvikling fra 1850 til i dag. Oslo: Cappelen Damm Akademisk.

Trzebiatowska, M. (2010). The advent of the 'EasyJet priest'. Dilemmas of Polish Catholic integration in the UK. Sociology, 44(6) 1055-1072.

Valen, S. (200o). T. S. Valen (1888-1977). En stridsmann i Guds verk. Aktiv Pensjonstid, 11(2), 12-15.

Vu Manh Hung, J. (2004). Våre menigheter. Vår Frue menighet - Ålesund. Broen, 45(3), 3 .

Aass, E. (1991). Byen som brant. Kristiansund 190o-1942, 2. del. Kristiansund: Kristiansund kommune. 


\title{
Elever i dialog med kristendommens fortellinger
}

\author{
Sidsel Lied \\ Høgskolen i Innlandet
}

\begin{abstract}
Sammendrag: Spørsmålene som stilles i denne artikkelen, setter søkelys på elevers dialoger med to av kristendommens fortellinger slik dialogene kommer til uttrykk i deres multimediale, skriftlige ytringer. Rammene elevene møtte fortellingene innenfor, var ulike. Tredje- og sjetteklassingenes ytringer ble skrevet innenfor rammen av kristendomsfaget i henholdsvis 1987/88 og 1990/91, mens andreklassingenes ytringer ble skrevet i 2018/19 innenfor rammen av KRLE-faget. Med bakgrunn i de to fagenes ulike mål for undervisningen kunne man forvente å finne personlige trosuttrykk i elevytringer som ble skrevet i kristendomsfaget, mens ytringer skrevet i KRLE ikke ville inneholde slike uttrykk i møte med kristendommens fortellinger. Disse forventningene ble ikke innfridd. Artikkelen drøfter dette funnet i lys av Mikhail Bakhtins teori om ytringers dialogiske karakter, og oppfordrer til videre studier knyttet til disse - og lignende - problemstillinger.
\end{abstract}

Nøkkelord: skolens religions- og livssynsfag, elever, multimediale uttrykk, trosuttrykk, dialog

\section{Skolens religions- og livssynsfag}

Skolen er det stedet i det offentlige rom hvor samfunnet formidler til den oppvoksende slekt den kunnskap det mener alle bør kjenne til. Kunnskaper om religioner og livssyn er et slikt kunnskapsområde (Lied, 2018).

Skolens religions- og livssynsfag har vært i stadig endring siden sent på 1980-tallet og til i dag. I Mønsterplan for grunnskolen fra 1987 (M87), som var gjeldende fram til 1997, het faget Kristendomskunnskap. Faget 
var altså et kristendomsfag, og mål for faget var bl.a. at undervisningen skulle lære elevene hva kristendommen betyr for den enkelte og for samfunnet, og stimulere elevene i deres personlige vekst og utvikling. Undervisningen i faget skulle gi grunnleggende innsikt i hva kristendom er, gi dem grunnlag for deres tro og veiledning for deres liv. Den skulle også være en hjelp for foreldrene i oppdragerarbeidet (Kirke- og undervisningsdepartementet, 1987).

Faget sto i en lang tradisjon. Norsk skoles religions- og livssynsfag startet som et kirkefag, men ble etter hvert et skolefag med kristendom som hovedinnhold (1739-1974). Det gikk i perioden 1974-1997 gjennom en fase med en tofagsløsning bestående av et kristendomsfag og et alternativt, ikke-obligatorisk livssynsfag for elever med foreldre som ikke tilhørte den norske kirke. I 1997 ble tofagsløsningen avløst av norsk skoles første flerreligiøse fag, Kristendomskunnskap med religions- og livssynsorientering (KRL), som var obligatorisk for alle elever, og som hadde åpenhet, gjensidig forståelse, toleranse og fredelig sameksistens i et flerkulturelt samfunn i fokus. KRL har siden innføringen gjennomgått flere revisjoner og hatt ulike navn, siste gang i 2015 da RLE-faget (Religion, livssyn og etikk) fra 2008 ble erstattet av KRLE (Kristendom, religion, livssyn og etikk). Mål for KRLE-faget er å være et allmenndannende fag som skal gi felles kunnskapsgrunnlag og referanserammer, bidra til innsikt og gi rom for dialog. Sentralt i faget står kunnskap om kristendommen, andre religioner og livssyn og «den funksjon disse har både som tradisjon og som aktuelle kilder til tro, moral og livstolkning» (Kunnskapsdepartementet, 2015, s. 1). Det skal ikke være forkynnelse i undervisningen.

\section{Problemstilling}

Barn skriver og tegner. Også når de er på skolen som elever. Under kristendomsfaget i M87 ytret elevene seg gjennom verbaltekst og tegning innenfor den konteksten som kristendomsfaget utgjorde, og de ytrer seg ved hjelp av de samme ytringsformene innenfor KRLE-faget i dag. Men som vi ser av beskrivelsene av de to fagene ovenfor, stiller fagenes målformuleringer ulike krav til undervisningen. Spørsmål som denne ulikheten kan reise, er: Sier elevers tekster og tegninger noe om de dialogene elevene 
går inn i, når de møter de samme fortellingene fra kristendommens fortellingsunivers innenfor rammen av de to ulike fagene? Det er mulig å tenke seg at en vil finne personlige trosuttrykk i multimediale ytringer fra elever som skrev og tegnet innenfor rammen av kristendomsfaget i M87, mens en ikke vil finne slike uttrykk i tekster og tegninger fra elever som ytret seg innenfor rammen av KRLE-faget, når temaet er kristendommens fortellinger. En slik antakelse kan begrunnes i at kristendomsfaget skulle gi trosgrunnlag og livsveiledning med kristendommen som utgangspunkt, mens KRLE-faget har som mål å gi kunnskap om ulike livstolkningstradisjoner. Men er det slik? Finner vi flere personlige trosuttrykk i elevytringer laget innenfor rammen av kristendomsfaget enn i KRLE-faget? Disse spørsmålene aktualiserer også spørsmålet om skolens religions- og livssynsfags påvirkningskraft.

Vi har få doktoravhandlinger og vitenskapelige publikasjoner med bakgrunn i prosjekter der grunnskoleelevers ytringer i møte med fortellinger fra grunnskolens religions- og livssynsfag er i fokus. Dette kommer fram i artikkelen $R E$ research in Hamar and Karlstad in a subject didactical and international context, som bl.a. presenterer en oversikt over norske doktoravhandlinger med religionsdidaktisk fokus mellom 1985 og 2011 (Osbeck \& Lied, 2012). Da det er barns og unges utvikling og læring som er hovedmål for skolen, er det viktig å lytte også til dem når skolens undervisning vurderes. Det er følgelig forskningsprosjekter med slike problemstillinger i fokus som denne artikkelen vil inspirere til.

\section{Materiale samt teoretiske og metodiske perspektiver}

Materialet som er utgangspunkt for undersøkelsen jeg presenterer her, er elevers ytringer laget i møte med to fortellinger: fortellingen om Jesu fødsel og lignelsen om sauen som ble funnet igjen. Elevytringene laget innenfor rammen av kristendomsfaget er hentet fra boka Jeg fant, jeg fant ... en bibeltekst: eleven som forsker og kunstner fra 1996 (Lied, 1996). De ble laget av tredjeklassinger i 1987/88 og sjetteklassinger i 1990/91 fra en skole $\mathrm{i}$ en vestlandsbygd. Ytringene fra KRLE-faget er laget av andreklassinger i 2018/19 - også disse fra en skole i en vestlandsbygd - i arbeid 
med de samme fortellingene. ${ }^{1}$ De geografiske miljøene ytringene ble laget i, er altså langt på vei de samme, men fagene de er laget innenfor rammen av, er ulike, og tidsforskjellen er ca. 30 år.

Når fortellingen om sauen som ble funnet igjen er tema, holder jeg ytringer fra sjetteklassinger i 1990/91 og andreklassinger fra 2018/19 opp mot hverandre. Det kan være problematisk å sammenligne ytringer fra elever med så stor aldersforskjell. Jeg kunne ha utvidet materialet med å hente inn ytringer fra sjetteklassinger også i 2018/19, og slik fått muligheten til å sammenligne ytringer fra sjetteklassinger som skrev og tegnet innenfor rammen av ulike fag. Grunnen til at jeg ikke har foretatt denne utvidelsen, er at jeg her kun ønsker å peke på trekk det kan være interessant å studere nærmere i en senere studie. Her presenterer jeg altså det som kan kalles en forstudie. At funnene likevel kan avstedkomme interessante refleksjoner, kommer jeg tilbake til i konklusjonen.

Elever bruker ofte både tekst og tegning i samme ytring når de skriftlig skal gi uttrykk for hva de tenker og mener. Noen ganger gir tekst og tegning samme informasjon, men de kan også utdype hverandre ved at det ene mediet gir tilleggsinformasjon som utfyller eller utdyper det som blir framstilt i det andre. Jeg leser derfor elevytringer som består av tekst og tegning sammen, som helhetlige ytringer der tekst og tegning i fellesskap uttrykker det elevene $ø$ nsker å formidle (Lied, 2004). De elevytringer jeg har valgt å presentere her, er valgt både ut fra informasjonsverdi og representativitet. Denne prioriteringen vil tidvis komme til syne i mine kommentarer til ytringene.

Det å skrive er å inngå i et kollektiv. Når vi skriver, beveger vi oss inn i et område som ligger mellom jeg-et og vi-et, for språket er ikke mitt, det er vårt, sier Karl Ove Knausgård (2019). Mikhail Bakhtin framhever det samme når han skriver at språket er individuelt og sosialt på samme tid: Ordene vi bruker, henter vi fra andre ytringer i vår kontekst, og språket vårt formes og utvikler seg i umiddelbart og uavbrutt samspill

1 Før 1997 begynte barn på skolen da de var sju år. Med Mønsterplanen av 1997 (L97) ble skolestart for seksåringer innført. Da jeg skrev boka Jeg fant jeg fant ... en bibeltekst i 1996, tilpasset jeg betegnelsene på klassetrinnene til det jeg visste ville komme i 1997. Det vil si at de som var andre- og femteklassinger på sent 1980- og tidlig 1990-tall omtales som tredje- og sjetteklassinger i boka - og i denne artikkelen. 
med andre. Ytringene våre er derfor fulle av andres ord, sier han. Når vi ytrer oss, er vi i kontinuerlig dialog både med dem vi snakker, skriver og tegner til, og med det sosiale og kulturelle fellesskapet vi er en del av; med de ytringene som allerede finnes innenfor dette fellesskapet, og med de som vi forventer skal komme. I dialogen er det hverken et første eller et siste ord, sier Bakhtin (1998). Vi er, med andre ord, i kontinuerlig dialog når vi kommuniserer, og enhver ytring er del av en større sammenheng.

Mange av dialogene som elevene går inn i på skolen, foregår i klasserommet. Klasserommet er mangfoldets sted. Elever og lærere som befolker dette rommet, er preget av ulike tekster, verdier, kulturer og praksiser. Klasserommet inneholder på denne måten mange ulike verdener (Dyson, 2002). Elevene deltar hele tiden, både bevisst og ubevisst, i de dialogene som foregår i klasserommet, mellom ulike deltakere og ulike verdener, og dialogene de fører, pågår både med det de hører og ser, og når de snakker, skriver og tegner (Evensen, 2002; Lied, 2007). Når de skriver og tegner, er de blant annet i dialog med innholdet de har møtt i undervisningen som de er opptatt med å skrive og tegne om, med læreren som skal lese ytringen deres, med sjangerregler de er vant til å uttrykke seg innenfor, og med kulturen som omgir dem i hverdagen (Lied, 2004).

Elevene er i dialog med sine omgivelser også når de møter skolens religions- og livssynsfag. De lytter og ser, leser, skriver og tegner for å forstå, skape mening i å forhandle med det lærestoffet de møter. I de dialogene de er i når de skriver og tegner, kan de innta ulike roller og posisjonere seg på ulikt vis i forhold til hvordan de opplever ytringssituasjonen og konteksten og de forventningene disse stiller dem overfor. De kan f.eks. gå inn i fortellerrollen og posisjonere seg som en dramatisk, nøktern eller poetisk forteller, eller de kan gå inn i rollen som filosof og posisjonere seg som enkel og klartenkt eller dypsindig og kompleks. Posisjoneringer den enkelte elev velger, skjer i et dialogisk samspill mellom elev og kontekst, og gir uttrykk for hvordan eleven ønsker å ytre seg i forhold til tema og i den aktuelle skrive- og tegnesituasjonen (Lied, 2004; Smidt, 1996). Når jeg leser og studerer elevers tekster og tegninger fra henholdsvis 1987/88, 1990/91 og 2018/2019 i møte med to av kristendommens fortellinger innenfor rammen av skolens religions- og livssynsfag, er det slike dialoger, roller og posisjoneringer jeg ser etter. 
Et av de begrepene jeg bruker, krever en nærmere presisering, nemlig begrepet multimedial ytring. Med begrepet $y$ tring mener jeg språklige uttrykk, tegninger og sammensatte uttrykk som er frambrakt for å kommunisere mening. Med multimedial ytring mener jeg informasjon som uttrykkes på ulike måter, f.eks. gjennom skrift, tale, bilde og andre visuelle midler, og som siden kombineres til ett sammensatt grafisk produkt. Jeg forstår altså skrift, tale og bilde som ulike medier som settes sammen til én multimedial ytring (Lied, 2004, s. 63-64; 2007, s. 38).

Jeg vil også poengtere at jeg bruker pronomenet han når jeg omtaler en elev. Hovedgrunnen til dette er knyttet til anonymisering. Det skal ikke gå fram av omtalen om det er gutt eller jente som har laget ytringen. Av samme grunn bruker jeg også hun om læreren, uavhengig av biologisk kjønn.

I det følgende presenterer jeg først ytringer fra elever i dialog med fortellingen om Jesu fødsel: fra tredjeklassinger i 1987 og andreklassinger i 2018. Så presenteres elevytringer laget i dialog med fortellingen om sauen som ble funnet igjen: fra sjetteklassinger i $1991 \mathrm{og}$ andreklassinger i 2019. Til slutt kommer mine konkluderende betraktninger.

\section{Elever i dialog med fortellingen om Jesu fødsel Tredjeklassinger i 1987}

Undervisningen som tredjeklassingene fikk om Jesu fødsel, var strukturert etter den bibelske progresjonen: Matteus sin fortelling ble presentert før Lukas sin framstilling, og forskjellene ble kommentert. Elevene fikk også en kort introduksjon om geografiske og kulturelle forhold i Israel på Jesu tid.

Hos Matteus er det et poeng at Josef først tenkte på å skille seg fra Maria fordi hun var gravid med et barn som ikke var hans. En engel overbeviste ham imidlertid om at barnet var unnfanget ved Den hellige ånd, og at han skulle ta Maria hjem til seg som sin kone. Fellesskapet mellom Maria og Josef i ansvaret for å gi Jesusbarnet et godt hjem er noe disse elevene understreket i ytringene sine: «Maria skal ha barn og josef skal hjelpe ho», skriver den ene eleven (Fig. 1). Og det er ikke noen tvil om at Maria skal ha barn, for magen strutter. Måten eleven har tegnet 
munnen hennes på, gjør at hun ser litt forskrekket ut. Josef, derimot, smiler. Maria behøver ikke være redd, for han skal «hjelpe ho». Elevens dialog med Matteus sin fortelling og engelens oppfordring til Josef er klar.

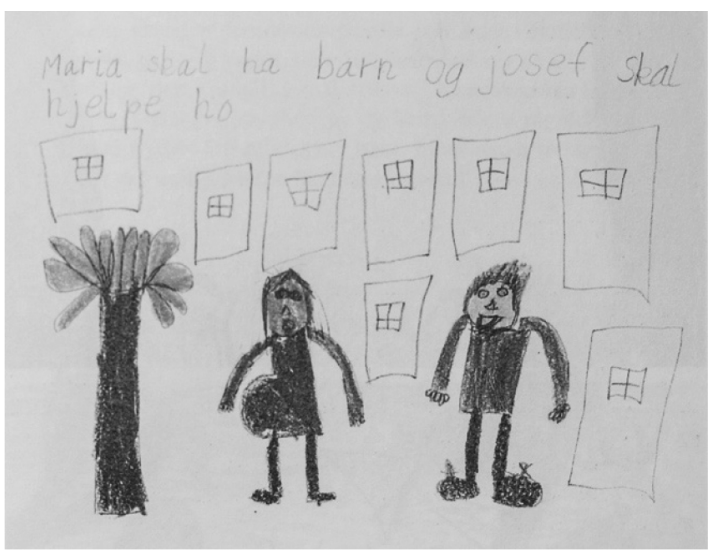

Fig. 1. Anonym barnetegning fra elev ved en norsk skole. Publisert med tillatelse fra foreldrene. Hentet fra Lied, S. (1996). Jeg fant, jeg fant ... en bibeltekst: Eleven som forsker og kunstner. Oslo: IKO-forlaget. Publisert med tillatelse fra IKO-forlaget. Bildet er ikke omfattet av bokens CC-lisens og kan ikke gjenbrukes uten særskilt tillatelse.

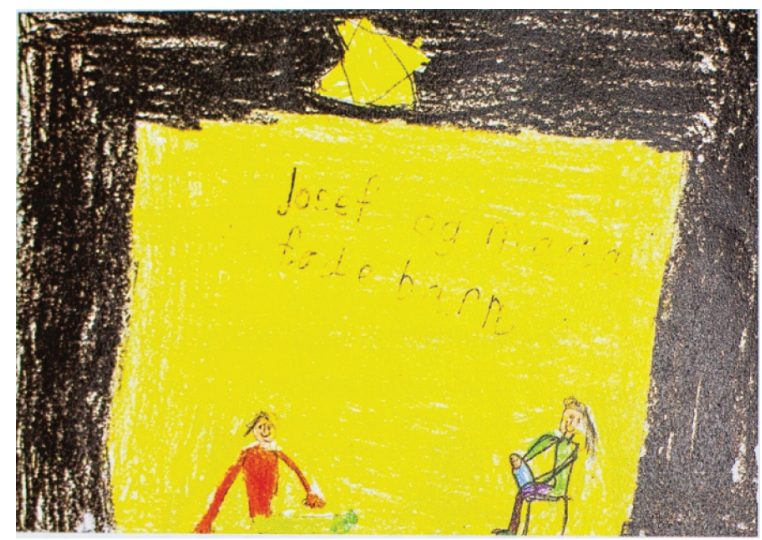

Fig. 2. Anonym barnetegning fra elev ved en norsk skole. Publisert med tillatelse fra foreldrene. Hentet fra Lied, S. (1996). Jeg fant, jeg fant ... en bibeltekst: Eleven som forsker og kunstner. Oslo: IKO-forlaget. Publisert med tillatelse fra IKO-forlaget. Bildet er ikke omfattet av bokens CC-lisens og kan ikke gjenbrukes uten særskilt tillatelse.

I Fig. 2 er dialogen med denne oppfordringen og det derav følgende samarbeidet mellom de to enda sterkere understreket: «Josef og Maria føde 
barn», står det inni det varme, gule rommet som huser den lille familien. Stjernen lyser, Maria holder barnet på fanget, mens en smilende Josef sitter på gulvet foran dem. Fargebruken skiller rommet fra mørket utenfor, og kontrasten mellom det gule og det svarte gjør at det er lett å sette den gule varmen i rommet i forbindelse med stjernen som lyser klar og stor utenfor. Også her er dialogen med Matteus klar: Fortellingen hans sier at stjernen som ledet vismennene fram til barnet, ble stående over det stedet der barnet var. I dialogen med fortellingen lar eleven stjernen gi lys til et rom preget av varme, omsorg og glede.

Det er interessant å merke seg at eleven som laget Fig. 1 har prøvd å gi uttrykk for at han vet noe om hvordan det så ut i landet der Jesus ble født. Vi finner både flate hustak og en palme i denne tegningen, noe vi også finner i flere av klassekameratenes tegninger (Lied, 1996). Eleven var altså i dialog med læreren og det hun fortalte, da han tegnet dette. Eleven som laget Fig. 2, kan også ha vært i dialog med læreren med sin framheving av sammenhengen mellom lyset fra stjernen og det varme lyset i det gule rommet. «Jeg vil vise læreren at jeg vet at stjernen sto og lyste over huset der Jesusbarnet var,» kan han ha tenkt. Begge disse elevene kan altså ha vært i dialog både med Matteus' fortelling om Jesu fødsel og med læreren som har undervist dem, da de skrev og tegnet. I ytringene sine har de i alle fall posisjonert seg som elever som husker det læreren sier og forteller, og som både har lyst og evne til å ytre seg om det de har møtt i undervisningen.

Noe av det typiske ved Lukas sin fortelling er engelens besøk hos hyrdene på marken. Dette besøket er i fokus i Fig. 3, og tredjeklassingens dialog med denne fortellingen er tydelig. Lukas poengterer at engelen kom, Herrens herlighet lyste over gjeterne, og budskapet ble forkynt: Denne dagen var det født en Frelser i Davids by. Eleven forbinder lyset med engelen og plasserer ham midt i strålekransen. Vi finner ham også i dialog med engelens budskap. Inne i snakkeboblen som går ut fra engelens munn, har han skrevet: «I dag er det født ein Frelsar i ei krybbe i Betlehem». At eleven vil framstille dette som et godt budskap, ser vi av de to gjeternes ansiktsuttrykk. De smiler. Det ser nesten ut som om sauene smiler, også. Men tredjeklassingen har vært i dialog med flere enn Lukas. Tradisjonen han var en del av, og 
som kom til uttrykk gjennom julespill, julekort og julesanger, gjorde seg gjeldende i det første utkastet til snakkebobleteksten som går ut fra engelens munn. Der hadde han skrevet at engelens budskap var at Frelseren var født «... i ein stall». Men læreren fortalte at Lukasfortellingen ikke sa noe om en stall, bare om en krybbe som barnet lå i. Dialogen med denne nye kunnskapen har eleven så prøvd å la komme til uttrykk gjennom snakkeboblen: Frelseren ble født i en krybbe i Betlehem (Lied, 1996).

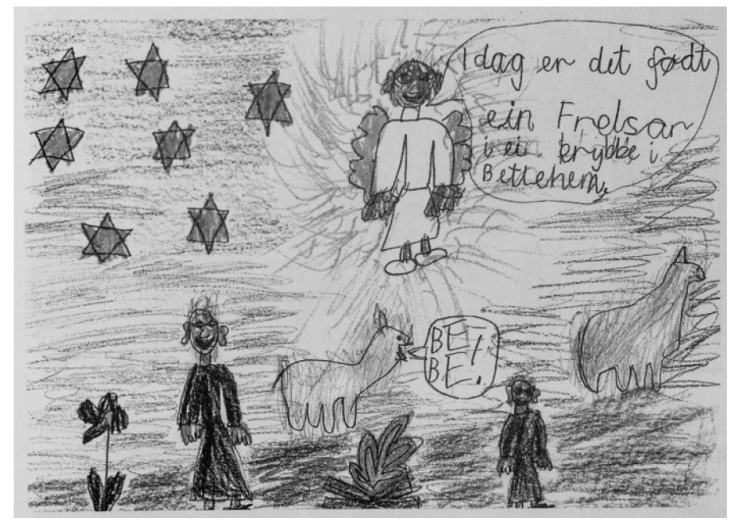

Fig. 3. Anonym barnetegning fra elev ved en norsk skole. Publisert med tillatelse fra foreldrene. Hentet fra Lied, S. (1996). Jeg fant, jeg fant ... en bibeltekst: Eleven som forsker og kunstner. Oslo: IKO-forlaget. Publisert med tillatelse fra IKO-forlaget. Bildet er ikke omfattet av bokens CC-lisens og kan ikke gjenbrukes uten særskilt tillatelse.

Gjennom den multimediale ytringen i Fig. 3 får vi et innblikk i den doble dialogen eleven har vært involvert $\mathrm{i}$, med tradisjonen på den ene siden og med ny kunnskap hentet fra fortellingen og læreren på den andre. Eleven posisjonerer seg altså her som en elev som både har kunnskap med seg til kristendomstimen og som lytter til det læreren sier - og som lar begge deler komme til uttrykk når han ytrer seg $\mathrm{i}$ tekst og bilde om hvordan han forstår Lukasfortellingen.

I disse ytringene fra 1987 ser vi tredjeklassinger i aksepterende dialog med den kristne fortellingen om Jesu fødsel. De uttrykker en grunnleggende kunnskap om og forståelse for kristen kultur og tradisjon og for det kristne bildet av Jesus, noe M87 uttrykker at undervisningen skal sikte mot (Kirke- og undervisningsdepartementet, 1987). De uttrykker ingen motforestillinger mot det de har hørt i undervisningen. 


\section{Andreklassinger i 2018}

Forskriften om KRLE-faget fra 2015 sier at undervisningen skal være saklig og uten forkynnelse. Men kunnskap om religion og livssyn som aktuelle kilder til tro, moral og livstolkning skal være sentralt i faget (Kunnskapsdepartementet, 2015). Læreren som har stått for undervisningen som andreklassingene fikk, sier at hun alltid knytter undervisningen om ulike religioner og livssyn opp mot tanken om vennskap og menneskets verdi, og at dette også var sentralt i undervisningen om kristendommen. Hun understreker at hun prøver å presentere det som er sentralt i hver religion på en slik måte at elevene forstår det. I kristendommen er fortellingen om Jesu fødsel sentral. I undervisningen om denne fortellingen skilte hun ikke mellom Matteus og Lukas sine framstillinger, men lot elevene møte det som sies i NT hos de to evangelistene om Jesu fødsel som én fortelling: Elementer fra Matteus og Lukas ble satt sammen slik at elevene møtte en helhetlig framstilling med Maria og Josef, gjetere og vismenn, engler og stjerne i samme fortelling - nettopp slik den tradisjonelt framstår når den skal gjengis i undervisnings- og populærkultursammenheng. Hun presenterte fortellingen i tre omganger i løpet av desember måned ved hjelp av ulike bøker som tilpasset framstillingen for barn, bl.a. gjennom bildebruk. At det er denne sammensatte fortellingen andreklassingene i 2018 har vært i dialog med, går fram av ytringene fra over halvparten av elevene: De har inkludert engler og reise til Betlehem fra Lukas og kongetittel og vismenn fra Matteus, slik vi ser det i de følgende ytringene.

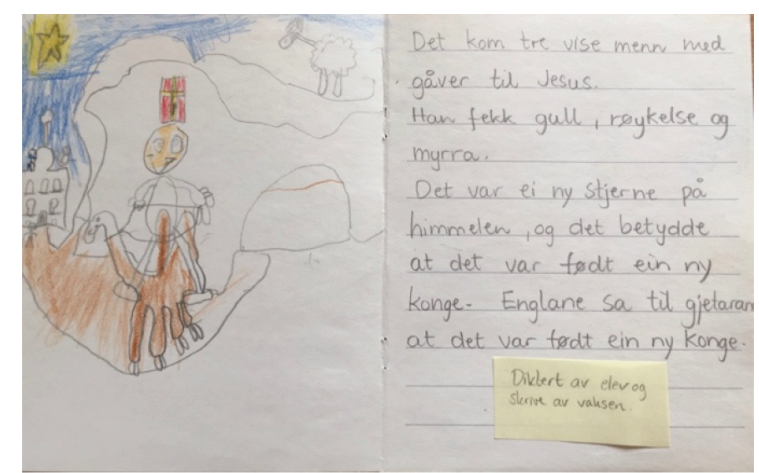

Fig. 4. Anonym barnetegning fra elev ved en norsk skole. Tegningene er publisert med tillatelse fra barna og foreldrene. Bildet er ikke omfattet av bokens CC-lisens og kan ikke gjenbrukes uten særskilt tillatelse. 


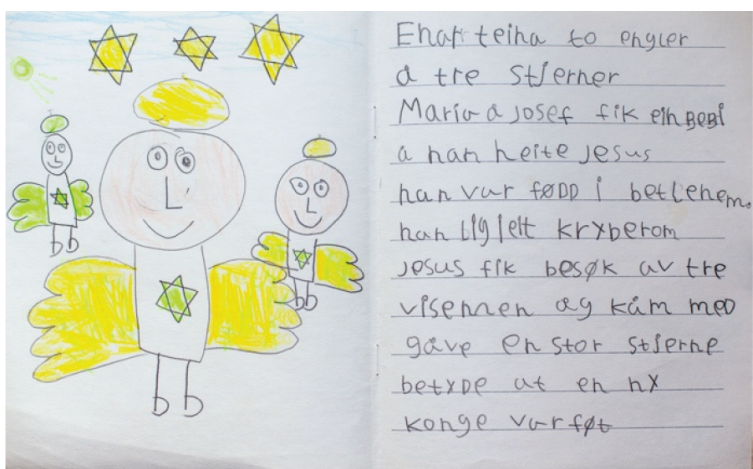

Fig. 5. Anonym barnetegning fra elev ved en norsk skole. Tegningene er publisert med tillatelse fra barna og foreldrene. Bildet er ikke omfattet av bokens CC-lisens og kan ikke gjenbrukes uten særskilt tillatelse.

I Fig. 4 er verbalteksten diktert av en elev, men skrevet ned av læreren. Tegningen har eleven imidlertid hatt ansvar for alene. Både i tekst og tegning kommer den sammensatte julefortellingen til uttrykk. Bildet har en vismann ridende på en kamel i fokus. Han rir langs en vei som går fra en hule eller et fjell mot et hus som ser ut som et slott med mennesker både foran og oppe på taket. En stjerne er tegnet øverst i venstre hjørne. Veien stopper imidlertid ikke ved slottet, men gjør en sving videre ut mot sauen i øverste høyre hjørne. Teksten sier: «Det kom tre vise menn med gåver til Jesus. Han fekk gull, røykjelse og myrra. Det var ei ny stjerne på himmelen, og det betydde at det var født ein ny konge. Englane sa til gjetarane at det var født ein ny konge.» Dialogen med julefortellingen kommer fram både i tekst og tegning: Følger vi rekkefølgen som verbalteksten presenterer, går vi samtidig veien som eleven har tegnet inn i bildet. Men ett element $\mathrm{i}$ denne ytringen merker seg ut: Over hodet på vismannen og i svingen på veien fra slottet mot sauen er et gult kors tegnet inn mot en rød bakgrunn. Dette kan tyde på at eleven er i dialog med Jesusfortellingen som helhet i ytringen sin, og at han vil vise leserne sine at han vet at denne fortellingen innbefatter både vismenn og kongetittel, kors og død. Er det slik, ser vi her en andreklassing som er i dialog både med lærerens fortelling om jul, med hele Jesusfortellingen slik han selv kjenner den, og med leserne sine. Han posisjonerer seg dermed som en 
elev med kunnskap på feltet han ytrer seg innenfor - til tross for at han helst vil ha hjelp til å skrive ned verbalteksten.

I fig. 5 ser vi nok en andreklassing i dialog med den sammensatte julefortellingen: Tegningen viser englene som synger med stjernehimmelen som bakgrunn, og teksten viser til Jesu fødsel og vismennene som ville ære en nyfødt konge. Som elevene fra 1987 er eleven opptatt av at det var Maria og Josef som sammen fikk Jesus. Men ytringen viser oss også dialogen eleven er i med kulturen som omgir ham. Midt i verbalteksten finner vi en referanse til det andre verset $\mathrm{i}$ julesangen Eit barn er født $i$ Betlehem: «han ligg i eit kryberom», skriver eleven. Eleven posisjonerer seg altså som en som kjenner fortellingen om Jesu fødsel både fra fortelling og sang.

I Fig. 6. er tegningens hovedperson en blid engel. At den er hovedperson, viser både størrelsen og den sentrale plasseringen den har fått. Den har glorie på hodet. Ved siden av engelen ser vi en smilende Maria. Mellom dem ligger Jesus trygt, like blid som de to andre. Stjernene stråler på himmelen, og sola skinner. Alt ånder glede, lys og trygghet.

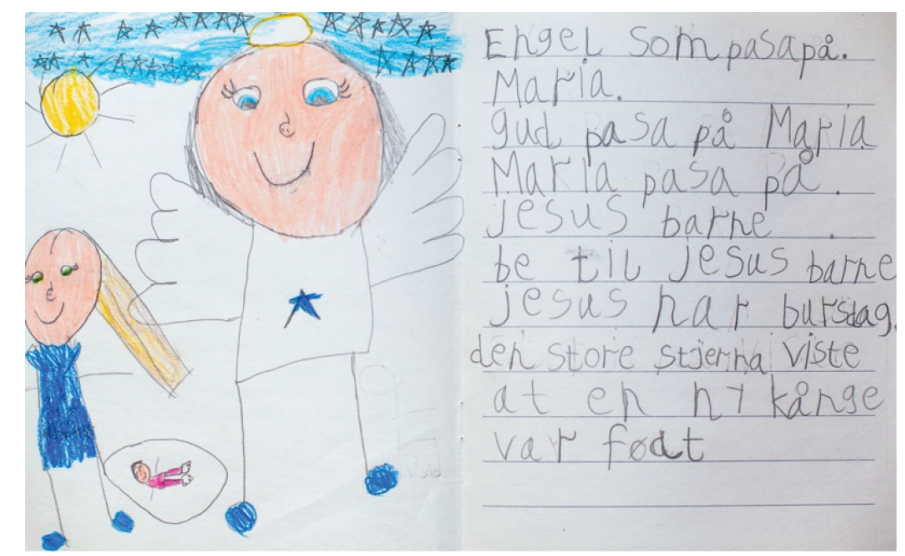

Fig. 6. Anonym barnetegning fra elev ved en norsk skole. Tegningene er publisert med tillatelse fra barna og foreldrene. Bildet er ikke omfattet av bokens CC-lisens og kan ikke gjenbrukes uten særskilt tillatelse.

Omsorgen som tegningen framhever, utdypes av teksten: «Engel som pasa på Maria. Gud pasa på Maria. Maria pasa på jesus barne. be til jesus barne. jesus har bursdag. den store stjerna viste at en ny kånge var født». 
Tryggheten og tilliten til at engelen og Gud passer på Maria og Jesus, gjennomsyrer den multimediale ytringen.

Det er interessant å legge merke til at både i Fig. 5 og 6 ser vi engler med stjerner på magen. Elevene som har laget de to ytringene, kan ha vært i dialog med noen av de bildene som fulgte lærerens presentasjon av julefortellingen. Men ingen av klassekameratene har denne detaljen med i sine tegninger. Kanskje har de to elevene inspirert hverandre i tegneprosessen, slik at det er dialogen mellom disse to vi ser rester av her?

Fig. 6 inneholder ett element som jeg ikke har funnet i de andre elevytringene om Jesu fødsel, hverken i de fra 1987 eller i de andre fra 2018, nemlig den klare oppfordringen om å be til Jesus. Siden denne eleven er den eneste som oppfordrer til bønn, er det neppe lærerens undervisning eleven er i dialog med når han skriver dette. En undervisning som oppfordrer til bønn, ville heller ikke vært i tråd med læreplanen for KRLE. Men denne eleven er ikke bare i dialog med undervisningen når han skriver og tegner på skolen. Ifølge Bakhtin er vi i kontinuerlig dialog med det sosiale og kulturelle fellesskapet vi er en del av, når vi ytrer oss, blant annet med erfaringer vi har gjort innenfor dette fellesskapet og med de tekstene som finnes her (Bakhtin, 1998). Det er derfor sannsynlig at oppfordringen til bønn kommer fordi eleven har vært i dialog med andre sider av sitt sosiale fellesskap enn fellesskapet i klasserommet da han skrev denne teksten.

Elevens ytring antyder likevel at dialogen med undervisningen har vært aktiv da han skrev og tegnet: I likhet med sju av de andre 18 ytringene jeg fikk fra vestlandsklassen, finner vi i Fig. 6 en framheving av at i og med Jesu fødsel var en ny konge født. Fordi så mange har understreket dette, er det mulig at læreren har vektlagt den nytestamentlige presiseringen av dette i sin undervisning. Elevens ytring tyder altså på at han har tatt med erfaringer fra andre sosiale sammenhenger som han er en del av, inn i dialogen med lærerens undervisning. Denne doble dialogen har ledet til forståelsen han er kommet fram til når det gjelder Jesu fødsel: Jesus er den nye kongen, Gud sørger for at han blir passet godt på, og vi må be til ham. Denne forståelsen har eleven ikke vært redd for å uttrykke i sin multimediale ytring, noe som viser at han 
opplever at det er ok å si hva han mener på skolen. Det antyder også at læringsmiljøet i klassen speiler et annet av KRLE-planens mål, nemlig gjensidig respekt og rom for undring og refleksjon (Kunnskapsdepartementet, 2015).

\section{Elever i dialog med lignelsen om sauen som ble funnet igjen Sjetteklassinger 1992}

M87 presiserte at den levende fortellingen måtte få rikelig plass i undervisningen, og at metoder som vender seg til fantasi og følelsesliv, og som tar i bruk skapende evner hos eleven, måtte få stor plass i kristendomsundervisningen (Kirke- og undervisningsdepartementet, 1987). I tråd med dette presenterte læreren lignelsen om sauen som ble funnet igjen gjennom fri fortelling som holdt seg nær til den bibelske framstillingen, slik at elevene skulle få en både engasjerende og tekstnær opplevelse av lignelsen. Deretter ga hun dem en viktig bakgrunnsinformasjon, nemlig at dette var en lignelse, og at noe av det sjangertypiske ved lignelser er at de peker utover seg selv og sier «noe mer». Elevene fortalte så lignelsen til hverandre, to og to, før de ble satt til å uttrykke hvordan de tolket lignelsen gjennom tekst og bilde (Lied, 1996).

Eleven som står bak den multimediale ytringen i Fig. 7, har posisjonert seg som en som tolker tekst: «Tolking» er overskriften han har gitt den verbale framstillingen sin. I lignelsestolkningen er han i dialog med den tradisjonelle forståelsen av denne fortellingen, nemlig at den sier noe om forholdet mellom Gud og mennesker. Han definerer menneskene som sauene og Gud som mannen som eide de 100, men mistet én. Han framhever Guds kjærlighet til menneskene og begrunner den i skapelsen. Eleven har tatt sine kreative evner i bruk for å karakterisere sauene, og har framstilt de 99 som flinke mens den ene er klønete: «Denne forteljinga betyr at vi er sauene og Gud mannen. Det viser at Gud er glad i alle. Han blir glad fordi han har skapt oss og ingenting kan erstatte oss. Dei 99 er flinke og den eine er klønete. Likevel jubler han. Han er glad i alle 'klønene' og." 

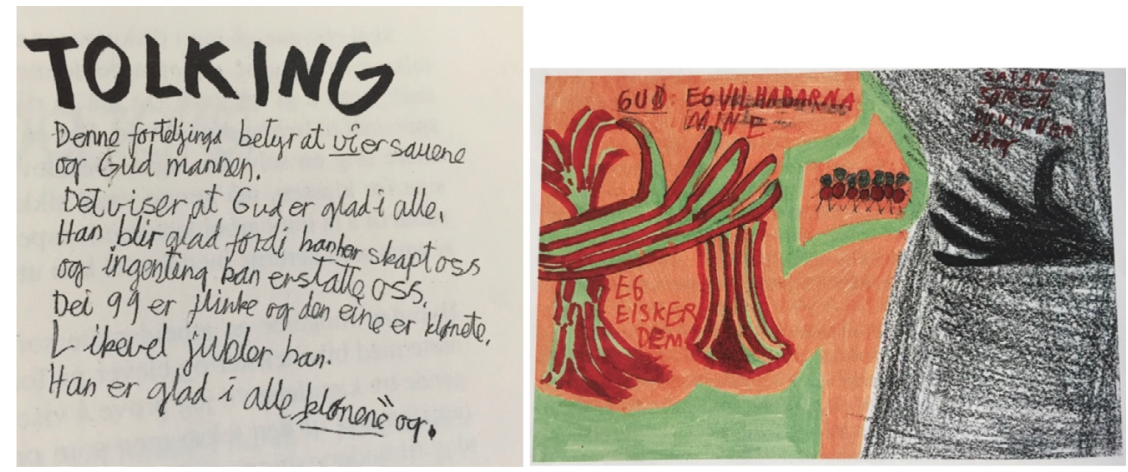

Fig. 7. Anonym barnetegning fra elev ved en norsk skole. Publisert med tillatelse fra foreldrene. Hentet fra Lied, S. (1996). Jeg fant, jeg fant ... en bibeltekst: Eleven som forsker og kunstner. Oslo: IKO-forlaget. Publisert med tillatelse fra IKO-forlaget. Bildet er ikke omfattet av bokens CC-lisens og kan ikke gjenbrukes uten særskilt tillatelse.

Kreativiteten kommer også til uttrykk i tegningen som følger denne teksten. Den er symbolmettet og uttrykksfull. Gud fremstilles som en hånd omgitt av varme og frodighet i form av farger som gulgrønn, oransje og rødt. Satan framstilles også som en hånd. Den er svart og omgitt av mørke. Menneskene, Guds barn, er tegnet helt på grensen mot den svarte hånden og mørket som omgir den. Men de er likevel trygt innenfor Guds varme. At de er trygge, understrekes av dialogen mellom Gud og Satan. «Eg vil ha barna mine. Eg elsker dem,» sier Gud. «Søren, du vinner nå og,» svarer Satan (Lied, 1996).

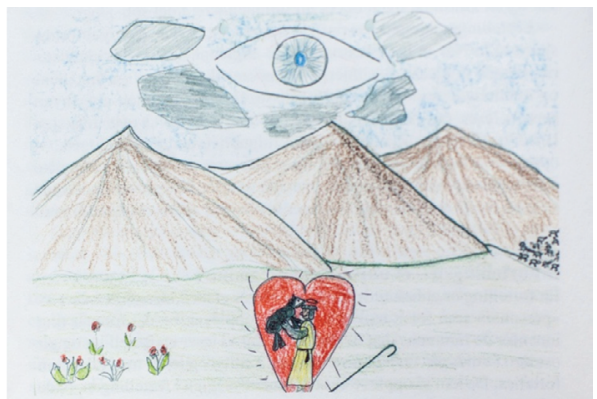

Dii 99 er mennestea og eg er den ines)

Fig. 8. Anonym barnetegning fra elev ved en norsk skole. Publisert med tillatelse fra foreldrene. Hentet fra Lied, S. (1996). Jeg fant, jeg fant ... en bibeltekst: Eleven som forsker og kunstner. Oslo: IKO-forlaget. Publisert med tillatelse fra IKO-forlaget. Bildet er ikke omfattet av bokens CC-lisens og kan ikke gjenbrukes uten særskilt tillatelse. 
Kjærligheten mellom sauene og hyrden, Gud og menneskene, kommer til uttrykk også i Fig. 8. Tegningen viser en sau og en hyrde. «Sauen må være svart,» sa eleven mens han tegnet. Fargen til tross er sauen plassert trygt i hyrdens armer inne i et rødt hjerte. Guds øye lyser som en sol over de to. Men som barn ofte gjør når de ytrer seg skriftlig, bruker også denne eleven både tekst og tegning for å få fram budskapet sitt: «(Dei 99 er menneska og eg er den eine)» skrev han ved siden av tegningen. Han går altså inn i rollen som den ene sauen som hadde gått seg bort, men som ble funnet igjen, og posisjonerte seg innenfor denne rollen som en svart sau. Her er han i dialog med det kulturelle fellesskapet han er en del av, og det meningsinnholdet som ligger i uttrykket «det sorte får», som brukes om den som ikke oppfører seg slik han burde, og som fører skam over dem han hører til. Ytringen i Fig. 8 viser altså at eleven forstår seg selv i denne rollen. Men i dialogen med fortellingen og den sosiokulturelle sammenhengen han var en del av, tolket han også mannen/hyrden som Gud. Dermed viser den multimediale ytringen at han forstår lignelsen slik: I Guds armer er det plass for sorte får - også slike som ham selv.

Ytringene i Fig. 7 og 8 viser elever som har tatt i bruk sine kreative evner i møte med den kristne bibels lignelser. I begge kommer det fram at elevene har vært i dialog med lærerens undervisning om lignelser som en fortellingssjanger som peker utover seg selv: De har forstått at skal en få tak i lignelsens budskap, kan en ikke slå seg til ro med at en sau er et dyr og at en hyrde er en mann. En må også lete etter «noe mer». Men ytringene avslører også en annen dialog, nemlig den med sentrale bestanddeler i den kristne tro, blant annet den kristne forståelsen av Gud og det kristne synet på mennesket. Disse elementene framheves i M87 som særdrag i kristendommen som elevene skulle få innsikt i gjennom faget som da het Kristendomskunnskap. Denne kunnskapen skulle, ifølge M87, oppleves viktig og aktuell og «være med på å gi grunnlag for deres tro» (Kirkeog undervisningsdepartementet, 1987, s. 103). Sjetteklassingenes ytringer fra 1992, med sine sterkt personlige uttrykk, antyder at elevene har opplevd undervisningen som så aktuell og relevant at de har tatt $\mathrm{i}$ bruk både kunnskap og kreativitet for å gi uttrykk for sine opplevelser i møtet med lærestoffet. 


\section{Andreklassinger i 2019}

Etter arbeidet med fortellingen om Jesu fødsel før jul 2018 la læreren opp til to uker temabasert undervisning for andreklassingene sine der seks av kristendommens fortellinger sto i fokus: to fra GT og fire fra NT. En av disse var lignelsen om sauen som ble funnet igjen. Før hun startet med å fortelle denne lignelsen, understreket hun at den var å finne i den kristne bibel og at den, ifølge den kristne tro, viser hvor mye Gud bryr seg om hvert enkelt menneske. Etter fortellerstunden og før hun satte elevene i gang med å tegne og skrive, lot hun dem se en liten filmsnutt på to minutter, der lignelsen var dramatisert. Filmsnutten var det siste elevene møtte før de begynte arbeidet med ytringene sine, og den gjorde inntrykk på elevene. «Den tok luven fra fortellingen,» sier læreren. Viktige elementer i filmen er at den knytter den ene sauens forsvinning til at sauen oppdager og følger etter en sommerfugl, og at dette leder den vekk fra flokken og ut i skogen, hvor den blir sittende fast i en grein. Disse elementene er ikke en del av den bibelske fortellingen, men de kommer fram i flere av elevenes ytringer: $\mathrm{Ni}$ av de 18 elevene har inkludert enten sommerfuglen, greinen, skogen eller en kombinasjon av disse i det de har skrevet og/eller tegnet.

Både i Fig. 9 og 10 ser vi andreklassingene i dialog med filmsnutten og de elementene den framhever. I Fig. 9 har eleven brukt teksten for å poengtere at sauen hadde fulgt en sommerfugl, gått seg vill og satt seg fast: «Den bortførande sauen. Sauen fant ein somerfugl og han følte den og han gikk seg vil. (...) Seuen hade søte seg fast. (...)» Det er tegningen som understreker at det var i skogen - representert av et tre - at mannen fant sauen igjen. I Fig. 10 skriver eleven at mannen ble redd da han telte sauene og så at en manglet: «(...) han fant han til slutt og han fant an i ein skog. Og foten sat fast i ei grein (...)» I begge disse multimediale ytringene kommer det positive forholdet mellom mannen og sauene fram. Begge tegningene viser at etter gjenforeningen smiler både sauene og mannen. I Fig. 10 er det riktignok ikke 100, men 'bare' 51 smilende sauer vi ser! Leser vi tekstene sammen med tegningene, ser vi at begge de to multimediale ytringene understreker at gleden over funnet av den bortkomne sauen førte til fest: «Manen blei så gla. Han inviterte ale naboane til ein stor fest får di seuen hade kåmt til bake» (Fig. 9). «Og han berte sauen på rygen. Og når dei kåm heimat so hadde dei fest får sauen» (Fig. 10). 


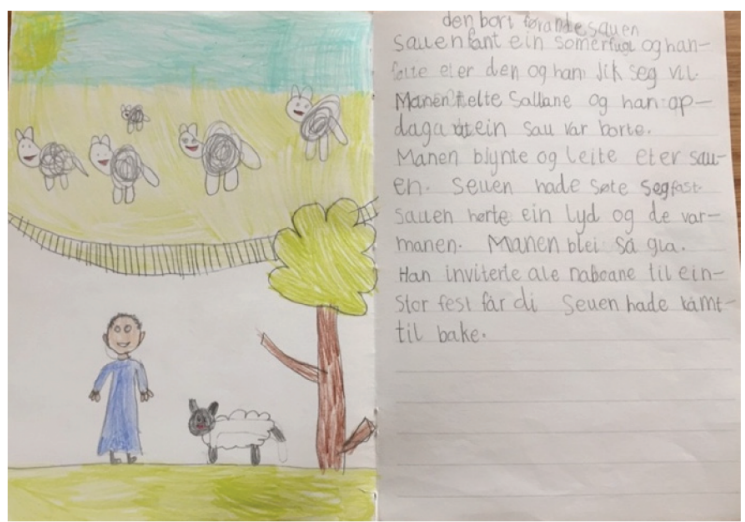

Fig. 9. Anonym barnetegning fra elev ved en norsk skole. Tegningene er publisert med tillatelse fra barna og foreldrene. Bildet er ikke omfattet av bokens CC-lisens og kan ikke gjenbrukes uten særskilt tillatelse.

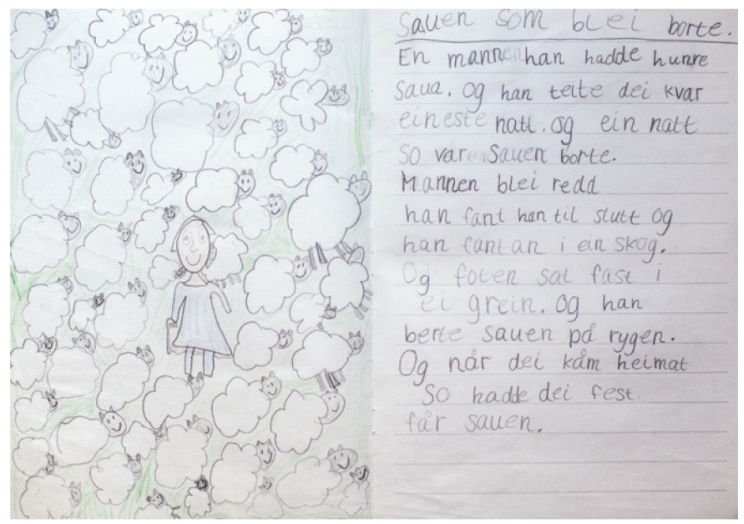

Fig. 10. Anonym barnetegning fra elev ved en norsk skole. Tegningene er publisert med tillatelse fra barna og foreldrene. Bildet er ikke omfattet av bokens CC-lisens og kan ikke gjenbrukes uten særskilt tillatelse.

Dialogene med filmsnuttens framstilling av lignelsen er til stede i begge ytringene. Elevene går inn i rollen som kjennere av fortellingen i filmsnuttens versjon. Men lærerens presisering av Gud-menneske-relasjonen og en potensiell dialog med lignelsen som en fortelling som har noe med dem selv å gjøre, ser ut til å ha fløyet bort sammen med sommerfuglen. Den eneste av de 18 ytringene fra 2019 som kan antyde et personlig engasjement utover fryden over selve fortellingen, er den vi ser i Fig 11: 


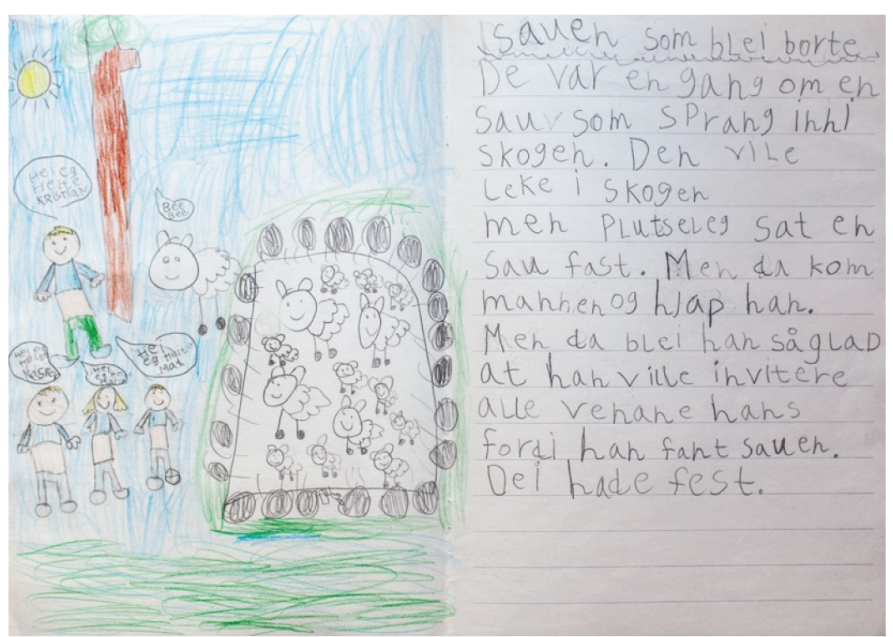

Fig. 11. Anonym barnetegning fra elev ved en norsk skole. Tegningene er publisert med tillatelse fra barna og foreldrene. Bildet er ikke omfattet av bokens CC-lisens og kan ikke gjenbrukes uten særskilt tillatelse.

Her ser vi gjestene som kommer på besøk til sauene og presenterer seg ved navn: «Hei eg heite Kristian», «Hei eg heite Kasper», «Hei eg heite Maria», «Hei eg heite Max» sier gjestene som kommer, ifølge snakkeboblene som er knyttet til dem. «Bee Bee» svarer den ene sauen. Gleden er stor både hos sauer og gjester. Men heller ikke her finner vi noe som viser at eleven ser at dette er en fortelling som har med forholdet mellom Gud og menneske å gjøre.

\section{Konkluderende betraktninger}

Spørsmål som jeg reiser innledningsvis i denne artikkelen, setter søkelyset på elevers dialoger med to av kristendommens sentrale fortellinger, slik de møtte dem i kristendomsundervisningen i 1987/88 og 1990/910g i KRLE-undervisningen i 2018/19. Målene for undervisningen i de to fagene var ulike: Sentrale mål i kristendomsundervisningen i M87 var at elevene skulle få et grunnlag til å forstå hva kristendom er og finne stimulans for egen trosutvikling. «Det elevene lærer i faget, skal være med på å gi grunnlag for deres tro og være til veiledning for deres liv» (Kirkeog undervisningsdepartementet 1987, s. 103), sa planen, men lærerne ble oppfordret til å ta hensyn til at elevene kunne ha ulik bakgrunn. Sentrale 
mål for undervisningen i KRLE fra 2015 er felles kunnskapsgrunnlag om ulike religioner og livssyn, og forståelse for ulike livstolkningstradisjoners funksjon som trosgrunnlag for mennesker. Det sies eksplisitt at undervisningen skal være saklig og upartisk og at den ikke skal inneholde forkynnelse (Kunnskapsdepartementet, 2015). Mot den bakgrunnen som disse målsettingene tegner, kunne man forvente å finne personlige trosuttrykk i multimediale ytringer fra elever som skrev og tegnet innenfor rammen av kristendomsfaget i M87 når temaet var kristendommens fortellinger, mens ytringene som er laget innenfor rammen av KRLE-faget, ikke ville inneholde slike trosuttrykk. Men det var ikke dette jeg fant.

I forbindelse med fortellingen om Jesu fødsel var det ingen av de multimediale ytringene fra tredjeklassingene i 1987 som inneholdt forkynnende oppfordringer eller personlige trosuttrykk. Dialogene som elevene var involvert i, var knyttet til fortellingens innholdsside. At de fant dialogen med fortellingen engasjerende, gir ytringene deres likevel klare signal på. I elevytringene fra 2018 som ble laget i forbindelse med denne fortellingen, fant jeg imidlertid et personlig trosuttrykk, nemlig en andreklassing som oppfordret sine lesere til å be til Jesusbarnet: Jesus er den nye kongen som Gud sørger for blir godt passet på, og vi må be til ham (se Fig. 6). Siden denne eleven var den eneste i klassen som oppfordret til bønn, er det lite sannsynlig at eleven var i dialog med lærerens undervisning på dette punktet. Det er heller rimelig å anta at han her var i dialog med andre sosiale sammenhenger han er en del av, for eksempel familien.

I forbindelse med lignelsen om sauen som ble funnet igjen var det imidlertid ytringene fra sjetteklassingene i 1991som skrev og tegnet innenfor rammen av kristendomsfaget, som inneholdt trosytringer. Elevene synes her å være i aksepterende dialog med kristendommen som trosgrunnlag, og ytringene antyder at elevene mente at innholdet i lignelsene var noe som gjaldt dem. «... vi er sauene og Gud mannen», skriver en elev (Fig. 7), mens en annen forteller oss at den ene - som er svart - det er han selv: «Dei 99 er menneska og eg er den eine» (Fig. 8). Når det gjaldt andreklassingene som arbeidet med lignelsen innenfor rammen av KRLE i 2019, var også de i positiv dialog med fortellingens innholdsside, men uttrykk for at fortellingen hadde noe med dem og deres tro og liv å gjøre, fant jeg ikke i deres multimediale ytringer. 
Jeg fant altså personlige trosuttrykk i elevytringer som var laget i forbindelse med kristendommens fortellinger, både innenfor rammen av kristendomsfaget fra 1987 og KRLE-faget fra 2015, dette til tross for at disse to fagene har ulike målformuleringer når det gjelder hva undervisningen skal bidra med til elevenes trosutvikling. Det kan være flere mulige forklaringer på dette:

Andreklassingenes lærer i 2018/19 understreker at hun ikke har noen problemer med å framholde at kristendommens fortellinger gir uttrykk for kristendommens syn, f.eks. på forholdet mellom Gud og mennesker, noe hun også gjorde i forbindelse med lignelsen om sauen som ble funnet igjen. Også i undervisningen om andre religioners fortellinger peker hun på hvordan viktige elementer i de respektive religionene framheves. Men i forbindelse med lignelsen om sauen forsvant det religiøse poenget sammen med sommerfuglen fra filmens framstilling. "Filmsnutten hadde stor gjennomslagskraft», sier hun. Dersom lærerens tolkning av filmens betydning for andreklassingenes dialog med fortellingen er riktig, kan dette være en forklaring på forskjellen mellom elevytringene fra sjetteklassingene i 1988 og andreklassingene fra 2019. Sjetteklassingene hadde nemlig ikke møtt denne filmen. De forholdt seg bare til den verbale bibelske fortellingen og det de hadde lært om lignelser.

En annen forklaring på ulikhetene kan være forskjellen i alder og modenhetsnivå på de to elevgruppene: Sjetteklassingene kan ha vært mer i stand til å forholde seg til det sjangertypiske ved lignelsen, og ha blikk for å lete etter «noe mer» i fortellingen. En så vidt krevende tolkningsoppgave er det mulig at andreklassingene ikke ville mestret, selv om de hadde blitt presentert for sjangeren lignelse i undervisningen. Men ytringen i Fig. 6, som er knyttet til fortellingen om Jesu fødsel, antyder at alder og modenhetsnivå ikke nødvendigvis er hele forklaringen. Den kan også signalisere at en elev som i én sammenheng både ønsker og er i stand til å gi uttrykk for personlig engasjement, ikke gjør det i alle sammenhenger: Selv om læreren hadde påpekt at lignelsen om sauen handler om forholdet mellom Gud og mennesker, var det i møte med julefortellingen og ikke med lignelsen at eleven valgte å komme med et personlig trosuttrykk.

Dette aktualiserer også spørsmålet om skolens religions- og livssynsundervisning er den sterkeste premissleverandøren når det gjelder elevers 
personlige livstolkning. Dette ble også tema i mitt doktorgradsarbeid fra 2004, der jeg undersøkte mellomtrinnselevers møter med fortellinger fra ulike religioner og livssyn i faget som da het KRL. Elevenes multimediale ytringer viste at de gikk inn i roller som reflekterende og innsiktsfulle tenkere i møte med lærestoffet. De brukte fortellingene både fra egen og andres religiøse og livssynsmessige tradisjon som dialogpartnere, og som utgangspunkt for refleksjoner knyttet til egen livstolkning. Men det var i møte med fortellinger fra den tradisjonen de hadde bakgrunn fra og som var en del av det kulturelle fellesskapet de tilhørte, at de oftest reiste de mest eksistensielle spørsmålene og førte de mest engasjerte debattene. Når de arbeidet med sin personlige tro og livstolkning, var de solid plantet i den sosiokulturelle konteksten de var en del av. Det de hadde med seg hjemmefra, utgjorde «brillene» de brukte i møte med ulike religioner og livssyn. Det de hadde med seg hjemmefra, ble forstålsesbakgrunn for det nye de møtte (Lied, 2004). Disse funnene gir også en mulig tolkningsramme for andreklassingens oppfordring i Fig. 6 laget innenfor rammen av KRLE-undervisningen i 2018 om å be til Jesusbarnet: Tro på Jesus og bønn til ham kan være en del av den tolkningsrammen eleven var vant til å bruke i møte med kristendommens fortellingsunivers. Av den grunn kan det ha vært et naturlig valg for ham å bruke denne rammen i møte med fortellingen fra dette universet på skolen. Han behøvde ingen oppfordring fra læreren eller hennes undervisning for å bruke den.

I denne artikkelen har jeg studert noen elevers multimediale ytringer for å se hva disse ytringene sier om elevenes dialoger med to av kristendommens sentrale fortellinger, innenfor rammen av henholdsvis kristendomsfaget fra M87 og KRLE-faget fra 2015. Jeg fant ingen markante forskjeller når det gjelder personlige trosuttrykk i ytringene som elevene laget i de to fagene. Jeg kan imidlertid ikke, med bakgrunn i disse funnene, si at skolens religions- og livssynsundervisning ikke er med på å prege elevenes kristendomsforståelse. Jeg kan heller ikke si at ulike målsettinger og profiler faget kan ha, ikke har betydning for elevenes arbeid med sin personlige livstolkning. Det jeg imidlertid kan si, er at dette er problemstillinger som det vil kunne være interessant å undersøke nærmere. Jeg håper denne artikkelen inspirerer til slik forskning. 


\section{Litteratur}

Bakhtin, M. M. (1998). Spørsmålet om talegenrane. Bergen: Ariadne forlag.

Dyson, A. H. (2002). The drinking god factor. A writing development mix for 'all children'. Written Communication. An International Quarterly of Research, Theory and Application, 19(4).

Evensen, L. S. (2002). Convention from below: Negotiating interaction and culture in argumentative writing. Written Communication. An International Quarterly of Research, Theory and Application, 19(3).

Kirke-og undervisningsdepartementet. (1987), Mønsterplan for grunnskolen M87. Nasjonalbiblioteket. Hentet fra https://www.nb.no/nbsok/nb/2aef891325ao 59851965d5b8ac193de5\#103

Knausgård, K. O. (2019, 27. april). Språket, bildene og litteraturen (s. 14-18). Klassekampen.

Kunnskapsdepartementet. (2015). Læreplan i kristendom, religion, livssyn og etikk (KRLE). Forskrift av 18. juni 2015. Hentet fra https://www.udir.no/klo6/RLE1-02/ Hele/Komplett_visning?depth $=06$ print $=1$

Lied, S. (1996). Jeg fant, jeg fant ... en bibeltekst: Eleven som forsker og kunstner. Oslo: IKO-forlaget.

Lied, S. (2004). Elever og livstolkingspluralitet i KRL-faget: Mellomtrinnselever i møte med fortellinger fra ulike religioner og livssyn. Doktoravhandling: Det Teologiske Menighetsfakultet (Høgskolen i Hedmark Rapport nr. 11 - 2004).

Lied, S. (2007). Kristne friskoler i en flerkulturell kontekst. Uppsala: Universitetstrykkeriet (Distribusjon: Swedish Science Press og Oplandske bokforlag).

Lied, S. (2018). Children's dialogue with values: Values in children's memorial messages in the aftermath of July $22^{\text {nd }} 2011$. I L. A. Kulbrandstad, T. O. Engen \& S. Lied (Red.), Norwegian perspectives on education and cultural diversity (s. 281-302). Newcastle: Cambridge Scholars Publishing.

Osbeck, C. \& Lied, S. (2012). RE research in Hamar and Karlstad in a subject didactical and international context. I S. Lied \& C. Osbeck (Red.), Religionsdidaktisk arbeid pågår. Religionsdidaktikk i Hamar og Karlstad (s. 1-29). Vallset: Oplandske Bokforlag.

Smidt, J. (1996). «jølposisjonering og skriveroller i skriving på skolen. Utbildning och demokrati. Tidsskrift för didaktik och utbildningspolitik, 5(3). 



\title{
Lex Borgen: Et blad i norsk skolehistorie om ikke-lutheraneres rett til å undervise i høyere utdanning
}

\author{
Torrey Seland \\ VID - Stavanger
}

Sammendrag: I Lov om Embedsmoends Troesbekjendelse av 1880, lett revidert i 1894, sto det blant annet at embetsmenn som har til oppgave å gi undervisning $\mathrm{i}$ kristendomskunnskap, skal «bekjende sig til Statens offentlige Religion.» På begynnelsen av 1970-tallet ble denne loven endret etter en lang debatt slik at også dissentere, i betydningen ikke-lutheranere, kunne undervise i kristendomskunnskap på universitetsnivå i det norske skolesystemet. Artikkelen beskriver nærmere bakgrunn og saksbehandling for denne endringen med særlig vekt på den rolle metodisten Peder Johan Borgen spilte i denne prosessen.

Nøkkelord: dissentere, statskirke, kristendomsundervisning, embetsmenns trosbekjennelse, Peder Borgen

\section{Innledning}

I 1970 opprettet Stortinget et nytt professorat i kristendomskunnskap ved Religionsvitenskapelig institutt, Universitetet i Bergen, med virkning fra 1. juli 1971. Universitetet gjorde ferdig - trodde de - en utlysningstekst som de sendte over til Kirke- og undervisningsdepartementet som rette vedkommende for utlysningen. Men forbauselsen var stor da

Sitering av denne artikkelen: Seland, T. (2020). Lex Borgen: Et blad i norsk skolehistorie om ikkelutheraneres rett til å undervise i høyere utdanning. I B. Løvlie, P. Halse \& K. Hatlebrekke (Red.), Tru på Vestlandet. Tradisjonar i endring (Kap. 15, s. 363-39o). Oslo: Cappelen Damm Akademisk. https://doi. org/10.23865/noasp.104.ch15

Lisens: CC BY-ND 4.o. 
utlysningsteksten kom på trykk i Norsk Lysingsblad 28. desember 1970, for der hadde teksten fått et tillegg. Departementet hadde nemlig funnet fram en gammel lov fra 1894 om Embedsmonds Troesbekjendelse, og lagt inn følgende bestemmelse i utlysningsteksten: «Innehaveren av embetet må bekjenne seg til Statens offentlige religion.» Saken vakte stor oppsikt i universitetsmiljøene, og også utover disse. Det hadde nemlig ikke vært nevnt noe om en slik bestemmelse ved utlysningen av det første professoratet på det samme instituttet i 1965. Religionsvitenskapelig institutt lå under Det historisk-filosofiske fakultet, og ingen ved de historiskfilosofiske fakultetene verken i Bergen eller Oslo var underlagt noen slik bekjennelsesplikt. Hvorfor var da denne bestemmelsen tatt med i denne nye utlysningen for Bergen? I denne artikkelen skisserer jeg noe av bakgrunnen for og behandlingen av denne saken for å finne svar på dette spørsmålet.

\section{Bakgrunnstegning}

Utover på 1960-tallet ble det en form for mobilisering om kristendomsundervisningen i grunnskolen som førte til at en rekke utdanningsinstitusjoner opprettet nye studietilbud i kristendomskunnskap på grunn- og mellomfagsnivå, og etter hvert også i hovedfag. Allerede i 1957 hadde det akademiske kollegium ved Universitetet i Oslo besluttet å opprette kristendomskunnskap mellomfag. ${ }^{.}$Den neste institusjonen som opprettet kristendomskunnskap som eget fag, var Norges Loererhøgskole i Trondheim, som opprettet sitt Religionsvitenskapelige institutt i 1964. Dernest kom Religionsvitenskapelig institutt ved Universitetet i Bergen, som opprettet kristendomskunnskap grunnfag og mellomfag i 1967, og ganske raskt deretter startet arbeidet med å utarbeide planer for et hovedfag i samme fag. Samme året kom også to private institusjoner med tilsvarende studietilbud, nemlig Menighetsfakultetet i Oslo, og det nystartede Norsk Lorerakademi i Bergen. ${ }^{2}$

1 Dette ble plassert i Religionshistorisk institutt, som tilhørte Det historisk-filosofiske Fakultet. Fra 1969 av ble det også mulig å ta eksamen i kristendomskunnskap hovedfag der.

2 Oppstarten av Norsk Lærerakademi skjedde ikke uten en viss både indrekirkelig og allmenn debatt. Se til dette Helland \& Jøssang, 2018. Ang MF, se Mogstad, 2008. 
Denne mobiliseringen var begrunnet i flere trekk i den allmenne samfunnsutviklingen, og for mange ikke minst innen skolepolitikken. Statskirkens innflytelse i samfunnet generelt og i skolesystemet spesielt hadde allerede vært under kritikk en god stund, en kritikk som etter hvert akselererte. Det samme gjaldt kritikken av faget kristendomskunnskap og dets plass i skolesystemet, en kritikk som kunne komme fra flere kanter, både fra de kretser som ønsket en frigjøring fra kristelig innflytelse i skolen mer generelt, en kritikk som utpå femtitallet fikk et sterkt talerør i Human-Etisk Forbund (stiftet i 1956), ${ }^{3}$ og det kom kritikk fra frikirkelig ikke-luthersk hold. Fra statskirkens side var mobiliseringen også begrunnet $\mathrm{i}$ at den så skolens kristendomsundervisning som Den norske kirkes dåpsundervisning, et standpunkt som førte både til kamp for selve undervisningens opprettholdelse og for dens konfesjonelle forankring.

\section{Skolepolitiske lovendringer og «dissenternes» rettigheter som lærere}

Midt på 180o-tallet hadde det kommet lovbestemmelser som regulerte «dissenternes» ${ }^{4}$ adgang og rettigheter i landet. ${ }^{5}$ I praksis ble deres rettigheter sterkt begrenset, og forble det i lang tid. Men ca. hundre år senere, i 1950-60-70-årene skjedde det flere ting innen skolepolitikken som la dype spor for de kommende årene, og ga utgangspunkt for videre reformer, også når det gjaldt dissenternes muligheter innen skolesystemet.

Dissenterloven av 1845 ga barn fra ikke-lutherske familier mulighet til å kreve fritak fra kristendomsundervisningen. ${ }^{6}$ Men noe tilsvarende

For en kort oversikt over utviklingen i Norge fra et idehistorisk synspunkt, se Aadnanes, 1988, spesielt s. 130-133, og 178-186.

4 Selve den begrepsbruken som er anvendt ovenfor, viser også noe av skillet og avstanden mellom majoritetskirken Den norske kirke og de ikke-lutherske frikirkene. På denne tiden ble medlemmer av de ulike frikirkene nemlig kalt «dissentere». Dette var en betegnelse som hadde vært i det norske lovverket siden 1845, og var blitt et fast begrep i det norske språket. En dissenter var per definisjon et medlem av et ikke-luthersk kristent trossamfunn utenfor statskirken. I dag er termen «dissenter» anakronistisk. Offisielt heter det nå «trossamfunn eller menigheter utenfor Den norske kirke.» At heller ikke denne betegnelsen er like tilfredsstillende for alle som ikke er medlemmer av majoritetskirken, er en annen sak.

5 Om denne tidlige lovgivningen, se Seierstad, 1923; Rygnestad, 1955; Breistein, 2003.

6 Jf. Dissenterloven av 1845, \$9: «Børn, der ikke skulle opdrages i den evangelisk-lutherske Lære, kunne forlanges undtagne fra Underviisningen i denne i de offentlige Skoler, hvorimod Skole- 
gjaldt ikke for barn av foreldre som ville være ikke-religiøse. Dissentere kunne derimot generelt ikke bli lærere i folkeskolen før langt senere, nemlig etter vedtak i landsfolkeskoleloven i 1915 og byskoleloven i 1917, og i faget kristendomskunnskap først i 1969. Medlemmer av Den evangelisk lutherske frikirke, eller andre lutherske frikirker, fikk undervisningsrett i skolens kristendomsfag allerede i $1935 .^{8}$

I 1959 kom det en ny lov for folkeskolen. ${ }^{9}$ Undervisningen i kristendomskunnskap skulle fortsatt være etter «den evangelisk-lutherske truvedkjenninga» (\$7), og de som underviste i faget måtte være medlemmer av «statskyrkja eller eit religions-samfunn som har den same læra som statskyrkja» (\$15.3).

Ti år senere kom det enda en ny lov om grunnskolen, som nå var på god vei til å bli 9-årig. ${ }^{10}$ I målbeskrivelsen for kristendomsfaget sto det fortsatt at elevene skulle ha kjennskap til «... den kristne barnelærdommen etter den evangelisk-lutherske læra» (\$7.4). Og fortsatt skulle det være anledning til fritak fra undervisning i kristendomskunnskap for barn av foreldre som ikke var medlemmer av Den norske kirke. Men når det gjaldt lærerne, kom det inn en ny bestemmelse som åpnet opp for dissenterne: «Den som skal undervise i kristendomskunnskap må undervise i samsvar med den evangelisk-lutherske læra», men det ble presisert at lærere som ikke hørte til Den norske kirke eller Den evangelisk-lutherske frikirke, hadde ikke plikt til å undervise i dette faget selv om de hadde kompetanse til det (\$17.3). Det ble nå altså ikke lenger krevd at lærerne i faget skulle være medlemmer av Den norske kirke «eller eit religions-samfunn som har den same læra som statskyrkja.» Dermed ble det for første gang i norsk skolehistorie bestemt at også ikke-lutherske frikirkelige kunne undervise i skolens kristendomsfag, så sant de underviste i samsvar med den evangelisk-lutherske lære, men med en presisering om at de hadde ikke plikt til å ta på seg slik undervisning. Rett, men ikke plikt. Som en

bestyrelsen paa ethvert Sted har at paase, at Børnenes Underviisning ei heller i religiøs henseende forsømmes.»

7 Se her Breistein, 2003, s. 252-255.

8 Se Breistein, 2003, s. 253-255.

9 Se Lov om folkeskolen frå 10. april 1959. Med merknader, reglement og instruksar. Utgitt av Kyrkjeog undervisningsdepartementet. Oslo 1959.

Lov av 13. juni 1969 om grunnskolen (Grunnskolelova). 
erstatning for de elever som ble fritatt for undervisning i kristendomskunnskap, ble det nå etter hvert også utviklet et annet fag beregnet på disse. I Mønsterplanen av 1974 ble faget kalt «livssynsorientering», og i 1987 endret faget navn til «livssynsfag».

\section{Mer fra debatten om «Dissentere» som lærere i kristendomskunnskap}

Før lov av 13. juni 1969 om grunnskolen (grunnskolelova) kom gikk det for seg en debatt både i frikirkelige og i statskirkelige kretser om kristendomsundervisningen, og om ikke-lutheraneres muligheter til å delta i denne. ${ }^{11}$

Norges Dissenterting, ${ }^{12}$ som var blitt etablert i 1903, hadde allerede i 1906 kommet med en klar oppfordring til myndighetene:

Dissentertinget, som beklager at velskikkede lærerkrefter blant dissenterne av konfesjonelle grunner er utelukket fra ansettelse i folkeskolen, anser det høyst påkrevet at religionsundervisningen i folkeskolen anlegges med objektiv undervisning etter bibelen som lærebok, således at adgang åpnes også for dissentere til ansettelse som lærere i folkeskolen.

Oppfordringen førte ikke til noe da, men viste holdningen blant mange dissentere. Dissenterne fikk, som nevnt ovenfor, generell adgang til læreryrket noen år senere, men ikke til å undervise i kristendomsfaget. Dissentertinget drøftet problemkomplekset flere ganger, men uten videre resultat. Forslaget ovenfor opplevdes nok av mange som for radikalt.

I 1945 ba Dissentertinget om at ikke-lutheranere måtte få undervise i kristendomskunnskap dersom de ga en skriftlig erklæring om lojalitet i undervisningen overfor lærebøkene og den evangelisk-lutherske konfesjon. En slik løsning ble drøftet flere ganger i årene framover; i etterkant kan en undres over om ikke en slik løsning måtte føles som ydmykende for dem det gjaldt.

\footnotetext{
11 Se her Breistein, 2003, s. 348-379.

12 Se f.eks. Norges Dissenterting gjennem 30 år; Breistein, 2003, s. 142-177.
} 
Et eksempel på hvordan de øverste lederne i Den norske kirke (DnK) tenkte på denne tiden, kan vi finne i protokollen fra DnKs bispemøte i 1950. Der ga de klart uttrykk for at

Bispemøtet finner at den foreslåtte erklæring fra dissenterlærernes side overfor vår kirke ikke er forsvarlig eller verdig for noen av partene. Fremgangsmåten vil bære preg av at man setter vedkommende aspirant i en tvangssituasjon: Hvis han underskriver kan han få post, hvis ikke er veien stengt for ham. Å avgi eller motta en erklæring som i større eller mindre grad må være i motstrid med vedkommendes overbevisning, kan ikke ansees tilbørlig. ${ }^{13}$

Komiteinnstillingen om lov om trossamfunn, avgitt av Dissenterlovkomiteen av 1957 ${ }^{14}$ i 1962, ga uttrykk for at en burde kunne løse litt på problemet med å akseptere at endel kirkesamfunn sto så nær Den norske kirke at de burde kunne godtas. Komitéen tenkte her først og fremst på Metodistkirken, Det norske misjonsforbund og Guds Menighet Vegårshei. De mente også at De frie evangeliske forsamlinger, Baptistkirken og pinsevennene riktignok sto noe fjernere, men «Formodentlig vil det være riktig å godta også disse etter synet i vårt folk i dag.» Men de ville ikke at selve lovteksten skulle angi hvilke trossamfunn som skulle godtas, det måtte det være opp til Kongen å avgjøre. De ville altså ikke ha noe av at de enkelte lærere skulle avgi noen erklæring om lojalitet, men at trossamfunnet som sådant skulle godkjennes.

I det videre arbeidet ble det imidlertid foreslått flere endringer. ${ }^{15}$ Daværende domprost i Bergen, Per Lønning, som sterkt framholdt skolens kristendomsundervisning som DnKs dåpsundervisning, beskrev forslaget om å godkjenne lærere fra visse kirkesamfunn som absurd. Da kunne han mye heller tenke seg en ordning som lot den enkelte lærer avgi løfte om lojalt å gå inn i kirkens dåpsundervisning. ${ }^{16}$ Han kunne ikke tenke seg en ordning hvor alle lærere i faget skulle underskrive en slik lojalitetserklæring, men at de som ikke hadde medlemskap i DnK, enten en var dissenter eller ikke hadde medlemskap i noe trossamfunn, kunne få

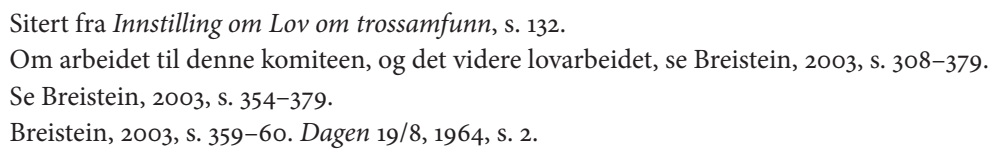


undervisningsrett ved å underskrive en slik lojalitetserklæring. ${ }^{17}$ Norges Frikirkeråd - tidligere Norges Dissenterting - ga i en uttalelse i desember 1967 sin tilslutning til det forslag til løsning på spørsmålet om dissenteres mulighet til å undervise i kristendomsfaget som Dissenterlovkomiteen av 1957 hadde satt fram, men de gikk sterkt imot at religionsundervisningen skulle betraktes som kirkens (=DnKs) sak. De kunne heller ikke godta at kristendomsfaget var Den norske kirkes dåpsundervisning. De godtok derimot, som en konsekvens av Grunnlovens paragraf 2, at undervisningen i faget skulle være konfesjonell. ${ }^{18}$

Ønsket om å la «dissentere» få adgang til skolens kristendomsundervisning hadde heller ikke stor oppslutning blant de lavkirkelige kristelige organisasjonene innen Den norske kirke (DnK); i alle fall ikke om en skal dømme etter en artikkel av Jon Kvalbein publisert så sent som i 1968, bare ett års tid før «Lov om trudomssamfunn og ymist anna», og den nye skoleloven kom. ${ }^{19}$ Kvalbein slo her innledningsvis fast at det var ingen borgerrett å være kristendomslærer. Kristendomsundervisningen var en del av DnKs dåpsopplæring: «Kristendomslæreren står ansvarlig overfor foreldrene, og er bærer av en kirkelig oppdragerfunksjon. Det er ingen borgerrett å utøve en kirkelig funksjon. Tvert imot må det være brudd på religionsfriheten å trenge seg inn i en annen kirkes indre anliggender.» Videre sa han at «Rammen om undervisningen i den lutherske tro må være klar. Vi tviler ikke på at flere dissenterlærere vil kunne åpne veien for en utvikling som vil svekke fagets karakter og innhold, og dermed imot dissenternes interesser - redusere den kristne påvirkning i vårt folk. $»^{20}$ De ulike forslag til løsning med ulike godkjennelsesformer mente han ville føre til spenninger som i det lange løp ville være uholdbare, og den konfesjonelle basis ville bli svekket. Norges Frikirkeråd hadde gitt uttrykk for at de ikke godtok at kristendomsundervisningen var DnKs dåpsundervisning; dette tolket han som et uttrykk for å svekke båndene mellom skole og kirke, «en utvikling som sikkert blir fremskyndet

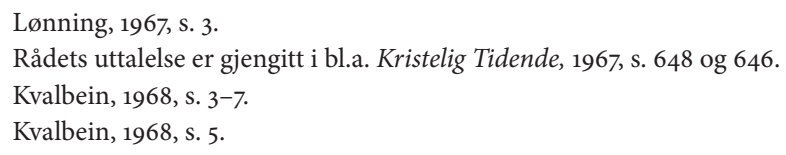


dersom dissenterne får adgang til å bli kristendomslærere. $\rangle^{21}$ Han synes også det var skremmende at det fra enkelte frikirkehold var blitt sagt at målet var en konfesjonsløs kristendomsundervisning, men her fant han å kunne støtte seg på lederne i DnK: «Ledere innen Den norske kirke har nesten enstemmig gått inn for å bevare den nåværende ordning. Denne ordning er ikke fullkommen. Men den er logisk. Den er i samsvar med kristendomsfagets konfesjonelle basis.»

Året etter kom de nye lovene. I det endelige arbeidet ble det gjort noen endringer. Spørsmålet om frikirkeliges rett til å undervise i kristendomskunnskap ble tatt ut av forslaget til Lov om trossamfunn og tatt inn i Grunnskoleloven. Dermed ble det slik at skoleloven av 1969 ga, som nevnt ovenfor, alle lærere - uansett kirkesamfunnstilhørighet eller ikke - rett til å undervise i kristendomskunnskap. Rett, men ikke plikt. Kvalbeins og andres restriktive syn ble nedstemt av Stortinget.

\section{Lov om Embetsmænds troesbekjendelse (1894)}

De som underviste i teologiske fag på Universitetsnivå skulle derimot også etter 1969 fortsatt være medlemmer av Den norske kirke. Bakgrunnen for dette lå i den gamle lovbestemmelsen fra 1880 om embetsmenns trosbekjennelse, ${ }^{22}$ lett justert 21. juli 1894:

Foruden Medlemmer af Kongens Raad og Dommere samt geistlige Embedsmænd, de under det theologiske Facultet hørende Universitetslærere og overhovedet Embedsmænd, hvem det påligger at give Undervisning i Kristendom, skal alle ved Folkeskolen eller til dens Fremme Ansatte Embedsmænd og Bestyrere av Skoler for den høiere Almendannelse bekjende sig til Statens offentlige Religion.

Kvalbein, 1968, s. 6.

Lov av 14. juni om Embedsmænds troesbekjendelse, \$1. Denne loven hadde sin bakgrunn i Grunnlovens $\$ 92$ om at alle embetsmenn måtte være medlemmer av statskirken. Se til dette Breistein, 2003, s. 83-85. 


\section{Dissenteren og universitetslæreren Peder Borgen som kasus}

Peder Johan Borgen (f. 1928) var metodist og tok teologisk embetseksamen ved Teologisk fakultet, Universitetet i Oslo, i 1953. Rett etter studiene hadde han søkt på forskningsstipend ved samme fakultet, men på grunn av at det lå undervisningsplikt til et slikt stipend, og han ikke tilhørte Den norske kirke, kunne han ikke bli tildelt slikt stipend. Han fikk imidlertid stipend fra Kirkenes Verdensråd og Metodistkirken, og i 1956 tok han en ph.d.-grad innen Det nye testamente ved Drew University i USA. Etter et par år som metodistprest i Harstad ble han stipendiat ved Norges allmennvitenskapelige forskningsråd $1958-62,{ }^{23}$ og ble dr.theol. ved Universitetet i Oslo i 1966 på en avhandling om Johannesevangeliet. På grunn av loven om Embedsmoends Troesbekjendelse kunne han derimot ikke få lærerstilling i teologi ved noe norsk lærested, og var i perioden 1962-66 professor ved Wesley Theological Seminary i Washington, USA. Mens han var der, søkte han i 1965 imidlertid på et nytt professorat i religionsvitenskap ved det nyopprettede religionsvitenskapelige instituttet ved Det historisk-filosofiske fakultet, Universitetet i Bergen. Det skulle også opprettes studietilbud i kristendomskunnskap der, og professoratet skulle danne faglig bakgrunn for dette. Vurderingskomiteen innstilte han som nr. 2 etter dr.theol. (og kort tid etter også dr.philos.) Alf Kragerud, som da fikk stillingen. Men også Borgen ble av komitéen vurdert kompetent som professor, og ble våren 1967 ansatt som universitetslektor og fikk kort tid etter opprykk som førstelektor. ${ }^{24}$ I det daglige arbeidet ved instituttet var det Borgen som hadde det praktiske hovedansvar for undervisningen i kristendomskunnskap, mens Kragerud underviste i religionsvitenskap. Den nye stillingen som ble utlyst i 1971, var en såkalt «åpen» stilling i kristendomskunnskap uten føringer for prioriterte fagområder, men de fleste regnet nok med at Borgen ville være både en aktuell og habil søker.

23 Han ble dr.theol. ved Universitetet i Oslo i 1966 på en avhandling om Johannesevangeliet (Bread from Heaven. An Exegetical Study of the Concept of Manna in the Gospel of John and the Writings of Philo. Supplements to Novum Testamentum Vol X. Leiden: Brill, 1965.)

24 Det har ikke lykkes meg å finne noen offentlig utlysning av denne stillingen; muligens skjedde ansettelsen ved en intern prosedyre. Det er i etterkant blitt påpekt av noen at denne ansettelsen egentlig var imot Lov om Embedsmænds Troesbekjendelse, men at Universitetet foretok ansettelsen som en liten test på Departementets holdning til denne loven. 


\section{Drøftinger om revisjon av Lov om Embedsmænds Troesbekjendelse}

Først i 1951 ble det for alvor tatt opp drøftinger om denne loven om Embedsmænds troesbekjendelse burde revideres med sikte på å fjerne unødvendig samvittighetstvang, men det gjaldt da primært de deler av loven som ikke angikk kirkelige saker og forhold. ${ }^{25}$ Departementet begrunnet dette nye revisjonsarbeidet med at «ingen offentlige eller kirkelige interesser er tjent med at embetsmenn som bare leilighetsvis i sin tjeneste får med kirkelige eller religiøse spørsmål å gjøre opprettholder sitt medlemskap i statskirken bare for å beholde sin stilling. $\|^{26}$ Det var altså bare annen halvdel av paragrafen som sto til debatt; her foreslo de at Kongen kunne gi dispensasjon. Men da departementet forela saken for biskopene, fikk de ikke mye medhold: Tre av biskopene frarådet endringer, fem var mer eller mindre positive i visse tilfeller, men bare for styrere av høyere allmennskoler, og kun én tilrådde full dispensasjonsadgang. Departementet fastholdt likevel sitt syn og satte fram forslag om at når det gjaldt embetsmenn under skolevesenet, kunne «Kongen i særlige tilfelle fravike denne bestemmelse når vedkommende ikke skal gi undervisning i kristendomskunnskap.» I det endelige resultatet av dette arbeidet, godkjent som lov 18. nov 1955, ble det i paragrafens siste ledd bestemt slik som foreslått av departementet at «for de foran nevnte embetsmenn og bestyrere (rektorer) under skolevesenet kan Kongen i særlige tilfelle fravike denne bestemmelse når vedkommende embetsmann ikke skal gi undervisning i kristendomskunnskap.» Men kravet om bekjennelse til «Statens offentlige religion» for universitetslærere eller «embetsmenn hvem der påligger å gi undervisning i folkeskolen» sto ikke til diskusjon, og ble ikke endret.

Men den diskusjonen kom i drøftelsene i og rundt Innstillingen om lov om trossamfunn, avgitt i 1962 av Dissenterlovkomitéen av 1957. Komitéen drøftet ulike synspunkter som var aktuelle helt på begynnelsen av 1960-tallet. I utgangspunktet fant den det naturlig at lærerne ved et teologisk fakultet hadde bekjennelsesplikt fordi deres vesentlige oppgave

\footnotetext{
25 Sakspapirene er tilgjengelig her: https://www.stortinget.no/no/Saker-og-publikasjoner/Stortingsforhandlinger/Saksside/?pid=1955-1961\&mtid=24\&vt=a\&did=DIVL23456

Odelstingsproposisjon nr. 64 (1954), s. 4.
} 
var å utdanne prester for statskirken. Fakultetet ble også brukt som høringsinstans av Kirkedepartementet i teologiske spørsmål, og professorene deltok i avstemningen foran bispevalg, noe som igjen forutsatte at de var medlemmer av statskirken. Komitéen mente derfor at det «etter forholdene hos oss ville være lite hensiktsmessig å sløyfe eller dempe bekjennelseskravet. Det må i og for seg være en rimelig ting at et trossamfunn får utdannet sine prester av lærere som deler samfunnets tro og bekjennelse. $\gg^{27}$

Komitéen mente videre at dette dreide seg primært om Universitetet i Oslo; for Bergen var spørsmålet ikke aktuelt fordi man der ikke hadde noe teologisk fakultet «og så vidt en kjenner til ikke regner med å få det i noen overskuelig fremtid.» Den "profetien» har for så vidt slått til, men "problemet» skulle senere vise seg å bli aktuelt i Bergen på en måte som en ikke forutså i årene fram til 1962.

Når det gjaldt undervisningen i kristendomskunnskap, så mente komitéen at saklig sett ville det ha vært naturlig om denne undervisningen var lagt til Det teologiske fakultet, og ikke som da til Det historiskfilosofiske fakultet ved Universitetet i Oslo (som da var det eneste aktuelle studiestedet i dette faget). Der var imidlertid verken den ene professoren som var ansatt der (H. Ludin Jansen), eller fakultetslektoren pålagt noen bekjennelsesplikt. Og de mente at det burde heller ikke komme på tale å underlegge professoren i alminnelig religionshistorie noen bekjennelsesplikt. Annerledes kunne det kanskje stille seg med universitetslektorer, men komiteens flertall fant at «hensynet til prinsippet om bekjennelsesfri virksomhet ved universitetets historisk-filosofiske fakultet må veie tyngst, og vil derfor ikke fremme forslag om å ta stillingen som universitetslektor i kristendomskunnskap med blant dem som er bekjennelsesbundet. ${ }^{28}$

Komitéen kom imidlertid også med noen vurderinger som en i ettertid kan mene ikke var særlig oppdaterte eller velinformerte. Komitéen ga her nemlig uttrykk for at de mente spørsmålet om behov for bekjennelsesplikt

27 Innstilling om Lov om trossamfunn, s. 142.

28 Innstilling om Lov om trossamfunn, s. 143. Dette gikk også metodisten Ragnar Horn og pinsevennen Martin Ski i komiteen inn for. Biskop Johannes Smidt dissenterte imidlertid, og mente at universitetslærere i kristendomskunnskap generelt burde være underlagt en bekjennelsesplikt fordi mellomfaget i kristendomskunnskap var så viktig for kvalifisering til undervisning i faget i den høyere skolen. 
for øvrig var mer av teoretisk enn av praktisk betydning: Stillingen som universitetslektor ville bare kunne besettes med en teolog; ved Menighetsfakultetet hadde bare lutheranere adgang, og ved Teologisk fakultet (TF) var det sjelden at noen studerte som ikke var medlem av statskirken. Komitéen uttalte derfor at

Det er liten mulighet for at noen som ikke er medlem av statskirken, skulle komme til å søke, og det ville for ansettelsesmyndigheten ikke være noen grunn til å ta noen utenfor statskirken. Det bør åpenbart heller ikke gjøres; å vedta lovbestemmelse for å hindre det, kan ikke være nødvendig. ${ }^{29}$

Men hva skjedde? Tre år senere (1965) søkte en «dissenter», metodisten Peder Borgen, på et nyopprettet professorat i religionsvitenskap ved Universitetet i Bergen; han ble innstilt som nr. 2 og fikk dermed ikke stillingen, men var ikke et ukjent navn i kirkelige kretser. Alle medlemmene i komiteen, inkludert metodisten Ragnar Horn, Oslo, kunne da ikke være ukjente med denne Borgen?30 Og hva tenkte de egentlig om nytten av kompetansekravene? Skulle de bare oversees og fravikes dersom en søker var kompetent, men «dissenter», slik at en lutheraner skulle gå foran uansett? Komitéen la ikke noen videre føringer, så her var det noen standpunkter som trengte videre drøftelse.

Og drøfting ble det, ikke minst da det i 1970 ble lyst ut et nytt professorat i kristendomskunnskap ved Religionsvitenskapelig institutt, Universitetet i Bergen.

\section{Nytt professorat i kristendomskunnskap i Bergen utlyses med klausul}

I 1970 søkte katolikken Kari E. Børresen (1932-2016) et dosentur i kristendommens idehistorie ved Teologisk fakultet, Universitetet i Oslo, men hun ble nektet bedømmelse under henvisning til loven fra 1894 om

29 Innstilling om Lov om trossamfunn, s. 144.

30 Det samme må en kunne si om pinsevennen Martin Ski, og professor Einar Molland, en av Peder Borgens lærere ved Teologisk fakultet som Peder hadde hatt mest kontakt med både i og etter studietiden. 
Embedsmoends Troesbekjendelse. ${ }^{31}$ Samme år opprettet Stortinget et nytt professorat i kristendomskunnskap ved Universitetet i Bergen, med virkning fra 1. juli 1971. Men forbauselsen var stor da utlysningsteksten kom på trykk 28. desember 1970 i Norsk Lysingsblad, for der hadde teksten fått et tillegg. Departementet hadde da nemlig funnet fram den gamle loven fra 1894, og lagt inn følgende bestemmelse i utlysningsteksten: «Innehaveren av embetet må bekjenne seg til Statens offentlige religion. Jf. Lov 21. juli 1894 om Embedsmænds Troesbekjendelse.»32 I denne loven fra 1894 sto det som nevnt ovenfor nemlig at «de under det theologiske Facultet hørende Universitetslærere og overhovedet Embedsmænd, hvem det påligger at give Undervisning i Kristendom, skal ... bekjende sig til Statens offentlige Religion.»

Saken vakte stor oppsikt i universitetsmiljøene, men også utover disse, og debatten ble preget av to forhold: for det første, spørsmålet om hvorfor denne bestemmelsen ble tatt i bruk nå, og ikke i 1965? Og for det andre, saken ble preget av det faktum at det allerede var en «dissenter» ansatt ved fakultetet som universitetslektor, og som ble betraktet som meget habil faglig sett og sannsynlig søker til stillingen. Denne universitetslektoren var metodisten Peder Johan Borgen. I tillegg spilte nok noen andre lokale faktorer inn i vestlandsbyen Bergen.

\section{Et ubesvart spørsmål?}

Hvorfor ble da denne gamle bestemmelsen fra 1894 tatt med i denne nye utlysningen for Bergen? Kunne det ha sin grunn i at det var en «dissenter» i lærerkollegiet i Bergen som ble betraktet som potensiell søker, eller var der andre årsaker? Ved henvendelser til departementet fikk en ikke noe klart svar på hvorfor de hadde satt inn denne klausulen, bare en henvisning til at «det ikke er noe spesielt ved denne sak, og at hele kunngjøringen er i samsvar med norsk lov.»33 Departementet hadde for så vidt

31 Hun fikk sine papirer i retur i uåpnet tilstand. Se også Borgen, 2004, s. 269-280, Børresen er omtalt s. 277; Også trykt i Borgen, 2009, s. 169-187. Se også Hafstad, 2008, s. 179-196. Hafstad kaller den nye loven som kom i 1972 for 'Lex Børresen', men 'Lex Borgen' ble brukt i Bergen. Se Norsk Lysingsblad nr. 301 - 88. årgang, 28. desember 1970, s. 1. 
rett i det, og som vi har gjort rede for ovenfor, hadde Dissenterlovkomiteen av 1955 i sin innstilling i 1962 heller ikke gått inn for å forandre denne delen av den gamle loven.

Men i mellomtiden var Skoleloven av 1969 kommet, og den ga ikke-lutheranere rett til å undervise i kristendomskunnskap i grunnskolen. I etterkant kan en kanskje si at Stortinget som den lovgivende forsamling «hadde glemt» å oppdatere den tilsvarende loven som gjaldt for embetsmenn som underviste i kristendomskunnskap. Men Dissenterlovkomiteen hadde jo på sin side gitt uttrykk for at det helst var et teoretisk spørsmål om noen ikke-lutheranere skulle finne på å søke på en slik stilling ved et universitet.

Men ser en nærmere etter, er det grunn til å tro at Børresen-saken ved Teologisk fakultet tidligere samme år hadde minnet departementet om den gamle loven fra 1894. Det var nemlig så sent som både i februar og i november 1970 blitt reist spørsmål i Stortinget om denne loven. 18. februar stilte representanten Berte Rognerud (H) følgende spørsmål til kirke- og undervisningsministeren: «Vil departementet ta skritt til å følge opp den endring i lov om grunnskolen som frafaller krav om bekjennelsesplikt for lærere til også å omfatte høyere undervisning, inklusive universitetsnivå?» Statsråd Kjell Bondevik $(\mathrm{KrF})$ svarte at spørsmålet var såpass vidtfavnende at departementet måtte arbeide videre med det før de kunne gi noe bindende svar. Rognerud fulgt opp med å spørre om ikke statsråden fant det rimelig at de samme retningslinjer som en hadde i den elementære skolen også burde gjelde for «lærere i de høyere undervisningsinstitusjoner», og Bondevik svarte bekreftende på det. ${ }^{34}$

11. november kom Berte Rognerud tilbake til spørsmålet om Lov om Embedsmænds Troesbekjendelse..$^{35}$ Kari Børresen hadde nemlig selv nå vært i kontakt med Rognerud og forelagt sin sak for henne. ${ }^{36}$ Rognerud hadde dermed fătt del i mer bakgrunnsinformasjon og refererte nå direkte både til Kari E. Børresen-saken, og til Peder Borgen:

\footnotetext{
Stortingstidende. Forhandlinger i Stortinget nr. 220, s. 1833-34. Stortingstidende. Tema: Kirker og geistlighet (Storting 1970/71), s. 678-68o.

Børresen refererer selv til en slik kontakt med Rognerud i brev av 13.4.20oo til Det teologiske fakultet i Oslo. Kopi av brev i Borgen samlingen, Nasjonalbiblioteket.
} 
En søker til det utlyste dosentur i Kristendommens idehistorie ved Det teologiske fakultet, Universitetet i Oslo, er blitt nektet bedømmelse under henvisning til Lov av 1894 om Embedsmænds Troesbekjendelse.

Vil departementet på bakgrunn av at Stortinget har opphevet bekjennelsesplikten for lærere i kristendomskunnskap i grunnskolen, foreslå at bekjennelsesplikten bortfaller også på universitetsnivå?

Rognerud viste i sitt innlegg videre til at under arbeidet med Lov om trossamfunn ble det gitt uttrykk for at kirkedepartementet ville fremme forslag til nye bestemmelser på dette området også i de forskjellige skole- og universitetslover. Statsråd Bondevik sa seg igjen langt på vei enig med Rognerud, men framholdt at en trengte tid med dette arbeidet; det var tross alt ikke så lenge siden Lov om Trudomssamfunn og ymist anna og den nye grunnskoleloven hadde kommet, og sistnevnte var faktisk ennå ikke trådt i kraft, og det ville heller ikke skje før om ca. et års tid.

Rognerud fulgte opp også dette svaret, og viste til at lærerstillinger ved de historisk-filosofiske fakultetene i Oslo og Bergen ikke er underlagt bekjennelsesplikt til tross for at loven fra 1894 i \$1, nr. 1 bestemmer «og overhodet embetsmenn, hvem det påligger å gi undervisning i kristendomskunnskap.» Og så kom hun med en direkte henvisning til Peder Borgen i Bergen (men uten å nevne navn):

En metodist studerte teologi ved det teologiske fakultet i Oslo. Som metodist kunne han ikke få bli stipendiat fordi det var belagt med undervisningsplikt. Men han kunne ta - og tok sin teologiske doktorgrad. Han har nu en lærerstilling i kristendomskunnskap ved Universitetet i Bergen. I Oslo søker en forhenværende dominikanermunk ${ }^{37}$ det ledige dosentur i kristendomskunnskap. Vedkommende er også underkastet bedømmelse uten at det har vært spørsmål om overenstemmelse med loven.

Bondevik svarte at departementet var klar over at det kunne være ulike regler for ulike fakultet, men at det på basis av loven fra 1894 ikke kunne dispenseres for lærere ved Teologisk fakultet.

37 Dette var antagelig Edvard D. Vogt (1923-2016). Jf. Lars Mjøsets beskrivelse av ham her: https:// sosiologen.no/essay/nekrolog/katolsk-prest-oikos-stifter-og-banebrytende-sosiolog/ 
På basis av denne diskusjonen i Stortinget må det være grunnlag for å si at her ligger hovedårsaken til at departementet satte inn den ovennevnte klausul i utlysningen for den nye stillingen i Bergen. De jobbet med saken, den hadde vært luftet i Stortinget, og de kjente til både Kari Børresen-saken og til metodisten i Bergen, Peder Borgen. De kunne dermed ikke unngå den gamle loven fra 1894 når utlysningen for den nye stillingen skulle lages.

Universitetet i Bergen var deretter tidlig i kontakt med Departementet, og henstilte til dette allerede i begynnelsen av januar om å trekke utlysningen, og ba departementet om å få til en endring i lov om embetsmenns trosbekjennelse slik at det ikke ble stilt andre krav til professorer enn til andre grupper av lærere i kristendomskunnskap ved universitetet. Universitetslektorer hadde nemlig ikke noe slikt krav over seg. Men før departementet kom så langt, hadde også representanten Tove Pihl (A) reist spørsmål i Stortinget 20. jan. 1971 om trekking av utlysningen. ${ }^{38}$ «Grunnen til at jeg har reist dette spørsmålet», sa hun til avisen Dagen, «er at jeg ser det som urimelig å opprettholde bekjennelsesplikten ved de høyere læreanstalter når den er avskaffet i den obligatoriske skole.. $\aleph^{39}$ Departementet presiserte i sitt svar at Universitetet i Bergen hadde bedt om at departementet trakk tilbake utlysningen, og utsatte saken til spørsmålet om lovendring var avgjort, ${ }^{40}$ og at det ville bli gjort.

Departementet trakk da også utlysningen tilbake allerede i slutten av januar 1971, og arbeidet med en lovendring fikk hurtigtogsfart.

\section{Debatt på Vestlandet om embetsmenns trosbekjennelse}

Allerede tidlig i januar 1971 kom debatten i gang i avisspaltene. 8. januar hadde Dagen et intervju med Per Lønning, ${ }^{41}$ da biskop i Borg, og han la

\footnotetext{
38 Stortingstidende. Tema: Embets- og tjenestemenn (Storting 1970/71), s. 1887-1888.

39 «En lov som har overlevd seg selv», Dagen, 19. jan. 1971, s. 1 og 4.

40 Bondevik opplyste i svaret til Tove Pihl også at «Seinare har Universitetet i Bergen opplyst at det var klår over at det ikkje kunne utnemnast nokon som ikkje står i statskyrkja, men Universitetet rekna med at vedkjenningskravet ville verte teke bort før ein kom så langt. Ei slik framgangsmåte ville vere uvanleg, for departementet kan ikkje på førehand vite kva Stortinget vil gjere av lovendringar.» Per Lønning (1928-2016), var domprost i Bergen 1964-1969; i 1969 ble han Biskop i Borg. I sin tid som domprost hadde han hatt kontakt med den jevngamle Peder Borgen både som universitetslærer og som aktiv metodist og som aktiv i økumenisk arbeid i Bergen.
} 
bredsiden til: «Kirken vinner bare en Pyrrhos-seier!» I denne saken har kirken alt å tape, intet å vinne, sa han: «Jeg for min del mener at dersom loven utvetydig må tolkes slik at det er nødvendig med et slikt konfesjonskrav, da er vi nødt til å endre loven. $»^{42}$ Subsidiært mente han at en kunne kanskje ha definert stillingen slik den ikke kom i strid med loven. Og så kom han med en uforbeholden støtte til Peder Borgen, som han nok regnet med var aktuell som søker:

I dette tilfellet må det virke desto mer provoserende siden alle sammen vet at den som har hatt ansvaret for denne gren av undervisningen helt fra det startet, tilhører et annet kirkesamfunn, og dermed får saken en ekstra brodd mot vedkommende person, hvis kvalifikasjoner jeg ikke har hørt noen trekke i tvil.

Lønning avslutter med å uttrykke sin undring over at frikirkelige lærere får lov å undervise i kristendomskunnskap i folkeskolen for 7 år gamle barn, mens vi ikke våger «å slippe dem til på voksne, selvstendige mennesker.»

Noen dager senere kom også Lønnings etterfølger som domprost i Bergen, Hans Høivik, på banen. Han poengterte at loven er der, og gir departementet dekning for sitt krav, men mente ellers at det hadde skjedd «mangt og meget» i de vel sytti årene siden 1894. Det var et annet klima på det kirkelige og religiøse plan, og «jeg mener det er helt riktig av departementet å ta dette spørsmålet opp til revurdering.» ${ }^{43}$ Høivik ga også støtte til argumentet som viste til den nye skoleloven, og til at professoratet lå under Det historisk-filosofiske fakultet. I tillegg pekte han på at det ble ikke stilt noe krav om kirketilhørighet ved utlysningen av et tilsvarende professorat i Trondheim i $1963 .{ }^{44}$

Jf. «Lønning mot 'tros-professor': Kirken vinner bare en Pyrrhos-seier!» Dagen, fredag 8. januar 1971, s. 1 og 8. Delvis gjengitt i Dagbladet (9. jan. 1971, s. 2) under overskriften «Utlysningen virker meget provoserende».

43 Intervju i Dagen, 16. jan 1971, s. 1 og 16.

44 Norges Lærerhøgskole i Trondheim (NLHT) ble dannet i 1922. I 1963 ble det utlyst et professorat i religionsvitenskap, med særlig vekt på kristendomskunnskap, og teologen dr.theol. Åge Holter ble ansatt av Lærerhøgskolens råd som professor i 1964. Universitetet i Trondheim ble opprettet ved stortingsvedtak i 1968. Da ble tre tidligere selvstendige institusjoner innlemmet i det nye universitetet: Norges lærerhøgskole, Norges tekniske høgskole og Det Kongelige Norske Videnskabers Selskab, Museet. Se nærmere om dette i Almås og Rian 1998. 
Men, presiserte Høivik, kirken bør likevel være våken. Av den som tilsettes måtte det kunne forlanges at han førte en undervisning som var i overenstemmelse «med kirkens lære og som kirken kan være tjent med.» Han tenkte seg her altså en undervisning som liksom undervisningen i grunnskolen var konfesjonelt bundet. Men ikke professoren som sådan. Og så la han til:

Når det gjelder den aktuelle situasjon med universitetslektor Peder Borgen som professorkandidat, føler jeg meg helt trygg på at kirkens interesser vil bli ivaretatt på den beste måte under hans ledelse.

Det avtegnet seg altså en argumentasjon som knyttes primært til to ting: den nye skolelovens åpning overfor ikke-lutheranere og de endrede samfunnsforhold. I tillegg skjønner en ikke helt hvorfor denne henvisningen til loven av 1894 måtte komme nå, og både Lønning og Høivik er nærmest brydd over at det rammet en person som allerede hadde hatt ansvar for kristendomsfaget i flere år.

Avisen Dagbladet gjenga ikke bare deler av Dagens intervju med Per Lønning, men fulgte opp samme dag med en lett indignert lederartikkel: «Vekk med bekjennelsesplikten.» ${ }^{45}$ Her gir de uttrykk for at «denne loven forekommer oss å være fullstendig overflødig og uten mening i våre dager.» Som argument viste de også til den nye skoleloven, og til de få stillinger som det måtte være aktuelt å opprettholde et slikt krav for; de geistlige embetsmenn (prestene) kunne, for eksempel, få dette fastlagt $\mathrm{i}$ lov om Den norske kirke. I en generell lov om embetsmenn hørte det ikke hjemme, mente avisens leder. Dagbladet støttet seg her også på synspunkter som tidligere stortingsmann Olav Kortner fremmet annet sted i samme avis. ${ }^{46}$

Debatten i Bergen ble også til en viss grad preget av den diskusjonen som hadde gått en stund tidligere om opprettelsen av Norsk Lærerakademi (NLA), og dets søknad om eksamensrett. Der hadde Det historisk-filosofiske fakultet ved Universitetet i Bergen frontet det standpunkt at de ikke kunne tilrå at eksamen fra Norsk Lærerakademi ble godkjent

\footnotetext{
45 «Vekk med bekjennelsesplikten», Dagbladet, 9. jan. 1971, s. 3.

46 «Loven bør oppheves», Dagbladet, 9. jan. 1971, s. 2 (intervju). 
som del av cand.mag.- eller cand.philol.-eksamen fordi akademiets krav om konfesjonsplikt for lærerne stred mot fakultetets prinsipper. Peder Borgen hadde på oppfordring levert en betenkning til fakultetet i denne saken. Han hadde imidlertid ikke fremmet en slik konklusjon, men pekt på visse faglige kriterier som burde bli oppfylt. ${ }^{47}$ Det er ikke helt enkelt å finne svar nå lenger på hvorfor fakultetet havnet på et standpunkt som gikk såpass utover Borgens betenkning. Men det er grunn til å tro at de knyttet spørsmålet om «fri forskning» til spørsmålet om frihet fra konfesjonsplikt også her. ${ }^{48}$

Vi får et inntrykk av hvordan en tenkte i de kretser som sto Lærerakademiet i Bergen nær, om en leser et innlegg professor Carl Fr. Wisløff skrev i Dagen allerede 10. mai 1967.49 Wisløff ga uttrykk for sin skepsis til at utdanningstilbudet i kristendomskunnskap var lagt til «universiteter og høyskoler.» Dermed hadde det kommet midt inn i «de teologiske brytninger» som da karakteriserte situasjonen, mente han, og som han karakteriserte som «svært vanskelige». Wisløff innrømmet at «Ingen vil nekte at det er mulig, for en akademisk lærer som har forutsetninger for det, å gi bekjennelsestro undervisning innen rammen av et universitetsinstitutt.» Men den totale situasjonen, mente han, var nå likevel slik at den kalte på en ny innsats. Og så pekte han på det nyopprettede instituttet ved Universitetet i Bergen, og la til:

Vi kan tenke på hvordan stillingen blir ved universitetet i Bergen. Den nye professor i religionsvitenskap er kjent for å innta radikale posisjoner. En nylig ansatt lektor hører til metodistkirken, en timelærer er katolsk prest. - Det er klart

Brev med «Uttalelse i anledning søknad fra Norsk Lærerakademi for kristendomsstudium og pedagogikk om godkjenning av eksamen i kristendomskunnskap på grunnfags- og mellomfagsnivå», datert 9. nov. 1970, til Det historisk-filosofiske fakultet.

48 Norsk Lærerakademi, som ble opprettet i 1968, fikk sin eksamensrett godkjent av departementet våren 1971, og da ikke minst på basis av at Norges Lærerhøgskole i Trondheim godkjente søknaden. Departementet utnyttet dermed uenigheten hos de faglige instansene. Det hører også med til saken at dette var den siste embetshandlingen statsråd Kjell Bondevik foretok før Borten-regjeringen måtte gå av 17. mars 1971 og Arbeiderpartiet overtok makten med Trygve Bratteli som statsminister, og Bjartmar Gjerde som Kirke- og undervisningsminister. Vedtaket ble sterkt kritisert i noen kretser, jf. bl.a. en artikkel i Arbeiderbladet 17. mars 1971 (s. 26): «Kjell Bondevik pådrar seg sluttstrid. Trumfet gjennom politisk sak etter avskjedssøknad». Se også Helland \& Jøssang, 2018. Carl. Fr. Wisløff, «NLA - en ny og viktig skanse», Dagen, onsdag 10. mai 1967, s. 2. 
at de som har som ideal at undervisningen skal svare til, og bygge på, vår kirkes bekjennelse og barnelærdom, ikke kan føle seg tilfreds med en slik situasjon.

Wisløff var en «høvding» blant det lavkirkelige lekfolk på denne tiden, og hans røst ble hørt, ikke minst på Vestlandet.50 Hans lavkirkelige holdning førte til at selv om han var ansatt ved Menighetsfakultetet, så støttet han heller Norsk Lærerakademi enn det nyopprettede institutt for kristendomskunnskap ved sin egen institusjon. ${ }^{11}$

Men det var også flere på Vestlandet som ytret sterke synspunkter i professor-saken, og som fremdeles var harme på at Det historiskfilosofiske fakultet ved Universitetet i Bergen hadde gått imot å godkjenne eksamen ved Norsk lærerakademi fordi de der hadde konfesjonsforpliktelse på sine lærere. Avisen Dagen kom her på banen igjen og kommenterte dette på lederplass..$^{22}$

Dagen gjentar her sitt standpunkt om at NLA står i en god norsk tradisjon: «Fordi kyrkja er luthersk, skal også kristendomsopplæringi i den offentlige skulen vera luthersk. Men når lærarane skal undervisa i lutherdom, må lærarutdanningi vera luthersk.» Dagens artikkel er nok preget av at den ikke hadde forstått eller ikke tok hensyn til at grunnskolens kristendomsundervisning ikke lenger var å betrakte som DnKs dåpsundervisning. ${ }^{53}$ Det tok også lang tid før denne oppfatningen ble tatt på alvor innen Den norske kirke. ${ }^{54}$

Men Dagen ytret samtidig en viss forståelse for at Universitetet i Bergen aksjonerte på vegne av et professorat som lå under Det historiskfilosofiske fakultetet. Men avisen hadde ikke syn for det argumentet at når ikke-lutheranere kunne undervise barn, måtte de også kunne undervise voksne i kristendomskunnskap, for faget har jo «vedkjenningsplikt». Den ordningen mente Dagen var «slett som lovgivningsprinsipp og

\footnotetext{
50 Jf. Sjaastad, 2016.

51 Slik Mogstad, 2008, s. 206.

52 «NLA og vedkjenningi». Dagen, 13. januar 1971, s. 3. Se også Bernh. Rønhovde, 1971.

53 Kirke- og undervisningskomiteen hadde nemlig uttalt at «Kirken har regnet kristendomsundervisningen i skolen som en del av sin dåpsopplæring. Komiteen vil i denne sammenheng presisere at kirken selv har ansvar for å gi dåpsundervisning i kirkelig forstand.» og mente dermed at Den norske kirke nok kan betrakte skolens kristendomsundervisning som dåpsundervisning, men at det er kirkens syn, ikke skolens. Breistein, 2003, s. 374-376. 
mykje tvilsam som etisk prinsipp.» For en kunne vel ikke mene at «ein ikkje-luthersk professor skal ha vedkjenningsplikt so lenge han står på katetret?»

Her hadde Dagen for noen et poeng, for bestemmelsen av 1894 angikk jo embetsmennenes/lærernes kirketilhørighet, altså et konfesjonskrav, og ikke krav om det var tilstrekkelig at undervisningen var i samsvar med den lutherske bekjennelse slik skoleloven av 1969 anga for lærerne i folkeskolen. Men det var den løsningen departementet kom fram til. En rekke aviser kommenterte saken i 1971, og mange uttalte seg for en revisjon.

Departementet startet - som nevnt ovenfor - ganske raskt sitt arbeid med en gjennomgang av embetsmannsloven fra 1894. Men det forsinket nok arbeidet ved at det ble regjeringsskifte på denne tiden, og Kjell Bondevik (KrF) ble 17. mars 1971 avløst av Bjartmar Gjerde (A) som kirke- og undervisningsminister. Bjartmar Gjerde opplyste imidlertid til Bergens Tidende allerede 28. april at de regnet med et endringsforslag som kunne bli behandlet av Stortinget i vårsesjonen. 14. mai ble det fremmet en odelstingsproposisjon ${ }^{55}$ som foreslo en særskilt lov som skulle regulere forholdene med hensyn til kristendomsfaget i høyere utdanning. Dette skjedde stort sett uten protester, men professorrådet ved Menighetsfakultetet protesterte på saksgangen ved å hevde ${ }^{56}$ at odelstingsproposisjonen var oversendt Stortinget «uten at det på forhånd er innhentet uttalelser fra de instanser som ellers pleier å uttale seg om saker av denne art, bl.a. biskopene og de teologiske fakulteter», og ba departementet trekke proposisjonen og innhente slike uttalelser. Departementet hevdet imidlertid i sitt svar at de mente at forberedelsene hadde skjedd på vanlig måte, at saken var godt belyst og at de ikke så noen grunn til å trekke den tilbake. Men departement og storting rakk ikke å sluttføre saken i vårsesjonen.

Det var flere grupperinger ved $\mathrm{UiB}$ som var i kontakt med de relevante myndighetene i Oslo. Universitetsledelsen i Bergen hadde konferanser med medlemmer av Stortinget og Regjeringen. Kristendomsstudentene ved instituttet engasjerte seg også både fordi de gjerne ville ha Borgen som professor, og fordi de så at det nye professoratet hadde betydning for

\footnotetext{
55 Ot. prp. nr. 62 (1970-71). Se https://stortinget.no/no/Saker-og-publikasjoner/Stortingsforhandlinger/Lesevisning/?p=1970-71\&paid=4\&wid=b\&psid=DIVL587\&pgid=b_1086 
hovedfaget i kristendom som var under oppbygging, og ville styrke dette. En gruppe av studentene, bl.a. Jorunn Ubostad og Birger Taranger, reiste til Oslo for å legge fram sin versjon av saken for departementet. De møtte ikke statsråden, men fikk snakke med ansatte på lavere nivå som arbeidet med saken. Der fikk de det inntrykk at denne saken egentlig var kurant, men det var likevel noen juridiske og forvaltningsmessige prosedyrer som måtte følges i den videre behandlingen..$^{57}$ Peder Borgen engasjerte seg også direkte i saken, og han var selv invitert til en samtale i Stortinget i Oslo. Han var også i direkte brevveksling med enkelte stortingsrepresentanter om saken, og hadde samtaler med bl.a. Per Karstensen (A), som var formann i Kirke- og undervisningskomiteen, og stortingsrepresentantene Lars Roar Langslet $(\mathrm{H})^{58}$ og Olav Totland (A).

For Borgen personlig hadde nok denne saken minst en dobbel bunn: For det første gjaldt det de frikirkeliges rettigheter til å få undervise i kristendomskunnskap/teologi helt til topps i det norske utdanningssystemet. Det var en kamp mot en diskriminering han hadde møtt selv helt siden han søkte på videre forskningsmuligheter etter teologistudiet. For det andre så gjaldt det en mulighet for ham personlig til å rykke opp i det norske utdanningssystemet. Ved vurderingen til professoratet i Bergen i 1967 hadde han fått professorkompetanse, men var fortsatt i stilling som førstelektor. På denne tiden hadde ikke førstelektorer eller andre adgang til å søke om "personlig opprykk» som professor. ${ }^{59}$ Dermed var det bare ved ansettelse $i$ en professorstilling - $i$ et professorat - at en kunne få tittel, rettigheter og plikter som professor. Og i Norge var det ikke mange professorater i Det nye testamentet på denne tiden. Ser en bort fra Menighetsfakultetet, var det to slike professorater ved Teologisk fakultet, men de var forbeholdt lutheranere. Dermed var etableringen av et nytt professorat i Kristendomskunnskap i Bergen en stor mulighet for Borgen. Selv om det var relativt «åpent» - kristendomskunnskap er et stort fagfelt var det naturlig at han som nytestamentlig teolog primært ville få dette

57 Fortalt av Jorunn Ubostad (1943-) i telefonsamtale 7. mai 2019. Hun kunne dessverre ikke lenger datere turen til Oslo.

58 Katolikken L. R. Langslet skrev allerede i 1967 en artikkel om bekjennelsesplikten: jf. Langslet, 1967, s. 456-462. Men denne artikkelen gjaldt primært gjaldt forholdet ved Universitetet i Oslo. Det var en rettighet som kom først på slutten av 1990-tallet. 
som sitt fagfelt. Men det var samtidig åpent nok til at personer med annen spesialisering innen faget kunne søke.

Det gikk imidlertid ikke så fort med denne lovendringen som først tenkt. På et møte i fakultetsrådet ved historisk-filosofisk fakultet 8. juni 1971 ble det vedtatt at dekanus skulle prøve å få til en avklaring om hvordan det lå an med ny utlysning av professoratet. En hadde da et håp om at det var mulig å foreta utlysning etter at proposisjonen hadde passert statsråd. ${ }^{60}$ Det viste seg at den muligheten ikke var reell, og dekanus Knut Erik Tranøy informerte Peder Borgen i brev av 1. juli samme år om at saken måtte stilles i bero. Det ville i praksis si: å vente til saken hadde gått igjennom de nødvendige instanser til full godkjennelse og sanksjon. Det var nok heller ikke alle på instituttet og fakultetet som var like ivrige etter å få en professor i kristendomskunnskap. Det var spenninger imellom religionsviterne og de som drev kristendomsfaget. Ved instituttets 50-årsjubileum i 2017 skrev professor Einar Thomassen ${ }^{61} \mathrm{om}$ tiden etter etableringen av instituttet at «Årelang strid fulgte. Religionsviterne betraktet kristendomskunnskap som en gjøkunge i instituttreiret som ville dominere og fortrenge den genuine religionsvitenskapen. Det endte med en dramatisk skilsmisse i 1985, da de to fagene endte opp med hvert sitt institutt.» ${ }^{62} \mathrm{Og}$ det endte videre med at instituttet for kristendomsfaget ble lagt ned i 1991.

Men loven ble behandlet i løpet av høstsesjonen; den ble sanksjonert 17. des. 1971, og trådte i kraft 1. jan. 1972. ${ }^{63}$ Vedtaket innebar at den gamle loven fra 1894 ble opphevet, en del om krav om medlemskap i Den norske kirke for kirkelig tjenestemann og ombudsmann og lærer ved teologisk fakultet ble tatt inn i Lov om Den norske kirkes ordning, ${ }^{64}$ og en ny lov kom til om undervisning i kristendomskunnskap i høyere utdanning.

\footnotetext{
60 Brev fra dekanus Knut Erik Tranøy til Universitetsdirektøren, datert 09.06.71. Borgens privatarkiv.

61 Einar Thomassen (f. 1951) tok sin religionsvitenskapelige utdanning ved Universitetet i Bergen, og ble førsteamanuensis der i 1986, professor fra 1993.

62 Einar Thomassen, "50 år med religions-vitenskap i Bergen", Bergens Tidende, 26. okt. 2017, s. 46.

$63 \mathrm{Se}$ https://stortinget.no/no/Saker-og-publikasjoner/Stortingsforhandlinger/Saksside/?pid=197o1981\&mtid=110\&vt=b\&did=DIVL120287: Om 1. Lov om kristendomsundervisningen ved vidaregåande skole, høgskole og universitet. 2. Lov om brigde i lov av 29. april 1953 om Den norske kirkes ordning, om avskiping av lov av 21. juli 1894 om Embedsmænds Troesbekjendelse m.m. 
Den nye lovteksten sa at den som underviser i kristendomskunnskap ved statlig, fylkeskommunal eller kommunal videregående skole, høgskole eller universitet, «skal undervise i samsvar med den evangelisk-lutherske lære.» Den gamle bestemmelsen ble imidlertid fortsatt gjort gjeldende for Teologisk fakultet i Oslo, dog med en mulighet for dispensasjon fra Kongen. ${ }^{65}$ Men den knesatte ellers et tilsvarende prinsipp som det en hadde i grunnskolen, at en ikke-lutheraner plikter ikke å undervise selv om en er kompetent til det. Altså rett, men ikke plikt. Men det åpnet opp for at Borgen og andre kompetente «dissentere» kunne søke på og bli tilsatt i teologiske/kristendomsfaglige professorater i Norge. Dermed ble den gamle loven om «embedsmænds troesbekjendelse av 1894» oppløst og erstattet av denne nye loven. Uoffisielt i universitetsmiljøet i Bergen ble loven derfor en stund kalt «Lex Borgen».

Borgen selv reflekterer litt $i$ et privat notat over hva denne nye loven innebar for ham og andre likesinnedes undervisning i kristendomskunnskap i en universitets- og høyskolesammenheng: ${ }^{66}$

En rimelig tolkning av lovens ordlyd er at saklig, informativ undervisning i den lutherske konfesjon skal gis og at denne undervisning skal være slik at en lutheraner gjenkjenner den fremstilte lære som sin lære. Paragrafen forbyr ikke fri historisk bibelforskning, heller ikke saklig og forsvarlig fremstilling av ulike konfesjoner, av ulike livssyn eller av andre religioner. Forskningen berøres ikke.

Vi kunne karakterisere en slik tolkning som «ikke opplæring i, men undervisning om.» Kanskje ville ikke alle i 1972 være enige om at dette var en fyllestgjørende tolkning av «skal undervise i samsvar med den evangelisk-lutherske lære,» men den senere virkningshistorien har nok vist at det er denne religionsvitenskapelige tolkningen som er blitt stående.

65 Endringen i Lov 29. april $1953 \mathrm{nr}$. 1 (Lov om Den norske kirkes ordning) gjorde at $\$ 67$ fikk denne ordlyden: «Kirkelig tjenestemann og ombudsmann og lærer ved et teologisk fakultet skal være medlem av Den norske kirke. Kongen kan i særlige tilfelle dispensere fra kravet for lærer ved teologisk fakultet.» Denne dispensasjonsretten skal ha blitt satt inn ved en direkte inngripen av statsråd Bjartmar Gjerde helt på slutten av prosessen. Konfesjonsplikten ble altså ikke opphevet ved Teologisk fakultet ved Universitetet i Oslo. Dette fikk konsekvenser for katolikken Kari E. Børresen. Først i 2000 ble hun professor ved TF. 
Etter dette kunne professoratet i Bergen bli lyst ut på nytt uten den omdiskuterte klausulen; det skjedde med kunngjøring 4. februar, og med søknadsfrist 20. mars 1972. ${ }^{67}$ Vurderingskommisjonen satte søkerne Peder Borgen og Torgny Bohlin på delt førsteplass. Dermed ble det opp til fakultetet å foreta en prioritering for den videre innstillingen. Det historisk-filosofiske fakultetet oppnevnte en intern komite til å foreta den videre vurdering og innstilling til professoratet, og deres foreløpige vurdering forelå i april 1973, og den endelige 14. sept. samme år. Dette arbeidet tok tid, og det ble tydelig at det var en viss diskusjon innad på fakultetet om hvilken profil, og dermed hvilken person, en skulle prioritere.

I mellomtiden hadde det imidlertid også blitt utlyst et professorat i «Det nye testamente og dets omverden» ved Universitetet i Trondheim; Peder Borgen søkte og ble utnevnt til dette ved vedtak i statsråd 15. juni 1973, og tiltrådte i september samme år. Han ble dermed den første ikke-lutheraner som ble professor i kristendomskunnskap/teologi i Norge. Etter dette trakk han seg som søker til stillingen i Bergen. Dermed ble svensken Torgny Bohlin utnevnt til det ledige professoratet der av Kongen i statsråd 9. nov. 1973.

\section{Oppsummering}

Den såkalte Dissenterloven av 1845 anerkjente at ikke-lutheranere - i datidens sjargong «dissentere» - kunne drive kirkelig virksomhet $\mathrm{i}$ kongeriket Norge. Men den åpnet ikke opp for «dissenternes» adgang til alle typer arbeid i samfunnet. I en egen særstilling her sto arbeid i skolesystemet, hvor de ikke fikk adgang til å delta: i første omgang ikke som lærere i det hele tatt, og etter at dette var endret, fremdeles ikke som lærere i kristendomskunnskap. «Dissenterne» førte en lang og intens kamp for å få dette endret.

Dette forbudet, som av mange ble oppfattet som et «yrkesforbud», gjaldt helt til topps i det norske utdanningssystemet. Det ble en «dissenters»

67 Det kom i alt fem søkere til stillingen i Bergen: dosent, teol.dr. Torgny Bohlin, Oslo; førstelektor Peder Borgen, Bergen; lektor teol.dr. Bengt Enstrøm, Gøteborg; dosent, teol.dr. Harry Lenhammer, Uppsala, og dosent, teol.lic. Alf Tergel, Uppsala. Vurderingskommisjonen fant bare de to første kompetente. 
arbeid ved Universitetet i Bergen som førstelektor i kristendomskunnskap fra 1967, og potensiell søker på et nyopprettet professorat i 1971, som ble en sterk medvirkende faktor til at Universitetet i Bergen da gikk i spissen for å få endret den gamle loven fra 1894 om «embedsmænds troesbekjendelse». I juni 1973 ble metodisten Peder J. Borgen den første ikke-lutheraner som ble utnevnt til professor i kristendomskunnskap/teologi i Norge.

\section{Anvendt litteratur}

\section{Aviser (Intervju/lederartikler etc.)}

(Stillingsutlysing). Norsk Lysingsblad nr. 138 - 83. årgang. 19. juni 1965, s. 1.

(Stillingsutlysing). Norsk Lysingsblad nr. 301 - 88. årgang. 28. desember 1970, s. 1.

(Intervju med Tove Pihl). «En lov som har overlevd seg selv», Dagen, 19. januar 1971, s. 1 og 4 .

(Intervju av Per Lønning). «Lønning mot 'tros-professor': Kirken vinner bare en Pyrrhos-seier!», Dagen, 8. januar 1971, s. $1+8$.

(Intervju med Olav Kortner). «Loven bør oppheves», Dagbladet, 9. januar 1971, s. 2. (Notis). «Utlysningen virker meget provoserende», Dagbladet, 9. januar 1971, s. 2. (Intervju av Hans Høivik). «Domprost Hans Høivik til Dagen: Hovedsaken er at kirkens interesser ivaretas», Dagen, 16. jan 1971, s. 1 og 16.

(Lederartikkel). «Vekk med bekjennelsesplikten», Dagbladet, 9. januar 1971, s. 3. (Lederartikkel). «NLA og vedkjenningi», Dagen, 13. januar 1971, s. 3.

\section{Offentlige dokumenter}

Dissenterloven av 1845 (Lov angaaende dem, der bekjende sig til den christelige

Religion, uden at være medlemmer af Statskirken).

Lov av 29. april 1953 om Den Norske Kirkes ordning; med endringer, sist ved lov av

8. juni 1984. Oslo: Grøndahl \& Søn, 1985.

«Norges Frikirkeråd uttaler seg om skolen og frikirkene», Kristelig Tidende 96 årg., 1967 , s. $648+646$.

Lov om folkeskolen frå 10. april 1959. Med merknader, reglement og instruksar. Utgitt av Kyrkje- og undervisningsdepartementet. Oslo 1959.

Innstilling om Lov om trossamfunn. Avgitt av Dissenterlovkomiteen av 1957. Justis- og politidepartementet: Oslo 1962.

Lov av 13. juni 1969 nr. 24 om Grunnskolen (Grunnskolelova). Oslo: Grøndahl Dreyer.

Stortingstidende. Forhandlinger i Stortinget nr. 220. 1970, s. 1833-34. 
Stortingstidende. Tema: Kirker og geistlighet (Storting 1970/71), s. 678-68o.

Stortingstidende. Tema: Embets- og tjenestemenn (Storting 1970/71), s. 1887-1888.

\section{Bøker og artikler}

Almås, K. \& Rian, D. (Red.) (1998). Kristendomsfag og religionsforskning i Trondheim (UniTRel Studieserie 1). Trondheim: Religionsvitenskapelig Institutt, NTNU.

Berge, O. (2009). Den kirkelige undervisningens historie i Norge i det 20. århundre. I T. Seland, (Red.), "Lor meg din vei ...» Kristen trosopploering i går og i dag. En historisk oversikt. Kyrkjefag Profil nr. 10. (s. 127-165). Trondheim: Tapir.

Borgen, P. (2004). Ute-økumenikk og hjemme-økumenikk. Hendelser og erfaringer. I K. O. Sandnes, H. Hegstad, G. Heiene \& S. Thorbjørnsen (Red.). Etikk, tro og pluralisme. Festskrift til Lars Østnor (s. 269-280). Bergen: Fagbokforlaget.

Borgen, P. 2009. Ute-økumenikk og hjemme-økumenikk 1950-1980. I P. Borgen, Vei utenfor Allfarvei. Studier i skjoringspunktet mellom kirkehistorie, personalhistorie og samfunnshistorie (s. 169-187) (Skrifter 2009 nr. 1.). Trondheim: Tapir Akademisk Forlag.

Breistein, I. F. (2003). «Har staten bedre borgere?» Dissenternes kamp for religiøs frihet 1891-1969. (KIFO Perspektiv nr. 14.) Trondheim: Tapir Akademisk Forlag.

Breistein, I. F. (2008). Frå luthersk presteskole til økumenisk utdanningssted. I B. T. Oftestad \& N. A. Røsæg (Red.), Mellom Kirke og Akademia. Det teologiske Menighetsfakultet 100 år, 1908-2008 (s. 221-238). Trondheim: Tapir Akademisk Forlag.

Hafstad, K. (2008). Det teologiske fakultet - økumenisk og tverr-religiøst? I S. A. Christoffersen (Red.), Menneskeverd. Festskrift til Inge Lønning (s. 179-196). Oslo: Forlaget Press.

Helland, K. \& Jøssang, L. G. (2018). Frå Akademi til høgskule. NLA 1968-2018. Bergen: Fagbokforlaget.

Kortner, O. (1971, 9. januar). Loven bør oppheves (intervju med Olav Kortner). Dagbladet.

Kvalbein, J. (1968). Dissentere som kristendomslærere. Fast Grunn, 20, s. 3-7.

Langslet, L. R. (1967). Bort med bekjennelsesplikten. Minervas Kvartalsskrift, 11, S. $456-462$.

Lønning, P. (1967, 16. juni). Dissenterne og kristendomsfaget. Dagen.

Løvlie, B. (2009). Katekese og kirkelig identitet. I T. Seland (Red.), «Lœr meg din vei ...». Kristen trosopplaring i går og i dag. En historisk oversikt. Kyrkjefag Profil nr. 10. (s. 167-186). Trondheim: Tapir akademisk forlag.

Mjøset, L. (2016). Oikos-stifter, katolsk prest - og banebrytende sosiolog Edvard Vogt er død. Sosiologen. Hentet fra https://sosiologen.no/essay/nekrolog/katolskprest-oikos-stifter-og-banebrytende-sosiolog/ 
Mogstad, S. (2008). MF og utfordringene fra skolen. I B. T. Oftestad \& N. A. Røsæg (Red.), Mellom Kirke og Akademia. Det teologiske Menighetsfakultet 100 år, 19082008 (s. 205-220). Tapir Akademisk Forlag: Trondheim.

Norges Dissenterting gjennem 30 ar. 1903-33. Utgitt av Dissentertinget, 1935. Oslo.

Norseth, K. (2008). MF og kvinneprestspørsmålet. I B. T. Oftestad \& N. A. Røsæg (Red.), Mellom Kirke og Akademia. Det teologiske Menighetsfakultet 100 år, 1902008 (s. 239-271. Tapir Akademisk Forlag: Trondheim.

Rygnestad, K. (1955). Dissentarspørsmålet i Noreg frå 1845 til 1891. Oslo: Lutherstiftelsens forlag.

Rønhovde, B. (1971, 9. januar). Professorat og lutherdom (kronikk, s. 3-4). Dagen.

Seierstad, A. (1923). Kyrkjelegt reformarbeid i Norig i nittande hundreaaret (Norvegia Sacra, 2.). Bergen: A/S Lunde.

Sjaastad, E. (2016). Carl Fredrik Wisløff. Presten som ble misjonsfolkets professor (Kyrkjefag Profil, 27). Kristiansand: Portal Forlag.

Thomassen, E. (2017, 26. oktober). 50 år med religions-vitenskap i Bergen. Bergens Tidende.

Wisløff, C. F. (1967, 10. mai). NLA - en ny og viktig skanse. Dagen.

Aadnanes, P. M. (1988). Frå moderne vantru til ny religiøsitet. Norsk livssynsdebatt $i$ hundre år. Oslo: Tano. 


\title{
Strid om misjon og kirke: H.P.S. Schreuders forhold til Det Norske Misjonsselskap, sett fra Madagaskar ${ }^{1}$
}

\section{Ottar Berge}

Høgskulen i Volda

\begin{abstract}
Sammendrag: Denne artikkelen gir en framstilling av hva som skjedde omkring striden mellom misjonsbiskop Schreuder og ledelsen i Det Norske Misjonsselskap. Schreuders rolle har blitt karakterisert ved hans personlighet og hans høykirkelighet. Han vakte oppsikt i Kristen-Norge ved sin pamflett om kirke og misjon. Han ble sendt til Sør-Afrika som misjonær, ordinert av en norsk biskop, og utsendt av Misjonsselskapet. Seinere ble han ordinert som misjonsbiskop. Han var selskapets overbestyrer på misjonsmarken og fikk biskoppelig ansvar også for Madagaskar.

Artikkelen drøfter Adolf Thunems alternative forståelse av begivenhetene ved studie av arkivmateriale og forskeres framstilling av striden. Styrken i konflikten blir her lagt på personlige motsetninger mellom folk som hadde samme kirkesyn og misjonssyn. Sekretær Christian Dons og Madagaskar-misjonær Lars Dahle (seinere ruvende generalsekretær) blir tillagt en kritisk rolle i striden.
\end{abstract}

Nøkkelord: Schreuder, Dons, Dahle, kirkesyn, misjonssyn, misjonær-ordning

\section{Innledning: Schreuders ettermæle}

Svært mye er skrevet om misjonsbiskop Hans Paludan Smith Schreuder (1817-1882) og hans arbeid. De ytre forhold ved hans person og arbeidet hans som misjonær og misjonsbiskop er lett tilgjengelig og kan

1 Dette kapitlet er ikke fagfellevurdert.

Sitering av denne artikkelen: Berge, O. (2020). Strid om misjon og kirke: H.P.S. Schreuders forhold til Det Norske Misjonsselskap, sett fra Madagaskar. I B. Løvlie, P. Halse \& K. Hatlebrekke (Red.), Tru på Vestlandet. Tradisjonar i endring (Kap. 16, s. 391-414). Oslo: Cappelen Damm Akademisk. https://doi. org/10.23865/noasp.104.ch16 Lisens: CC BY-ND 4.0. 
rekapituleres. De har også vært lite omstridt. Motsetninger og debatt har imidlertid oppstått når biografer og historikere har ønsket å belyse Schreuders personlighet og å gi årsaksforklaring til hans holdning i den striden som førte til et brudd med Det Norske Misjonsselskap (NMS). I denne konteksten har et begrepspar blitt brukt nærmest som slagord, nemlig høykirkelig og egenrådig og med varianten høykirkelig autokrat. Det har også vært benyttet karakteristikker som autoritor og steil. ${ }^{2}$ Schreuders teologi og holdning i striden er utførlig framstilt også av John Nome ${ }^{3}$ og Olav Guttorm Myklebust ${ }^{4}$ i deres sentrale arbeid. NMSmisjonæren Adolf Thunem ønsket ved sin omfattende bok om Schreuder i 1944 å gi et bidrag til en nyansert forståelse av Schreuders person og livsgjerning. Det gir en viss korreksjon av det gjengse bildet. 5 Jeg vil undersøke og drøfte i hvilken grad Thunems arbeid kaster nytt lys over konflikten mellom NMS og Schreuder.

\section{En teolog forut for sin tid}

Hans Paludan Smith Schreuder var vestlending. Han ble født i Sogndal i 1817 , hvor faren var overrettsprokurator. Faren fikk embete som fogd i Farsund, og familien flyttet dit. Det var etter at Schreuder var konfirmert, i 1832. Faren tilhørte en slekt med mange geistlige og moren en slekt med tilknytning til forskjellige embetsmiljø. Men de hadde også opphold i Christiania. Miljøet rundt familien Schreuder var preget av det spirende engasjementet i norsk kristenliv for misjon i fjerne land. Den spiren kom som påvirkning fra kontinentet og England. Han hadde sett misjonærvirke som sitt livsmål, og studerte derfor teologi.

Schreuders teologiske embetseksamen 1841 ble vurdert til beste karakter. Deretter tok han umiddelbart fatt på ett års medisinstudium med sikte på den tjeneste i det fremmede for evangeliet. Ved slutten av dette studieåret fikk han trykket publikasjonen Nogle ord til Norges Kirke om

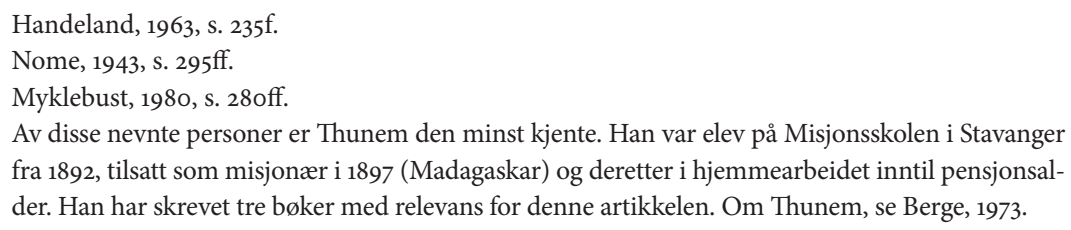
fra 1892, tilsatt som misjonær i 1897 (Madagaskar) og deretter i hjemmearbeidet inntil pensjonsalder. Han har skrevet tre bøker med relevans for denne artikkelen. Om Thunem, se Berge, 1973. 
christelig Pligt med Hensyn til Omsorg for ikkechristne Medbrødres Salighed. ${ }^{6}$ Den ble av hans samtid sett på som sensasjonell og utfordret til begeistring og mye motbør, også utenfor kirkelige kretser.

I Christiania var det dannet en «kirkelig misjonsforening» som Schreuder søkte tilknytning til. Et halvt år før NMS ble dannet i Stavanger (1842), hadde denne misjonsforening etablert seg som Schreuder-komiteen, et organ for utsendelse og underhold av Hans Paludan Smith Schreuder som misjonær i Zulu-land. Da imidlertid etableringen i Stavanger hadde fått sin formelle start som misjonsorganisasjon, ble Schreuder erkjent som ordinær utsending for denne organisasjonen.

Etter dette spesielle studieåret søkte Schreuder ordinasjon. I sin søknad til biskopen skrev Schreuder at han at han som misjonær i Sør-Afrika $ø$ nsket at erholde den til lovligen at predike Ordet og forvalte Sakramenterne fornødne Indvielse af den norske kirke? Biskopen mottok søknaden og ga den den varmeste anbefaling, og den fikk departementets tilslutning. Men all velvilje til tross, søknaden støtte definitivt an mot en kirkerettsbestemmelse. For å bli ordinert måtte ordinanden være utnevnt til et bestemt embete. Departementet besluttet da i en kgl.res. av 8. des. 1842 at Schreuder kunne få innvilget søknaden om ordinasjon $u d e n$ at Ordinanden ved Invielsen erholder Ret til i Norge at udføre ministrielle Forretninger .... ${ }^{8}$ Ordinasjonsgudstjenesten fant sted 10. mai 1843. Myklebust refererer til flere av de tilstedeværende som skrev om de mektige inntrykk som Schreuders preken og avskjedsord gjorde på forsamlingen. ${ }^{9}$

Vel to uker senere tok Schreuder avskjed ved en gudstjeneste i Vår Frelsers Kirke. Etter råd fra teologer og samfunnsorienterte venner tok han båt til London for å sondere britisk kirkeliv med dets misjonstenkning og -miljø. En avgjørende årsak til London-oppholdet var også nødvendigheten av å forstå ledende politisk tenkning og møte samtidens sentrum for kolonimakt. Med utgangspunkt i hans tid i London og hans nærkontakt med kirkelige, misjonale og politiske miljøer vil jeg seinere

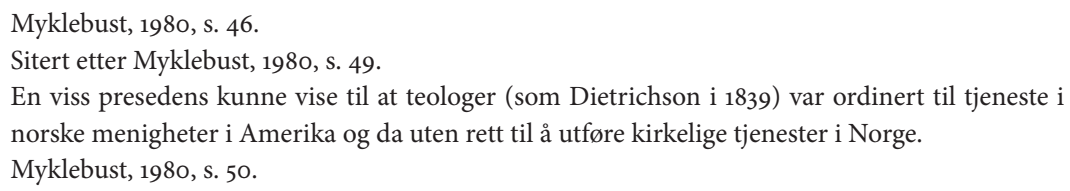


i artikkelen se på hans liv i sørlige Afrika og hans arbeid som misjonær der. Forutsetningen for tilstrekkelig innsikt $i$ hans virke som misjonær er imidlertid at en kjenner hans spesielle posisjon som misjonsbiskop, vigslet i Norge av en norsk biskop og som tilsatt som misjonsprest av en norsk organisasjon, Det Norske Misjonsselskap.

\section{Fra misjonsprest til misjonsbiskop}

I 1866 ble Schreuder hjemkalt til Norge av Misjonsselskapets hovedstyre for å bli vigslet til biskop over Den norske kirkes misjonsmark. Historisk sett fikk Misjonsselskapet med dette en avsporing, betegnet som Schreuderstriden. Den har gitt årsak til vurdering av og standpunkt til personen H.P.S. Schreuder. Karakteriseringene (som nevnt i innledningen) har florert i en viss periode og ble særlig viktig i årene rundt utgivelsen av Misjonsselskapets historieverk i 1942. Slik er tenkesettet og begrepene blitt noe av årsaksforklaringen til bruddet mellom Schreuder og Misjonsselskapet i 1872. Det var ikke tilfellet ved utgivelsen av selskapets festskrift til 50-årsjubileet i 1892, hvor bruddet knapt nok er problematisert. ${ }^{10}$ En kan i dag spørre om søkelyset heller skulle ha vært på diskusjonen innad i NMS om dets søknad i 1864 til Kirkedepartementet om ordinasjon av en misjonsprest i Zululand til biskop. Helt fra tiden for den diskusjonen hadde det i Misjonsselskapets selvforståelse ligget en ulmende uro: Var det nødvendig og riktig for selskapet å ha misjonsbiskop? Konkret avdekket spørsmålet en uenighet om hvordan selskapets struktur skulle form-es, og hvor misjonsbiskopens plass i denne måtte være.

\section{Schreuders og Misjonsselskapets kirkesyn}

På Det Norske Misjonsselskaps generalforsamling i 1867 deltok også bergenspresten, skribenten og kirkehistorikeren Daniel Thrap. Hans dagboksnotater fra generalsamlingen, men også fra bispeordinasjonen, gir et

10 Festskrift til Det Norske Missionsselskaps Jubileum. Redaktører var de tidligere Madagaskar-
misjonærene Lars Dahle og Simon E. Jørgensen. De to kapitlene hvor bruddet er omtalt, er
skrevet av Jørgensen. 
interessant innblikk i generalforsamlingen og de følgende begivenhetene. Han referer den talen hovedstyrets formann, Constatinius Bruun, holdt under festen ved Schreuders ordinasjon. Der ser Bruun for seg en framtid da det ikke skulle være tale om Missionsvenner og deres arbeid, men om een missionerende Kirke. ${ }^{11}$ Dette er i overensstemmelse med tanker ledende menn i NMS hevdet, spesielt klart uttrykt av ledelsen ved sekretærene Peter Blessing og Christian Dons, så vel som av biskop Schreuder. ${ }^{12}$

Misjonsselskapets første sekretær, Andreas Hauge (1850-1852), hadde da skrevet (i 1850/51) en programartikkel om selskapet som menighetenes sak og ikke en organisasjon avsondret fra det allmenne kirkesamfunn og den virksomhet det skal drive; har derfor et kirkelig preg. ${ }^{13}$ I samme bane tenkte hans to etterfølgere, Blessing og Dons. Misjonsforeninger er nødvendige, men de må innordnes i kirken som helhet, hevdet Blessing. ${ }^{14}$ I en artikkel i Norsk Tidsskrift for Misjon (NTM) blir Dons som tenker og strateg analysert og sitert:

Prinsipielt er det kirken, menigheten - den empiriske, den institusjonelle kirke/ menighet - som skal drive misjon, hevder Dons, men under statskirkeforhold lar det seg ikke gjøre å organisere arbeidet på denne måte. ${ }^{15}$

I orienteringen om Misjonsselskapet til Salmebokkomiteen ved begynnelsen av $1867^{16}$ og i lignende orientering til biskopen i Hamar (Halvor Folkestad) skrev hovedstyret at selskapet gjør sin gjerning til fremme av kirkelivets orden og utvikling og avviker fra kirken bare i ytre, administrativt henseende.

Myklebust understreker i begge sine bøker om biskop Schreuder ${ }^{17}$ at det var full overensstemmelse mellom Misjonsselskapet og

\footnotetext{
Daniel Thraps dagbøker IV, s. 105.

Lett tilgjengelig i Misjonsarkivet i arkivboksene med deres navn.

Norsk Missionstidende 1850/51, 142.

Norsk Missionstidende 1854/55, 202.

Myklebust, O. G. (1977). Dons som misjonstenker. Norsk Tidsskrift for Misjon, 1977, 10.

27. februar og 10. desember.

Myklebust er forfatter av den del av Misjonsselskapets historieverk til 10o-årsjubileet som omfatter selskapets arbeid i Sør-Afrika. Det utgjør en vesentlig del av bind III. I 1980 kom hans H.P.S. Schreuder. Kirke og misjon. Og i 1986 Én var den første - studier og tekster til forståelse av H.P.S. Schreuder.
} 
misjonsbiskopen i kirkesynet. ${ }^{18}$ Han poengterer at bruddet mellom NMS og Schreuder ikke hadde sin årsak i kontrære kirkesyn. I drøftingen av dette slår Myklebust fast at det er langt seinere at det ble moderne å fokusere på høykirkelighet/lavkirkelighet.

En særlig gjennomslagskraft fikk denne oppfatningen gjennom det historieverk som kom ut i forbindelse med Misjonsselskapets 100-årsjubileum. ${ }^{19}$

Med dette er en klar motsetning mellom Myklebust og Nome belyst. Det gjelder betydningen av kirkesynet som årsak til splittelsen mellom Misjonsselskapet og biskop Schreuder. Alt på tidlig tidspunkt i historieverket benytter Nome utsagn som tenderer å karakterisere Schreuder som en høykirkelig prest og biskop. Som beskrivelse av hele hans tjenestetid i NMS kan Nome uttrykke det slik:

At Schreuder hadde et høykirkelig syn på kirken og embetet fremgår av hele hans kirkelige holdning og hans uttalelser ved flere anledninger. Helt fra først av var det, (...) hans mening at han representerte den norske kirkes misjon. Og da konflikten mellom Schreuder og selskapet senere satte inn (...) begynte han å skjelne enda skarpere enn før mellom Misjonsselskapets misjon og kirkens misjon. ${ }^{20}$

Det er viktig i dag å huske at fram til 1860 var Schreuder eneste ordinerte misjonær i Misjonsselskapet. Men selskapet hadde i sin tjeneste i SørAfrika folk med praktisk yrkeserfaring som utøvet praktiske tjenester i misjonsarbeidet og i oppbyggingen/utbyggingen av det, og også hadde vitne-tjeneste. Disse medarbeiderne til Schreuder hadde betegnelsen misjonsassistenter. Da første kandidatkullet fra Misjonsskolen, utdannet i årene 1843-48, kom i tjeneste i Zululand, var de også tilsatt som misjonsassistenter. Tenkningen både i ledelsen og hos misjonsfolket ellers var imidlertid at selskapets misjonærer skulle være forkynnere og ha presteutdannelse. Målet for studiet på Misjonsskolen var å utdanne teologer som skulle ordineres. Og en rapport fra misjonsskolens forstander etter første året viser at skolen hadde gitt undervisning i Skrifttolkning (Det gamle og det nye Testamente), Kirkehistorie, Troslore, Pastoralteologi

\footnotetext{
Myklebust, 1980, s. 284.

Myklebust, 1980, s. 280 .

Nome, 1943, s. 262.
} 
og Språk. ${ }^{21}$ Men etter norsk ordning og lovverk var de ikke teologer og kunne følgelig ikke ordineres. Og begrepet misjonær var ennå ikke en yrkestittel, og den eneste mulige tittel var den etablerte. Da den første teolog, ordinert i Norge mars 1861, ble tatt imot av Schreuder og innsatt som misjonsprest, var elleve misjonsassistenter i arbeid. Av disse var fire utdannet på Misjonsskolen.

\section{Presteutdannelse og bispeordinasjon}

Før Schreuder etablerte seg med misjonsstasjon i Zululand, hadde han hatt én medhjelper, som han selv hadde tilsatt. Schreuder traff han i London på reisen til Sør-Afrika i det nevnte opphold i London. Foruten å oppsøke politiske og kirkelige autoriteter nyttet han tiden så godt han kunne og søkte kontakt også med det europeiske miljøet i byen med sikte på kunnskap om landet og folket han skulle til. I det miljøet traff han også på en norsk smed og dyrlege, E. E. Thommessen, som tilbød han sin tjeneste. De reiste sammen til Natal, hvor de steg i land 1. januar 1844. Neste året foretok Schreuder og Thommessen en ekspedisjon med oksevogn med sikte på å finne egnet sted for fast etablering i landet, men de måtte returnere med uforrettet sak. Kongen i Natal, Mpande, ville ikke ha noen hvite bosatt i sitt land.

Det var Zululand Schreuder hadde tatt sikte på, og kong Mpandes holdning skapte et gedigent problem. Han drøftet situasjonen med både misjonærer i Port Natal og med misjonsledelsen i Norge. Lederne i Norge fant situasjonen så vanskelig at de tok den opp med kretsene. Det tok veldig lang tid. Ledelsen var i sterk villrede og ga ikke Schreuder noe svar. Han måtte da handle på egen hånd. Han sonderte og vurderte alternativ i andre deler av Afrika og var i 1847, som vel kjent, i Kina. Mens han var der, vurderte han også India. Han fant alt dette unyttig og vendte tilbake til Sør-Afrika.

Schreuder søkte så fornyet kontakt med kong Mpande. Av flere årsaker, bl.a. medisinsk/kirurgisk hjelp av Schreuder, fikk han et betydelig landområde og tillatelse til å anlegge misjonsstasjonen Umpumulu i 1850. Da

Birkeli \& Strand, 1959, s. 14. 
sto Schreuder igjen aleine, for medhjelperen som kom med han fra London, hadde vendt tilbake til Norge.

Da misjonen var etablert i Zululand og tok til å fungere med misjonsstasjon, ble det klart at behovet for flere aktive i misjonsarbeidet var til stede. Selve erfaringen med medhjelper hadde lagt et spor som kom til å etablere en tjenlig og god ordning for etableringsfasen for Misjonsselskapets arbeid i Zululand. Det var imidlertid - helt fra starten på 1850-tallet og like til saken fikk sin løsning i april 1866 - viktig for selskapet å få mer geistlig betjening for misjonsarbeidets skyld. Dette er et felt som opptar Nome og som han gjør omfattende rede for i historieverket. ${ }^{22}$ Det første kullet fra Misjonsskolen ble, som omtalt, ferdig utdannet i 1848. Misjonsselskapet fant ingen løsning på ordinasjonsproblemet for disse og andre ikke-ordinerte teologer.

Både Kirkedepartementet og de norske biskopene ble forespurt i ordinasjonsspørsmålet. ${ }^{23}$ De pekte i sine individuelle svar på Schreuder og sa at han som teolog og ordinert prest kunne ordinere verdige kandidater blant misjonærene. Mot sitt ønske ordinerte Schreuder den av sine kolleger som kollegene og Hovedstyret hadde utpekt som kandidat til å ordineres. Hva Schreuders vegring var bundet i, er det gitt flere forklaringer til. De viktigste er gitt av professor John Nome i hans bidrag $1943 \mathrm{i}$ Misjonsselskapets historieskrift og av professor Olav G. Myklebust.

Nome skriver at Schreuders vegring mot at han, som ordinær prest $\mathrm{i}$ den norske kirke, skulle ordinere, var knyttet til hans teologi om ordinasjon. Nome orienterer slik:

For Schreuder har åpenbart «den biskopelige Myndighed» stått som noe avgjort høyere enn den prestelige, og vært den instans som (ved biskopens håndspåleggelse) har kunnet meddele til ordinanden de særegne nådegaver som trengtes til det geistlige embedets rette betjening. ${ }^{24}$

22 Nome, 1943, s. 258 og kapitlene Ordinasjonssaken og Schreuders kirkesyn og Om Scheuders høykirkelighet.

Ses enklest og klarest i sekretærens protokoller i 1854, 1858 og 1859 for ut- og inngående korrespondanse. Redegjøres for av Myklebust, 1980, se særlig kapitlet Statskirkelig betraktning?

Nome, 1943, s. 262. 
Myklebust hevdet at Schreuders vegring hadde sammenheng med at han, som prest i den norske kirke, var forpliktet på denne kirkens ordninger. Og ordningen for ordinasjon var at den ble utført av en biskop, og om det ikke skjedde, var det etter forordning av biskop i særlige tilfeller. Schreuder gjorde derfor krav på at det ble gitt biskoppelig bemyndigelse til den aktuelle situasjonen. Han gjorde samtidig oppmerksom på at dette ikke ga noen løsning for NMS for framtiden. Myklebust holder altså fram at i ordinasjonssaken var det viktig for Schreuder at han var ordinert i en kirke med kirkerettslige ordninger og slik måtte være lydig mot disse.

Når så Schreuder omsider faktisk ordinerte, ${ }^{25}$ med sin teologiske holdning uendret og uten særegen bemyndigelse fra noen biskop, var det på grunn av Hovedstyrets bestemmelse og ut fra departementalt og biskoppelige råd. For misjonsarbeidets skyld måtte Misjonsselskapet få en temporær praksis, en nødløsning, og det ble arbeidet videre, internt og overfor de norske biskopene og Kirkedepartementet, for en varig ordning. En langvarig prosess førte fram til at selskapet søkte om bispeordinasjon for Schreuder. Den 28. april 1866 ble det ved kgl. resolusjon gitt tillatelse til at Schreuder kunne bli viet til biskop over den norske kirkes misjonsmark, og bispeordinasjonen fant sted i Bergen samme år. Biskopen i Bergen, Hersleb Birkeland, foresto handlingen i domkirken søndag 8. juli.

Oppholdet i Norge ble relativ kortvarig. I oktober sendte Hovedstyret skriv til samtlige misjonsprester om bispeordinasjonen og drøftingene mellom hovedstyret og biskopen. I brevet ble det klargjort at Schreuder gjennom den høye kirkelige verdighet han hadde mottatt, som en selvfølge ville innta en annen stilling mellom misjonærene enn tidligere. Dette må sees i relasjon til at han da i flere år hadde vært leder av selskapets arbeid på dets misjonsmark med betegnelsen overbestyrer. Det sentrale i drøftingene var avtalene om forholdet mellom misjonsledelsen og misjonsbiskopen. Disse skulle så redegjøres for i skriv til kretsstyrene og deretter legges fram til drøfting og avgjørelse på generalforsamlingen året etter.

25 Misjonærene Lars Larsen, Tobias Udland og Oddmund Oftebro, utdannet fra Misjonsskolen, ble ordinert i Empangeni 22. april 186o. 
Det basale var den forfatningsform som lå i avtalene. Endringene ble drøftet i kretsene og ikke mindre av misjonærene i Zululand. Raskt kom tre element til å bli avgjørende viktig i diskusjonene som foregikk, og som ble retningsgivende for hvordan selskapets grunnregler etter hvert utviklet seg:

1. Misjonsbiskopen skulle ha den avgjørende myndighet i ordinære saker.

2. I større saker skulle han samrå seg med Hovedstyret og innhente dets samtykke som høieste Instans.

3. Misjonærkonferansen, som til da hadde fungert og hatt stor grad av myndighet, skulle opphøre. Biskopen kunne imidlertid, når han anså det fornødent, samrå seg med de misjonærer som var ordinert. ${ }^{26}$

Disse punktene er tre sider av samme sak: den at misjonærene skulle utføre sitt arbeid under biskopens tilsyn og anvisning. Det siste elementet ble en merkesak for misjonærene.

To momenter må her omtales, for å sette generalforsamlingsvedtaket i relieff. På møte på siste forhandlingsdag hadde skolelærer Øvrum et innlegg om nådegavenes plass i misjonsgjerningen og fremmet forslag til forandring av $\$ 16$ i misjonærinstruksen slik at den kunne gjøre det mulig å anvende alle de nådegaver som Herren gir til menigheten, uten dermed å ordinere dem til prester.

Det andre er et brev fra Hovedstyret til Schreuder, som er datert bare to år etter vedtakene i Kristiansand. Brevet er datert 14. august $1871 .{ }^{27}$ Der utfordrer styret biskopen til å skrive et forslag til en statuttmessig ordning for misjonærkonferanser.

$26 \$ 15$ i Misjonsselskapets ordning etter 1866/1867 var slik: «Misisonspræsten har Overbestyrelsen af Menigheden; Missionsmedhjælperen er ham underordnet og forpligtet til i sin Virksomhed at rette sig efter hans Anviisning. Missionsbiskopen har Overbestyrelsen af Menighederne og Stationerne. Missionærene er ham underordnede og forpligtede til i sin Virksomhed at rette sig efter hans anviisning."

Etter 1866/67 har $\$ 18$ også en passus som gjelder biskopens forhold til misjonærene: «..., ligesom han har Anledning til, naar han maatte ansee det fornødent, at sammenkalde og i de vigtigste Tilfælde om mulig bør sammenkalde Missionspræsterne for at høre deres Betænkning og Raad.»

27 Aktstykker, 1876, s. 174-185. Aktstykker ble utgitt som et orienteringsskrift fra hovedstyret i 1876 til orientering for kretsstyrene og for generalforsamlingen 1873 med utvalg av korrespondanser, i hovedsak mellom Schreuder og Hovedstyret i 1860-årene og fram til Schreuders avgang. Opprinnelig et orienteringsskriv til kretsstyrene og deres medlemmer, foran generalforsamlingen i 1873. 
Disse momentene har ikke noen felles årsak eller annen sammenheng med hverandre, men nevnes her som eksempel for å forstå at generalforsamlingens vedtak bidro til uro. Ikke minst i forbindelse med forfatningsreformen. Generelt kan en si at uroen preget Misjonsselskapets arbeid i alle kretsene og kretsmøtene, og medvirket til at hovedledelsen skrev det nevnte brevet til Schreuder. Trondhjems krets og Stavanger krets var særlige områder for uro, og på generalforsamlingen i $1873 \mathrm{kom}$ dette sterkt fram. Her ble betenkningen skolelærer Øvrum leverte og omtalte på møtet tre år tidligere, gjenstand for omfattende debatt. ${ }^{28}$ Det merkelige er at Øvrums anliggende, med den til dels stormfulle diskusjonen, ebbet ut. Noe av årsaken må ligge i at den teologiske vind alt var i ferd med å snu, og at en intern, to-delt, sak hadde vekket misjonsfolkets oppmerksomhet.

\section{Sekretærens rolle}

Uroen som gjorde seg gjeldende i Misjonsselskapets rekker, ble altså erfart i selskapets ledelse. Men det er også et faktum at lederskapet, i alle fall sekretæren, lot seg trekke inn i uroen på en måte som på ingen måte minsket den. Her gjelder det først og fremst private brev som var skrevet til og fra Misjonsselskapets sekretær fra 1865 til 1875, Christian Dons (1836-1885). Den innvirkning sekretærens opptreden hadde for uroen, har flere forskere omtalt, men klart vektlagt forskjellig. Nome nærmest neglisjerer den, Myklebust beklager ledelsens opptreden, og Thunem tillegger den avgjørende vekt med en hard dom over Christian Dons.

Thunem viser til brev fra enkeltpersoner og grupper til Dons. Det var henvendelser fra misjonsmarkene og fra NMS-engasjerte folk i Norge til og fra sekretær Dons. ${ }^{29}$ De som skrev til Dons, refererte til rykter av ulike slag og ga Dons informasjon som han la vekt på og lot hovedstyret få del i. Ytterligere betent ble det ved at Dons selv brevvekslet med misjonærene og ved det både utvirket kommenterende brev fra flere og kunne inspirere til egne initiativ fra misjonærer. Misjonsarkivet har overbevisende antall brev med reaksjoner mot denne praksisen hos selskapets sekretær.

\footnotetext{
28 Aktstykker, 1876, s. 17.

29 Framkommer over mange sider i Aktstykker, særlig i perioden slutten på 1860-tallet t.o.m. 1872.
} 
I sin Schreuder-biografi karakteriserer Thunem denne privatkorrespondansen og Dons saksbehandling slik: Misjonsselskapets sekretær og den samlede hovedbestyrelse gikk biskop Schreuder forbi. ${ }^{30}$

En må videre undre seg over et annet forhold som ikke ble påaktet av mange, men som vises tydelig i misjonsarkivet. Som sekretær i organisasjonen var Dons også redaktør av Norsk Missionstidende. Der fant han det også mulig å redigere brev og innlegg, og det så mye at det ble reagert på det fra mange hold. Dette ble en ytterligere belastning for forholdene i misjonsmiljøene, for ikke å snakke om forholdet mellom misjonsbiskop og misjonsledelse. I Norge reagerte misjonsfolket svært negativt på den behandlingen selskapets sekretær og hovedstyre ga ett bestemt brev, nemlig brevet av 14. mai 1872 fra Schreuder. I dette brevet hadde biskopen to betydningsfulle meddelelser. For det første sa han opp sin overbestyrelse av Misjonsselskapets arbeid på Madagaskar. Videre varslet han et seinere brev med formell oppsigelse i Det Norske Misjonsselskap. ${ }^{31}$ Bakgrunnen for dette brevet var en purring fra selskapets side om forslag til statutter for misjonærkonferanser. Svaret fikk selskapet 14. mai 1872 med svar på hovedstyrets spørsmål. Samtidig sa han opp sin overbestyrelse av Misjonsselskapets arbeid på Madagaskar.32

Brevet fra Schreuder ble mottatt av ledelsen i Stavanger i begynnelsen av juli. Hovedstyret handlet raskt og hadde 15. juli ferdig svarbrev til biskopen ${ }^{33}$. Kjernen i det Dons skrev, er:

... og er det vort Haab til Gud, at Han vil have forhindret denne Beslutnings Iværksettelse ialdfald indtil De mottager disse Linier.

Dons har i samme brev også inntrengende utsagn til Schreuder om at besinde sin Beslutning. ... Vi betviler meget om, at noget Ord fra vor Side skulde kunne udrette noget Synderligt.

\footnotetext{
30 Thunem, 1944, s. 216.

31 Thunem, 1944. Originalbrev arkivert i Misjonsarkivet. Misjonsselskapets arkiv i Stavanger har i denne sak fyldige mapper. Thunems Schreuder-biografi kan på mange konkrete steder konfronteres med arkivets materiale. Sidene $217-223$ i boken er forbilledlig i sitt oppsett. En ser, ved ettersyn, at bokens sider gir pålitelig oversikt over saksgangen de nevnte brevene fra Schreuder i mai og tiden etterpå fikk. 
Besvarelsen av Schreuders brev av 14. mai ble relativt hurtig fulgt opp med brev til Madagaskar, vel en halv måned etter mottakelsen av brevet fra Schreuder. Men det brevet prost Borchrevink fikk i november/desember 1971, var Lars Dahles konferanseforslag og noen kommentarer fra Dons. Fra Antananarivo fulgte vedlagt et brev skrevet av Dahle hvor han klargjør for kollegaene sin befatning med saken. 13. november 1872 hadde ledelsen skrevet et orienterende skriv til i alle fall misjonærene i Antananarivo. Thunem beskrev innholdet i det slik: ${ }^{34}$

Privatbrev om bestyrelsens stilling vedrørende Madagaskar-misjonen og tilstilet dem copier av styrets brev til Schreuder av 14nde og 15nde juli og til kretsstyrene av 12de august 1872 .

Vel to måneder etter Hovedstyrets svarbrev til biskopen skrev styret et orienteringsbrev til kretsstyrene om saken og situasjonen. Brevet er datert 23. september 1872. Dette inneholder følgende uventede linjer:

Imidlertid maa vi tilstaae, at vi, uagtet de vanskelige Opgaver, som Situastionen i mange Retninger forelægger, næsten have følt det som en Lettelse at mottage Biskopens Opsigelse. ${ }^{35}$

I februar 1873 ble to nye brev til kretsstyrene skrevet. ${ }^{36}$ Disse henger innholdsmessig sammen, og begge ble annonsert i det første av disse to brevene som informasjonsskriv angjeldende vort Selskabs Stilling til Biskop Schreuder. Og der skrev hovedstyret at det

i egenskab af Selskabets Hovedbestyrelse vanskelig vilde kunde være med paa at effectuere fornyede Bestræbelser for at bevæge Biskopen til at blive staaende.

Og at hensikten med brevene ikke var å

Æske Kredsbestyrelsernes Erklæring om, hvorvidt Biskop Schreuders Opsigelse af sin Overbestyrerstilling i Missionen nu endelig bør modtages eller ikke.

Dette siste merket mange av kretsstyrene seg. Et flertall av dem kommenterte at dette måtte være brudd på selskapets Grundregler om å ikke

\footnotetext{
34 Thunem, 1944, s. 217.

35 Aktstykker, 1876, s. 327-329.

36 Aktstykker, 1876, s. 390-404.
} 
forhøre seg hos kretsstyrene. Men noen omtalte det overhodet ikke i sitt svar. Flere andre saker ble tatt med i noen av kretsstyrenes svar til ledelsen. Ingen av kretsstyrene slo alarm og krevde tiltak av noen art i forhold til gjeldende grunnregler. Lesning videre $i$ annet materiale gir inntrykk av at kretsstyrene ble oppfattet av hovedledelsen som en gruppe som, ved sin taushet, hadde gitt Hovedstyret sin tilslutning i saken som brevet omhandlet.

Ledelsen i Stavanger blir stadig mer overbevist at forholdet til Schreuder som biskop måtte finne sin avslutning. To skriv til Schreuder ble forfattet, 3. og 7. april 1873, ${ }^{37}$ hvor han ble underrettet om at hans oppsigelse ville bli mottaget fra Selskapbets side. Hovedstyret betraktet biskopen som fratrådt sin innehavde Stilling som Overbestyrer for Madagaskarmissionen.

Når det gjelder Misjonsselskapets arbeid i Zululand, ville ikke ledelsen gå til definitive Afgjørelser og overlot til biskopen og de øvrige misjonærer å ta midlertidige avgjørelser.

Under de nåværende extraordinære tilstande bliver Forholdet mellom Biskop Schreuder og Eder for det Første at ordne ved Eders egne frie forhandlinger med Biskopen.

Samtidig bad Hovedstyret biskopen om å bli stående i tjenesten og stillingen fram til avgjørelse var fattet i den kommende generalforsamlingen.

Etter at Hovedstyret hadde sendt sine brev til Schreuder, fikk den brev fra ham datert 24. februar 1873, hvor han trakk sin oppsigelse tilbake og sa seg villig til indtil videre at forsette som Biskop for den norske Misjonsmark. Dette var under forutsetning at det norske Missionsselskab respecterer den Myndighed og Rettigheder, der tilkommer mig som Biskop. Om de ikke kunne enes, skulle saken gå til voldgift. ${ }^{38}$

Den 3. juni skrev hovedstyret til kretsstyrene at det fastholdt biskopens oppsigelse i samsvar med det de hadde skrevet til dem, og underrettet biskopen og misjonærene i begge land. 39

\footnotetext{
37 Aktstykker, 1876, s. 439-448.

38 Aktstykker, 1876, s. 404-408.

39 Aktstykker, 1876, s. 453-457. 
I dagene fra 28. juli til 1. august 1873 ble Det Norske Misjonsselskaps 13 . ordentlige generalforsamling holdt i Drammen. De to siste dagen av juli ble brukt til å drøfte det overordnede tema på generalforsamlingen: «... at modtage og fastholde Biskop Schreuders Opsigelse». Det var satt opp seks drøftingspunkter. Ett av disse omfattet også hvordan Misjonsselskapet videre skulle være strukturert om de overordnede tema fikk flertall. Ved avstemmingen ble det avgitt 208 stemmer for å akseptere biskop Schreuders oppsigelse fra sin stilling som misjonær i Zululand for Det Norske Missionselskap. 149 stemmer ble avgitt mot. ${ }^{40}$

I denne perioden var det en parallell utvikling i Misjonsselskapet, som er av betydning for å kunne følge behandlingen misjonsbiskopen fikk. Denne må følgelig vies oppmerksomhet her. Det som skjedde, fant sted ved en norsk misjonsprest på Madagaskar, men kom til syne først mange tiår seinere, og da i Norge. Her må jeg derfor gå år tilbake for å kunne følge behandlingen av Schreuder.

\section{Misjonsselskapets historieverk}

På begynnelsen av 1930-tallet ble det realitet i tanken om at Misjonsselskapet skulle ha et jubileumsskrift til sitt forestående 100-årsjubileum. Jubileumsbokkomiteen ble opprettet i 1932 med tidligere Madagaskarmisjonær Adolf Thunem som formann og med selskapets generalsekretær, Einar Amdahl, som ett av de øvrige medlemmene. Da John Nome ble tilknyttet Misjonsskolen, ble han også delaktig, og etter hvert svært aktiv, i arbeidet med jubileumsboken, men var ikke oppnevnt av hovedstyret i NMS til komiteen som ordinært medlem.

Tidlig i sin bok Misjonen $i$ fare $^{41}$ forklarer Thunem et ønske han la fram for generalsekretær Amdahl i september 1937 om en «konferens» mellom generalsekretæren, hovedstyreformannen og seg selv. Ønsket gjaldt boken som flere da var i ferd med å skrive sine bidrag til, bl.a. Amdahl, som han henvendte seg til. Det gjaldt stoffvalg, utvalget av emner og valg av «retning» for jubileumsskriftet, dvs. selskapets offisielle selvbilde.

\footnotetext{
40 Aktstykker, 1876, s. $482 \mathrm{f}$.

41 Thunem, 1953, s. 9.
} 
Ønsket begrunnet han ved å forklare formålet med «konferensen» og ved å sette fram en forutsetning for samtale. Formålet var å gjøre hans to samtalepartnerne kjent med visse ømtålige historiske forhold, som han uttrykte det. ${ }^{42} \mathrm{Og}$ forutsetningen var at det han selv kom til å bringe fram, måtte bli mellom dem. De måtte derfor avgi løfte om taushet.

«Konferensen» ble gjennomført vel fire måneder seinere, i løpet av tre møter à tre timer noen dager i februar 1938. Av det Thunem skriver om dette, er det to uttalelser som - når den kan leses i lys av andre av hans utsagn og andres skriftlige utsagn - blir bærende for denne artikkelen og være sentral for selve framstillingen i den. ${ }^{43}$

Jeg sa fra at hvis man ville søke den egentlige årsak til striden mellom Misjonsselskapet og biskop Schreuder, så måtte man «ta billett - fra Zululand til Madagaskar» Og jeg føyde til at saklig og historisk sett ville det vel være riktig å omtale denne strid i forbindelse med Madagaskar-misjonen, ...

Formannen nevnte, idet han på det siste møtet takket for hva jeg hadde påpekt, at for ham var «omtrent alt nytt», et arbeid av «stor betydning». Og - la han til: «pastor Thunem hadde vel ikke noe imot å overlevere det (mitt arbeid) til Nome?» Og: om jeg ikke syntes «det kunne være bra at Nome tok det vesentlige av Schreuder-striden?»

Lesere av dette vil kunne merke seg to spesielle moment: 1. Replikken om «billett til Madagaskar». 2. Omtalen av Nome som bruker av Thunems stoff. Etter bare noe over ett år med Nome på arenaen ble to tema berørt, som raskt skulle bli årsak til meget spent forhold mellom Nome og Thunem.

Punktet om at Nome skulle overta stoffet som Thunem $\mathrm{i}$ «konferensen» la fram, reagerte Thunem umiddelbart på, negativt og skarpt. Han framholdt at både han selv og Nome hadde sine definerte oppdrag: Nomes oppdrag handlet om stoff om det som førte til dannelsen av Misjonsselskapet

42 Thunems uttrykksmåte gjør at han kan oppleves dunkel/kryptisk. Gjennomgående kan det virke som han benytter «halvkvedete viser», som ved uttrykket visse ømtålige forhold, og ikke direkte sier hva det gjelder. Lesere må da sammenholde antydninger/setninger fra andre deler av det samme skriftet.

Thunem, 1953, s. 11f. 
og ikke dets historie etter stiftelsen. ${ }^{44}$ Siden Thunem reagerte på den måten og helt umiddelbart, vil en kunne oppfatte dette som så emosjonelt ladet at det ville kunne bli en stor sak i relasjonen mellom Thunem og Nome og føre til strid. På kort tid ble det også slik. Men ikke primært på grunn av Thunems mulige følelser av å «miste noe» til Nome. Misjonen i fare, helhetlig lest og satt inn i sin sammenheng, dvs. relatert til annet arkivstoff, gjør at vi vet at Thunem satt på ukjent materiale innen oppdraget han hadde. Hans reaksjon kom av at han hadde arbeidet seg fram til at flere av dem som satt i jubileumsbokkomiteen og/eller satt og skrev til historieverket, som Nome og Amdahl, hadde ganske andre oppfatninger om årsaker til og konsekvenser av vesentlige fakta i det som hadde skjedd i løpet av Misjonsselskapets utvikling. Dette hadde han bl.a. forstått ut fra samtalene i bokkomiteen og kjempet mot der. Skulle deres versjon være det som ble brukt, ville det gi en ukorrekt framstilling av vesentlige sider av selskapets historie, særlig når det gjaldt Madagaskar - og det i Det Norske Misjonsselskaps eget historieverk!

Flere utsagn i komitedrøftingene ga Thunem en samlet karakteristikk av i Misjonen i fare. ${ }^{45}$ Disse utsagnene lå til grunn for Thunems ønske, nærmest krav, om en «konferens» med NMS-ledelsen. I artikkelen Skuffelser og svik i boken Dømmekraft i krise? drøfter jeg utsagnet uholdbare uttalelser og Thunems karakteristikk av dem som hadde hevdet dem. ${ }^{46}$ Jeg trekker der den slutning at Thunem, ved å uttrykke seg slik, ville vise at det på møter i komiteen var framsatt klare løgner.

Det er dette som ligger i punkt 1 ovenfor med det uttrykket ta billett til Madagaskar, sentralt under «konferens»-samtalene og i den nevnte boken hans. Den saken som Thunem omtaler med billeduttrykket, var viktigste årsaken til hans behov for «konferens» med selskapets ledelse. Det han gjorde ved denne kryptiske, nesten tildekte uttalelsen, var å be sine meddebattanter være med på å se hva som hadde funnet sted i selskapet, allment, men spesielt på Madagaskar. ${ }^{47} \mathrm{I}$ klar tale betyr det at Thunem retter

Nome var på dette tidspunktet ikke noe ubeskrevet blad for NMS-miljøet i Stavanger. To år før han ble tilsatt som lærer ved Misjonsskolen, hadde han fått i oppdrag av Hovedstyret å skrive om foranledningen til Misjonsselskapets stiftelse.

Dette ble nok kommunisert. Jf. omtalen av Thunems særegne tendens til «dunkel» uttrykksmåte. 
lyskasteren mot Lars Dahle og hans opponerende holdning til Schreuder, og de tiltak han sto for. Thunem peker de facto på Dahles intensjon om å omordne misjonærenes arbeidssituasjon på Madagaskar: å bringe tilbake misjonærkonferansen og utarbeide statutter for den. Og hans utsagn gikk nok lenger enn som så. Han mente Dahle rett og slett motarbeidet avtalen i 1866 mellom selskapets ledelse og Schreuder - med tilhørende styrebeslutning og påfølgende vedtak på generalforsamlingen. Med sitt billedlige uttrykk knytter Thunem altså opp til offisielle og fattede vedtak i Misjonsselskapet og til det egenrådige «ombyggingsarbeidet»av strukturen på selskapets arbeid på Madagaskar, som Dahle utførte etter at han kom dit i 1870. Med det hadde Thunem plassert den markante misjonsskikkelsen Lars Dahle i den sentrale posisjonen han var overbevist om at han reelt fikk for Misjonsselskapets utvikling.

\section{Markante personligheter og sentrale problem}

To overskrifter på side 315 og side 321 i Myklebusts bok H.P.S. Schreuder. Kirke og misjon er fristende å henvise til. Dette fordi ordvalget for overskriftene gir beskrivende angivelse av forholdet mellom tre lederpersonligheter i NMS i disse årene: Christian Dons contra Schreuder og Lars Dahle contra Schreuder.

Christian Dons er alt omtalt. Han var Misjonsselskapets sekretær og en sterk personlighet som i kirke- og misjonsforståelse hadde sammenfallende standpunkter med Schreuder, noe som kommer tydelig fram i disse to kapitlene i Myklebusts bok. Men han tar også fram at det i utpreget grad var uoverensstemmelser av personlig art mellom Dons og Schreuder. Nome går i historieverket lite inn på personbeskrivelser og ønsker å beskrive indre forhold ved å prioritere reaksjoner og vedtak i Stavanger innen organer i NMS. I siste hovedavsnitt av verket tegner han imidlertid noen streker og karakteriserer enkelte sentrale personer som var aktive i de beslutningene som omtales, særlig på generalforsamlingene i 1867, 1870 og 1873 .

De bilder av sekretærene som Nome skisserte, viser en viss likhet med Myklebusts beskrivelser av dem. Når det gjelder Dons, er Myklebust sin beskrivelse av både han og hans forhold til Schreuder denne: 
Vi møter hos begge en sårbarhet, en mistenksomhet, en tilbøyelighet til ikke å ta alt i beste mening, som må karakteriseres som unormal. ${ }^{48}$

Motsetningsforholdet var der, på tross av meningslikhet i teologi og kirkesyn.

Lars Dahle (1843-1925) var også vestlending, født i Isfjorden i Romsdal. Etter fullført utdanning ble han ordinert av Schreuder i Sør-Afrika i 1870, og begynte som misjonær på Madagaskar samme året. Han gir i sin detaljrike selvbiografi fra 1921 flere utsagn om teologiske og ordningsmessige forhold. En kan med enkelhet si at teologisk sto han og Schreuder sammen og hadde i kirkesyn felles plattform. Vi har altså å gjøre med tre samtidige ledere i NMS med sammenfallende oppfatning i teologi og kirkesyn, Dons, Schreuder og Dahle. Men disse har hver sin holdning til og engasjement for ordningsspørsmål i NMS.

Det som gjorde at Dahle og Schreuder kom i et motsetningsforhold til hverandre, var spørsmålet om hvem som skulle lede selskapets arbeid på Madagaskar, og hvordan ledelsen skulle være. Ut fra sin oppfatning av sitt mandat opprettet Schreuder, som vi har sett, Madagaskar som prosti og innsatte legen og presten Christian Borchgrevink som prost. Dette var vanskelig for Dahle å akseptere. Han så muligens Schreuders utnevnelse som en ren forbigåelse av seg selv, for han hadde gjort bemerkelsesverdige studier på Misjonsskolen og hadde fått ledelsens øyne på seg. Sterkest kom dette til uttrykk ved at han fikk det uhørte tilbudet om gratis videre studier ved teologistudiet på universitetet og deretter to års studier i Danmark/Tyskland/Sveits/Holland og England.

Dahle opplevde ganske raskt realiteten i problemene NMS hadde ved ett bispedømme i to så atskilte land og med den bestemmende del av ledelsen så langt borte som i Nord-Europa. Og han reagerte tidlig mot biskopens tjenestevei-tenkning som byråkratisk og håpløst tungvint, ja, umulig. Sin studiereise i Europa brukte han mye til å studere hvordan misjonsselskapene han hadde kontakt med hadde bygget opp sin organisasjon. ${ }^{49}$ Før han reiste, hadde også Dons gitt han det rådet at han skulle

\footnotetext{
48 Myklebust, 1980, s. 322.

49 Dahle, 1923, s. 100-110.
} 
observere kontakten de enkelte misjonsselskapenes ledelse hadde med misjonærene på misjonsmarken.

Det er svært interessant å lese referat fra Misjonærkonferansen på Betafo 3.-5. mars $1872 .^{50}$ Et sentralt tema på saklisten dreide seg om misjonærkonferansens myndighet til å øve tilsyn med den enkelte misjonærens liv og utøvelse av sitt embete. Lars Dahle sto for innledningen til samtalen. Det sentrale i hans innledning var det han på studiereisen hadde erfart. Han orienterte om at de fleste misjonsselskap hadde lagt den kontrollerende myndighet til konferansen.

Fra drøftingene ble det ikke gjengitt så mye, men det står at man etter en kort diskusjon kunne konkludere i to punkter. Referatet gir inntrykk av at det var allmenn tilslutning til ønsket om å få en forfatning med basis i Misjonærkonferansen. Styrken i en slik forfatning var at man ikke var så utsatt for enkeltpersoners vilkårlighet. Den andre delen av konklusjonen ble i ettertid viet mye oppmerksomhet og ble diskutert videre i kollegiet på Madagaskar og i misjonens ledelse. Den ga uttrykk for et visst forbehold ved at konferanseforfatningens myndighet skulle anses som en nødvendig løsning på det problemet som besto $\mathrm{i}$ at det ikke var en styrende myndighet på Madagaskar. Man kunne altså forstå konferansens myndighet som overdratt fra biskopen, som holdt til i det sørlige Afrika. Det kan se ut som om man ville forene en kollegial forfatning og en aksept av episkopal ledelse, men reelt var det en situasjonsbetinget tilslutning til Dahles prinsipielle syn.

\section{Byråkrati og tjenestevei}

Dahle hadde nyttet Betafo-møtet som utprøving av sine ideer og for å sondere terrenget. Han konfererte også etterpå med flere kolleger om endringer av struktur og ordninger. På dette grunnlaget skrev han et forslag til ordning av og statutter for misjonærkonferanse på Madagaskar,

50 Det var ikke offisiell misjonærkonferanse, men dette var et misjonærmøte Dahle hadde tatt initiativ til. Det ble skrevet regulært referat som ved misjonærkonferanser og omtalt og referert til av flere som misjonærkonferansen for 1872. Er i Misjonsarkivet plassert som ordinært misjonærkonferansereferat. 
som han sendte som brev, direkte til Dons. ${ }^{51} \mathrm{Vi}$ kan anta at en årsak til det er at Dons hadde foreslått for Dahle at han skulle merke seg hvordan misjonsselskapene strukturerte sin organisasjon med hensyn til stedlig ledelse og dennes forhold til hovedledelsen.

Dahles forslag hadde 14 nummererte punkter, som ble presentert for ledelsen i NMS som enstemmige anbefalinger fra misjonærene. Av de 14 punktene er det ett som gjelder forhold som var usedvanlig brennbart, nemlig at misjonærkonferansen skulle føre konferanseprotokoll. Denne skulle sendes separat både til biskopen og ledelsen i Stavanger.

I august og september hadde hovedstyret flere brev til et par misjonærer på Madagaskar om saken Dahle reiste. Først 10. oktober skrev styret offisielt brev til prost Christian Borchgrevink med redegjørelse, som også inneholdt samtlige 14 punkt i Dahles brev. Informasjon om dette fikk Schreuder, ikke fra Dahle selv, men fra selskapets sekretær. Det underlige er at det orienterende brevet om saken først ble skrevet til Schreuder 13. januar 1872.

Schreuder var i og for seg ikke imot selve ideen i Dahles brev, men det han reagerte voldsomt mot, var at brevet, og dermed forslaget til strukturendring i NMS, ikke kom tjenestevei om prosten og ham, men direkte til selskapets sekretær, Dons, som så forela det for Hovedstyret og igangsatte en saksbehandlingsprosess. I brev til Dahle, datert 24. februar 1872, ga han uttrykkelig beskjed om at Dahle for ettertiden måtte gå tjenestevei, og sende sine forslag via biskopen.

Hovedstyret var nødt til å reagere, og det ga Dahle en korreks i tråd med biskopens brev. I form var styrets brev skarpt. Til saksinnholdet $\mathrm{i}$ brevet var imidlertid sekretæren enig med Dahle. Denne «mildhet i det skarpe» som behandlingen Dahles brev fikk, er en klar pekepinn om det.

Brevet i februar fra Schreuder ble behandlet i hovedstyremøte et halvt år seinere, den 23. september 1872. Brevet ble da utførlig kommentert i relasjon til misjonærene på Madagaskar og utformet i et brev datert 10. oktober. Først 18. november besluttet Hovedstyret å sende det brevet som det hadde skrevet til Madagaskar-misjonærene, til deres biskop i Zululand. Dette ble effektuert først 10. januar (1873). Det meget bemerkelsesverdige, 
sett i historisk perspektiv, er administrasjonens tempo i saksbehandlingen og styrets oppfølging av sine egne vedtak i saken.

\section{Konklusjon}

Interessen i denne artikkelen er det bildet historieskrivningen har gitt av misjonsbiskop Schreuder, ikke minst knyttet til hans sorti fra Misjonsselskapet. Jeg har gått til dels utførlig inn på begivenhetene ved arkivstudier og forskeres syn på konflikten for å gi leseren et inntrykk av begivenhetenes gang. Jeg har langt på vei sett betydningen av det syn Adolf Thunem gjorde gjeldende i sin ulykksalige befatning med Misjonsselskapets historie..$^{52}$ Jeg har også sjekket hans framstilling med arkivmateriale, og funnet dokumentasjonen tilfredsstillende. Etter hans framstilling blir de viktigste grunnene til Schreuder-striden fortiet. Grunnen til bruddet ligger ikke i ulike kirkesyn, eller syn på misjonen. Man kan nok si at selve ordningen med misjonsbiskop i et misjonsselskap ville kunne støte på strukturelle problemer i forholdet mellom en organisasjon og en kirkeinstitusjon. Den biskoppelige rolle kunne bli lite konstruktiv når avstandene var så store. Man kan ha likt syn på kirkens rolle i misjonen uten å være enig i organiseringen. De organisatoriske prosessene var der som underliggende problem. Når skylden for bruddet blir lagt på Schreuders høykirkelighet og embetssyn, så underslår det hva Thunem brakte på banen med sin metaforiske pekepinn om å «løse billett til Madagaskar». Det er de personlige motsetningene som skaper eller forsterker støyen, sammen med irregulære handlinger og uenighet om organisering.

Sekretær Dons går delvis bak ryggen til Schreuder, og Lars Dahle går direkte til ledelsen med sine forslag til omorganisering. Stoff med stor sprengkraft lå i det faktum at forfatningsforslaget som Dahle sendte til Stavanger, i hovedtrekk var i ferd med å bli realisert på Madagaskar ganske raskt etter at Dahle hadde sendt de 14 sidene til Dons og da Schreuder skrev sitt refsende brev til Dahle 24. februar 1872. Etter misjonærkonferansen på Betafo hadde Dahle kontakt med kolleger og dannet enhet i saken. Denne enhet i kollegiet gjorde det deretter mulig for den handlekraftige

Se fyldigere framstilling i Berge, 2013. 
Dahle å få sine kolleger med på nærmest irregulær strukturering av arbeidet på Madagaskar i samsvar med ideene i brevet til Dons. I utvidet og endret form ble disse tilretteleggingene omgjort til ordinær ordning for selskapets arbeid - og da både på Madagaskar og Sør-Afrika - etter at Misjonsselskapet i 1873 hadde forlatt ordningen med misjonsbiskop. Dahle forble på misjonsfeltet og ble i 1877 den første ordinære og reglementære tilsynsmann for arbeid på Madagaskar.

Det ligger nær å oppfatte at noe av spillet omkring Misjonsselskapets arbeid med sin egen historie, er å dekke Dahle, Amdahls legendariske forgjenger. At Thunem seinere lar seg utnevne av Nasjonal Samling som generalsekretær i Misjonsselskapet under krigen, tar ikke troverdigheten fra hans kritikk.

\section{Kilder og litteratur}

\section{Arkiv}

\section{Misjonsarkivet - Misjonshøgskolen (MHS)}

Misjonsarkivet for Det Norske Misjonsselskap for Madagaskar, Isoraka, Antananarivo, i dets tilstand i 2007. Aktuelt for dette arbeidet: i hovedsak usystematisk lagrete referat fra misjonærkonferanser og -møter på 1870-tallet.

Norsk Missionstidende 1850/1851 og 1854/1855.

\section{Riksarkivet}

Daniel Thraps dagbøker 1869-1910, RA 4Ao7711, Ms 8vo, 28-32.

\section{Bøker og artikler}

Aktstykker til Belysning af Forholdet mellem Biskop Schreuder og Det Norske Missionsselskap. (1876). Stavanger: Det Norske Missionsselskap.

Berge, O. (1973/2013). Skuffelser og svik. I T. Austad, O. Berge \& J. O. Ulstein, Dømmekraft $i$ krise. Holdninger $i$ kirken til jøder, teologi og NS under okkupasjonen. Kyrkjefag Profil 18. (s. 187-265). Trondheim: Akademika forlag.

Birkeli, E. \& Tidemann Strand, C. (1959). Kallet og veien. Det Norske Misjonsselskaps Misjonsskole 1850-1959. Stavanger: Misjonsselskapets Forlag.

Birkeli, F. (1952). Politikk og misjon. De politiske og interkonfesjonelle forhold på Madagaskar og deres betydning for den norske grunnlegging 1861-1875. Oslo: Egedeinstituttet. 
Dahle, L. (1923). Tilbakeblik paa mit Liv - og sarlig paa mit missionsliv: D.2: fra min Ankomst til Madagaskar til min hjemreise derfra (1870-1887). Stavanger: Det Norske Missionsselskaps trykkeri.

Danbolt, E. (1943). Historieskriving og historiediktning. Norsk Teologisk Tidsskrift, $239 f f$.

Danbolt, E. (1948). Det Norske Misjonsselskaps misjonoerer 1842-1948. Stavanger: Det Norske Misjonsselskap.

Handeland, O. (1963). Fram kristmenn, korsmenn: Hovedlinjer og førerskikkeler i norsk hedningemisjon: 1. Bergen: Lunde forlag.

Jørgensen, T. (1992). I tro og tjeneste. Det norske misjonsselskap 1842-1992. Stavanger: Misjonshøgskolen.

Myklebust, O. G. (1980). H.P.S. Schreuder. Kirke og misjon. Oslo: Egedeinstituttet / Gyldendal Norsk Forlag.

Myklebust, O. G. (1986). Èn var den første. Studier og tekster til forståelse av H.P.S. Schreuder. Oslo: Land og Kirke/Gyldendal Norsk Forlag.

Nome, J. (1942). Demringstid, fra misjonsinteresse til misjonsselskap. Stavanger: Det Norske Misjonsselskap.

Nome, J. (1943). Det Norske Misjonsselskaps historie i norsk kirkeliv, I og II. Stavanger: Det Norske Misjonsselskap.

Thunem, A. (1944). Biskop Hans Paludan Smith Schreuder. Det norske misjonsselskaps første misjonoer. Oslo: Centralforlaget.

Thunem, A. (1953). Misjonen i fare. Om fakta og fareforhold i forbindelse med N.M.S. Stavanger: Eget forlag. 


\section{Om forfatterne}

Arne Apelseth er professor emeritus i nynorsk skriftkultur ved Høgskulen i Volda. Han har særleg arbeidd med korleis skriftbasert kultur fekk relevans for allmugen og korleis slik kultur vart oppfatta og utvikla seg i lågare samfunnslag under påtrykk frå reformasjon, opplysningstid og nasjonsbygging. Ei doktoravhandling (2004) og fleire artiklar i tida 19902020 utforskar emnet. E-post: aapelseth@gmail.com

Anders Aschim er professor i religion, livssyn og etikk ved Høgskolen i Innlandet. Han er teolog og historikar og har særleg arbeidd med bibelfag og med nyare norsk kultur- og kyrkjehistorie. E-post: anders.aschim@inn.no

Ottar Berge er amanuensis emeritus ved Høgskulen i Volda. Berges faglige interessefelt har vært praktisk teologi, særlig homiletikk og kateketikk. E-post: ottar.berge@tussa.com

Leidulv Øyvind Grimstad har vore sokneprest i Møre bispedømme, Hareid. Han er utdanna sjukepleiar, diakon og prest med mastergrad i kulturmøte. E-post: leidulv.grimstad@gmail.com

Per Halse er professor ved Høgskulen i Volda. Halse er teolog med tilleggsutdanning i historie og pedagogikk. Han har PhD-grad frå UiO i 2009 på ein monografi om framveksten av nynorsk kyrkjespråk. Andre faglege interessefelt er skule-, kyrkje- og kulturhistorie, bibelomsetjing og salmedikting. E-post: Per.Halse@hivolda.no

Kristin Hatlebrekke er førstelektor ved Hogskulen i Volda. Hatlebrekke underviser hovudsakleg i lærarutdanningane og fagleg hovudområde er religionsdidaktikk. Andre interesseområde er kristendomshistorie og skulehistorie. E-post: Kristin.Hatlebrekke@hivolda.no 
Hildegunn Valen Kleive er førsteamanuensis ved Høgskulen i Volda. Forsknings- og undervisningsområdene hun har arbeidet med er særlig knyttet til hverdagsreligion, minoritetsungdoms forhold til religion, og religion i skolen. Arbeidet er særlig knyttet ungdom med bakgrunn i muslimske og hinduistiske tradisjoner. E-post: hildegunn.valen.kleive@ hivolda.no

Sidsel Lied er professor emerita ved Høgskolen i Innlandet. Lieds undervisningsområde har vært religionspedagogikk, og hennes forskning har spesielt vært rettet mot elevers ytringer i form av tegninger og skriftlige verbaltekster. E-post: sidsel.lied@gmail.com

Arnljot Løseth er professor i historie ved Avdeling for samfunnsfag og historie, Høgskulen i Volda. Han har arbeidd mykje med region- og kysthistorie, sosial, politisk og økonomisk historie på 180o- og 1900-talet. E-post: al@hivolda.no

Birger Løvlie, Dr. theol. 1995, er dosent emeritus ved Høgskulen i Volda. Løvlie er teolog og pedagog, og har hatt kristendoms-, kultur- og skolehistorie som sitt faglige hovedområde. E-post: bl@hivolda.no

Torrey Seland er professor emeritus fra 2014. Forskningsområder er Det nye testamente, urkristendommens historie, og diasporajødedommen med særlig vekt på Filon av Aleksandria.

Åsa Thorstvedt har mastergrad i teologi. Thorstvedt var gjennom mange år ansatt i Klepp frikyrkje og fra 2020 ansatt i Krogedal begravelsesbyrå. Thorstvedts faglige interesseområde er kirkehistorie og praktisk teologi. E-post: aasa.thorstvedt@gmail.com

Andreas Tjomsland er doktorgradsstipendiat ved Høgskulen i Volda og Universitetet i Agder, og arbeider med eit prosjekt om indremisjonsrørsla på Nordvestlandet gjennom 1900-talet. E-post: andreas.tjomsland@ hivolda.no 
Jan Ove Ulstein er dosent emeritus ved Hogskulen i Volda. Ulsteins fagområdet er systeamtisk teologi, særleg i forhold til hermenutikk og relasjonen kyrkje/samfunn, og i stor grad retta mot det praktiskkyrkjelge feltet. E-post: jou@hivolda.no

Per Magne Aadnanes er professor emeritus ved Høgskulen i Volda. Mag. art. idéhistorie 1975. Dr. philos. 1996. E-post: permaadnanes@gmail.com

Olaf Aagedal er forskar ved KIFO (Institutt for kyrkje-, religions- og livssynsforsking). Aagedals faglege hovudområde er forsking om religiøs kultur og religiøse og nasjonale ritual. 



\section{Tidligere utgivelser i Kyrkjefag Profil}

Nr. 1: Jan Ove Ulstein og Per M. Aadnanes (red.): «Jeg gikk meg over sjø og land...». Bidrag til kyrkjefaga. Festskrift til Ottar Berge på 65-årsdagen (2001).

Nr. 2: Jan Ove Ulstein (red.): Kateketen i fokus. Nokre perspektiv på katekettenesta (2001).

Nr. 3: Per M. Aadnanes (red.): Kyrkjeleg undervisning og utdanning. Ein konferanserapport (2003).

Nr. 4: Torrey Seland: Paulus i Polis. Paulus' sosiale verden som forståelsesbakgrunn for hans liv og forkynnelse (2004).

Nr. 5: Jan Ove Ulstein (red.): Ungdom i rørsle 1. Aktørar og arbeidsformer (2004).

Nr. 6: Jan Ove Ulstein (red.): Ungdom i rørsle 2. Faglege perspektiv og utfordringar (2004).

Nr. 7: Birger Løvlie: «Kor mykje stort...». Matias Orheim, hans bidrag til vestnorsk kultur-og kristenliv (2007).

Nr. 8: Ottar Berge: Åndene og Ånden. Refleksjoner omkring møtet mellom afrikansk religion og kristen livsforståelse (2008).

Nr. 9: Ralph Meier, Birger Løvlie og Arne Redse (red.): Danning, identitet og dialog. Festskrift til Jan Ove Ulstein og Per M. Aadnanes (2009).

Nr. 10: Torrey Seland (red.): «Lor meg din vei ...». Kristen trosopploering i går og i dag. En historisk oversikt (2009). 
Nr. 11: Bjørn Sandvik: Språkstrid og salmesang - Vår nynorske salmeskatt (2010).

Nr. 12: Arne Redse: Kinesisk religion og religiøsitet (2010).

Nr. 13: Per Halse mfl. (red.): Guds folk og folkets Gud. Festskrift til Birger Løvlie (2011).

Nr. 14: Jan Ove Ulstein og Per Magne Aadnanes (red.): Vegar i vegløysa. Ungdom, identitet, og livssynsdanning i det postmoderne (2011).

Nr. 15: Tormod Engelsviken mfl. (red.): Nye guder for hvermann. Femti år med alternativ spiritualitet (2011).

Nr. 16: Per Halse: Gudsord og folkespråk. Då nynorsk vart kyrkjemål (2011).

Nr. 17: Asbjørn Simonnes (red.): Digital trusopploring (2011).

Nr. 18: Torleiv Austad, Ottar Berge og Jan Ove Ulstein: Dømmekraft $i$ krise? Holdninger i kirken til jøder, teologi og NS under okkupasjonen (2012).

Nr. 19: Knut-Willy Sæther (red.): Kristen spiritualitet. Perspektiver, tradisjoner og uttrykksformer (2013).

Nr. 20: Bente Afset, Kristin Hatlebrekke og Hildegunn Valen Kleive (red.): Kunnskap til hva? Om religion i skolen (2013).

Nr. 21: Brynjulf Hoaas: The Doctrine of Conversion in the Theology of Martin Chemnitz. What It Is and How It Is Worked (2013).

Nr. 22: Tom Erik Hamre, Erling Lundeby og Arne Redse (red.): Barnetro og trosopploering. Festskrift til Egil Sjåstad på 65-årsdagen (2014).

Nr. 23: Knut-Willy Sæther og Karl Inge Tangen (red.): Pentekosale perspektiver (2015).

Nr. 24: Bente Afset, Birger Løvlie og Arne Helge Teigen (red.): Festskrift til Arne Redse (2015). 
Nr. 25: Gunnar Innerdal og Knut-Willy Sæther (red.): Festskrift til Svein Rise (2015).

Nr. 26: Brynjulf Hoaas: The Gift of The Lord's Supper (2016).

Nr. 27: Egil Sjaastad: Carl Fr. Wisløff. Presten som ble misjonsfolkets professor (2016).

Nr. 28: Anders Aschim, Olav Hovdelien og Helje Kringlebotn Sødal (red.): Kristne migranter i Norden (2016).

Nr. 29: Bente Afset, Birger Løvlie og Arne Redse (red.): Toleranse religion - konflikt (2017).

Nr. 30: Knut-Willy Sæther: Naturens skjønnhet. En studie av forholdet mellom estetikk, teologi og naturvitenskap (2017).

Nr. 31: Svein Rise: Treenig teologi - historisk, systematisk, kontekstuelt (2017).

Nr. 32: Njål Skrunes, Gunhild Hagesæther og Bjarne Kvam (red.): Kristne grunnskoler. Begrunnelse - innhold - handlingsrom (2018).

Nr. 33: Bente Afset, Arne Redse og Anders Aschim (red.): Religion og etikk i skole og barnehage (2019).

Nr. 34: Andreas Aarflot: Varslingsklokken. Berte Kanutten Aarflot bondekone og vekkerrøst (2020).

Nr. 35: Gunhild Hagesæther, Gunnar Innerdal og Bjarne Kvam (red.): NLA Høgskolen. Fagutvikling og sjølvforståing på kristen grunn (2020). 
